$\underset{\text { Royal Ontario Museum }}{\mathrm{RO̊} M}$
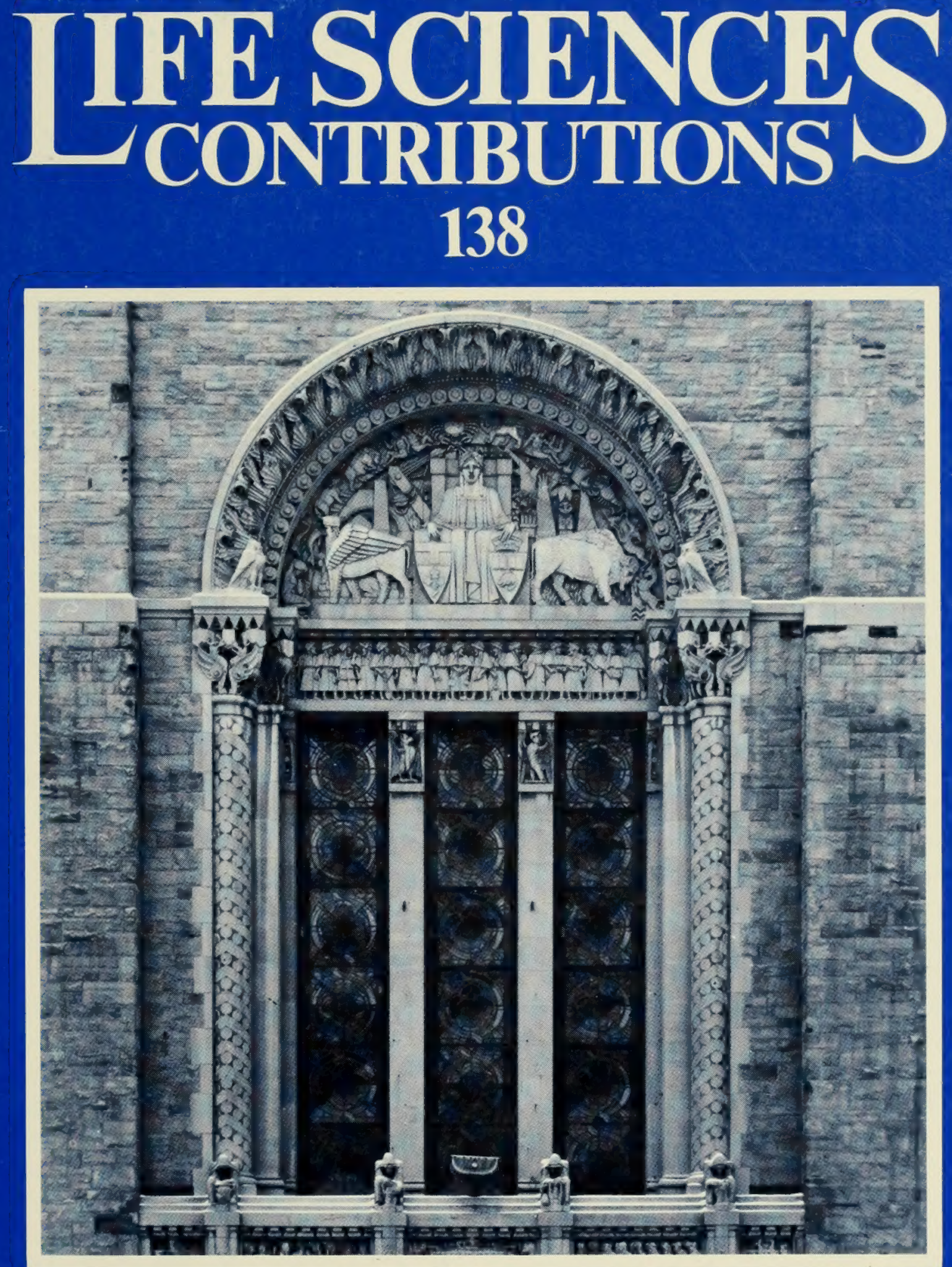

Brachiopoda and Biostratigraphy of the Silurian-Devonian Delorme Formation in the District of Mackenzie, the Yukon

David G. Perry 


\section{ROYAL ONTARIO MUSEUM LIFE SCIENCES PUBLICATIONS INSTRUCTIONS TO AUTHORS}

Authors should prepare their manuscripts carefully according to the following instructions; failure to do so will result in the manuscript's being returned to the author for revision. All manuscripts are considered on the understanding that they are not currently offered for publication elsewhere.

1. General Papers for publication are accepted from ROM staff members and research associates, and from researchers reporting on work done with ROM collections. Monographs on the flora and/or fauna of Ontario may be considered for publication by authors not affiliated with the ROM. Financial contributions towards publication will be welcome. Authors are expected to write clearly and concisely and to omit any material not essential for an understanding of the main theme of the paper.

2. Format Manuscripts (including captions, synonymies, literature cited, and tables) should be typed with double space on $11^{\prime}$ ' $\times 8 \frac{1}{2}$ " paper with a $1 \frac{1 / 2}{2}$ ", margin on all sides. Three xerox copies should be submitted to the Senior Editor of the Editorial Board; the original should be retained by the author(s). The submission should include a separate sheet giving the author(s) names and affiliations, the title of the publication, the series for which it is submitted, the number of typed pages, the number of tables, and the number of plates or figures. Manuscripts should normally be organized in the following order: Contents, Abstract, Introduction, Materials and Methods, Results, Discussion, Conclusions, Summary (if manuscript is long), Acknowledgements, Appendices, and Literature Cited. Authors are encouraged to include foreign-language translations of the Summary, if appropriate. Main headings should be centred; subheadings should be left-justified to the text margin. The first line of the first paragraph in each new section should not be indented. Literature citations in the text should be in the form "Jones (1972)" or "(Jones, 1972)" or "'(Smith, 1960:71-79, fig. 17)".

3. Standard Sources The primary authority on questions of format and style is Guide to Authors, available from ROM Publication Services. For matters not covered in the Guide, consult CBE Style Manual (Fifth Edition). Other standard sources are as follows: for
English spelling, The Concise Oxford Dictionary; for Canadian place names and coordinates, Canada Gazetteer Atlas; for the spelling of geographic names, The Times Atlas.

4. Abstract All papers must be preceded by a short, factual abstract, about one per cent of the text in length. The abstract may be followed by four to six key words in parentheses.

5. Taxonomy The name of a taxon should be given in full in headings, at the beginnings of paragraphs, and at its first occurrence in the text. Give the authority and date, if appropriate, with the first mention of each taxon, but not thereafter. Taxonomic papers, particularly synonymies, should follow the layout in Life Sciences Contributions beginning with No. 136. International Codes of Biological Nomenclature must be followed.

6. Literature Cited A complete list of references, in alphabetical order of authors, must be given at the end of the paper. When two or more works of one author are cited, they should be listed chronologically. The names of journals should not be abbreviated. For correct bibliographic form, see Life Sciences Contributions beginning with No. 136.

7. Tables All tables should be typed on separate sheets and numbered consecutively in arabic numerals in the order of their first mention in the text. Mark the location of each table in the margin of the text.

8. Plates, Figures, and Text-figures Illustrations may be designated according to the conventions of the author's discipline; in some disciplines grouped photographs of scientific subject matter are commonly termed Plates, while line drawings and locality and other illustrations that occupy a full page or less are Text-figures. Usage must be consistent throughout the paper. A full-page illustration for a Contribution, with its caption, should be sized to fit an area of $17.3 \times$ $22.75 \mathrm{~cm}$; for Occasional Papers, the area is $14.1 \times$ $21.2 \mathrm{~cm}$. If captions are lengthy, they may be placed on the facing page. A scale or magnification factor should be included. Authors are reminded that when illustrations are reduced magnification factors will change, and that they are responsible for the conversion. For details, see Guide to Authors. 


\section{Brachiopoda and Biostratigraphy of the Silurian-Devonian Delorme Formation in the District of Mackenzie, the Yukon}

\section{Errata}

On front cover, spine, p. i, p. iii, p. iv, and p. 1, the title should read: Brachiopoda and Biostratigraphy of the SilurianDevonian Delorme Formation in the District of Mackenzie.

p. 1, line 2, "in the Yukon" should read "in the District of Mackenzie".

p. 2, line 2, left column, "in the Yukon" should read "in the District of Mackenzie"

p. 6, line 12 under Late Lochkovian Brachiopods, right column, "in the Yukon" should read "in the District of Mackenzie". 
Digitized by the Internet Archive in 2011 with funding from University of Toronto 


\title{
Brachiopoda and Biostratigraphy of the Silurian-Devonian Delorme Formation in the District of Mackenzie, the Yukon
}

\author{
David G. Perry
}

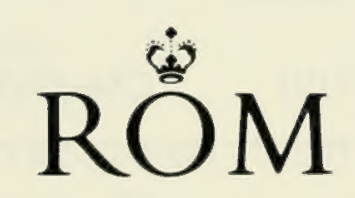

ROYAL ONTARIO MUSEUM 
ROYAL ONTARIO MUSEUM

PUBLICATIONS IN LIFE SCIENCES

The Royal Ontario Museum publishes three series in the Life Sciences:

Contributions: a numbered series of original scientific publications.

Occasional Papers: a numbered series of original scientific publications, primarily short and of taxonomic significance.

Miscellaneous Publications: an unnumbered series on a variety of subjects.

All manuscripts considered for publication are subject to the scrutiny and editorial policies of the Life Sciences Editorial Board, and to independent refereeing by two or more persons, other than Museum staff, who are authorities in the particular field involved.

LIFE SCIENCES EDITORIAL BOARD

Senior editor: J. R. Tamsitt

Editor: D. R. Calder

Editor: J. C. Barlow

External editor: C. S. Churcher

Financial assistance for publication was provided by the University of British Columbia and the Geological Survey of Canada. A suite of topotypes and reference specimens is deposited with the Geological Survey of Canada, Institute of Sedimentary and Petroleum Geology, in Calgary, Alberta.

\footnotetext{
Canadian Cataloguing in Publication Data

Perry, David G. (David George), 1947-1979.

Brachiopoda and biostratigraphy of the Silurian-

Devonian Delorme Formation in the District of

Mackenzie, the Yukon

(Life sciences contributions, ISSN 0384-8159; no. 138)

Bibliography: p.

ISBN 0-88854-304-2

1. Brachiopoda, Fossil. 2. Paleontology - Silurian.

3. Paleontology - Devonian. 4. Paleontology -

Mackenzie Mountains (N.W.T. and Yukon). I. Royal

Ontario Museum. II. Title. III. Series.

QE796.P47 $1984 \quad 564^{\prime} .8^{\prime} 097191 \quad$ C84-098524-X
}

Publication date: 15 October 1984

ISBN 0-88854-304-2

ISSN 0384-8159

(C) The Royal Ontario Museum, 1984

100 Queen's Park, Toronto, Canada, M5S 2C6

PRINTED AND BOUND IN CANADA AT THE ALGER PRESS 


\section{Contents}

$\begin{array}{ll}\text { Foreword xi } & \\ \text { Abstract } 1 & \\ \text { Introduction } 2 & \\ \text { Lithostratigraphy } & 2\end{array}$

Biostratigraphy: Discussion of the Faunal Elements 4

Materials and Methods 11

Systematic Palaeontology 12

Craniops Hall, $1859 \quad 12$

Craniops sp. $1 \quad 12$

Orbiculoidea d'Orbigny, $1847 \quad 13$

Orbiculoidea sp. 113

Schizotreta Kutorga, $1848 \quad 13$

Schizotreta sp. $1 \quad 14$

Philhedra Koken, $1889 \quad 14$

Philhedra sp. $1 \quad 14$

Acanthocrania Williams, $1943 \quad 15$

Acanthocrania sp. $1 \quad 15$

New genus hesperorthid sp. $1 \quad 15$

Dolerorthis Schuchert and Cooper, $1931 \quad 16$

"Dolerorthis" sp. $1 \quad 16$

"Dolerorthis" smithi sp. nov. 16

"Dolerorthis" borealis Lenz, 1977a 17

Ptychopleurella Schuchert and Cooper, $1931 \quad 18$

Ptychopleurella sp. $1 \quad 18$

Skenidioides Schuchert and Cooper, $1931 \quad 18$

Skenidioides variabilis Lenz, 1977a 19

Skenidioides blussoni sp. nov. 19

Cortezorthis Johnson and Talent, 1967a 20

Cortezorthis maclareni Johnson and Talent, 1967a 20

Cortezorthis cf. C. windmillensis (Johnson and Talent, 1967a) 21

Cortezorthis norfordi Lenz, 1977a 22

Cortezorthis perryi Lenz, 1977a 22

Protocortezorthis Johnson and Talent, 1967a 23

Protocortezorthis aff. P. fornicatimcurvata (Fuchs, 1919) 23

Protocortezorthis natlensis sp. nov. 23

?Protocortezorthis sp. $1 \quad 24$

Dalejina Havlíček, $1953 \quad 25$

Dalejina sp. 125

Dalejina gabrielsei sp. nov. 26

Resserella Bancroft, $1928 \quad 27$

Resserella elegantuloides (Kozlowski, 1929) 27

Didymoparcium Lenz, 1977a 28

Didymoparcium costata Lenz, 1977a 28

Schizophoria King, $1850 \quad 29$

Schizophoria paraprima Johnson, Boucot, and Murphy, $1973 \quad 29$

Schizophoria cf. S. nevadaensis Merriam, $1940 \quad 30$

Schizophoria delormensis sp. nov. 30

Schizophoria sp. $1 \quad 31$ 
Salopina Boucot, $1960 \quad 32$

Salopina submurifer Johnson, Boucot, and Murphy, 1973

Muriferella Johnson and Talent, 1967b 33

Muriferella masurskyi Johnson and Talent, 1967b 33

Miniprokopia Havlíček 34

Miniprokopia havliceki sp. nov. 34

Phragmophora Cooper, 195536

Phragmophora cooperi sp. nov. 36

Mystrophora Kayser, $1871 \quad 37$

Mystrophora arctica Lenz, 1977a 37

Kayserella Hall and Clarke, $1892 \quad 38$

Kayserella cf. K. costatula Lenz, 1977a 38

Grayina Boucot, 197538

Grayina magnifica arctica Lenz, 1977a 38

Conchidium Oehlert, $1887 \quad 39$

Conchidium sp. $1 \quad 39$

Gypidula Hall, $1867 \quad 40$

Gypidula pelagica lux Johnson, Boucot, and Murphy, 197340

Gypidula cf. G. boucoti Lenz, 1977a 42

Gypidula sp. $1 \quad 42$

Gypidula cf. G. kayseri (von Peetz, 1901)

43

Gypidula sp. 243

Gypidula sp. $3 \quad 44$

Gypidula sp. $4 \quad 44$

Procerulina Andronov, $1961 \quad 44$

?Procerulina sp. 144

Sieberella Oehlert, $1887 \quad 44$

Sieberella sp. $1 \quad 44$

Carinagypa Johnson and Ludvigsen, $1972 \quad 45$

?Carinagypa cf. C. careopleura Johnson, 1975a

Carinagypa praeloweryi (Johnson, 1970) 45

Carinagypa cf. C. loweryi (Merriam, 1940)

Clorinda Barrande, $1879 \quad 46$

Clorinda garretti sp. nov. 46

Clorindina Khodalevich, $1939 \quad 47$

Clorindina sp. $1 \quad 47$

Leptaenisca Beecher, $1890 \quad 47$

Leptaenisca cf. L. concava (Hall, 1857) 47

Leptagonia M'Coy, $1844 \quad 48$

Leptagonia sp. $\quad 48$

Leptagonia costarugosa sp. nov. 49

Eoschuchertella Gratsianova, $1974 \quad 50$

Eoschuchertella cf. E. murphyi (Chatterton, 1973) 50

Eoschuchertella sp. 151

Eoschuchertella sp. 251

Aesopomum Havlíček, 196551

Aesopomum sp. 51

Aesopomum varistriatus Johnson, 1970

Aesopomum irregularis sp. nov. 52

Brachyprion Shaler, 186553

"Brachyprion" sp. 153 
Strophonella Hall, $1879 \quad 53$

Strophonella sp. $1 \quad 53$

Mesodouvillina Williams, $1950 \quad 53$

Mesodouvillina sp. 153

Mesodouvillina cf. M. stelcki Lenz, 1977a 54

Mesodouvillina delormei sp. nov. 54

Mclearnites Caster, $1945 \quad 55$

Mclearnites cf. M. invasor Johnson, $1970 \quad 55$

Cymostrophia Caster, $1939 \quad 55$

Cymostrophia sp. $\quad 55$

Megastrophia Caster, $1939 \quad 56$

Megastrophia iddingsi (Merriam, 1940) 56

Megastrophia transitans Johnson, $1970 \quad 56$

Strophodonta Hall, 185257

Strophodonta sp. $1 \quad 57$

Strophodonta sp. $2 \quad 57$

Leptostrophia Hall and Clarke, $1892 \quad 58$

Leptostrophia magna sp. nov. $\quad 58$

Phragmostrophia Harper, Johnson, and Boucot, $1967 \quad 59$

Phragmostrophia merriami Harper, Johnson, and Boucot, $1967 \quad 59$

Phragmostrophia mucronata Lenz, 1977a 60

Parapholidostrophia Johnson, 1971a 60

Parapholidostrophia prima sp. nov. 60

Strophochonetes Muir-Wood, $1962 \quad 61$

“'Strophochonetes" filistriata (Walcott, 1884) 61

Parachonetes Johnson, $1966 \quad 63$

Parachonetes macrostriatus (Walcott, 1884) 63

New genus chonetid sp. $1 \quad 64$

Chattertonia Johnson, $1976 \quad 65$

Chattertonia mackenzia sp. nov. 65

Stegerhynchus Foerste, 190966

Stegerhynchus cf. S. angaciensis Chernyshev, $1937 \quad 66$

Stegerhynchus sp. $1 \quad 68$

Machaeraria Cooper, $1955 \quad 68$

Machaeraria paraformosa Lenz, 1977a 68

Thliborhynchia Lenz, 1977a 69

Thliborhynchia julli Lenz, 1967a 69

Thliborhynchia pedderi (Lenz, 1973) 70

Thliborhynchia kerri mackenziensis subsp. nov.

Ancillotoechia Havlíček, 195972

Ancillotoechia cf. A. gutta Johnson, Boucot, and Murphy, $1973 \quad 72$

Ancillotoechia sp. $1 \quad 72$

Ancillotoechia sp. $2 \quad 72$

Ancillotoechia sp. $3 \quad 72$

Nymphorhynchia Rzhonsnitskaia in Khalfin, $1956 \quad 74$

Nymphorhynchia nympha (Barrande, 1879) 74

Werneckeella Lenz, $1971 \quad 74$

Werneckeella hartensis Lenz, $1971 \quad 74$

Trigonirhynchia Cooper, 194275

Trigonirhynchia cf. T. occidens (Walcott, 1884) 75

Hebetoechia Havlíček, 195975 
Hebetoechia cf. H. hebe (Barrande, 1847)

Sphaerirhynchia Cooper and Muir-Wood, 1951

Sphaerirhynchia sp. $\quad 76$

Decoropugnax Havlíček, 196076

?Decoropugnax sp. $\quad 76$

Isopoma Torley, $1934 \quad 78$

Isopoma cf. I. alecto (Barrande, 1847)

Linguopugnoides Havlíček, 196079

Linguopugnoides cf. L. carens (Barrande, 1879)

79

Linguopugnoides stelcki sp. nov.

Athyrhynchus Johnson, 1973b 81

Athyrhynchus susanae Johnson, 1973b

81

Athyrhynchus sp. 181

Athyrhynchus boucoti sp. nov.

82

Leiorhynchus Hall, 186083

“'Leiorhynchus', sp. 83

Phoenicitoechia Havlíček, 1960

?Phoenicitoechia sp. 83

Indeterminate rhynchonellid 84

Atrypa Dalman, $1828 \quad 84$

Atrypa cf. A. nevadana Merriam, 1940

Atrypa nieczlawiensis Kozlowski, 1929

Atrypa cf. A. aspiformis Lenz, 1977b

Desquamatia Alekseeva, 1960b 86

Desquamatia Alekseeva, 1960b (subgenus) 86

Desquamatia (Desquamatia) cf. D. (D.) filistriata Lenz, 1977b 86

Desquamatia sp. $1 \quad 86$

Reticulatypra Savage, $1970 \quad 87$

Reticulatrypa neutra Johnson, Boucot, and Murphy?, 1973 87

Reticulatrypa variabilis Johnson, Boucot, and Murphy, 1976

Spinatrypa Stainbrook, $1951 \quad 87$

Spinatrypa jonesi sp. nov. 88

Invertrypa Struve, 1961 (subgenus) 88

Spinatrypa (Invertrypa) echinocostata Lenz, 1977b 88

Spinatrypina Rzhonsnitska1a, $1964 \quad 89$

Spinatrypina symmetrica Perry, Boucot, and Gabrielse, 1981

Atrypina Hall and Clarke, $1893 \quad 89$

Atrypina simpsoni Johnson, 1970

Atrypina chattertoni sp. nov. 89

Atrypina sp. $1 \quad 90$

Spirigerina d'Orbigny, $1849 \quad 91$

Spirigerina supramarginalis (Khalfin, 1948) 91

Spirigerina marginaliformis Alekseeva, 1960a 91

Spirigerina intermedia sp. nov. 92

Vagrania Alekseeva, $1959 \quad 93$

Vägrania cf. V. intermediafera (Khodalevich, 1951)

Vagrania johnsoni sp. nov. 95

Vagrania sp. 196

Toquimaella Johnson, 196796

Toquimaella kayi Johnson, 196796

Gracianella Johnson and Boucot, $1967 \quad 97$ 
Gracianella lissumbra lissumbra Johnson, Boucot, and Murphy, 1976

Gracianella plicumbra Johnson and Boucot, 1967

Gracianella cryptumbra Johnson, Boucot, and Murphy, 1973

Davidsoniatrypa Lenz, $1968 \quad 98$

Davidsoniatrypa johnsoni Lenz, 196898

Ogilviella Lenz, $1968 \quad 99$

Ogilviella rotunda Lenz, $1968 \quad 99$

Carinatina Nalivkin, $1930 \quad 100$

Carinatina sp. $\quad 100$

Biconostrophia Havlíček, 1956100

Biconostrophia cf. B. knorrensis Perry, $1979 \quad 100$

Notoparmella Johnson, 1973a 100

Notoparmella gilli Johnson, 1973a 100

Notoparmella fila sp. nov. 101

Plicanoplites Havlíček, 1974101

Plicanoplites bisulcata (Lenz, 1977b) 102

Indeterminate ?notanopliid 102

Atrypoidea Mitchell and Dun, 1920

Atrypoidea planata sp. nov. 103

Atrypoidea sp. 104

Holynatrypa Havlíček, $1973 \quad 104$

Holynatrypa sp. 104

Cryptatrypa Siehl, $1962 \quad 104$

Cryptatrypa lenticula sp. nov. 105

Cryptatrypa sp. $1 \quad 106$

Meristella Hall, $1859 \quad 107$

Meristella cf. M. robertsensis Merriam, $1940 \quad 107$

Didymothyris Rubel and Modzalevskaia, $1967 \quad 107$

Didymothyris sp. $1 \quad 107$

Collarothyris Modzalevskaia, 1970108

Collarothyris cf. C. canaliculata (Wenjukow, 1899) 108

Nucleospira Hall, $1859 \quad 110$

Nucleospira cf. N. laevigata Lenz, 1977b 110

Rhynchospirina Schuchert and LeVene, $1929 \quad 110$

Rhynchospirina sp. $1 \quad 110$

Howellella Kozlowski, $1946 \quad 111$

Howellella cf. H. khalfini Kulkov, 1963111

Howellella cycloptera (Hall, 1859)? 112

Howellella sp. $1 \quad 112$

Howellella sp. $2 \quad 114$

Delthyris Dalman, $1828 \quad 115$

Delthyris sp. 115

Callispirifer gen. nov. 115

Callispirifer teniostrakon gen. nov. et sp. nov. 115

Howittia Talent, $1956 \quad 117$

Howittia sp. 117

Cyrtinopsis Scupin, $1896 \quad 117$

?Cyrtinopsis cf. C. cooperi Gill, $1942 \quad 117$

Plicocyrtina Havlíček, $1956 \quad 118$

Plicocyrtina sinuplicata Havlíček, $1956 \quad 118$

Spinella Talent, $1956 \quad 118$ 
?Spinella sp. $\quad 118$

Warrenella Crickmay, $1953 \quad 120$

Warrenella sekwensis Ludvigsen and Perry, 1975

Reticulariopsis Frederiks, $1916 \quad 121$

Reticulariopsis? warreni sp. nov. 121

Spirinella Johnston, 1941

122

Spirinella rootensis sp. nov.

122

Ambocoelia Hall, $1860 \quad 124$

Ambocoelia cf. A. praecox Kozlowski, 1929

Ambocoelia rugosa sp. nov.

124

Metaplasia Hall and Clarke, 1893

Metaplasia sp.

125

Plicoplasia Boucot, 1959

125

Plicoplasia acutiplicata Lenz, 1972

Cyrtinaella Frederiks, 1916

Cyrtinaella cf. C. causa Johnson, 1970

Cyrtina Davidson, 1858

126

Cyrtina impressio sp. nov. 126

Cyrtina clagueae sp. nov. 127

Cyrtina spp. 127

Indeterminate spiriferid

127

Indeterminate terebratulid

Acknowledgements

129

Appendix 131

Literature Cited 141

Plates 151 


\section{Foreword}

David George Perry was killed in a helicopter accident on 2 August 1979 while carrying out geological work in the Rocky Mountains near Banff, Alberta.

The present study was completed in 1974 as a doctoral dissertation at the University of Western Ontario and was being prepared for publication at the time of David Perry's death. The portions of the manuscript completed before his death include almost the entire taxonomy section, the references, the plates and plate descriptions, and the appendix. The manuscript, however, lacked an introduction and the lithostratigraphy and biostratigraphy sections necessary as background to the extensive taxonomy. These as well as the accompanying text-figures were extracted from the original thesis, revised, and updated by A. C. Lenz. In the preparation of these sections, an effort was made to retain the stylistic aspects of David Perry's writing as much as possible.

The task of preparing the manuscript for publication was undertaken by ROM staff members. R. D. James and J. H. McAndrews from the Life Sciences Editorial Board guided the manuscript through review and acceptance. P. $\mathrm{H}$. von Bitter and D. H. Collins of the Department of
Invertebrate Palaeontology, along with $\mathrm{R}$. Ludvigsen of the Geology Department at the University of Toronto, interpreted reviewers' comments and changes. J. Burke and J. Waddington of the Department of Invertebrate Palaeontology spent many hours modifying the manuscript with the assistance of C. Lockett and J. Hawken of Publication Services.

The brachiopod collection was shipped intact to the Royal Ontario Museum in May 1978. Type and figured specimens were isolated from the main collection by $\mathrm{J}$. Waddington after David Perry's death. Curatorial interpretation was necessary since some specimens had been assigned duplicate numbers in the manuscript and in other instances different views of the same specimen were assigned separate numbers. Two specimens of Mesodouvillina delormi sp. nov. (ROM 33508, 33509) recorded from sample S-7, P7WA1731.3 m, were found with specimens from sample S-7, P7WA203.3 m. It is not known which sample number is correct.

Department of Invertebrate Palaeontology Royal Ontario Museum 



\title{
Brachiopoda and Biostratigraphy of the Silurian-Devonian Delorme Formation in the District of Mackenzie, the Yukon
}

\begin{abstract}
The Delorme platform facies of dolostone and argillaceous limestone, which occurs in the central and eastern parts of the study area in the Mackenzie Mountains, in the Yukon, is of Ludlovian to late early-Lochkovian age. Shallow-water, subtidal faunas of the platform facies are of low diversity and include large numbers of two or three genera of brachiopods, high-spired gastropods, and fish plates. Locally, intertidal to supratidal environments are indicated by desiccation cracks, salt hoppers, stromatolites, and intraformational carbonate breccias.

Near a regional facies change from carbonate to shale at the western edge of the study area, the formation is locally highly diachronous and includes strata of parts or of all of the Ludlovian to Zlichovian interval. A late Silurian to early Devonian regression is documented at the northwestern edge of the study area, where shallow-water carbonates of the Delorme Formation overlie beds of the Road River Formation shale that are successively younger basinwards.

The Delorme sections near the facies transition at the western margin yield prolific faunas of silicified brachiopods and conodonts of late Lochkovian to Zlichovian age from argillaceous limestones and minor dolostones. The Pridolian and early Lochkovian brachiopod faunas are not as abundant or diverse. The brachiopod faunas have affinity with those of the Old World Bohemian Subprovince and are similar to faunas from Royal Creek in the Yukon. The late Lochkovian fauna is correlative with the Quadrithyris Zone of Nevada and the Spirigerina Unit of northern Canada, and the Pragian fauna is correlative with the Davidsoniatrypa johnsoni fauna of Royal Creek. The generic composition of the Delorme and central Nevada brachiopod faunas shows the greatest similarity in the late Lochkovian, strong dissimilarity in the Pragian, and moderate similarity in the Zlichovian. Mystrophora, Phragmophora, and Miniprokopia, genera previously unknown in North America, occur in the Delorme Zlichovian. The late Pragian Acrospirifer kobehana Zone and the Zlichovian Eurekaspirifer pinyonensis Zone in Nevada are not separately distinguishable in the Delorme.

The Delorme brachiopod faunas are divisible into the following biostratigraphic units: a general Ludlovian Conchidium and Pridolian Gracianella fauna, and lower Lochkovian pelagica, upper Lochkovian spirigerina, Pragian Davidsoniatrypa johnsoni, and lower Zlichovian pseudolivonica-Vagrania johnsoni-Megastrophia iddingsi faunas.

In this study, 105 genera, one subgenus, 163 species, and four subspecies are described. These include one new genus and species Callispirifer teniostrakon; 28 new species comprising "Dolerorthis" smithi, Skenidioides blussoni, Protocortezorthis natlensis, Dalejina gabrielsei, Schizophoria delormensis, Miniprokopia havliceki, Phragmophora cooperi, Clorinda garretti, Leptagonia costarugosa, Aesopomum irregularis, Mesodouvillina delormei, Leptostrophia magna, Parapholidostrophia prima, Chattertonia mackenzia, Linguopugnoides stelcki, Athyrhynchus boucoti, Spinatrypa jonesi, Atrypina chattertoni, Spirigerina intermedia, Vagrania johnsoni, Notoparmella fila, Atrypoidea planata, Cryptatrypa lenticula, Reticulariopsis? warreni, Spirinella rootensis, Ambocoelia rugosa, Cyrtina impressio, and Cyrtina clagueae; and one new subspecies Thliborhynchia kerri mackenziensis.
\end{abstract}




\section{Introduction}

The Upper Silurian and Lower Devonian strata of the Mackenzie Mountains, in the Yukon, including those in the study area, have been mapped on a reconnaissance scale of 1:250 000 by the Geological Survey of Canada. The region in the eastern part of the study area was mapped in 1957 during Operation Mackenzie (Douglas and Norris, 1960, 1961, 1963); in 1963 and 1965-67, Operations Nahanni and Selwyn of the Geological Survey of Canada mapped the western part of the study area (Gabrielse, Blusson, and Roddick, 1973; Blusson, 1971). The stratigraphic framework established by Douglas and Norris (1961) in the eastern part of the area of study is applicable to, and has been used in, the west Mackenzie Mountains with only minor changes (Gabrielse, Blusson, and Roddick, 1973; Blusson, 1971).

The recognition of stratigraphic units of marine origin over a distance of approximately $200 \mathrm{~km}$ perpendicular to the trend of the sedimentary basin implies that the formations were deposited in widespread, relatively stable sedimentary environments, although any one formation may be strongly diachronous from one side of the basin to the other. The Delorme Formation displays relatively uniform lithology over a wide part of the study area, but near the "shale-out" margin in the western Mackenzie Mountains (Text-fig. 1) there is considerable lithologic variation. The more easterly, cratonward Delorme sections of the Root Basin range in age more or less consistently from Ludlovian to early Lochkovian, whereas those along the "shale-out" margins may include strata representing any part or all of the Ludlovian to Zlichovian interval.

The purpose of this study is to describe, illustrate, and elucidate the fauna of the Delorme Formation and to determine its age and correlation with other Silurian to Devonian sequences in western North America. Detailed studies were originally made of the brachiopod, conodont, and trilobite faunas, but only the brachiopods, which constitute the major portion of the fauna, are discussed in this study.

\section{Lithostratigraphy}

The Delorme Formation was defined by Douglas and Norris (1961) as a "sequence of buff- and light-brownweathering, thinly bedded limestones, dolomites, and shales that overlie the Whittaker Formation and underlie the Camsell Formation". The type locality is near the headwaters of Pastel Creek on the Delorme Range in the vicinity of section 6 (Text-fig. 1). The formation is commonly recessive, saddle-forming, and in part taluscovered; in areas away from the type locality it weathers orange and buff-orange. The stratigraphic thicknesses attributed to the Delorme Formation in the Delorme and Whittaker ranges (Douglas and Norris, 1961) -990 m and $1158 \mathrm{~m}$ respectively - are in the order of 20 per cent too thick.

At the type locality (section 6) the Delorme is only partially exposed. The upper one-third of the formation consists of recessive, platy, micritic limestones which contain a restricted fauna of ostracodes and high-spired gastropods. In the middle one-third of the Delorme, several brachiopod coquinas occur in the silty and shaly limestones of the unit. The brachiopod coquinas are of low diversity. The upper part of the lower one-third of the Delorme comprises highly recrystallized dolostones which contain a few coquinas of coarsely silicified brachiopods. The basal beds of the Delorme are highly argillaceous, black, platy limestones which contain silicified trilobites and very poorly preserved graptolites. The lower contact with the Whittaker Formation is gradational and is drawn where the buff-orange weathering colour of the Delorme predominates over the dark-grey-weathering shaly limestones of the Whittaker.

In the nearby Whittaker Anticline (sections 7 and 13, Text-fig. 1) the Delorme Formation forms a recessive unit dissected by incised streams. The upper one-third of the Delorme is predominantly argillaceous limestone containing an abundant but low-diversity fauna of brachiopods, bryozoans, and trilobites (including the early Lochkovian subspecies Warburgella rugulosa canadensis Ormiston). The middle one-third of the formation consists of interbedded limestones and dolostones, containing a few low-diversity faunas of spiriferid, rhynchonellid, atrypid, and strophomenid brachiopods. The lower onethird of the formation is composed of orange-weathering, micritic, flaggy dolostone which contains a few highspired gastropods. The lower contact with the shale and argillaceous limestone of the Whittaker is distinct.

The Delorme is poorly exposed and relatively thin in the northeasternmost part of the area (section 13, Text-fig. 1), where it comprises a monotonous sequence of interbedded platy dolostones and slightly argillaceous limestones. Fossils are scarce and poorly preserved throughout the section. High-spired gastropods are locally abundant in the lower part of the sequence. Coquinas of an abraded Mesodouvillina-type strophomenid brachiopod occur sporadically in the argillaceous limestones from the upper part of the section. To the northwest of section 13, the 


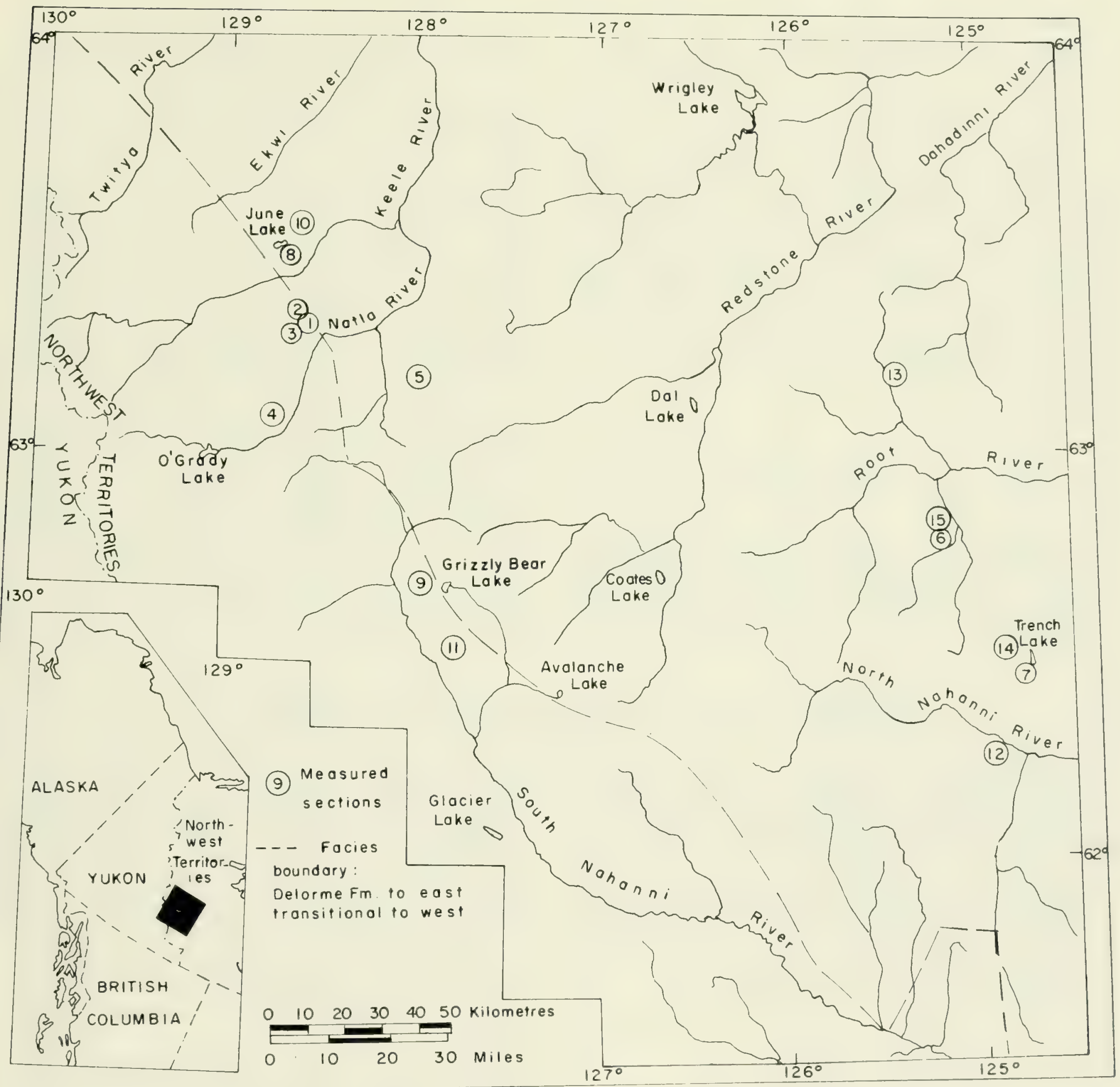

Text-fig. 1 Index map of area showing locations of measured sections.

Delorme becomes still thinner and consists of very recessive, poorly fossiliferous to nonfossiliferous, thinbedded, mudcracked dolostones, some of which contain halite pseudomorphs and intraformational dolostone breccias, a condition persisting also in the central part of the region (for example, the Coates Lake area).

In the June Lake area (sections 8 and 10, Text-fig. 1) the Delorme is approximately $460 \mathrm{~m}$ thick. The upper one-half of the formation comprises a resistant sequence of medium-bedded dolostones and limestones containing a sparse fauna of large, smooth ostracodes. This unit is underlain by a recessive unit of very argillaceous dolostones containing brachiopods, trilobites, and a few poorly preserved graptolites. The lower one-third of the formation is represented by a sequence of brownweathering, argillaceous limestones, grading downwards into very thin-bedded, recessive, black shales of the Road River Formation.

Southwards to sections 1 to 3 (Text-fig. 1) thicknesses range from 160 to $460 \mathrm{~m}$, and the typical orange 
weathering of the Delorme is less distinct. Sections 1 to 3 , which are approximately on or near the facies boundary, were extensively sampled because they contain wellpreserved, extremely diverse (over 100 genera of brachiopods), silicified faunas throughout. The rocks are predominantly limestone and are moderately resistant and therefore better exposed than equivalent dolostone sections. The name Delorme is used for these limestones because the rocks in question possess some of the familiar weathering features of the true Delorme, are obviously partly coeval, and occupy a similar stratigraphic position.

The Delorme Formation thins appreciably near the line of regional facies change compared to platform sections to the east. At section 9 (Text-fig. 1) the Delorme thins to less than $90 \mathrm{~m}$.

\section{TRANSITIONAL FACIES OF THE ROAD RIVER FORMATION}

The Road River Formation was defined by Jackson and Lenz (1962) for a sequence of argillaceous graptolitic strata in the southern Richardson Mountains of the northern Yukon. Southwest of the line of facies change in
Selwyn Basin, graptolitic shales, argillaceous limestones, and lesser amounts of black chert, which are stratigraphic equivalents of various units including the Delorme Formation, were assigned to the Road River Formation by Gabrielse, Blusson, and Roddick (1973). The age of the strata represented by the Road River facies is variable, depending on the distance from the major facies change. The thickness of the shales is difficult to estimate because of structural complexity, but it is probably greater than that of correlative carbonates in the central part of the study area. "Transitional facies" is a term used informally by Gabrielse, Blusson, and Roddick (1973) for strata intermediate between the carbonate and shale sections representing, in part at least, the Delorme Formation in the area of Grizzly Bear Lake and Avalanche Lake. Sections 1 to 3 , which are assigned to the Delorme Formation in this study, may be referred to transitional facies by others (for example, Gabrielse, Blusson, and Roddick); nevertheless, beds within true Delorme sections can be traced into these sections. At Grizzly Bear Lake (section 9), the unit that Gabrielse, Blusson, and Roddick might call transitional facies is here recognized as two units comprising an underlying Road River Formation and an overlying Delorme Formation.

\section{Biostratigraphy: Discussion of the Faunal Elements}

This section discusses some of the principal biostratigraphically important brachiopod elements of the Delorme faunas, and comparisons and correlations are made with two areas in particular: the Royal Creek area of the northern Yukon and the Great Basin area of Nevada. For a summary of the stadial terminology and biostratigraphic units and for stratigraphic ranges and the correlation of a large portion of the Delorme brachiopod fauna, the reader is referred to Text-figures 2 and 3 respectively.

\section{SILURIAN BRACHIOPODS}

Ludlovian and Pridolian brachiopod faunas of the Delorme are too poorly represented to formulate a zonal sequence, although a number of general correlations are made from the occurrence of a few moderately well-known shells. A few genera such as Gracianella, Atrypoidea, Conchidium, Reticulatrypa, Spirinella, and Collarothyris, none of which is known outside the Silurian, appear to have potential biostratigraphic use in western North America. Age assignments suggested by these genera and their species are in agreement with those suggested by the closely associated conodont and graptolite faunas. In the Ludlovian to Pridolian sequence in Nevada, the boundary between the stages is not recognized at a specific horizon, although there is a marked reduction in the number of representatives of the family Pentameridae (for example, Conchidium) in the late Ludlovian; during the early or middle Pridolian they completely disappear without any apparent environmental changes in the host strata. This is referred to as the Pentamerid Rule by Johnson, Boucot, and Murphy (1973) and may hold true in northwestern Canada, since the younger Pridolian faunas known from Royal Creek (Lenz and Pedder, 1972) also lack Pentameridae.

In the Delorme, Gracianella plicumbra appears to range through the Ludlovian to early Pridolian interval and is associated locally with $G$. lissumbra?, a species that in Nevada occurs in beds of Ludlovian and Pridolian age (Johnson and Boucot, 1967). The occurrence of $G$. plicumbra at section 6 (Text-fig. 1), $215 \mathrm{~m}$ above the base of the Delorme, suggests a Ludlovian age, because Johnson (pers. comm., 1974) comments that the associated shells from this collection, Reticulatrypa cf. $R$. variabilis and Spirinella sp. D, are also known from Ludlovian beds in central Nevada. At section 11, in the transitional facies (GSC locality 69062), G. plicumbra occurs with Reticulatrypa cf. $R$. neutra (a Nevada Pridolian element), Delthyris, and Spirinella sp. D. The 
age is uncertain although comparison with the Nevada sequence suggests a Pridolian age. G. cryptumbra from near the top of the Road River Formation at section 2 suggests a Pridolian age because this species has been reported from Pridolian strata in Nevada (Johnson, Boucot, and Murphy, 1973). True Didymothyris with the prominent ventral valve mystrochial plates occurs in association with G. plicumbra, Atrypoidea, Conchidium, Spirinella, and Reticulatrypa in the beds of Ludlovian age at S-6, about $215 \mathrm{~m}$ above the base of the Delorme. Collarothyris cf. C. canaliculata is probably of Ludlovian age at sections 5, 9, and 10, because of the associated brachiopod and/or graptolite faunas.

\section{EARLY LOCHKOVIAN BRACHIOPODS}

The Silurian-Devonian boundary is not exposed at any of the Delorme sections studied, and in most cases it occurs in rather poorly fossiliferous strata. In Nevada, the early Lochkovian is marked by the disappearance of Gracianella and Atrypoidea and by the introduction of Schizophoria, Aesopomum varistriatus, and Lissatrypa. In the Delorme the disappearance of Gracianella and Atrypoidea, combined with the incoming of Aesopomum varistriatus, abundant Cyrtina, and Salopina submurifer, appears to mark the early Lochkovian strata, although in Nevada $S$. submurifer also occurs within the upper range of Gracianella.

Gypidula pelagica lux is found in beds $100 \mathrm{~m}$ below the top of the Delorme at Cathedral Mountain (the southeasternmost part of the study area), suggesting correlation of these beds with those above the Pridolian-Lochkovian contact. The species occurs in early Lochkovian beds in central Nevada. Atrypa nieczlawiensis and Ancillotoechia gutta are also known from the upper part of the early Lochkovian in Nevada. In the Delorme Atrypa nieczlawiensis, which occurs in beds with $G$. pelagica lux at Cathedral Mountain, also occurs in beds approximately $415 \mathrm{~m}$ below the top of the Delorme at S-7 and within the transitional facies at S-11. The collection from S-7 also contains Ancillotoechia cf. A. gutta some $120 \mathrm{~m}$ below the oldest collection of the early Lochkovian trilobite Warburgella rugulosa canadensis. At S-1 and S-2 the occurrence of Rhynchospirina, Notoparmella gilli, and Spirigerina marginaliformis indicate a probable late early-Lochkovian age. A fauna of similar composition is described from the Lower Windmill Limestone of central Nevada by Johnson (1973a). Mesodouvillina delormei sp. nov. occurs very commonly in strata in the upper one-third of the Delorme at S-6 and S-7 and in the lower beds of the Delorme at S-1 and S-2 at Natla River, and is probably of late early-Lochkovian age.

On the whole, early Lochkovian brachiopod faunas are not particularly well known from the Delorme or from any locality in northwestern or arctic Canada. Several of the genera and species characteristic of the overlying or Spirigerina Unit have their initial occurrences in strata of probable early Lochkovian age, and separation of the lower limit of the late Lochkovian shelly fauna zones is not clear. Shells such as Machaeraria paraformosa, Spirigerina supramarginalis, and Ogilviella cf. O. prolifica may begin within the early Lochkovian of the Delorme Formation.

\section{LATE LOCHKOVIAN BRACHIOPODS (QUADRITHYRIS ZONE-SPIRIGERINA SUPRAMARGINALIS UNIT)}

Faunas younger than early Lochkovian are recognized from Delorme beds only at sections 1 to 4 ; in addition, brachiopod-bearing Delorme strata of late Lochkovian through Zlichovian age are probably present near the Delorme to Road River "shale-out" in the vicinity of the southeasternmost part of the South Nahanni River area, although they have not as yet been documented. The upper Lochkovian strata contain a highly diagnostic brachiopod fauna that is recognized from Nevada, the Arctic Islands, Royal Creek in the Yukon, east-central Alaska, eastern Australia, central USSR, and the western part of the study area in the Yukon. In Nevada this fauna is commonly known as the Quadrithyris Zone, and in northwestern and arctic Canada it is referred to the Spirigerina supramarginalis Unit. The term Quadrithyris Zone is not applied to the fauna in northern Canada because of the absence of the name bearer, Quadrithyris, in Upper Lochkovian strata of the area; Spirigerina is probably the most common element in these strata.

The Quadrithyris Zone was proposed by Johnson (1965) for the shelly megafauna of the Upper Windmill Limestone at Coal Canyon in central Nevada. Lenz (1966) proposed the name Spirigerina Unit for the distinctive, equivalent, late Lochkovian brachiopod fauna dominated by the Old World Province Silurian holdover Spirigerina at Royal Creek in the Yukon. Distribution of important elements in the late Lochkovian Spirigerina Unit of the Delorme follows (see also Text-fig. 3).

"Dolerorthis" is a common element in late Lochkovian of the Delorme and is also known from Nevada, Royal Creek, and the Mandagery Park Formation of New South Wales (Johnson, 1970; Savage, 1971; Lenz and Pedder, 1972). Cortezorthis cf. C. windmillensis, originally described from the late Lochkovian in central Nevada, occurs commonly in the upper part of the Delorme Spirigerina Unit and from beds of similar age in the Canadian Arctic. C. windmillensis is regarded as the initial member of the Cortezorthis lineage, which became quite 
widespread in the Pragian and Zlichovian. Shells assigned to Resserella elegantuloides occur low in the Spirigerina Unit at section 2. Similar shells in Nevada are assigned a mid-Lochkovian age by Johnson (1973a). Savage (1974) reports the same species from beds of early Lochkovian age in New South Wales. Salopina submurifer continues from underlying strata and extends through the Delorme Spirigerina Unit into the Pragian. Muriferella masurskyi, an evolutionary derivative of $S$. submurifer, first occurs low in the Delorme Spirigerina Unit. It should be noted that in Nevada $S$. submurifer and $M$. masurskyi do not have overlapping ranges (Johnson, 1973a), whereas in northern Canada they do.

Grayina magnifica arctica ranges from near the base of the Delorme Spirigerina Unit well up into the Pragian. Quadrithyris Zone representatives of the Grayina magnifica group are known from central Nevada, the Mandagery Park Formation of New South Wales, and the Solovian Limestone of the Altai and Ural mountains of the USSR. Grayina magnifica arctica at Royal Creek has a similar Lochkovian to Pragian age range to that in the Delorme Formation. Clorinda garretti sp. nov. has a restricted late Lochkovian range in the Delorme, and this distinctive shell has potential zonal value when its distribution becomes known in other sequences.

Aesopomum varistriatus occurs in the Delorme Spirigerina Unit and older Lochkovian beds and has much the same stratigraphic range as in central Nevada. Representatives of $A$. varistriatus are present in the Spirigerina Unit at Royal Creek.

Machaeraria paraformosa occurs most abundantly in the lower part of the Delorme Spirigerina Unit and in older Lochkovian beds. Several species of Machaeraria have been described from the upper Lochkovian beds in North America and Australia, although distinctions drawn between them are less than adequate. The presence of Machaeraria appears to be a marker for the lower part of the Quadrithyris Zone-Spirigerina Unit or slightly older beds. Thliborhynchia pedderi is an evolutionary derivative of Machaeraria and occurs commonly near the top of the Spirigerina Unit in the Delorme and at Royal Creek. This species is also known, although less commonly, from the late Lochkovian of Bathurst Island. One possible representative of $T$. pedderi has been recovered from the Quadrithyris Zone in Nevada. T. kerri mackenziensis subsp. nov. is a very fine-ribbed subspecies which occurs in the lower part of the Spirigerina Unit at Royal Creek and in the Delorme Formation.

In Nevada Atrypina simpsoni is confined to the Quadrithyris Zone. Delorme Formation representatives occur only in the highest beds of the Spirigerina Unit and in the overlying Pragian. Ogilviella cf. O. prolifica occurs commonly in the lower range of the Delorme Spirigerina Unit. Ogilviella rotunda, a very similar and closely related species, is described from beds of similar age at Royal Creek. Johnson (1975a) reports $O$. cf. $O$. rotunda from beds of late Lochkovian age in the Arctic Islands. The type of $O$. prolifica was described by Savage (1974) from the Mandagery Park Formation of New South Wales. Spirigerina supramarginalis is a geographically very widespread late Lochkovian species that occurs in central Nevada, Royal Creek, the Arctic Islands, the Delorme Formation, the Solovian Limestone of the Altai Mountains, and the Mandagery Park Formation of New South Wales. Savage (1974) reported the species from early Lochkovian beds of New South Wales; however, the shells in question appear to bear too numerous costae and are better assigned to the older $S$. marginaliformis. $S$. supramarginalis ranges throughout the Spirigerina Unit in the Delorme at section 1. Toquimaella kayi is distributed throughout the Delorme Spirigerina Unit. At Royal Creek it occurs most commonly in the upper part of the unit. In Nevada T. kayi is known from the Quadrithyris Zone.

\section{PRAGIAN BRACHIOPODS}

The top of the underlying Spirigerina Unit is marked by the disappearance of $S$. supramarginalis, Toquimaella kayi, Thliborhynchia pedderi, Cortezorthis cf. C. windmillensis, and Clorinda garretti sp. nov. The Pragian fauna of the Delorme Formation includes long-ranging genera such as Cortezorthis, Muriferella, Salopina, and Atrypina, which extend upwards from the late Lochkovian, as well as a host of new taxa, many of which have strong affinity with faunas of Bohemia and the northern Ural Mountains. Several of the commonly occurring shells from this unit are known from the Koněprusy Limestone, a unit correlated with the Pragian by Boucěk, Horný, and Chlupáč (1966). At Royal Creek, Pragian shelly faunas have been assigned to the Gypidula-Davidsoniatrypa Unit, a unit that includes the upper part of the Monograptus yukonensis Zone (Lenz, 1968).

Cortezorthis norfordi, a form transitional between the late Lochkovian $C$. cf. $C$. windmillensis and the Zlichovian $C$. maclareni, occurs in the lower beds of the Delorme Pragian. Shells very similar to the Royal Creek Gypidula boucoti are common in beds in the Delorme Pragian. The large, thick-shelled Aesopomum irregularis sp. nov., with undifferentiated socket plates and cardinal process, is common in the Pragian of both areas Megastrophia transitans occurs in the lowest beds of the Delorme Pragian, whereas in Nevada it ranges through the upper Spinoplasia through kobehana Zones, which are middle and upper Pragian. Delorme Pragian elements of Cymostrophia, Nymphorhynchia nympha, and Plicocyrtina sinuplicata are closely related to forms from the Upper Koněprusy Limestone of Bohemia. N. nympha is 


\begin{tabular}{|c|c|c|c|c|c|c|}
\hline Brachiopods & Ludlovian & Pridolian & $\begin{array}{c}\text { Lower } \\
\text { Lochkovian }\end{array}$ & $\begin{array}{c}\text { Upper } \\
\text { Lochkovian }\end{array}$ & Pragian & Zlichovian \\
\hline \\
\hline \multirow{2}{*}{\multicolumn{7}{|c|}{$\begin{array}{l}\text { "Dolerorthis" spp. } \\
\text { Cortezorthis maclareni } \\
\text { C. cf. C. windmillensis }\end{array}$}} \\
\hline & & & & & & \\
\hline \multirow{2}{*}{\multicolumn{7}{|c|}{$\begin{array}{l}\text { C. norfordi } \\
\text { Protocortezorthis natlensis }\end{array}$}} \\
\hline \multirow{2}{*}{\multicolumn{7}{|c|}{$P$. aff. $P$. fornicatimcurvata }} \\
\hline & & & & & & \\
\hline \\
\hline \multicolumn{7}{|l|}{ Didymoparcium costata } \\
\hline \multicolumn{7}{|l|}{$\begin{array}{l}\text { Schizophoria paraprima } \\
\text { S. cf. S. nevadaensis }\end{array}$} \\
\hline \multirow{2}{*}{\multicolumn{7}{|c|}{$\begin{array}{l}\text { Schizophoria spp. } \\
\text { Salopina submurifer }\end{array}$}} \\
\hline \multirow{2}{*}{\multicolumn{7}{|c|}{$\begin{array}{l}\text { Salopina submurifer } \\
\text { Muriferella masurskyi }\end{array}$}} \\
\hline & & & & & & \\
\hline \multicolumn{5}{|l|}{ Miniprokopia havliceki } & \\
\hline \multicolumn{7}{|l|}{$\begin{array}{l}\text { Mystrophora arctica } \\
\text { Kayserella cf. K. costatula }\end{array}$} \\
\hline \multicolumn{7}{|l|}{ Grayina magnifica arctica } \\
\hline \multirow{2}{*}{\multicolumn{7}{|c|}{$\begin{array}{l}\text { Conchidium sp. } 1 \\
\text { Gypidula pelagica lux }\end{array}$}} \\
\hline & & & & & & \\
\hline \multirow{2}{*}{\multicolumn{7}{|c|}{$\begin{array}{l}\text { Sieberella spp. } \\
\text { Carinagypa loweryi? }\end{array}$}} \\
\hline \multirow{2}{*}{\multicolumn{7}{|c|}{$\begin{array}{l}\text { Carinagypa loweryi? } \\
\text { C. praeloweryi } \\
\text { Clorinda garretti }\end{array}$}} \\
\hline & & & & & & \\
\hline \multirow{2}{*}{\multicolumn{7}{|c|}{$\begin{array}{l}\text { Clorinda garretti } \\
\text { Clorindina sp. } \\
\text { Leptaenisca } \mathrm{cf} \text { L. concava }\end{array}$}} \\
\hline \multirow{2}{*}{\multicolumn{7}{|c|}{$\begin{array}{l}\text { Leptaenisca cf. L. concava } \\
\text { Leptagonia spp. }\end{array}$}} \\
\hline & & & & & & \\
\hline \multicolumn{7}{|l|}{ Eoschuchertella spp. } \\
\hline \multirow{2}{*}{\multicolumn{7}{|c|}{$\begin{array}{l}\text { Aesopomum spp. } \\
\text { Strophonella sp. } 1\end{array}$}} \\
\hline & & & & & & \\
\hline Mesodouvillina spp. & & & & & & \\
\hline $\begin{array}{l}\text { M. delormei } \\
\text { Mclearnites cf. M. invasor }\end{array}$ & & & & & & \\
\hline Cymostrophia sp. & & & & & & \\
\hline Megastrophia iddingsi & & & & & & \\
\hline Strophodonta spp. & & & & & & \\
\hline Leptostrophia magna & & & & & & \\
\hline Phragmostrophia merriami & & & & & & \\
\hline P. mucronata & & & & & & \\
\hline $\begin{array}{l}\text { Parapholidostrophia prima } \\
\text { "Strophochonetes" filistriata }\end{array}$ & & & & & & \\
\hline Parachonetes macrostriatus & & & & & & \\
\hline Chattertonia mackenzia & & & & & & \\
\hline Stegerhynchus spp. & & & & & & \\
\hline Machaeraria paraformosa & & & & & & \\
\hline Thliborhynchia julli & & & & & & \\
\hline T. pedderi & & & & & & \\
\hline $\begin{array}{l}\text { T. kerri mackenziensis } \\
\text { Ancillotoechia sno. }\end{array}$ & & & & & & \\
\hline $\begin{array}{l}\text { Ancillotoechia spp. } \\
\text { A. cf. A. gutta }\end{array}$ & & & & & & \\
\hline Nymphorhynchia cf. N. nympha & & & & & & \\
\hline Trigonirhynchia cf. T. occidens & & & & & & \\
\hline Sphaerirhynchia sp. & & & & & & \\
\hline
\end{tabular}

Text-fig. 3 Composite range chart of the principal brachiopods of the Delorme Formation. 


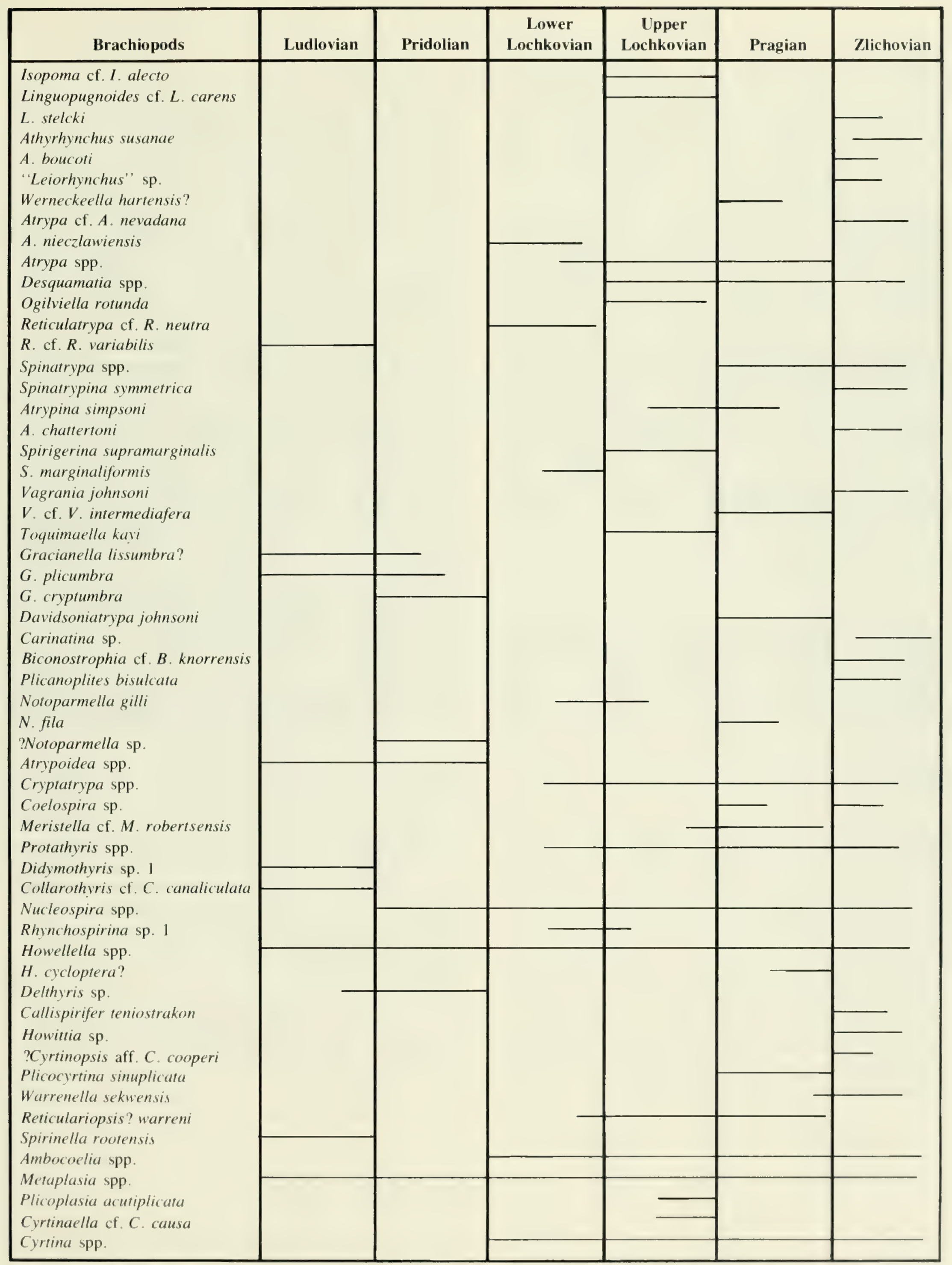


confined to the basal beds of the Delorme Pragian, whereas at Royal Creek it occurs in highest Lochkovian and lowest Pragian beds. Delorme shells of Thliborhynchia julli, Werneckeella hartensis, and Davidsoniatrypa johnsoni have previouly been recorded only from the Gypidula-Davidsoniatrypa Unit at Royal Creek and are endemic to northwestern Canada. Vagrania cf. $V$. intermediafera occurs commonly in the Royal Creek and Delorme Pragian. Very similar shells are reported from supposed Eifelian beds of the northern Urals (Khodalevich and Breivel, 1959; Alekseeva, 1962); however, the position of these beds relative to the North American succession is not certain. The presence of Howellella cycloptera? in the Delorme Pragian is regarded as important because the species occurs near the top of the Spinoplasia Zone in central Nevada (Johnson, 1970). Large Howellella of this type are thought by Johnson (1975a) to be ancestral to Acrospirifer, and in Europe the Howellella to Acrospirifer transition occurs close to the Gedinnian-Siegenian boundary of the Rhenish sequence; that is, approximately mid-Pragian.

\section{ZLICHOVIAN BRACHIOPODS}

Correlation of the Delorme brachiopod fauna to a position within the Zlichovian zonal scheme of Bohemia is uncertain because of the provincial nature of the brachiopod faunas.

The Zlichovian of Nevada has been divided into a lower Eurekaspirifer pinyonensis Zone and a more informal upper E. pinyonensis/Brachyspirifer Zone (Johnson, 1977).

Cortezorthis maclareni is abundant throughout the Delorme Zlichovian and is also known from beds of similar age in the Arctic Islands. Muriferella masurskyi occurs commonly in the Zlichovian of Nevada, Delorme, and Royal Creek, although it is known from older strata at the latter two localities. The small dicaelosiid Didymoparcium costata occurs in the higher Zlichovian beds in the Delorme Formation and at Royal Creek. Miniprokopia and Phragmophora are both recorded for the first time in North America in Zlichovian strata of the Delorme Formation. Mystrophora, which occurs in Zlichovian beds of the study area and of Royal Creek, was previously recorded only from middle Devonian strata.
Carinagypa loweryi and Carinagypa praeloweryi are represented by a few shells from Zlichovian beds of the Delorme. $C$. loweryi has previously been reported from Zlichovian beds of the Michelle Formation (Johnson and Ludvigsen, 1972) and the E. pinyonensis Zone of Nevada.

Phragmostrophia merriami occurs throughout the Zlichovian of the Delorme and has previously been reported from Zlichovian strata at Royal Creek and elsewhere in the northern Yukon, in the Arctic Islands, and in central Nevada. Megastrophia iddingsi occurs throughout the Delorme Zlichovian, in the higher Zlichovian beds at Royal Creek, and in the E. pinyonensis Zone of Nevada. Parapholidostrophia prima sp. nov. occurs in the Delorme Zlichovian and is the probable ancestor of $P$. harperi alluded to by Johnson (1971a) from Emsian (in part, Zlichovian) beds of the Arctic Islands. "Strophochonetes" filistriata occurs throughout the Delorme Zlichovian and in the $E$. pinyonensis Zone of Nevada. Parachonetes macrostriatus is found in the higher Zlichovian beds of the Delorme, Royal Creek, and Nevada. The genus is also known from probable late Emsian beds of New South Wales (Chatterton, 1973) and Emsian beds of the Urals and the Kuznetsk Basin (Rzhonsnitska1a, 1960). Chattertonia occurs infrequently throughout the Delorme and Royal Creek Zlichovian; the lowest occurrences probably represent the oldest known productids.

Athyrhynchus susanae occurs in the Delorme Zlichovian and has previously been reported from strata dated as "late Emsian" from the Arctic Islands and the Nevada $E$. pinyonensis Zone (Johnson, 1973b).

Warrenella sekwensis is recognized throughout the Delorme Zlichovian and in slightly older strata. It is also known from a collection sent by J. G. Johnson from beds of "late Emsian" age on Young Island in arctic Canada. $W$. sekwensis was regarded as the oldest known representative of the Warrenella lineage by Ludvigsen and Perry (1975). Biconostrophia occurs in high Zlichovian beds at section 3; this is the first reported occurrence of the genus from outside Bohemia, where it occurs commonly in the Zlichov Limestone.

Delorme brachiopods from the highest part of the sequences include representatives of Coelospira, Carinatina, coarsely ribbed Spinatrypa, Athyrhynchus susanae, Kayserella cf. K. costatula, and Carinagypa loweryi. 


\section{Materials and Methods}

The Delorme Formation was measured and sampled by the writer at 12 localities across the central Mackenzie Mountains (Text-figs. 1, 3) during the summers from 1969 to 1972 . Five other sections and samples were obtained from the work of other individuals. Sections were measured by means of a $1.5 \mathrm{~m}$ "Jacob's staff". Macrofossil collections were made where fossils were readily visible. The amount of material collected from any one section was dependent upon the mode of preservation, the abundance of the fossils, and the time available in the field. Sections 1 to 3 were extensively sampled and measured in greater detail than the other sections because they contain abundant, diverse silicified faunas. Approximately $2750 \mathrm{~kg}$ of rock were collected from them. In other sections silicified beds, though rarely encountered, were sampled whenever they were present. In the predominantly dolostone facies of the Delorme Formation of the central part of the study area, fossils were few and poorly preserved and so yielded only small collections. The Delorme Formation was sampled systematically for macrofossils near its upper and lower contacts; in addition, samples of approximately $2 \mathrm{~kg}$ each for conodonts were derived from the matrix of the macrofossil collections.

Transportation to and from the sections was provided by helicopter from base camps at Macmillan Pass (YukonNorthwest Territories border), and the villages of Tungsten, Wrigley, and Fort Norman in the Northwest
Territories. Helicopter support was essential because there were few lakes suitable for fixed-wing aircraft, no roads, and local relief of up to $1350 \mathrm{~m}$.

At many places in the northwestern part of the study area the calcareous skeletal materials of the invertebrate fauna are replaced by silica and can be readily etched out by the use of diluted hydrochloric acid and/or acetic acid. Acid residues with diameters greater than $1.00 \mathrm{~mm}$ were examined for macrofossils. Some 40000 identifiable brachiopods and a few hundred trilobites were recovered from the residue of approximately $3200 \mathrm{~kg}$ of rock.

Calcareous brachiopods and trilobites were split out of limestone blocks, and where they were well enough preserved, the brachiopods were serially sectioned.

Microfossil samples were dissolved in diluted acetic acid to isolate siliceous and phosphatic elements. Some 265 samples from the Delorme Formation, weighing approximately $350 \mathrm{~kg}$ in total, were dissolved to isolate conodonts. Residues with diameters greater than $0.063 \mathrm{~mm}$ were retained. Heavy mineral separates contained approximately 9000 identifiable conodont elements of which 65 per cent were from sections 1, 2, and 3 (Sekwi Anticline).

The brachiopods and trilobites were painted matt black and dusted with ammonium chloride before being photographed. All photographs were taken by the author using a Rolleiflex SL-66 camera and an extension bellows system. 


\section{Systematic Palaeontology}

Species already formally described from western or arctic North America are not redescribed unless new or conflicting morphologic data are available from the Delorme Formation collections. New taxa known only from a few shells are illustrated and described but are not formally named. Taxa known only from fragmentary materials are illustrated and briefly discussed.

All illustrated specimens are assigned Royal Ontario Museum numbers (ROM) and are housed at the Royal Ontario Museum in Toronto, Ontario. Auxiliary collections are also housed at the same institution.

References to fossil collections consist of a section number (for example, S-1) followed by a sample number (for example, A100.0 m) indicating the stratigraphic position relative to a particular datum. Basic geographic coordinates and stratigraphic data for brachiopod-bearing sections are listed in the Appendix, with detailed section descriptions for S-1 to S-3.
Fossil material from the Geological Survey of Canada collections are referred to by the GSC locality numbers. All references to OLDA collections are to fossil collections made from S-1 in August 1969, when very heavy snow cover obscured 80 per cent of the strata. This section was remeasured in 1970 and the old collections (OLDA) were assigned new stratigraphic measurements to correspond as closely as possible to the 1970 measurements. OLDA stratigraphic measurements should therefore be regarded as approximate. Any fossil collection with the letter $\mathrm{T}$ following the stratigraphic horizon represents a collection from talus believed to be derived from that level (for example, S-1, A100T m).

In discussing the preservation and the amount of material available for study of individual species a listing is often given in the form 33A, 27B, and 46P (33 articulated shells, 27 brachial valves, and 46 pedicle valves).

\section{Phylum Brachiopoda Duméril Class Inarticulata Huxley Order Lingulida Waagen \\ Superfamily Lingulacea Menke Family Craniopsidae Williams, 1963}

\section{Genus Craniops Hall, 1859}

TYPE SPECIES

Orbicula? squamiformis Hall, 1843:108.

Craniops sp. 1

Pl. 1, figs. 6-14

\section{REFERRED SPECIMENS}

Craniops sp. 1 occurs in strata of Zlichovian age in S-3, at $466.3 \mathrm{~m}$ below the top of the Delorme Formation. It is represented by $1 \mathrm{~A}, 3 \mathrm{~B}$, and $3 \mathrm{P}$ coarsely recrystallized silicified shells. Material illustrated includes ROM 33104-33108 from S-3, sample S4-466.3 m.

\section{EXTERIOR}

The small calcareous (now silicified) shells are longitudinally suboval in outline and are gently ventribiconvex in lateral profile. The shells are less than $4.5 \mathrm{~mm}$ in maximum dimension. The apices are situated slightly posterior to the centre of the shell, and the growth form is holoperipheral. Attachment scars are present on both valves, although the pedicle attachment scar is much more prominent. No trace of a foramen is preserved. The ornament consists of fine concentric growth lamellae. No trace of radial ornament is preserved.

\section{PEDICLE VALVE INTERIOR}

A weakly raised lip marks the margin of the pedicle valve. An indistinct median platform is present in the pedicle valve. The pedicle anterior adductor muscles are represented by a V-shaped muscle scar which points anteriorly, whereas the pedicle posterior adductors are represented by a crescentic muscle scar which caps, but is distinct from, the V-shaped scar. The shell substance is thick in relation to the small size of the shells.

\section{BRACHIAL VALVE INTERIOR}

A weakly raised lip marks the margin of the brachial valve. Muscle scars are not discernible in the brachial valve because of coarse recrystallization of the shells.

\section{DISCUSSION}

The outline of the shell and the shape of the muscle field are quite similar to that of the Emsian $C$. australis Chatterton. The presence on both valves of apparent attachment scars (areas of suppressed and flattened concentric ornament) was also noted by Chatterton (1973), who suggested that the ventral scar was more likely the real attachment scar because of its closeness to the shell posterior. In the Delorme material the attachment scar on the pedicle valve is much more prominent. The usefulness of Craniops sp. 1 or $C$. australis biostratigraphically can 
be better evaluated when more is known about these calcareous inarticulates.

C. patina (Hall and Clarke), a species whose morphology is close to that of $C$. australis, occurs in the
"Corniferous" Limestone at DeCewville, Ontario (Hall and Clarke, 1892), in beds now assigned to the Bois Blanc Formation, which are dated as late Emsian by Boucot and Johnson (1968).

\section{Order Acrotretida Kuhn \\ Superfamily Discinacea Gray \\ Family Discinidae Gray, 1840 \\ Subfamily Orbiculoideinae Schuchert and LeVene, 1929}

\section{Genus Orbiculoidea d'Orbigny, 1847}

\section{TYPE SPECIES}

Orbicula forbesi Davidson, 1848:334.

\section{Orbiculoidea sp. 1}

Pl. 1, figs. 15-20

\section{REFERRED SPECIMENS}

Orbiculoidea sp. 1 occurs in strata of early and mid-Lochkovian age in the Delorme Formation, in S-1, at $548.6 \mathrm{~m}$, and in $\mathrm{S}-2$, at $248.4-336.8 \mathrm{~m}$, respectively, below the top of the formation. Material illustrated includes ROM 33109, 33110 from S-2, sample B248.4$265.2 \mathrm{~m}$; and ROM 33111 from S-1, sample A548.6T m. Orbiculoidea sp. 1 is very abundant in strata of S-2 bearing ostracoderms (Pionaspis) and conularids, where it is represented by several dozen fragmentary, phosphatic dorsal and ventral valves.

\section{EXTERIOR}

The shells are large, circular in outline, and commonly up to $30 \mathrm{~mm}$ in diameter. The lateral profile is strongly dorsibiconvex to convexiplane. The broadly conical brachial valve is up to $10 \mathrm{~mm}$ deep and is often asymmetric with the beak closer to the posterior margin. The thin, phosphatic shell displays holoperipheral growth. The concentric ornament comprises numerous closely spaced growth lamellae. Radial ornament is lacking.

\section{PEDICLE VALVE INTERIOR}

The pedicle valve is covered internally by the impress of the growth lamellae. The muscle scars are not impressed in the pedicle valve. The interior of the pedicle valve bears a posteriorly directed, inflated, keyhole-shaped protuberance, which has a low, centrally divided ridge extending posteriorly from it. An oval opening near the base of the "keyhole" protuberance probably represents an obliquely directed pedicle opening, although no openings have been observed on the fragmentary external surfaces available for study.

\section{BRACHIAL VALVE INTERIOR}

Growth lamellae are clearly impressed internally on the brachial valve. A low ridge extends anteriorly from the apex of the brachial valve. No muscle impressions were recognized.

\section{DISCUSSION}

The shells in question clearly belong to Orbiculoidea; however, comparison with other species is not possible because of the fragmentary nature of the shells combined with the fact that no Devonian representatives have been described from western or arctic North America. The thin shells disintegrate upon etching in acetic acid and exfoliate when undergoing preparation with a vibratool or bevelled needle. A feature similar to the pedicle protuberance of Orbiculoidea sp. 1 is illustrated by Hall and Clarke (1892, pl. IV).

Orbiculoidea sp. 1 is confined to a lithotope represented by finely laminated, very argillaceous limestones and limy shales. Brachial valves are convex upwards and are commonly exposed on bedding planes. The flat pedicle valves are rarely exposed. The associated fauna on the same bedding planes includes conularids and ostracoderm plates. A few thin ( $15 \mathrm{~mm}$ ) bioclastic lenses of bryozoans, brachiopods, and gastropods occur occasionally as interbeds. The fragile nature of the inarticulate brachiopods and the conularids suggests that they were deposited in a quiet-water environment and were quickly buried before scavengers such as the turriculate gastropods of the bioclastic lenses discovered them. The associated lingulid brachiopods are found parallel to bedding surfaces, not in their normal vertical growth position. Other poorly preserved specimens of Orbiculoidea have been recovered from beds of late Lochkovian and Pragian age of the Delorme Formation at S-1.

\section{Genus Schizotreta Kutorga, 1848}

TYPE SPECIES

Orbicula elliptica Kutorga, 1846:123, in Moore, 1965:285. 
Schizotreta sp. 1

Pl. 1, figs. 21-23; Pl. 2, figs. 1, 2

\section{REFERRED SPECIMENS}

Schizotreta sp. 1 occurs in strata of early Pragian age in $\mathrm{S}-2$, at $105.2-140.2 \mathrm{~m}$ below the top of the Delorme Formation. It is represented by four brachial valves. Material illustrated includes ROM 33112 from S-2, sample B $105.2 \mathrm{~m}$; and ROM 33113 from S-2, sample B128.6 m.

\section{EXTERIOR}

The subcircular shells are less than $8 \mathrm{~mm}$ in diameter. The dorsal valve is flat to very slightly convex in lateral profile. The dorsal beak is slightly closer to the posterior margin than to the anterior margin. The ornament consists of well-developed concentric fila, which are subdued near the beak and become more prominent marginally. The fila are of variable height along their circumference. The thick, phosphatic shell displays holoperipheral growth.

\section{PEDICLE VALVE INTERIOR}

No pedicle valves were recovered.

\section{BRACHIAL VALVE INTERIOR}

The two prominent adductor muscle impressions form a segmented muscle field that converges anteriorly but whose lobes do not touch. The lobes of the muscle field become narrower anteriorly. The cavity that results from the dorsal beak protuberance is situated medially between and slightly posterior to the muscle scar lobes. The interior of the shell is smooth, except near the margins where it is crenulated by the impress of the concentric fila.

\section{DISCUSSION}

The coarsely developed concentric fila, the very gently convex dorsal valve, and the slope of the diductor muscle scar are characteristic of the genus. Hall and Clarke (1892, pl. IV, fig. 6) illustrate $S$. conica Dwight from the Trenton (Ordovician) of New York State, which has an identical adductor muscle field, although the concentric fila are not as pronounced. Schizotreta occurrences are reported from the Middle Ordovician and Silurian in the brachiopod treatise (Moore, 1965). The younger occurrence here is not unexpected considering the meagre data available on the distribution of many inarticulate brachiopods. No representatives of the genus have previously been recorded from Lower Devonian strata of western or arctic North America .

Other poorly preserved, possible conspecific representatives of the genus have been recovered from beds of early Lochkovian age at S-1.

\section{Suborder Craniidina Waagen \\ Family Craniidae Menke, 1828}

\section{Genus Philhedra Koken, 1889}

\section{TYPE SPECIES}

Philhedra baltica Koken, 1889:465.

\section{Philhedra sp. 1}

Pl. 2, figs. 3-8

\section{REFERRED SPECIMENS}

Philhedra sp. 1 occurs in strata of Zlichovian age in S-1, at 62.5-68.6 $\mathrm{m}$ below the top of the Delorme Formation. It is represented by four finely silicified dorsal valves. Material illustrated includes ROM 33114-33116 from S-1, sample A62.5-68.6 m.

\section{EXTERIOR}

The small, subcircular brachial valves are less than $9 \mathrm{~mm}$ in diameter. The thick shell substance was calcareous (now silicified). The brachial valves are convex and broadly subconical in profile. The apex of the valve is eccentric and is the focal point of high, thin, radiating costae separated by deep interspaces. The costae increase by implantation. A few subparallel crenulations near the shell periphery are the only suggestion of concentric ornament. The apex of the valve either is free of costae or has highly suppressed costae. The shape of the shell is controlled by the shape of the surface to which it was attached.

\section{PEDICLE VALVE INTERIOR}

No pedicle valve was recovered. The pedicle valve of the genus is assumed to have been noncalcareous, as suggested by other workers.

\section{BRACHIAL VALVE INTERIOR}

Two pairs of slightly raised, circular adductor muscle scars are present. One pair is located near the posterior(?) margin, the other pair near midlength of the shell. The pair near midlength is larger and is situated on a low platform. The position of the muscle scars in relation to the beak is variable because of the eccentricity of the beak. This may result in confusion of the posterior with the anterior, unless it is accepted that the muscle scars nearest the shell margin are the posterior pair. The entire interior of the shell, including the muscle scars, is covered with extremely fine pits. 


\section{DISCUSSION}

No pedicle valve was found. It is commonly accepted that the pedicle valves of most members of this family were composed of organic matter and served as a base for cementation to the substrata. The external radial costae distinguish Philhedra from the closely related genus Acanthocrania, which has somewhat similar internal musculature. Rodriguez and Gutschick (1967) applied the name Crania rowleyi Gurley to a Mississippian taxon of very similar morphology to Philhedra $\mathrm{sp}$. 1. The genus Crania is known only from Cretaceous to Recent strata and has much more subdued radial ornament than Philhedra. C. rowleyi should be assigned to Philhedra. Kozlowski (1929) illustrated the external morphology of a Philhedra from the Lower Devonian of Podolia; however, no internal views are illustrated.

\section{Genus Acanthocrania Williams, 1943}

\section{TYPE SPECIES}

Crania spiculata Rowley, 1908:74

\section{Acanthocrania sp. 1}

Pl. 2, figs. 9, 10

\section{REFERRED SPECIMEN}

Acanthocrania sp. 1 is represented by one fragmentary silicified dorsal valve (ROM 33117) from beds of Zlichovian age in S-1, at 62.5-68.6 $\mathrm{m}$ below the top of the Delorme Formation (sample A62.5-68.6 m).

\section{EXTERIOR}

The brachial valve has an irregular, subcircular outline and is moderately convex in lateral profile. The calcareous (now silicified) shell is approximately $7 \mathrm{~mm}$ in diameter. The umbo is situated near the posterior margin. Ornamentation consists of irregular, faint concentric growth lines; irregularly distributed, coarse, hollow spines; and a micro-ornament of very fine papillae.

\section{PEDICLE VALVE INTERIOR}

The pedicle valve of the genus is unknown and is assumed to be thin or uncalcified.

\section{BRACHIAL VALVE INTERIOR}

Two pairs of very lightly impressed, subcircular adductor muscle scars are discernible. The posterior adductor pair is adjacent to the valve margin, whereas the anterior pair is more widely separated and situated near midlength of the shell, slightly anterior to the umbo. The interior of the valve is covered with very fine pits; larger pits mark the position of the exterior hollow spines. One major growth line is impressed internally.

\section{DISCUSSION}

Acanthocrania has previously been described from strata of Ordovician through Carboniferous age. The external ornament of $A$. papillifera (Roemer) as illustrated by Wright (1972), and of $A$. spinosa Rodriguez and Gutschick (1967) is very similar to that of the Delorme specimen. Wright (1972) suggested that this craniacean lacked a calcified pedicle valve. The genus has not previously been recorded from the Lower Devonian of western or arctic North America.

\section{Class Articulata Huxley \\ Order Orthida Schuchert and Cooper \\ Suborder Orthoidea Schuchert and Cooper \\ Superfamily Orthacea Woodward \\ Family Hesperorthidae Schuchert and Cooper, 1931}

\section{New genus hesperorthid sp. 1}

Pl. 2, figs. 11-19

\section{REFERRED SPECIMENS}

New genus hesperorthid sp. 1 occurs in strata of late Lochkovian to early Pragian age in S-1, at OLDA336.8$481.6 \mathrm{~m}$ below the top of the Delorme Formation. Material illustrated includes ROM 33118,33119 from S-1, sample OLDA336.8 m; and ROM 33120 from S-1, sample OLDA481.6T m. These coarsely silicified shells are the only representatives of the taxon available.

\section{EXTERIOR}

The ventral valve is subpentagonal, and the dorsal valve is transversely subrectangular in outline. The lateral profile is markedly ventribiconvex. A prominent, broadly $\mathrm{V}$-shaped sulcus is present in the dorsal valve; opposite the sulcus is a slight carination in the ventral valve. The ventral interarea is high, flat, and apsacline. The hinge line is approximately two-thirds of the maximum shell width. The delthyrium is open and encompasses an angle of approximately $35^{\circ}$. The dorsal interarea is low, anacline, and narrow. The costae are coarse, angular, and steep-sided; they bifurcate on the pedicle valve and trifurcate on the brachial valve near the anterior margins. 


\section{PEDICLE VALVE INTERIOR}

The hinge teeth are triangular, stubby projections of the interarea; they are inclined anteriorly and directed laterally. The dental plates are very short and are confined to the umbonal region. A faint, anteriorly arcuate ridge joins the base of the dental plates and encloses the muscle field. The costae are strongly impressed over the anterior two-thirds of the shell.

\section{BRACHIAL VALVE INTERIOR}

The deep, anterolaterally directed dental sockets are bounded posteriorly by the interarea and anteromedially by the bladelike brachiophores. The ventral edges of the brachiophores extend parallel to the margin of the notothyrium; the brachiophore bases join the shell wall and extend a shorter distance anteriorly than the ventral edge. The long shaft of the subrectangular cardinal process divides the notothyrial cavity. The impress of the dorsal sulcus is visible from the base of the cardinal process to the anterior margin. Low ridges extend from the brachiophores to the impressed sulcus and define an oval muscle field. The impressions of the lateral costae extend from the edge of the muscle field to the anterolateral margins. The trifurcations of the costae are impressed only along the margins of the shell.

\section{DISCUSSION}

At a glance the specimens in question appear similar to the more coarsely costate representatives of "Dolerorthis" borealis Lenz; however, the costae on the specimens in question are much more angular and show dorsal trifurcation, and their dorsal cardinalia are distinct. The trifurcation of the costae and the absence of prominent growth lamellae distinguish the species from representatives of Ptychopleurella.

\section{Subfamily Dolerorthinae Öpik, 1934}

\section{Genus Dolerorthis Schuchert and Cooper, 1931}

TYPE SPECIES

Orthis interplicata Foerste, 1909:76, pl. 3, fig. 44.

\section{"Dolerorthis"' sp. 1}

Pl. 2, figs. 20-22

?"Dolerorthis"' sp. Johnson, Boucot, and Murphy, 1973:13, pl. 1, figs. 10-13

\section{REFERRED SPECIMEN}

"Dolerorthis" sp. 1 is represented by only one silicified dorsal valve (ROM 33121) from beds of probable Pridolian age of the transitional facies of Gabrielse, Blusson, and Roddick (1973) in S-11, at 186.0-193.5 m above the top of the Whittaker Formation.

\section{DISCUSSION}

"Dolerorthis" sp. 1 is probably conspecific with specimens of "Dolerorthis" sp. illustrated by Johnson, Boucot, and Murphy (1973) from strata of Pridolian age in the Roberts Mountains Formation of central Nevada. The Pridolian "Dolerorthis" sp. 2 of Lenz (1977a) lacks a dorsal sulcus and has a more equant outline than "Dolerorthis" sp. 1. "Dolerorthis" borealis Lenz has fewer and coarser costae, and "Dolerorthis" smithi sp. nov. has a much less pronounced dorsal sulcus and a thicker shell substance. Characteristic morphologic features of "Dolerorthis" sp. 1 are the suboval, transverse outline, the prominent dorsal sulcus, and costae that increase by both bifurcation and intercalation.

\section{"Dolerorthis" smithi sp. nov.}

Pl. 2, figs. 27-43

\footnotetext{
"Dolerorthis" sp. 1 Lenz, 1977a:53, pl. 1, figs. 1, 2.

"Dolerorthis", sp. 1 Jackson, Lenz, and Pedder, 1978, pl. 11 , figs. 1,2 .
}

\section{DIAGNOSIS}

A "Dolerorthis" of moderate convexity with numerous fine costellae and finely dendritic pallial markings in mature shells

\section{ETYMOLOGY}

The species is named after R. E. Smith, a palaeontologist involved in the study of Lochkovian brachiopods of the Arctic.

\section{REFERRED SPECIMENS}

"Dolerorthis" smithi sp. nov. occurs in beds of late Lochkovian age in S-1, at 470.9-493.8 $\mathrm{m}$ below the top of the Delorme Formation. It is not an abundant taxon and is represented by only $15 \mathrm{~B}$ and $10 \mathrm{P}$ silicified shells. Material illustrated includes holotype ROM 33123 from S-1, sample A493.8 m; paratype ROM 33124 from S-1, sample A484.6 m; and paratypes ROM 33125-33129 from S-1, sample A470.9 m.

\section{EXTERIOR}

The brachial valves are subquadrate in outline, whereas the pedicle valves tend to be subpentagonal. The lateral profile is biconvex and the pedicle valve becomes more convex posteriorly. The prominent pedicle umbo is 
situated posterior to the hinge line. The hinge line is straight and wide but slightly less than the maximum shell width, which is attained anterior to midlength. In mature shells, the cardinal angles are obtuse and rounded. In immature shells the anterior commissure is slightly deflected by a weak dorsal sulcus. The ventral interarea is high, flat, triangular, and slightly apsacline. It is cleft medially by an open, subparallel-sided delthyrium with a rounded apex. The dorsal interarea is wide, low, triangular, and orthocline to slightly anacline. The large, triangular notothyrium encompasses an angle of $65^{\circ}-70^{\circ}$. The dorsal beak is slightly incurved. Radial ornament consists of numerous ( 20 to 25 at $5 \mathrm{~mm}$ anterior to the beak), moderate-sized, subangular to rounded costellae that increase by both bifurcation and implantation. Costellae are costellate to multicostellate, increase in breadth anteriorly, and tend to form bundles around the primary costae. Small specimens have fewer and much coarser costae relative to large shells. Concentric ornament consists of fine, slightly lamellose growth lines, which are only clearly discernible along the anterior margins (four to five per millimetre).

\section{PEDICLE VALVE INTERIOR}

The platelike, laterally directed hinge teeth are extensions of the delthyrial margin of the interarea and have a slight anterior curvature. The hinge teeth are supported laterally by dental lamellae which reach the muscle-bounding ridges on the valve floor. The anterior bounding ridges of the adjustor muscle field project anteromedially from the base of the dental lamellae and die out before reaching the diductor muscle platform. The centrally located adductor muscle platform is narrow, elongate, rectangular, and separated from the flanking diductor scars by weakly developed ridges. The diductor scars are very narrow, elongate, and slightly widened anteriorly. The adjustor scars are flat-bottomed, anteriorly widening, and inclined at $40^{\circ}$ to the shell iloor. The muscle field on the whole is smooth apically and becomes slightly faceted on the elevated anterior margin, which is located slightly anterior to the hinge line. The valve periphery is strongly crenulated by the impress of costellae. No vascular markings are preserved in the ventral valves available for study.

\section{BRACHIAL VALVE INTERIOR}

The small brachiophores are rectangular in cross section and are directed anteroventrally, parallel to the margins of the notothyrium. The small, anterolaterally directed sockets are bounded medially by the edges of the brachiophores and basally by recurved fulcral plates, which extend from the ventral edge of the brachiophores and curve dorsally to join the margin of the interarea. The notothyrial cavity is partially filled with callus, which is continuous anteriorly with a wide, low, gently rounded myophragm that extends to the anterior margin in small shells and fades out posterior to the margin of large shells. The high, elongate, bladelike cardinal process narrows posteriorly and extends along the length of the notothyrial cavity. The posterior adductor muscle field is clearly impressed on mature shells. A prominent pair of anterolaterally directed ridges mark the anterior edge of the posterior adductor field. A complex system of dendritic pallial markings is developed in mature shells. The interior of the shell is crenulated by the impress of costellae.

\section{DISCUSSION}

"Dolerorthis" smithi sp. nov. is readily distinguished from "Dolerorthis" sp. 1 from strata of Pridolian age by its greater dorsal convexity and its much more equant outline. " $D$." borealis Lenz of late Lochkovian and early Pragian age has fewer and coarser costae and a prominent dorsal myophragm. The development of prominent, finely dendritic pallial markings is characteristic of mature shells. Juvenile shells of the taxon have fewer and stronger costae and cannot readily be distinguished from small shells of " $D$." borealis

\section{"Dolerorthis" borealis Lenz, 1977a}

Pl. 2, figs. 44-58

?"Dolerorthis"' sp. Johnson, 1970:69, pl. 1, figs. 1-11.

"Dolerorthis" borealis Lenz, 1977a:52, pl. 1, figs. 5-26.

"Dolerorthis" sp. 2 Jackson, Lenz, and Pedder, 1978, pl. 11, figs. 3-9.

\section{REFERRED SPECIMENS}

"D." borealis occurs in the Delorme Formation in upper Lochkovian and lowest Pragian strata at S-2 and upper Lochkovian beds at S-1. It is not an abundant taxon and is represented by only 7B and 4P silicified shells. Material illustrated includes ROM 33130-33133 from S-2, sample B166.1-182.5 m; and ROM 33135 from S-2, sample B181.4-182.9 m.

\section{DISCUSSION}

This species shows considerable variation in the strength and number of costae. Generally it bears fewer and coarser costae than "D." smithi sp. nov. "D." borealis does not bear the coarse, angular costae of the new genus of hesperorthid, its dorsal interarea is lower, and its brachiophores are free of the valve floor distally. $D$. packhami Savage (1971) is a slightly smaller species of late Lochkovian age from the Mandagery Park Formation of New South Wales. Savage noted the variable development of the cardinal process, a feature observed in the 
collections from both Royal Creek and the Sekwi Mountain map-area. The probable representatives of "D." borealis from central Nevada (Johnson, 1970) are from upper Lochkovian beds of the Quadrithyris Zone. The species ranges through the late Lochkovian and
Pragian at Royal Creek and appears to extend only into the earliest Pragian in the Delorme Formation.

A specimen assigned to "Dolerorthis" borealis Lenz? (ROM 33122, P1. 2, figs. 23-26) was recovered from S-1, sample OLDA493.8T m.

\section{Subfamily Glyptorthinae Schuchert and Cooper, 1931}

\section{Genus Ptychopleurella Schuchert and Cooper, 1931}

TYPE SPECIES

Orthis bouchardi Davidson, 1847:64.

\section{Ptychopleurella sp. 1}

Pl. 2, figs. 59-62

\section{REFERRED SPECIMEN}

Ptychopleurella sp. 1 is represented by a single silicified ventral valve (ROM 33136) from beds of Ludlovian age in
$\mathrm{S}-9$, at $161.2 \mathrm{~m}$ below the top of the Delorme Formation (sample L161.2 m).

\section{DISCUSSION}

The small size, greater ventral-valve depth, open, subparallel-sided delthyrium, and lamellose concentric ornament distinguish the taxon from "Dolerorthis". Lenz (1977a) recorded the genus from Pridolian strata of the Royal Creek area in the Yukon. The genus is known from beds of Wenlockian through early Lochkovian age in central Nevada (Johnson, Boucot, and Murphy, 1973, 1976).

\section{Family Skenidiidae Kozlowski, 1929}

\section{Genus Skenidioides Schuchert and Cooper, 1931}

\section{TYPE SPECIES}

S. billingsi Schuchert and Cooper, 1931, 1932:72, pl. 10, figs. $6,8,10-14$.

\section{DISCUSSION}

The genus Skenidioides has a long stratigraphic range (mid-Caradocian to Zlichovian) in northwestern Canada. This longevity of stratigraphic range is probably related to the fact that the genus is most abundant in offshore Benthic Assemblage position 4 to 5 (sensu Boucot, 1975), which probably had more uniform environmental conditions through time than shallower, nearer-shore biotopes. The only obvious morphologic trend in the Delorme Formation representatives is a general increase in the size of shells from younger beds. Despite the wealth of intricate internal structures in Skenidioides, the taxa involved are difficult to use biostratigraphically because of the high degree of variation in specimens within single collections. Lenz (1977a) named a Lochkovian taxon, S. variabilis, because of the variability in rib numbers. Skenidioides and its convergent homoeomorph, the dalmanellacean Mystrophora, of Zlichovian to Givetian age, both became extinct near the end of the Givetian. Both are found in the same biotopes of the Delorme Formation, although Mystrophora never attained the widespread development or geographic distribution of Skenidioides.

Skenidioides shells from more argillaceous strata commonly develop extended hinge lines and ventral interareas that extend beyond the actual shell cavity. These features suggest that the shell was anchored with the ventral interarea facing downwards onto a soft substrate. Caradocian species from the Northwest Territories occur in argillaceous, probable deeper-water shelf limestones, whereas species of similar age in southern Ontario occur in shallower-water shelf mudstones with abundant Lingula preserved in growth position. A Skenidioides species from the Wenlock of the basal Road River Formation near Grizzly Bear Lake in the District of Mackenzie occurs with a very diverse brachiopod fauna of small shells, phosphatized graptolite internal moulds, and phosphatized moulds of trilobites, which suggest a deeper-water, open, marine environment. In the Delorme Formation, poorly preserved Ludlovian and Pridolian Skenidioides occur in argillaceous limestones containing abundant ostracoderm faunas. The Lochkovian to Zlichovian Skenidioides occur throughout the Delorme section and must have been well adapted to a shallow-water habitat, to judge from the abundant epifauna of encrusting tabulate corals on many of the larger brachiopod shells. From the faunal lists of Johnson (1970) it appears that Skenidioides is absent from the Quadrithyris through Eurekaspirifer pinyonensis Zones in central Nevada. Recently, Johnson, Penrose, and Wise (1978) reported Skenidioides from probable deeper water bank-edge beds of the Quadrithyris Zone in central Nevada. The preceding distributions in central Nevada suggest that the Nevada faunas of late Lochkovian through 
Zlichovian age are of shallower-water, nearer-shore communities compared to their counterparts in northwestern Canada (Boucot, 1975; Savage, Perry, and Boucot, 1979).

\section{Skenidioides variabilis Lenz, 1977a \\ Pl. 3, figs. 1-53}

Skenidioides variabilis Lenz, 1977a:54, pl. 1, figs. 27-48.

\section{REFERRED SPECIMENS}

S. variabilis occurs in abundance in beds of Lochkovian to early Pragian age in the Delorme Formation and in a single collection of early Zlichovian age. Other younger Zlichovian collections contain Skenidioides blussoni sp. nov. $S$. variabilis is represented by $4 \mathrm{~A}, 132 \mathrm{~B}$, and $122 \mathrm{P}$ well-preserved silicified shells from the Delorme Formation-in S-1, at A62.5-536.4 $\mathrm{m}$ and OLDA $327.7-527.3 \mathrm{~m}$, in S-2, at 32.0-246.9 m, and in S-3, at $624-685.8 \mathrm{~m}$, respectively, below the top of the formation-and from S-4, at $22.9 \mathrm{~m}$ below the top of the Road River Formation in the transitional facies (Gabrielse, Blusson, and Roddick, 1973). Material illustrated includes ROM 33137-33143 from S-1, sample A62.5-68.6 m; ROM 33144 , 33145 from S-1, sample A410.0 m; ROM 33146, 33147 from S-1, sample OLDA384.0 m; ROM 3314833150 from S-1, sample OLDA388.6 m; ROM 33151, 33152 from S-2, sample B105.2 m; ROM 33153-33155 from S-2, sample B128.6 m; ROM 33156, 33157 from S-2, sample B225.6 m; and ROM 33158 from S-3, sample $\mathrm{S} 4-624.8 \mathrm{~m}$.

\section{DISCUSSION}

Lenz (1977a) recorded $S$. variabilis from Pridolian through Zlichovian strata at Royal Creek in the Yukon. The species is distinguished by its highly mucronate outline and the irregular and variable number of its costae when compared to well-known Devonian species such as S. billingsi (Schuchert and Cooper), S. lewisi (Davidson) (see Kozlowski, 1929), and S. robertsensis Johnson, Boucot, and Murphy. The fragmentary Skenidioides shells available from strata of Ludlovian and Pridolian age of the Delorme Formation are much smaller and are less transverse in outline than $S$. variabilis; that is, their outline is closer to that of $S$. robertsensis. The Ludlovian species S. henryhousensis Amsden (1958), is a much less transverse shell and has a clearly apsacline ventral interarea. Compared to $S$. blussoni sp. nov. from strata of younger Zlichovian age of the Delorme Formation, $S$. variabilis has a wider hinge line, coarser ornament, a more catacline to protocline ventral interarea, and anteriorly inclined brachiophores.
A few additional details of the morphology of $S$. variabilis are added to supplement the description of Lenz (1977a). The ventral interarea is commonly catacline or procline and is more rarely of apsacline orientation. The ventral costae most commonly increase by bifurcation, and the dorsal costae by intercalation. The dorsal valve commonly has three or four fewer costae than the ventral valve. The dorsal septum rarely extends to the anterior margin and commonly terminates at about three-quarters of the shell length.

The occurrence of $S$. variabilis in S-1, sample A62.5-68.6 m, is of interest: its stratigraphic separation is $251.5 \mathrm{~m}$ from the nearest sample bearing the taxon lower in the section. The intervening beds are interpreted to be of shallower-water origin, in consideration of their lithology, the diversity of the fauna, and the sedimentary structures. Lenz (1977a) suggested that the rather systematic variation in the number of costae through the stratigraphic section at Royal Creek was related to bathymetric changes (that is, fewer costae in shallower water). This same relationship appears to hold in the Delorme Formation. Recent brachiopods show variable number of costae in response to differences in energy and turbidity conditions. For this reason the number of costae was not used as a criterion for speciation.

\section{Skenidioides blussoni sp. nov. Pl. 3, figs. 54-96}

\section{DIAGNOSIS}

A moderately transverse Skenidioides with a variable number of costae and an apsacline ventral interarea.

\section{ETYMOLOGY}

The species is named after the geologist S. L. Blusson, who made the first detailed geologic maps of the Sekwi Mountain map-area (Blusson, 1971).

\section{REFERRED SPECIMENS}

$S$. blussoni sp. nov. occurs in strata of Zlichovian age in $\mathrm{S}-3, \quad 53.3-492.3 \mathrm{~m}$ below the top of the Delorme Formation. Material illustrated from S-3 includes holotype ROM 33159 and paratypes ROM 33160-33166 from sample S-4-64.0-65.5 m; paratypes ROM 33167-33170 from sample S4-143.3 m; and paratypes ROM 33171-33173 from sample $\mathrm{S} 4-466.3 \mathrm{~m}$.

\section{EXTERIOR}

The shell outline is transversely subquadrate, with the width about twice the length; the lateral profile is strongly biconvex. The ventral valve is three to four times as deep as the dorsal valve. The ventral interarea is commonly higher than wide and is triangular, apsacline, and cleft 
medially by an open delthyrium encompassing an angle of approximately $35^{\circ}$. The dorsal interarea is low, flat, broadly triangular, and anacline. The hinge line usually coincides with the maximum shell width. Some dorsal valves have slightly extended hinge lines that end in acute cardinal angles. The cardinal angles of ventral valves vary from gently acute to gently obtuse. The flanks of the pedicle valve slope off laterally with little curvature. The profile of the dorsal valve is gently curved, and is divided medially by a shallow, anteriorly flaring sulcus. The anterior commissure is re-entrant because of the presence of the dorsal sulcus. Opposite the centre of the dorsal sulcus, a wide space exists between the costae of the ventral valve. Both dorsal and ventral valves bear strongly rounded costae separated by either narrow or broadly U-shaped interspaces, depending upon the costae density. The number of costae varies from 16 to 26 , commonly with two or three more on the ventral valve. The costae commonly increase by implantation; bifurcation occurs only on shells of high costal density. A few shells do not show increase of costae anteriorly. Concentric ornament consists of widely spaced, moderately impressed growth lines, which become more closely spaced anteriorly.

\section{PEDICLE VALVE INTERIOR}

The hinge teeth are short, subrectangular in posterior profile, laterally directed, anteriorly inclined, and supported by the thickening of the delthyrial margin; the margin is continuous with the lateral edges of the U-shaped spondylium. The spondylium is supported apically by a ridge that is variably developed, ranging from a septum to an apical callus infilling. The spondylium extends to about one-half to two-thirds of the length of the valve. The peripheral margin of the shell is crenulated by the impress of the costae.

\section{BRACHIAL VALVE INTERIOR}

The sockets are deep and expand laterally. They are bounded posteriorly by the interarea, medially by the brachiophores, and anteriorly by the fulcral plates, whose medial edges are joined to the brachiophores and whose posterolateral margins join the valve wall. The lateral ends of the sockets are open. The brachiophores diverge at approximately $70^{\circ}$ and are inclined slightly anteroventrally. They change in shape from bladelike basally to extended laterally and become thin, triangular extensions distally. The cruralium consists of two U-shaped lobes whose anterior margins extend anteromedially from the brachiophore bases to the median septum. The cruralium extends over the anterior one-third of the valve and is fused to the valve floor over most of this distance. The high, thin median septum increases in height to about two-thirds of the shell length, whereupon it terminates quite abruptly. The cardinal process is small and triangular in plan view; it flares anteriorly from the apex and is formed by a slight thickening of the septum. The muscle impressions are small, oval areas located anterior to the cruralium and close to the septum. The peripheral margins are crenulated by the impress of the costae.

\section{DISCUSSION}

The distinction between $S$. variabilis and $S$. blussoni sp. nov. has already been discussed in the section on $S$. variabilis. As illustrated by Biernat (1959), S. polonicum Gürich from the Middle Devonian of the Holy Cross Mountains in Poland is less transverse, bears a more pronounced ridge supporting the spondylium, and has distinct dorsal adductor muscle impressions and a more posteriorly inclined ventral interarea. Few other interiors of Devonian Skenidioides species are known.

\section{Suborder Dalmanelloidea Schuchert and Cooper Superfamily Dalmanellacea Schuchert Family Dalmanellidae Schuchert, 1913 Subfamily Cortezorthinae Johnson and Talent, 1967a}

\section{Genus Cortezorthis Johnson and Talent, 1967a}

\section{TYPE SPECIES}

Cortezorthis maclareni Johnson and Talent, 1967a:146, pl. 19, figs. $1-20$; pl. 20, figs. 28, 29.

\section{Cortezorthis maclareni Johnson and Talent, 1967a}

$$
\text { Pl. 4, figs. } 1-40
$$

Hypsomyonia? sp. A. McLaren in Fortier et al., 1963:320. Cortezorthis maclareni Johnson and Talent, 1967a:146, pl. 19, figs. 1-20; pl. 20, figs. 28,29
Cortezorthis maclareni-Perry, Boucot, and Gabrielse, 1981:300, pl. 1, fig. 14.

?Cortezorthis cf. C. maclareni-Perry, Boucot, and Gabrielse, 1981:300, pl. 1, figs. 3-13.

\section{REFERRED SPECIMENS}

C. maclareni occurs in beds of Zlichovian age of the Delorme Formation in S-1, at 7.6-68.6 m, and in S-3, at $36.6-573.0 \mathrm{~m}$, respectively, below the top of the formation. It is represented by $85 \mathrm{~A}, 1425 \mathrm{~B}$, and $1060 \mathrm{P}$ well-preserved silicified shells. Material illustrated from S-3 includes ROM 33174, 33175 from sample S4-53.5- 
$54.9 \mathrm{~m}$; ROM 33176 from sample $\mathrm{S} 4-64.0-65.5 \mathrm{~m}$; ROM 33177-33181 from sample S4-143.3 m; ROM 33182 from sample S4-257.6 m; ROM 33183-33185 from sample S4-502.9-507.5 m; and ROM 33186 from sample S4$519.7 \mathrm{~m}$. Material illustrated from S-1 includes ROM 33187 from sample A7.6-10.7 m.

\section{DISCUSSION}

C. maclareni was originally described from the lower member of the Blue Fiord Formation on southwestern Ellesmere Island and was ascribed to an Emsian or Eifelian age (Johnson and Talent, 1967a; McLaren, Norris, and Cumming, 1970). Johnson (1975a) noted that no Cortezorthis is known from strata as young as Middle Devonian. More recent geological studies on Ellesmere Island (Pedder and Klapper, 1977; Trettin, 1978:55) show that much of the Blue Fiord Formation is of Zlichovian age. The specimens from the Delorme Formation are of early to mid-Zlichovian age.

Some minor differences and additional morphologic information are presented to complement the original description of Cortezorthis maclareni. There are no obvious differences in the relationships of length to width in specimens separated over a stratigraphic distance of $500 \mathrm{~m}$ in the Delorme Formation. The apical angle of the delthyrium in the Delorme specimens is more variable, with a range of $45^{\circ}-80^{\circ}\left(45^{\circ}-60^{\circ}\right.$ in Johnson and Talent $)$. A larger amount of callus fills the apex of the delthyrium of the Delorme specimens. The dorsal adductor muscle field is slightly more elongate than on material from Ellesmere Island. Contrary to the materials from the Arctic, the Delorme specimens have well-developed radial grooves on the posterior, rather than the anterior adductor muscle scars. The ridge separating the posterior and anterior dorsal adductor scars extends anterolaterally across the prominent raised margin of the muscle field. The peripheral and lateral septa on the dorsal valve show considerable variation in development since septa of three orders of magnitude can be recognized in most specimens, as opposed to two orders noted by Johnson and Talent. All of the anteriorly located lateral septa thicken ventrally. The increased thickness of any one septum is matched by the termination of one or more of the lower order of septa. This suggests that the probable purpose of the thickened septa was to serve as a filtering device to control the size of particles entering the brachiopod when the valves gaped. If all the septa developed to the same height, their ventral thickening would form a solid wall of shell material. The peripheral septa are much more strongly developed anteriorly in both valves; their development is more regular, however, in the ventral valve. Costellae number between 14 and 18 in $5 \mathrm{~mm}$ at a point $10 \mathrm{~mm}$ anterior to the dorsal beak, compared to 10 to 15 in the type materials. Features such as the number of costellae in a given distance should be used not as definitive criteria in separating dalmanellid shells but rather as supplementary data, because valid comparisons of costellae number are available only if the shells being compared are of equal size

Changes in shape during ontogeny are from transverse, dorsally sulcate forms, to intermediate forms that develop a distinct ventral carina, to mature shells with a more subdued ventral carina and dorsal sulcus resulting in a rectimarginate anterior commissure, or even a slight reversal of sulcation in large specimens. Small shells do not have raised muscle platforms, and their peripheral septa are more subdued and of uniform size

Many of the collections of Cortezorthis maclareni from section S-3 contain slightly abraded, disarticulated shells covered by encrusting auloporid corals. Most, but not all, of the corals grow on exterior surfaces of the valves. Specimens that show little evidence of abrasion most commonly have auloporid encrustations only near the anterior margins of valves, most often the pedicle and sometimes the brachial. The auloporid corallites are directed anteriorly. A possible explanation is that $\mathrm{Cor}$ tezorthis had a functional pedicle by which it could attach itself to the substrata in an inclined position with the ventral valve directed upwards and protecting the dorsal valve from direct light penetration. The ventral anterior surface would then be a favourable place for the corallites both to receive food from the feeding currents generated by brachiopods and to be exposed to direct light.

\section{Cortezorthis cf. C. windmillensis (Johnson and Talent, 1967a) \\ Pl. 4, figs, 41-46}

Protocortezorthis windmillensis Johnson and Talent, 1967a:158, pl. 21, figs. 1-13.

Protocortezorthis windmillensis-Johnson, 1970:17, pl 4 , figs. 3-19.

Cortezorthis aff. C. windmillensis-Johnson, 1975a:17, pl. 1, figs. 5-11, 16, 17

\section{REFERRED SPECIMENS}

C. cf. C. windmillensis is represented in the Delorme Formation by only a few specimens (12B and 7P) from strata of late Lochkovian age-in S-1, at $470.9 \mathrm{~m}$, and $\mathrm{S}-2$, at 166-182.9 $\mathrm{m}$, respectively, below the top of the formation. Material illustrated includes ROM 33188. 33189 from S-1, sample A470.9 m; and ROM 33190 , 33191 from S-2, sample B 166-182.9 m.

\section{DISCUSSION}

C. cf. C. windmillensis differs only slightly from the type material from the late Lochkovian Quadrithyris Zone in central Nevada and also shows close affinity to late 
Lochkovian forms from the Arctic Archipelago. Costellae are finer and occur in greater numbers on the Delorme shells ( 20 to 25 in $5 \mathrm{~mm}$ at a point $5 \mathrm{~mm}$ anterior to the beak). Some of the Nevada shells illustrated by Johnson and Talent bear considerably finer and more numerous costellae than the numbers cited by Johnson and Talent (12 to 15 in $5 \mathrm{~mm}$ at $10 \mathrm{~mm}$ anterior to the beak). The dorsal muscle-bounding ridges are not isolated from the brachiophore bases to the same degree in the Delorme shells as in the Nevada specimens. The characteristic low dorsal septum and the central radial septa are well developed, as in the type specimens. The dorsal cardinalia and muscle scars are identical in outline to those of the type specimens; the ventral muscle scars are similar. Small crural fossettes are present on the anterior edge of the hinge teeth of the Delorme shells. The Delorme specimens are closer to the Nevada $C$. windmillensis in that they have a weakly developed dorsal septum, whereas some of the Cornwallis Island representatives assigned to $C$. aff. $C$. windmillensis by Johnson (1975a) show a more continuous, better-developed dorsal septum. Ventral valves of Cortezorthis are commonly more carinate than those of Protocortezorthis in order to accommodate the high dorsal median septum. The ventral carina is clearly impressed internally on $C$. cf. $C$. windmillensis .

Originally, it was thought that the species windmillensis was the evolutionary end member of the protocortezorthid lineage because of its incipient dorsal septum. Studies by J. G. Johnson, A. C. Lenz, and the writer show that Protocortezorthis and Cortezorthis coexisted in the Early Devonian. Species showing the development of a dorsal septum are best placed in the genus Cortezorthis.

C. windmillensis (Johnson and Talent)-C. norfordi Lenz-C. maclareni Johnson and Talent belong to an evolutionary lineage, as documented by their related morphologic structures and their stratigraphic position. Through the Early Devonian the lineage is marked by the increased height of the septum, increased carination, and progressive development of the dorsal muscle scar.

\section{Cortezorthis norfordi Lenz, 1977a}

Pl. 5, figs. 1-11

Cortezorthis norfordi Lenz, 1977a:56, pl. 2, figs. 21-26, 29-38

\section{REFERRED SPECIMENS}

C. norfordi is represented by $4 \mathrm{~A}, 76 \mathrm{~B}$, and $67 \mathrm{P}$ silicified specimens from the Delorme Formation-in S-1, at 318.5-448.1 m, and in S-3, at $121.9 \mathrm{~m}$, respectively, below the top of the formation. Material illustrated includes ROM 33192-33196 from S-1, sample A442.0 m; and ROM 33197, 33198 from S-2, sample B121.9 m.

\section{DISCUSSION}

C. norfordi occurs commonly in beds of late Lochkovian and early Pragian age of the Royal Creek area (Lenz, 1977a) and in beds of similar age from the Delorme Formation in the Sekwi Mountain map-area. C. norfordi differs from the younger $C$. maclareni Johnson and Talent in its smaller size, more elongate dorsal muscle field, less well developed radial peripheral septa, and more convex ventral valve. $C$. norfordi resembles $C$. windmillensis (Johnson and Talent) from the Lochkovian of central Nevada in external morphology, although internally it has a much better developed ventral median septum and stronger radial peripheral septa. C. cortezensis Johnson and Talent from the Zlichovian Eurekaspirifer pinyonensis Zone of Nevada is also of similar external morphology, although the presence of prominent fulcral and dental plates and a deeper pedicle valve on $C$. norfordi distinguish it from $C$. cortezensis. The much finer radial ornament on $C$. norfordi readily distinguishes it from $C$. perryi Lenz, which has an overlapping stratigraphic range in the area. The stratigraphic occurrence and the gross morphologic similarity of $C$. norfordi and $C$. maclareni suggest that norfordi was a probable ancestor of maclareni.

\section{Cortezorthis perryi Lenz, 1977a}

Pl. 5, figs. 12-18

Cortezorthis perryi Lenz, 1977a:57, pl. 3, figs. 1-29.

Cortezorthis sp. Jackson, Lenz, and Pedder, 1978, pl. 11, figs. 10-16.

\section{REFERRED SPECIMENS}

$C$. perryi is represented in the Delorme Formation by only $8 \mathrm{~B}$ and $2 \mathrm{P}$ coarsely silicified specimens. Material illustrated includes ROM 33199-33202 from S-1, A342.9 m and OLDA336. $8 \mathrm{~m}$.

\section{DISCUSSION}

Stratigraphically, $C$. perryi occurs within the upper range of $C$. norfordi. It is found in Pragian strata at Royal Creek and in Pragian beds of the Delorme Formation at S-1, 336.8-344.4 $\mathrm{m}$ below the top of the Formation. At Royal Creek it is found in some of the same collections as $C$. norfordi; in the Delorme Formation, however, it occurs to the exclusion of other cortezorthinids.

The most obvious difference between $C$. perryi and other species is the coarse, angular costae on this species. There are considerably fewer costae than on other species and the costae increase by trifurcation and bifurcation. Dorsal valves of $C$. norfordi and $C$. perryi, which are of similar size, bear approximately 20 and 12 costae respectively in $5 \mathrm{~mm}$ at a point $5 \mathrm{~mm}$ anterior to the beak. 
Some costae are much stronger than others. The dorsal muscle field is elongate and oval in shape and is divided by a thin median septum. Fulcral plates are absent, and dental plates and crural fossettes are well developed. A relatively deep, V-shaped dorsal sulcus is developed anteriorly.

C. perryi bears some similarity to C. maclareni in the development of bundled costae and the more elongate outline of the dorsal muscle field. It was probably derived directly from a more coarsely costate Protocortezorthis, rather than from a Cortezorthis of the norfordi or windmillensis morphology.

\section{Genus Protocortezorthis Johnson and Talent, 1967a}

\section{TYPE SPECIES}

Orthis fornicatimcurvata Fuchs, 1919:58, pl. 5, figs. 1-6.

\section{Protocortezorthis aff. P. fornicatimcurvata (Fuchs, 1919)}

Pl. 5, figs. 19-33

Protocortezorthis aff. P. fornicatimcurvata-Johnson, 1975a:18, pl. 2, figs. 12-15.

Protocortezorthis aff. $P$. fornicatimcurvata-Lenz, 1977a:55, pl. 2, figs. 1-20, 27, 28.

Protocortezorthis sp. Jackson, Lenz, and Pedder, 1978, pl. 9, figs. 1-6, 14.

\section{REFERRED SPECIMENS}

Protocortezorthis aff. $P$. fornicatimcurvata occurs in upper Lochkovian beds in the Delorme Formation, in S-1, at 519.7-536.4 $\mathrm{m}$ and OLDA423.7-492.2 $\mathrm{m}$, and in S-2, at $221.0-225.6 \mathrm{~m}$, respectively, below the top of the formation. It is represented by $6 \mathrm{~A}, 72 \mathrm{~B}$, and $52 \mathrm{P}$ silicified shells. Material illustrated includes ROM 33203-33205 from S-1, sample A528.8 m; ROM 33206, 33207 from S-1, sample A536.4 m; and ROM 33208-33210 from S-2, sample B221.0 m.

\section{DISCUSSION}

The genus Protocortezorthis has a relatively wide stratigraphic range (Wenlockian of Gotland; Ludlovian of the Welsh Borderland and the Venezuelan Andes; Gedinnian and Siegenian of western Europe and Nova Scotia; Monograptus yukonensis Zone and beds of older Lochkovian age of northern Canada). Johnson (1975a) suggested that the generic name Protocortezorthis be restricted to forms with stable morphology, that is, species resembling $P$. fornicatimcurvata. Species of cortezorthinids heralding the morphology of typical Cortezorthis are best placed in that genus. Walmsley and Boucot (1975) proposed Protocortezorthis as one of five subgenera of Isorthis.
Although these various dalmanellids are closely related, the grouping of all into the genus Isorthis does not seem useful because Protocortezorthis has a distinctive morphology that can stand alone.

Lenz (1977a) reported abundant representatives of $P$. aff. $P$. fornicatimcurvata in beds of both upper Lochkovian and Pragian age of the Royal Creek area where the taxon overlaps much of the ranges of Cortezorthis norfordi and Cortezorthis perryi. In the stratigraphic sections of the Sekwi Mountain map-area $P$. aff. $P$. fornicatimcurvata occurs within the lower range (Lochkovian) of $C$. norfordi or below it. $P$. fornicatimcurvata is documented (Walmsley and Boucot, 1975) from Gedinnian beds in the following strata: Hüinghauser and Brednech Schichten of Germany; Grès de Gdoumont of Belgium; Bostów Beds in the Holy Cross Mountains of Poland; Schistes de Méricourt, Couches de Drocourt, and Calcaire d'Angres of northern France; and the Stonehouse Formation of Nova Scotia. $P$. aff, $P$. fornicatimcurvata differs only slightly from representatives of $P$. fornicatimcurvata in western Europe and Nova Scotia (Walmsley and Boucot, 1975; Harper, 1973), which are commonly preserved as casts and moulds. The dorsal muscle platform of the population from northern Canada sometimes has less well developed brachiophore bases and a gap between them and the muscle-bounding ridges, suggesting a potential relationship with $C$. windmillensis, the oldest described member of the Cortezorthis lineage. The ventral muscle field is slightly shorter than that of the European population of $P$. fornicatimcurvata, and there is no trace of the low dorsal septum of Cortezorthis.

Several species of Cortezorthis and Protocortezorthis occur more or less in succession in the same collections both in the Sekwi Mountain map-area and in the Royal Creek area; this suggests that the protocortezorthidcortezorthid lineage was quite plastic, with several members branching off from it at different times in the Early Devonian. In the Delorme Formation no obvious environmental differences are suggested by the host strata of Cortezorthis and Protocortezorthis collections. Johnson (1975a) reached similar conclusions, namely that Protocortezorthis did not give rise to Cortezorthis orthogenetically but rather Cortezorthis branched off from the Protocortezorthis lineage and coexisted with it for a time in the Early Devonian.

\section{Protocortezorthis natlensis sp. nov. Pl. 5, figs. 34-44}

\section{DIAGNOSIS}

A small Protocortezorthis with a well-defined dorsal sulcus, a wide dorsal median myophragm, and an incurved ventral beak. 


\section{ETYMOLOGY}

The specific name is after the Natla River, which is close to the type locality in the Mackenzie Mountains.

\section{REFERRED SPECIMENS}

$P$. natlensis sp. nov. occurs in S-3, at $143.3 \mathrm{~m}$ below the top of the Delorme Formation, in beds of Zlichovian age. It is represented by $14 \mathrm{~B}$ and $10 \mathrm{P}$ silicified specimens. Material illustrated includes holotype ROM 33211 and paratypes ROM 33212 and 33214-33216 from S-3, sample S4-143.3 m.

\section{EXTERIOR}

The shells are small (5-8 $\mathrm{mm}$ in width), with a transversely subrectangular dorsal valve and a shieldshaped ventral valve. The lateral profile is slightly ventribiconvex. The pedicle beak is relatively long, pointed, and moderately incurved over a triangular, concave interarea. The ventral interarea is apsacline and is about two-thirds of the maximum shell width, which is attained posterior to midlength of the shell. The delthyrium is open and triangular and ecompasses an angle of $35^{\circ}-40^{\circ}$. The dorsal beak is inconspicuous and very weakly incurved over a low, triangular, flat interarea. A weakly developed, narrow fold occurs on the pedicle valve; the brachial valve bears a strongly developed, V-shaped sulcus. The ornament consists of subangular costae that increase by both bifurcation and implantation. The costae are finer on the central part of the sulcus. On the dorsal valve, at $3 \mathrm{~mm}$ anterior to the beak, there are seven costae in $2 \mathrm{~mm}$.

\section{PEDICLE VALVE INTERIOR}

The hinge teeth are short, thick, anterolaterally directed processes. The dental plates are short and diverge towards the floor of the valve; in some cases they are welded to the valve wall. The muscle field is not impressed. A shallow, elongate medial depression is developed over the anterior one-third of the shell. Low radial crenulations are well developed along the periphery of both valves.

\section{BRACHIAL VALVE INTERIOR}

The sockets are deep, wide, and directed anterolaterally. The sockets are bounded posteriorly by the inner edges of the interarea and medially by the lateral edges of the massive brachiophores, the distal ends of which are free and overhang the valve floor. The muscle-bounding ridges extend from the brachiophore bases and curve gently to the midline at a point anterior to midlength of the shell, where they define an oval muscle field. The muscle field is divided by a broad myophragm; the latter becomes less distinct anteriorly, where it is represented only by the impress of the dorsal sulcus. The individual adductor muscle scars are deeply impressed against the myo- phragm. The posterior and anterior adductors are separated by a very faint ridge that diverges anterolaterally from the midline. Posteriorly a myophragm extends into the notothryial cavity and forms the base for the small, bulbous cardinal process.

\section{DISCUSSION}

P. natlensis sp. nov. is the youngest North American representative described and one of the youngest occurrences known of the genus Protocortezorthis. It closely resembles other members of the genus in the nature of the dorsal sulcus, the elongate dorsal muscle scars, and the low median myophragm. An assignment to Isorthis is precluded because of the presence of the dorsal sulcus and the inclination of the ridges separating the anterior and posterior adductor muscle scars. The dorsal muscle scars do not show lateral curvature anterior to the brachiophore bases, a feature typical of Salopina. The absence of a dorsal median septum rules out direct affinity with Cortezorthis because even immature specimens of $C$. maclareni, which occurs in the same collection, have a well-developed septum anteriorly. The moderate incurvature of the ventral beak and the small angle of the delthyrial opening on this species are features not found on previously described species of Protocortezorthis. The association of the ventral and dorsal valves of this taxon is certain since it is visible on one of the specimens illustrated, an articulated shell that was later broken open. The Zlichovian occurrence of $P$. natlensis sp. nov. further documents the coexistence of Protocortezorthis and Cortezorthis in the Early Devonian.

\section{?Protocortezorthis sp. 1}

$$
\text { Pl. 5, figs. } 45-48
$$

\section{REFERRED SPECIMENS}

The material available for study consists of a brachial and a pedicle valve, both silicified, from S-1, at OLDA336. $8 \mathrm{~m}$ below the top of the Delorme Formation. Material illustrated includes ROM 33217, 33218.

\section{EXTERIOR}

The strongly convex ventral valve has a subpentagonal outline and a high, apsacline interarea, which extends over one-half of the maximum shell width and is cleft medially by an open delthyrium. The dorsal valve is characterized by a semicircular outline, a dorsal sulcus, a narrow hinge line, and a low, apsacline interarea. The ornament consists of numerous bundled and bifurcating rounded costae.

\section{PEDICLE VALVE INTERIOR}

The massive, blunt hinge teeth project anterodorsally. The dental plates are prominent and join with the well- 
developed muscle-bounding ridges, which encompass a firmly impressed, teardrop-shaped muscle field. The diductor scars are deeply impressed on the flanks of a wide, low myophragm, which forms the adductor muscle platform.

\section{BRACHIAL VALVE INTERIOR}

Massive, anterolaterally directed brachiophores bound the small, deep sockets posteromedially. The sockets are floored by poorly developed fulcral plates. The dorsal sulcus is gently impressed, and a medial bladelike ridge develops over the posterior one-quarter of the shell and is continuous with the central lobe of the trilobed cardinal process. The muscle field is elongate and oval in shape and bounded laterally by low, distinct ridges continuous with the brachiophore bases. The muscle field extends to midlength of the shell, and the anterior and posterior adductors are separated by a linear depression directed perpendicular to the medial ridge. The shell substance of both valves is thick and the brachial valve appears to be punctate.

\section{DISCUSSION}

This may well represent a new genus, but the material at hand is insufficient for the definition of a new taxon. The pedicle valve bears some resemblance to Schizophoria; however, the muscle field is much more massive than in Schizophoria shells of similar size. The single collection available occurs in beds of probable early Pragian age.

\section{Family Rhipidomellidae Schuchert, 1913 Subfamily Rhipidomellinae Schuchert, 1913}

\section{Genus Dalejina Havlíček, 1953}

\section{TYPE SPECIES}

Dalejina hanusi Havlíček, 1953:5, pl. 1, figs. 10, 12-14; pl. 2, fig. 4 .

\section{DISCUSSION}

There is considerable difficulty in distinguishing the genera Aulacella Schuchert and Cooper (1931) and Dalejina. Chatterton (1973) pointed out that the features used for the distinction (the reversal of fold and sulcus and the presence of a narrow ridge separating the anteromedial portion of the ventral diductor muscle scars in Dalejina) are less than adequate, and he suggested, therefore, that Dalejina is a junior synonym of Aulacella. Chatterton's discussion appears partially valid; nevertheless, all previously described shells of this type from western North America have been referred to Dalejina, and so the shells from the Delorme Formation are referred to the genus Dalejina for the purpose of avoiding much taxonomic confusion and for ease of comparison with other taxa from western and arctic North America. Biernat (1959) illustrated Aulacella eifelensis (Schnur), the type species of Aulacella, and her illustrations show a ventral muscle field that is much more strongly impressed compared to the almost smooth ventral interior of the Delorme Dalejina. Some of the Nevada species of Dalejina illustrated by Johnson (1970) have a moderately impressed ventral muscle scar.

\section{Dalejina sp. 1}

Pl. 6, figs. 4-28

?Dalejina sp. A Johnson, 1970:81, pl. 8, figs. 13-20.
Dalejina sp. 1 Lenz, 1977a:59, pl. 3, figs. 30, 33, 35, 37, 41 ; pl. 4, figs. $1-10,14$

\section{REFERRED SPECIMENS}

Dalejina sp. 1 occurs in strata of late Lochkovian and early Pragian age in the Delorme Formation, in S-1, at $442.0 \mathrm{~m}$ and OLDA384.0-416.1 m, and in $\mathrm{S}-2$, at $105.2 \mathrm{~m}$, respectively, below the top of the formation. Poorly preserved representatives of the genus Dalejina, possibly of Dalejina sp. 1, occur in several older collections from S-1 and S-2.Dalejina sp. 1 is represented by $44 \mathrm{~A}, 52 \mathrm{~B}$, and $40 \mathrm{P}$ coarsely silicified shells. Material illustrated includes ROM 33219,33220 from S-1, sample A442.0 m; ROM 33221-33225 from S-1, sample OLDA388.6 m; ROM 33226 from S-1, sample OLDA416.1 m; and ROM 33227-33229 from S-2, sample B $105.2 \mathrm{~m}$.

\section{EXTERIOR}

The outline varies from transversely suboval to elongate. It is biconvex in lateral profile. The cardinal angles are rounded and obtuse, and the maximum width is developed near midlength. The dorsal sulcus is shallow, very gently rounded in profile, and more prominent posteriorly. The ventral interarea is moderately high, triangular, narrow, apsacline, slightly incurved, and cleft medially by an open delthryrium enclosing an angle of approximately $65^{\circ}$. The dorsal interarea is low, narrow, and triangular, and is anacline to orthocline in profile. The dorsal beak is small and prominent. Radial ornament consists of fine, subangular, hollow costellae, which number 13 in $5 \mathrm{~mm}$ at a point $5 \mathrm{~mm}$ anterior to the beak. The costellae increase anteriorly by bifurcation and implantation. The costellae are crossed by prominent concentric growth lines anteriorly. 


\section{PEDICLE VALVE INTERIOR}

The hinge teeth are stout, stubby, triangular extensions of the delthyrial margins. The dental plates are short and are welded to the posterolateral shell wall over most of their length; they diverge slightly ventrally. A small amount of pedicle callist is developed apically. The muscle field is elongate and oval in shape, very weakly impressed, and enclosed anteriorly by a weakly developed ridge extending from the base of the dental plates. The adductor and diductor scars are indistinct. In a few shells a very low myophragm divides the anterior portion of the muscle field. The shell periphery of both valves is crenulated by the impress of costellae; the ridges that correspond to the external interspaces of the costellae are flat-topped and grooved medially.

\section{BRACHIAL VALVE INTERIOR}

The sockets are deep and expand and diverge laterally; they are bounded posteriorly and dorsally by the shell wall, and anterolaterally by relatively thick, bladelike brachiophores. The brachiophores are attached to the posterior shell wall and curve sharply ventrally. The medial edges of the brachiophores (brachiophore processes) are extended further anteriorly and ventrally than the lateral edges. The cardinal process is a small, stubby, stout, posteroventrally bilobate structure; it is situated between the brachiophore bases and gently directed posteriorly. A low, rounded, moderately well defined myophragm extends from the cardinal process anterior to midlength of the shell. The adductor muscle field is weakly impressed, elongate and oval in shape, and divided into two pairs of muscle scars by a faint ridge directed perpendicular to the medial myophragm. The posterior pair of muscle scars is much shorter than the anterior pair. Weak muscle-bounding ridges extend from the bases of the brachiophores and define an oval muscle field.

One peculiar dorsal valve was noted in a collection from $\mathrm{S}-1$, sample A442.0 $\mathrm{m}$, bearing Dalejina sp. 1. The cardinal process is more elongate than in other Dalejina sp. 1. A low, medially convergent pair of plates extend from the medial edge of the brachiophores to the valve floor over a short distance and seemingly mark the boundary of the diductor muscle field adjacent to the cardinal process. Similar structures are known in Dalmanella (sensu stricto). Other morphologic features of this specimen are identical to Dalejina sp. 1 (see Pl. 6, figs. $1-3)$.

\section{DISCUSSION}

Dalejina sp. 1 differs from the younger Dalejina gabrielsei sp. nov, in being of smaller size and more convex profile, and in having weakly impressed muscle fields in both valves. Dalejina sp. 1 bears close resemblance to Dalejina $\mathrm{sp}$. A described by Johnson
(1970) from the Quadrithyris Zone and from the slightly older Lower Windmill Limestone (Johnson, 1973a) of Nevada. The absence of a persistent brachial sulcus, of moderately impressed muscle fields, and of a pedicle myophragm is diagnostic of the taxon. It differs from $D$. subfrequens Johnson, Boucot, and Murphy of the early Lochkovian of central Nevada in lacking a prominent, anteriorly extended medial ridge in the ventral valve, in having a less pronounced pedicle muscle field, and in being generally wider than long. The coarsely silicified mode of preservation and the lack of large collections preclude the erection of a new taxon.

\section{Dalejina gabrielsei sp. nov.} Pl. 6, figs. 29-50

\section{DIAGNOSIS}

A moderate-sized Dalejina of lenticular profile, this species has a large number of costellae, lacks ventral muscle impressions even in gerontic shells, and has subdued dorsal muscle scars.

\section{ETYMOLOGY}

The species was named after H. Gabrielse, of the Geological Survey of Canada, who has mapped large areas of the Mackenzie Mountains.

\section{REFERRED SPECIMENS}

D. gabrielsei sp. nov. occurs in beds of latest Pragian and of Zlichovian age in the Delorme Formation, in S-1, at 62.5-100.6 m, and in S-3, at 53.3-515.1 m, respectively, below the top of the formation. It is represented by $314 \mathrm{~A}$, $823 \mathrm{~B}$, and 631P well-preserved silicified shells. Material illustrated includes holotype ROM 33230 and paratypes 33231-33233 from S-1, sample A62.5-68.6 m; paratypes ROM 33234-33236 from S-3, sample S4-64.0-65.5 m; and paratypes ROM 33237-33239 from S-3, sample S4-466.3 m.

\section{EXTERIOR}

The ventral valve is subpentagonal in outline, whereas the dorsal valve is transversely suboval in outline. The lateral profile is markedly ventribiconvex in small shells and becomes subequally biconvex in larger shells. The ventral umbo is low, and the beak is moderately incurved. The hinge line is short, being less than one-half of the maximum shell width, which is attained near midlength in small shells and anterior to midlength in large shells. The weak dorsal sulcus and ventral fold sometimes cause a slight deflection of the rectimarginate anterior commissure. The triangular ventral interarea is low, narrow, flat, and apsacline, and is cleft medially by an open, triangular delthyrium enclosing an angle of $65^{\circ}-80^{\circ}$. The dorsal interarea is slightly anacline in profile. Ornament consists 
of subangular, hollow, radial costellae that increase anteriorly by both bifurcation and implantation. Twelve to 16 costellae occur within $5 \mathrm{~mm}$ at a point $5 \mathrm{~mm}$ anterior to the beak. The shell substance is punctate.

\section{PEDICLE VALVE INTERIOR}

The hinge teeth are stout, triangular, widely divergent processes and bear very shallow crural fossettes ventromedially. The stout dental plates are strongly directed anterolaterally and are fused to the shell wall. A well-developed pedicle callist fills the apex of the valve. The muscle field is not impressed. The internal surface of the shell is smooth and is marked peripherally by two orders of grooves.

\section{BRACHIAL VALVE INTERIOR}

The small, deep sockets expand anterolaterally. The posteromedial ends of the sockets are covered by the interarea, whereas the posterior walls and the bases of the sockets are formed by the posterior wall and the floor of the valve respectively. The prominent bladelike brachiophores are thickened anterolaterally and form the anteromedial walls of the sockets. Ventrally, the brachiophores are inclined medially and overhang the notothyrial cavity. The anteromedial knife-edge of the brachiophore extends further anteriorly than does the lateral edge. The notothyrial platform supports a posteroventrally directed, pillarlike cardinal process, which swells ventrally and narrows posteriorly. A broad, rounded myophragm extends from the cardinal process to midlength of the shell. In a few shells the adductor scars are very weakly impressed at the margin of the notothyrial platform; the lateral margins of these muscle scars appear to diverge anteriorly. One shell from S-1, sample A62.5-68.6 m, has clearly impressed, elongate, teardrop-shaped adductor scars on either side of the myophragm. The lateral muscle-bounding ridges diverge until two-thirds of their length and then gently converge medially. The posterior adductor pair is much smaller than the anterior pair.

\section{DISCUSSION}

D. gabrielsei sp. nov. lacks strongly impressed muscle scars, which leaves little but the external shape and ornament to compare with other known species. Johnson used such features as the shell's external shape, size, and thickness to distinguish three species of Dalejina in Nevada; however, these features are less than adequate for the assignment of a species. In $D$. gabrielsei sp. nov. of the Delorme the larger the shell the greater the dorsal convexity. D. gabrielsei $\mathrm{sp}$. nov. differs from other species described from Zlichovian strata (Havlíček, 1953, 1977a; Johnson, 1970; Chatterton, 1973) in that it consistently lacks the ridge dividing the ventral muscle field and that the muscle field itself is not discernible even in the well-preserved shells representing all but the earliest growth stages. It has more numerous, finer costellae which show less regular bifurcation than the types species, $D$. hanusi, from the Pragian of Czechoslovakia. In comparison with $D$. gabrielsei sp. nov., D. ampulla from the Zlichovian of Czechoslovakia has impressed muscle fields and has a larger cardinal process and a more circular outline. The well-developed pedicle callist of D. gabrielsei sp. nov, is common to other Zlichovian Dalejina. The same species of Dalejina occurs at Royal Creek in the Zlichovian collection RC1-339.9 m of Lenz (1977a, b).

One possible important palaeoecological observation from Dalejina occurrences in the Delorme Formation is that the relative abundance of Dalejina is inversely proportional to the relative abundance of the genus Schizophoria. This might suggest that Dalejina and Schizophoria occupied similar palaeoenvironments and were competitors for the same ecologic niche in the Delorme Formation.

Family Dalmanellidae Schuchert, 1913

Subfamily Resserellinae Lazarev, 1970

\section{Genus Resserella Bancroft, 1928}

\section{TYPE SPECIES}

Orthis canalis J. de C. Sowerby in Murchison, 1839:630, pl. 13, fig. 12a.

Resserella elegantuloides (Kozlowski, 1929) Pl. 7, figs. $1-10$

Dalmanella elegantuloides Kozlowski, 1929:63, text-figs $9 \mathrm{a}, 10,11$; pl. 2, figs. 1-16.
Parmorthis elegantuloides-Nikiforova, 1954:48, pl. 2, figs. 3-6.

Resserella elegantuloides-Walmsley and Boucot, 1971:514, pl.98, fig. 8; pl.99, fig. 1

Resserella elegantuloides-Johnson, 1973a:1019, pl. 1, figs. 16-20.

Resserella elegantuloides-Johnson, Boucot, and Murphy, 1973:17, pl. 14, figs. 1-21.

\section{REFERRED SPECIMENS}

$R$. elegantuloides occurs in strata of mid- to late 
Lochkovian age in S-2, at $225.6 \mathrm{~m}$ below the top of the Delorme Formation, in the lower range of Spirigerina supramarginalis. Only $1 \mathrm{~B}$ and $5 \mathrm{P}$ well-preserved silicified shells are available for study. Material illustrated includes ROM 33240-33242, from S-2, sample B225.6 m.

\section{EXTERIOR}

The shells are small, less than $8 \mathrm{~mm}$ in diameter. Pedicle valves are transversely suboval in outline with a markedly ventribiconvex lateral profile. The ventral valves show a slight decrease in curvature from posterior to anterior and are approximately three times as deep as the dorsal valves. The weakly convex dorsal valve has a broad, shallow sulcus anteriorly. The straight hinge line is about three-quarters of the maximum shell width, which is attained near midlength. The cardinal angles are gently rounded and obtuse. The triangular ventral interarea is of moderate height and is gently incurved and apsacline in profile; it is cleft medially by an open, triangular delthyrium which encloses an angle of $35^{\circ}-40^{\circ}$. The triangular dorsal interarea is low, flat, and anacline. External ornament is finely parvicostellate. The arrangement of the dorsal medial costellae appears to follow the typical pattern of resserellids as noted by Walmsley (1965). Faint, widely spaced concentric growth lines are visible on both valves. The costellae are finer near the midline of each valve and commonly increase by implantation.

\section{PEDICLE VALVE INTERIOR}

The short hinge teeth are triangular in cross section and are elongated laterally parallel to the hinge line. Shallow, but distinct crural fossettes are present on the anteromedial face of the teeth below the level of the plane of commissure. Short, strongly anterolaterally divergent dental lamellae support the teeth and define a shallow umbonal cavity. The muscle field is not impressed. In the umbonal cavity there is a broad, poorly defined, rectangular myophragm, which probably marks the site of adductor muscle attachment. The shell margins are weakly crenulated by the impress of the costellae.

BRACHIAL VALVE INTERIOR

The small, knoblike cardinal process is directed postero- ventrally from a broad, rounded myophragm, which corresponds to the impress of the sulcus. The impressed sulcus broadens and becomes less distinct anteriorly. The cardinal process and myophragm are flanked by deep grooves in the cardinal area. The long, triangular, prismlike brachiophores are slightly divergent and are inclined, strongly ventrally and weakly laterally, towards the anterior. The muscle platform is weakly impressed and appears to flare slightly anteriorly. The shell substance is punctate.

\section{DISCUSSION}

$R$. elegantuloides is known from lower Lochkovian strata in central Nevada (Johnson, Boucot, and Murphy, 1973; Johnson, 1973a). In Nevada $R$. elegantuloides is common in the lower Lochkovian of the Roberts Mountains Formation and also occurs in slightly younger strata of the Lower Windmill Limestone; it is not known, however, in the Quadrithyris Zone of the Upper Windmill Limestone.

The specimens of $R$. elegantuloides from the Delorme Formation are about two-thirds of the size of the type material from Podolia and only slightly smaller than specimens illustrated from central Nevada (Johnson, Boucot, and Murphy, 1973; Johnson, 1973a). The ventral umbo of the small Delorme specimens is not extended as far posterior to the hinge line as in the type material. The dorsal interior is very similar to that of the Nevada representatives and differs slightly from the dorsal musculature drawn by Kozlowski (1929, text-fig. 10). These conclusions could be the result of the author's misinterpreting the exceedingly weakly impressed muscle scars on the dorsal valve of $R$. elegantuloides available from the Delorme. The Delorme occurrence is important because it marks the only resserellid known from the Ludlovian-Zlichovian interval in northwestern Canada.

Savage (1974) illustrated a specimen of $R$. elegantuloides from the early Lochkovian of New South Wales. This shell has a dorsal myophragm and has less prominent brachiophores and slightly finer and more numerous costellae than either the Nevada or the Delorme shells. The dorsal muscle scars of Savage's material do not correspond very closely to those in Kozlowski's drawing (1929).

\section{Family Dicaelosiidae Cloud, 1948}

\section{Genus Didymoparcium Lenz, 1977a}

TYPE SPECIES

Didymoparcium costata Lenz, 1977a:62, pl. 7, figs. $26-40$
Didymoparcium costata Lenz, 1977a $\mathrm{Pl}$. 7, figs. 13-21

\section{REFERRED SPECIMENS}

D. costata occurs in S-3, in a few Zlichovian collections 
from the interval $36.6-507.5 \mathrm{~m}$ below the top of the Delorme Formation. The 17A, 17B, and 9P shells available for study are rather coarsely silicified. Specimens illustrated include ROM 33244 from S-3, sample S4-36.6 m; and ROM 33245-33248 from S-3, sample S4-502.9-507.5 m.

\section{DISCUSSION}

$D$. costata was first discovered in beds of Zlichovian age of the Delorme Formation and was subsequently recovered and described from the Zlichovian of Royal Creek by Lenz (1977a). The Delorme material generally has one or two more costae than the material reported by Lenz. On the Delorme specimens the delthyrium tends to have subparallel sides, and the ventral, "spondylium-like" plate is usually cemented to the valve floor.

Didymoparcium is assigned to the family Dicaelosiidae because of its small size and because both valves are bilobed, resulting in the emargination of the anterior commissure. Internally these specimens do not closely correspond to many of the features described for the dicaelosiids (Johnson, 1972; Wright, 1968a, b). Neither prominent dorsal septa (Epitomyonia, Teichertina) nor ventral septa (Epitomyonia) are present. The ribbing of these specimens is quite coarse relative to their small size, and the costae extend from the posterior to the anterior without increasing in number. The plate in the ventral valve is similar in structure to that of Mystrophora, but the dorsal valve is completely different and the ribs are much coarser in Didymoparcium. The relatively high ventral interarea and the lateral profile are similar to those of Teichertina. Wright (1968a) noted several evolutionary trends in the Dicaelosiidae, of which the following appear to hold for the Zlichovian Didymoparcium: reduction of dental plates, decrease in emargination, and increase in brachial convexity in younger individuals.

\section{Superfamily Enteletacea Waagen \\ Family Schizophoriidae Schuchert and LeVene, 1929 \\ Subfamily Schizophoriinae Schuchert and LeVene, 1929}

\section{Genus Schizophoria King, 1850}

\section{TYPE SPECIES}

Conchyliolithus (Anomites) resupinatus Martin, 1809, pl. 49 , figs. $13,14$.

\section{DISCUSSION}

The schizophoriids are a difficult group to work with because their morphology is very plastic throughout the Devonian. The features used to separate various species of Schizophoria in the Delorme Formation are established from the average morphology of several collections. A few individuals from any one collection may show slight variation from the average. Features such as shell thickness, the development of ridges dividing muscle fields, the shape of the cardinal process, and the overall size are used here for distinguishing species. It is realized that most of these features are often determined by the ontogenetic stage. Therefore, in order to make sense of a continuous sequence of schizophoriids ranging in age from early Lochkovian to Zlichovian, it is necessary to compare shells of similar size, and to base interpretations on large collections since these may provide representative samples of the populations. In central Nevada Schizophoria is absent from the intervening faunas between the Quadrithyris and Eurekaspirifer pinyonensis Zones. This break in the Schizophoria sequence is possibly the result of displacement by Dalejina (which probably occupied the same ecologic niche as Schizophoria) or, as suggested by Johnson (1974a), of a shallower-water environment during the intervening time. The stratigraphic separation of Schizophoria in central Nevada adds a false sense of security to the speciation of the Schizophoria found there which, like representatives of the genus in the Delorme Formation, no doubt followed a gradational morphologic development (see Johnson, 1970, pls. 8, 9; Johnson, Boucot, and Murphy, 1973, pls. 10, 11).

In the Schizophoria collections of the Delorme Formation thin-shelled varieties usually occur in more argillaceous, bryozoan-rich strata, which are probably of quieter, deeper-water origin, whereas thick-shelled varieties are more common in clean, bioclastic carbonates and often have an abundant epifauna growing on the shells, indicating more agitated, shallower-water origin.

\section{Schizophoria paraprima Johnson, Boucot, and Murphy, 1973 \\ Pl. 7, figs. 22-32}

Schizophoria paraprima Johnson, Boucot, and Murphy, 1973:24, pl. 10, figs. 19-34; pl. 11, figs. 1-11

?Schizophoria cf. S. paraprima-Lenz, 1977a:62, pl. 4, figs. $11,12,15-37,40,42-44$.

?Schizophoria cf. S. paraprima-Jackson, Lenz, and Pedder, 1978, pl. 4, figs. 29, 30, 34.

\section{REFERRED SPECIMENS}

$S$. paraprima is represented by $30 \mathrm{~B}$ and $24 \mathrm{P}$ silicified shells of the early Lochkovian of the Delorme Formation - in S-2, at 336.8-344.4 m below the top of the 
formation. Material illustrated includes ROM 33249-33252 from sample B336.8 m.

\section{DISCUSSION}

S. paraprima was reported by Johnson, Boucot, and Murphy (1973) from strata of early Lochkovian age in the Roberts Mountains Formation of central Nevada. Lenz (1977a) reported the taxon from Lochkovian and Pragian beds of the Royal Creek area of the northern Yukon, although his concept of the species was less restrictive. In the Delorme Formation, at S-2, S. paraprima occurs above the highest occurrence of Gracianella and is commonly found with Salopina submurifer Johnson, Boucot, and Murphy; like the Nevada representatives, it is of early Lochkovian age.

The specimens from the basal beds of the Delorme Formation at S-2 possess features characteristic of $S$. paraprima such as the small size, thin shell, lack of a fold and sulcus, and presence of a broad, flat ridge separating the ventral diductor muscle scars. The Delorme material has a pair of vascular canals extending from the dorsal adductor scars and bifurcating a short distance anterior to the muscle field. Younger Delorme collections of Schizophoria delormensis sp. nov. contain shells that differ from $S$. paraprima only in being of larger size and in having a less well developed, rectangular ventral myophragm. The rectangular platform separating the ventral diductor scars is the feature stressed by Johnson, Boucot, and Murphy for distinguishing $S$. paraprima. A delthyrial angle of slightly less than $90^{\circ}$ is attributed to S. paraprima; however, from the specimens illustrated by Johnson, Boucot, and Murphy (1973), it appears that this angle is too large; to judge from the Delorme material, an angle of $60^{\circ}-70^{\circ}$ is more reasonable.

When Lenz (1977a) reported S. cf. S. paraprima from Lochkovian and Pragian beds in the Royal Creek area, he interpreted $S$. cf. $S$. paraprima in a broad sense and included some specimens (Lenz, 1977a, pl. 4, figs. $22-24,26,30,36,40,42)$ that appear to deviate from the standard ornament of $S$. paraprima. These specimens are of post early-Lochkovian age.

\section{Schizophoria cf. S. nevadaensis Merriam, 1940}

$$
\text { Pl. 7, figs. 33-56 }
$$

Orthis impressa Walcott, 1884:115, pl. 13, fig. 13, not Hall, 1843.

Schizophoria nevadaensis Merriam, 1940:79, pl. 7, figs. 1,2 .

Schizophoria nevadaensis_Cooper, 1944:357, pl. 140, figs. 6,7 .

Schizophoria nevadaensis_Johnson, 1970:88, pl. 9, figs $1-18$.
Schizophoria sp. cf. S. nevadaensis-Ludvigsen, 1970, pl. 1, figs. 22-24.

Schizophoria nevadaensis—Johnson, 1975b:951, pl.4, figs. $7-15$.

\section{REFERRED SPECIMENS}

$S$. cf. S. nevadaensis occurs commonly in strata of Zlichovian age in the Delorme Formation, in S-1, at 62.5-68.6 m, and in $\mathrm{S}-3$, at $36.6-573.0 \mathrm{~m}$, respectively, below the top of the formation. Although the shell is of relatively large size and is thick, it is rarely well preserved in the Delorme. Most shells are highly abraded or are preserved only at the thicker posterior portions. Only smaller shells remain articulated. The species is represented by 104A, 1072B, and 1040P silicified shells. Material illustrated includes ROM 33253-33259 from S-1, sample A62.5-68.6 m; ROM 33260 from S-3, sample S4-53.3-54.9 m; ROM 33261 from S-3, sample S4-64.0$65.5 \mathrm{~m}$; ROM 33262 from $\mathrm{S}-3$, sample $\mathrm{S} 4-473.4 \mathrm{~m}$; and ROM 33263-33265 from S-3, sample S4-502.9-507.5 m.

\section{DISCUSSION}

$S$. cf. $S$. nevadaensis is distinguished from other Delorme Schizophoria by its large size and the widely diverging plates supporting the brachiophores. The ventral muscle field is more deeply impressed and more divergent than in Schizophoria delormensis sp. nov. Schizophoria sp. 1 has a prominent dorsal median ridge extending anteriorly from the cardinal process to the anterior edge of the muscle field. Two of the illustrated specimens of $S$. cf. $S$. nevadaensis show adventitious growth developments, evidence of parasites living under the mantle of the brachiopod ( $\mathrm{Pl} .7$, figs. 40, 55). The brachiopod secreted a layer of shell material over parasitic ?worm tubes. $S$. nevadaensis occurs commonly in the Zlichovian Eurekaspirifer pinyonensis Zone at Lone Mountain in central Nevada and in strata of similar age in the Michelle Formation of the northern Yukon (Johnson, 1970; Ludvigsen, 1970). The average size of the Delorme $S$. cf. $S$. nevadaensis is smaller than that of the type material from Nevada, although some of the Delorme shells are as large or larger. S. multistriata (Hall) is similar in overall size and outline to $S$. cf. $S$. nevadaensis; however, the pedicle valve is less convex and the brachiophores are less widely divergent on the former. Shells illustrated from Lowther Island in the Arctic Archipelago by Johnson (1975b) appear identical to the Delorme representatives of S. nevadaensis.

\section{Schizophoria delormensis sp. nov.} Pl. 8, figs. 1-21

\section{DIAGNOSIS}

A moderate-sized, thin-shelled Schizophoria with inter- 
nally impressed costellae, moderately divergent brachiophores, and weakly impressed, elongate dorsal and ventral muscle fields bounded by prominent extensions of the brachiophore bases and the dental plates.

\section{ETYMOLOGY}

The species is named after the occurrence in the Delorme Formation in the western Mackenzie Mountains.

\section{REFERRED SPECIMENS}

$S$. delormensis sp. nov. occurs in strata of probable mid-Lochkovian age in the Delorme Formation, in S-1, at $544.1 \mathrm{~m}$ and OLDA527.4 m, in S-2, at $221.0-254.5 \mathrm{~m}$, and in S-3, at $685.8 \mathrm{~m}$, respectively, below the top of the formation. It is represented by $10 \mathrm{~A}, 490 \mathrm{~B}$, and $555 \mathrm{P}$ well-preserved silicified shells. Material illustrated includes paratypes ROM 33266, 33267 from S-1, sample A544.1 m; holotype ROM 33268 and paratypes ROM 33269-33274 from S-2, sample B254.5 m; and paratypes ROM 33275-33278 from S-3, sample S4-685.8 m.

\section{EXTERIOR}

The shell outline is variably transverse to elongate. The lateral profile is biconvex to dorsibiconvex in large shells The maximum width is developed near midlength. The cardinal angles are gently rounded and obtuse. The short hinge line is one-half to one-third of the maximum width. The ventral interarea is apsacline, high, flat, narrow, and triangular, and the beak is slightly incurved. The interarea is cleft medially by an open, triangular delthyrium encompassing an angle of $55^{\circ}-60^{\circ}$. The dorsal interarea is moderately high, flat, and anacline. Ornament consists of fine, hollow, radial costellae numbering 17 to 18 in $5 \mathrm{~mm}$ at a point $10 \mathrm{~mm}$ anterior to the beak. The occasional costella is slightly more robust than its adjoining costellae. The very fine, closely spaced costellae increase anteriorly by bifurcation and implantation. The shell substance is punctate.

\section{PEDICLE VALVE INTERIOR}

The small hinge teeth are triangular in profile and prism-shaped in cross section, and are directed dorsally and inclined anteriorly. The hinge teeth are supported by erect, parallel dental plates whose ventral edges join with the muscle-bounding ridges. Distinct, shallow crural fossettes are located on the medial edge of the hinge teeth. The muscle field is narrow, elongate, subrectangular, and open anteriorly; it is divided medially by a low, rounded, indistinct myophragm that develops over the anterior portion. The myophragm is flanked by a pair of elongate, narrow, shallow depressions, which probably served as the site of attachment of the adductor muscle. In a few shells the myophragm is elongate, and rectangular, approaching the myophragm of $S$. paraprima in shape.
The lateral cavities are deep and open. The whole interior of both valves is crenulated by the impress of fine costellae.

\section{BRACHIAL VALVE INTERIOR}

The small, shallow sockets are bounded posteriorly by the posterior edge of the fulcral plates, basally by the fulcral plates, and anteromedially by the brachiophores. The U-shaped fulcral plates are attached to the underside of the interarea and are sharply curved basally to form a distinct ridge joining the brachiophores. The posterior portions of the sockets are partially covered by the interarea. The thin, bladelike brachiophores are directed anteroventrally; they diverge at approximately $55^{\circ}$ on the ventral surface but are more strongly divergent basally. The brachiophore bases are joined to distinct ridges which outline an elongate, teardrop-shaped muscle field. The muscle field is divided medially by a threadlike myophragm; the posterior and anterior adductors are not delineated. The cardinal process is trilobate, with each lobe made up of U-shaped lamellae. The central blade of the cardinal process narrows posteriorly, projects ventrally, and is directed perpendicular to the hinge line. The flanking lobes are directed ventrolaterally and each has a distinct base. The shell substance is thin in both valves.

\section{DISCUSSION}

$S$. delormensis sp. nov. differs from $S$. paraprima Johnson, Boucot, and Murphy from early Lochkovian strata of central Nevada and older strata of the Delorme Formation by its larger size, the absence of the rectangular, low myophragm in the ventral valve, and the presence of impressed costellae over the entire shell interior. $S$. fragilis Kozlowski, from strata of similar age in Podolia, has a prominent long, narrow, ridgelike myophragm dividing the ventral diductor scars (Kozlowski, 1929, text-fig. 20) and lacks strongly impressed costellae.

\section{Schizophoria sp. 1}

Pl. 8, figs. 22-44

\section{REFERRED SPECIMENS}

Schizophoria sp. 1 occurs in strata of late Lochkovian to early Pragian age in the Delorme Formation, in S-1, at $359.7-536.4 \mathrm{~m}$ and OLDA $493.8 \mathrm{~m}$, and in $\mathrm{S}-2$, at $166.1-182.9 \mathrm{~m}$, respectively, below the top of the formation. Shells are generally poorly preserved despite the thick shell material. Schizophoria sp. 1 is represented by $13 \mathrm{~A}, 425 \mathrm{~B}$, and $322 \mathrm{P}$ silicified shells. Material illustrated includes ROM 33279-33283 from S-1, sample A442.0 m; ROM 33284, 33285 from $S-1$, sample A487.7 m; ROM 33286 from S-1, sample OLDA374.9 m: ROM 33287 from S-1, sample OLDA $388.6 \mathrm{~m}$; and ROM 33288-33293 from S-2, sample BI66.1-182.9 m. 


\section{EXTERIOR}

The shells are of various shapes-some longer than wide, others wider than long-and all are markedly dorsibiconvex in lateral profile. Some shells show a slight development of a ventral sulcus anteriorly. The hinge line is narrow, less than one-half of the maximum shell width, which is attained slightly anterior to midlength. The cardinal angles are rounded and obtuse. The high, apsacline ventral interarea is slightly incurved and is cleft medially by an open delthyrium, which encompasses an angle of approximately $60^{\circ}$. The low, flat dorsal interarea is anacline to orthocline in profile. Ornament consists of fine, closely spaced, hollow costellae, which are too poorly preserved for an accurate rib count. Shells from samples A470.9 m, A487.7 m, and B166.1-182.9 m show a peculiar rib pattern in that they appear to be fascicostellate, with approximately every tenth costella much more prominent than adjacent costellae. This feature seems to be enhanced by incomplete silicification and abrasion. These more prominent costellae may represent the primary costellae and are possibly slightly more resistant to abrasion. A few shells showing a similar pattern were observed in the other collections bearing Schizophoria sp. 1. An ornament of weakly developed concentric growth lines is preserved along the anterior margin of the shells.

\section{PEDICLE VALVE INTERIOR}

The hinge teeth are short, stubby projections and are triangular in profile and in cross section. The dental plates are slightly divergent basally and join with the musclebounding ridges anteriorly. The elongate, oval muscle field is moderately impressed to either side of a prominent rounded medial myophragm. The costellae are impressed along the anterior margin of both valves.

\section{BRACHIAL VALVE INTERIOR}

The wide sockets diverge laterally and are bounded posteriorly by the posterior edge of the U-shaped fulcral plates, basally by the fulcral plates, and anteromedially by the brachiophores. The posterior portions of the sockets are covered by the interarea. The fulcral plate forms a distinct ridge and thickens the brachiophore along the line of junction of the two plates. The bladelike brachiophores are directed anterolaterally and diverge basally. The brachiophore bases are widely divergent and join with the prominent muscle-bounding ridges, which diverge and then converge towards the midline anteriorly. The anterior margin of the elongate, oval muscle field is weakly impressed. The adductor field is divided medially by a prominent rounded to subangular myophragm along its length. The large anterior adductor muscle scars are separated from the small posterior pair by prominent ridges, which diverge anterolaterally from the midline at approximately $70^{\circ}$. The erect, bladelike cardinal process is directed ventrally and tapers posteriorly. The cardinal process is of the same lamellar structure as in other Schizophoria, although the lateral lobes of the process are not as well developed as in $S$. delormensis sp. nov.

\section{DISCUSSION}

Schizophoria sp. 1 is probably a new species; however, it is not formally named here because of the rather poor state of preservation of all the specimens available. Schizophoria sp. 1 bears closest resemblance to $S$. cf. $S$. nevadaensis Merriam but is distinguished by its smaller size, proportionately thicker shell, and less divergent brachiophores, as well as by the size of the myophragm that divides the dorsal adductor muscle scars, the angle of its separation, and the peculiar fascicostellate ribbing that is readily apparent on slightly abraded shells of Schizophoria sp. 1. Schizophoria sp. 1 is the most plastic of the Delorme Schizophoria in morphologic variability. Specimens assigned to ?Protocortezorthis sp. 1 bear some resemblance to Schizophoria sp. 1 but differ from it in their coarser and more angular costae.

\section{Subfamily Draboviinae Havlícek, 1950}

\section{Genus Salopina Boucot, 1960}

\section{TYPE SPECIES}

Orthis lunata J. de C. Sowerby in Murchison, 1839:611, pl. 5, fig. 15.

Salopina submurifer Johnson, Boucot, and Murphy,
$\begin{aligned} & 1973 \\ & \text { Pl. 7, figs. 11, 12; Pl. 8, figs. 45-54; P1. 9, figs. 1-25 }\end{aligned}$

Salopina cf. S. crassiformis_Johnson and Talent, 1967a, pl. 9, figs. 15-27.
Salopina submurifer Johnson, Boucot, and Murphy, 1973:26, pl. 11, figs. 15-23; pl. 12, figs. 1-19.

Salopina submurifer-Johnson, 1973a:1019, pl. 1, figs. 5-11.

Salopina submurifer-Lenz, 1977a:64, pl . 5, figs. 35, 40; pl. 6, figs. 1-26, 28-31.

Salopina submurifer-Jackson, Lenz, and Pedder, 1978, pl. 4, figs. 1-9.

\section{REFERRED SPECIMENS}

$S$. submurifer occurs most commonly in beds of early Lochkovian to early Pragian age in the Delorme 
Formation-in S-1, at 338.3-544.1 $\mathrm{m}$ and OLDA388.6$527.3 \mathrm{~m}$, in $\mathrm{S}-2$, at $225.6-336.8 \mathrm{~m}$, and in $\mathrm{S}-3$, at $560.8-685.8 \mathrm{~m}$, respectively, below the top of the formation and in early Pragian beds of S-4 in the transitional facies of Gabrielse, Blusson, and Roddick (1973). It is represented by $7 \mathrm{~A}, 86 \mathrm{~B}$, and $89 \mathrm{P}$ silicified shells. Material illustrated includes ROM 33294-33298 from S-2, sample B336.8 m; ROM 33299-33301 and ROM 33243 from S-2, sample B225.6 m; ROM 33302-33304 from S-1, sample A536.4 m; ROM 33305 from S-3, sample S4-624.8 m; and ROM 33306-33309 from S-3, sample S4-685.8 m.

\section{DISCUSSION}

S. submurifer is reported from early Gedinnian strata of the Roberts Mountains Formation (Johnson, Boucot, and Murphy, 1973) and from the mid-Lochkovian Windmill Limestone (Johnson, 1973a) in central Nevada. For the most part, specimens referred to $S$. submurifer from the Delorme Formation are of Lochkovian age; although elsewhere some end members of the evolutionary lineage of this species range as high as the early Pragian.

The oldest collection of $S$. submurifer from the Delorme Formation occurs $36.6 \mathrm{~m}$ above a bed containing a Pridolian fauna with Gracianella cryptumbra Johnson and Boucot in section S-2. The Delorme specimens show features characteristic of the species such as the following: a subquadrate outline; a strongly ventribiconvex profile; rounded radial costellae; a short ventral muscle field bounded laterally by divergent dental lamellae; fulcral plates forming the bases of the sockets between the interarea and the prismlike brachiophores; anterior ends of the brachiophores connected to muscle-bounding ridges, which flare laterally and become subparallel anteriorly; a dorsal muscle field divided by a low myophragm, which may or may not extend to the anterior margin; and peripheral crenulations marking the interior of both valves.

The distinction between $S$. submurifer and members of the genus Muriferella is less clear in northwestern Canada than in Nevada, where the two taxa were originally defined. In Nevada the two genera occur at widely separated stratigraphic intervals and appear morphologically distinct because $S$. submurifer has a myophragm whereas $M$. masurskyi Johnson and Talent has a dorsal septum. However, in the Delorme Formation and at Royal Creek (Lenz, 1977a) they are not separated stratigraphically, and within some collections from the Delorme Formation there is a wide range of variation in the dorsal septa and myophragms of the specimens, with some forms assignable to $M$. masurskyi and others to $S$. submurifer. The presence or absence of a dorsal septum is the most distinctive means of separation of the two genera. As for other features, Muriferella tends to be larger and possesses a more angular, fascicostellate ornament and a more pronounced dorsal sulcus; however, these features are not sufficient to warrant generic separation.

$S$. submurifer is regarded as the ancestor of $M$. masurskyi (see Johnson, Boucot, and Murphy, 1973), and it is reasonable that the stratigraphic ranges of the two overlap since it is unlikely that one species would become extinct immediately upon giving rise to the other. $S$. submurifer might better be regarded as a species of Muriferella. The stratigraphic overlap in the evolution of the dorsal septum of $M$. masurskyi and $S$. submurifer makes the two of less value for precise correlation of strata in northwestern Canada. Johnson (1973a:1016) suggested that the transition of $S$. submurifer to Muriferella was a simple orthogenetic one; this should have significant value for strata correlation.

Salopina crassiformis (Kozlowski) is distinguished from $S$. submurifer in that the bounding ridges of the dorsal muscle scars on the former converge anteriorly, whereas those of the latter are subparallel. The range of variation in some of the Delorme collections of $S$. submurifer supports the suggestion of Johnson, Boucot, and Murphy that the differences between these two species may be attributed to intraspecific variation. This problem cannot be resolved since Kozlowski's material is not available for comparison .

There is considerable variation in costellae strength, number, and angularity in any one $S$. submurifer collection. In general, however, ornament becomes more fascicostellate in the stratigraphically younger forms and coarser costae develop on shells of late Lochkovian and early Pragian age. Other morphologic features are relatively constant, suggesting that this intraspecific variation may be related to the changing environments of S-1, S-2, and S-3 in response to shallowing associated with the Tippecanoe Sequence regression of the Early Devonian. This regression reached a maximum in the Pragian (Perry and Lenz, 1979). Lenz (1977a) noted the same trend in the representatives of $S$. submurifer from Royal Creek.

\section{Genus Muriferella Johnson and Talent, 1967b}

\section{TYPE SPECIES}

Muriferella masurskyi Johnson and Talent, 1967b:46, pl. 9, figs. $1-14$.

\section{Muriferella masurskyi Johnson and Talent, 1967b} Pl. 9, figs. 26-67; Pl. 10, figs. $1-12$

Muriferella masurskyi Johnson and Talent, 1967b:46, pl. 9 , figs. $1-14$. 
Muriferella masurskyi-Johnson, 1970:90, pl. 10, figs. $1-17$.

Muriferella sp. cf. M. masurskyi-Ludvigsen, 1970, pl. 1, figs. 10-15.

Muriferella sp.-Lenz, 1973, pl. 1, figs. 11, 12, 15-17. Muriferella aff. M. masurskyi-Lenz, 1977a:65, pl.6, figs. $39-57$.

Salopina sp. 1 Lenz, 1977a:65, pl. 6, figs. 27, 32-38.

Muriferella sp. Jackson, Lenz, and Pedder, 1978, pl. 9, figs. $11-13,17$.

\section{REFERRED SPECIMENS}

M. masurskyi is a common species in the Delorme Formation, in S-1, at $62.5-475.5 \mathrm{~m}$, in S-2, at $105.2-$ $254.5 \mathrm{~m}$, and in $\mathrm{S}-3$, at $53.3-624.8 \mathrm{~m}$, respectively, below the top of the formation. Material illustrated includes ROM 33310-33313 from S-1, sample A442.0 m; ROM 33314-33316 from S-1, sample A62.5-68.6 m; ROM 33318-33320 from S-2, sample B254.5 m; ROM 3332133324 from S-2, sample B 128.6 m; ROM 33317 from S-3, sample S4-624.8 m; ROM 33330, 33331 from S-3, sample S4-513.6-515.1 m; ROM 33332-33335 from S-3, sample S4-161.5-164.9 m; and ROM 33325-33329, 33355 from S-3, sample S4-64.0-65.5 m.

\section{DISCUSSION}

M. masurskyi has previously been reported from the Zlichovian Eurekaspirifer pinyonensis Zone of the Cortez Mountains in central Nevada (Johnson, 1970) and from beds of Lochkovian and Pragian age in northwestern Canada (Ludvigsen, 1970; Lenz, 1977a). The Delorme Formation representatives occur in beds of probable mid-Lochkovian through Zlichovian age, being more common in the Pragian and Zlichovian beds.

The Delorme $M$. masurskyi are on the average smaller than those from central Nevada (about three-quarters of the size). The ventral valve is commonly two to three times as deep as the dorsal valve. The dorsal valve bears a V-shaped sulcus that widens anteriorly. A low dorsal septum is situated on the impress of the sulcus, extends to the anterior margin, and undergoes little change in height over its entire length. The ventral interarea is flat, apsacline, and cleft medially by an open delthyrium which encompasses an angle of about $30^{\circ}$. The ventral muscle platform is short, being confined to the delthyrial cavity. The costellae are rounded in cross section and are more prominent than those of Salopina submurifer Johnson, Boucot, and Murphy.

It is difficult to distinguish $M$. masurskyi from late evolutionary forms of Salopina submurifer, as previously discussed (see p. 33). M. masurskyi is distinguished from $M$. punctata (Talent) by its larger size and its lower and wider dorsal septum. $M$. hillae Chatterton from the Warroo Limestone of late Early Devonian age in New South Wales is distinct in that it bears a much higher, more triangular dorsal septum in lateral profile and is less transverse in outline. Chatterton (1973) suggested that $M$. hillae gave rise to the Middle Devonian genus Vallomyonia. Havlíček (1977a) suggested that Vallomyonia Johnson should be regarded as a member of the genus Prokopia Havlíček; however, the morphology of the septum of Vallomyonia is closer to that of Muriferella. Vallomyonia is not recorded until well into the Eifelian, and to judge from the wide stratigraphic separation of Vallomyonia and $M$. masurskyi in Nevada and from their distinct morphology, Vallomyonia was probably derived from a younger representative of the muriferellid line than M. masurskyi. Savage (1974) illustrated a small species of Muriferella from beds of early Lochkovian age in the Maradana Shale in New South Wales; this again documents an older occurrence of the genus than the type Australian and Nevadan material. Specimens illustrated by Ludvigsen (1970) were compared to $M$. masurskyi but were not regarded as strictly conspecific because of their smaller size. Considering the wide variation in size in $M$. masurskyi populations, the Michelle Formation specimens from the northern Yukon are here assigned to the same species.

In Nevada $M$. masurskyi occurs in the Eurekaspirifer pinyonensis Zone of the Cortez Range in host strata of "black terrigenous limestone facies"' (Johnson, 1970:38). In the Delorme Formation $M$. masurskyi is most abundant in host strata of black, argillaceous limestone. The restricted distribution of $M$. masurskyi in Nevada is likely a result of facies control. In central Nevada it would not be unexpected if Muriferella was found in the more westerly argillaceous facies, in beds older than those of the $E$. pinyonensis Zone.

Family Prokopiidae Wright, 1965 (ex Prokopiinae Wright, 1965:338).

\section{Genus Miniprokopia Havliček, 1971a}

\section{TYPE SPECIES}

Miniprokopia miniconcha Havlíček, 1971a:230, pl. 1, figs. 1, 2,6,7
Miniprokopia havliceki sp. nov.

Pl. 10, figs. 13-41

DIAGNOSIS

A small, evenly costellate, thick-shelled, dorsally sulcate 
Miniprokopia of transversely subrectangular outline, with a thick dorsal septum that increases in height gradually towards the anterior margin.

\section{ETYMOLOGY}

The species is named after Vladimir Havlíček, who first recognized the genus.

\section{REFERRED SPECIMENS}

Miniprokopia havliceki sp. nov. is represented by $2 \mathrm{~A}$, 59B, and 37P well-preserved silicified shells of Zlichovian age from S-1, at $62.5-68.6 \mathrm{~m}$ below the top of the Delorme Formation. Material illustrated includes holotype ROM 33342 and paratypes ROM 33336-33341, 3334333346 from S-1, sample A62.5-68.6 m.

\section{EXTERIOR}

The shells are small, approximately $2.5 \mathrm{~mm}$ wide, transversely subrectangular in outline, and ventribiconvex in profile, with the pedicle valve two to three times as deep as the brachial valve. The cardinal angles are rounded and obtuse. The hinge line is straight and extends over three-quarters of the maximum shell width, which is attained near midlength. The ventral beak is slightly incurved over a flat, high interarea, which is cleft medially by a delthyrium enclosing an angle of $50^{\circ}$. In gerontic shells a delthyrial plate covers the apex of the delthyrium (PI. 10, fig. 36). The dorsal interarea is moderately deep, flat, and anacline. The dorsal valve has a well-developed, $\mathrm{V}$-shaped sulcus, which produces a re-entrant anterior margin. The costellae are relatively strong and rounded; they increase anteriorly by implantation, bifurcation, and occasionally trifurcation. The costellae number approximately 30 along the anterior margin of mature shells. Growth lines are prominent anteriorly on larger shells.

\section{PEDICLE VALVE INTERIOR}

The hinge teeth are short, stubby, triangular thickenings of the interarea wall. The dental plates are very short, commonly welded to the interarea, and strongly divergent laterally. The muscle pad is confined to the delthyrial cavity and is less well developed than in Muriferella or Salopina. The anterior half of the shell is clearly marked by the impress of costellae, which form low, peripheral septa separated by grooves. The shell substance is thick relative to the small shell size.

\section{BRACHIAL VALVE INTERIOR}

The sockets are shallow and widely separated, expand and open laterally, and are bounded posteroventrally by the interarea wall and anteromedially by long, distally pointed, subhorizontal, platelike brachiophores. The brachiophores are welded to the shell wall, forming the bases of the sockets in much the same manner as do the fulcral plates in Schizophoria; they are free of the valve floor for their entire length, extending anteroventrally parallel to the plane of the anacline interarea, curving anteriorly, and developing subparallel crural processes anterior to the sockets. A thick, high dorsal septum develops from a wide median myophragm at about one-third of the length of the myophragm, and gradually increases in height towards the anterior margin. Posteriorly a bilobed cardinal process is located on the median ridge, free of the posterior valve margin. Anteriorly the valve margin is strongly impressed with peripheral radial septa.

\section{DISCUSSION}

Miniprokopia has previously been reported from the Lower and Middle Devonian of Bohemia (Havlíček, 1971a, 1977a). M. havliceki sp. nov. is of early Zlichovian age, which strengthens the affinity of this fauna with the Old World Bohemian genus.

$M$. havliceki sp. nov. is slightly larger than species of Miniprokopia reported from Czechoslovakia, yet smaller than most representatives of Prokopia. The teeth are supported by very short, widely divergent dental plates. The dorsal muscle field is not impressed and the ventral muscle field is only weakly impressed, as in $M$. miniconcha, the type species. The shallow, rounded brachial sulcus is characteristic of the genus. The low peripheral septa of $M$. havliceki sp. nov. and of other described species are separated from the valve margins by a shallow groove. When compared to $M$. miniconcha or $M$. lyriconcha, $M$. havliceki sp. nov. has much more numerous radial costellae, is a slightly larger size, and lacks the ventral hook on the dorsal septum found on $M$. miniconcha or M. lyriconcha Havlíček. The absence of the elevated dorsal muscle platform and the presence of the ventral muscle pad on $M$. havliceki sp. nov. suggest a closer relationship to Miniprokopia than to Prokopia. The dorsal septum on $M$. havliceki sp. nov. is not as high as on Prokopia and other Miniprokopia, and its height increase anteriorly is gentle compared to the logarithmic height increase on the other taxa.

The high, thick, subtriangular septum and the free brachiophores distinguish $M$. havliceki sp. nov. from Salopina and Muriferella. The absence of an elevated dorsal muscle platform distinguishes the species from Mystrophora and Kayserella. The dorsal spectrum of Phragmophora is higher and more triangular and terminates anterior to the valve margin, as opposed to that on $M$. havliceki sp. nov. which extends to the valve margin. Small Cortezorthis are distinguished from $M$. havliceki sp. nov. by the presence of free brachiophores and the absence of the ventral valve carination in the latter. $M$. havliceki sp. nov. occurs with Muriferella masurskyi, and its ventral valves are difficult to distinguish from some valves of $M$ 
masurskyi. Both taxa have somewhat divergent dental plates, although those of $M$. masurskyi are longer and enclose a larger muscle platform.

The Prokopiinae was proposed as a subfamily of the Kayserellidae by Wright (1965); Anderson, Boucot, and Johnson (1969) subsequently placed Kayserella in the family Mystrophoridae. Prokopiinae is raised to the familial level in this study.

\section{Genus Phragmophora Cooper, 1955}

\section{TYPE SPECIES}

Phragmophora schnuri Cooper, 1955:50, pl. 12, figs. 12-26.

\section{Phragmophora cooperi sp. nov. Pl. 10, figs. $42-63$}

\section{DIAGNOSIS}

A small, unequally costellate Phragmophora with an erect ventral beak, which lacks a delthyrial cover, and with a high dorsal median septum, which terminates a very short distance before the anterior margin.

\section{ETYMOLOGY}

The species is named after G. A. Cooper, who proposed the genus.

\section{REFERRED SPECIMENS}

Phragmophora cooperi sp. nov. occurs only in S-1, at 62.5-68.6 $\mathrm{m}$ below the top of the Delorme Formation. It is represented by $1 \mathrm{~A}, 11 \mathrm{~B}$, and $5 \mathrm{P}$ well-preserved silicified specimens in strata of early Zlichovian age. Material illustrated includes holotype ROM 33351 and paratypes ROM 33347-33350, 33352-33353 from sample A62.5-68.6 m

\section{EXTERIOR}

The shells are small, of semioval outline, slightly wider than long, and moderately ventribiconvex in lateral profile. The ventral valve has a very prominent carina to accommodate the high dorsal septum. The dorsal valve bears a shallow, V-shaped sulcus posteriorly; the sulcus rapidly expands laterally and becomes indistinct anteriorly. The anterior commissure has only a small, ventrally directed deflection. The high, flat ventral interarea is catacline to slightly apsacline and cleft by an open delthyrium which encompasses an angle of $30^{\circ}$. The interarea extends over two-thirds of the maximum shell width, which is attained posterior to midlength. The dorsal interarea is flat, low, and of anacline orientation. The costellae are stronger and more pronounced medially; they increase by bifurcation and intercalation. A prominent medial ventral costella marks the pedicle carina. The shell substance is punctate Weakly developed growth lines are visible over the whole shell.

\section{PEDICLE VALVE INTERIOR}

The hinge teeth are short, triangular thickenings of the interarea wall and are directed laterally. The dental plates are very short and are directed anterolaterally; occasionally they are welded to the interarea wall by callus. Weakly developed ridges extend anteromedially from the bases of the dental plates and define the muscle field. At the anterior end of the muscle field is a subrectangular depression that accommodates the highest part of the dorsal septum. The costellae are strongly impressed over the anterior one-quarter of the shell.

\section{BRACHIAL VALVE INTERIOR}

The shallow sockets expand anterolaterally and are covered posteriorly by the interarea. The brachiophores and the shell wall form the floor and the posterior and anterior walls of the sockets. The stout, long brachiophores diverge at approximately $30^{\circ}$, are strongly directed anteroventrally, and taper distally. Some specimens have fulcral plates that form the bases of the sockets, although in most cases the thickening of the brachiophore bases encompasses the fulcral plates. Prominent, subparallel muscle-bounding ridges extend anteriorly from the brachiophore bases to about two-thirds of the length of the shell. The anterior margin of the muscle field merges gently into the valve floor. The muscle field is elevated on a thickened platform whose lateral bounding ridges overhang the valve floor. The muscle field is divided medially by a triangular median septum, which increases in height exponentially from the cardinal process until a maximum height is reached near the anterior margin of the muscle field. The anterior face of the septum is steeply inclined and does not reach the anterior margin of the valve. The apex of the septum is thickened and appears to consist of two plates. The notothyrial platform is marked by two ridges that extend from the brachiophores to the median septum. A bilobed, triangular, stubby, posteriorly tapering cardinal process fills the notothyrial cavity and commonly protrudes above the plane of the interarea. The costellae are strongly impressed over the anterior onequarter of the shell.

\section{DISCUSSION}

The only other reported occurrences of the genus are those of Phragmophora schnuri from beds of Eifelian age in Germany (Cooper, 1955) and Givetian age in the Holy Cross Mountains of Poland (Biernat, 1959). The presence in western North America of this genus of the Old World Realm again displays the high degree of faunal exchange 
that must have existed between northwestern North America and Europe during the Early Devonian.

The Delorme $P$. cooperi sp. nov. represents the oldest-recorded occurrence of the genus. $P$. cooperi sp. nov. differs from $P$. schnuri in lacking a delthyrial cover and in having an erect ventral beak, less divergent, longer brachiophores, and a dorsal septum that terminates closer to the valve margin. Biernat (1959) noted that a delthyrial cover first develops in shells the size of the $P$. cooperi $\mathrm{sp}$. nov. The absence of this feature, therefore, is considered real and not just a function of ontogenetic stage. Biernat (1959) described the radial ornament of mature forms of $P$. schnuri as consisting of costae arranged in fascicules such that one can distinguish the higher, more conspicuous costae from the secondary ones. This feature is readily seen in $P$. cooperi sp. nov. Biernat also noted the presence of a central costa on the ventral valve and of a furrow marking the centre of the dorsal sulcus. All of these are visible in $P$. cooperi sp. nov. (Pl. 10, figs. 49, 51, 59, 63).

\section{Family Mystrophoridae Schuchert and Cooper, 1931}

\section{Genus Mystrophora Kayser, 1871}

\section{TYPE SPECIES}

Orthis areola Quenstedt, 1871:589, pl. 57, fig. 27.

\section{Mystrophora arctica Lenz, 1977a}

Pl. 11, figs. $1-20$

Mystrophora arctica Lenz, 1977a:67, pl. 8, figs. 1-5, 10, 11.

Mystrophora arctica-Perry, 1979, pl. 1, figs. 3-7.

\section{REMARKS}

The taxon is redescribed with better-preserved specimens than those available to Lenz (1977a) from the northern Yukon.

\section{REFERRED SPECIMENS}

$M$. arctica Lenz occurs in beds of Zlichovian age in S-3, at 53.3-507.5 $\mathrm{m}$ below the top of the Delorme Formation. It is represented by $3 \mathrm{~A}, 69 \mathrm{~B}$, and $29 \mathrm{P}$ moderately well preserved silicified shells. Material illustrated includes ROM 33356-33359 from S-3, sample S4-64.0-65.5 m; ROM 33360 from $\mathrm{S}-3$, sample $\mathrm{S} 4-80.8 \mathrm{~m}$; and ROM 33361-33363 from S-3, sample S4-466.3 m.

\section{DIAGNOSIS}

A Mystrophora with an erect to gently incurved ventral beak, numerous costae of unequal strength, and a high, triangular cruralium, and lacking any trace of a ventral septum.

\section{EXTERIOR}

The shells are transversely subrectangular to subpentagonal in outline; mature shells are approximately twice as wide as long. The lateral profile is markedly ventribiconvex with a pedicle valve four or five times as deep as the brachial valve. The hinge line is straight, slightly less than the maximum shell width, which is attained slightly anterior to midlength. The cardinal angles are obtuse and rounded. The ventral interarea is high and steeply apsacline. Mature shells show a greater incurvature of the beak. The dorsal interarea is flat to slightly concave and anacline. The delthyrium is open and triangular, encompasses an angle of $30^{\circ}$, and has a small, apical deltidial plate. The V-shaped dorsal sulcus deepens and widens from the beak to the anterior margin. The anterior margin of the pedicle valve is indented opposite the dorsal sulcus. The low, angular costae increase by bifurcation and intercalation and are of uneven strength. A few prominent growth lines are visible anteriorly.

\section{PEDICLE VALVE INTERIOR}

The short, triangular hinge teeth project parallel to the plane of the interarea. Shallow crural fossettes are developed on the anterior side of the teeth. The short dental plates diverge anteriorly and basally and are joined slightly above the valve floor by a horizontal plate, which rests locally on the valve floor and has a concave anterior margin. The plate extends anteriorly about one-quarter of the length of the delthyrium, is elevated slightly above the valve floor, and commonly bears growth lamellae. The interior of the valve is clearly crenulated by the impress of the costae. A distinct, narrow, depressed lip rims the anterior margin of both valves.

\section{BRACHIAL VALVE INTERIOR}

The deep sockets have the form of laterally directed slits and are bounded posteriorly by the interarea, anteromedially by the brachiophores, and laterally by the fulcral plates. The long brachiophores are triangular in cross section and directed ventrolaterally. The short outer plates of the cruralium join to the anterior edges of the brachiophores. The inner plates of the cruralium are joined to the median septum and to the outer plates of the cruralium. The cruralium is markedly $\mathrm{V}$-shaped and extends over two-thirds of the shell length. It is divided medially by a low median septum and a cardinal process. Lateral to the median septum the floor of the cruralium bears a strong crenulation, which probably represents the 
margin of the adductor muscle scars. The median septum reaches maximum height at the point of termination of the cruralium, then slopes sharply to the anterior margin of the shell. Posteriorly a distinct, laterally directed ridge extends from the brachiophores and outer cruralium plates, merges with the median septum, and forms a knoblike, bilobed cardinal process, which narrows posteriorly.

\section{DISCUSSION}

$M$. arctica Lenz is known from beds of Zlichovian age in the Delorme Formation and from beds of similar age in the Royal Creek area of the northern Yukon. It differs from the type species, $M$. areola (Quenstedt), in lacking a ventral septum and in having a less incurved ventral beak, a wider hinge line, and a weaker crenulation of the cruralium. The presence of a ventral median septum in Mystrophora is prefaced by a question mark in Wright (1965:H339). The specimen from which this septum is described by Cooper (1955, pl. 11, fig. 50) is a scraped calcareous shell, and the septum may be an artificially sculptured feature. No ventral septum is evident in the serial sections of Schuchert and Cooper (1932). Boucot, Johnson, and Talent (1969) re-illustrated specimens of $M$. areola of Cooper (1955) from the Eifelian of Germany, and of Anderson, Boucot, and Johnson (1969) from the Eifelian of Burma; however, no details of internal structures were presented. $M$. arctica has a slightly irregular development of costae and costellae compared to $M$. areola; nevertheless, they are probably closely related.

Genus Kayserella Hall and Clarke, 1892

TYPE SPECIES

Orthis lepida Schnur, 1853:218, pl. 45, fig. 9.

\author{
Kayserella cf. $K$. costatula Lenz, 1977a \\ PI. 11, figs. 21-23
}

Kayserella costatula Lenz, 1977a:66, pl. 7, figs. 41-59. Kayserella sp. Jackson, Lenz, and Pedder, 1978, pl. 11, figs. 17-23.

\section{REFERRED SPECIMEN}

Kayserella cf. $K$. costatula is represented by a single silicified brachial valve (ROM 33364) of Zlichovian age from S-3, at $143.3 \mathrm{~m}$ below the top of the Delorme Formation (sample S4-143.3 m).

\section{DISCUSSION}

$K$. costatula was first described from beds of Pragian age in the Royal Creek area. The Delorme $K$. cf. $K$. costatula is of Zlichovian age, whereas the genus is known only from beds of Eifelian and/or Givetian age in Germany, Poland, Appalachian North America, and Burma (Cooper, 1955; Biernat, 1959; Anderson, Boucot, and Johnson, 1969), and from Frasnian beds of Western Australia (Veevers, 1959). The Delorme occurrence provides a closer stratigraphic link between the older beds bearing Kayserella in the northern Yukon and the younger occurrences of Kayserella elsewhere.

$K$. costatula differs from other described species of the genus in its coarser costation and more extensive, spoon-shaped brachial muscle platform. It is readily distinguished from Mystrophora in having much coarser costation, a more distinct dorsal sulcus, and an adductor platform which rests almost on the valve floor. Skenidioides also has finer ornament and a more elevated dorsal cruralium than $K$. costatula .

\section{Order Pentamerida Schuchert and Cooper \\ Suborder Syntrophiidina Ulrich and Cooper \\ Superfamily Porambonitacea Davidson \\ Family Parastrophinidae Ulrich and Cooper, 1938}

\section{Genus Grayina Boucot, 1975}

TYPE SPECIES

Anastrophia magnifica Kozlowski, 1929:140, text-fig. 42, pl. 4, figs. 14-16.

Grayina magnifica arctica Lenz, 1977a

Pl. 11, figs. 24-45

Grayina magnifica arctica Lenz, 1977a:81, pl. 14, figs. 1, $3-5,7-17$.

\section{REFERRED SPECIMENS}

G. magnifica arctica is not an abundant element in the Delorme Formation faunas, although it is found locally in beds of both late Lochkovian and early Pragian age. It is represented by only $6 \mathrm{~B}$ and $9 \mathrm{P}$ silicified shells from $\mathrm{S}-1$, at 448.1-536.4 $\mathrm{m}$ and OLDA388.6 $\mathrm{m}$, from $\mathrm{S}-2$, at 142.3$225.6 \mathrm{~m}$, and from $\mathrm{S}-3$, at $685.8 \mathrm{~m}$, respectively, below the top of the formation. Material illustrated includes ROM 33369, 33370 from S-1, sample A528.8 m; ROM 33371, 33372 from S-1, sample A448.1 m; ROM 33365, 33377 from S-1, sample OLDA388.6 m; ROM 33367, 33368 
from S-2, sample B225.6 m; and ROM 33366 from S-3, sample $\mathrm{S} 4-685.8 \mathrm{~m}$.

\section{DISCUSSION}

G. magnifica arctica occurs only in beds of Pragian age at Royal Creek, whereas the Delorme occurrences also include Lochkovian strata.

Alate shells of the Anastrophia magnifica species group of Kozlowski (1929) were evaluated by Savage (1971), who separated them from the Anastrophia deflexa species group, which has shorter hinges and more rounded posterior margins. Boucot (1975) proposed the genus Grayina for the alate shells. The G. magnifica arctica representatives were morphologically stable throughout their Lochkovian and early Pragian range in the Delorme Formation. G. magnifica arctica differs from $A$. magnifica Kozlowski (1929) in its more transverse and asymmetric outline. The northern Canadian subspecies is distinguished from G. magnifica australis (Savage, 1971), G. magnifica from central Nevada (Johnson, 1970; Johnson, Boucot, and Murphy, 1973), and G. magnifica from the Altai region in the USSR (Kulkov, 1963) by its more transverse and symmetric outline and greater number of costae. The Delorme taxon is regarded as a geographical subspecies of the Grayina magnifica species group.

The fold and sulcus of $G$. magnifica arctica become much more prominent in later growth stages. The number of costae on the fold and sulcus depends on the growth stage; the lateral costae on these parts often increase by bifurcation, and commonly the increase is asymmetric, occurring only on one side of the shell. Costae on the fold and sulcus may also increase by implantation; flank costae increase by bifurcation near the fold and sulcus. The development of alate cardinal extremities occurs in mature shells

\section{Superfamily Pentameracea M'Coy \\ Family Pentameridae, M'Coy, 1844 \\ Subfamily Pentamerinae M'Coy, 1844}

\section{Genus Conchidium Oehlert, 1887}

\section{TYPE SPECIES}

Anomia bilocularis Hisinger, 1799:285.

\section{Conchidium sp. 1}

PI. 12, figs. 1-26

\section{REFERRED SPECIMENS}

Shells referred to Conchidium sp. 1 are coarsely silicified and commonly the anterior margin is not preserved. They occur in S-6, at $193.5 \mathrm{~m}, \mathrm{~S}-8$, at $131.1 \mathrm{~m}$, and in S-9, at 41.8-67.4 m, respectively, above the base of the Delorme Formation. Material illustrated includes ROM 3338033387 from S-6, sample C47-237.7 m; ROM 33388 from S-8, sample C47-248.4 m; ROM 33379 from S-8, sample S2-0-12.2 m; ROM 33389 from S-9, sample L146.3 m; and ROM 33390-33394 from S-9, sample L166.1$173.7 \mathrm{~m}$.

\section{DISCUSSION}

In the Delorme Formation Conchidium sp. 1 occurs in beds of Ludlovian age at several widely distributed localities. The articulated shell from S-8 was the only representative found at this locality and externally it appears similar to other Conchidium sp. 1, although it may be a Kirkidium (Pl. 12, figs. 1-5). More robust pedicle valves predominate in the silicified specimens from S-6 and S-9. Both small brachial valves from early growth stages and posterior fragments of large, thicker-shelled brachial valves are present. These shells bear welldeveloped brachial processes and clearly belong to Conchidium (see Amsden, Boucot, and Johnson, 1967).

Commonly the ventral beak of Conchidium sp. 1 is erect and protrudes well beyond the dorsal valve, but some shells have incurved ventral beaks. The ventral spondylium is deep, V-shaped, anteriorly elongated, and supported by a median septum over its entire length. Shell ornament consists of rounded radial costae that increase anteriorly by bifurcation and die out on the lateral extremities of the valve. The dorsal valves bear prominent flanges formed by the posterior extensions of the brachial processes. The inner plates are flattened and gently tilted medially; the outer plates diverge slightly towards the shell floor.

Externally the Delorme shells are similar to Conchidium alaskense Kirk and Amsden (1952) of Late Silurian age from southeastern Alaska, although the septum does not support the spondylium over its entire length in the Alaskan species. The Delorme shells are considerably more coarsely ribbed than Pridolian representatives of Conchidium described by Lenz (1977a:86) from the Royal Creek area. In overall morphology they are similar to Conchidium microlocularis Johnson, Boucot, and Murphy (1976) of Ludlovian age from central Nevada; however, the Nevada species is considerably smaller (one-half to one-quarter of the size). 


\section{DISCUSSION}

The family Gypidulidae is represented by a diverse group of shells in the late Lochkovian to early Zlichovian interval at S-1, S-2, and S-3. Even when much rock is dissolved, most collections yield only a few gypidulid shells; moreover these are commonly fragmentary with less diagnostic, more robust posterior parts of the pedicle valves predominating. In western and arctic North America relatively few gypidulids have been described from this time interval. The literature from the USSR on Early Devonian gypidulids is extensive; however, for the most part it describes shells preserved in the calcareous state, and direct comparisons of the internal structures of silicified shells and of serial sections are difficult.

The terminology used in morphologic descriptions of the gypidulids follows Amsden (1964). In faunal lists the commonly occurring designation Gypidula sp. is used as a catch-all term for posterior fragments of ventral valves, and the category possibly includes members of Sieberella and/or Carinagypa that cannot be distinguished from ventral fragments alone. The feature used here to separate Sieberella from Gypidula is the nature of the brachial plates: in Sieberella the plates are in contact initially and then diverge strongly to form a cruralium elevated above the valve floor; in Gypidula the plates are separate initially and grow subparallel. Carinagypa is distinguished from Gypidula in that the former had distinct ledges formed by the brachial processes and the latter has smoothly curving brachial plates. The presence of prominent costae anteriorly on Clorindina is used to separate it from Clorinda.

\section{Subfamily Gypidulinae Schuchert and LeVene, 1929}

\section{Genus Gypidula Hall, 1867}

\section{TYPE SPECIES}

Gypidula typicalis Amsden, 1953:140.

\section{Gypidula pelagica lux Johnson, Boucot, and Murphy, 1973 \\ Pl. 11, figs. 46-53, Text-fig. 4}

Gypidula sp.-McLaren, Norris, and McGregor, 1962, pl. 8, figs. $1-3$.

Gypidula pelagica-Johnson, 1970, pl. 15, figs. 12-15.

Gypidula pelagica lux Johnson, Boucot, and Murphy, 1973:31, pl. 18, figs. 1-18; pl. 19, figs. 1-12.

Gypidula pelagica lux-Lenz, 1977a:85, pl. 15, figs. $39-43 ; \mathrm{pl} .16$, figs. $1-5$.

Gypidula pelagica lux-Jackson, Lenz, and Pedder, 1978, pl. 8, figs. 13-16.

\section{REFERRED SPECIMENS}

$G$. pelagica lux is represented by $32 \mathrm{~A}, 1 \mathrm{~B}$, and $11 \mathrm{P}$ well-preserved calcareous shells from $91.4 \mathrm{~m}$ below the top of the Delorme Formation at Cathedral Mountain in the South Nahanni River area $\left(61^{\circ} 43^{\prime} \mathrm{N}, 125^{\circ} 38^{\prime} \mathrm{W}\right)$ of the District of Mackenzie. A few shells (10B and 12P) from the silicified faunas of early Lochkovian age below the top of the Delorme Formation-from S-1, sample A536.4 m, and from S-2, sample B336.8 m-are tentatively assigned to $G$. pelagica lux. Other possible representatives lack the distinctive anterior margin. Material illustrated includes ROM 33373, 33374 from Cathedral Mountain and ROM 33375 from the same locality, which was serially sectioned.

\section{DISCUSSION}

In the Delorme Formation $G$. pelagica lux is common only in the calcareous faunas at Cathedral Mountain, although it does occur consistently in lower Lochkovian beds. Similarly, at Royal Creek the taxon is not commonly preserved in the silicified faunas (Lenz, 1977a).

$G$. pelagica is an important zonal fossil for the early Lochkovian because of its short stratigraphic range and its common occurrence at geographically widespread localities in the Old World Realm. Characteristic features are the nearly smooth exterior, which on some shells is modified by faint plication of the square ventral fold and by the prominent tonguelike extension of the dorsal sulcus. Bohemian representatives commonly develop an indistinct median furrow in the ventral fold which gently indents the middle of the sulcus tongue. North American representatives from Nevada and from the Delorme Formation at Cathedral Mountain commonly lack or have very weakly developed plications on the fold and suclus. The Nevada and Delorme shells are assigned to $G$. pelagica lux, a subspecies distinguished from the type material by its fewer and less prominent plications and by the strongly developed posterior curvature of its dorsal valve.

A few modifications to the description of $G$. pelagica lux by Johnson, Boucot, and Murphy (1973) are noted here. Some of the Delorme shells develop two or three very faint undulations in the fold and sulcus. The dorsal interior illustrated by Johnson, Boucot, and Murphy appears atypical of $G$. pelagica, to judge from interiors of both silicified and calcareous shells from the Mackenzie Mountains and Royal Creek. Shells of $G$. pelagica lux in northern Canada have developed longer outer plates than 


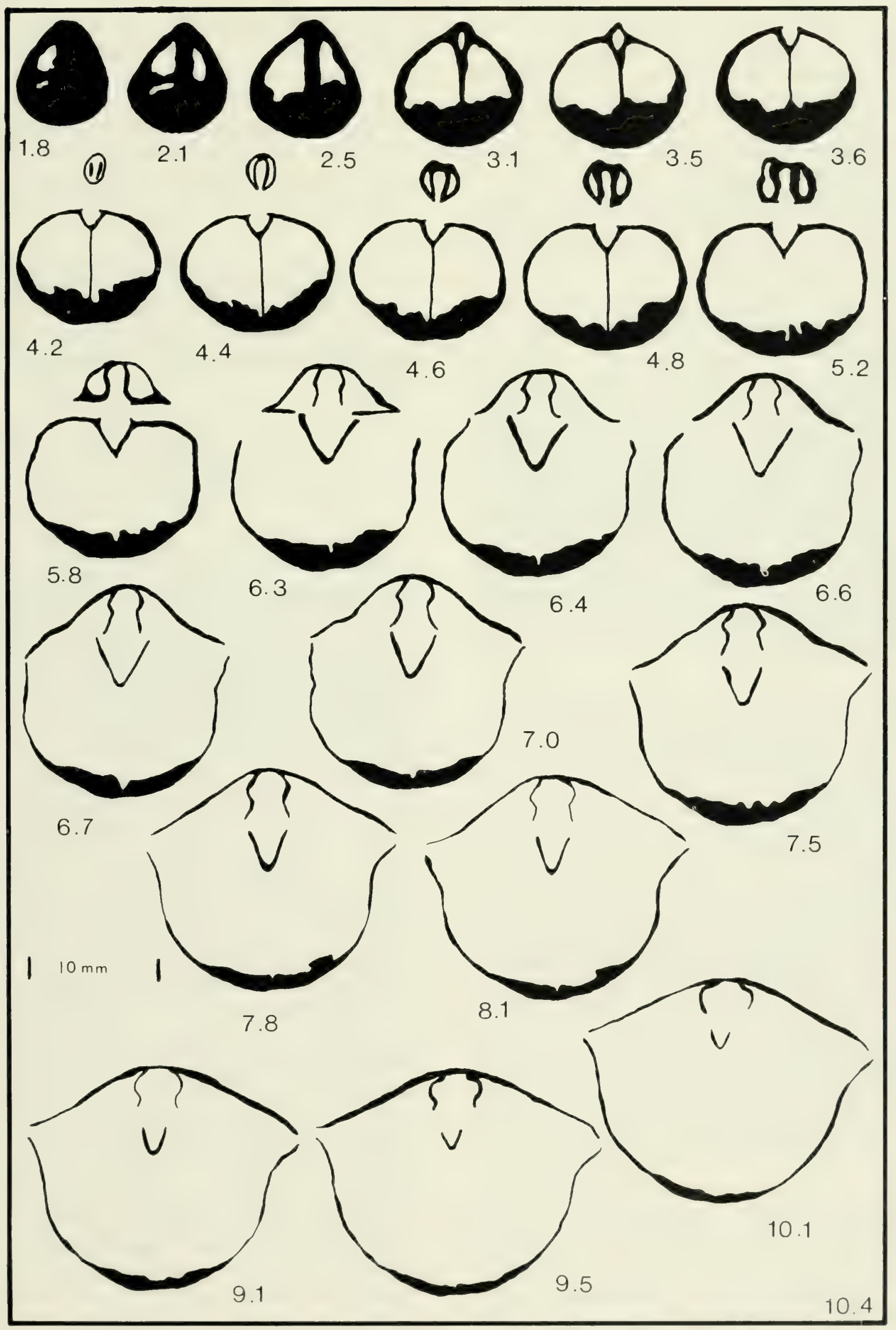

Text-fig. 4 Gypidula pelagica lux Johnson, Boucot, and Murphy

Camera lucida drawings of serial transverse sections; measurements are distances in $\mathrm{mm}$ from pedicle beak; ROM 33375. 
those shown by Johnson, Boucot, and Murphy (1973, pl. 18, figs. 16).

Some of the dorsal valves of the Delorme silicified shells questionably assigned to $G$. pelagica lux develop very low carinae on the most medial extensions of the inner plates (approximately halfway to the valve floor). These carinae appear to represent the posterior extensions of the brachial processes. The carinae are not as prominent as those of Carinagypa careopleura Johnson. The latter species is much larger and lacks even a weakly developed dorsal sulcus and ventral fold.

Johnson, Boucot, and Murphy (1973) commented on the close external affinity of $G$. pelagica lux and Gypidula olga Khodalevich (1939), but they made no definite statement regarding the relationships of the two shells because the specimens of $G$. olga were poorly illustrated. Malygina and Sapelnikov (1973) showed G. olga with prominent high carinae at the junction of the inner and outer plates. These structures are much more pronounced than in any $G$. pelagica lux; the outer plates of $G$. olga converge away from the valve floor, whereas those of $G$. pelagica lux first diverge from the valve floor and then converge medially. The shells illustrated by Malygina and Sapelnikov (1973) have a much more prominent rectangular fold than in $G$. pelagica lux.

\section{Gypidula cf. G. boucoti Lenz, 1977a Pl. 12, figs. 27-33}

Gypidula boucoti Lenz, 1977a:85, pl. 15, figs. 1-14, 18. Gypidula sp. 1 Jackson, Lenz, and Pedder, 1978, pl. 11, figs. $24,25,27-30$.

\section{REFERRED SPECIMENS}

$G$. cf. G. boucoti is represented by $38 \mathrm{~B}$ and $32 \mathrm{P}$ silicified shells that are commonly poorly preserved, often crushed with only the posterior two-thirds identifiable. The specimens are from beds of early Pragian age in S-1, at 272.8-342.9 $\mathrm{m}$ and OLDA278.9 $\mathrm{m}$, and in S-2, at $32.0-128.6 \mathrm{~m}$, respectively, below the top of the Delorme Formation. Material illustrated includes ROM 3339533397 from S-1, sample A342.9 m; and ROM 33398, 33399 from S-1, sample A274.3 m.

\section{DISCUSSION}

$G$. cf. G. boucoti occurs in early Pragian beds of the Delorme Formation and in Pragian beds at Royal Creek (Lenz, 1977a). It is characterized by a large size, a strongly convex pedicle valve, a weakly convex dorsal valve, and weak to moderately strong plications, which develop over the medial part of the shell. The plications increase anteriorly by implantation. Internally the outer plates of the dorsal valve are lyre-shaped in cross section and diverge anteriorly. The ventral spondylium is supported by a prominent median septum, which continues a short distance anterior to the spondylium. A few shells from sample S-1, A432.9 m, develop conjunct Sieberella-type outer plates, although externally they are identical to the other shells. The same feature was observed in the type materials from Royal Creek by Lenz.

Externally the shells are close to Sieberella sieberi, type species of Sieberella (see Barrande, 1879, pl. 26, figs. 25, 30,33 ); however, only a few shells bear the joined outer plates of the type species. G. coeymanensis from the Appalachian Lower Devonian has a similar outline, although its ribs are coarser and its ventral beak has greater curvature (see Bowen, 1967; Anderson and Makurath, 1973).

\section{Gypidula sp. 1}

Pl. 12, figs. 34-44

\section{REFERRED SPECIMENS}

Gypidula sp. 1 is represented by fragmentary silicified shells from beds of early Pragian age in the Delorme Formation, in S-1, at 272.8-338.3 $\mathrm{m}$ and OLDA278.9$374.9 \mathrm{~m}$, and in $\mathrm{S}-2$, at $32.0-39.6 \mathrm{~m}$, respectively, below the top of the formation. Material illustrated includes ROM 33400-33402 from S-1, sample OLDA336.8 m; and ROM 33403-33405 from S-2, sample B32.0 m.

\section{DISCUSSION}

Gypidula sp. 1 occurs in beds of early Pragian age of the Delorme Formation in the Sekwi Anticline and has not as yet been recognized elsewhere. It is characterized by very prominent $\mathrm{V}$-shaped plications which extend from just anterior to the beak and cover the entire shell. The plications increase in number anteriorly in an irregular manner-commonly by bifurcation, although on some shells only by implantation. The pedicle valve is more convex than the brachial. The ventral valve bears a low fold, and the brachial valve a corresponding sulcus. The ventral spondylium is elongate, deep, and supported by a short median septum. The inner plates of the dorsal valve are inclined medially, and a very faint ridge marks the junction of the inner plates and the brachial process. The outer plates curve laterally and then medially to the valve floor. In some shells the brachial apparatus is divided medially by a low myophragm in its anterior half; posteriorly a pair of ridges converge towards the midline at a point well anterior to the apex of the valve forming a structure resembling a cardinal process, the probable site of diductor muscle attachment. A deep, troughlike cavity is situated between the cardinal process and the valve apex .

Gypidula sp. 1 shows some similarity to Carinagypa 
praeloweryi (Johnson) because of the very weak carinae at the junction of the inner and outer plates and the presence of similar, though more abundant and more prominent, plications. The ribbing is similar to that on Sieberella pryiforma Johnson of the Trematospira Zone (Pragian) of central Nevada, but none of the shells assigned to Gypidula sp. 1 has the medially conjunct brachial plates of the other species.

\section{Gypidula cf. G. kayseri (von Peetz, 1901) Pl. 13, figs. 5-16}

?Pentamerus kayseri von Peetz, 1901:377, pl. 3, fig. $8 \mathrm{~A}-\mathrm{C}$.

?Gypidula kayseri-Alekseeva et al., 1970, pl. 3, fig. 14. ?Gypidula cf. G. kayseri-Johnson, 1975a:21, pl. 3, figs. $1-5$.

?Gypidula sp. 1 Lenz, 1977a:84, pl. 15, figs. 15-17, 19-38.

\section{REFERRED SPECIMENS}

Gypidula cf. G. kayseri is represented by $33 \mathrm{~B}$ and $42 \mathrm{P}$ silicified shells from the Delorme Formation-from beds of late Lochkovian age in S-1, at $484.6-493.8 \mathrm{~m}$ and OLDA527.3 m, and beds of late Lochkovian and early Pragian age in S-1, at 128.6-221.0 m, respectively, below the top of the formation. Material illustrated includes ROM 33414-33416 from S-1, sample A484.6 m; ROM 3341033412 from S-2, sample B $128.6 \mathrm{~m}$; and ROM 33413 from S-2, sample B166.1-182.9 m.

\section{DISCUSSION}

Fragmentary remains probably closely related to Gypidula kayseri occur in beds of late Lochkovian and early Pragian age in the Sekwi Anticline area of the western Mackenzie Mountains. The shells are highly variable in the development of coarse plicae. The ventral valve commonly bears a low fold with a $\mathrm{V}$-shaped median furrow bounded by two prominent plications and with two pairs of weaker flank plications. Some shells show only one or two undulose ventral plications. The dorsal valve bears four to six wide, undulose plications, which are sometimes symmetrically positioned such that a dorsal sulcus develops with a medial plication. Internally the ventral spondylium is supported by a median septum which decreases in height to midlength of the shell. The brachial plates extend to about midlength, are lyre-shaped, and diverge slightly anteriorly. In a few shells the brachial plates are medially conjunct, as in Sieberella.

Johnson (1975a) illustrated G. cf. G. kayseri from strata of late Lochkovian age on Cornwallis Island. Lenz (1977a) illustrated a Gypidula from upper Lochkovian and Pragian strata of Royal Creek that is very similar to $G$. cf.
G. kayseri except that it is smaller. Sieberella cf. S. problematica (Barrande) of the late Lochkovian Quadrithyris Zone in central Nevada has fewer and less robust ribs than $G$. cf. G. kayseri. The sieberellid-type dorsal valves found in some Delorme Formation collections may represent a true Sieberella; however, the amount of variation occurring in the degree of convergence of the outer plates of these dorsal valves appears to preclude the affinity with Sieberella.

\section{Gypidula sp. 2}

PI. 13, figs. 17-29

Gypidula sp. Lenz, 1973, pl. 1, figs. 30, 31, 34.

\section{REFERRED SPECIMENS}

Gypidula sp. 2 is represented by 28B and 55P moderately well preserved silicified shells from beds of late Lochkovian age in the western Mackenzie Mountains, in S-1, at $466.3-470.9 \mathrm{~m}$, and in $\mathrm{S}-2$, at $225.6 \mathrm{~m}$, respectively, below the top of the Delorme Formation. Material illustrated includes ROM 33421, 33422 from S-1, sample A466.3 m; ROM 33417-33420 from S-1, sample A470.9; and ROM 33423-33425 from S-2, sample B225.6 m.

\section{DISCUSSION}

This is a very coarsely plicate shell with a more regular disposition of plications than on Gypidula cf. G. kayseri. The ventral valve is two to three times deeper than the dorsal valve and has a moderately incurved beak. The shell bears a ventral fold with three high, rounded to subangular plications. The ventral flanks bear one to three pairs of plications, which decrease in strength laterally. The medial plication of the dorsal fold and the adjacent flank costae do not always initiate at the beak and may not develop until about midlength. The dorsal valve bears a sulcus bounded by two strong plications and divided medially by a slightly more rounded plication. The flanks bear one to two pairs of lateral plications. The ventral interior bears a deep spondylium supported apically by a median septum. The brachial plates are of the common lyre shape but are shorter than in most Gypidula. A few shells show the sieberellid-type outer plates that are almost medially conjunct.

The ribbing pattern on the shells illustrated by Lenz (1973) from the Quadrithyris Zone (late Lochkovian) of Bathurst Island is identical to that on Gypidula sp. 2. The ventral valve from Bathurst Island illustrated by Lenz appears much less elongate, but part of its anterior margin is broken off. Gypidula pseudoacutolobata forma $\propto$ forma of Malygina and Sapelnikov (1973, pl. 24, figs. 1, 2) is close to Gypidula sp. 2 but has an additional plication in the dorsal sulcus. 
Gypidula sp. 3

Pl. 13, figs. $30-36$
?Procerulina sp. 1

Pl. 11, figs. 54, 55

\section{REFERRED SPECIMENS}

Gypidula sp. 3 is represented by 7B and 11P fragmentary silicified shells from beds of Zlichovian age in S-1, at 62.5-68.6 $\mathrm{m}$ below the top of the Delorme Formation, in the western Mackenzie Mountains. Material illustrated includes ROM 33426-33429 from S-1, sample A62.5$68.6 \mathrm{~m}$.

\section{DISCUSSION}

Gypidula sp. 3 is a large, strongly ventribiconvex, and highly multiplicate taxon that occurs locally in Zlichovian strata. The plications are more numerous than on Gypidula sp. 1 and bifurcate infrequently in an irregular manner. The dorsal plications appear higher and less rounded than the ventral plications. The brachial plates have the lyre shape typical of gypidulids and lack carinae. The ventral spondylium is supported by a short medial septum. Neither fold nor sulcus is developed.

\section{Gypidula sp. 4}

Pl. 13, figs. $37-47$

\section{REFERRED SPECIMENS}

Gypidula sp. 4 occurs in S-6, at $204.2 \mathrm{~m}$ above the base of the Delorme Formation in strata of Ludlovian age. It is represented by $16 \mathrm{~B}$ and $42 \mathrm{P}$ fragmentary silicified shells Material illustrated includes ROM 33430-33432 and 33434-33438 from S-6, sample C47-248.4 m.

\section{DISCUSSION}

Gypidula sp. 4 is a Ludlovian taxon with highly plastic external morphology. The ventral valve of Gypidula sp. 4 either is smooth or bears a low fold with a medial furrow or one to four medial plications. The dorsal valve commonly has a poorly developed sulcus with one or two plications. Internally the ventral spondylium is supported apically by a septum which extends a variable distance anteriorly along the valve floor. The brachial plates are long and lyre-shaped.

A few shells bear some resemblance to Gypidula? biloba Johnson from beds of Ludlovian age of the Sevy Dolomite in Nevada, although none of the Delorme shells shows as pronounced a bilobation as illustrated by Johnson and Reso (1964).

\section{Genus Procerulina Andronov, 1961}

\section{TYPE SPECIFS}

Pentamerus acutolobatus procerulus Barrande, 1879:60.

\section{REFERRED SPECIMEN}

?Procerulina sp. 1 is represented by one silicified ventral valve (ROM 33378) from S-3 in beds of probable late Lochkovian age at the base of the Delorme Formation (sample S4-685.8 m).

\section{DISCUSSION}

The genus Procerulina is a coarsely plicate gypidulid with a pair of very strong plications defining the ventral fold. It has previously been reported by Johnson (1975a) from the upper Lochkovian of arctic Canada. The shell has a prominent ventral fold bounded by two high, parallel plications, which extend anteriorly from just anterior to the beak. The valve flanks have two pairs of prominent lateral plications. Coricentric growth lamellae are developed anteriorly. Internally a short, wide spondylium is supported by a short median septum. The shell interior is strongly corrugated by the impress of the plications.

The genus Procerulina typically does not have such well-developed flank plications, and hence this single valve is only tentatively included in the genus.

\section{Genus Sieberella Oehlert, 1887}

\section{TYPE SPECIES}

Pentamerus sieberi von Buch in Barrande, 1847:465, pl. 21 , figs. 1,2 .

Sieberella sp. 1

Pl. 14, figs. $1-4$

\section{REFERRED SPECIMENS}

A few fragmentary shells of Sieberella sp. 1 occur in Lochkovian and/or Pragian beds of the Delorme Formation, in S-1, S-2, and S-3. Material illustrated includes ROM 33442 from S-1, sample A318.5 m; and ROM 33439-33441 from S-1, sample A470.9 m.

\section{DISCUSSION}

Sieberella is poorly represented in the Delorme Formation brachiopod fauna and is recognized only from fragmentary, silicified shells. A specifically indeterminate, strongly plicate Sieberella sp. 2 (not illustrated) is represented by only a few shell fragments in beds of Zlichovian age at S-3. Sieberella sp. 1 is a smooth form occurring in beds of late Lochkovian and/or early Pragian age in S-1, S-2, and S-3. The dorsal valves bear carinae marking the junction of the inner plates and the brachial process. The ventral valves of Sieberella $\mathrm{sp}, 1$ have a spondylium floor that is much more anterodorsally curved than on the associated Gypidula shells. 
Genus Carinagypa Johnson and Ludvigsen, 1972

\section{TYPE SPECIES}

Gypidula loweryi Merriam, 1940:81, pl. 7, fig. 9

?Carinagypa cf. C. careopleura Johnson, 1975a

Pl. 12 , figs. $45-47$; Pl. 13 , figs. $1-4$

\section{REFERRED SPECIMENS}

?Carinagypa cf. C. careopleura is represented by $40 \mathrm{~B}$ and $60 \mathrm{P}$ silicified shells from beds of late Lochkovian and early Pragian age in the Delorme Formation, in S-1, at 233.2-487.7 $\mathrm{m}$ and OLDA278.9-336.8 $\mathrm{m}$, and in S-2, at $128.6 \mathrm{~m}$, respectively, below the top of the formation. Material illustrated includes ROM 33406, 33407 from S-1, sample A442.0 m; and ROM 33408, 33409, 33458 from $\mathrm{S}-1$, sample OLDA336.8 m.

\section{DISCUSSION}

Johnson (1975a) first reported the species from beds of late Lochkovian age on Bathurst Island. By virtue of its morphology and stratigraphic position, $C$. careopleura may be a smooth ancestor of Carinagypa loweryi (Merriam).

Most of the shells are without a fold and sulcus, although a few have a low rectangular ventral fold and an accompanying dorsal sulcus. The shells are ventribiconvex in lateral profile. The ventral spondylium is supported by a median septum, which extends only a short distance anterior to the spondylium. The spondylium is flanked laterally by a dimpled area possibly representing impressions of the gonadal sacs. The brachial plates are lyre-shaped, extend to near midlength of the shell, and diverge slightly anteriorly.

\section{Carinagypa praeloweryi (Johnson, 1970)}

$$
\text { Pl. 14, figs. 8-14 }
$$

Gypidula cf. coeymanensis-Merriam, 1940, pl. 11, fig. 16.

Gypidula praeloweryi Johnson, 1970:97, pl. 15, figs. 1-8.

\section{REFERRED SPECIMENS}

C. praeloweryi is represented by $4 \mathrm{~B}$ and $10 \mathrm{P}$ fragmentary, silicified shells from beds of probable early Zlichovian age in the Delorme Formation, in S-1, at 62.5-68.6 m, and in S-3, at 560.8-573.0 m, respectively, below the top of the formation. Material illustrated includes ROM 33446 from S-1, sample A62.5-68.6 m; and ROM 33444, 33445 from S-3, sample S4-560.8-573.0 m.

\section{DISCUSSION}

C. praeloweryi occurs in strata of late Pragian to Zlichovian age of the Acrospirifer kobehana Zone in central Nevada and in strata of similar age in the Delorme Formation. There is some ambiguity as to the generic affinity of $C$. praeloweryi. It was originally described as essentially a Gypidula loweryi with well-developed radial plications, and with internal structures "essentially as in G. loweryi" (Johnson, 1970:97). The Delorme silicified shells bear out this statement in that low carinae are present where the inner plates and the brachial processes join. After the erection of the genus Carinagypa Johnson and Ludvigsen (1972), Johnson (1974a:817) still assigned the species praeloweryi to the genus Gypidula, probably on the basis of its plicate shell; however, on the basis of its internal structure it is here assigned to Carinagypa.

The Delorme $C$. praeloweryi specimens bear relatively strong radial plications over the anterior three-quarters of the shell. The dorsal interior shows brachial plates very similar to those on C. loweryi (Merriam) and has a weakly developed carina at the junction of the inner plates and the brachial processes. A deposit of shell material on the posteromedial portion of the inner plates slightly restricts the posterior brachial cavity and probably served as the site of diductor muscle attachment, as suggested for $C$. loweryi by Johnson (1970)

\section{Carinagypa cf. C. loweryi (Merriam, 1940) Pl. 14, figs. 5-7}

Pentamerus comis Walcott, 1884:169, pl. 3, fig. 7; pl. 14, figs. $15,15 \mathrm{a}, 15 \mathrm{~b}$; pl. 15, figs. 5, 5a, 5b.

Gypidula loweryi Merriam, 1940:81, pl. 7, fig. 9.

Gypidula loweryi-Cooper, 1944:305, pl. 115, figs. 4, 5.

"Gypidula" loweryi-Gauri and Boucot, 1968:119, pl. 20, fig. 4; pl. 21, fig. 1

Gypidula loweryi-Johnson, 1970:98, pl. 13, figs. 8-17; pl. 14, figs. 1-20.

"Gypidula" loweryi-Ludvigsen, 1970, pl. 1, figs. 16-19.

Carinagypa loweryi-Johnson and Ludvigsen, 1972:128, text-fig. 3.

Carinagypa loweryi?-Perry, Boucot, and Gabrielse, 1981, pl. 1, figs. 25-30.

\section{REFERRED SPECIMENS}

Two silicified dorsal valves are assigned to $C$. cf. $C$ loweryi from S-3, at $466.3 \mathrm{~m}$ below the top of the Delorme Formation. Material illustrated includes ROM 33443 from S-3, sample S4-466.3 m.

\section{DISCUSSION}

C. loweryi is well known in central Nevada from beds of Zlichovian age of the Eurekaspirifer pinyonensis Zone and occurs in a similar stratigraphic position in northwestern Canada. The Delorme $C$. cf. $C$. loweryi specimens are 
poorly preserved; however, the smooth exterior, the brachial-plate development, and the carinate ventral edges of the ribbonlike brachial processes are distinctive. At the posteromedial edges of the inner plates local thickening of shell material probably marks the site of diductor attachment. Similar structures were observed in the Nevada $C$. loweryi. Several of the posterior fragments of pedicle valves identified from the Zlichovian beds of S-3 probably belong to $C$. loweryi; however, this cannot be proven.

\section{Subfamily Clorindinae Rzhonsnitskaıa, in Khalfin, 1956}

\section{Genus Clorinda Barrande, 1879}

\section{TYPE SPECIES}

Clorinda armata Barrande, 1879:109, pl. 119, figs. 1-4.

\section{Clorinda garretti sp. nov.} Pl. 14, figs. 15-27

Clorinda sp. Lenz, 1977a:82, pl. 14, figs. 18-30.

\section{DIAGNOSIS}

A small Clorinda with a very high dorsal fold, a subequally biconvex lateral profile, and a markedly transverse outline.

\section{ETYMOLOGY}

The species is named after Robert Garrett, a geologist with the Geological Survey of Canada.

\section{REFERRED SPECIMENS}

Clorinda garretti sp. nov. occurs in beds of late Lochkovian and possibly earliest Pragian age in the Delorme Formation, in S-1, at $493.8-528.8 \mathrm{~m}$ and OLDA423.7-493.8 $\mathrm{m}$, and in $\mathrm{S}-2$, at $166.1-221.0 \mathrm{~m}$, respectively, below the top of the formation. It is represented by $5 \mathrm{~A}, 33 \mathrm{~B}$, and $51 \mathrm{P}$ well-preserved silicified shells. Material illustrated includes paratypes ROM 33449-33451 from S-1, sample A528.8 m; and holotype ROM 33447 and paratype ROM 33448 from S-2, sample B166.1-182.9 m.

\section{EXTERIOR}

The shells are small $(0.5-1.5 \mathrm{~cm}$ in width) and of a subrhomboid outline. Small shells are strongly extended transversely; larger shells are more equant. The lateral profile varies from equally biconvex to slightly dorsibiconvex. The hinge line is short; maximum shell width is developed near midlength. The pedicle beak is only slightly incurved over the dorsal valve. The interarea is apsacline and cleft by a relatively large, open delthyrium. The ventral valve has a shallow, smoothly concave sulcus over the anterior one-third of the shell; the sulcus curves dorsally to form a long tongue meeting the brachial fold.
The brachial fold develops between the beak and one-quarter of the length, then increases in height and width anteriorly, forming a prominent $\mathrm{V}$-shaped deflection in the anterior commissure. The crest of the fold is gently arched in lateral profile and makes a positive angle of approximately $40^{\circ}$ with the plane of the lateral commissure. Radial ornament is lacking and concentric growth lines are present on only a few shells, where they are weakly developed over the anterior margin.

\section{PEDICLE VALVE INTERIOR}

The teeth are small, fragile projections extending from the anterior junction of the spondylium and the shell wall. The spondylium is a moderately deep, $\mathrm{V}$-shaped structure and extends to about one-fifth of the shell length. The spondylium is supported by a very short receding median septum. The shell interior is devoid of muscle scars.

\section{BRACHIAL VALVE INTERIOR}

The sockets consist of a pair of shallow, anterolaterally directed grooves located between the shell wall and the brachial plates. The brachial plates are not differentiated from true socket plates. The brachial plates are slightly divergent basally and more strongly divergent anteriorly. They are joined to the shell floor over one-quarter of the shell length. The bases of the brachial plates extend a shorter distance anteriorly than do the ventral edges. Along the inner side of each brachial plate is a pair of prominent, medially to ventromedially projecting carinae. These carinae apparently represent the inwardly deflected dorsal and ventral edges of the brachial processes. The shell interior does not have a clearly defined muscle field.

\section{DISCUSSION}

The genus Clorinda is widely distributed in Lower Devonian strata of the Old World Faunal Realm (Kozlowski, 1929; Kulkov, 1963, 1970; Drot, 1969; Lenz 1977a). The Delorme shells are of late Lochkovian and/or earliest Pragian age.

The very high dorsal fold and the small shell size of $C$. garretti sp. nov. distinguish it from other previously described species. Internally the dorsal valves develop a double pair of dorsal carinae, which apparently represent the inwardly deflected dorsal and ventral edges of the 
brachial processes. These features were first described by Drot (1969) for Clorinda aff. C. pseudolinguifera Kozlowski and Clorinda maiderensis Drot, and subsequently by Johnson and Ludvigsen (1972) for the type species, Clorinda armata. In the Delorme shells the brachial processes extend farther anteriorly than either the inner or outer plates.

Clorinda pseudolinguifera Kozlowski (1929) is larger and has a more convex pedicle valve, a lower, more rounded fold, and less divergent brachial plates. C. substantiva Kulkov (1967) has a V-shaped fold and sulcus and prominent growth lines; $C$. exista Kulkov has a more anteriorly flaring fold and sulcus than $C$. garretti sp. nov. C. parva, as illustrated in Kulkov $(1963,1970)$, Alekseeva et al. (1970), and Sapelnikov (1972), is not as strongly biconvex in profile and has much weaker dorsal carinae than $C$. garretti sp. nov.

\section{Genus Clorindina Khodalevich, 1939}

\section{TYPE SPECIES}

Clorindina uralica Khodalevich, 1939:11, pl. 16, figs.

$11 \mathrm{a}-\mathrm{c}$.

\section{Clorindina sp. 1}

Pl. 14, figs. 28-32

\section{REFERRED SPECIMEN}

A single, excellently preserved silicified dorsal valve (ROM 33452) occurs in a bed of early Pragian age in S-1, at OLDA388.6 $\mathrm{m}$ below the top of the Delorme Formation.

\section{DISCUSSION}

Clorindina is known from several localities in Lower and Middle Devonian strata in the USSR; however, it has not previously been reported from North America.

The Delorme shell is characterized by its low convexity (excluding the fold), transversely oval outline, two prominent plications on the fold, and one very much reduced plication with one or two very weakly developed plications lateral to it. Internally the inner plates converge medially, a strong carina develops at the junction of the inner and outer plates, and the outer plates diverge towards the valve floor. The entire brachial-plate system is relatively short. A deep trough separates the inner plates posteromedially and is floored by shell callus. The lower carina that marks the base of the brachial process is present, although it is not well preserved.

\section{Order Strophomenida Öpik \\ Suborder Strophomenoidea Öpik \\ Superfamily Strophomenacea King \\ Family Strophomenidae King, 1846 \\ Subfamily Leptaenoideinae Williams, 1953}

Genus Leptaenisca Beecher, 1890

\section{TYPE SPECIES}

Leptaena concava Hall, 1857:47; Hall, 1859:197, pl. 18, fig. 2

\section{Leptaenisca cf. L. concava (Hall, 1857)}

$$
\text { Pl. 14, figs. 33-44 }
$$

Leptaenisca concava-Cooper, 1944:343, pl. 132, figs. $34,35$.

Leptaenisca concava-Amsden, 1958:80, pl. 5, figs. 10-24, text-fig. 17.

\section{REFERRED SPECIMENS}

Leptaenisca cf. L. concava occurs in lower Pragian strata of the Delorme Formation, in S-1, at OLDA384.0 m, and in $\mathrm{S}-2$, at $105.2 \mathrm{~m}$, respectively, below the top of the formation. It is represented by only $3 \mathrm{~B}$ and $1 \mathrm{P}$ silicified shells. Material illustrated includes ROM 33453-33455 from S-2, sample B $105.2 \mathrm{~m}$; and ROM 33456 from S-1, sample OLDA384.0 m.

\section{DISCUSSION}

Leptaenisca cf. $L$. concava closely resembles the specimens of $L$. concava illustrated by Amsden (1958). Although the external ornament is lacking on the Delorme material, presumably as a result of silicification and possibly of abrasion, the close similarity of the dorsal interiors suggests that the Delorme shells are conspecific with those of Amsden from the Haragan Formation of Oklahoma. The mid-Lochkovian Leptaenisca illustrated by Johnson, Boucot, and Murphy (1973) has less prominent adductor muscle scars and lacks lateral bounding ridges.

Leptaenisca concava has previously been reported from the Haragan Formation of Oklahoma (Amsden, 1958), the Helderberg Limestone of New York (Hall, 1857) and Maryland (Schuchert and Maynard, 1913), the Birdsong Shale of western Tennessee (Dunbar, 1919), and the Bailey Limestone of Missouri (Tansey, 1922). These 
occurrences are in strata of probable mid-Lochkovian age, and all are within the geographic limits of the Appohimchi Faunal Subprovince (Boucot, 1975). Other occurrences of the genus in the Nevada part of the Old World Cordilleran Subprovince are from the $F$ fauna of the Roberts Mountains Formation (mid-Lochkovian, Johnson, 1973a) and from the Quadrithyris and Spinoplasia Zones (late Lochkovian to early Pragian). The Delorme Leptaenisca most closely resembles the Roberts Mountains F fauna specimens. Rather than reflecting a temporal relationship, however, this resemblance is more likely a function of the relative preservation of shells from different localitiesthe $\mathrm{F}$ fauna material is well preserved, whereas that illustrated by Johnson (1970) is very coarsely silicified. Leptaenisca is also known from strata of probable Lochkovian age from Victoria in Australia and from the Baton Formation of New Zealand (Boucot et al., 1966). The Australian specimens show a peculiar split dorsal myophragm rather than the depression developed between the cardinal process and the spiral impressions of the North American representatives. The Australian shells also lack the dorsal breviseptum characteristic of $L$. cf. $L$. concava. The Australian and New Zealand occurrences are of interest in terms of palaeobiogeography since their presence in strata of similar age to the Appalachian occurrences indicates that migration rates of Leptaenisca were relatively rapid.

Lenz (1977a) reported Leptaenisca from Zlichovian strata in the Royal Creek area. The occurrence of brachiopods of Appalachian affinity in the Old World Realm of northwestern Canada is not totally unexpected in strata of early Pragian age since several brachiopod taxa of the Appohimchi Subprovince have been documented from late Lochkovian and early Pragian strata in Nevada (Boucot, Johnson, and Talent, 1969; Johnson, 1971b). Johnson (1971b) could not explain the absence of many of these Appalachian endemics in strata of similar age in northwestern Canada. Subsequent studies by Lenz (1972) documented the presence of another Appalachian genus, Plicoplasia, at Royal Creek, and in the Delorme Formation several further taxa of Appalachian affinity are recorded. The fact that the maximum withdrawal of the epicontinental seas from the craton occurred during the Pragian probably accounts for restriction in the amount of faunal exchange between these geographically widespread localities (Savage, Perry, and Boucot, 1979; Perry and Lenz, 1979). Most of these Appalachian endemic taxa occur in slightly younger strata in northwestern North America than in central Nevada, suggesting slow migration rates between Nevada and northwestern Canada.

\section{Subfamily Leptaeninae Hall and Clarke, 1895}

\section{Genus Leptagonia M'Coy, 1844}

TYPE SPECIES

Producta analoga Phillips, 1836:215.

\section{DISCUSSION}

Silurian and Devonian leptaenid brachiopods have commonly been placed in the genus Leptaena without strict regard to the morphologic character of other members of the subfamily Leptaeninae. Leptagonia has typically been reserved for Carboniferous taxa. Nevertheless, the taxa at hand have a well-defined ventral muscle field, laterally divergent cardinal process lobes, and a prominent dorsal rim, as in Leptagonia. Havlíček (1967) used the presence of the dorsal rim as a feature diagnostic of the genus Lepidoleptaena. However, this feature varies greatly with ontogeny and apparently with substrate type: the dorsal rim is much better developed in mature shells and shells that are markedly geniculate, and it presumably served to elevate the feeding area away from a muddy substrate. Havlíček (1967) proposed the genus Leptaenopoma for shells with a median process between the main cardinal process lobes. This feature was recognized in a few of the smaller-sized shells, and it too seems to record ontogenetic change.

\section{Leptagonia sp.}

Pl. 14, figs. $45-48$

\section{REFERRED SPECIMEN}

One strongly geniculate shell (ROM 33457) with prominent ventrolateral "pouches" is illustrated and is from beds of early Pragian age in S-1, at OLDA370.3 m below the top of the Delorme Formation.

\section{DISCUSSION}

Fragments of Leptagonia are common in several of the Lochkovian and early Pragian collections from the Delorme; however, most are poorly preserved and cannot be identified beyond the generic level. The genus Leptagonia is a common taxon of highly variable morphology throughout much of the Lower Devonian sequence at Royal Creek (Lenz, 1977a). The greatest abundance of Leptagonia is commonly in the argillaceous micritic limestones, suggesting that it was well suited to living on a soft substrate.

The specimen illustrated bears close similarity to Leptagonia sp. 2 of Lenz (1977a), although the Delorme taxon is from younger beds. 


\section{Leptagonia costarugosa sp. nov.}

Pl. 15, figs. $1-12$

Leptaena sp. C Johnson, 1970:105, pl. 16, figs. 5-7. Leptagonia sp. 1 Lenz, 1977a:69, pl. 8, figs. 42, 45-55; pl. 9, figs. 1-20, not figs. 22-24.

Leptagonia sp. Perry, Boucot, and Gabrielse, 1981, pl. 1, figs. 31-38.

\section{DIAGNOSIS}

A Leptagonia with numerous prominent $\mathrm{U}$-shaped rugae of high relief with superimposed fine radial costellae and with clearly differentiated dorsal adductor muscle pairs.

\section{ETYMOLOGY}

The specific name is from the Latin costa-rib, and rugosus - rough, in reference to the pronounced concentric rugae crossed by fine radial ribs.

\section{REFERRED SPECIMENS}

Leptagonia costarugosa sp. nov. occurs in the Delorme Formation-in S-1, at $62.5-68.6 \mathrm{~m}$, and in $\mathrm{S}-2$, at $105.2 \mathrm{~m}$, respectively, below the top of the formationand in the transitional facies of Gabrielse, Blusson, and Roddick (1973) in the western Mackenzie Mountains-in $\mathrm{S}-4$, at $38.1 \mathrm{~m}$ above the top of the Road River Formation. Several fragmentary shells that are probably conspecific with $L$. costarugosa sp. nov. are present throughout the Zlichovian part of S-3. L. costarugosa sp. nov. is represented by $45 \mathrm{~B}$ and 33P well-preserved silicified shells. Material illustrated includes holotype ROM 33459 and paratypes ROM 33460-33463 from S-1, sample A62.5-68.6 m.

\section{EXTERIOR}

The shells are transversely subrectangular in outline, commonly up to $25 \mathrm{~mm}$ in width. The cardinal angles are acute as a result of a slight alation of the posterior margin. The hinge line is long and straight and is commonly the line of maximum shell width; a few shells have not developed any alation and have slightly obtuse cardinal angles, and on these shells the maximum width develops just posterior to midlength. The lateral profile is planoconvex. The ventral interarea is long, low, flat, and apsacline. The dorsal interarea is much shorter, low, flat, and anacline. The deltidial plates cover the apex of the open, subtriangular delthyrium. The apex of the pedicle valve is perforated by a small opening. The shell ornament consists of strongly developed concentric rugae separated by U-shaped interspaces. The rugae and interspaces are crossed by numerous fine, rounded radial costellae, which extend to the anterior margin. Nine to 10 slightly irregular concentric rugae are commonly developed posterior to the line of geniculation. The dorsally directed geniculation is greatest (a $90^{\circ}$ angle) near the midline and decreases laterally. The weak dorsal fold and the ventral sulcus account for the medial deflection of the anterior commissure. In some mature shells the rugae are deflected slightly laterally near the posterior margin because of lateral alation.

\section{PEDICLE VALVE INTERIOR}

The small, anterodorsally directed hinge teeth are knoblike and triangular in cross section. The hinge teeth are supported basally by dental lamellae, which join with high muscle-bounding ridges; the muscle-bounding ridges overhang the valve floor anteriorly and laterally and define a subcircular muscle field, which has a raised anterior margin. The muscle field is divided by a broad raised myophragm with a central threadlike ridge. A pair of anteriorly expanding, triangular diductor muscle scars flank the broad myophragmal structure; a narrow, elongate pair of adductor scars rests on the raised part of the myophragm and is separated by the threadlike ridge. The interior of the shell is crenulated by the impress of the rugae.

\section{BRACHIAL VALVE INTERIOR}

The deep, narrow sockets are located posterolateral to the cardinal process bases, which form the anterior walls of the sockets. The cardinal process lobes are conjunct posterodorsally, broadly divergent anteriorly, directed posteroventrally, and separated by a deep pit. The posterior face of the cardinal process is partially covered by a low, medially cleft chilidium. The posterior adductor muscle field is composed of a pair of strongly posteriorly impressed, slightly elongate, oval areas. The posterior adductors are separated medially by a myophragm formed by the central support of a Y-shaped structure whose distal "arms" extend from the socket plates to the middle of the valve. In some shells the two distal "arms" never join into a central support; instead they consist of a pair of myophragmal structures dividing the muscle field. The posterior adductors are separated from the anterior adductors by a prominent transverse ridge, the anterior pair being situated anteromedially to the posterior pair. The anterior adductors occupy elongate, oval pits; the latter are separated posteriorly by a median pit and anteriorly by a short median breviseptum, which extends a variable distance forwards from the muscle field. A prominent, high peripheral ridge is developed along the line of geniculation. Areas lateral to the visceral disc are highly pustulose. The concentric rugae are impressed only near the anterior and lateral margins.

\section{DISCUSSION}

In Nevada L. costarugosa sp. nov. is common in the Acrospirifer kobehana Zone (late Pragian and early 
Zlichovian), although it is known locally from the younger Eurekaspirifer pinyonensis Zone; as in northern Canada, Leptagonia is common in many Zlichovian fossil collections of the $E$. pinyonensis Zone, but poor preservation prevents specific identification. At Royal Creek Lenz (1977a) recorded $L$. costarugosa sp. nov. from Pragian and Zlichovian strata. Faunas of similar stratigraphic setting in the Mount Lloyd George area of northeastern British Columbia also contain representatives of the species (Perry, Boucot, and Gabrielse, 1981).

L. costarugosa sp. nov, is distinguished from other Leptagonia species by the greater number of concentric rugae and the strongly impressed nature of the dorsal muscle field on this species. Some of the older representa- tives of Lenz's Leptagonia sp. 1 are not included in $L$. costarugosa sp. nov. because their morphology is far closer to the much more transverse shell of the Leptagonia sp. illustrated here (Pl. 14, figs. 45-48). Leptagonia zlichovensis Havlíček from the Zlichov Limestone of the Barrandian has a less impressed dorsal muscle field, fewer rugae, and a more transverse outline than the Delorme taxon. Leptagonia goldfussiana (Barrande) from the Pragian of the Barrandian is much more transversely elongated, has a greater number of concentric rugae of unequal size, and has stronger costellae. These Czechoslovakian representatives of Leptagonia illustrated by Havlíček (1967) appear to be closely related to the shells from the Delorme Formation.

\section{Superfamily Davidsoniacea King Family Schuchertellidae Williams, 1953 Subfamily Schuchertellinae Williams, 1953}

\section{Genus Eoschuchertella Gratsianova, 1974}

\section{TYPE SPECIES}

Eoschuchertella popovi Gratsianova, 1974:83, pl. 13, figs. 1-9.

\section{DISCUSSION}

Gratsianova (1974) proposed Eoschuchertella for shells lacking pseudopunctae and formerly assigned to Schuchertella in open nomenclature. The distinction made by several authoris between Eoschuchertella and Drahanostrophia Havlíček (1967) is not clear. Both are impunctate, but the brachiophores of Drahanostrophia are supposedly straight, widely divergent, and not tied to the shell floor except near the hinge margin. Shells assigned to Drahanostrophia by Lenz (1977a) have curved brachiophores tied to the shell floor near the posterior margin of the shell and are therefore better assigned to Eoschuchertella. Similarly, shells assigned to Drahanostrophia burrenensis Savage (1971) have brachiophores tied to the shell floor, and these shells are very similar to fragmentary early to mid-Lochkovian representatives of Eoschuchertella sp. listed in faunal lists from the Delorme Formation.

The related genus Iridistrophia Havlíček has an open delthyrium and much more prominent dental plates. It is especially common in Lochkovian faunas of the Arctic Archipelago (Smith, 1976a). Only one representative of this genus was recovered from the Delorme Formation, from a Pragian bed below the top of the formation at S-2, sample B128.6 m

On the whole Eoschuchertella is of limited use biostratigraphically because external ornament is the only distinctive shell structure that can be used for comparison.
Shell thickness appears highly variable and seems to reflect the energy level of the depositional environment (thicker shell-higher energy). Within some collections even the external ornament is quite variable; it is necessary, therefore, to compare large collections of several tens of specimens in order to recognize any morphologic variation.

\section{Eoschuchertella cf. E. murphyi (Chatterton, 1973)} Pl. 15, figs. 13-19

Schuchertella murphyi Chatterton, 1973:63, pl. 14, figs. $1-17$.

Eoschuchertella cf. E. murphyi-Perry, 1979, pl. 1, figs. 22-25.

\section{REFERRED SPECIMENS}

The Delorme Formation representatives are from beds of early Zlichovian age in S-1, at 62.5-68.6 m below the top of the formation. The species is represented by $15 \mathrm{~B}$ and 31P well-preserved silicified shells. Material illustrated includes ROM 33464-33467 from S-1, sample A62.5$68.6 \mathrm{~m}$.

\section{DISCUSSION}

The type material of $E$. murphyi is from strata of probable late Zlichovian age in the "Receptaculites" Limestone of New South Wales, whereas the occurrence in the Delorme Formation is possibly of early Zlichovian age. The external ornament of the Delorme and Australian shells is identical with regard to costellae density (6 to 8 per $2.5 \mathrm{~mm}$ at a point $5 \mathrm{~mm}$ anterior to the beak) and costellae insertion. Both shells show the same irregularly developed nodes on the costellae and lack dental lamellae and muscle 
scars. The Australian shells have a bilobed cardinal process, a feature only weakly developed in the Delorme shells. The Eoschuchertella representatives from the Zlichovian of S-3 have finer ornament and a ventral myophragm, and a few bear short dental plates. Eoschuchertella sp. 1 has a much thicker shell than E. murphyi.

\section{Eoschuchertella sp. 1}

Pl. 15, figs. 20-34

\section{REFERRED SPECIMENS}

Eoschuchertella sp. occurs in the Delorme Formation in beds of Pragian age, in S-1, at 330.-338.3 m, and in S-2, at $32.0 \mathrm{~m}$, respectively, below the top of the formation. It is represented by 22B and 19P well-preserved silicified shells. Material illustrated includes ROM 33468-33473 from S-2, sample B32.0 m.

\section{DISCUSSION}

Shells very similar to Eoschuchertella sp. 1 (referred to "Schuchertella" sp. B by Johnson [1970]) occur in the Pragian Spinoplasia and Trematospira Zones in central Nevada. The Delorme material has a thick shell and no dental lamellae; some shells have developed a poorly differentiated bilobed cardinal process, as recorded in the Nevada specimens. The development of dorsal musclebounding ridges and medial myophragms is highly variable in the Delorme shells. The most distinctive feature is the thick shell. A new taxon is not proposed because shell thickness is often a response to the environment, with thicker shells developed in forms living in relatively high energy life zones.

\section{Eoschuchertella sp. 2}

Pl. 15, figs. 35-45

\section{REFERRED SPECIMENS}

The exact distribution and taxonomic limitations of this group are not certain because of the poor preservation of many of the shells. Several hundreds of fragmentary representatives are present in the Lochkovian and early Pragian strata of S-1, S-2, S-3, and S-4. Material illustrated includes ROM 33474-33476 from beds of early Pragian age at S-1, sample A442.0 m; and ROM 33477 , 33478 from strata of late Lochkovian age at S-3, sample S4-685.8 m.

\section{DISCUSSION}

A few finely costellate Eoschuchertella with prominent bilobed cardinal processes are illustrated. The material is not abundant and is often fragmentary, which prevents further identification. It should be noted that the costellae density and size are highly variable among shells from the same collection. Often, prominent ridges support the hinge teeth, but they die out before reaching the valve floor.

\section{Genus Aesopomum Havlíček, 1965}

TYPE SPECIES

Strophomena aesopea Barrande, 1879, pl.92, fig. 4, pl. 133, fig. 2.

\section{Aesopomum sp.}

PI. 16, figs. 1, 2

\section{REFERRED SPECIMEN}

One shell of Zlichovian age (ROM 33480) from S-3, sample S4-176.8 m, is illustrated; other potential members of this species are highly fragmentary and cannot be identified with certainty.

\section{DISCUSSION}

Aesopomum is present in many of the Delorme collections of Lochkovian through Zlichovian age, although it is rarely abundant or well preserved. Aesopomum shells are typically distorted and twisted, and commonly only the posterior part of the shell is preserved. The distorted nature of the shells relates to their attachment mechanism to other shells and the substrate. Aesopomum is strongly reminiscent of Permian orthotetaceans but does not possess pseudopunctae.

Only a few Zlichovian Aesopomum were recovered. They have paired cardinal process lobes that are continuous with the socket ridges as in the early Pragian Aesopomum irregularis sp. nov. The external ornament consists of fine, threadlike costellae separated by deep interspaces and increasing anteriorly by intercalation.

\section{Aesopomum varistriatus Johnson, 1970}

$$
\text { Pl. 16, figs. 3-13 }
$$

Aesopomum varistriatus Johnson, 1970:111, pl. 17, figs . 9-14

Aesopomum varistriatus - Johnson, Boucot, and Murphy, 1973:39, pl. 20, figs. 17-23.

Aesopomum varistriata-Lenz, 1977a:79, pl. 11, figs. $31-35,41,42,45,46$

\section{REFERRED SPECIMENS}

A. varistriatus occurs in the Delorme Formation-in S-1. at 470.9-536.4 $\mathrm{m}$ and OLDA423.7-493.8 m, and in S-2. at $166.1-344.4 \mathrm{~m}$, respectively, below the top of the formation-and in the transitional facies of Gabrielse. Blusson, and Roddick (1973) - in S-11. at $211.5 \mathrm{~m}$ above the top of the Road River Formation. It is represented by 
$21 \mathrm{~B}$ and 12P coarsely silicified shells. Material illustrated includes ROM 33483 from S-2, sample B344.4 m, ROM 33484 , 33485 from S-2, sample B181.4-182.9 m, and ROM 33481,33482 from $\mathrm{S}-11$, sample $211.5 \mathrm{~m}$.

\section{DISCUSSION}

In the Delorme Formation $A$. varistriatus ranges throughout the Lochkovian; at Royal Creek representatives occur in both Lochkovian and Pragian strata, and in central Nevada the species occurs in beds of early Lochkovian age. Johnson (1970) referred a late Lochkovian form from within the Quadrithyris Zone to $A$. cf. A. varistriatus. On this shell the socket ridges and the cardinal process form a more or less continuous structure, whereas $A$. varistriatus has discrete and separate cardinal process lobes and socket plates. The $A$. cf. $A$. varistriatus shell is closely allied to the younger Delorme representatives of $A$. irregularis sp. nov. In the younger collections of $A$. varistriatus the cardinal process shows more tendency to become bilobed with diverging distal lobes and in this respect approaches the morphology of some shells of $A$. irregularis sp. nov.

\section{Aesopomum irregularis sp. nov.}

Pl. 16, figs. 14-30

\section{DIAGNOSIS}

An Aesopomum with the cardinal process and socket plates joined together into a continuous structure. The costellae vary from fine, threadlike structures to coarser, wirelike ones that are often interrupted by irregularities in shell shape.

\section{ETYMOLOGY}

The specific name refers to the irregular nature of the shell shape and costellae size.

\section{REFERRED SPECIMENS}

Aesopomum irregularis sp. nov. occurs in beds of early Pragian age in the Delorme Formation-in S-1, at OLDA336.8 $\mathrm{m}$ and OLDA338.3-385.6 $\mathrm{m}$, and in S-2, at $32.0-80.8 \mathrm{~m}$, respectively, below the top of the formation-and in the transitional facies of Gabrielse, Blusson, and Roddick (1973)-in S-4, at $38.1 \mathrm{~m}$ above the base of the Whittaker Formation. It is represented by 3A, 51B, and 29P coarsely silicified shells. Material illustrated includes paratypes ROM 33486, 33488 and holotype ROM 33487 from S-1, sample A338.3 m; paratype ROM 33489 from S-1, sample $345.9 \mathrm{~m}$; and paratypes ROM 33490-33493 from S-1, sample OLDA336.8 m.

\section{EXTERIOR}

The shell outline is subcircular but often highly distorted. The lateral profile is moderately ventribiconvex with a rounded brachial valve and a conical to subpyramidal pedicle valve. The high, apsacline ventral interarea varies from being planar to being strongly curved anteriorly. The interarea is cleft by a triangular delthyrium, which is covered for one-half to three-quarters of its length by a convex deltidium. Growth lines on the interarea run parallel to the hinge line. Radial ornament consists of costellae of very fine to medium strength, which increase anteriorly by implantation. The costellae are better preserved on the ventral valve. Concentric ornament consists of prominent irregularly developed growth lines.

\section{PEDICLE VALVE INTERIOR}

The hinge teeth are thin to highly thickened cylindrical structures projecting dorsally, parallel to the plane of the interarea. Prominent ridges support the teeth along the lateral edges of the delthyrium but die out before reaching the valve apex. On one shell these ridges develop into prominent anterolaterally divergent dental plates. Some shells bear a low, narrow medial myophragm dividing the muscle field. Muscle scars are preserved only on a few shells; the diductor muscle scars are elongate and completely surround a pair of posteromedially located, elongate, oval adductor muscle scars. Most shells have sufficiently thick shell material that the costae are impressed anteriorly only. No traces of pseudopunctae are preserved on either valve.

\section{BRACHIAL VALVE INTERIOR}

Prominent widely divergent socket plates define deep, triangular sockets. The medial edges of the socket plates are continuous with the cardinal process. Only one shell shows differentiation between the cardinal process and the socket plates. In some shells the cardinal process bears a medial furrow on both the anterior and posterior faces; in others it is highly thickened and forms a dorsally tapering structure, triangular in cross section. The cardinal process is commonly directed either slightly posterior or slightly anterior to the dorsal direction. Some shells develop a distinct, divergent, bilobed distal extremity on the cardinal process. The highly thickened socket plates overhang the valve floor and the posterior parts of the muscle field. The muscle field is impressed only in a few shells. Where present, it is of subcircular outline, is divided medially by a low myophragm, and is restricted to the posterior one-third of the shell.

\section{DISCUSSION}

$A$. irregularis sp. nov. occurs in beds of Pragian age and appears to have been derived from $A$. varistriatus. It is distinguished from $A$. varistriatus by its larger size and the more continuous nature of the structure of its cardinal process and socket plates. A. regularis Lenz has finer, more regular costellae, a more regular external shape, and 
a relatively small cardinal process. Large specimens of $A$. irregularis sp. nov. approach the morphology of $A$. aesopeum, as illustrated by Havlíček (1967) from the Pragian and Zlichovian of the Barrandian.

\section{Family Stropheodontidae Caster, 1939}

\section{Genus Brachyprion Shaler, 1865}

\section{TYPE SPECIES}

Strophomena leda Billings, 1860:55, figs. 2, 3.

\section{“Brachyprion"' sp. 1}

Pl. 15, figs. $46-48$

\section{REFERRED SPECIMEN}

"Brachyprion" sp. 1 is represented by only one fragmentary silicified dorsal valve from beds of Zlichovian age in S-3 below the top of the Delorme Formation (ROM 33479 , sample S4-502.9-507.5 m).

\section{DISCUSSION}

Although the material is closely related to the genus Brachyprion, the cardinalia of this specimen differ from those on a true Brachyprion; however, one specimen is insufficient representation for the erection of a new genus, and so open nomenclature is used.

The shell in question is close to " $B$." mirabilis Johnson, which is described from the late Lochkovian Quadrithyris Zone in Nevada. The Delorme shell bears the same parvicostellate ornament interrupted by concentric rugae (probably better described as the "seersucker" ornament of Caster [1939]) as on the Nevada shells. There are at least eight fine costellae between the more prominent costellae, although they are only recognizable near the anterior margin of the shell. The cardinal process of the Delorme shell is more posteriorly inclined but bears grooves on the posteroventral surfaces of the lobes similar to the grooves on " $B$." mirabilis. The socket ridges are low, widely set apart from the cardinal process, and inclined at about $40^{\circ}$ to the hinge line. The cardinal process is supported by a very low, rounded myophragm; the latter gives rise anteriorly to a pair of subparallel, pustulose brace plates, which are separated medially by a very faint myophragm. The shell interior is marked by the impressed concentric seersucker pattern and pseudopunctae.

\section{Genus Strophonella Hall, 1879}

\section{TYPE SPECIES}

Strophomena semifasciata Hall, 1863:210.
Strophonella sp. 1

Pl. 16, figs. 31-33

\section{REFERRED SPECIMEN}

Strophonella sp. 1 is represented by only one ventral valve from beds of Zlichovian age in S-3, below the top of the Delorme Formation (ROM 33494, sample S4-64.0$65.6 \mathrm{~m})$.

\section{DISCUSSION}

Strophonella sp. 1 is recognized from one large resupinate ventral valve in the Delorme Zlichovian. In the Royal Creek area the genus is sparsely represented in what are interpreted to be carbonates of shallow-water origin (Lenz, 1977a). Perry, Boucot, and Gabrielse (1981) report several fragmentary shells of a similar Strophonella from beds of probable Zlichovian age in northeastern British Columbia. The external ornament is comparable to that of $S$. cf. $S$. punctulifera from the late Pragian Acrospirifer kobehana Zone of central Nevada, although the Delorme shell has a much larger, radially ribbed ventral muscle scar.

The ventral muscle field is large and teardrop-shaped, with well-developed radial ridges. The ventral process is a small protuberance in the apex of the valve. The pseudopunctae are well preserved on the shell interior, and only faint impressions of the costae are visible near the shell periphery. The costae are sharp, V-shaped, and prominent; near the anterior margin they number about 17 in $20 \mathrm{~mm}$.

\section{Genus Mesodouvillina Williams, 1950}

\section{TYPE SPECIES}

Stropheodonta (Brachyprion) subinterstrialis var. seretensis Kozlowski, 1929:96, pl. 4, figs. 1-7, text-figs. 28, 29.

Mesodouvillina sp. 1

Pl. 16, figs. 34-38; Pl. 17, figs. 1, 2

\section{REFERRED SPECIMENS}

Mesodouvillina sp. 1 is represented by $5 \mathrm{~A}$ and $8 \mathrm{~B}$ silicified shells from beds of Zlichovian age at S-3, $64.0-492.3 \mathrm{~m}$ below the top of the Delorme Formation. Material illustrated includes ROM 33495, 33496 from S-3. sample S4-64.0-65.5 m; and ROM 33498 from S-3, sample $\mathrm{S} 4-492.2 \mathrm{~m}$. 


\section{DISCUSSION}

Mesodouvillina sp. 1 occurs in Zlichovian beds in association with Mclearnites cf. $M$. invasor Johnson. Mesodouvillina sp. 1 is distinguished from Mclearnites cf. $M$. invasor by the raised peripheral rim, posteromedially conjunct brace plates, and wider spacing of more prominent costellae on the former species. Mesodouvillina sp. 1 has much finer parvicostellate ornament than either Mesodouvillina delormei sp. nov. or Mesodouvillina cf. M. stelcki; its shell is more planoconvex, its socket ridges are more strongly divergent, and its brace plates are less divergent anteriorly.

\section{Mesodouvillina cf. M. stelcki Lenz, 1977a}

Pl. 16, figs. 39-41; Pl. 17, figs. 3, 4

Mesodouvillina stelcki Lenz, 1977a:73, pl. 12, figs. 1-12. Mesodouvillina sp.-Jackson, Lenz, and Pedder, 1978, pl. 12, figs. $3,4,7-10,12,15$.

\section{REFERRED SPECIMENS}

Mesodouvillina cf. M. stelcki is represented by two poorly preserved, silicified dorsal valves from beds of early Pragian age in S-1, at $436.5 \mathrm{~m}$, and $\mathrm{S}-2$, at $121.9 \mathrm{~m}$, respectively, below the top of the Delorme Formation. Material illustrated includes ROM 33499 from S-1, sample A436.5 m; and ROM 33497 from S-2, sample B121.9 m.

\section{DISCUSSION}

M. stelcki occurs at Royal Creek in the lower part of the Monograptus yukonensis Zone (Pragian). M. cf. M. stelcki has a less regular shape and is more unevenly parvicostellate than the type species $M$. subinterstrialis seretensis. $M$. costatuloides Johnson, Boucot, and Murphy (1973) from the Pridolian of central Nevada is much more strongly costate than the shells from northwestern Canada. On the Delorme shells the raised rim in the dorsal valve near the point of geniculation is slightly more pronounced than on most of the Royal Creek shells. The dorsal muscle field, the distinctly bilobed cardinal process, and the density of the parvicostellate ornament are identical to the type material.

\section{Mesodouvillina delormei sp. nov.} Pl. 17, figs. 5-25

\section{DIAGNOSIS}

A Mesodouvillina with a pedicle tube opening, strongly pustulose brace plates, and a greater density of secondary costellae between the primaries of the brachial valve than on the pedicle valve.

\section{ETYMOLOGY}

The name of the species refers to its widespread occurrence in the Delorme Formation in both the platform-carbonate facies to the east and the carbonates near the regional facies change to the west.

\section{REFERRED SPECIMENS}

Mesodouvillina delormei sp. nov. occurs in S-1, at $528.8 \mathrm{~m}$, in S-2, at $336.8 \mathrm{~m}$, in S-6, at $356.6 \mathrm{~m}$, and in $\mathrm{S}-7$, at $13.7-589.8 \mathrm{~m}$, respectively, below the top of the Delorme Formation in beds ranging in age from early to mid-Lochkovian. It is represented by $100 \mathrm{~A}$ calcareous shells and 107B and 82P fragmentary silicified shells. Material illustrated includes the following shells from S-7: holotype ROM 33504 from sample P7WA2033.3 m; and paratypes ROM 33508-33512 from sample P7WA1731.3 m, ROM 33505-33507 from sample P7WA2033.3 m, and ROM 33500-33502 from sample CH27WA $181.4 \mathrm{~m}$.

\section{EXTERIOR}

The shell is subsemicircular in outline and moderately concavoconvex in lateral profile. The degree of concavity of the dorsal valve increases with size and some large shells are slightly geniculate. The maximum width of the shell is developed either at the hinge line or at midlength, depending on whether or not the posterolateral corners are extended. The low, triangular, apsacline ventral interarea is cleft medially by a narrow, triangular delthyrium, which is covered by a convex pseudodeltidium. The low, subrectangular dorsal interarea is of hypercline orientation. The dorsal margin of the ventral interarea is denticulate. The shell ornament is parvicostellate with five to seven much weaker secondary costellae between the primaries near the anterior margin. Dorsal valves have several more secondary costellae between the major costellae. Smaller shells more consistently develop the "seersucker' (Caster, 1939) ornament of discontinuous concentric rugae (Pl. 17, fig. 20). Primary costellae are more prominent in small shells

\section{PEDICLE VALVE INTERIOR}

The ventral protuberance is a small, low, inverted-Vshaped ridge with its apex touching the inner side of the plate closing the apex of the delthyrium. A small circular pedicle tube extends from a point immediately anterior to the ventral protuberance, posteriorly beneath it, and forms a very small, circular opening at the apex of the delthyrium. The pedicle tube is visible in nearly all shells, although it is apparently atrophied in a few of the larger specimens. The diductor muscle field is subcircular; it is strongly impressed and bounded by distinct ridges posterolaterally but is very weakly impressed anteriorly. A prominent rounded myophragm divides both the adductor and the diductor muscle fields. The adductor muscle scars are small, elongate, oval, and restricted to the posterior 
one-sixth of the diductor field; they are clearly impressed only in large shells. The costellae are weakly impressed posterior to the muscle field.

\section{BRACHIAL VALVE INTERIOR}

The cardinal process lobes are disjunct, subparallel, curved ventroposteriorly, and strongly medially grooved posteroventrally. The low, short socket plates are set well to the side of the cardinal process base and diverge from the hinge line at $25^{\circ}-30^{\circ}$. The subtriangular adductor muscle scars are weakly impressed and are bounded anteriorly by low, rounded ridges, which diverge from the base of the cardinal process at about $60^{\circ}$ to the midline. The cardinal process is supported medially by a low, rounded myophragm, which extends a variable distance anteriorly. The posterior and anterior adductor scars are not differentiated. A pair of slightly anteriorly divergent, strongly pustulose brace plates initiate just anterior to the base of the cardinal process. Brace plates are better preserved in the small shells. The shell interior is covered by the impress of costellae.

\section{DISCUSSION}

Mesodouvillina delormei sp. nov. occurs in the Delorme Formation only in beds of early and mid-Lochkovian age in the eastern shallow-water carbonate facies and in the western carbonate facies near the regional facies change to more basinal sediments. $M$. delormei sp. nov. lacks the strongly corrugated shell of $M$. costatuloides Johnson, Boucot, and Murphy, from the Pridolian of Nevada, and does not have the cordate ventral muscle field of $M$. cf. $M$. varistriata (Conrad), from the Quadrithyris Zone of central Nevada. The muscle scars of $M$. delormei sp. nov. differ from those of the type species, Strophodonta (Brachyprion) subinterstrialis var, seretensis Kozlowski, but the external ornament is quite similar. In none of the published descriptions of Mesodouvillina is a feature similar to the pedicle tube of $M$. delormei sp. nov. described. A new species of Mesodouvillina described by Smith (1976a) from the Lochkovian of the Canadian Arctic is somewhat similar, although the pustules on the brace plates of that species are greatly elongated.

\section{Genus Mclearnites Caster, 1945}

\section{TYPE SPECIES}

Brachyprion mertoni McLearn, 1924:61, pl. 4, figs. 16-18; pl. 28, fig. 12

\section{Mclearnites cf. M. invasor Johnson, 1970} Pl. 17, figs. 26, 27

Mclearnites invasor Johnson, 1970:118, pl. 24, figs. 1-8.

\section{REFERRED SPECIMENS}

Mclearnites of. $M$. invasor is represented in the Delorme collections by one brachial valve (ROM 33513) and one probable pedicle-valve fragment from beds of Zlichovian age in S-3 (sample S4-492.3 m).

\section{DISCUSSION}

In central Nevada $M$. invasor occurs in beds of late Pragian age of the Acrospirifer kobehana Zone, and in the Delorme Formation it occurs in slightly younger beds. The Delorme shell has more prominent brace plates than those illustrated by Johnson (1970). Compared to Mesodouvillina delormei sp. nov., $M$. cf. $M$. invasor has a more prominent dorsal median myophragm, a more planar dorsal valve, and cardinal process lobes that are distinctly separated and are directed ventrally.

\section{Genus Cymostrophia Caster, 1939}

\section{TYPE SPECIES}

Strophomena stephani Barrande, 1848:230, pl. 20, fig. 7 (see Havlíček, 1967:127).

\section{Cymostrophia sp.}

PI. 17, figs. 28, 29

\section{REFERRED SPECIMEN}

Cymostrophia is represented by one pedicle valve (ROM 33514) from beds of early Pragian in S-1, at $330.7 \mathrm{~m}$ below the top of the Delorme Formation (sample A330.7 m)

\section{DISCUSSION}

The Delorme shell is very close to the type species, $C$. stephani, which is known from beds of Pragian age in Bohemia, and from Lower Devonian beds of the Ural, Salair, and Altai mountain ranges of USSR (Havlíček, 1967). A very similar shell from the Pragian Monograptus yukonensis Zone at Royal Creek is referred to $C$. cf. $C$. stephani by Lenz (1977a). Johnson (1975b) illustrated Cymostrophia sp. from Zlichovian beds of the Disappointment Bay Formation from Lowther Island in arctic Canada. This taxon has a very prominent "seersucker" ornament

The Delorme Cymostrophia is highly transverse, $52 \mathrm{~mm}$ wide, and strongly geniculate anteriorly. Externally the radial ornament is parvicostellate and is crossed by discontinuous concentric rugae, which create the "seersucker' pattern (Caster, 1939). Between the primary costellae are very fine capillae. The "seersucker" ornament is not developed on the geniculate trail of the valve; however, the primary costellae are much more 
strongly developed on the trail than elsewhere. The ventral muscle field is large, is subtriangular in outline, and has an arcuate anterior margin strongly scalloped by radial corrugations.

Genus Megastrophia Caster, 1939

\section{TYPE SPECIES}

Strophomena (Strophodonta) concava Hall, 1857:140, fig. 1 .

\section{Megastrophia iddingsi (Merriam, 1940)}

Pl. 18, figs. 1-41

Strophodonta demissa Walcott, 1884:118, pl. 2, figs. 9, 9a, 9b; not Conrad, 1842.

Stropheodonta iddingsi Merriam, 1940:79, pl. 6, fig. 6. Megastrophia iddingsi-Johnson, 1970:122, pl. 26, figs. $1-16$.

Megastrophia n. sp. aff. M. iddingsi-Ludvigsen, 1970 , pl. 1, figs. 20, 21.

Megastrophia iddingsi-Lenz, 1977a:73, pl. 10, figs. 27-33.

Megastrophia iddingsi-Perry, Boucot, and Gabrielse, 1981, pl. 2, figs. 7-22.

Megastrophia iddingsi-Perry, 1979, pl. 1, fig. 20.

\section{REFERRED SPECIMENS}

$M$. iddingsi occurs in S-1, at $62.5-68.6 \mathrm{~m}$, and $\mathrm{S}-3$, at 53.3-507.5 m, respectively, below the top of the Delorme Formation in beds of Zlichovian age. The Delorme $M$. iddingsi is represented by $189 \mathrm{~A}, 230 \mathrm{~B}$, and $823 \mathrm{P}$ excellently preserved silicified shells. Several somewhat aberrant forms are illustrated to show the range of variation within a large sample of a population. Material illustrated includes ROM 33520-33524 from S-1, sample A62.5-68.6 m; ROM 33525, 33527-33534 from S-3, sample S4-143.3 m; ROM 33526 from S-3, sample S4-64.0-65.5 m; and ROM 33535-33539 from S-3, sample $\mathrm{S} 4-176.8 \mathrm{~m}$

\section{DISCUSSION}

In Nevada $M$. iddingsi occurs in the Zlichovian Eurekaspirifer pinyonensis Zone, and in northwestern Canada it occurs in beds of similar age. The Delorme shells of $M$. iddingsi are clearly conspecific with the type material from Nevada, although they show a much greater range of variation in internal structures. The description of the type material fails to show the extent of variation in internal structures because it is based on calcareous shells of which only a limited number of internal moulds could be prepared.
The most diagnostic features of $M$. iddingsi are the subcircular outline and strongly concavoconvex lateral profile. The internal structures of gerontic shells are in many ways close to those of Phragmostrophia; however, the strong angular geniculation in Phragmostrophia is rarely developed in Megastrophia. In Megastrophia the dorsal muscle platform is more elongate, and the anterior muscle scars are more divergent. Yet even though the external shapes of Megastrophia and Phragmostrophia are quite different, Plates 18 and 20 show the close similarity of the musculature and cardinalia of the two genera. Because of these internal similarities, the possibility should be considered that $P$. merriami and $M$. iddingsi are much more closely related than is indicated by their present classification in different families.

The ventral adductor muscle scars on $M$. iddingsi are firmly impressed into the base of the ventral protuberance. In some shells a second, medially grooved ventral protuberance develops between the anterior adductor scars just anterior to the posterior protuberance. In most shells a ridge separates the adductor scars and continues anteriorly to divide the cordate diductor muscle field. The cardinal process lobes project posteroventrally, commonly more posteriorly than in Phragmostrophia. The socket plates are fused to the cardinal process bases and diverge from the hinge line at about $20^{\circ}$. The anterior adductor scars are situated anteromedially to the deeply impressed posterior adductors, are elevated on a medial platform, and diverge anteriorly. On immature shells these divergent ridges are pustulose brace plates. The median septum begins at about midlength of the anterior adductor scars, gradually increases in height to about midlength of the shell, then decreases and disappears well before the anterior margin. The shell surface is pseudopunctate; the anterolateral parts of the shell are crossed by subparallel, shallow grooves, which probably represent the vascular markings.

\section{Megastrophia transitans Johnson, 1970 \\ Pl. 18, figs. $42-48$}

Megastrophia transitans Johnson, 1970:120, pl. 25, figs. $1-19$.

\section{REFERRED SPECIMENS}

$M$. transitans occurs in beds of early Pragian age in S-1, at 436.5-442.0 $\mathrm{m}$ and OLDA416.1 $\mathrm{m}$ below the top of the Delorme Formation. $M$. transitans is not very abundant in the Delorme and is represented by $38 \mathrm{~A}, 1 \mathrm{~B}$, and $6 \mathrm{P}$ well-preserved silicified shells. Material illustrated includes ROM 33540-33543 from S-1, sample A436.5 m.

\section{DISCUSSION}

In Nevada $M$. transitans occurs most commonly in the 
Trematospira Zone, although it does occur in younger beds of the Acrospirifer kobehana Zone and in the upper beds of the Rabbit Hill Limestone at Rabbit Hill in Nevada which probably belong to the older Spinoplasia Zone. The Delorme representatives are confined to beds of early Pragian age.

The Delorme representatives appear to differ from those illustrated from Nevada in having a larger number of secondary costellae between the primary costellae; however, the Nevada shells from the Trematospira Zone clearly show at least five secondary costellae between the primaries. The Delorme ventral valves show the large, cordate diductor muscle scars that surround the posteriorly located, oval adductor scars. Adductor scars are strongly impressed posteriorly and are divided by a low myophragm with a medial furrow. The dorsal interior is known only from a small fragmentary shell but shows cardinal process lobes that project posteriorly and recurve dorsally posterior to the hinge line, as in the Nevada material. $M$. transitans has a thinner shell, is considerably smaller, and has more prominent ornament than $\boldsymbol{M}$. iddingsi.

\section{Genus Strophodonta Hall, 1852}

\section{TYPE SPECIES}

Strophomena demissa Conrad, 1842:258, pl. 14, fig. 14.

\section{Strophodonta sp. 1}

Pl. 17, figs. 35-38

\section{REFERRED SPECIMENS}

Strophodonta sp. 1 is represented by $1 \mathrm{~B}$ and $2 \mathrm{P}$ silicified shells from S-3, at $143.3 \mathrm{~m}$ and 560.8-573.0 $\mathrm{m}$ below the top of the Delorme Formation in strata of Zlichovian age. Material illustrated includes ROM 33518 from S-3, sample S4-143.3 m; and ROM 33519 from S-3, sample S4$560.8-573.0 \mathrm{~m}$.

\section{DISCUSSION}

Strophodonta sp. 1 is distinguished from Strophodonta filicosta Johnson from the Pragian Trematospira Zone of central Nevada by its much larger size, much more prominent ventral muscle field, and more arcuate dorsal brace plates, which are divided by a myophragm. A very similar and probably conspecific taxon occurs in Zlichovian collections from the Eids Formation on southwestern Ellesmere Island (B. Jones, pers. comm., 1978).

The material at hand is too limited for formal description; however, pertinent morphologic features are noted since the taxon may be of biostratigraphic significance. Ventral valve ornament is finely costellate ( 16 costellae in $10 \mathrm{~mm}$ near the anterior margin). The diductor muscle field is large, firmly impressed, and teardropshaped, occupying two-thirds of the shell length and one-half of the width. The narrow, raised, elongate oval adductor scars are separated by a distinct furrow and extend over one-half of the length of the diductor muscle field. A relatively small ventral protuberance is supported by two anteriorly divergent ridges which bound the adductor muscle field posteriorly; short muscle-bounding ridges are joined posteriorly to the interarea. The shell interior is crenulated by the impress of the costellae. The dorsal valve illustrated from S-3, sample S4-143.3 m, is assumed to belong to the taxon because of its similar external ornament and size. The posteroventrally divergent cardinal process lobes are flanked laterally by other, widely divergent cardinal process lobes; these in turn are flanked laterally by widely divergent socket plates and muscle-bounding ridges. The cardinal process is supported anteromedially by a rounded myophragm, which tapers and disappears a short distance anterior to it but which re-appears at about two-thirds of the shell length. The posterior adductor muscle scars are moderately impressed. The anterior adductor scars adjoin arcuate, pustulose brace plates, which extend to one-half of the length of the shell.

\section{Strophodonta sp. 2}

Pl. 17, figs. 30-34

\section{REFERRED SPECIMENS}

Strophodonta sp. 2 is represented by $2 \mathrm{~B}$ and $2 \mathrm{P}$ moderately well preserved silicified shell fragments from beds of early Pragian age in S-1, at $442.0 \mathrm{~m}$ below the top of the Delorme Formation. Material illustrated includes ROM 33515-33517 from S-1, sample A442.0 m.

\section{DISCUSSION}

The shells are not complete enough for formal description, but because they may be of biostratigraphic significance, they are illustrated here, and pertinent features are noted.

The shells are subsemicircular in outline and planoconvex in lateral profile. Shell ornament is poorly preserved but appears to be finely multicostellate. The interareas of both valves are strongly denticulated adjacent to the line of commissure over the medial two-thirds of the shells. The ventral diductor muscle field is large and strongly impressed and is semicircular in outline with a squared-off anterior margin. The diductor field completely encloses the distinct, elongate, oval adductor scars, which are situated posteriorly, immediately anterior to the ventral protuberance. The diductor field is weakly radially striated anterolaterally. A prominent myophragm extends anteriorly from the adductor muscle field and divides the diductor field. The costellae are impressed on the shell 
periphery. The dorsal valve has strong, widely set apart, elongate cardinal process lobes projecting slightly posterior to the ventral direction. Prominent socket ridges are set close to the cardinal process bases but are disjunct from them and diverge at about $40^{\circ}$ from the hinge line. The anterior adductor scars are large, deeply impressed, and delineated laterally by prominent muscle-bounding ridges. The anterior adductors are situated medially, slightly anterior to the posterior adductors, and consist of elongate, narrow impressions bounded laterally by narrow, slightly divergent, pustulose brace plates.

\section{Family Leptostrophiidae Caster, 1939}

\section{Genus Leptostrophia Hall and Clarke, 1892}

\section{TYPE SPECIES}

Strophomena (Strophodonta) magnifica Hall, 1857:54.

\section{Leptostrophia magna sp. nov.} Pl. 19, figs. 1-17

Leptostrophia? sp. D?—Johnson, 1970:128, pl. 29, fig. 9.

\section{DIAGNOSIS}

A large Leptostrophia with fine costellate ornament, weakly developed concentric rugae, and strong radial ridges developed in the ventral diductor muscle field.

\section{ETYMOLOGY}

The specific name is from the Latin magna-large, in reference to the very large size of the shell.

\section{REFERRED SPECIMENS}

Leptostrophia magna sp. nov. occurs in beds of Zlichovian age in S-3, at $36.6-507.5 \mathrm{~m}$ below the top of the Delorme Formation. It is represented by $78 \mathrm{~A}, 177 \mathrm{~B}$, and $252 \mathrm{P}$ silicified shells. The shells are thin relative to their large size and only the posterior part of the brachial valve is commonly preserved. Material illustrated includes paratype ROM 33549 from S-3, sample S4-100.6; holotype ROM 33544 and paratypes ROM 33545, 33546 from S-3, sample S4-176.8 m; paratypes ROM 33547, 33548 from S-3, sample S4-257.6 m; and paratypes ROM 3355033552 from S-3, sample S4-502.9-507.5 m.

\section{EXTERIOR}

The species is very large (up to $60 \mathrm{~mm}$ in width). The shell outline is subsemicircular. The lateral profile is planoconvex, with the pedicle valve only gently convex. The hinge line is straight and marks the point of maximum shell width, although the posterolateral corners are often broken off. The ventral interarea is low and apsacline, whereas the dorsal interarea is very low to nonexistent and is steeply anacline. Both interareas are denticulate along their entire width. The ventral interareas of small shells bear a narrow triangular delthyrium covered by a convex pseudodeltidium. The pseudodeltidium was not observed in large shells. The external ornament consists of very poorly preserved, fine, rounded radial costellae. Some small shells appear to have a pseudoparvicostellate ornament of relatively widely spaced primary costellae with apparently smooth intervening areas. Poorly preserved concentric rugae are visible on some shells. The shell substance is thin, although some very large shells are relatively thickened posteriorly.

\section{PEDICLE VALVE INTERIOR}

The ventral protuberance is clearly developed only in large shells, where it is small and ridgelike. The large, triangular diductor muscle field extends beyond midlength of the shell, is strongly impressed posteriorly but weakly impressed anteriorly, and is radially divided by prominent ridges. The posterolateral muscle-bounding ridges overhang the muscle field distinctly. The adductor muscle scars are confined to the posterior one-quarter of the diductor field, which is situated immediately anterior to the ventral protuberance on an elevated platform. The adductor scars are divided medially by a low myophragm that continues to the anterior edge of the diductor field. The interiors of the shells are covered by pseudopunctae, and the costellae are weakly impressed in a few of the thinner shells.

\section{BRACHIAL VALVE INTERIOR}

In small shells the cardinal process consists of two subparallel, platelike, posteriorly grooved lobes, whereas in large shells the lobes are slightly divergent and strongly grooved ventroposteriorly. The cardinal process lobes are flanked by socket ridges that diverge at approximately $40^{\circ}$ to the hinge line. Anteriorly the base of the cardinal process is supported by a low, rounded median myophragm which divides the adductor muscle field. The adductor muscle field is bounded posterolaterally by prominent muscle-bounding ridges that diverge from the myophragm at approximately $45^{\circ}$ to it and become subparallel anteriorly. The posterior and anterior adductors are not differentiated, and the anterior margin of the adductor muscle field is indistinct. 


\section{DISCUSSION}

The ventral valve of $L$. magna sp. nov. appears identical to that of Leptostrophia? sp. D? of Johnson (1970) from the Eurekaspirifer pinyonensis Zone of central Nevada. Leptostrophia sp. D from the Acrospirifer kobehana Zone of central Nevada has much stronger radial ornament and less prominent radial grooving of the ventral diductor muscle field. L. explanata (Sowerby), illustrated by Jahnke (1971) from beds of Zlichovian age of the Erbslochgrauwacke in the Harz Mountains in Germany, is probably closely related to the Delorme $L$. magna sp. nov. Other Leptostrophia identified from the Delorme Formation are very fragmentary, poorly preserved shells, and certainly not all are conspecific with $L$. magna sp. nov.

\section{Family Pholidostrophiidae Stainbrook, 1943}

\section{Genus Phragmostrophia Harper, Johnson, and Boucot, 1967}

\section{TYPE SPECIES}

Phragmostrophia merriami Harper, Johnson, and Boucot, 1967:430, pl. 7, figs. 5-8; pl. 8, figs. 4, 5.

\section{Phragmostrophia merriami Harper, Johnson, and Boucot, 1967 \\ Pl. 20, figs. 1-31}

Strophodonta calvini Walcott, 1884:122, pl. 13, fig. 6; not Miller, 1883.

Phragmostrophia merriami Harper, Johnson, and Boucot, 1967:430, pl. 7, figs. 5-8; pl. 8, figs. 4, 5.

Phragmostrophia sp. aff. P. merriami Harper, Johnson, and Boucot, 1967, pl. 8, fig. 1.

Phragmostrophia sp. Harper, Johnson, and Boucot, 1967, pl. 8, figs. 6-9.

Phragmostrophia sp.-Ludvigsen, 1970, pl. 2, figs. 9-12.

Phragmostrophia merriami-Johnson, 1970:131, pl. 26, fig. 17; pl. 27, figs. 1-20.

Phragmostrophia aff. P. merriami-Perry, Klapper, and Lenz, 1974:1070, pl. 1, figs. 26-32.

Phragmostrophia cf. P. merriami-Johnson, 1975b:952, pl. 1, figs. 1-8.

Phragmostrophia cf. P. merriami-Lenz, 1977a:77, pl. 11 , figs. 13-27.

Phragmostrophia merriami-Perry, Boucot, and Gabrielse, 1981 , pl. 2, fig. 24.

Phragmostrophia merriami-Perry, 1979, pl. 1, figs. $17-19,21$.

\section{REFERRED SPECIMENS}

$P$. merriami occurs in S-1, at 7.6-233.2 $\mathrm{m}$, and in S-3, at 53.3-573.0 m, respectively, below the top of the Delorme Formation in beds of late Pragian and Zlichovian age. It is represented by 229A, 307B, and 982P well-preserved silicified shells. Material illustrated includes ROM 33562 , 33563 from S-1, sample A62.5-68.6 m; ROM3356433566 from S-3, sample S4-64.0-65.5 m; ROM3356733571 from S-3, sample S4-143.3 m; ROM 33572, 33573 from S-3, sample S4-161.5-164.6 m; ROM 33574-33577 from S-3, sample S4-449.6 m; and ROM 33578, 33579 from sample S-3, S4-560.8-573.0.

\section{DISCUSSION}

$P$. merriami is a common taxon in the Eurekaspirifer pinyonensis Zone of central Nevada and has been recovered from one collection from the Acrospirifer kobehana Zone. Shells from beds of late Zlichovian age of the Ogilvie Formation in the northern Yukon fall within the range of variation shown by the large silicified collections of $P$. merriami from the Delorme Formation.

Unfortunately the description of the type material of Pragmostrophia fails to show the extent of the range of variation in internal structures within the genus because it was based on calcareous shells and only a limited number of internal moulds could be prepared. Some of the Delorme shells assigned to $P$. merriami are clearly conspecific with the type material, although other shells from the same collection show a considerable range of variation in dorsal internal structures. The continuous range of morphology suggests that the Delorme shells do belong to $P$. merriami and that the species has a more variable brachial interior than originally described. The numerous illustrations on Plate 20 show this variation.

The shells illustrated by Harper, Johnson, and Boucot (1967) as $P$. merriami or some closely related taxonomic designation are considerably smaller in overall size than the Delorme shells ( 40 to 50 per cent). The ventral valve is not always strongly convex; often its convexity is limited to the geniculate trail, which always bears at least a slight posterior indentation. The body cavity is not large in most shells. The socket plates are sometimes fused to the cardinal process lobes by secondary shell thickening in larger shells but are disjunct in small shells. The cardinal 
process lobes are medially grooved distally. The dorsal anterior adductor scars are situated medially and slightly anterior to the posterior scars and are not always clearly impressed. The muscle platform is variably developed with an anteromedial pit being well developed only in small shells. The breviseptum increases in height anteriorly. The brachial ridges are situated anterolaterally in relation to the muscle platform and are clearly developed only in some shells. The height of the peripheral ridge is highly variable, although it is always greater near the junction with the breviseptum. The geniculate trail is crossed by subparallel grooves, which probably reflect the vascular system.

\section{Phragmostrophia mucronata Lenz, 1977a} Pl. 20, figs. 32-43

Phragmostrophia mucronata Lenz, 1977a:76, pl. 11, figs. 1-12.

Phragmostrophia sp. Jackson, Lenz, and Pedder, 1978, pl. 9, figs. $15,16,18-21,26$.

\section{REFERRED SPECIMENS}

Phragmostrophia mucronata occurs in strata of early Pragian age in the Delorme Formation-in S-1, at 321.6-448.1 $\mathrm{m}$ and OLDA301.8-388.6 $\mathrm{m}$, and in S-2, at $105.2-121.9 \mathrm{~m}$, respectively, below the top of the formation-and in the transitional facies of Gabrielse, Blusson, and Roddick (1973) — in S-4, at $38.1 \mathrm{~m}$ above the base of the Road River Formation. The shells commonly occur as articulated specimens, and dorsal interiors are not common. The Delorme material is represented by $175 \mathrm{~A}, 16 \mathrm{~B}$, and $83 \mathrm{P}$ well-preserved silicified shells. Material illustrated includes ROM 33580 from S-1, sample A321.6; ROM 33583-33586 from S-1, sample A436.5 m; and ROM 33581, 33582 from S-1, sample A442.0 m.

\section{DISCUSSION}

The same species occurs in beds of early Pragian age at Royal Creek. $P$. mucronata is clearly the ancestor of $P$. merriami. Morphologic structures of $P$. mucronata differ only slightly from those of small shells of $P$. merriami: the former species has a less extensive dorsal muscle platform, more anterior elongation of the anterior adductor muscle scars, and a less well developed dorsal breviseptum, and lacks a prominent ventral protuberance. $P$. mucronata is distinguished externally from similar-sized shells of Megastrophia transitans by its smoothly parvicostellate ornament, compared with the crest-and-furrow parvicostellate ornament of $M$. transitans. Internally the dorsal valve of $M$. transitans lacks the muscle platform, the angular geniculation, and the anteromedial ridge of $P$. mucronata.

\section{Genus Parapholidostrophia Johnson, 1971a}

\section{TYPE SPECIES}

Parapholidostrophia harperi Johnson, 1971a:310, pl. 39, figs. $1-18$.

\section{Parapholidostrophia prima sp. nov.} Pl. 19, figs. 18-31

\section{DIAGNOSIS}

A thick-shelled Parapholidostrophia with a prominent stout cardinal process, a dorsal muscle platform, and a variably developed muscle-pad system in the ventral valve.

\section{ETYMOLOGY}

The specific name is from the Latin prima-first, in reference to this being the oldest named representative of the genus.

\section{REFERRED SPECIMENS}

Parapholidostrophia prima sp. nov. occurs in S-3, at 176.8-519.7 $\mathrm{m}$ below the top of the Delorme Formation in beds of Zlichovian age. It is represented by $55 \mathrm{~A}, 52 \mathrm{~B}$, and 66P excellently preserved silicified shells. Material illustrated includes paratypes ROM 33553, 33554, 33556-33558, and holotype ROM 33555 from S-3, sample S4-519.7 m; and paratypes ROM 33559-33561 from S-3, sample S4-176.8 m.

\section{EXTERIOR}

The shells are large (commonly $35 \mathrm{~mm}$ in width) and have a subsemicircular outline and a planoconvex lateral profile. The ventral valve is of low convexity and has essentially flat flanks extending from the ventral beak. The long, straight hinge line marks the point of maximum shell width. The cardinal angles are acute to slightly auriculate. The low, flat ventral interarea is broadly triangular and apsacline. The narrow, triangular delthyrium is completely closed by a gently convex pseudodeltidium. The dorsal interarea is wide, low, flat, and slightly hypercline. Both interareas are smooth except for a denticulate flange along the medial two-thirds of the shell adjacent to the line of commissure. The external ornament is parvicostellate with strong primary costellae and with at least six very fine costellae intervening between each primary. The costellae are more strongly developed anteriorly. The concentric ornament consists of very weak growth lines.

\section{PEDICLE VALVE INTERIOR}

The internal flanges are denticulate over the medial two-thirds of the shell with longer denticulations near the midline. The hinge teeth and dental lamellae are markedly 
thickened, blunt, and triangular in cross section, and have well-developed umbonal cavities lateral to them. The muscle field expands anteriorly and has an arcuate, bilobate, anteriorly convex margin. On the whole the shape of the muscle field is quite variable, sometimes with a scalloped anterior margin and radial grooves. The muscle field is one-third to one-half of the shell length and is bounded by distinct muscle-bounding ridges. The ventral protuberance is a triangular to bilobed, knoblike structure joined to the interarea by a prominent medial ridge. A low, rounded medial myophragm extends anteriorly from the ventral protuberance and may develop one or two further knoblike structures anterior to that protuberance. The adductor muscle scars are narrow, subparallel, elongate, oval structures and may be elevated on the anterior knoblike structures. The anterior and posterior adductor muscle scars are not clearly differentiated. The pseudopunctate shell structure is evident in strongly pustulose areas anterolateral to the muscle field, but the flanks of the shell are more weakly pustulose. The anterior and lateral brims of the shell are flat and bear subparallel, weakly impressed vascular markings.

\section{BRACHIAL VALVE INTERIOR}

The internal denticulate flange has the form of a comblike ridge, which expands slightly laterally along the medial portion of the posterior margin. The deep, wide sockets expand laterally. The cardinal process lobes are stout and are directed ventrally (in some cases slightly ventrolaterally). The thick, strong socket plates are attached to the cardinal process lobes and form an angle of about $30^{\circ}$ with the hinge line. The adductor muscle scars are strongly impressed posterolaterally against the socket ridges. The posterior adductors are anterolaterally elongate and oval in shape and are raised on an elevated platform. The posterior adductors are subdivided by a rounded medial myophragm, which extends a short distance anterior from the cardinal process. A shallow, elongate, oval pit separates the anterior end of the myophragm from a prominent, high, short breviseptum, which extends variably from one-half to two-thirds of the shell length. The posterior adductor impressions are indistinct but probably occupied a short, oval area flanking the medial pit. The flanks of the muscle platform are strongly sloping anterolaterally and are strongly pustulose compared to the remainder of the shell. A low, flat peripheral margin is developed posterior to the anterior margin and is crossed by shallow, subparallel grooves of the vascular system.

\section{DISCUSSION}

The type species of Parapholidostrophia occurs in the Warrenella kirki Zone of probable late Eifelian age in central Nevada. Johnson (1971a) reported a smaller, thinner-shelled species of Parapholidostrophia from beds of Zlichovian age on Bathurst Island. P. prima sp. nov. is distinguished from the type species by the stouter cardinal process and socket ridges, the development of a dorsal muscle platform, and the variable muscle-pad development in the ventral valve. The shell from the Michelle Formation in the northern Yukon that was assigned to ?Megastrophia sp. nov. by Ludvigsen (1970) is in many ways reminiscent of $P$. prima sp. nov., although it is distinguished from the latter by its concave pseudodeltidium, much less massive socket plates, and less developed dorsal muscle platform.

Johnson (1971a) suggested that Parapholidostrophia belongs to the group of pholidostrophiids that includes Mesopholidostrophia and Pholidostrophia, which are characterized by a thin body cavity and a semicircular outline, as opposed to the other group, which includes Teichostrophia, Nadiastrophia, and Phragmostrophia; these last three species have a thicker body cavity, a subquadrate outline, and specialized internal morphologic structures. $P$. prima sp. nov. appears to belong to the first group because of its semicircular outline, planoconvex lateral profile, and parvicostellate ornament, although internally it appears more akin to the Phragmostrophia group. The phylogeny of these Early Devonian pholidostrophiids is at present unclear and requires further study.

\section{Suborder Chonetoidea Muir-Wood Superfamily Chonetacea Bronn Family Chonetidae Bronn, 1862 Subfamily Strophochonetinae Muir-Wood, 1962}

Genus Strophochonetes Muir-Wood, 1962

TYPE SPECIES

Chonetes cingulata Lindström, 1860:374, pl. 13, fig. 19; Johnson, 1970, pl. 30, figs. 1-5.
"Strophochonetes" filistriata (Walcott, 1884)

Pl. 21, figs. $1-40$

Chonetes filistriata Walcott, 1884:127, pl. 13, figs. 15, $15 \mathrm{a}$. 
Chonetes cf. C. filistriata-Merriam, 1940; pl. 7, fig. 10.

Chonetes filistriata-Merriam, 1940, pl. 11, fig. 14.

Devonochonetes filistriata Muir-Wood, 1962:44.

"Strophochonetes" filistriata-Johnson, 1970:133, pl. 31, figs. 1-17.

"Strophochonetes" filistriata-Ludvigsen, 1970, pl. 2, figs. 1-3.

\section{REFERRED SPECIMENS}

"S." filistriata occurs commonly in the Zlichovian part of S-1 and S-3, at 62.5-68.6 and $15.2-576.1 \mathrm{~m}$, respectively, below the top of the Delorme Formation. Wellpreserved dorsal valves are not common in the $328 \mathrm{~A}, 7 \mathrm{~B}$, and 499P silicified specimens because of their very fragile, thin-shelled nature. Material illustrated from S-3 includes ROM 33589-33591 from sample S4-519.7 m; ROM 33592, 33593 from sample S4-492.2 m; ROM 33594-33601 from sample S4-64.0-65.5 m; and ROM $33602-33604$, 33606-33609 from sample S4-15.2$22.9 \mathrm{~m}$.

\section{EXTERIOR}

The shells are of small to medium size, are transversely subquadrate to hemicircular in outline, and are distinctly concavoconvex, rarely planoconvex, in lateral profile. The commissure is flat, although a slight ventral sulcus develops in some larger specimens. The maximum shell width is commonly developed anterior to midlength; however, in some shells a greater or equal width is developed along the hinge line where the cardinal angles are acute and extended into small auricles. Many specimens have rounded, obtuse cardinal angles of slightly more than $90^{\circ}$. The wide, low, flat ventral interarea is catacline to very slightly hypercline and is cleft medially by an open delthyrium with a rounded apex. The delthyrium is rimmed posteroventrally by a low ridge, which projects perpendicular to the plane of the interarea. The dorsal interarea is higher than the pedicle interarea and varies from catacline to slightly anacline. A prominent posteriorly directed node is developed in the chilidium over the cardinal process. The ornament consists of fine radial costellae that increase by both bifurcation and implantation. Costellae number from 18 to 20 in $5 \mathrm{~mm}$ at a distance of $5 \mathrm{~mm}$ anterior to the ventral beak. The hollow spines attached to the ventral margin of the pedicle interarea project perpendicular to the hinge line, then curve posteromedially. Commonly a pair of spines flank the delthyrium, and another two spines are situated near the lateral margins. However, the spacing of the spines is not symmetric; moreover, some specimens develop a spine on only one flank, and some have two spines on one side and one on the other.

\section{PEDICLE VALVE INTERIOR}

The hinge teeth are stubby, triangular thickenings of the interarea wall and are supported ventrally by short, rounded dental ridges flanking the delthyrial opening. A low median septum extends over the anterior one-sixth of the shell. The septum is thick at the posterior end, then thins and gradually decreases in height anteriorly. The abutment of the septum against the apex of the delthyrium tends to infill and round the apex. The diductor muscle field is triangular and expands anteriorly at an angle of $60^{\circ}-65^{\circ}$. The margins of the muscle field are distinct laterally but indistinct anteriorly. The whole shell interior is strongly crenulated by the impress of costellae.

\section{BRACHIAL VALVE INTERIOR}

The massive, distally bilobed cardinal process is directed posteriorly. Widely divergent $\left(130^{\circ}-160^{\circ}\right)$, thick socket ridges support the proximal end of the cardinal process. The socket ridges gradually disappear laterally. At a short distance anterior to the cardinal process a pair of laterally separated, low, rounded anderidia (lateral septa of Sadlick, 1965) diverge at $25^{\circ}-30^{\circ}$ and extend to midlength. A low, rounded breviseptum extends from just anterior to the posterior margin of the anderidia to about three-quarters of the shell length and reaches its maximum height at midlength. The interior of the shell is weakly crenulated by the impress of the costellae.

\section{DISCUSSION}

"S." filistriata is confined to the Eurekaspirifer pinyonensis Zone in central Nevada and has not been widely recorded from elsewhere in western North America except locally in the Michelle Formation of the northern Yukon. Muir-Wood (1962) assigned Chonetes filistriata to Devonochonetes despite the fact that Walcott (1884, fig. 15) clearly showed the spines emerging almost perpendicular to the hinge line-Devonochonetes is characterized by spines inclined at a low angle to the hinge line. As discussed by Johnson (1970) "S." filistriata from the $E$. pinyonensis Zone differs from the type species of the genus ( $S$. cingulata) in lacking an enlarged median capilla in the ventral valve and having a breviseptum in the dorsal valve. The specimens in question here are placed in open nomenclature, pending the erection of a new genus should the distinctions noted above prove to be of taxonomic importance.

The minor variations noted in the above descriptions of the Delorme specimens are a function of their being silicified and more completely preserved. The Delorme shells differ from the specimens cited by Lenz (1973) as Strophochonetes sp. from the Lochkovian strata of the Stuart Bay Formation on Bathurst Island in lacking a 
ventral median capilla and in being of larger size. In S-3, where "S." filistriata is present throughout $560.1 \mathrm{~m}$ of strata, there is an overall trend of increase in size of younger representatives of the species.

In several instances the thin shells of "S." filistriata have suffered minor injuries during life (implied by bumps, nodes, dislocation, and suppression of costellae), causing somewhat asymmetric shells to develop (PI. 21, figs. 25-29, 34).

\section{Subfamily Parachonetinae Johnson, 1970}

\section{Genus Parachonetes Johnson, 1966}

\section{TYPE SPECIES}

Chonetes macrostriata Walcott, 1884:126, pl. 2, fig. 13(?); pl. 13, figs. 14, 14a, 14b, 14c.

\section{Parachonetes macrostriatus (Walcott, 1884)}

\section{Pl. 21, figs. 41-64}

Chonetes macrostriata Walcott, 1884:126, pl. 2, fig. 13(?); pl. 13, figs. 14, 14a, 14b, 14c.

Chonetes macrostriata-Merriam, 1940:55, pl. 6, fig. 4. Chonetes macrostriatus - Cooper, 1944:345, pl. 134, fig. 16.

Longispina macrostriatus-Muir-Wood, 1962:47.

Parachonetes macrostriatus - Johnson, 1966:367, pl. 62, figs. $1-17$; pl. 63 , figs. $1-3$.

Parachonetes macrostriatus_Johnson, 1970:136, pl. 32, figs. 1-18; pl. 33, figs. 1-5.

Parachonetes macrostriatus-Ludvigsen, 1970, pl. 2, figs. 4-8.

Parachonetes macrostriatus?-Perry, Boucot, and Gabrielse, $1981, \mathrm{pl} .2$, figs. 25-27.

\section{REFERRED SPECIMENS}

$P$. macrostriatus occurs in the Zlichovian part of S-3, at 64.0-65.5 $\mathrm{m}$ below the top of the Delorme Formation. It is not abundant ( $4 \mathrm{~A}, 9 \mathrm{~B}$, and $14 \mathrm{P})$, but it is represented by several finely silicified shells, which show features not well known previously because earlier specimens were calcareous. Material illustrated from S-3 includes ROM 33614-33619 from sample S4-64.0-65.5 m; ROM 33612, 33613 from sample S4-257.6 m; and ROM 33610, 33611 from sample $\mathrm{S} 4-502.9-507.5 \mathrm{~m}$.

\section{EXTERIOR}

The shells are transversely shield-shaped in outline, with rounded, slightly obtuse cardinal angles. Some large shells develop flat auriculations laterally. The auriculate shells have acute cardinal angles. The shell is strongly concavoconvex in lateral profile. The hinge line is long and straight. The maximum shell width is commonly developed at about one-third of its length. Medially the ventral interarea is orthocline to slightly anacline and cleft by a triangular delthyrium. The beak is gently incurved in small specimens, with increased incurvature in large shells. In articulated specimens the delthyrium is filled by the convex distal portion of the cardinal process. In gerontic shells the hinge teeth and tooth supports fill the lateral portions of the anterior end of the delthyrium. The delthyrium encompasses an angle of approximately $100^{\circ}$. The low dorsal interarea is catacline to slightly hypercline. The notothyrium is filled with a swollen, convex cardinal process; this cardinal process bears a basal covering plate, and posteriorly it consists of a quadrilobate myophore, which fills the apex of the delthyrium. Small, strongly laterally inclined spines are located on the posterior edge of the ventral interarea. Only the spine bases are preserved; on a specimen $28 \mathrm{~mm}$ wide there are about 8 to 10 , regularly spaced spine bases on each side of the beak. Radial ornament consists of low costae originating from both the beak and lateral portions of the hinge line. The costae increase by bifurcation and number seven to eight per $5 \mathrm{~mm}$ at a point $10 \mathrm{~mm}$ anterior to the ventral beak. The costae are often irregular and discontinuous. The ventral shell substance is very thick $(1-2 \mathrm{~mm})$ relative to the much thinner dorsal valves.

\section{PEDICLE VALVE INTERIOR}

The hinge teeth are triangular in cross section and develop from extensions of the delthyrial margins. They have a slight anterodorsal curvature and are supported by a subtle thickening of the delthyrial margins. The low median septum is developed anterior to the apex of the beak, divides the vascular trunks, and extends to one-third of the shell length, whereupon it rapidly decreases in height and width anteriorly. The diductor muscle scars are very weakly impressed, widely divergent, and teardrop-shaped, and extend to midlength. The posterior adductor scars are strongly impressed and elongate, flare slightly anteriorly, and are separated by the higher portion of the median septum, which is located posterior to the diductor scars. The anterior adductor scars are oval in shape, weakly impressed, and separated by the lower portion of the median septum. The diductor muscle scars curve round the anterior adductor scars. The vascular trunks are weakly impressed anterior to the adductor scars. The interior 
surface is pustulose, owing to the internal projection of the pseudopunctae, and is weakly crenulated marginally by the impress of the costae.

\section{BRACHIAL VALVE INTERIOR}

The broadly divergent sockets extend under the posterolateral margins of the cardinal process. The sockets are bounded posteriorly by the interarea wall and anteriorly by low, rounded ridges, which become markedly reduced at their junction with the plates supporting the cardinal process. The cardinal process is bilobate anteriorly and quadrilobate posteriorly. The lobes are separated anteriorly and are convergent posteriorly. The anterior portion of the cardinal process encompasses a weakly impressed alveolus posteriorly and laterally. The anterior portions of the cardinal process lobes are fused with two anderidia; the anderidia diverge at $16^{\circ}-18^{\circ}$ and increase in height to a point close to their anterior termination, at about one-third of the shell length. Very low, probable muscle-bounding ridges extend from the anterior end of the anderidia and define the oval adductor scars. The thin median septum initiates anterior to the cardinal process and alveolus, increases in height to the point of maximum valve curvature, and then decreases in height anteriorly and disappears before reaching the anterior margin. Some specimens appear to have a median septum that divides posteriorly into two very low ridges; these ridges fuse with the plates supporting the cardinal process. The posterolateral and anteromedial portions of the valves are pustulose, and crenulations developed along the anterior margins reflect the impress of the costae.

\section{DISCUSSION}

In central Nevada $P$. macrostriatus is found in the Zlichovian Acrospirifer kobehana and Eurekaspirifer pinyonensis Zones. Probable representatives have been recorded from northern British Columbia, Royal Creek, and the Arctic Archipelago. The Delorme material is regarded as conspecific with representatives of $P$. macrostriatus from Nevada and from the Michelle Formation in the northern Yukon, and minor differences noted in the descriptions result from the features of the silicified Delorme shells being more readily interpreted than those of the internal moulds prepared from the calcareous shells collected elsewhere. $P$. macrostriatus is distinguished from $P$. verneuilli (Barrande) from the Upper Koněprusy Limestone in Czechoslovakia by its less regular and less distinct costae both externally and internally. P. macrostriatus is an Old World Realm element with a wide distribution in Zlichovian strata.

\section{Subfamily ?Chonetinae Bronn, 1862}

\section{New genus chonetid sp. 1}

$$
\text { Pl. 20, figs. } 44-48
$$

\section{REFERRED SPECIMENS}

Only the silicified, articulated specimen illustrated (ROM 33587 ) and three fragmentary ventral valves were available for study, from Zlichovian beds at S-1 (sample A62.5-68.6 m).

\section{EXTERIOR}

The shells are small ( $4 \mathrm{~mm}$ in width) and are transversely suboval in outline. The lateral profile is markedly concavo- or planoconvex. The maximum width is developed at the hinge line. The cardinal angles are rounded and acute. The flat, low ventral interarea is catacline and cleft medially by a triangular delthyrium, the apical half of which is covered by a convex deltidium. The dorsal interarea is extremely narrow. The ventral valve is very markedly geniculate, such that the dorsal valve appears to terminate anteriorly against a ventral geniculate trail. A very small ventral sulcus is developed in the geniculate trail. The shell surface appears smooth. Four spine bases are located along the ventral margin of the interarea. The fragments of hinge spines preserved on the pedicle valve are strongly inclined posteroventrally. One spine extends posteroventrally about $1 \mathrm{~mm}$, then curves sharply laterally and extends another $1 \mathrm{~mm}$.

\section{DISCUSSION}

The material at hand is very distinctive but insufficient in quantity for the erection of a new taxon. Associated with this taxon is "Strophochonetes" filistriata, which is relatively well preserved and shows little evidence of abrasion; this suggests that the lack of ornament on the new genus chonetid sp. 1 is not merely a secondary feature. The smooth shell, deltidial cover, and highly accentuated geniculation distinguish this small chonetid from any other Devonian chonetid described. This Delorme chonetid does not represent an early growth stage of "S." filistriata since specimens of the latter that are as small as the Delorme specimens in question here show well-developed costellae. Specimens of early growth stages of Protochonetes latus Chatterton (1973) are devoid of ornament but differ from the Delorme chonetid specimens in being much smaller ( $1 \mathrm{~mm}$ in diameter) and in showing the development of a supra-apical foramen, a feature not observed in the Delorme shells. 


\section{Suborder Productoidea Waagen \\ Superfamily Productacea Gray \\ Family Productellidae Schuchert and LeVene, 1929 \\ Subfamily Productellinae Schuchert and LeVene, 1929}

\section{Genus Chattertonia Johnson, 1976}

\section{TYPE SPECIES}

Spinulicosta campbelli Chatterton, 1973:78, pl. 18, figs. $1-26$.

Chattertonia mackenzia sp. nov.

Pl. 20, figs. 49-54; Pl. 22, figs. 1-16

Chattertonia sp. Chatterton and Perry, 1978, pl. 2, fig. 8.

\section{DIAGNOSIS}

A small productellinid with highly divergent sockets, a subparallel, bilobed, yokelike cardinal process, and anderidia flanking a low dorsal median septum.

\section{ETYMOLOGY}

The specific name refers to the type area in the western Mackenzie Mountains of the District of Mackenzie.

\section{REFERRED SPECIMENS}

Productaceans are rare and poorly known from strata of Zlichovian age. The Delorme specimens probably represent one of the oldest known occurrences of the suborder. Chattertonia mackenzia sp. nov. is represented by $2 \mathrm{~A}$, $1 \mathrm{~B}$, and $3 \mathrm{P}$ silicified shells from S-1, at $62.5-68.6 \mathrm{~m}$, and in S-3, at 161.5-492.2 m, respectively, below the top of the Delorme Formation. Material illustrated includes holotype ROM 33620 and paratypes ROM 33621-33623 from S-1, sample A62.5-68.6 m; paratype ROM 33624 from S-3, sample S4-492.2 m; and paratype ROM 33588 from sample S4-161.5-164.6 m.

\section{EXTERIOR}

In profile the shell is strongly concavoconvex; in outline mature shells are elongate and immature forms are transverse. The interareas of both valves are sublinear, and the anacline pedicle interarea is slightly higher medially than the dorsal interarea. The pedicle beak is strongly incurved and cleft medially by an open, subtriangular delthyrium, which is wider than high. The maximum shell width is developed between the hinge line and midlength. The cardinal angles are acute and preserved only in immature shells; the flat posterolateral flanks are commonly broken off in mature shells. A row of spine bases is present along the ventral hinge line; laterally the spines are displaced slightly anterior to the hinge line and inclined at approximately $45^{\circ}$. Spines are scattered irregularly over the ventral valve, and proximally they project at a high angle to the shell. The spines initiate from spine ridges, which are well developed only on immature shells. The brachial valve is without spines, but faint costation is developed. Growth lines appear to be absent.

\section{PEDICLE VALVE INTERIOR}

The thin, fine hinge teeth are laterally elongated extensions of the interarea and are not supported by dental plates. Narrow, elongate adductor scars are moderately impressed posteriorly but not impressed anteriorly, and are situated in the deepest part of the valve. Very faintly impressed, flabellate diductor muscle scars enclose the adductor scars. A low median septum divides the adductor muscle field and extends anteriorly, becoming a threadlike myophragm near the anterior margin. The septum is markedly thicker where it subdivides the adductor muscle field. A low, anteriorly elongated ventral process is located apically and is distinct from the ventral septum. External ornament corrugates the anterior internal margin of the valve.

\section{BRACHIAL VALVE INTERIOR}

The cardinal process is a yokelike, bilobed structure; the lobes are only slightly divergent distally, are joined anteriorly by secondary shell material, and are grooved posterodorsally, resulting in a quadrilobate posterior surface. A low median septum initiates anterior to the cardinal process and extends to approximately midlength of the shell, reaching its maximum height halfway along its length. A pair of low anderidia initiate just anterior to the cardinal process, diverge at approximately $50^{\circ}$, and extend to about one-quarter of the length of the median septum. A pair of socket ridges are welded to the base of the cardinal process and diverge at $15^{\circ}-20^{\circ}$ to the hinge line. The adductor muscle scars are not impressed. The interior of the valve is extremely pustulose, reflecting the pseudopunctae.

\section{DISCUSSION}

Chattertonia mackenzia sp. nov. shows close similarity to Chattertonia campbelli (Chatterton, 1973) from beds of probable late Zlichovian age from the top of the "Receptaculites" Limestone and the middle part of the Warroo Limestone near Yass in New South Wales. The bizarre spine development of $C$. campbelli is not evident in C. mackenzia sp. nov.; however, this is possibly a result of preservation. In $C$. campbelli the cardinal process lobes are more divergent and emerge from a more distinct basal column, and the socket ridges are less divergent. The 
similar dorsal median septum, dorsal anderidia, and gross external morphology suggest a close relationship between the two species. From the associated conodont and brachiopod faunas, it appears that the Australian Chattertonia are probably slightly younger than the Delorme shells.

Chattertonia is distinct from Spinulicosta. Chattertonia has a prominent cardinal process with a thick, yokelike structure-resembling a half ring-across the interior of its bases. Spinulicosta has more discrete cardinal process lobes without a yoke. Chattertonia lacks an alveolus in the anteromedial region of the bases of the cardinal process lobes and has prominent anderidia. The concept of the genus Spinulicosta Nalivkin is established from the specimens of $S$. muirwoodi Johnson (1971a) from the Eifelian of central Nevada (Muir-Wood and Cooper, 1960, pl. 33, fig. 15), which are consistent with the type material of $S$. muirwoodi from the Middle Devonian of New York (Johnson, 1976). S. prima Chatterton and Perry (1978), from beds of probable earliest Eifelian age in the eastern Mackenzie Mountains, shows a cardinal process and an alveolus typical of Spinulicosta, yet it possesses anderidia. It is probable that this form, or a related taxon, was derived from Chattertonia and gave rise to later Spinulicosta.

Chatterton (1973) discussed at length the affinities of early productoids. Muir-Wood and Williams (in Moore, 1965:439) suggested that productoids were unrelated to chonetoids and evolved from strophomenoids-being derived probably from Leptaenisca, a strophomenoid genus with prominent brachial ridges. However, as suggested by Chatterton, early productoids seem closer to chonetoids than to strophomenoids. The anderidia of $C$. campbelli, C. mackenzia, and S. prima appear much closer to the anderidia of genera such as Parachonetes and Protochonetes than to the brachial ridges of Leptaenisca, and similar features are not known in other strophomenoids. The spines of both chonetoids and productoids are hollow; those of the strophomenoid Barbaestrophia Havlíček are solid. The ornament of spine ridges in Spinulicosta and Chattertonia is more reminiscent of Parachonetes than of any strophomenoid. The cardinal processes of early productoids resemble those of chonetoids and strophomenoids equally.

\section{Order Rhynchonellida Kuhn Superfamily Rhynchonellacea Gray \\ Family Rhynchotrematidae Schuchert, 1913 \\ Subfamily Rhynchotrematinae Schuchert, 1913}

\section{Genus Stegerhynchus Foerste, 1909}

TYPE SPECIES

Rhynchonella (Stegerhynchus) whitii-praecursor Foerste, 1909:96, pl. 3, figs. 47a, 47b, 47c.

Stegerhynchus cf. S. angaciensis Chernyshev, 1937 Pl. 22, figs. 17-31; Text-fig. 5

Stegerhynchus decemplicatus angaciensis Chernyshev, 1937:29, 71, pl. 1, figs. 15-18, text-figs. 1, 2.

Stegorhynchella angaciensis-Khalfin, 1960:102, pl. S-28, figs. $5 a, 5 b, 5 c$.

Siegerhynchus angaciensis-Lenz, 1970:488, pl. 85, figs. 16-29.

Stegerhynchus angaciensis-Lenz, 1977a:88, pl. 17, figs. $7-10,12-29$

\section{REFERRED SPECIMENS}

Siegerhynchus cf. S. angaciensis occurs at S-10, in strata of probable Pridolian age. It is represented by 80 calcareous, articulated shells of which three were serially sectioned. Material illustrated includes ROM 33625-33628 from S-10, sample S1-152.4 m, and ROM 34197 from the same collection, which was serially sectioned.

\section{DISCUSSION}

$S$. cf. $S$. angaciensis occurs at $48.8 \mathrm{~m}$ above ?Notoparmella sp. 1, $30.5 \mathrm{~m}$ above Gracianella plicumbra?, and $152.4 \mathrm{~m}$ above graptolites of Ludlovian to early Pridolian age. No definitive Lochkovian faunas were recognized in the section, and thus by virtue of its stratigraphic position, $S$. cf. $S$. angaciensis is assumed to occur in some part of the Pridolian. In areas of Royal Creek and Prongs Creek in the northern Yukon $S$. angaciensis occurs in Pridolian strata (Lenz, 1970, 1977a). J. G. Johnson (pers. comm., 1974) reported an identical shell from beds of late Pridolian age on western Prince of Wales Island, in association with Atrypoidea foxi Jones. S. angaciensis was originally described from beds of the Upper Silurian in western Mongolia and Tuva by Chernyshev (1937) and was subsequently identified from the Altai region by Khalfin (1960). The genus Stegorhynchella Rzhonsnitska1a is not well known, and all discussion here is centred on Stegerhynchus, which is regarded as the senior synonym of Stegorhynchella.

Appalachian Silurian representatives of Stegerhynchus 


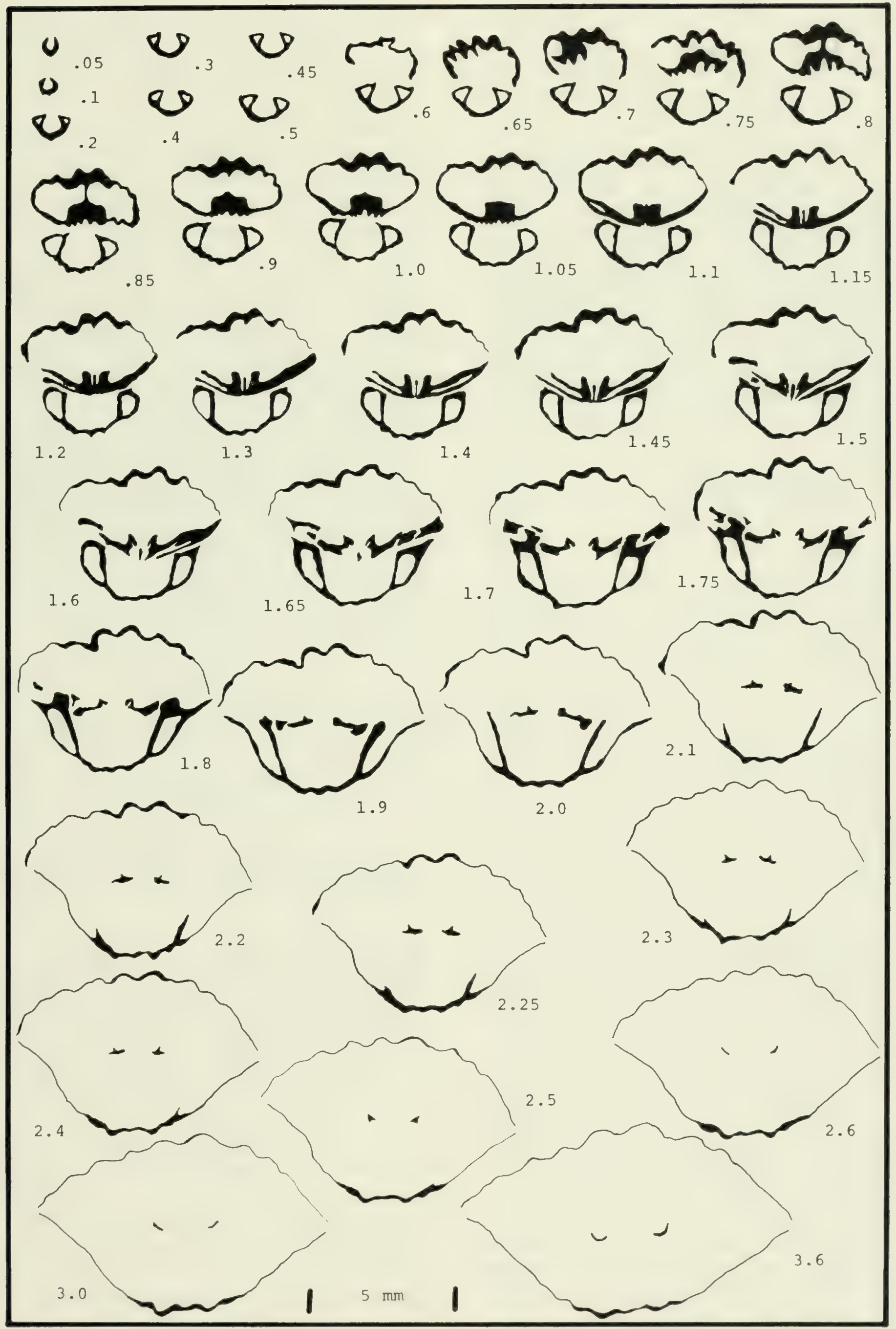

Text-fig. 5 Stegerhynchus cf. S. angaciensis Chernyshev.

Camera lucida drawings of serial transverse sections; measurements are distances in $\mathrm{mm}$ from pedicle beak: ROM 34197 
have a short septum or ridge supporting the thickened dorsal cardinal area. Specimens of $S$. angaciensis Chernyshev illustrated by Lenz (1970, 1977a) from beds of Pridolian age at Prongs and Royal creeks may or may not have a distinct ridge or septum supporting the dorsal cardinalia. The cardinal processes of these silicified shells do not show the marked incurvature of those on the Delorme shells; the latter appear to be covered by a pad of shell material. However, the Delorme shells illustrated are larger and probably represent more mature growth stages. Lenz's shells have less pronounced exterior ornament and are slightly less transverse in outline. The micro-ornament of very fine growth lines is similar. Yukon specimens of Lenz $(1970,1977$ a) that were examined by the writer do not have the submesothyridid pedicle opening described by Lenz but rather a hypothyridid opening, as in the Delorme shells.

\section{Stegerhynchus sp. 1}

Pl. 22, figs. 32-43

\section{REFERRED SPECIMENS}

Stegerhynchus sp. 1 occurs only in S-2, at $221.0 \mathrm{~m}$ below the top of the Delorme Formation in strata of late
Lochkovian age. It is represented by four articulated shells. Material illustrated includes ROM 33629-33632 from S-2, sample B221.0 m.

\section{DISCUSSION}

Stegerhynchus sp. 1 shows some resemblance to $S$. angaciensis Chernyshev in that it bears two prominent costae both on the fold and on the sulcus. S. angaciensis is more inflated and has less divergent costae on the fold. The prominent bladelike cardinal process and the notothyrium-supporting ridge on both species are very similar. The shells are readily distinguished from the associated rhynchonellids Machaeraria paraformosa Lenz, Thliborhynchia pedderi Lenz, and Thliborhynchia kerri mackenziensis subsp. nov. by the much coarser and more angular costae. Closer affinity of Stegerhynchus sp. 1 to $S$. angaciensis is not suggested at this time since a shell showing well-preserved exterior and interior features is not available. Shells illustrated and identified by Lenz (1970, 1977a) as S. angaciensis from beds of Pridolian age differ only in being of more inflated and less transverse form, and in having a higher fold resulting in a lesser amount of divergence of the costae on the dorsal fold.

\section{Subfamily Orthorhynchulinae Cooper, 1956}

\section{Genus Machaeraria Cooper, 1955}

\section{TYPE SPECIES}

Rhynchonella formosa Hall, 1857:76.

\section{DISCUSSION}

Machaeraria and the closely related Thliborhynchia are common elements of the Lochkovian and/or early Pragian faunas of the Delorme Formation. They are a difficult group to work with because of the variability both of the gross morphology and of the costation. When various ontogenetic stages of the two genera are compared, there is essentially a full range of gradation between them. Machaeraria is common in Lower Devonian strata round the world and within several faunal provinces. Johnson (1975a) stated that Machaeraria is not known from outside the Quadrithyris Zone on the Arctic Islands and in Nevada; however, both Machaeraria and Thliborhynchia occur at several levels in the Lochkovian and early Pragian strata at Royal Creek. Machaeraria has been reported from the Solovian Limestone in the Altai Mountains (Gratsianova, 1967), whose fauna is probably correlative with the Quadrithyris Zone. Thliborhynchia is separated from Machaeraria by its "pinched" profile, sharp costae, and less well developed fold and sulcus.

\section{Machaeraria paraformosa Lenz, 1977a} Pl. 23, figs. 1-42

Machaeraria paraformosa Lenz, 1977a:89, pl. 18, figs. 6-26.

\section{REFERRED SPECIMENS}

Machaeraria paraformosa occurs in S-1, at 510.5$548.6 \mathrm{~m}$ and OLDA23.7-527.3 $\mathrm{m}$, and in S-2, at 221.0$225.6 \mathrm{~m}$, respectively, below the top of the Delorme Formation. These beds are of probable late Lochkovian age with the possible exception of beds from 533.4$548.6 \mathrm{~m}$ at $\mathrm{S}-1$, which are probably slightly older. This taxon is extremely abundant in the lower range of Spirigerina supramarginalis and slightly lower at both $\mathrm{S}-1$ and $\mathrm{S}-2$; it is represented by $411 \mathrm{~A}, 255 \mathrm{~B}$, and $149 \mathrm{P}$ excellently silicified shells. Material illustrated includes ROM 33641-33644 from S-1, sample A536.4 m; ROM 33637-33640 from S-1, sample A528.8 m; ROM 3363433636 from S-1, sample A515.1-516.6 m; and ROM 33645-33653 from $\mathrm{S}-2$, sample B221.0 m

\section{DISCUSSION}

M. paraformosa occurs commonly in strata of mid to late Lochkovian age at Royal Creek (Lenz, 1977a) and in beds 
of similar age in the Delorme Formation of the western Mackenzie Mountains. The following details can be added to the description of Lenz (1977a). The crura are subcircular in cross section and attached to the medial edge of the crural base-inner hinge plate complex. The crura are directed anteriorly initially, curve strongly ventrally or slightly posteroventrally, and extend close to the pedicle valve floor. In large shells the umbonal regions of both valves are considerably thickened by callus into which the muscle fields are impressed.

This species differs from the type species, $M$. formosa Cooper (1955), in the greater number of costae on its fold, sulcus, and flank, and in its low brachial median myophragm. Related species of Machaeraria have been recorded from the lower beds of the Lower Devonian in the Sayano-Altai region (Khalfin, 1960), from the Altai region (Kulkov, 1963; Gratsianova, 1967), and from Australia (Savage, 1971, 1974).

$M$. paraformosa is quite similar to Machaeraria sp. from the Quadrithyris Zone of central Nevada, except that Johnson (1970) noted the absence of bifurcation of the costae on the latter shells, whereas bifurcating costae are common on small shells of $M$. paraformosa from the Delorme Formation and from Royal Creek. Specimens of Machaeraria sp. illustrated by Johnson (1975a) from the late Lochkovian Quadrithyris Zone of the Arctic Archipelago are more transverse and occasionally bear bifurcating costae on the fold and sulcus. Bifurcation close to the anterior margin has been observed only on small shells of $M$. paraformosa from the Delorme Formation. $M$. cf. M. formosa (Hall) of the Quadrithyris Zone from the Mandagery Park Formation of New South Wales (Savage, 1971) is more transverse and less inflated than M. paraformosa. Specimens identified as Zlichorhynchus? sp. by Savage (1971, pl. 71, figs. 35-38) may well be an early growth stage of his $M$. cf. $M$. formosa, to judge from the shape of early growth stages of the Delorme Machaeraria. M. whittingtoni Bowen (1967) from the early Lochkovian Keyser Limestone of Pennsylvania is slightly more transverse and possesses longer, more widely divergent dental lamellae than the Delorme specimens.

\section{Genus Thliborhynchia Lenz, 1967a}

\section{TYPE SPECIES}

Thliborhynchia julli Lenz, 1967a:1188, pl. 161, figs. $1-34$.

\section{Thliborhynchia julli Lenz, 1967a}

$$
\text { PI. 23, figs. 43-64 }
$$

Thliborhynchia julli Lenz, 1967a:1188, pl. 161, figs. $1-34$.
Thliborhynchia julli Lenz, 1977a:91, pl. 19, figs. 17-21, 23-40.

Thliborhynchia julli_Jackson, Lenz, and Pedder, 1978, pl. 13, figs. 1-11.

\section{REFERRED SPECIMENS}

Thliborhynchia julli occurs in S-1, at 278.9-390.1 m, and in S-2, at 32.0-80.8 m, respectively, below the top of the Delorme Formation. It is relatively uncommon in the Delorme and is represented in S-1, at OLDA306.3 m, by only one specimen. A few fragmentary shells from the Zlichovian of section S-4 include representatives of Thliborhynchia species close to $T$. julli. $T$. julli is represented by $10 \mathrm{~A}, 18 \mathrm{~B}$, and $23 \mathrm{P}$ rather poorly preserved, silicified shells. Material illustrated includes ROM 33659, 33660 from S-1, sample A318.5 m; ROM 33656 from S-1, sample A330.7 m; ROM 33657 from S-1, sample A359.7 m; ROM 33658 from S-1, sample A $374.9 \mathrm{~m}$; and ROM 33654, 33655 from S-2, sample B $80.8 \mathrm{~m}$.

\section{DISCUSSION}

$T$. julli is relatively uncommon in the Delorme, but where present it is closely associated with the occurrence of Plicocyrtina sinuplicata Havlíček. At Royal Creek this same association holds, and $T$. julli is assigned an early Pragian age. Shells of $T$. julli from S-1, at A318.5 m and A330.7 $\mathrm{m}$, show the large range of variation within the species and approach the morphology of some Machaeraria.

$T$. julli was proposed by Lenz (1967a) for machaerariids with coarse, sharp costae and a pronounced pinching of the posterior portions of the beaks. The brachiopod genus Franklinella Lenz (1973), proposed for shells intermediate between Machaeraria and Thliborhynchia, has proved to be a homonym for a previously named ostracode taxon and is now assigned to Thliborhynchia. Thliborhynchia pedderi (Lenz) is distinguished from $T$. julli by its less pronounced lateral extremities, more numerous and more rounded costae, and more pronounced fold and sulcusand thus its more rotund shape. However, these features are not of generic significance, and the two taxa are best considered, as at present, species of Thliborhynchia.

The cardinalia of Thliborhynchia are quite variable during ontogeny. Shells illustrated by Lenz (1967a) were of young and of probably mature individuals; there were apparently no gerontic shells. In the Delorme collections and in new collections from Royal Creek a few interesting morphologic changes appear in gerontic shells. The dorsal valve becomes considerably more inflated, and the dorsal beak more incurved. The inner hinge plates close off and cover the anterior part of the deep trench that houses the cardinal process. The inner hinge plates touch but are not 
fused, and the cardinal process is usually still visible posteriorly. If the cardinal process is cut off, the diductor muscles are attached to the surfaces of the inner hinge plates, creating an anteriorly divergent, bilobed muscle scar or depression on those surfaces. In gerontic shells the dorsal muscle field expands gently anteriorly to about one-third of the shell length, whereupon very low anterior bounding ridges curve sharply medially and intersect the midline at a $45^{\circ}$ angle.

\section{Thliborhynchia pedderi (Lenz, 1973)} Pl. 24, figs. 1-41

Franklinella pedderi Lenz, 1973:1405, pl. 2, figs. 15-34. Thliborhynchia pedderi-Jackson, Lenz, and Pedder, 1978, pl. 18, figs. 33-36, pl. 19, figs. 1-16, 22.

\section{REFERRED SPECIMENS}

$T$. pedderi occurs in S-1, at 466.3-470.9 m, and in S-2, at $221.0 \mathrm{~m}$, respectively, below the top of the Delorme Formation. It is represented by $20 \mathrm{~A}, 17 \mathrm{~B}$, and $18 \mathrm{P}$ silicified shells. Material illustrated includes ROM 33671-33677 from S-1, sample A470.9 m; ROM 3366533670 from S-1, sample A466.3 m; and ROM 3367833681 from S-2, sample B221.0 m.

\section{DISCUSSION}

$T$. pedderi occurs in strata of late Lochkovian age commonly associated with Spirigerina supramarginalis. The acme zone of $T$. pedderi is stratigraphically separated from its probable descendant Thliborhynchia julli by some 60-100 $\mathrm{m}$ both in the Delorme Formation and at Royal Creek. In the Delorme a few fragmentary shells without excessive posterior "pinching" and with abundant finer costae do occur in beds with Thliborhynchia julli, and several of these have been illustrated here and referred to Thliborhynchia spp. (Pl. 23, figs. 65-71, ROM 3366133664). $T$. cf. $T$. pedderi has also been identified in materials collected by A. C. Lenz from the beds of upper Lochkovian age in the Windmill Limestone of central Nevada (Pl. 22, figs. 44-48, ROM 33633).

$T$. pedderi is distinct from Thliborhynchia kerri mackenziensis subsp. nov., which bears much finer costae. Some of the larger representatives of Machaeraria paraformosa Lenz approach the morphology of $T$. pedderi. The occurrence of $M$. paraformosa stratigraphically below $T$. pedderi and occasionally associated with it in both the western Mackenzie Mountains and the Royal Creek area and the relatively close morphology of the two species suggest that $M$. paraformosa, $T$. pedderi, and $T$. julli form a distinct Lochkovian-Pragian lineage in the northern Cordillera. Although Machaeraria has a worldwide distribution in the Lower Devonian of several faunal provinces, Thliborhynchia is known only from Nevada and northwestern and arctic Canada, of which northwestern Canada shows the greatest abundance.

The shells from Bathurst Island assigned to $T$. kerri are more finely costellate than $T$. pedderi, which is also known from that island (Lenz, 1973). Shells from Cornwallis Island that were illustrated and identified by Johnson as T. kerri (1975a, pl. 5, figs. 21-23; pl. 6, figs. 1-3) are more likely juveniles of $T$. pedderi.

The Delorme representatives of $T$. pedderi are dominated by large gerontic shells showing two divergent morphologic trends, both of which are developed to a lesser degree in the Royal Creek collections. The majority of the large shells are very globose and slightly longer than wide. Both valves are gently convex with lateral margins ranging from steep to almost vertical. The dorsal valve is two to three times deeper than the pedicle valve. The marked inflation of both valves on the large shells tends to camouflage the high dorsal deflection of the anterior commissure; the commissure forms from the prominent fold on smaller shells. Other large shells are highly transverse, with deep anterolateral "pockets" developed on both sides of the strongly impressed ventral sulcus. The shells illustrated from S-2, sample B221.0 m, show the early stages of development of $T$. pedderi. Note the open delthyrium, sharper costae, irregular costae insertion, and more pronounced fold and sulcus. Internal morphologic features additional to those described by Lenz (1973) are noted below.

The triangular, slightly dorsomedially concave inner hinge plates are attached to the outer socket plates and project medially; they are disjunct, free of the valve floor, and overhang a slightly thickened notothyrial cavity. The notothyrial cavity bears a low, elongate, ridgelike cardinal process. The free crural bases are welded to the medial edges of the inner hinge plates. In some large shells the hinge plates are thickened medially and touch near their anterior margin. The crura are triangular in shape, with the apex of the triangle pointing ventrally, and they reach well into the ventral valve cavity. A low median myophragm sometimes supports the cardinal process for a short distance anteriorly. The dorsal muscle field is elliptical in outline, gently impressed, elongated anteriorly, about twice as long as wide, and divided medially by a very low ridge. The dental plates are set close to the shell wall and diverge slightly anteriorly; in large shells the lateral chambers are filled with callus. The ventral diductor muscle field is teardrop-shaped, widens anteriorly, and is moderately impressed in large shells. The diductor field is divided medially by a low, narrow, anteriorly widening platform, which marks the site of the adductor muscle attachment. 
Thliborhynchia kerri mackenziensis subsp. nov.

Pl. 25, figs. 1-30

\section{DIAGNOSIS}

A geographic subspecies of Thliborhynchia kerri (Johnson, 1975a) with even finer wirelike costellae than on $T$. kerri kerri.

\section{ETYMOLOGY}

The name of the subspecies is in reference to its only known occurrence, in the western Mackenzie Mountains.

\section{REFERRED SPECIMENS}

Thliborhynchia kerri mackenziensis subsp. nov. occurs in $\mathrm{S}-1$, at 515.1-528.8 $\mathrm{m}$ and OLDA423.7-515.1 $\mathrm{m}$, and in $\mathrm{S}-2$, at $221.0 \mathrm{~m}$, respectively, below the top of the Delorme Formation. It is not abundant, but several exquisitely preserved silicified shells (12A, 33B, and 36P) occur within the lower range of Spirigerina supramarginalis; the subspecies is therefore assigned a late Lochkovian age. The same taxon is possibly represented by a few poorly preserved specimens from the Spirigerina beds at Royal Creek. Material illustrated includes paratypes ROM 33689-33691 from S-1, sample A528.8 m; paratypes ROM 33687, 33688 from S-1, sample A515.1$516.6 \mathrm{~m}$; holotype ROM 33694 and paratype 33695 from S-1, sample OLDA423.7 m; and paratypes ROM 3369633700 from S-2, sample B221.0 m. Sample OLDA423.7 $\mathrm{m}$ was collected from a snow-covered section, and the position estimated for this sample is probably too high since it contains both $T$. kerri mackenziensis subsp. nov. and $S$. supramarginalis; the former is known only as high as $515.1 \mathrm{~m}$ and the latter only as high as $466.3 \mathrm{~m}$ in the more accurately measured section.

\section{EXTERIOR}

The elongate shells are subtriangular in outline, with a moderately rounded anterior margin, and are markedly dorsibiconvex in lateral profile. In mature shells the dorsal valves are approximately twice as deep as the ventral valves; small shells are subequally biconvex. The hinge line is extremely narrow, and the maximum width of the shell is reached near the anterior margin. The erect, apsacline pedicle beak extends well beyond the dorsal beak. The foramen is submesothyridid in mature shells; small shells have an open, triangular delthyrium, which lacks conjunct deltidial plates anteriorly. Both valves have long, straight to very slightly concave, posterolateral margins. The junction of the lateral flanks with the vertical sides of the shell margins approaches $90^{\circ}$. The anterior commissure is uniplicate. A prominent flat-bottomed to gently rounded ventral sulcus develops a weak medial ridge anteroventrally and has an inverted, V-shaped anterior profile. The dorsal fold has medially inclined margins and a gently rounded crest. Very small shells lack a fold and sulcus. The anterior ventral flanks are flat and occasionally develop low, rounded ridges adjacent to the geniculate lateral margin. The costellae are very fine and wirelike and increase anteriorly by implantation. The vertical lateral margins of the shell are smooth. T. kerri mackenziensis subsp. nov. possesses approximately 33 per cent more costellae than shells of $T$. kerri kerri of similar size (three to four costellae per millimetre at the anterior margin of a shell $17 \mathrm{~mm}$ long).

\section{PEDICLE VALVE INTERIOR}

The small, anteriorly directed, blunt, knoblike hinge teeth are inclined slightly dorsomedially. The short, vertical dental lamellae diverge anteriorly parallel to the shell wall and define high, narrow lateral chambers commonly filled with secondary shell material. The lightly impressed muscle field is subtriangular in outline and extends to about one-quarter of the shell length; the diductor scars are narrow, subparallel to the shell margin, and divided medially by an adductor muscle platform that widens anteriorly and is weakly striated longitudinally.

\section{BRACHIAL VALVE INTERIOR}

The socket plates are joined to the posterolateral shell wall and curve gently ventromedially. They delineate open, deep, anteriorly widening sockets. In plan view the inner socket plates are triangular with dorsal concavity. They tend to partially constrict the notothyrial cavity. An elongate, narrow, low cardinal process projects from the notothyrial callus of the deep cavity separating the inner socket plates. The crural bases are attached to the anteromedial edge of the inner socket plates. The crura are subrectangular with moderate anteroventral curvature. The muscle field is weakly impressed and varies in shapefrom triangular and anteriorly expanding in small shells to suboval in large shells; it is divided medially by a low myophragm. In mature shells the notothyrial cavity and associated structures are thickened by secondary shell material. The anterior of the shells is faintly crenulated by the impress of costellae.

\section{DISCUSSION}

T. kerri mackenziensis subsp. nov. differs from $T$. kerri kerri principally in having more numerous and finer costellae. The Delorme Formation taxon has a more distinct fold and sulcus and is more elongate. T. kerri mackenziensis subsp. nov. differs from the genus Sicorhyncha Havlíček (1961) in having a more elongate, triangular outline and a much finer ornament, and in lacking the subparallel addition of costae on the fold and sulcus. $T$. pedderi has much stronger costae and is more rotund than $T$. kerri mackenziensis subsp. nov. 


\section{Family Trigonirhynchiidae McLaren in Schmidt and McLaren, 1965}

\section{Genus Ancillotoechia Havlíček, 1959}

\section{TYPE SPECIES}

Rhynchonella ancillans Barrande, 1879, pl. 36, figs. 1, 2, 4. 5 .

\section{Ancillotoechia cf. A. gutta Johnson, Boucot, and Murphy, 1973 \\ Pl. 24, figs. 56-60; Text-fig. 6}

"Camarotoechia" sp.-McLaren, Norris, and McGregor, 1962, pl. 7, figs. 7-9.

Ancillotoechia gutta Johnson, Boucot, and Murphy, 1973:43, pl. 22, figs. 1-19.

Ancillotoechia gutta-Lenz, 1977a:92, pl. 20, figs. 14-22.

\section{REFERRED SPECIMENS}

The Delorme Formation Ancillotoechia cf. A. gutta is represented by $50 \mathrm{~A}$ calcareous shells from $\mathrm{S}-7$, at $408.4 \mathrm{~m}$, and from S-12, at $717.8 \mathrm{~m}$, respectively, below the top of the formation. Material illustrated includes ROM 33686 from S-7, sample P7WA1911.1 m, and the serially sectioned specimen ROM 33721 from the same locality.

\section{DISCUSSION}

The Delorme shells are very similar to the Nevada $A$. gutta except that the serial sections of a Delorme specimen show the development of a plate covering the anterior part of the septalium. It is quite possible that this structure existed but is not preserved on the Nevada silicified shells since a specimen illustrated by Johnson, Boucot, and Murphy (1973, pl. 18, fig. 12) and two specimens illustrated by Lenz (1977a, pl. 20, figs. 16, 22) appear to show a broken edge of a cover plate. Only calcareous shells are preserved in the eastern, shallow-water, low-diversity communities of the Delorme Formation. A. cf. A. gutta occurs in the early Lochkovian $\mathrm{F}$ fauna in central Nevada, in Delorme strata that bear Ozarkodina remscheidensis, and some $200 \mathrm{~m}$ below the lowest occurrences of Warburgella rugulosa canadensis Ormiston at locality 2 of Chatterton and Perry (1977). In the vicinity of locality 2 the early Lochkovian part of the sequence is anomalously thick and may encompass more than $400 \mathrm{~m}$ of strata.

\section{Ancillotoechia sp. 1}

Pl. 24, figs. 42-46

\section{REFERRED SPECIMENS}

Only one well-preserved, silicified, articulated shell (ROM 33692 ) is available for study from S-1, at $538.0 \mathrm{~m}$ below the top of the Delorme Formation, in strata of early to mid-Lochkovian age (sample A538.0T m).

\section{DISCUSSION}

Ancillotoechia sp. 1 differs from A. gutta Johnson, Boucot, and Murphy in having higher costae, a much more prominent ventral beak, a more elongate outline, and a less pronounced dorsal fold. The septalium is open and is apparently not covered by the inner hinge plates.

\section{Ancillotoechia sp. 2}

Pl. 24, figs. 47-55

\section{REFERRED SPECIMENS}

Ancillotoechia sp. 2 occurs in strata of mid-Lochkovian and possible early Lochkovian age in S-1, at 538.0 $553.2 \mathrm{~m}$ and OLDA538.0 $\mathrm{m}$ below the top of the Delorme Formation. It is represented by $468 \mathrm{~A}, 1 \mathrm{~B}$, and $2 \mathrm{P}$ well-preserved silicified shells, nearly all of which, unfortunately, are filled with crystalline quartz. Material illustrated includes ROM 33682-33685 from S-1, sample A538.0T m.

\section{DISCUSSION}

Ancillotoechia sp. A of Johnson (1975a) from the Quadrithyris Zone of Prince of Wales Island in arctic Canada is closely comparable. This species is slightly larger and more inflated, but the overall outline and the smooth umbones of the two species are quite similar. The Delorme shells have a longer dorsal septum and do not exhibit such a well-defined fold. An external homoeomorph of Ancillotoechia sp. 2 occurs in beds of probable Ludlovian age at S-9, but its interior is unknown, except for the presence of a dorsal septum.

Ancillotoechia sp. 2 is characterized by its small, elongate, subtriangular shape with its smooth umbones, coarsely costate anterior margins, and dorsal septalium partially covered by inner hinge plates. The dorsal fold is low and subrectangular in profile. The costae are simple, nonbifurcating, and rounded in profile. The dorsal septum gradually decreases in height to its termination near three-quarters of the shell length.

\section{Ancillotoechia sp. 3}

Pl. 25, figs. 31-60

\section{REFERRED SPECIMENS}

The silicified shells representing Ancillotoechia sp. 3 are poorly preserved. It is represented by $73 \mathrm{~A}, 22 \mathrm{~B}$, and $19 \mathrm{P}$ shells from S-1, at 338.3-396.2 $\mathrm{m}$ and OLDA336.8 $344.4 \mathrm{~m}$, and from S-3, at $\mathrm{S} 4-685.8 \mathrm{~m}$, respectively, below the top of the Delorme Formation from beds of 


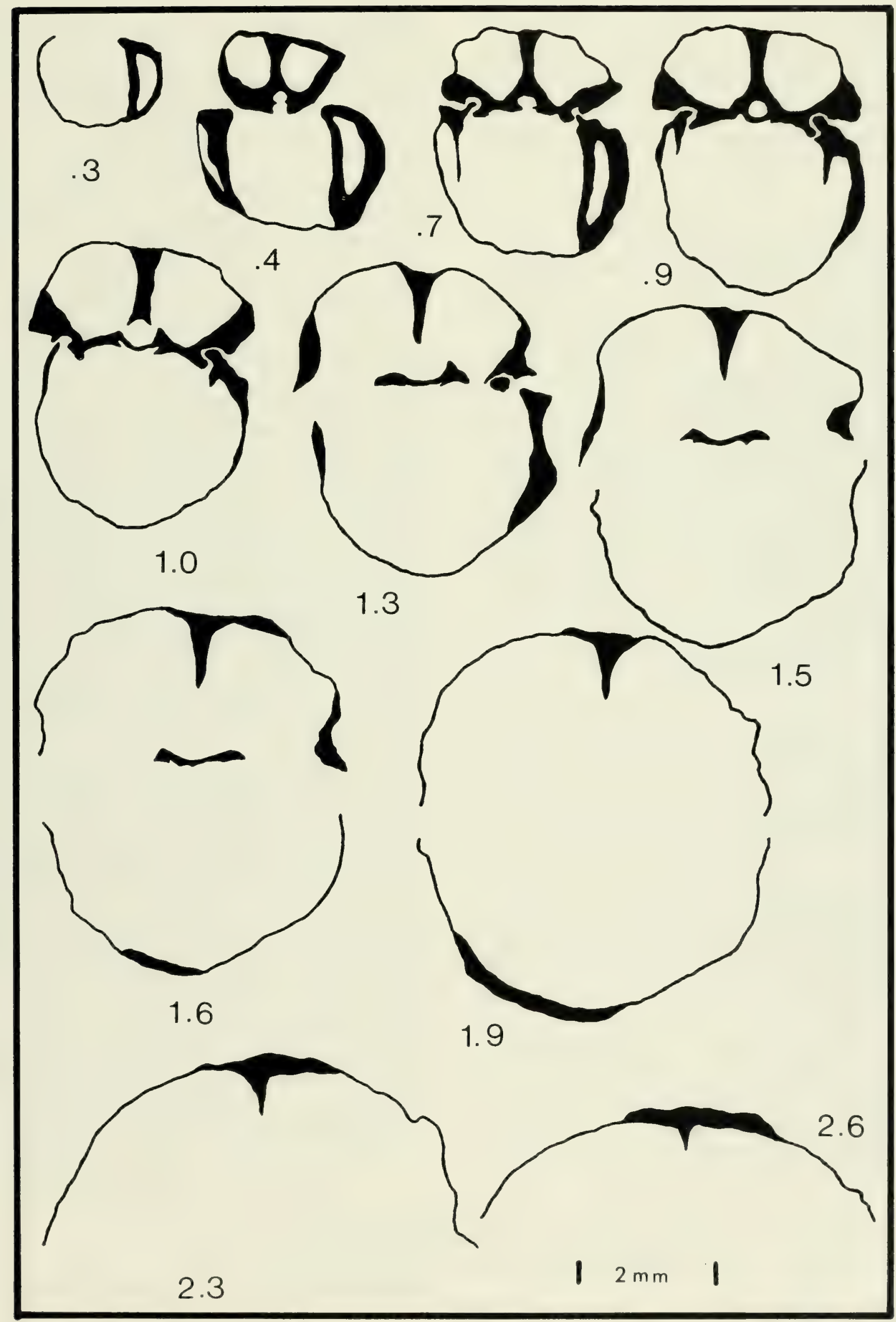

Text-fig. 6 Ancillotoechia cf. A. gutta Johnson, Boucot, and Murphy

Camera lucida drawings of serial transverse sections; measurements are distances in $\mathrm{mm}$ from pedicle beak: ROM 33270. 
probable latest Lochkovian to early Pragian age. Material illustrated includes ROM 33705, 33706 from S-1, sample A390.1 m; ROM 33701-33704 from S-1, sample A385.6 m; ROM 33711 from S-1, sample OLDA336.8 m; and ROM 33707-33710, 33712-33716 from S-3, sample S4-685.8 m.

\section{DISCUSSION}

Ancillotoechia sp. 3 is distinguished from other named Ancillotoechia by its coarser and less numerous costae, its thicker shell, and the development of very prominent dental plates. The numerous small shells from S-3, sample S4-685.8 m, are considerably smaller than the other shells assigned to the taxon, although the morphologic details appear similar.

The costae are high, simple, and separated by deep interspaces; they only increase by implantation in the smallest shells. The pedicle beak is erect, and deltidial plates infill only the anterior portion of the delthyrium of large shells. A thick median septum supports the dorsal septalium, which in specimens from sample S4-685.8 m was probably covered by a plate in early growth stages.

\section{Genus Nymphorhynchia Rzhonsnitskaia in Khalfin, 1956}

\section{TYPE SPECIES}

Nymphorhynchia bischofioides Rzhonsnitskaıa, 1956:53; in Khalfin (1956).

\section{Nymphorhynchia nympha (Barrande, 1879)}

$$
\text { Pl. 26, figs. 1-37 }
$$

Terebratula nympha Barrande, 1847:66, pl. 20, fig. 6 . Rhynchonella nympha-Barrande, 1879:28, 169, pl. 29, figs. 10-14; pl. 93, fig. III; pl. 147, fig. VII-2, pl. 153, figs. I-X. (not pl. 93, fig. IV=Astutorhyncha simulans [Barrande, 1879]).

Rhynchonella (Camarotoechia) nympha-Scupin, 1906:236, pl. 11, fig. 12.

Stegerhynchus nympha-Havlíček, 1961:85, pl. 9, figs. 7-13, text-fig. 29.

Stegerhynchus nympha-Kulkov, 1963:47, pl. 3, figs. 7-12.

Stegerhynchus nympha-Drot, 1964:103, pl. 19, figs. 6-8.

?Stegerhynchus nympha-Gratsianova, 1967:66, pl. 6, figs. 1, 2 .

Nymphorhynchia nympha-Tyazheva in Tyazheva and Zhavoronkova, 1972:73, pl. 26, figs. 12-15.

Nymphorhynchia nympha-Lenz, 1977a:93, pl. 21, figs. $1-12,28-35$.

Nymphorhynchia nympha-Jackson, Lenz, and Pedder, 1978, pl. 10, figs. 5-14.

\section{REFERRED SPECIMENS}

N. nympha occurs in S-1, at OLDA353.6-388.6 m, in $\mathrm{S}-2$, at $128.6 \mathrm{~m}$, and in S-3, at $685.6 \mathrm{~m}$, respectively, below the top of the Delorme Formation. It is represented by $101 \mathrm{~A}, 62 \mathrm{~B}$, and $21 \mathrm{P}$ shells, some of which are exquisitely preserved. Material illustrated includes ROM 33729 from S-1, sample OLDA388.6 m; ROM 3372233728 from S-2, sample B128.6 m; and ROM 33730 33736 from S-3, sample S4-685.8 m.

\section{DISCUSSION}

The type specimen of $N$. nympha is from the Pragian Konéprusy Limestone of Bohemia; the Delorme specimens conform very closely with topotypic materials present in the collections of A. J. Boucot of Oregon State University. The Delorme shells assigned to $N$. nympha are from beds of latest Lochkovian and early Pragian age. $N$. nympha occurs in beds of latest Lochkovian and early Pragian age within the Monograptus yukonensis Zone at Royal Creek. Other occurrences of the species listed in the synonymy are of similar age, with the exception of the occurrence in supposed Emsian beds in North Africa, reported by Drot (1964).

The development of a complete covering plate over the septalium was observed in only one shell. In his serial sections Havlíček (1961) showed the inner hinge plates close together, but not forming a continuous plate. Lenz (1977a) noted the occasional development of a cover plate. The posterior parts of the ventral beaks of the Delorme shells are rather imperfectly preserved; however, in some small shells fragments of what appear to be deltidial plates enclose the anterior of the delthyrium. Well-preserved mature shells show a more strongly curved ventral beak than noted by Lenz (1977a). The pedicle muscle field is oval in shape and is confined to the posterior part of the shell, between the dental plates. The number of flank costae appears to be consistently greater on the ventral valve.

A shell from S-2, B221.0 m (ROM 33737, Pl. 26, figs. 38-42) probably represents a new species of Lochkovian Nymphorhynchia. This species has fewer, coarser, more rounded costae. Only one articulated shell is available.

\section{Genus Werneckeella Lenz, 1971}

\section{TYPE SPECIES}

Werneckeella hartensis Lenz, 1971:845, pl. 97, figs. 1-55; text-fig. 1.

Werneckeella hartensis Lenz, 1971

PI. 27, figs. 57-59

Werneckeella hartensis Lenz, 1971:845, pl. 97, figs. $1-55$, text-fig. 1. 
Werneckeella hartensis Lenz, 1977a:95, pl. 22, figs. 17-30, 35, 36.

Werneckeella hartensis-Jackson, Lenz, and Pedder, 1978, pl. 13, figs. 12-24.

\section{REFERRED SPECIMENS}

The material from the Delorme Formation is poorly preserved and is represented by only $3 \mathrm{~A}$ and $1 \mathrm{P}$ silicified shells from beds of early Pragian age at S-1 and S-2. The shell illustrated is ROM 33778 from S-2, sample B $105.2 \mathrm{~m}$ (below the top of the formation)

\section{DISCUSSION}

Lenz (1977a) reported $W$. hartensis from beds of latest Lochkovian and early Pragian ages at Royal Creek. Johnson (1974a) and Johnson, Penrose, and Wise (1978) listed the genus Werneckeella from strata of late Lochkovian and Pragian ages in central Nevada.

$W$. hartensis is distinguished from Linguopugnoides by the prominent furrow in the dorsal valve and by the shorter dental lamellae. The characteristic triangular, anteriorly widening, raised dorsal muscle field was not seen in the available shells, although a high, narrow median septum and a narrow septalium were present.

\section{Genus Trigonirhynchia Cooper, 1942}

\section{TYPE SPECIES}

Uncinulina fallaciosa Bayle, 1878, pl. 13, figs. 13-16.

\section{Trigonirhynchia cf. T. occidens (Walcott, 1884)}

$$
\text { PI. 26, figs. } 43-63
$$

Rhynchonella? occidens Walcott, 1884:152, pl. 15, figs. $3,3 a, 3 b$

Trigonirhynchia occidens-Johnson, 1970:147, pl. 38, figs. 22-26; pl. 39, figs. 6-28.

Trigonirhynchia aff. T. occidens-Perry, Klapper, and Lenz, 1974:1071, pl. 2, figs. 12-19; text-fig. 6.

\section{REFERRED SPECIMENS}

Trigonirhynchia cf. $T$. occidens occurs in S-1, at $7.6-68.6 \mathrm{~m}$, and in S-3, at $64.0-507.5 \mathrm{~m}$, respectively, below the top of the Delorme Formation in strata of Zlichovian age. In the Delorme it is represented by $12 \mathrm{~A}$, 8B, and 9P silicified shells. Material illustrated includes ROM 33738, 33739, 33745 from S-1, sample A7.6$10.7 \mathrm{~m}$; ROM 33740 from S-1, sample A62.5-68.6 m; ROM 33741, 33742 from S-3, sample S4-64.0-65.5 m; and ROM 33743, 33744 from S-3, sample S4-143.3 m

\section{DISCUSSION}

The Delorme shells are well preserved but for the most part appear to represent juvenile individuals. The species is common in several collections but always in low abundance. In central Nevada $T$. occidens is found in low abundance at several localities from the Zlichovian Eurekaspirifer pinyonensis Zone. A very similar, but generally larger shell was reported from beds of Zlichovian age of the Ogilvie Formation in the northern Yukon (Perry, Klapper, and Lenz, 1974).

It is difficult to compare the Delorme shells to the types from central Nevada because small shells predominate in the former occurrences; however, the smaller specimens illustrated from Nevada are quite similar to the Delorme shells. Generally the Nevada type shells have two or three more costae on each valve and have a slightly more prominent fold and sulcus. For this reason the Delorme specimens are only tentatively assigned to $T$. occidens. Internally a few of the well-preserved shells, like those from Nevada, show well-developed, thin, vertical dental lamellae which diverge slightly anteriorly and define narrow lateral chambers. In the dorsal valve the crura are T-shaped in cross section (as described by Johnson, 1970) and are attached to the inner edges of the socket plates. The dorsal edges-the stems of the T-shapes-are continuous with the crural bases and united to them medially to form a short, narrow, deep septalium; the septalium is supported by a median septum, which extends almost to midlength of the shell. The crural flanges - the caps of the T-shapes-join medially over the anterior part of the septalium and form a cover plate. The crura of the Delorme $T$. cf. $T$. occidens curve strongly anteroventrally.

\section{Family Uncinulidae Rzhonsnitskara in Khalfin, 1956 Subfamily Hebetoechiinae Havlíček, 1960}

Genus Hebetoechia Havlíček, 1959

TYPE SPECIES

Terebratula hebe Barrande, 1847:442.
Hebetoechia cf. H. hebe (Barrande, 1847) Pl. 25, figs. 61-67; Text-fig. 7

\section{REFERRED SPECIMENS}

Hebetoechia cf. $H$. hebe occurs in S-12, at the top of the Delorme Formation; in S-7, at $13.7 \mathrm{~m}$ below the top of the 
Delorme; and in the Rouge Range, at $121.9 \mathrm{~m}$ below the top of the Delorme $\left(63^{\circ} 25^{\prime} \mathrm{N}, 126^{\circ} 00^{\prime} \mathrm{W}\right)$. It is represented by several hundred calcareous shells, nearly all of which are small, probably juvenile forms. Material illustrated includes ROM 33718 from S-7, sample CH27WA274.3 m; ROM 33717 from S-12, sample TRDW $3483.9 \mathrm{~m}$; and the serially sectioned shell ROM 33748 from S-12, sample TRDW3483.9 m.

\section{EXTERIOR}

The shells are small (maximum dimension, $11 \mathrm{~mm}$ ) and of subpentagonal outline. The maximum width is developed anterior to midlength and is approximately equal to the length. The lateral profile is equally biconvex to slightly dorsibiconvex. The pedicle beak is slightly incurved. The fold and sulcus are weakly developed over the anterior one-third of the shell. The pedicle sulcus is occupied by a gently curved tongue. The anterior margin is uniplicate and serrate. The umbones have suppressed costae. The costae begin a short distance anterior to the posterior margin. The costae are rounded, are wider than high, and number four or five on the brachial fold, commonly three on the pedicle sulcus, and six to eight on the lateral flanks. The costae are separated by rounded, U-shaped interspaces. Longitudinal costal grooves are poorly developed along the anterior margin of the tongue.

\section{PEDICLE VALVE INTERIOR}

The hinge teeth are small and are supported by dental plates for a short distance anteriorly. Muscle scars are not impressed.

\section{BRACHIAL VALVE INTERIOR}

The short septalium is supported by a median septum, which extends less than one-quarter of the length of the shell. The septalium is either open or partially filled with callus. The crura curve gently anteroventrally.

\section{DISCUSSION}

The Delorme $H$. cf. $H$. hebe appears close to the type species, although the costae initiate slightly more posteriorly in the Delorme material than in other species. The Delorme shells are of probable early to mid-Lochkovian age, and they are commonly found in beds with Ozarkodina remscheidensis remscheidensis (Ziegler) and Proetus (Coniproetus) whittakerensis Chatterton and Perry near the top of the Delorme Formation in the Root Basin. Smith (1976a) reported the taxon from beds of early Lochkovian age in the Canadian Arctic Archipelago, where it is represented by considerably larger shells.

\section{Genus Sphaerirhynchia Cooper and Muir-Wood, 1951}

\section{TYPE SPECIES}

Terebratula wilsoni Sowerby, 1818:38.

\section{Sphaerirhynchia sp. \\ Pl. 27, figs. 1-3}

\section{REFERRED SPECIMENS}

Only three poorly preserved silicified shells were recovered from the Delorme Formation, in S-2, at $300.2 \mathrm{~m}$ below the top. Material illustrated includes ROM 33749 , 33750 from S-2, sample B300.2 m.

\section{DISCUSSION}

The three articulated shell fragments available are quite similar to Sphaerirhynchia sp. of Johnson (1973a) from the mid-Lochkovian of central Nevada. The associated brachiopod fauna includes the genus Rhynchospirina, which is also known from the mid-Lochkovian of central Nevada. Despite their poor preservation, these shells confirm the close generic affinity of early to midLochkovian brachiopod faunas in northern Canada and central Nevada.

The Delorme Sphaerirhynchia have a thicker shell than $S$. gibbosa (Nikiforova) from the lower Lochkovian of the Roberts Mountains Formation in Nevada; this feature was also noted by Johnson (1973a) for specimens of Sphaerirhynchia from beds of mid-Lochkovian age. Other differences from $S$. gibbosa are the much less well developed fold and sulcus, slightly finer costation, and nearly vertical dental lamellae of the Delorme shells.

\section{Subfamily Hypothyridininae Rzhonsnitskaı, in Khalfin, 1956}

Genus Decoropugnax Havlíček, 1960

\author{
TYPE SPECIES \\ Terebratula berenice Barrande, 1847:77, pl. 17, fig. 8 .
}

\section{?Decoropugnax sp. \\ Pl. 27, figs. 4-8}

\section{REFERRED SPECIMENS}

?Decoropugnax $\mathrm{sp}$. is represented by $4 \mathrm{~A}$ and $\mathrm{IP}$ poorly preserved silicified shells from beds of probable mid- 


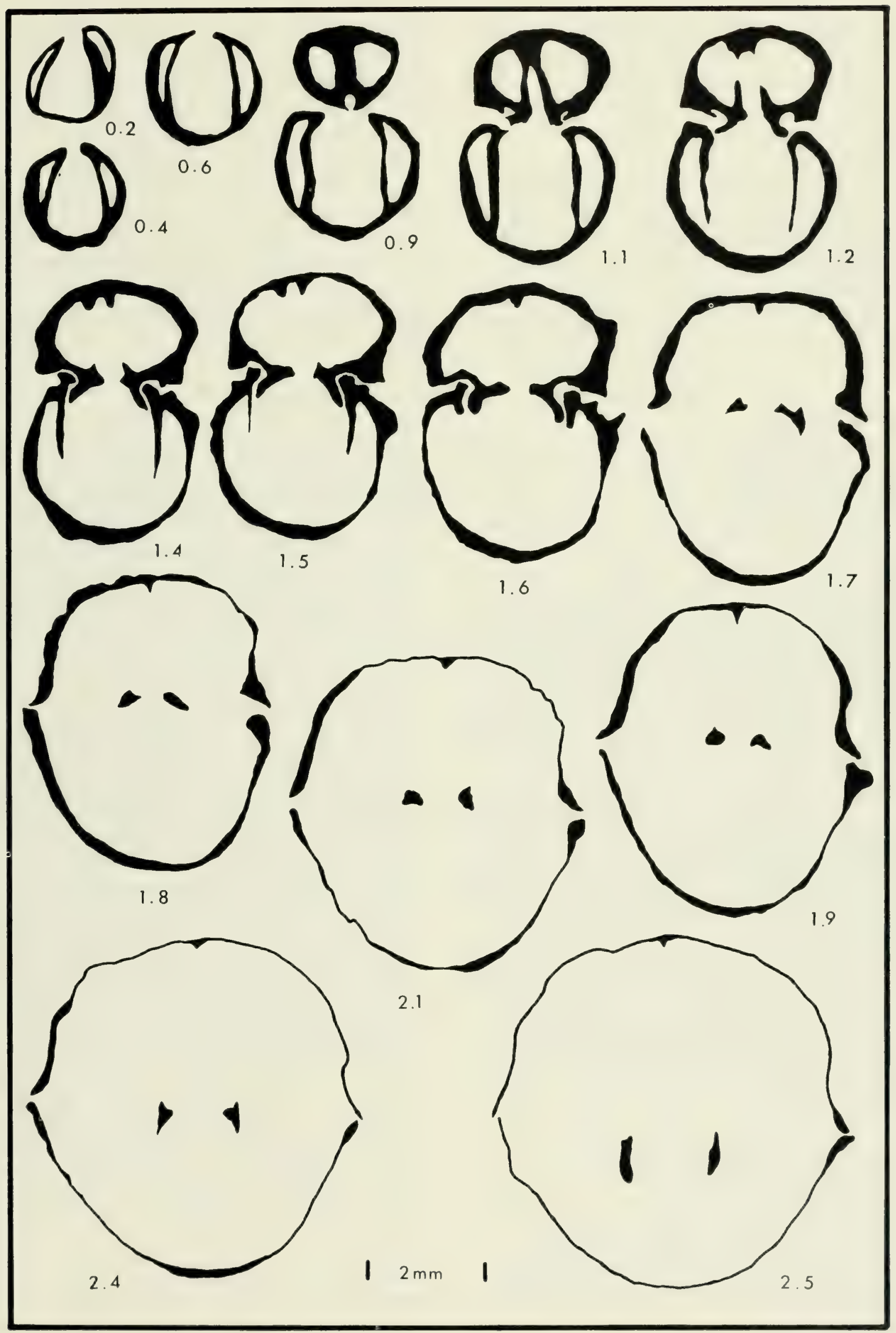

Text-fig. 7 Hebetoechia cf. H. hebe (Barrande).

Camera lucida drawings of serial transverse sections; measurements are distances in $\mathrm{mm}$ from pedicle beak; ROM 33478 
Lochkovian age in S-1, at $536.4 \mathrm{~m}$ below the top of the Delorme Formation. Illustrated material includes ROM 33751,33752 from S-1, sample A536.4 m.

\section{DISCUSSION}

These shells differ from Decoropugnax in having poorly developed dental plates and fewer and slightly coarser costae. The Bohemian type representative of Decoropugnax is from Ludlovian strata; Lenz (1974) reported a possible Decoropugnax from probable Ludlovian strata of the Whittaker Formation in the eastern Mackenzie Mountains. The shells are small, subrounded to subpentagonal in outline, and dorsibiconvex in lateral profile. The ventral palintrope is wide, low, curved, and cleft medially by an open delthyrium. The dorsal fold is low and indistinct; the ventral sulcus is shallow and rounded. Ornament consists of very low, weakly rounded costae that extend from the posterior to the anterior margin. The costae are more faintly developed posteriorly and on the extreme lateral flanks. There are three or four costae on the fold and sulcus and five or six on the lateral flanks. Internally the shells are simple, with fused dental lamellae and large, stubby hinge teeth. The delicate crura are ventrolaterally inclined and anteriorly divergent.

\section{Family Pugnacidae Rzhonsnitskaâa, in Khalfin, 1956}

\section{Genus Isopoma Torley, 1934}

\section{TYPE SPECIES}

Terebratula brachypycta Schnur, 1853:178, pl. 23, fig. 6 .

\section{DISCUSSION}

The writer intends here to clarify the usage of generic names of several external near homoeomorphs of small, posteriorly smooth rhynchonellids. The four genera concerned are Werneckeella Lenz (1971), Linguopugnoides Havlíček (1960), Katunia Kulkov (1963), and Isopoma Torley (1934). Werneckeella is differentiated from Linguopugnoides by the slight furrow along the length of its dorsal valve and by its distinctive, raised, triangular, anteriorly widening dorsal muscle field. Both genera have deltidial plates-contrary to Schmidt and McLaren (1965) and Lenz (1971). Katunia and Isopoma develop external shapes similar to those of the first two genera; however, the interiors of the latter two are simple and lack dorsal septalia and septa. Katunia has muchthickened hinge plates, a low dorsal myophragm, and obsolescent dental lamellae; Isopoma has thin, fragile hinge plates and lacks dental plates. Ancillotoechia is easily separated from these four genera by its sharper beak and more angular costae, and by the common occurrence of its septalium cover plate.

\section{Isopoma cf. I. alecto (Barrande, 1847) Pl. 27, figs. 9-22}

Terebratula alecto Barrande, 1847:42, pl. 20, fig. 2. Atrypa alecto-Barrande, 1879, pl. 34, figs. 1, 2. Isopoma alecto-Havlíček, 1961:40, pl. 4, fig. 6; textfig. 7.

REFERRED SPECIMENS

Isopoma cf. I. alecto occurs in S-1, at 470.9-493.8 m and
OLDA493.8 m, and in S-2, at 166.1-182.9 m, respectively, below the top of the Delorme Formation in beds of late Lochkovian age bearing Spirigerina supramarginalis . The silicified shells are not particularly abundant (33A, 23B, and 38P). Material illustrated includes ROM 33756, 33757 from S-1, sample A493.8 m; ROM 33753-33755 from S-1, sample A470.9 m; and ROM 33758-33761 from S-2, sample B181.4-182.9 m.

\section{EXTERIOR}

The shells are transversely subtriangular to subpentagonal in outline and biconvex to slightly dorsibiconvex in lateral profile. The largest shell is approximately $13 \mathrm{~mm}$ wide, and the maximum width is developed anterior to midlength. The erect pedicle beak extends beyond the dorsal beak. The orthocline palintrope is gently rounded and cleft medially by an open, triangular delthyrium. The delthyrium is partially closed anteriorly in mature shells, producing a submesothyridid foramen. The posterior part of the shell is smooth; the lateral flanks vary from gently convex to strongly geniculate and slightly concave. On a few dorsal valves there is a faint medial furrow extending over the whole length of the valve. The rectangular dorsal fold develops near the posterior margin and commonly bears two to four large, rounded costae which are separated by U-shaped interspaces. Most of the shells bear four costae on the fold, although very small shells have as few as two costae. The ventral sulcus bears two or three large, rounded costae on the dorsally directed tongue. The anterior commissure is uniplicate and highly serrated. The lateral flanks bear two or three large, rounded costae. Concentric ornament is not present. Large shells have a more prominent fold and sulcus; very small shells bear an almost rectimarginate, serrated anterior commissure.

\section{PEDICLE VALVE INTERIOR}

The small, anterolaterally directed hinge teeth are widely separated and are supported by very thin dental lamellae in 
early growth stages; the lamellae are subsequently welded to the shell wall. The subrectangular muscle field is moderately impressed and extends to approximately one-third of the shell length; it is divided medially by a low, rounded myophragm. The shell interior is smooth except near the anterior margin, where it is strongly crenulated. The shell substance is relatively thick.

\section{BRACHIAL VALVE INTERIOR}

The shallow sockets are directed anterolaterally; the thin socket plates curve ventrally and bound the sockets medially. The triangular inner hinge plates are fused to the socket plates and restrict, but do not close the notothyrium. The crural bases are attached to the medial edge of the unsupported inner hinge plates, forming a low ridge along their medial edge. The crura are oval in shape (the long axis is vertical) and diverge and curve gently anteroventrally. A low, distinct myophragm extends from the notothyrial cavity to about one-third of the shell length and divides the dorsal muscle field. The muscle scars are moderately impressed and comprise an elongate, narrow posterior adductor pair and a longer, anteriorly widening anterior adductor pair. The muscle scars and myophragm are recognizable only in some small shells. The interior of the shell is smooth except near the anterior margin, where the costae are impressed into relatively thick shell material.

\section{DISCUSSION}

This is the first report of the genus in North America.I. cf. 1. alecto and Linguopugnoides are readily separated by the absence of the dorsal septum on the former and the finer anterior costae and gentler lateral curvature externally on the latter. $I$. cf. I. alecto is distinct from Katunia in the delicate structure of its hinge plates and in the unsupported nature of its crural bases. The presence of poorly developed dental lamellae in very small shells is not regarded as significant enough to warrant separation of these small specimens from the genus Isopoma. The late Lochkovian occurrence of Delorme shells is slightly older than the Pragian occurrences of Bohemian representatives of the species.

\section{Genus Linguopugnoides Havlíček, 1960}

\section{TYPE SPECIES}

Rhynchonella (nympha) carens Barrande, 1879, pl. 122, figs. IV, V.

Linguopugnoides cf. L. carens (Barrande, 1879) Pl. 27, figs. 23-28

Rhynchonella (nympha) carens Barrande, 1879, pl. 122, figs. IV, V.
Rhynchonella nympha-Siemiradzki, 1906:170, pl. 7, fig 2.

Camarotoechia carens-Kozlowski, 1929:155, pl. 9, figs. 5-17; text-fig. 48

Camarotoechia carens-Nikiforova, 1937:37, pl. 4, fig. 4.

Camarotoechia carens-Nikiforova, 1954, pl. 10, figs. 6-9.

Linguopugnoides carens-Havlíček, 1961:94, pl. 11, figs. 1, 2.

Linguopugnoides carens-Savage, 1971:409, pl. 72, figs. 12-19.

Linguopugnoides cf. L. carens-Lenz, 1973, pl. 1, figs. $19,24,32,37,38$.

\section{REFERRED SPECIMENS}

Linguopugnoides cf. $L$. carens occurs in strata of late Lochkovian age in S-1, at $470.9 \mathrm{~m}$ and OLDA475.5 m, and in S-2, at $166.1 \mathrm{~m}$, respectively, below the top of the Delorme Formation. The specimens are poorly preserved, and many fragmentary specimens cited as ?Linguopugnoides sp. in previous workers' faunal lists are probably $L$. cf. $L$. carens. The tax on is represented by $13 \mathrm{~A}, 4 \mathrm{~B}$, and $4 \mathrm{P}$ silicified shells. Material illustrated includes ROM 33673 from S-1, sample A470.9 m; ROM 33674 from S-1, sample OLDA475.5 m; and ROM 33765, 33766 from S-2, sample B166.1 m.

\section{DISCUSSION}

$L$. cf. $L$. carens is commonly associated with Spirigerina supramarginalis and Toquimaella kayi in the Delorme Formation and is known from the Quadrithyris Zone beds of Bathurst Island (Lenz, 1973). It is also present in southeastern Australia, in the Mandagery Park Formation (Savage, 1971), which is locally correlative with the lower part of the Quadrithyris Zone. The Delorme shells appear identical to those illustrated by Savage (1971) as L. carens and to those illustrated by Lenz (1973) as $L$. cf. $L$. carens. Externally the Delorme shells compare favourably with the shells illustrated by Kozlowski (1929) and Havlíček (1961), and serial sections of the latter shells would also agree with the features observed on the Delorme specimens. $L$. cf. $L$. carens differs from Linguopugnoides stelcki sp. nov. in its smaller size, more prominent costae, more transverse outline, more prominent dental lamellae, and higher dorsal median septum.

Linguopugnoides strigata Gratsianova and Linguopugnoides remissus Gratsianova do not differ greatly from $L$. carens and may in fact be junior synonyms of it. Features used to distinguish these shells include the ratio of width to length of the shell, the degree of flank plication, and the number of plications on the fold. These features show 
considerable variation in $L$. carens. The distribution of $L$. carens-in the Arctic Islands, the northern Canadian Cordillera, Podolia, Bohemia, and probably the Altai Mountains of Siberia (interpreted from Gratsianova, 1967)-suggests that this taxon is a useful zonal index for late Lochkovian strata.

Characteristic morphologic features of the shell are the subtriangular outline, the dorsibiconvex profile, and the prominent ventral tongue filling the large dorsal deflection. Internally a prominent relatively low dorsal septum supports a short septalium formed by medial convergence of the crural bases. The crura are horizontally flattened, thin plates; the latter extend a short distance anteriorly from the crural bases, and then curve strongly ventrally and slightly posteriorly, almost touching the floor of the pedicle valve.

\section{Linguopugnoides stelcki sp. nov.}

$$
\text { Pl. 27, figs. 29-46 }
$$

\section{DIAGNOSIS}

A rotund, teardrop-shaped, anteriorly smooth rhynchonellid with a prominent anterior commissure deflection outlining a fold that is indistinct dorsally. A prominent dorsal median septum supports a small septalium.

\section{ETYMOLOGY}

The species is named after C. R. Stelck, a palaeontologist of the University of Alberta.

\section{REFERRED SPECIMENS}

Linguopugnoides stelcki $\mathrm{sp}$. nov. occurs in S-1, at 62.5-68.6 $\mathrm{m}$ below the top of the Delorme Formation in strata of early Zlichovian age. It is represented by $13 \mathrm{~A}$, 2B, and $1 \mathrm{P}$ well-preserved silicified shells. Material illustrated includes holotype ROM 33769 and paratypes ROM 33767, 33768, 33770-33773 from S-1, sample A62.5-68.6 m.

\section{EXTERIOR}

The shells are of moderate size (largest dimension, $19 \mathrm{~mm}$ ) teardrop-shaped in outline, and markedly dorsibiconvex in lateral profile. The brachial valve is three times deeper than the pedicle valve. The pedicle beak is gently incurved and is cleft medially in small shells by an open, triangular delthyrium. Conjunct deltidial plates develop at the anterior of the delthyrium of large shells, forming a submesothyridid foramen. The dorsal valve is evenly convex with the deepest part of the shell developed slightly posterior to the anterior margin. The pedicle valve is gently convex except near the lateral margins, where it is strongly curved dorsally. The valves are smooth over the posterior one-half of the shell. The indistinct, subrectangular dorsal fold is only slightly raised above the level of the dorsal umbo. The ventral sulcus is broadly U-shaped and develops over the anterior one-third of the shell. The ventral tongue is strongly curved anteriorly. The anterior commissure is strongly uniplicate and undulose, reflecting the very weak plications on the fold, sulcus, and lateral margins. The fold bears one or two gently rounded plicae anteriorly; the sulcus has three plicae developed on the tongue; the lateral margins have two to four weak plicae, the most lateral of which are evident only because of undulations in the commissure. Some shells show faint bifurcation of the primary plicae adjacent to the anterior wall. The concentric ornament of variably impressed growth lines shows that the shells grew considerably in length and depth during ontogeny.

\section{PEDICLE VALVE INTERIOR}

The massive hinge teeth comprise dorsally directed, spherical knobs that are widely set apart. They are supported by prominent vertical, slightly anteriorly divergent dental plates, which define narrow umbonal chambers. The shell interior is smooth except near the anterior margin .

\section{BRACHIAL VALVE INTERIOR}

Much of each socket is situated well above the level of the commissure. The socket plates join the posterolateral shell margin and curve strongly ventrally and slightly laterally. The disjunct inner hinge plates are fused to the socket plates and extend a short distance dorsally before bending sharply medially. The crural bases are fused to the base of the inner hinge plates medially, and they form the lateral walls of a deep, narrow, short septalium. The septalium is supported by a prominent median septum, which dies out near midlength of the shell. The crura are triangular in cross section, diverge gently, and curve strongly anteroventrally from the medial edges of the inner socket plates. The weakly impressed, narrow, elongate dorsal adductor muscle field is divided by the anterior one-half of the median septum. The anterior of the shell is smooth except near the anterior margin, where it is corrugated by the impress of the plicae.

\section{DISCUSSION}

$L$. stelcki sp. nov. differs from the older late Lochkovian $L$. cf. $L$. carens found in underlying strata in that it has less numerous costae, a more prominent dorsal deflection of the anterior commissure, and a more elongate outline. It is distinct from L. glaberrhynchus Perry, Klapper, and Lenz (1974), found in beds of late Zlichovian age of the Ogilvie Formation in the northern Yukon. L. glaberrhynchus is more transverse and has a wider, lower fold, a more lenticular lateral profile, a greater number of costae, and a more prominent dorsal median septum. 


\section{Genus Athyrhynchus Johnson, 1973b}

\section{TYPE SPECIES}

Athyrhynchus susanae Johnson, 1973b:467, pl. 1, figs 1-14; pl. 2, figs. $1-11$; pl. 3, figs. $1-12$; text-fig. 2 .

\section{DISCUSSION}

Athyrhynchus is an anteriorly costate leiorhynchid whose importance in western and arctic North America has only recently been recognized. The genus is known from Zlichovian strata of the Eurekaspirifer pinyonensis Zone of the Cortez Range in central Nevada; from strata of similar age (Disappointment Bay Formation) on Lowther and Cornwallis Islands, in the Arctic Archipelago; and from slightly older Zlichovian beds of the Michelle Formation in the northern Yukon (Johnson, 1973b). Perry, Klapper, and Lenz (1974) reported the genus from beds in the Ogilvie Formation of the northern Yukon that are correlative in age with the Nevada and Arctic Island occurrences. Recognition of the type species and of a slightly older (late Pragian-early Zlichovian) species in the Delorme Formation attests to the biostratigraphic significance and widespread distribution of this taxon endemic to the Cordilleran Region.

\section{Athyrhynchus susanae Johnson, 1973b}

Pl. 28, figs. $8-17$

"Leiorhynchus", sp. Johnson, 1970:150, pl. 40, figs. 10-15.

Athyrhynchus susanae Johnson, 1973b:467, pl. 1, figs. 1-14; pl. 2, figs. 1-11; pl. 3, figs. 1-12; text-fig. 2 . Athyrhynchus susanae-Johnson, 1975b:963, pl. 2, figs. $1-8$.

\section{REFERRED SPECIMENS}

A. susanae is represented by only $1 \mathrm{~A}, 6 \mathrm{~B}$, and $1 \mathrm{P}$ well-preserved silicified shells. Several other crushed, articulated shells from S-3 have tentatively been identified as ?Athyrhynchus sp. (Pl. 28, figs. 1-7, ROM 33779 , 33780). A. susanae occurs in S-3, at 64.0-217.9 m below the top of the Delorme Formation in beds of Zlichovian age. Material illustrated includes ROM 33781 from S-3, sample S4-161.5-164.6 m; ROM 33782-33784 from S-3, sample S4-176.8 m; and ROM 33785 from S-3, sample S4-217.9 m.

\section{DISCUSSION}

The one exquisitely preserved silicified internal mould from sample $\mathrm{S} 4-161.5-164.6 \mathrm{~m}$ allows comment to be made on the morphologic structures described by Johnson (1973b). Two structures are confirmed: the saccate (apocopate) mantle canal system, and the arcuate areas of the gonadal sacs adjacent to the ventral diductor muscle field. Leiorhynchus, a member of the same family, is stated to have a system of saccate (lemniscate) gonadal sacs and mantle canal (Moore, 1965:133); however, this was not confirmed in the detailed studies of the genus Leiorhynchus by Sartenaer (1961). The large amount of internal variation in Athyrhynchus is confirmed (a similar conclusion was reached by Sartenaer (1961) for Leiorhynchus). The large size, the presence of only two or three costae on the fold and sulcus, and the development of a bilobed cardinal process distinguish Athyrhynchus from other rhynchonellid genera.

The phyletic relationships between $A$. susanae and the Athyrhynchus from the Michelle and Ogilvie formations of the northern Yukon are not clear and must await the collection of more and better-preserved material from these two formations.

\section{Athyrhynchus sp. 1 \\ Pl. 28, figs. 18-28}

\section{REFERRED SPECIMENS}

Athyrhynchus sp. 1 occurs in S-1, at 62.5-208.8 $\mathrm{m}$ below the top of the Delorme Formation in beds of late Pragian to early Zlichovian age. It is represented by $2 \mathrm{~A}, 43 \mathrm{~B}$, and 15P large, thin-shelled, predominantly crushed silicified shells. Material illustrated includes ROM 33786-33792 from S-1, sample A62.5-68.6 m; and ROM 33793, 33794 from S-1, sample A205.7-208.8 m.

\section{EXTERIOR}

The shells are similar to $A$. susanae except that they show no sign of a dorsal fold, a ventral sulcus, or any anterior costation, and that they are slightly larger and more lenticular in profile. Growth lines are not evident on the shells of Athyrhynchus sp. 1

\section{PEDICLE VALVE INTERIOR}

The small, bladelike hinge teeth are situated well anterior to the posterior margin and directed anterolaterally. The hinge teeth are formed from a thickening of the shell wall and are supported by short dental plates, which are convergent basally. The teeth define deep, narrow umbonal chambers. The lateral profile of the dental plates is concave anteriorly. Some shells bear the probable remains of conjunct deltidial plates. The elongate, oval ventral muscle scar is weakly impressed and is divided medially by a low myophragm situated well anterior to the ventral beak. The areas of the gonadal sacs and the mantle canal system are not preserved 


\section{BRACHIAL VALVE INTERIOR}

The elongate, cylindrical sockets are directed anterolaterally. They are defined anteromedially by the socket ridges, which are attached to the outer hinge plates. The medial edges of these hinge plates are deflected dorsally to form a septalium. The septalium is supported by a long, thin dorsal septum of moderate height, which continues anteriorly to a point slightly beyond midlength of the shell The median septum thickens near the junction with the septalium. Two nodes are commonly developed on the medial edge of the outer hinge plates and thicken to close off the septalium anteriorly partially or completely. Most shells bear an elongate dorsal muscle scar flanking the median septum; however, a few shells show a more triangular ridge-bounded adductor scar, as is found on $A$. susanae. Some shells show evidence of resorption of the dorsal septum, as described by Johnson in $A$. susanae. The crura are attached to the medial corner of the outer hinge plates, just anterior to the septalium.

\section{DISCUSSION}

These shells probably represent a new species that is closely related to $A$. susanae; however, poor preservation of the specimens precludes the erection of a new taxon in this study. The reason for the crushed nature of the large collection of Athyrhynchus sp. 1 from A62.5-68.6 m is difficult to explain considering the excellently preserved, fully three dimensional nature of associated brachiopods in the same collection. The most likely explanation is that the collection was derived from a single highly compacted, shaly lamina. The occurrence of an individual lamina containing abundant, compressed leiorhynchids has been noted by the writer in the Givetian shales of the Hamilton Group in southwestern Ontario, and in the argillaceous limestones of the Nahanni Formation in the District of Mackenzie, Northwest Territories.

Athyrhynchus? sp. illustrated by Lenz (1977a) is morphologically intermediate between Athyrhynchus sp. 1 and $A$. susanae Johnson in that it has a fold and sulcus but has reduced numbers of costae except on the fold and sulcus. Lenz's taxon is also of Zlichovian age.

\section{Athyrhynchus boucoti sp. nov.}

Pl. 28, figs. 29-39

\section{DIAGNOSIS}

An Athyrhynchus with numerous strong plications along its anterior margin and showing no development of a fold or sulcus

\section{ETYMOLOGY}

The species is named after A. J. Boucot, a palaeontologist of Oregon State University

\section{REFERRED SPECIMENS}

Athyrhynchus boucoti sp. nov. occurs in S-1, at 210.3$233.2 \mathrm{~m}$ below the top of the Delorme Formation in strata of late Pragian age. It is represented by $31 \mathrm{~B}$ and $3 \mathrm{P}$ silicified shells. Because the shell material on this species is thin, the silicified specimens are not particularly well preserved. One bed, with abundant, nestlike accumulations of $A$. boucoti sp. nov., has been replaced by secondary chert. Material illustrated includes holotype ROM 33796 and paratypes ROM 33795, 33797-33800 from S-1, sample A210.3-233.2 m.

\section{EXTERIOR}

The large, subcircular shells are slightly dorsibiconvex in lateral profile. The anacline, sharp ventral beak is gently incurved; the apsacline dorsal beak is moderately incurved. The triangular delthyrium lacks deltidial plates. The shell umbones are smooth. The anterior one-third to two-thirds of the shell is marked by strong, rounded plications with deep, narrow interspaces. The plications are more weakly developed near the lateral margins of the shell.

\section{PEDICLE VALVE INTERIOR}

The small, thin, bladelike hinge teeth are located well anterior to the beak. They are directed anterolaterally, inclined dorsally, and supported by strong, slightly ventrally convergent dental plates, which define deep umbonal chambers. The bases of the dental plates bound the posterior portion of the diductor muscle field. The large, oval diductor muscle scars encompass a small, oval adductor field near their anterior margin. A low platform is developed on the ventral-valve floor between the dental plates. The shell interior is crenulated peripherally by the impress of radial plications.

\section{BRACHIAL VALVE INTERIOR}

The elongate, cylindrical sockets are directed strongly anterolaterally and bounded posterolaterally by the shell wall and anteromedially by well-defined socket ridges. The medial edges of the outer hinge plates curve dorsally to join the median septum and form a septalium. The dorsal median septum is swollen and thickened near the junction with the septalium. The median septum continues anteriorly as a moderately high, knife-edged blade and in some shells extends well anterior to midlength. The thickened portion of the septum is composed of two or three distinct plates of shell material. The septum is flanked by what appears to be a pair of very elongate, narrow, dorsal adductor tracks, which initiate well anterior to the septalium and extend to approximately midlength of the shell. One shell shows the development of very weakly impressed, triangular muscle scars. The anterior edges of the outer hinge plates are commonly curved sharply both 
ventrally and medially and form the inner hinge plates. The crura are attached to the medial, anterior extensions of the inner hinge plates. A true cardinal process is lacking; however, the steeply, posteromedially sloping faces of the outer hinge plates may have served together as the site of attachment of the diductor muscle.

\section{DISCUSSION}

This new species is closely related to $A$. susanae and possibly represents an ancestor of the latter species. Although a true cardinal process is lacking on $A$. boucoti sp. nov., the homologous structure formed by its ventrally curved outer hinge plates probably evolved into the bilobed process present in gerontic specimens of $A$. susanae. The other shell structures of $A$. boucoti sp. nov.- with the exception of the strong anterior plications - appear very close to those of the type species. Intervening stratigraphically between occurrences of $A$. boucoti sp. nov. and of $A$. susanae is Athyrhynchus sp. 1 with a smooth exterior, a possible new species.

\section{Genus Leiorhynchus Hall, 1860}

\section{TYPE SPECIES}

Orthis quadracostata Vanuxem, 1842:168, text-fig. 42, no. 2 .

\section{“Leiorhynchus"'sp. \\ Pl. 27, figs. 47-56}

Athyrhynchus? sp. Lenz, 1977a:96, pl. 22, figs. 31-34, 37-41; text-fig. 4.

\section{REFERRED SPECIMENS}

"Leiorhynchus" sp. occurs in beds of late Pragian age in $\mathrm{S}$-1. It is represented by 1A, 1B, and 3P fragmentary silicified shells. Material illustrated includes ROM 33774 33777 from S-1, sample A272.8 m.

\section{DESCRIPTION}

The subtriangular shells are markedly dorsibiconvex in lateral profile. The length of the shells is only slightly greater than the depth. The dorsal valve bears a smooth, high, subrectangular fold; the ventral valve has a corresponding sulcus and tongue, which may bear up to three weakly developed costae near the line of commissure. The shell surface is smooth, with no trace of costation or plication other than on the tongue of the sulcus. The pedicle valve has conjunct deltidial plates and an apical foramen. The short dental lamellae are convergent ventrally, then divergent basally, and support low, thin, bladelike hinge teeth. The suboval diductor muscle scar extends from within the area bounded by the dental lamellae to about one-third of the shell length. A narrow, elongate adductor muscle scar is situated within the posterior part of the diductor field. The dorsal interior of the Royal Creek shells shows the development of a septalium, which is supported by a relatively low median septum and is covered posteriorly by a plate. The crura extend anteriorly from the lateral margins of the septalium. Cardinal process structures were not recognized in the one fragmentary dorsal valve available for study.

\section{DISCUSSION}

The shells assigned to "Leiorhynchus" sp. could represent a new genus related to Leiorhynchus or possibly another new species of Athyrhynchus. Shells assigned to Athyrhynchus? sp. by Lenz (1977a) appear identical to the Delorme taxon. Although Lenz stated that his shells were from Zlichovian strata, a check of his stratigraphic data shows them to be of late Pragian age. The ventrally convergent and basally divergent form of the dental lamellae, and their continuation around the posterior portion of the ventral muscle field, suggest a closer relationship to Leiorhynchus than to Athyrhynchus.

\section{Family uncertain}

\section{Genus Phoenicitoechia Havlíček, 1960}

\section{TYPE SPECIES}

Terebratula phoenix Barrande, 1847:75, pl. 17, fig. 2.

\section{?Phoenicitoechia sp.}

Pl. 28, figs. $40-44$

\section{REFERRED SPECIMENS}

?Phoenicitoechia sp. is represented by 7A and IP poorly preserved silicified shells from S-1, at OLDA $475.5 \mathrm{~m}$ below the top of the Delorme Formation in strata of late
Lochkovian age. Material illustrated includes ROM 33801-33803 from S-1, sample OLDA475.5T m.

\section{DISCUSSION}

The teardrop-shaped outline is more elongate than on the type species. The development of coarse plications adjacent to the valve margin is consistent with that of the type species, as are internal features such as prominent vertical, slightly anteriorly divergent dental plates and a dorsal septalium supported by a high, bladelike median septum.

The type Phoenicitoechia is recorded from beds of late Pragian age in Bohemia. 


\section{Indeterminate rhynchonellid \\ $\mathrm{Pl}$. 25, figs, 68, 69}

\section{REFERRED SPECIMEN}

This distinctive indeterminate form is represented by the posterior half (ROM 33719) of a large silicified dorsal valve from S-3, at $519.7 \mathrm{~m}$, below the top of the Delorme Formation in Zlichovian strata (sample S4-519.7 m).

\section{DISCUSSION}

Distinctive features are the long, low, stout septum and the prominent septalium supported by the septum. The diductor muscle impressions are situated on the posteroventral face of the inner hinge plates and have slightly upraised medial margins that appear to represent early stages of cardinal process development. Costae are numerous, strong, and rounded; approximately 20 costae are developed immediately adjacent to the posterior margin of the valve.

This shell shows some similarity to specimens of early growth stages of Pleiopleurina, a taxon known from the Pragian of central Nevada (Johnson, 1970).

\section{Order Spiriferida Waagen Superfamily Atrypacea Gill Family Atrypidae Gill, 1871 Subfamily Atrypinae Gill, 1871}

\section{DISCUSSION}

The subfamily Atrypinae is by far the most abundant and morphologically diverse group within the Lower Devonian atrypaceans of the Delorme Formation. In the Delorme the Atrypinae are represented by thousands of shells. Large silicified collections show a considerable range of variation for most species. Occasionally, a few poorly preserved representatives of two or three genera and/or species appear to be present in a single collection and are merely listed as Atrypa spp. (see Pl. 28, figs. 45-47), since they cannot be accurately identified.

Most detailed studies of the Atrypinae have been of calcareous shells. Calcareous collections never show the full range of variation of a species, as can be seen in silicified collections; the net result of these studies, therefore, may be an oversplitting of the Atrypinae. Serial sections of calcareous shells yield only a first insight into the total variation of shell interiors, both because of the physical limit to the number of serial sections that can be made and because slight differences in shell orientation in various serial sections may lead to problems in the interpretation of structures

\section{Genus Atrypa Dalman, 1828}

\section{TYPE SPECIES}

Anomia reticularis Linné, 1758:702.

Atrypa cf. A. nevadana Merriam, 1940

$$
\text { Pl. 29, figs. 1-17 }
$$

Atrypa nevadana Merriam, 1940:83, pl. 7, figs. 18, 19. Atrypa nevadana - Cooper, 1944:319, pl. 121, figs. 6, 7. Atrypa nevadana-Johnson, 1970:56, pl. 41, figs. 5-17.
Atrypa cf. A. nevadana-Perry, Boucot, and Gabrielse, 1981, pl. 3, figs. 1-9.

\section{REFERRED SPECIMENS}

In the Delorme Formation $A$. cf. A. nevadana occurs in beds of late Pragian and Zlichovian age in S-1, at 7.6-274.3 m, and in S-3, at 64.0-573.0 m, respectively, below the top of the formation. The species is represented by $305 \mathrm{~A}, 484 \mathrm{~B}$, and $237 \mathrm{P}$ excellently silicified shells. Material includes ROM 33810-33813 from S-1, sample A7.6-10.7 m; ROM 33805 from S-3, sample S4-492.3 m; ROM 33806 from $\mathrm{S}-3$, sample $\mathrm{S} 4-475.5 \mathrm{~m}$; and ROM 33807-33809 from S-3, sample S4-274.3 m.

\section{DISCUSSION}

Atrypa nevadana is known from strata of late Pragian to Zlichovian age of the Eurekaspirifer pinyonensis and Acrospirifer kobehana Zones of central Nevada. A. cf. A. nevadana appears very similar to the representatives described from central Nevada. Minor morphologic differences noted are at least partially the result of the Nevada representatives being calcareous shells and the Delorme specimens being silicified shells. $A$. cf. $A$. nevadana is distinguished from Atrypa aspiformis Lenz by its overall larger size, coarser costellae, and less prominent, frilly ornament. Within the Delorme Formation the geographic, stratigraphic, and palaeoenvironmental distributions of $A$. cf. $A$. nevadana closely parallel those of Cortezorthis maclareni Johnson and Talent.

A few details of the morphology of the dorsal valve are presented to supplement the description of Johnson (1970). At the point of junction of the spiralia and the crural processes a prominent $\mathrm{V}$-shaped jugum initiates and extends anterodorsally to about one-fifth of the shell length, between the whorls of the spiralia. The spiralia 
consist of at least 10 spiral whorls of decreasing diameters and with axes that are directed slightly medially and nearly touch at the dorsal umbo. A distinct myophragm extends from the notothyrial platform to the anterior edge of the muscle field. The adductor muscle field is broad, bilobate, longitudinally striate, and moderately impressed; it extends to one-third of the shell length. Some shells have a broader, more strongly striate posterior adductor pair that partially surrounds a more firmly impressed, suboval anterior adductor pair.

The jugum of $A$. cf. $A$. nevadana is preserved in some silicified shells and is similar in form to that illustrated by Struve (1955, pl. 1, fig. 2) for Gruenewaldtia. Copper (1967a:1179) questioned earlier reports by Alekseeva (1962) and Boucot, Johnson, and Staton (1965) that the jugum of individual atrypid species or genera may be either disjunct or conjunct: "from a functional and practical point of view this would appear to be unlikely". However, the Delorme shells of $A$. cf. A. nevadana clearly show both medially disjunct and medially connected juga. Therefore, the presence of jugal processes that are firmly connected medially appears a real and variable feature in the Atrypinae.

\section{Atrypa nieczlawiensis Kozlowski, 1929}

Pl. 29, figs. 18-23

Atrypa reticularis var. nieczlawiensis Kozlowski, 1929:170, pl. 8, figs. 14-17.

Atrypa sp. McLaren, Norris, and McGregor, 1962, pl. 8, figs. 4-6.

Atrypa nieczlawiensis-Johnson, Boucot, and Murphy, 1973:47, pl. 29, figs. 14-27.

Atrypa nieczlawiensis-Jackson, Lenz, and Pedder, 1978, pl. 8, figs. 10-12, 17.

\section{REFERRED SPECIMENS}

A. nieczlawiensis occurs in beds of early Lochkovian age in S-7, at $408.4 \mathrm{~m}$, and in S-12, at $717.8 \mathrm{~m}$, respectively, below the top of the Delorme Formation, and in S-11, in the Road River-Delorme-Camsell transitional facies, at $211.5 \mathrm{~m}$ above the top of the Whittaker Formation. The species is represented by $88 \mathrm{~A}$ calcareous shells and $2 \mathrm{P}$ silicified shells. Material illustrated includes ROM 33816 from S-7, sample P7WA1912.6 m; and ROM 33815 from $\mathrm{S}-11$, at $211.5 \mathrm{~m}$ above the top of the Whittaker Formation.

\section{DISCUSSION}

In Nevada, Podolia, and the Canadian Arctic Archipelago, A. nieczlawiensis occurs in strata of early Lochkovian age. McLaren, Norris, and McGregor (1962) reported Atrypa sp. and Gypidula sp. from Map-unit 5 of Douglas and
Norris (1961) at Cathedral Mountain in the South Nahanni River area, Northwest Territories. The collections of A. C. Lenz from beds that are $91.4 \mathrm{~m}$ below the top of the Delorme Formation, at or near the Map-unit 5 locality at Cathedral Mountain, include Atrypa nieczlawiensis and Gypidula pelagica lux (see Pl. 11, figs. 46-51).

$A$. nieczlawiensis is probably closely related to true $A$. reticularis but is distinguished from the latter by its prominent narrow costellae separated by deep, slitlike interspaces that are crossed by distinct, delicate growth lamellae. The Delorme shells are commonly weakly dorsibiconvex; only a few shells are equibiconvex. The hinge teeth are suboval in cross section, with their long axes subparallel to the hinge line, and are separated from the posterior valve margin by a distinct groove. The double set of plates below each tooth (described by Johnson, Boucot, and Murphy, 1973) is preserved in the silicified shells. The hinge tooth is supported by a plate that curves to the posterior valve wall; the plate is in turn supported by a thin, vertical, anterolaterally divergent dental plate. The two plates are separated by a small, conical cavity.

\section{Atrypa cf. A. aspiformis Lenz, 1977b}

Pl. 29, figs. 24-45

Atrypa aspiformis Lenz, 1977b:112, pl. 26, figs. 1-10, 13,14

\section{REFERRED SPECIMENS}

Atrypa cf. A. aspiformis is represented by 551A, 483B, and $318 \mathrm{P}$ well-preserved silicified shells ranging in age from mid-Lochkovian to early Pragian-in S-1, at $396.2-544.1 \mathrm{~m}$ and OLDA370.3-527.3 $\mathrm{m}$, in $\mathrm{S}-2$, at $80.8-225.6 \mathrm{~m}$, and in S-3, at $624.8-685.8 \mathrm{~m}$, respectively, below the top of the Delorme Formation. Material illustrated includes ROM 33817-33821 from S-1, sample A470.9 m; ROM 33822, 33824, 33825 from S-2, sample B128.6 m; and ROM 33826, 33827 from S-2, sample B181.4-182.9 m.

\section{DISCUSSION}

Finer costae, a smaller overall size, a greater density of growth lamellae, and the occasional development of large frills on $A$. cf. $A$. aspiformis distinguish it from $A$. nevadana. Small shells of $A$. cf. A. aspiformis are ventribiconvex; mature shells are strongly dorsibiconvex in lateral profile. The early growth stages of $A$. cf. $A$. aspiformis approach the morphology of Spinatrypina, although the growth lamellae are more regularly imbricate in Spinatrypina. Most ventral valves bear dental lamellae and have a lightly impressed, teardrop-shaped muscle field. Brachial valves bear strongly impressed, widely separated, divergent, and anteriorly elongated muscle 
scars, which are flanked by pustulose areas. The muscle scars are separated medially by a low, wide myophragm with a medial furrow. Shell ornament consists of fine costellae, which increase commonly by both bifurcation and implantation and which are crossed by closely spaced growth lamellae. Several collections of $A$. cf. $A$. aspiformis yield aberrant forms with long frills extending beyond the anterior margin for up to one-third of the shell length. Individual shells may bear more than one frill. The frills are restricted to the anterior one-quarter of the shell and always occur over that area, never forming the actual anterior margin of the shell. The frills develop subequally on both valves. Not all the shells within a single collection bear frills. The frills bear subdued costellae and lack growth lines. The functional purpose of the frill development is not known; if its sole purpose were to raise the anterior edge of the shell above the sediment-water interface and thereby to prevent the shell from sinking into the soft substrate, its presence on both valves would seem to be redundant.

\section{Subfamily Variatrypinae Copper, 1979}

\section{Genus Desquamatia Alekseeva, 1960a}

\section{TYPE SPECIES}

Desquamatia khavae Alekseeva 1960a:421, text-fig. 3.

\section{DISCUSSION}

Desquamatia is used here for shells with rounded, multicostellate ornament, with a dorsibiconvex lateral profile, commonly with well-developed dental plates, and with very much subdued growth lines that are discernible only adjacent to the anterior margin. Deltidial plates are present and are sometimes conjunct in mature shells. Johnson and Boucot (1968) pointed out the close similarity of the type material of Anatrypa Nalivkin (1941) to $D$. khavae and suggested that Desquamatia might be better regarded as a subgenus of Anatrypa since the only obvious difference between them is the longer hinge line of Anatrypa. However, since the Lower Devonian Desquamatia and Anatrypa have not been thoroughly investigated (recent studies by Copper [1979] on atrypids in northwestern Canada are mainly concerned with the revision of younger, Middle Devonian atrypids), Desquamatia is used here to be consistent with previous usage in northwestern Canada.

Desquamatia is a common element in many of the Lochkovian and Pragian collections from the Delorme Formation. In general the Pragian representatives have wider costae, which increase commonly by implantation, whereas the Lochkovian shells have narrower costae, which increase by bifurcation.

\section{Subgenus Desquamatia Alekseeva, 1960a}

Desquamatia (Desquamatia) cf. D. (D.) filistriata Lenz, 1977b

Pl. 30, figs. 1-5

Desquamatia filistriata Lenz, 1977b:116, pl. 26, figs. 11, 12, 15-21.

\section{REFERRED SPECIMENS}

Desquamatia (D.) cf. D. (D.) filistriata occurs in beds of late Pragian and early Zlichovian age in S-3, at 560.8-624.8 $\mathrm{m}$ below the top of the Delorme Formation. It is represented by $7 \mathrm{~A}, 13 \mathrm{~B}$, and $7 \mathrm{P}$ well-preserved silicified shells. Material illustrated includes ROM 33828-33830 from S-3, sample S4-560.8-573.0 m.

\section{DISCUSSION}

Desquamatia (D.) cf. D. (D.) filistriata has broader, less numerous costae with fewer bifurcations than does the Lochkovian Desquamatia sp. 1. Its dorsal valve is different from that on the type material from beds of Pragian age at Royal Creek in having a more prominent broader, median myophragm with a medial groove.

\section{Desquamatia sp. 1}

Pl. 30, figs. 6-12

\section{REFERRED SPECIMENS}

Desquamatia sp. 1 occurs in strata of mid to upper Lochkovian age in the lower range of Spirigerina supramarginalis in $\mathrm{S}-1$, at $528.8-536.4 \mathrm{~m}$ below the top of the Delorme Formation. It is represented by $126 \mathrm{~A}$, 69B, and 56P well-preserved silicified shells. Material illustrated includes ROM 33831-33833 from S-1, sample A528.8 m.

\section{DISCUSSION}

Desquamatia sp. 1 is of mid to late Lochkovian age. Characteristic features include the large number of bifurcating costellae ( 12 to 14 costellae in $5 \mathrm{~mm}$ at a point $5 \mathrm{~mm}$ anterior to the beak) and the presence of a medial dorsal furrow. The dorsal muscle field is separated posteriorly by a wide myophragm and anteriorly by a prominent furrow. In mature shells the lateral profile varies from subequally biconvex to strongly dorsibiconvex. The costellae are considerably finer and more numerous than in the Zlichovian D. cf. D. filistriata Lenz. 


\section{Genus Reticulatrypa Savage, 1970}

\section{TYPE SPECIES}

Reticulatrypa fairhillensis Savage, 1970:663, pl. 102, figs. $1-31$.

\section{DISCUSSION}

Features of the genus Reticulatrypa that distinguish it from Atrypa are its lenticular, equibiconvex profile, its more numerous growth lamellae, and its more abundant costae. Spinatrypina has more widely spaced costae and more imbricate, less numerous growth lamellae than Reticulatrypa. Atrypinella Khodalevich (1939) is bisulcate and is more coarsely costate than Reticulatrypa.

A few shells from the lower part of the Spirigerina supramarginalis beds of S-2 are assigned to Reticulatrypa cf. $R$. granulifera (Barrande). These shells bear very fine costellae interrupted by closely spaced growth lamellae; the costellae lack punctae, which have been noted in some shells assigned to $R$. granulifera (see Lenz, 1977b:115).

\section{Reticulatrypa neutra Johnson, Boucot, and Murphy?, 1973}

P1. 30, figs. 29-38

?Reticulatrypa neutra Johnson, Boucot, and Murphy, 1973:49, pl. 2, figs. 1-18.

\section{REFERRED SPECIMENS}

$R$. neutra? occurs in beds of early Lochkovian age in the Delorme Formation-in S-2, at $336.8 \mathrm{~m}$ below the top of the formation - and in beds of Pridolian and probable early Lochkovian age in the transitional facies of Gabrielse, Blusson, and Roddick (1973) - in S-11, at 185.9-193.5 m and $211.5 \mathrm{~m}$ above the top of the Whittaker Formation. The species is represented by $54 \mathrm{~A}, 35 \mathrm{~B}$, and $12 \mathrm{P}$ silicified shells. Material illustrated includes ROM 33841-33845 from S-2, sample B336.8 m.

\section{DISCUSSION}

In Nevada $R$. neutra occurs in beds of Pridolian age in the
Roberts Mountains Formation. R. neutra? is slightly larger than the type material from Nevada. Only the early growth stages of the Delorme shells develop obvious carination and a distinct dorsal sulcus. The anterior commissure is rectimarginate in large shells of $R$. neutra?, whereas in the type material it is deflected slightly ventrally. $R$. fairhillensis Savage from the late Lochkovian of New South Wales has less prominent costellae and shows complete reversal of the anterior commissure deflection. $R$. norrisi Lenz from the Lochkovian of Royal Creek is more inflated and has a more regular system of costellae increase. The Delorme specimens have closely spaced, imbricate growth lamellae, costellae that increase by both bifurcation and implantation, a transversely suboval outline, and a lenticular lateral profile-all of which suggest close affinity to $R$. neutra.

\section{Reticulatrypa variabilis Johnson, Boucot, and Murphy, 1976 \\ Pl. 30, figs. 39-59}

Reticulatrypa variabilis Johnson, Boucot, and Murphy, 1976:73 pl. 47, figs. 13-26.

\section{REFERRED SPECIMENS}

$R$. variabilis occurs in beds of Ludlovian age in S-6, at $193.5 \mathrm{~m}$ and $204.2 \mathrm{~m}$ above the base of the Delorme Formation. It is represented by $95 \mathrm{~A}, 27 \mathrm{~B}$, and $18 \mathrm{P}$ excellently preserved shells. Material illustrated includes ROM 33855 from S-6, sample C47-237.7 m; and ROM 33846-33854 from S-6, sample C47-248.4 m.

\section{DISCUSSION}

$R$. variabilis occurs in strata of Ludlovian age in central Nevada. The Delorme $R$. variabilis is distinguished from $R$. neutra? by its more elongate, subpentagonal outline, its less numerous, more rounded costellae, and its more prominent, erect ventral beak. It is more coarsely costate than the older Ludlovian R. savagei Johnson, Boucot, and Murphy and the younger Lochkovian $R$. norrisi Lenz.

\section{Subfamily Spinatrypinae Copper, 1979}

\section{Genus Spinatrypa Stainbrook, 1951}

\section{TYPE SPECIES}

Atrypa aspera var. occidentalis Hall, 1858:515, pl. 6, figs. $3 a-d$.

\section{DISCUSSION}

The genera Spinatrypa, Invertrypa, and Spinatrypina comprise a closely related group with the Spinatrypinae. Spinatrypa is used here for strongly dorsibiconvex shells with undulose ribs arranged in interrupted rows. Invertrypa is regarded as a subgenus of Spinatrypa and includes equally biconvex to ventribiconvex shells with low, widely spaced ribs bearing prominent fluted spines. Both Spinatrypa and Invertrypa have incurved beaks. Spinatrypina is characterized by tubular-imbricate ribbing and a straight beak (Copper, 1967b). The study of the spinatrypid group has been largely confined to Eifelian through Frasnian species. Descriptions of Lower Devonian spinatrypids are not common-only a handful of species are 
described from western or arctic North America. Spinatrypids are common elements in the Delorme Pragian and Zlichovian, although they are never abundant or well preserved.

\section{Spinatrypa jonesi sp. nov. Pl. 31, figs. 1-11}

\section{DIAGNOSIS}

A Spinatrypa of dorsibiconvex profile with prominent growth lamellae rising away from the crests of the medium strength costae anteriorly and forming fluted, spinelike structures.

\section{ETYMOLOGY}

The species is named after Brian Jones, palaeontologist at the University of Alberta.

\section{REFERRED SPECIMENS}

Spinatrypa jonesi sp nov. occurs in beds of Pragian age in $\mathrm{S}-1$, at 207.3-342.1 $\mathrm{m}$ and OLDA278.9-353.6 $\mathrm{m}$, and in $\mathrm{S}-2$, at $32.0 \mathrm{~m}$, respectively, below the top of the Delorme Formation. It is represented by $28 \mathrm{~A}, 54 \mathrm{~B}$, and $29 \mathrm{P}$ well-preserved silicified shells. Material illustrated includes holotype ROM 33860 from S-1, sample A207.3$208.8 \mathrm{~m}$; paratypes ROM 33862-33864 from S-1, sample OLDA336.8 m; and paratype ROM 33861 from S-2, sample B32.0 m.

\section{EXTERIOR}

The shells are moderately large, elongate to transverse in outline, and strongly dorsibiconvex in lateral profile. The hinge line is short and curved. The maximum shell width develops posterior to midlength. The ventral beak is moderately incurved, pierced by a subhypothyridid foramen, and bounded posteriorly by thin, conjunct deltidial plates. The dorsal fold and ventral sulcus are developed over the anterior of large shells. The ventral sulcus is weak and bears an elongate tongue. The strong, rounded costae become broader anteriorly. The number of costae varies from four to seven in $5 \mathrm{~mm}$ at a point $10 \mathrm{~mm}$ anterior to the beak. The costae are crossed by prominent highly frilly growth lamellae with variable spacing. The growth lamellae rise anteriorly away from the crests of the costae and form fluted, spinelike structures.

\section{PEDICLE VALVE INTERIOR}

The dorsally directed hinge teeth are widely set apart, suboval in cross section, and supported by dental lamellae. The muscle field is weakly impressed and consists of a small, suboval adductor field surrounded by a large, teardrop-shaped diductor field, which extends to one-third of the shell length. The anterior two-thirds of the shell is crenulated by the impress of costae

\section{BRACHIAL VALVE INTERIOR}

The sockets are bounded posterolaterally by the shell wall and anteromedially by prominent socket plates which diverge from the shell wall. The sockets are partially covered posteriorly by the recurved socket plates. A low, corrugated ridge crosses the socket diagonally along its length. Secondary shell material forms a low notothyrial platform between the sockets. A low median myophragm extends anteriorly from the notothyrial platform and subdivides the muscle field. The muscle field consists of two distinct, oval muscle scars, which extend to about one-third of the shell length. Shell material flanking the muscle scars is pustulose. The shell periphery is variably crenulated by the impress of the costae.

\section{DISCUSSION}

Spinatrypa jonesi sp. nov. is readily distinguished from $S$. (Invertatrypa) echinocosta (Lenz) by its dorsibiconvex profile, smaller and more numerous costae, and overall smaller size. It is clearly distinct from the younger Zlichovian Spinatrypina symmetrica Perry, Boucot, and Gabrielse, which has narrower and higher costae and much less lamellose growth lamellae.

\section{Subgenus Invertrypa Struve, 1961}

\section{TYPE SPECIES}

Spinatrypa kelusiana Struve, 1956:385, pls. 1-3.

\section{Spinatrypa (Invertrypa) echinocostata Lenz, 1977b} Pl. 31, figs. 21-27

Spinatrypa echinocostata Lenz, 1977b:117, pl. 27, figs. $1-15$.

\section{REFERRED SPECIMENS}

Spinatrypa (Invertrypa) echinocostata is represented by $3 \mathrm{~A}, 3 \mathrm{~B}$, and $1 \mathrm{P}$ coarsely silicified shells in beds of mid to late Pragian age in $\mathrm{S}-1$, at $175.2-342.9 \mathrm{~m}$ and OLDA $370.3 \mathrm{~m}$, and in $\mathrm{S}-2$, at $32.0 \mathrm{~m}$, respectively, below the top of the Delorme Formation. Material illustrated includes ROM 33870 from S-1, sample A175.2 m; ROM 33869 from S-1, sample OLDA370.3 m; and ROM 33871 from S-2, sample B32.0 m.

\section{DISCUSSION}

This species is common in beds of mid to late Pragian age at Royal Creek. It is characterized by a large size and by broad, rounded costae crossed by lamellose growth lamellae, which often extend as tubelike or clublike spines. Costae increase infrequently, and by bifurcation or implantation. The shell is equally biconvex to slightly dorsibiconvex and has an incurved pedicle beak. Internally the ventral muscle field consists of a large, teardrop- 
shaped, longitudinally striated diductor field that surrounds a small, oval adductor field. The brachial valve has a well-developed notothyrial platform and ventrally directed crura. The ornament is similar to that on $S$. curvirostra Copper (1967b) from the Lower Givetian of Germany but the German species is more strongly dorsibiconvex and shows a greater increase in the number of costae.

\section{Genus Spinatrypina Rzhonsnitskaıā, 1964}

\section{TYPE SPECIES}

Spinatrypina margaritoides Rzhonsnitskâa, 1964:101, pl. 1, figs. 1-8.

Spinatrypina symmetrica Perry, Boucot, and Gabrielse, 1981

Pl. 31, figs. 12-20

Spinatrypina symmetrica Perry, Boucot, and Gabrielse, 1981:300, pl. 3, figs. 13-30.

\section{REFERRED SPECIMENS}

S. symmetrica is represented by $30 \mathrm{~A}, 11 \mathrm{~B}$, and $8 \mathrm{P}$ small, moderately well preserved silicified shells from beds of Zlichovian age in S-3, at $64.0-507.5 \mathrm{~m}$ below the top of the Delorme Formation. Material illustrated includes ROM 33865,33866 from S-3, sample S4-64.0-65.5 m; ROM 33868 from S-3, sample S4-176.8 m; and ROM 33867 from S-3, sample S4-502.9-507.5 m.

\section{DISCUSSION}

The type material of $S$. symmetrica is from beds of probable Zlichovian age near Mount Lloyd George in north-central British Columbia. It differs from $S$. asymmetrica Johnson and Flory (1972), which has more numerous and more prominent costae and which shows a prominent curvature of the dorsal median costa. The prominent ventral sulcus and dorsal fold developed in some of the central Nevada $S$. asymmetrica are absent in the Delorme material. Middle Devonian Spinatrypina of Copper (1967b) are more circular in outline and lack the high, more widely spaced costae of $S$. symmetrica.

\section{Subfamily Atrypininae McEwan, 1939}

\section{Genus Atrypina Hall and Clarke, 1893}

\section{TYPE SPECIES}

Leptocoelia imbricata Hall, 1857:108.

\section{Atrypina simpsoni Johnson, 1970 Pl. 32, figs. 1-12}

Atrypina simpsoni Johnson, 1970:159, pl. 43, figs. 5-16. Atrypina simpsoni-Johnson, 1973a:1023, pl. 5, figs. 1-3.

Atrypina cf. A. simpsoni-Lenz, 1977b:112, pl. 23, figs. $1-5$.

\section{REFERRED SPECIMENS}

A. simpsoni is represented by $11 \mathrm{~A}$ and $1 \mathrm{~B}$ silicified shells from beds of late Lochkovian and early Pragian age in $\mathrm{S}-1$, at $272.8-475.5 \mathrm{~m}$ and OLDA336.8-388.6 $\mathrm{m}$ below the top of the Delorme Formation. Material illustrated includes ROM 33880, 33881 from S-1, sample A330.7 m; ROM 33882 from $\mathrm{S}-1$, sample OLDA336.8 m.

\section{DISCUSSION}

The type $A$. simpsoni is described from the late Lochkovian Quadrithyris Zone of central Nevada. A similar species with a flatter profile and a larger number of costae is known from the lower Lochkovian of the Roberts Mountains Formation. Characteristic features of $A$. simpsoni include two prominent ventral plications, which initiate near the beak and serve to delineate the ventral fold; on some shells these central ventral plications bifurcate near the anterior margin. Two pairs of ventral flank plications are much more weakly developed. The brachial valve has a medial plication dividing the sulcus, and two or three flank costae which may or may not bifurcate anteriorly. The interior of the Delorme $A$. simpsoni was not observed.

Most of the Delorme $A$. simpsoni are slightly younger than their Nevada counterparts. They are distinguished from the early Zlichovian Atrypina chattertoni sp. nov. by their smaller size, more elongate outline, and sharper, more prominent, and more abundant flank plications, as well as by their lack of the prominent dorsal sulcus and ventral fold developed in $A$. chattertoni sp. nov. $A$. simpsoni at Royal Creek is also from Pragian beds. The species has not yet been recovered from the Arctic Archipelago and may represent an Appalachian genus that only reached northwestern Canada after the passage of considerable time in the Early Devonian.

\section{Atrypina chattertoni sp. nov.}

Pl. 32, figs. 13-32

\section{DIAGNOSIS}

A very coarsely plicated, markedly ventribiconvex Arrypina with a distinct ventral fold divided by a prominent median furrow 
ETYMOLOGY

The species is named after B. D. E. Chatterton of the University of Alberta.

\section{REFERRED SPECIMENS}

Atrypina chattertoni sp. nov. is represented by $56 \mathrm{~A}, 4 \mathrm{~B}$, and $4 \mathrm{P}$ silicified shells from $\mathrm{S}-1$, at $62.5-68.6 \mathrm{~m}$ below the top of the Delorme Formation, and possibly by one specimen from S-1, at 278.9-281.9 m below the top of the formation. A. chattertoni sp. nov. is of early Zlichovian age; if the specimen from sample A278.9-281.9 m belongs to this species and is not a morphologic end member of $A$. simpsoni, the age range of the new species extends into the late Pragian. Material illustrated includes holotype ROM 33883 and paratypes ROM 33884-33889 from S-1, sample A62.5-68.6 m

\section{EXTERIOR}

The shell outline is semicircular to transverse, and the lateral profile is strongly ventribiconvex. The greatest ventral-valve convexity develops at the anterior margin. The erect, elongate pedicle beak bears an apical, elongate, oval foramen. The ventral interarea is small and triangular. The dorsal beak is moderately incurved over the dorsal interarea. The wide, straight hinge line extends to the gently rounded cardinal anges (approximately $90^{\circ}$ ). The maximum shell width is developed slightly anterior to the hinge line. The rounded radial plications are crossed by prominent concentric, lamellose growth lines. The growth lines are irregularly spaced and sometimes form distinct rugae. Two high, rounded central plications in the ventral valve split from the fold at about one-quarter to one-third of the shell length and form a distinct, intraplicate fold. The central plications are flanked by a pair of less prominent flank plicae. Occasionally the central plications bifurcate and form short, indistinct plications near the anterior margin. The dorsal valve bears a central plication initiating directly opposite the bifurcation of the ventral fold, expanding anteriorly, and dividing the sulcus. The sulcus is flanked by two pairs of rounded lateral plications. Occasionally a very low, indistinct, third lateral plication develops.

\section{PEDICLE VALVE INTERIOR}

The hinge teeth are large, triangular in plan view, and not supported by dental lamellae. They are attached to the margin of the interarea and directed dorsomedially. The apical foramen is developed by coalescence of the deltidial plates near the hinge line. Small specimens have an open delthyrium with a rounded apex. The muscle scars are not impressed. Both valves are strongly corrugated internally by the impress of plications.

\section{BRACHIAL VALVE INTERIOR}

The socket plates are divided medially by a deep trench and are thick medially, at the point of their attachment to the valve wall; the valve wall forms the posterior wall of the socket. The socket plates are directed anterodorsally and then become thinner and curve laterally, parallel to the posterior margin of the valve. The wide ventral surface of each socket plate is flat and is enclosed apically by a slightly overhanging dorsal interarea. The low, triangular, anacline dorsal interarea is cleft by a triangular notothyrium. A prominent rounded myophragm divides the posterior one-third of the shell.

\section{DISCUSSION}

A. chattertoni sp. nov. is distinguished from $A$. simpsoni by its larger size, transverse outline, more prominent central plications on the ventral valve, and more prominent ventral fold. It is similar to A. hami Amsden (1958) from Helderbergian (early Lochkovian) strata of the Bois d'Arc Formation of Oklahoma. A. hami is larger and has a markedly incurved ventral beak and a flatter dorsal valve. This occurrence of Atrypina in the Delorme Formation represents one of the youngest known of the genus.

\section{Atrypina sp. 1}

Pl. 32, figs. 33-40

\section{REFERRED SPECIMENS}

Atrypina sp. 1 is represented in the Delorme by two articulated and numerous disarticulated specimens of early Pragian age from S-2, at $105.2 \mathrm{~m}$ below the top of the Delorme Formation. Material illustrated includes ROM 33890, 33891 from S-2, sample B105.2 m.

\section{DISCUSSION}

Atrypina sp. 1 shows some similarity to weakly plicate representatives of $A$. simpsoni from the Quadrithyris Zone of central Nevada (Johnson, 1970, pl. 43, figs. 11, 15). The specimen illustrated by Johnson (1973a, pl. 5, figs. 1-3) and assigned to $A$. simpsoni from the Lower Windmill Limestone of central Nevada is only slightly more plicate than the Delorme Atrypina sp. 1. Atrypina sp. 1 is much smaller and less transverse and has much weaker radial ornament than $A$. chattertoni sp. nov. It is distinct from Delorme shells assigned to $A$. simpsoni in that its radial ornament is much more subdued, only one very faint lateral pair of plications is visible, and the splitting of the ventral fold is poorly developed. With respect to external morphology, Atrypina sp. 1 appears very similar to A. talenti Savage (1970) from beds of the upper Lochkovian Quadrithyris Zone of New South Wales. The protruding ventral beak, rounded apical foramen, and 
rounded subdued costae of $A$. talenti are similar to those of Atrypina sp. 1; however, $A$. talenti has a greater number of lateral plications on some shells. The Delorme Atrypina sp. 1 is of early Pragian age.

\section{Subfamily Zygospirinae Waagen, 1883}

\section{DISCUSSION}

Amsden (1974) demonstrated that Spirigerina was derived from the zygospirinids. Johnson and Boucot (1972) classified Spirigerina with the carinatinids; however, Amsden's phylogeny appears more tenable.

\section{Genus Spirigerina d'Orbigny, 1849}

\section{TYPE SPECIES}

Terebratula marginalis Dalman, 1828:143, pl. 5, figs. $6 \mathrm{a}-\mathrm{c}$.

\section{Spirigerina supramarginalis (Khalfin, 1948)} Pl. 31, figs. 28-47

Atrypa supramarginalis Khalfin, 1948:159, pl. 2, fig. 10; pl. 4, figs. 4-7.

Plectatrypa supramarginalis-Kulkov, 1960:452, pl. D-70, figs. 9, 10 .

Spirigerina supramarginalis-Kulkov, 1963:70, pl. 5, figs. 11-13.

Spirigerina supramarginalis-Gratsianova, 1967:100, pl. 10, figs. $1-3$.

Spirigerina supramarginalis-Johnson, 1970:157, pl. 42, figs. $1-10$.

Spirigerina supramarginalis-Tyazheva and Zhavoronkova, 1972:113, pl. 32, figs. 7-10.

Spirigerina supramarginalis-Johnson, 1975a:8, pl.8, figs. 1-26.

Spirigerina supramarginalis-Lenz, 1977b:119, pl. 25, figs. 1-35, 39.

Spirigerina supramarginalis_-Jackson, Lenz, and Pedder, 1978, pl. 9, figs. 24, 25, 29-31.

Spirigerina supramarginalis-Johnson, Penrose, and Wise, 1978, pl. 1, figs. 22-30.

\section{REFERRED SPECIMENS}

S. supramarginalis is represented by $72 \mathrm{~A}, 20 \mathrm{~B}$, and $34 \mathrm{P}$ well-preserved silicified shells in the Delorme Formation. It occurs in beds of late Lochkovian age in S-1, at 466.3-528.8 $\mathrm{m}$ and OLDA423.7-515.1 $\mathrm{m}$, and in S-2, at $166.1-221.0 \mathrm{~m}$, respectively, below the top of the formation. Some crushed shells from S-3, sample S4$624.8 \mathrm{~m}$, also below the top of the Delorme, possibly belong to $S$. supramarginalis, but their specific identity is uncertain because of poor preservation. Material illustrated includes ROM 33874, 33875 from S-1, sample
A519.7 m; ROM 33872, 33873 from S-1, sample A470.9 m; and ROM 33876-33878 from S-2, sample B221.0 m.

\section{DISCUSSION}

S. supramarginalis is a geographically widespread species in strata of late Lochkovian age from western and northern North America, and Asiatic and Uralian USSR. $S$. supramarginalis is not nearly as abundant in the Delorme late Lochkovian as in the Spirigerina Unit at Royal Creek, where it locally represents up to 50 per cent of the total brachiopod fauna. As mentioned by Johnson (1975a), S. supramarginalis shows considerable variation in the number of costae, within the limits of the relatively small number of costae characteristic of the species. Another seemingly constant characteristic of specimens from the Delorme Formation and Royal Creek is the strong dorsal deflection of the ventral sulcus tongue. This tongue is usually smooth or bears only very weakly developed costae near its dorsal extremity. The Spirigerina shells of the Quadrithyris Zone in Nevada were originally assigned to the finer and more abundantly ribbed "Plectatrypa cf. $P$. sibirica' by Johnson (1965) but subsequently assigned to the coarser ribbed $S$. supramarginalis by Johnson (1970). Compared to S. marginaliformis, S. supramarginalis has stronger, less numerous (usually less than 15) costae, which split near the anterior commissure; $S$. marginaliformis bears more numerous (usually more than 25) costae, which split well posterior to the anterior margin. S. supramarginalis is closely associated with Toquimaella kayi in western North America, where the two species have similar stratigraphic ranges. In the Delorme collections the number of $T$. kayi is several orders of magnitude greater than the number of $S$. supramarginalis.

\section{Spirigerina marginaliformis Alekseeva, 1960b} Pl. 31, figs. 48-52

Atrypa marginalis Nikiforova, 1937:42, pl. 8, figs. 1-8. Atrypa marginalis-Khodalevich, 1939:47, pl. 25, figs $1-3$.

Spirigerina marginaliformis Alekseeva, 1960b:65, pl. 7, fig. 1.

Plectatrypa marginalis sibirica Rzhonsnitskaia in Sarycheva, 1960, pl. 53, fig. 24.

Spirigerina marginaliformis-Alekseeva, 1962:161, pl. 9 , fig. 10 ; text-figs. 76,77 
Spirigerina marginaliformis-Johnson, Boucot, and Murphy, 1973:50, pl. 25, figs. 1-7.

Spirigerina marginaliformis_Johnson, 1973a:1023, pl. 3 , figs. 6-14.

Spirigerina supramarginalis-Savage, 1974:40, pl. 11, figs. 1-9.

Spirigerina (Spirigerina?) supramarginalis sibirica Rzhonsnitskaia, 1975:70, pl. 16, figs. 2, 3; text-fig. 22.

Spirigerina marginaliformis-Lenz, 1977b:119, pl. 24, figs. 5-16, 22, 23.

Spirigerina marginaliformis_-Jackson, Lenz, and Pedder, 1978, pl. 8, figs. 23-26, 33.

\section{REFERRED SPECIMEN}

$S$. marginaliformis is represented by one well-preserved silicified shell (ROM 33879) from S-1, at $544.1 \mathrm{~m}$ below the top of the Delorme Formation (sample A544.1 m). It occurs in beds approximately $15 \mathrm{~m}$ below $S$. supramarginalis and is of early or mid-Lochkovian age.

\section{DISCUSSION}

As was mentioned above, this species is distinguished from the younger $S$. supramarginalis by its fine, more numerous costae. The Delorme specimen and those from Royal Creek are consistently of larger size than representatives of $S$. supramarginalis at a similar stage of ontogenetic development. The distribution of $S$. marginaliformis is not as widespread as that of $S$. supramarginalis, and it is not known in great abundance from any region of western North America. It is found in beds equivalent to the lower part of the lower Lochkovian Gypidula pelagica Unit at Royal Creek and in beds of early and mid-Lochkovian age in central Nevada. The specimens illustrated by Savage (1974) from the early Lochkovian Maradana Shale of New South Wales have abundant fine costae and are clearly assignable to $S$. marginaliformis rather than to $S$. supramarginalis.

The parts of the stratigraphic section at S-1 that are of Pridolian and lower and mid-Lochkovian age are considerably condensed relative to those of late Lochkovian age. Probable Ludlovian graptolites occur only $30 \mathrm{~m}$ below $S$. marginaliformis.

\section{Spirigerina intermedia sp. nov.}

Pl. 32, figs. 41-49

?Spirigerina supramarginalis-Savage, 1970:659, pl. 102, figs. $42-49$.

\section{DIAGNOSIS}

A Spirigerina that has abundant low, rounded costae, a weakly developed fold and sulcus, and hence a relatively shallow shell.

\section{ETYMOLOGY}

The specific name is from the Latin intermediatusbetween, in reference to its stratigraphic position between $S$. marginaliformis and $S$. supramarginalis.

\section{REFERRED SPECIMENS}

Spirigerina intermedia sp. nov. occurs stratigraphically between $S$. marginaliformis and $S$. supramarginalis in $\mathrm{S}-1$, at $536.4 \mathrm{~m}$ and OLDA527.3 $\mathrm{m}$ below the top of the Delorme Formation in beds of probable mid-Lochkovian age. Some 17A, 7B, and 11P well-preserved silicified shells are available for study. Material illustrated includes holotype ROM 33894, and paratypes ROM 33892, 33893, 33895, 33896 from S-1, sample A536.4 m.

\section{EXTERIOR}

The shells vary from transversely to longitudinally suboval in outline and are strongly dorsibiconvex in lateral profile. The maximum height of the dorsal valve is posterior to midlength of the shell except in gerontic shells, where the anterior margin of the dorsal fold marks the maximum valve height. The moderately elongate, pointed ventral beak is pierced apically by a circular subhypothyridid foramen. The short hinge line is curved, and maximum shell width is developed near or anterior to midlength. The pedicle valve has a shallow sulcus posteriorly that is strongly curved dorsally into a tonguelike projection near the anterior margin. Ornament comprises very low, rounded radial costae (more than 20 on mature shells), which increase by both implantation and bifurcation. The centrally located costae are more prominent than the lateral costae. Concentric ornament is subdued; a few growth lamellae are visible near the anterior margin of some shells.

\section{PEDICLE VALVE INTERIOR}

The thin, oval hinge teeth are widely set apart and are strongly inclined anterodorsally. The hinge teeth are supported by prominent short, vertical dental lamellae, which remain distinguishable from the shell wall in large shells. A T-shaped structure is formed at the junction of the dental plates and the hinge teeth. A weakly impressed, subtriangular muscle field extends over the posterior one-quarter of the shell and appears longitudinally striated in some shells. The costae are weakly impressed over the anterior two-thirds of the shell.

\section{BRACHIAL VALVE INTERIOR}

The large sockets are separated medially and are confined by the crescentic socket plates, which initiate at the posterior shell wall and then curve strongly ventrolaterally. A small, unsupported, ridgelike structure is attached to the medial edges of the sockets and marks the site of crural attachment. The anteriorly directed crura curve 
strongly ventrolaterally and almost touch the posterolateral flank of the pedicle valve. The muscle scars are not impressed. A wide, low medial myophragm divides the anterior two-third of the shell. The radially corrugated shell interior reflects the costation of the shell.

\section{DISCUSSION}

The more suppressed radial ornamentation on $S$. intermedia sp. nov. distinguishes it from both $S$. supramarginalis and $S$. marginaliformis, although the large number of its costae would suggest a closer affinity to $S$. marginaliformis. Lenz and Pedder (1972) list specimens of Spirigerina sp. in the lower Lochkovian at Royal Creek, at RC1-86.6-89.4 m. Although calcareous and partially exfoliated, these shells possess numerous costae with low relief. This collection is also from beds between occurrences of $S$. supramarginalis and $S$. marginaliformis (S. sibirica of Lenz and Pedder, 1972). The specimens illustrated and assigned to $S$. supramarginalis by Savage (1970) are close to $S$. intermedia and distinct from $S$. supramarginalis.

\section{Subfamily ?Atrypinae Gill, 1871}

\section{Genus Vagrania Alekseeva, 1959}

\section{TYPE SPECIES}

Atrypa kolymensis Nalivkin, 1936:17, pl. 2, fig. 8.

\section{DISCUSSION}

Johnson (1967) assigned Vagrania and its probable ancestor Toquimaella to the Subfamily Karpinskiinae; the presence of "long vascular ridges" in Vagrania, Toquimaella, Eokarpinskia, and Karpinskia appears to be the basis for his classification. Copper $(1973,1979)$ placed the vagraniids in the same subfamily. The four genera all possess long parallel ridges in the pedicle valve. In Toquimaella and Vagrania the ridges are relatively low and wide and are the shape of an inverted $\mathrm{V}$ in cross section; in Karpinskia and Eokarpinskia thay are bladelike in cross section (see Nikiforova and Iakovlev, 1937, text-figs. 7-1-7-10 for Eokarpinskia; Chernyshev, 1885, pl. 7, figs. 81, 86 for Karpinskia; Chernyshev, 1893, pl. 9, fig. 1 for Karpinskia; Bublitschenko, 1927, pl. 49, figs. 1a-g, 6a, b for Karpinskia; Rzhonsnitskaia in Sarycheva, 1960, fig. 326 for Karpinskia; Johnson, 1967 , pl. 111, fig. 6 for Karpinskia).

The cross section of the vascular ridge of the pedicle valve is regarded to be of lesser significance than the form of the cardinalia. The cardinalia of Eokarpinskia and Karpinskia are closely allied and do not have much in common with those of Toquimaella or Vagrania, which are more similar to the cardinalia of Atrypa (Perry, Boucot, and Gabrielse, 1981). The crenulated dental sockets and the depressed area between the sockets (probable site of diductor attachment) on Vagrania are reminiscent of many Atrypinae. Karpinskia and Eokarpinskia have prominent posterior, bosslike areas for diductor attachment (with or without short, median, bladelike structures). Karpinskia and Eokarpinskia lack lateral branches on their ventral vascular ridges. Several vagraniids ( $V$. atrypiforma Perry, Boucot, and Gabrielse, $V$. johnsoni sp. nov., and Vagrania sp. 1) bear prominent vascular ridges in both valves; dorsal vascular ridges are not recorded in the karpinskiids. $V$. atrypiforma has a frill typical of atrypids, but unknown in karpinskiids, although present in carinatininids. In comparison to Vagrania, Toquimaella is more multicostate and has unbranched costae. Toquimaella and Vagrania appear more closely related to the Atrypinae than to either the Karpinskiinae or the Carinatininae (the latter being where Boucot, Johnson, and Staton, 1965 placed Vagrania; see Johnson and Boucot, 1972 for a later opinion).

Rzhonsnitska1a and Mizens (1977) have recently revised the genus Vagrania and assigned some of its members to a new genus Totia. Totia is a vagraniid homoeomorph related to the carinatininids. Totia has well-developed dental lamellae, whereas Vagrania essentially lacks them.

Vagrania cf. V. intermediafera (Khodalevich, 1951) Pl. 33, figs. $1-13$

Atrypa intermediafera Khodalevich, 1951:62, pl. 20, figs. $3 \mathrm{a}-\mathrm{c}, 4 \mathrm{a}-\mathrm{d}$; pl. 22, figs. 1 $\mathrm{a}-\mathrm{c}, 2 \mathrm{a}-\mathrm{d}, 3 \mathrm{a}-\mathrm{d}$.

Vagrania intermediafera-Alekseeva, 1962, pl. 9, figs. $11 \mathrm{a}-\mathrm{c}$; text-fig. 80 .

Vagrania aff. V. intermediafera-Johnson, 1967:875, text-fig. 2

Totia aff. T. intermediafera-Lenz, 1977b:118, pl. 23, figs. $27-43$

Vagrania aff. $V$. intermediafera-Jackson, Lenz, and Pedder, 1978, pl. 14, figs. 1-9.

Vagrania cf. $V$. intermediafera-Perry, Boucot, and Gabrielse, 1981:300, pl. 4, figs. 26-30.

\section{DIAGNOSIS}

A Vagrania with a prominent orthocline ventral interarea and high, closely spaced costae. The vascular system is well developed and shows two or three orders of lateral branching. 


\section{REFERRED SPECIMENS}

Vagrania cf. $V$. intermediafera occurs in beds of early to mid-Pragian age in S-1, at 330.7-396.2 $\mathrm{m}$ and OLDA306.3-353.6 m, and in S-2, at 39.6-80.8 m, respectively, below the top of the Delorme Formation. It is represented by $131 \mathrm{~A}, 111 \mathrm{~B}$, and $88 \mathrm{P}$ well-preserved silicified shells. Material illustrated includes ROM 33899, 33900 from S-1, sample A342.9 m; ROM 33901, 33902 from S-1, sample A345.9 m; ROM 33903-33905 from S-1, sample A385.6 m; and ROM 33906 from S-1, sample OLDA353.6 m.

\section{EXTERIOR}

The shell outline varies from transversely to longitudinally oval. Shells often appear to show primary asymmetry. The lateral profile is strongly dorsibiconvex in mature shells and ventribiconvex in small shells. The hinge line is short and curved, with rounded cardinal angles. The prominent erect, orthocline ventral beak defines a large, flat interarea, which is pierced apically by a large subhypothyridid foramen. The conjunct deltidial plates bound the foramen anteriorly. A minor dorsal fold and ventral sulcus develop anteriorly in large shells. Strong, high costae extend from the beak to the anterior margin and become increasingly round and wide anteriorly. Intercostal spaces are of similar size to the costae. The costae increase several times anteriorly, most commonly by bifurcation on the ventral valve and by both bifurcation and implantation on the dorsal valve; the costae on the ventral valve are more closely spaced because their increase by bifurcation is more consistent than the costal increase on the dorsal valve. On a large shell costae number five in $5 \mathrm{~mm}$ at a point $10 \mathrm{~mm}$ anterior to the pedicle beak, and eight in $5 \mathrm{~mm}$ at a point $20 \mathrm{~mm}$ anterior to it. In later growth stages, lamellose concentric growth lines near the anterior margin of the shell show the change in growth direction from anterior to dorsoventral, resulting in the increased thickness of the body cavity.

\section{PEDICLE VALVE INTERIOR}

The hinge teeth are stout, basally triangular in cross section, and distally cylindrical. They project well above the plane of commissure. The dental plates are only visible in juvenile shells and are enclosed in shell callus in large shells. The muscle field is subtriangular to teardropshaped and extends over one-third to one-half of the valve length. The muscle field is gently raised above the valve floor and bounded laterally by the hinge-tooth bases and the vascular ridges, and anteriorly by a distinct arcuate ridge joining the two main branches of the vascular system. The two main trunks of the vascular system extend from just anterior to the base of the hinge teeth and curve gently, laterally and then medially, to a point just posterior to the anterior commissure. Three or four pairs of secondary branches project laterally from the main trunk, and they in turn bifurcate once, occasionally twice, near the lateral margins. The shell substance is thick and the costae are not impressed internally.

\section{BRACHIAL VALVE INTERIOR}

The sockets are closely set together medially and are separated by a narrow, wedge-shaped notothyrial platform. The deep sockets diverge strongly anterolaterally; they are bounded posteriorly by the shell wall and anteromedially by the stout inner socket plates. The crura are attached to the medial edges of the socket plates and directed anteroventrally. Spiralia were not preserved in the shells available for study. The notothyrial platform is supported by a wide, rounded myophragm, which subdivides the subcircular muscle field posteriorly. The muscle field is strongly impressed posteriorly and weakly impressed anteriorly. The costae are weakly impressed internally near the valve periphery.

\section{DISCUSSION}

The type material of $V$. intermediafera is from supposed Eifelian beds (in the Russian zonation scheme-probably corresponding to Zlichovian or slightly older in the scheme used here) of the northern Urals. The same species occurs commonly in the Pragian Monograptus yukonensis Zone at Royal Creek. Lenz (1977b) assigned representatives of intermediafera to the genus Totia; however, the prominent vascular markings and the absence of dental plates indicate a much closer affinity to the genus Vagrania.

Internal structures of the type material are known only from serial sections, and details of the vascular system are unknown. The costae development of the Delorme $V$. cf. $V$. intermediafera is very similar to the Uralian representatives. $V$. cf. $V$. intermediafera is separated from Vagrania johnsoni sp. nov. by its more numerous, less flattened costae and by its lack of a raised dorsal vascular system. The Eifelian $V$. gronbergi from Nevada is smaller, bears fewer costae, and is much less inflated than $V$. cf. $V$. intermediafera. The rib pattern of a few shells from the youngest occurrence of Toquimaella kayi at S-1 approaches that of $V$. cf. $V$. intermediafera, in that a few of the ribs bifurcate close to the anterior margin. Unfortunately a direct evolutionary link between $T$. kayi and $V$. cf. $V$. intermediafera cannot be traced because of a $70 \mathrm{~m}$ stratigraphic separation. Some of the intervening collections with shells identified as Atrypa spp. include specimens that may be early growth stages of vagraniids; however, in the absence of mature shells, it is impossible to assign these specimens with confidence to either Toquimaella or Vagrania 
Vagrania johnsoni sp. nov. Pl. 33, figs. 14-34

\section{DIAGNOSIS}

A large, thick-shelled, coarsely costate, subcircular vagraniid with well-developed vascular markings in both valves.

\section{ETYMOLOGY}

The species is named after J. G. Johnson, a Devonian brachiopod specialist at Oregon State University.

\section{REFERRED SPECIMENS}

Vagrania johnsoni sp. nov. occurs in beds of latest Pragian to early Zlichovian age in S-1, at $178.3-239.3 \mathrm{~m}$, and in S-3, at 560.8-573.0 m, respectively, below the top of the Delorme Formation. It is represented by 28A, 62B, and $37 \mathrm{P}$ excellently silicified shells. Material illustrated includes holotype ROM 33907 and paratypes ROM 33908 33912 from S-1, sample A178.3-181.4 m.

\section{EXTERIOR}

The shell outline is subcircular and the lateral profile is strongly dorsibiconvex. The length of the shell is usually greater than its width. The brachial valve curves evenly from posterior to anterior, with its maximum height attained anterior to midlength of the shell. The ventral valve is very gently curved. The pedicle beak is upright to slightly incurved and is pierced by a circular subhypothyridid foramen. In mature specimens the anterior edge of the foramen is defined by a pair of small, triangular, conjunct deltidial plates. The ventral interarea is moderately high and flat. Ornament consists of 12 to 15 high, rounded radial costae separated by costal interspaces that are twice as wide as the costae near the anterior margin. Costae increase by bifurcation or intercalation only near the posterior margin. The primary pair of median costae on the pedicle valve bifurcate at about the same distance anterior to the beak. The median costa of the brachial valve is flanked by a pair of intercalated costae slightly anterior to the beak. Prominent concentric, sometimes imbricate, growth lamellae develop near the anterior margin of the shell. The shell substance is thick.

\section{PEDICLE VALVE INTERIOR}

The stout hinge teeth are triangular in cross section. They are attached to the inner edge of the posterior ventral margin and are directed dorsomedially. The dental lamellae are visible only in the earliest growth stages and are completely enveloped by secondary shell material in large shells. The subtriangular ventral muscle field is strongly impressed and bounded laterally by prominent ridges extending anteriorly from the base of the hinge teeth, and anteriorly by a high arcuate ridge. The adductor muscle scar is broad and occupies the floor of the muscle field. Narrow diductor scars are weakly impressed along the lateral edges of the muscle field. Beyond the anterolateral corners of the muscle field is a set of elongate, branching vascular ridges. The main trunks diverge slightly, decrease in height anteriorly, and recurve medially near the anterior margin. Two lateral branches are developed anterolaterally. The interior of mature shells is corrugated by the impress of costae only near the anterolateral margins.

\section{BRACHIAL VALVE INTERIOR}

The deep, elongate sockets are set into the shell margin and extend slightly posteromedially from it. The sockets are bounded medially by the anterolaterally divergent socket plates, which recurve posterodorsally to partially cover the posterior end of the sockets. A pair of grooves separates the socket ridges from the thickened medial lobes of the crural bases on the ventral face of the cardinalia. In large shells the sockets are supported by thick umbonal callus deposits, which form a notothyrial platform between the sockets. A low, wide myophragm extends from the notothyrial platform to about one-third of the shell length and subdivides the transversely oval adductor muscle field. The adductor muscle scars are strongly impressed and bounded both laterally and anteriorly by prominent ridges. In mature shells distinct vascular ridges diverge anterolaterally from the anterolateral corners of the muscle field and extend to midlength of the shell, where they split and die out. The shell interior is crenulated anteriorly by the impress of costae.

\section{DISCUSSION}

Vagrania johnsoni sp. nov. is distinguished from the Eifelian V. gronbergi Johnson (1968) and the type species V. kolymensis (Nalivkin, 1936) by its coarser, more rounded, and less numerous costae. Externally it appears quite similar to $V$. sosvaensis (Khodalevich, 1951), except that it lacks the slight dorsal fold and dental lamellae of the Uralian species. Younger Zlichovian representatives of Vagrania sp. 1 from the Ogilvie Formation of the northern Yukon (S-15 of Perry, Klapper, and Lenz, 1974) possess large, rounded plications similar to those on $V$. johnsoni sp. nov.; however, they bear more numerous costae, are more triangular in outline, have a dimpled shell interior, and have a more complex system of vascular markings than the new Delorme species.

One pedicle valve of $V$. johnsoni sp. nov, bears well-developed?parasitic worm tubes cemented onto the valve floor. This particular shell shows an irregular system of vascular markings, which are probably the result of worm infestation. 
Vagrania sp. 1

Pl. 33, figs. 35-40

Vagrania sp. 2 Perry, Boucot, and Gabrielse, 1981:300, pl. 4, figs. 20-25.

\section{REFERRED SPECIMENS}

Vagrania sp. 1 is represented by several dozen fragmentary silicified valves and a few crushed and/or distorted calcareous shells from beds in the Ogilvie Formation$67 \mathrm{~m}$ and $10 \mathrm{~m}$ below the top of the formation-located at $65^{\circ} 23^{\prime} \mathrm{N}, 140^{\circ} 47^{\prime} \mathrm{W}$, in the western Ogilvie Mountains of the northern Yukon (S-15 of Perry, Klapper, and Lenz, 1974:1094). Material illustrated includes ROM 3391333916 from S-15, sample $100.6 \mathrm{~m}$.

\section{DISCUSSION}

The formal naming and description of Vagrania sp. 1 must await the collection of additional specimens. The associated conodont fauna is indicative of a late Zlichovian age and includes the following taxa identified by $\mathrm{G}$. Klapper: Pandorinellina exigua n. subsp. A ( $\mathrm{P}$ element), Sannemannia glenisteri Klapper ( $\mathrm{I}, \mathrm{S}_{2}, \mathrm{M}_{2}$, elements), Polygnathus perbonus perbonus (Phillip) (P element, late form), Polygnathus serotinus Telford ( $\mathrm{P}$ element).

Vagrania sp. 1 has large, rounded costae, as in $V$. johnsoni sp. nov.; however, on the former costae are more numerous and more triangular in outline and vascular markings more complex. The intercostal spaces are similar in size to the costae. Vascular markings are clearly preserved on the ventral valves where the primary branches extend anteriorly and anterolaterally from the anterior edges of the muscle field. The primary branches bifurcate at least twice before reaching the shell margin. A prominent "dimpled" pattern is shown on illustrations of Dentatrypa kolymensis (Dentatrypa is regarded as a junior synonym of Vagrania) in Cherkesova (1969).

\section{Genus Toquimaella Johnson, 1967}

\section{TYPE SPECIES}

Toquimaella kayi Johnson, 1967:876, pl. 111, figs. 1-5, 7-30.

\section{Toquimaella kayi Johnson, 1967}

Pl. 34, figs. 1-14

Toquimaella kayi Johnson, 1967:867, pl. 111, figs. 1-5, 7-30.

Toquimaella kayi-Boucot, Johnson, and Talent, 1969, pl. 5, figs. 3-7.

Toquimaella kayi-Johnson, 1970:160, pl. 42, figs. 11-23; text-fig. 6.
Toquimaella kayi-Ormiston, 1973, pl. 1, figs. 17-20.

Toquimaella kayi-Lenz, 1977b:118, pl. 23, figs. 6-26.

Toquimaella kayi-Jackson, Lenz, and Pedder, 1978, pl. 9, figs. 22, 23, 27, 28, 31 .

Toquimaella kayi-Perry, Boucot, and Gabrielse, 1981:300, pl. 4, figs. 35-38.

\section{REFERRED SPECIMENS}

Toquimaella kayi is locally very abundant in the Delorme Formation and is represented by $511 \mathrm{~A}, 612 \mathrm{~B}$, and $613 \mathrm{P}$ excellently silicified shells. It occurs in beds of late Lochkovian age equivalent to the Quadrithyris Zone of central Nevada and the Spirigerina Unit of the northern Yukon. The species is found in S-1, at 466.3-519.7 m and OLDA435.9-527.3 m, and in S-2, at $166.1-182.9 \mathrm{~m}$, respectively, below the top of the Delorme Formation. Material illustrated includes ROM 33917-33919 from S-1, sample A484.6 m; ROM 33920-33923 from S-1, sample A $487.7 \mathrm{~m}$; and ROM 33924 from S-2, sample B 166.1$182.9 \mathrm{~m}$.

\section{DISCUSSION}

T. kayi is known from the Quadrithyris Zone at Ikes Canyon in central Nevada (Johnson, 1967), from beds of late Lochkovian age at Royal Creek (Lenz, 1977b), and from beds of late Lochkovian age in the Salmontrout Limestone of east central Alaska (Ormiston, 1973). Toquimaella is distinguished from Vagrania by its much finer costellae with less prominent splitting and implantation. Vagrania bears prominent growth lamellae near the anterior commissure; these lamellae are not developed in Toquimaella. The interiors of the two genera are very similar. In any one collection of $T$. kayi there is considerable variation in shell shape and in the number and strength of the costellae. A general trend from smaller, more finely costellate shells in older beds to larger shells with fewer and coarser costellae in younger beds is shown in collections from S-1. This trend supports the notion that Toquimaella is ancestral to Vagrania. It should be emphasized that even in the highest collections of T. kayi most of the shells have the fine costellae typical of Toquimaella.

Additional morphologic features noted in the Delorme silicified T. kayi follow. Some shells bear a more prominent interarea than those illustrated by Johnson (1967). Deltidial plates are absent, even in the bestpreserved shells. The area anterolateral to the dorsal and ventral muscle fields is commonly pustulose, as in many of the representatives of the subfamily Carinatininae. The myophragm dividing the dorsal muscle field consists of two ridges separated by a medial groove, which probably formed as a result of the impression of the muscle field. The sockets bear the typical atrypoid diagonal, longitudi- 
nal ridge and are corrugated. Plate 34 , fig. 12, shows evidence that the shells were capable of opening to a considerable degree without restriction by the hinge mechanism.

Family Carinatinidae Johnson, 1973

Subfamily Gracianellinae Johnson, 1973

Genus Gracianella Johnson and Boucot, 1967

\section{TYPE SPECIES}

Gracianella lissumbra Johnson and Boucot, 1967:871, pl. 109, figs. 21-40.

\section{Gracianella lissumbra lissumbra Johnson, Boucot, and Murphy, 1976 \\ Pl. 35, figs. 5-12}

Gracianella lissumbra Johnson and Boucot, 1967:871, pl. 109, figs. 21-40.

Gracianella lissumbra lissumbra Johnson, Boucot, and Murphy, 1976:80, pl. 50, figs. 1-19.

Gracianella lissumbra-Lenz, 1977b:122, pl. 27, figs. $16-25,58$.

Gracianella lissumbra-Jackson, Lenz, and Pedder, 1978, pl. 5, figs. 20-22, 24.

\section{REFERRED SPECIMENS}

Gracianella lissumbra lissumbra occurs in strata of Ludlovian and/or Pridolian age in S-9, at 21.3-29.0 m below the top of the Delorme Formation. It is represented by $6 \mathrm{~B}$ and $9 \mathrm{P}$ silicified specimens. Material illustrated includes ROM 33503 and 33948-33951 from S-9, sample L166.1-173.7 m.

\section{DISCUSSION}

G. lissumbra lissumbra was reported by Johnson and Boucot (1967) from Ludlovian and Pridolian strata and by Johnson, Boucot, and Murphy (1976) from Ludlovian strata of the Roberts Mountains Formation in central Nevada. The fauna of Nevada contains abundant $G$. lissumbra lissumbra in association with conodonts of the Ludlovian Polygnathoides siluricus Zone. Conodonts a few metres below the occurrence of $G$. lissumbra lissumbra in the Delorme Formation belong to the mid-Ludlovian Ancoradella ploeckensis Zone. The shells from Royal Creek are assigned a Pridolian age (Lenz, 1977b).

Both valves are smooth or bear very faint, threadlike radial ornamentation. The small size, simple internal structure, transversely oval outline, and smooth, relatively. flat valves are identical to those on the type materials. $G$. lissumbra costata Johnson, Boucot, and Murphy has well-developed radial costae on the flanks.

Both $G$. lissumbra lissumbra and G. plicumbra are present in the collection from S-9, L166.1-173.7 $\mathrm{m}$. The collection spans an interval of $8 \mathrm{~m}$, and it should not be assumed that the two taxa necessarily occur together in the same bed.

\section{Gracianella plicumbra Johnson and Boucot, 1967} Pl. 35, figs. 13-49

Gracianella plicumbra Johnson and Boucot, 1967:871, pl. 109, fig. 41; pl. 110, figs. 1-24.

Gracianella plicumbra-Johnson, Boucot, and Murphy, 1976:81, pl. 49, figs. 1-24.

Gracianella plicumbra-Jackson, Lenz, and Pedder, 1978, pl. 7, figs. 17-19, 21, 22.

\section{REFERRED SPECIMENS}

Gracianella plicumbra occurs in Ludlovian and/or Pridolian strata in the Delorme Formation-in S-9, at 21.3$33.8 \mathrm{~m}$ below the top of the formation, and in S-6, at 193.5-204.2 $\mathrm{m}$ above the base of the formation - and in the transitional facies of Gabrielse, Blusson, and Roddick (1973) - in S-11, at 185.9-193.5 $\mathrm{m}$ above the top of the Whittaker Formation. G. plicumbra is represented by 139A, 10B, and 9P silicified shells. The collection from $\mathrm{S}-6$, sample C47-248.4 $\mathrm{m}$, is large and well preserved, although all but two of the shells are filled with quartz crystals. Material illustrated includes ROM 33958 from S-9, sample L161.2 m; ROM 33955, 33956 from S-9, sample L166.1-173.7 m; ROM 33952-33954 from S-11, 185.9-193.5 $\mathrm{m}$ above the top of the Whittaker Formation; ROM 33957, 33959 from S-6, sample C47-237.7 m; and ROM 33960, 33961 from S-6, sample C47-248.4 m.

\section{DISCUSSION}

Gracianella plicumbra Johnson and Boucot occurs in strata of Ludlovian age in the Roberts Mountains Formation in central Nevada. It has an elongate, suboval outline and is ventribiconvex in lateral profile. It differs from $G$. lissumbra lissumbra by the presence of welldeveloped, rounded costae; however, the costae are not nearly as prominent as in its probable descendent $G$. reflexa Johnson, Boucot, and Murphy. A few costae arise by bifurcation in $G$. plicumbra, whereas the costae in $G$. reflexa are simple and undivided. The brachial valve bears a moderately to deeply impressed median sulcus. The prominent ventral cavity is developed slightly posterior to midlength of the shell. The hinge teeth are short and the 
sockets are simple. The shell lacks the impressed muscle-bounding ridges observed in G. crista Johnson and Boucot.

The occurrence in the transitional facies at S-11 suggests that $G$. plicumbra possibly ranges into strata of Pridolian age. A phosphatized internal mould closely resembling G. plicumbra (ROM 33947) was recovered from acetic acid residues of S-10, at approximately $122 \mathrm{~m}$ above the base of the Delorme Formation (Pl. 35, figs. 1-4). Graptolites from beds $122 \mathrm{~m}$ below this sample were identified as Pristiograptus cf. P. dubius thuringicus (Jaeger), suggesting a mid-Ludlovian to early Pridolian age.

\section{Gracianella cryptumbra Johnson, Boucot, and Murphy, 1973 \\ Pl. 36, figs. 1-25}

Gracianella cryptumbra Johnson, Boucot, and Murphy, 1973:56, pl. 3, figs. 1-20.

Gracianella cryptumbra-Lenz, 1977b:122, pl. 27, figs. $26-44,51$.

Gracianella cryptumbra-Jackson, Lenz, and Pedder, 1978, pl. 7, figs. 10-16.

\section{REFERRED SPECIMENS}

G. cryptumbra occurs in beds of probable Pridolian age in the Delorme Formation. It is represented by $9 \mathrm{~A}, 57 \mathrm{~B}$, and 10P well-preserved silicified shells. Material illustrated includes ROM 33963-33971 from S-2, sample B373.4 m.

\section{DISCUSSION}

Gracianella cryptumbra is reported from Pridolian strata of the Roberts Mountains Formation in central Nevada (Johnson, Boucot, and Murphy, 1973). The oldest collection from the Mackenzie Mountains is from the Road River Formation at S-2, sample B411.5T m, where it co-occurs with fish of probable Pridolian age, including Ariaspis. The youngest collection is from the Delorme Formation at S-2, sample B $373.4 \mathrm{~m}$, and it occurs $29 \mathrm{~m}$ below lower Lochkovian beds bearing Salopina submurifer and Schizophoria paraprima.

$G$. cryptumbra most closely resembles $G$. lissumbra lissumbra in size and internal structure; however, $G$. lissumbra lissumbra is smooth externally. The very small size distinguishes $G$. cryptumbra from some $G$. umbra (Barrande). G. cryptumbra is distinguished from $G$. plicumbra by its weaker radial ornamentation.

The majority of the shells of $G$. cryptumbra are transversely suboval in outline and planoconvex in lateral profile. The large apical angle (greater than $90^{\circ}$ ), low costae - which become indistinct anteriorly-and weak sulcation of the dorsal valve are characteristic of the species. Growth lines mark points of reduction in the strength of the costae. The interior of the pedicle valve has a pronounced marginal lip, a prominent ventral cavity, and short, unsupported hinge teeth. The dorsal cardinalia consist of a pair of widely divergent inner socket ridges, which meet at the valve apex and define a small notothyrial cavity.

\section{Subfamily Carinatininae Rzhonsnitskaia, 1960}

\section{Genus Davidsoniatrypa Lenz, 1968}

\section{TYPE SPECIES}

Davidsoniantrypa johnsoni Lenz, 1968:183, pl. 32, figs. 1-28.

\section{Davidsoniatrypa johnsoni Lenz, 1968}

Pl. 36, figs. 26-61

Davidsoniatrypa johnsoni Lenz, 1968:183, pl. 32, figs. $1-28$.

Davidsoniatrypa johnsoni-Johnson and Boucot, 1972, pl. 2, figs. 6-13.

Davidsoniatrypa johnsoni-Lenz, 1977b:120, pl. 29, figs. 1-13, 15-17.

Davidsoniatrypa johnsoni-Jackson, Lenz, and Pedder, 1978, pl. 11, figs. 26, 31-34.

Davidsoniatrypa johnsoni-Perry, Boucot, and Gabrielse, 1981:300, pl. 3, figs. 49-51

\section{REFERRED SPECIMENS}

$D$. johnsoni is not nearly as abundant nor as well preserved in the Delorme Formation as in occurrences at Royal Creek. It occurs in S-1, at ?301.8-385.6 m below the top of the Delorme Formation. D. johnsoni is represented by $3 \mathrm{~A}, 10 \mathrm{~B}$, and $2 \mathrm{P}$ coarsely silicified specimens. Material illustrated includes ROM 33972-33977 from S-1, sample A385.6 m; ROM 33978-33982 from S-1, sample OLDA336. $8 \mathrm{~m}$; and ROM 33983, 33984 from S-1, sample OLDA370.3 m.

\section{DISCUSSION}

Davidsoniatrypa johnsoni has previously been reported from Royal Creek (Lenz, 1968, 1977b), where it occurs in strata of early Pragian age below and in the lower part of the Monograptus yukonensis Zone.

The Delorme specimens are generally smaller than shells from Royal Creek. Characteristic features of the Delorme specimens are as follows: a transverse, suboval shell outline; a prominent ventral carina with a correspond- 
ing sharp, V-shaped dorsal sulcus; numerous fine, tubercular costellae; conjunct deltidial plates; a dorsal valve with shallow depressions flanking the impress of the sulcus to accommodate the pedicle spiral cones; and ventral valves that lack dental plates and sometimes bear broad, low, dorsoventrally directed cones reflecting the structure of the brachidium.

D. johnsoni is an important faunal element at Royal Creek in the early Pragian Gypidula boucoti-Davidsoniatrypa Unit (Lenz, 1968, 1977b); however, its limited stratigraphic occurrence and low abundance in the Delorme Formation suggest that the palaeoenvironments of the Delorme were unfavourable to the species. Most carinatininids are common in shallow-water, reefal carbonate sediments.

\section{Genus Ogilviella Lenz, 1968}

\section{TYPE SPECIES}

Ogilviella rotunda Lenz, 1968:181, pl. 31, figs. 1-35.

\section{DISCUSSION}

The close similarity of the two described species of Ogilviella $-O$. rotunda Lenz and $O$. prolifica Savageand the fact that the original description of the genus does not account for the full range of variation of the type species necessitate the presentation of a full description of $O$. rotunda.

\section{Ogilviella rotunda Lenz, 1968}

PI. 30, figs. 13-28

Ogilviella rotunda Lenz, 1968:181, pl. 31, figs. 1-35. Ogilviella rotunda-Lenz, 1977b:121, pl. 28, figs. 1-16. Ogilviella rotunda-Jackson, Lenz, and Pedder, 1978, pl. 9, figs. 33-39.

?Ogilviella cf. $O$. rotunda-Johnson, Penrose, and Wise, 1978, pl. 1, figs. 15-17.

\section{REFERRED SPECIMENS}

$O$. rotunda occurs commonly in beds of late Lochkovian age in S-1, at 475.5-536.4 $\mathrm{m}$ and OLDA423.7-527.3 m, and in S-2, at 221.0-225.6 m, respectively, below the top of the Delorme Formation. It is represented by 299A, 96B, and 92P well-preserved silicified shells. Material illustrated includes ROM 33834-33838 from S-1, sample A528.8 m; and ROM 33839, 33840 from S-2, sample $\mathrm{B} 221.0 \mathrm{~m}$.

\section{EXTERIOR}

The shells are subcircular, commonly slightly longer than wide in outline, and subequally biconvex in lateral profile. The greatest shell width and thickness are developed near midlength. Most ventral valves have a narrow, carinate umbo; a small, straight, pointed beak; and a narrow, apsacline interarea. The subhypothyridid foramen is bounded anteriorly by conjunct deltidial plates. A variably developed ventral fold and a corresponding dorsal sulcus extend along the shell length. The fold bears one central plication, which bifurcates within a short distance of the posterior margin and forms two strong plications separated by a narrow median furrow. These two strong plications may bifurcate anteriorly. The sulcus is divided by a prominent medial rib. The fold and sulcus broaden anteriorly to form a gently sulcate anterior commissure. The flank costae are more widely spaced and increase commonly by bifurcation and less often by insertion. The number of plications varies from 16 to 24 on each valve in shells $10 \mathrm{~mm}$ in diameter (the average size of mature shells). Growth lines are only weakly developed anteriorly.

\section{PEDICLE VALVE INTERIOR}

Small shells and most larger shells bear short dental lamellae, which support the anterolaterally divergent hinge teeth. The teeth are separated from the interarea by a distinct groove. The ventral muscle field is not impressed. The shell interior is weakly crenulated by the impress of costae. Anterior to the muscle field the floor of some shells is strongly depressed, a feature reminiscent of the ancestral genus Gracianella.

\section{BRACHIAL VALVE INTERIOR}

The sockets diverge at approximately $100^{\circ}$. The socket plates curve sharply posteriorly and meet the valve wall, where they form the floor of the sockets. The socket plates are disjunct medially. A small notothyrial platform is developed between the socket plates. The crura are bladelike ridges attached to the inner edges of the socket plates; the crura first extend ventrally and then curve anteriorly. The spiralia consist of at least four whorls, the first of which extends close to the anterior margin of the valve. A low, wide myophragm extends a short distance anteriorly from the notothyrial platform. The adductor muscle scars are widely separated laterally, weakly impressed, wider than long, and weakly striated longitudinally. The muscle scars are separated posteromedially by a myophragm, and anteriorly by a shallow furrow. The shell interior is weakly crenulated by the impress of the costae. The dorsal sulcus is gently impressed over its length.

\section{DISCUSSION}

$O$. rotunda is known from the upper Lochkovian Spirigerina beds at Royal Creek and from upper Lochkovian beds of central Nevada (Johnson, Penrose, and Wise, 1978). The other described species, $O$. prolifica, is reported from the upper Lochkovian Mandagery Park 
Formation of New South Wales (Savage, 1970). Some of the Delorme collections show enough internal variation to cover the total of the morphologic ranges attributed to $O$. rotunda and $O$. prolifica. This large amount of variation in collections of Ogilviella suggests that the two species might be better regarded as conspecific, or at most as geographic subspecies. The lenticular profile and the prominent medial dorsal-sulcus plication originally ascribed to $O$. prolifica are also present in some $O$. rotunda.

\section{Genus Carinatina Nalivkin, 1930}

TYPE SPECIES

Orthis arimaspus Eichwald, 1840 in Nalivkin, 1930:104.

\section{Carinatina sp.}

Pl. 35, figs. 50-52

\section{REFERRED SPECIMEN}

One fragmentary silicified ventral valve (ROM 33962) was recovered from Zlichovian beds of the Delorme Formation at S-3 (sample S-4-64.0-65.5 m).

\section{DISCUSSION}

Features distinctive of Carinatina sp. are as follows: a wide, straight hinge line: a ventral carina, which becomes obsolescent anteriorly as the valve becomes sulcate; radial costae of variable strength; geniculate margin and frill development; and an oval, weakly impressed muscle field. The valve interior is not marked by the spiral impressions of the brachidium that are found in some specimens of Carinatina lowtherensis Johnson and Boucot. Otherwise the shells are quite similar to $C$. lowtherensis, which occurs in Zlichovian beds of arctic Canada (Johnson and Boucot, 1972) and the northern Yukon (Pedder and Klapper, 1977; Perry, 1979).

\section{Genus Biconostrophia Havlíček, 1956}

\section{TYPE SPECIES}

Biconostrophia spirifera Havlíček, 1956:154, pl. 7, figs. $23,24,27$.

\section{Biconostrophia cf. B. knorrensis Perry, 1979}

Pl. 36, figs. 62-64; Pl. 37, figs, 1-16

Biconostrophia sp. Perry, Boucot, and Gabrielse, 1981:300, pl. 3, figs. 47, 48 .

\section{REFERRED SPECIMENS}

Only a few fragmentary silicified specimens (5A, 3B, and $5 \mathrm{P})$ of $B$. cf. B. knorrensis were recovered from S-3, at 36.6 $449.6 \mathrm{~m}$ below the top of the Delorme Formation. Material illustrated includes ROM 33985 from S-3, sample S4-36.6 m; and ROM 33986-33991 from S-3, sample S4-449.6 m.

\section{DISCUSSION}

The genus Biconostrophia has been reported previously from Zlichovian beds of Bohemia (Havlíček, 1956), north central British Columbia (Perry, Boucot, and Gabrielse, 1981), and the Knorr Range in the northern Yukon (Perry, 1979). The occurence of $B$. cf. B. knorrensis in the Delorme Formation is consistent with the Old World Realm affinities of the brachiopod fauna as a whole.

Biconostrophia is distinguished from Davidsoniatrypa by its coarser and less numerous costae; this distinction is clear when representatives of the two Delorme genera are compared. Carinatina is separated from Biconostrophia by its less transverse outline, geniculated margin, shorter hinge line, and greater number of costae, and because it has dental plates.

\section{Family Notanopliidae Gill, 1969}

\section{Genus Notoparmella Johnson, 1973a}

\section{TYPE SPECIES}

Notoparmella gilli Johnson, 1973a:1026, pl. 4, figs. 1-17; pl. 5, figs. 4,5 .

Notoparmella gilli Johnson, 1973a Pl. 32, figs. 50-53

Notoparmella gilli Johnson, 1973a:1026, pl. 4, figs. 1-17; pl. 5 , figs. 4,5 .

\section{REFERRED SPECIMENS}

One dorsal valve of Notoparmella gilli occurs in mid-Lochovian strata in S-2, at $254.5 \mathrm{~m}$ below the top of the Delorme Formation. Material illustrated includes ROM 33897 from S-2, sample B254.5 m; and ROM 33898 from "East side of Coal Canyon-Upper Windmill Limestone" in central Nevada (collected by A. C. Lenz, 1970).

\section{DISCUSSION}

In Nevada, Johnson (1973a) and Johnson, Penrose, and Wise (1978) report this taxon from beds of Lochkovian age in the lower and upper Windmill Limestone. The occurrences of $N$. gilli, $N$. fila sp. nov., and Plicanoplites bisulcata (Lenz) described here are the first recognized 
occurrences of notanopliids in northwestern Canada with the exception of Johnson's report of a Notoparmella from the Sutherland River Formation of Devon Island. Smith (1976a) reported numerous specimens of Notoparmella from strata of early Lochkovian age on Prince of Wales Island. Other members of the notanopliid family are known from the Lower and/or Middle Devonian of Australia, China, and eastern North America, and from the Middle Devonian of Morocco.

The genus Notoparmella shows somewhat similar morphologic features to the Australian genus Boucotia with the exception of the presence of the inner socket ridges in Notoparmella. The smooth brachial valve of the Delorme shell shows features characteristic of $N$. gilli: the dorsal sulcus with a medial rib and the widely divergent sockets bearing inner socket ridges.

\section{Notoparmella fila sp. nov.}

$$
\text { Pl. 34, figs. 43-50 }
$$

\section{DIAGNOSIS}

A gently biconvex Notoparmella with weakly developed, threadlike costellae on the lateral flanks.

\section{ETYMOLOGY}

The specific name is from the Latin filum-thread, in reference to the weakly developed radial ornament

\section{REFERRED SPECIMENS}

Notoparmella fila sp. nov. occurs at S-3, in the basal beds of the Delorme Formation, which are of latest Lochkovian or of early Pragian age. Monograptus cf. M. yukonensis occurs some $98 \mathrm{~m}$ above this collection. It is represented by $1 \mathrm{~A}, 1 \mathrm{~B}$, and $3 \mathrm{P}$ silicified shells. Material illustrated includes holotype ROM 33942 and paratypes ROM 33940, 33941 , 33943 from S-3, sample S4-685.8 m.

\section{EXTERIOR}

The thin, small shells are shield-shaped in outline and gently biconvex in lateral profile. The straight hinge line extends over two-thirds of the maximum shell width, which is reached slightly anterior to midlength. The apsacline interarea of the pedicle valve is small and mostly occupied by an open triangular delthyrium. The brachial valve lacks an interarea, and parts of the sockets are exposed. The pedicle valve is gently convex and develops a median furrow, which bears a faint medial rib in some shells. The brachial valve is less convex than the pedicle valve and bears a wide, flaring sulcus with poorly defined margins. A threadlike median costella extends from the umbo to the anterior margin. Weakly developed flank costellae number about three per millimetre at the anterior margin of a shell that is $5 \mathrm{~mm}$ in diameter

\section{PEDICLE VALVE INTERIOR}

The large hinge teeth are widely set apart, directed laterally, and attached to the posterior shell surface just below the small interarea. Dental lamellae are absent. The umbonal cavity is partially covered by the anteriorly expanding, weakly impressed, triangular diductor muscle field, which is divided medially by a rounded myophragm. The muscle field extends to one-third of the shell length and occupies one-half of the maximum shell width. Subparallel ridges near the anterior margin of the valve are part of the median myophragm and mark the insertion of a weakly developed rib within the ventral sulcus. Contrary to Johnson (1973a), they are probably not part of the vascula media.

\section{BRACHIAL VALVE INTERIOR}

The wide divergent sockets are shallow. The inner socket ridges are strongly curved posteroventrally and are attached to the anteromedial face of the socket plates. The distal ends of the socket ridges meet at the apex of the notothyrium and form an inverted-V-shaped structure. The median myophragm has a distinct furrow and extends from the cardinalia to the anterior margin of the shell. The shell interior is weakly crenulated by the impress of costellae.

\section{DISCUSSION}

Notoparmella fila sp. nov. shows close affinity to the type species, $N$. gilli, with the exception of the more prominent rib development and the more convex dorsal valve of $N$. fila sp. nov. The stratigraphic occurrence of $N$. fila is considerably higher than that of $N$. gilli.

\section{Genus Plicanoplites Havlíček, 1974}

\section{TYPE SPECIES}

Plicanoplia peculiaris Havlíček, 1973:338, pl. 1, figs. 1-9; generic name occupied; renamed Plicanoplites Havlíček, 1974, p. 170

\section{DISCUSSION}

Shells here assigned to Plicanoplites have previously been assigned to Sibirispira? by Johnson, Boucot, and Murphy (1973) and by Lenz (1977b). Sibirispira Alekseeva (1968) is an atrypacean that is somewhat larger in size, is more inflated, and lacks a ventral sulcus. Johnson. Boucot. and Murphy (1973) illustrated a shell assigned to Sibirispira? sp. from beds of early Lochkovian age at Birch Creek in central Nevada. Similar shells (ROM 34120, 34121, Pl. 42. figs. 56-59) were recovered from $\mathrm{S}-11$, at $211.5 \mathrm{~m}$ above the Whittaker Formation in the transitional facies of Gabrielse, Blusson, and Roddick (1973). The genus was not observed elsewhere in the Delorme except in Zlichovian strata, where it occurs locally in moderate 
abundance. Plicanoplites has been described previously only from the Dvorce-Prokop (Pragian) and Třebotov limestones (Dalejean) of Bohemia (Havlíček, 1973, 1977b).

\section{Plicanoplites bisulcata (Lenz, 1977b) Pl. 34, figs. 15-42}

Sibirispira? bisulcata Lenz, 1977b:121, pl. 29, figs. 14, $18-31$.

\section{REFERRED SPECIMENS}

Plicanoplites bisulcata occurs commonly in beds of Zlichovian age in S-1, at $62.5-68.6 \mathrm{~m}$, and in S-?, at 53.3-519.7 $\mathrm{m}$, respectively, below the top of the Delorme Formation. It is represented by $178 \mathrm{~A}, 45 \mathrm{~B}$, and $43 \mathrm{P}$ excellently silicified shells. Material illustrated includes ROM 33925-33930 from S-1, sample A62.5-68.6 m; and ROM 33931-33939 from S-3, sample S4-143.3 m.

\section{DISCUSSION}

Externally $P$. bisulcata shows considerable similarity to $P$. macer Havlíček. $P$. macer is distinguished by its somewhat resupinate ventral valve, fewer costae, and narrower hinge line. Internal details of the Czechoslovakian shells are not known. The Delorme representatives are confined to strata of Zlichovian age. Lenz (1977b) found the same species in Zlichovian beds at Royal Creek.

Morphologic structures additional to those noted by Lenz (1977b) in his description of the more coarsely silicified specimens from Royal Creek follow. A low, broad, gently rounded pedicle fold is cleft by a narrow furrow. A low, smooth muscle pad is confined to the posterior three-quarters of the floor of the delthyrial cavity. Anterior to the muscle pad are two elongate, triangular to suboval depressions (adductor? muscle scars), which are confined laterally by the musclebounding ridges. The muscle field is divided medially by a myophragm formed by the impress of the ventral furrow. In the brachial valve the crural bases are attached medially to the socket plates and the crura extend anteroventrally as thin, bladelike structures. Very weak muscle-bounding ridges extend from near the lateral margins of the sockets; they first converge medially, then extend anteroventrally as subparallel, thin, bladelike structures, defining a subcircular pair of posterior adductor muscle scars and a narrow, more elongate pair of anterior adductor scars.

\section{Indeterminate ?notanopliid Pl. 34, figs. $51-58$}

\section{REFERRED SPECIMENS}

The indeterminate ?notanopliid occurs in S-10, at $103.6 \mathrm{~m}$ above the base of the Delorme Formation, and is represented by 25 articulated calcareous specimens. Graptolites from the base of the formation are of mid-Ludlovian to early Pridolian age. Material illustrated includes ROM 33944-33946 from S-10, sample S1C.

\section{EXTERIOR}

The small (3-4 $\mathrm{mm}$ in maximum width) subrectangular shells are biconvex to planoconvex in lateral profile. The hinge line is straight, and the maximum width is attained near midlength. The low, apsacline ventral interarea is approximately one-half of the maximum width and is cleft by a small, triangular delthyrium. The dorsal sulcus bears a prominent medial costa, and a corresponding groove is developed in the ventral fold. Wide, low, rounded costae extend from the posterior to the anterior margins and increase by intercalation (small costae) and bifurcation (larger costae). The dorsal valves bear four prominent flank costae, and the ventral valves three to four flank costae. The costae are crossed by conspicuous growth lines anteriorly. Costae caused marked crenulations in the anterior commissure.

The interior of the shells is unknown; the small size makes them difficult to work with, and many are infilled with coarsely crystalline calcite, causing the shells to disintegrate upon roasting and scraping

\section{DISCUSSION}

The affinity of this small, distinctive shell is not certain; however, it appears to fit within Johnson's (1973a) concept of the brachiopod family Notanopliidae. The notanopliids are small, shield-shaped genera with various types of ribbing ranging from the sharp, distinct costae of Callicalyptella Boucot and Johnson (1972) from the Lower Devonian Roberts Mountains Formation at Carlin Gold Mine in Nevada, to the smooth Notoparmella gilli Johnson from the Windmill Limestone in central Nevada. The relationship of the notanopliids to Gracianella is indicated by the scroll-like dorsal cardinalia present in both, and by the dorsal myophragm present in the notanopliids and sometimes in Gracianella as well. Johnson (1973a) suggested that either Gracianella or Dnestrina was the probable ancestor of the notanopliids at some time in, or slightly before, the earliest Devonian. The development of ribbing and fold and sulcus in Gracianella would suggest that it is the more likely ancestor. Considering the age (mid-Ludlovian to early Pridolian) and the combined gracianellid and notanopliid characteristics of the shells in question here, they probably belong to a new genus that is morphologically intermediate between Notoparmella and Callicalyptella. The characteristics of the outline and profile of the Delorme shells, and their dorsal sulcus with a prominent medial rib, 
all substantiate the above relationship, as does the presence of faint ribbing on Notoparmella fila sp. nov. (late Lochkovian to early Pragian). In view of the ranges of the genera involved it is most likely that Gracianella coexisted with the notanopliids for a time during the late Pridolian

\section{Family Lissatrypidae Twenhofel, 1914 Subfamily Septatrypinae Kozlowski, 1929}

\section{Genus Atrypoidea Mitchell and Dun, 1920}

\section{TYPE SPECIES}

Meristina(?) australis Dun, 1904:318, pl. 61, figs. 3, $3 \mathrm{a}-\mathrm{c}$.

\section{Atrypoidea planata sp. nov. Pl. 37, figs. 22-41}

\section{DIAGNOSIS}

A markedly elongate, gently dorsibiconvex Atrypoidea, which lacks a distinct fold or sulcus but has an anterior commissure that is gently sulcate ventrally.

\section{ETYMOLOGY}

The specific name is from the Latin planatus - smoothed, in reference to the very smooth nature of the shell and the lack of fold and sulcus.

\section{REFERRED SPECIMENS}

Atrypoidea planata sp. nov. occurs in strata of probable Ludlovian age in S-6, at 193.5-204.2 m above the base of the Delorme Formation. It is represented by $246 \mathrm{~A}, 34 \mathrm{~B}$, and 44P excellently preserved silicified shells. Material illustrated includes holotype ROM 33997 and paratypes ROM 33998-34004 from S-6, sample C47-248.4 m.

\section{EXTERIOR}

The shells are one and one-half times longer than wide and are subpentagonal in outline. The lateral profile is ventribiconvex in the early growth stages and markedly dorsibiconvex in more mature shells. The hinge line is very short, and the maximum width is reached posterior to or at midlength. The posterior one-half of each valve shows much greater convexity than the gently sloping anterior margins. The anterior of the brachial valve forms part of the rounded dorsal deflection of the anterior commissure. The pedicle beak is slightly incurved or erect. The very small pedicle interarea is cleft by an open, subtriangular delthyrium. Deltidial plates only rarely constrict the delthyrium anteriorly. The shell surface is smooth with the exception of a few faint growth lines, which are developed anteriorly. Some large shells develop a median furrow in the dorsal valve.

\section{PEDICLE VALVE INTERIOR}

The hinge teeth are transversely oval in cross section, and posteriorly they are separated from the interarea by a distinct groove. They are attached to the shell wall just below the interarea and are not supported anteriorly. There is a gently raised platform of shell material in the delthyrial cavity, and the muscle scars are not impressed. The shell interior is smooth.

\section{BRACHIAL VALVE INTERIOR}

The sockets expand anterolaterally; they are bounded posteriorly by the shell wall and basally and anteromedially by the socket plates. The crural bases are welded to the medial edges of the socket plates. The crural bases touch medially and have markedly concave ventral surfaces. The medial edges of the crural bases are thickened at the point of attachment of the anterolaterally divergent, cylindrical crural processes. The crural processes are joined to the spiralia, which comprise at least seven dorsally directed, slightly medially inclined spiral whorls. A weakly developed, broad myophragm with a medial groove extends from the notothyrial cavity and subdivides the muscle field. The very weakly impressed muscle field appears to consist of two broadly subrectangular, longitudinally striated scars, which extend over the posterior one-third of the shell.

\section{DISCUSSION}

Recent work by Copper (1977) has shown Atrypella to be a junior synonym of Atrypoidea. Shells illustrated as Atrypella? sp. by Johnson, Boucot, and Murphy (1973) from the Pridolian of central Nevada are quite similar to Atrypoidea planata sp. nov., although the Nevada taxon has a greater deflection of the anterior commissure. $A$. planata sp. nov. differs from other described species by the more elongate outline and the gently sloping anterior one-half of its shell, which is unmodified by a fold or sulcus. In comparison, A. scheii (Kirk and Amsden, 1952)? is a larger, more equidimensional shell; $A$. shrocki (Cooper, 1942) has a more incurved ventral beak and bears a more prominent fold; and A. tenuis (Kirk and Amsden) from the Late Silurian of southeastern Alaska has a smaller ventral beak and bears a more pronounced dorsal myophragm. A carinata (Johnson in Johnson and Reso, 1964) from the late Silurian Sevy Dolomite of eastern Nevada has a more strongly deflected anterior 
commissure and a more prominent dorsal myophragm, and Late Silurian A. foxi (Jones, 1974) and A. erebus Jones (1979) have a much more circular outline than the new species. The Pridolian A. phoca longa (Nikiforova, 1970) has a similar outline to the Delorme taxon but is more strongly inflated and has a more prominent fold and sulcus. The type $A$. phoca (Salter), as illustrated by Smith and Johnson (1977), tends to be more inflated and has a slightly more prominent anterior deflection. The probable late Ludlovian to Pridolian A. prunum (Dalman, 1828) and A. saaremaaensis Copper and Rubel (in Copper, 1977) are elongate shells; each has only a moderately developed anterior deflection of the commissure, but has an atrophied pedicle and a more incurved beak than $A$. planata sp. nov.

The faunal list for sample C47-248.4 $\mathrm{m}$ from $\mathrm{S}-6$ includes a variety of brachiopod taxa. The Atrypoidea specimens were found in a thin $(5 \mathrm{~cm}$ thick), silty, dolomitic limestone lens with associated fish scales and are not directly associated with the other brachiopods. Similar associations are reported from arctic Canada by Smith (1976b). Atrypoidea species have been widely used as index fossils for Upper Silurian shallow-water carbonate strata of arctic Canada; however, Jones (1974) and Smith (1976b) suggest that Atrypoidea is a faciesdependent fossil with a variation in size and shape between different lithotopes and that there is some difficulty in establishing criteria by which particular chrono-species can be recognized. Jones (1977) pointed out the rather wide range of variation within some Atrypoidea species such as $A$. phoca.

The Atrypoidea from S-2, at 373.4 and 411.5 T below the top of the Delorme Formation, are poorly preserved shells of variable size and shape. Atrypoidea sp. of uncertain specific identity from $\mathrm{S}-11$ are mentioned below.

\section{Atrypoidea sp.}

Pl. 37, figs. 17-21; Text-fig. 8

?Atrypella sp.-Johnson, Boucot, and Murphy, 1973:53, pl. 8, figs. 11-15.

\section{REFERRED SPECIMENS}

Atrypoidea sp. occurs at S-11, 185.9-193.5 m above the top of the Whittaker Formation, in the transitional facies of Gabrielse, Blusson, and Roddick (1973). Material illustrated includes ROM 33992-33995 and the serially sectioned shell ROM 33996, all from S-11, sample 185.9-193.5 m.

\section{DISCUSSION}

The specimens in question here are of uncertain specific identity and are too few in number and too poorly preserved to warrant further comment.

\section{Genus Holynatrypa Havlíček, 1973}

\section{TYPE SPECIES}

Holynatrypa crucifera Havlíček, 1973:339, pl. 1, figs. $10-14$; pl. 2, figs. $1-4$.

\section{Holynatrypa sp.}

Pl. 39, figs. 38-47; Pl. 42, figs. 52-55

Lissatrypa? sp. Perry, Boucot, and Gabrielse, 1981:300, pl. 2, figs. $37-42$.

\section{REFERRED SPECIMENS}

Holynatrypa $\mathrm{sp}$. is represented by $6 \mathrm{~A}, 3 \mathrm{~B}$, and $1 \mathrm{P}$ silicified shells in beds of Zlichovian age in S-1, at 62.5-68.6 m, and in S-3, at 161.5-164.6 m, respectively, below the top of the Delorme Formation. Material illustrated includes ROM 34056, 34057 from S-1, sample A62.5-68.6 m; and ROM 34055, 34117-34119 from S-3, sample S4-161.5-164.6 m.

\section{DISCUSSION}

The genus Holynatrypa was recognized only in Bohemia before the discoveries in the Delorme Formation and in north-central British Columbia. In Bohemia it occurs in the Dalejean Tŕebotov Limestone. Its Delorme occurrence again confirms the close ties between the Bohemian and northern Cordilleran Old World Realm faunas. Unfortunately the material at hand is too poorly preserved for specific identification, although it appears to conform quite closely to the type species.

The Delorme Formation shells are more elongate than $H$. crucifera. The low convexity of the dorsal valve, the rectimarginate anterior commissure, and the concentric growth lamellae are external features characteristic of the Delorme material. A characteristic ventral feature is the subtriangular raised muscle field supported anteriorly by a prominent ridge. The dorsal interior has a prominent median myophragm over the posterior one-third of the shell.

\section{Genus Cryptatrypa Siehl, 1962}

\section{TYPE SPECIES}

Terebratula philomela Barrande, 1847:387.

\section{DISCUSSION}

In the Delorme Formation Cryptatrypa is common in middle and upper Lochkovian and Zlichovian beds; it is less abundant in Pragian beds. In many collections it is represented only by small, subtriangular, articulated shells of lenticular lateral profile and with protruding, upright ventral beaks. Many of the shells are filled with quartz, and when identified from external characteristics alone, 


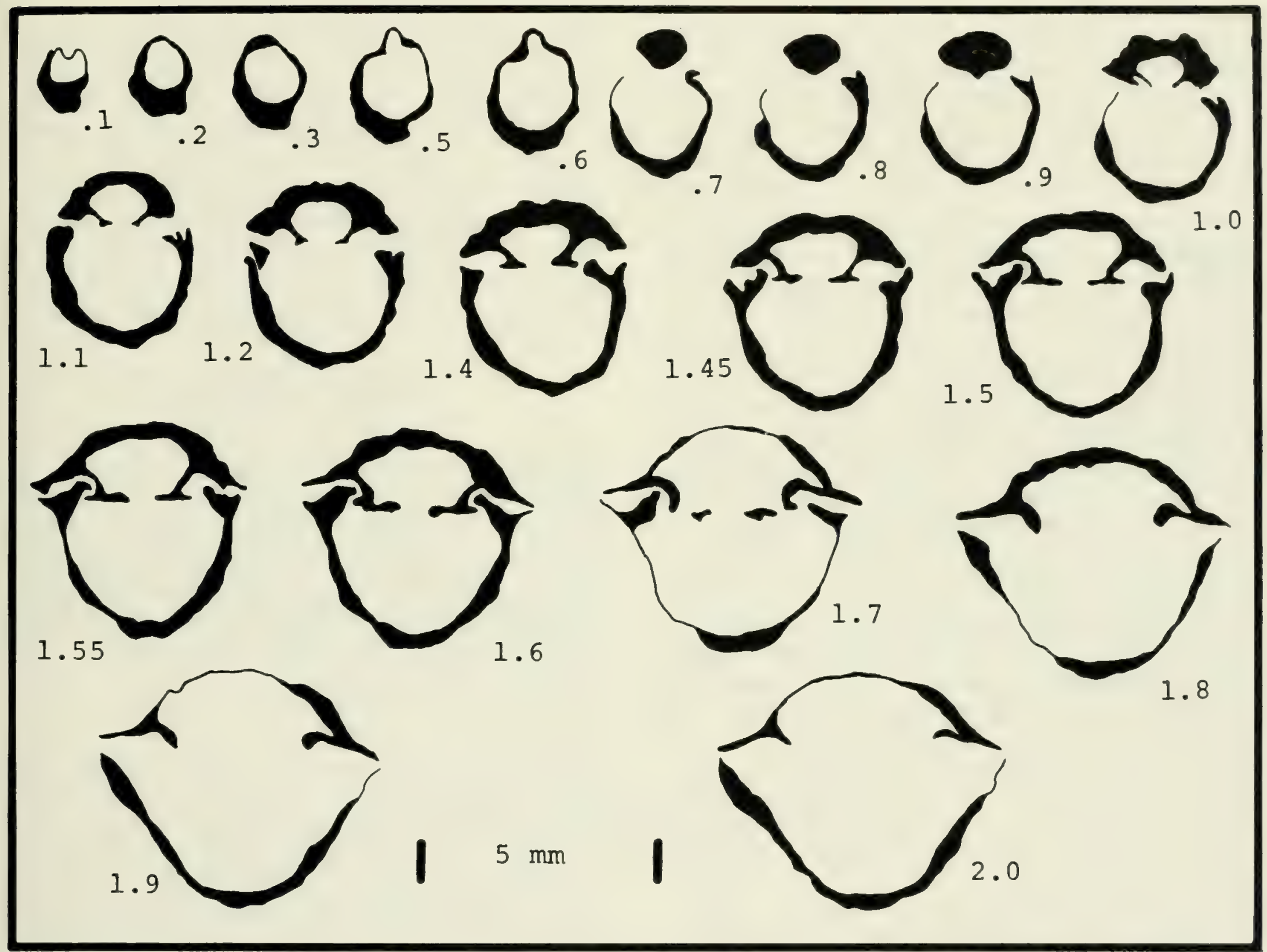

Text-fig. 8 Atrypoidea sp.

Camera lucida drawings of serial transverse sections; measurements are distances in mm from pedicle beak; ROM 33996.

small Cryptatrypa are easily confused with Protathyris sensu lato. At Royal Creek, Lenz (1977b) recorded Cryptatrypa from Pridolian beds and the CryptatrypaProtathyris consortium from upper Lochkovian and Pragian beds (there is contradiction in the occurrences between the text of Lenz [1977b] and table 1 of Lenz [1977a] with regard to Cryptatrypa and Protathyris distributions). The Zlichovian Cryptatrypa of the Delorme Formation are distinctive and are described below as a new species, C. lenticula; a few of the upper Lochkovian Delorme shells are described here as Cryptatrypa sp. 1.

\section{Cryptatrypa lenticula sp. nov.}

Pl. 40, figs. $1-27$

\section{DIAGNOSIS}

A Cryptatrypa with a prominent ventral beak and an open delthyrium, which is oval in outline and lens-shaped in lateral profile.

\section{ETYMOLOGY}

The specific name is derived from the Latin lenticulolens shaped, in reference to the gently biconvex lateral profile

\section{REFERRED SPECIMENS}

Cryptatrypa lenticula sp. nov. occurs in beds of Zlichovian age in $\mathrm{S}-1$, at $62.5-68.6 \mathrm{~m}$, and in $\mathrm{S}-3$, at 94.5-576.1 $\mathrm{m}$, respectively, below the top of the Delorme Formation. It is represented by $92 \mathrm{~A}, 6 \mathrm{~B}$, and $6 \mathrm{P}$ silicified shells. Material illustrated includes holotype ROM 34058 and paratypes ROM 34059-34065 from S-3, sample S4-161.5-164.6 m; paratype ROM 34066 from S-3, sample S4-502.9-507.5 m; and paratype ROM 34067 from S-1, sample A62.5-68.6 m.

\section{EXTERIOR}

The shell is subequally biconvex, oval in outline, and lens-shaped in lateral and transverse profiles. The brachial 
valve is subcircular in outline. The ventral beak is pointed, prominent, and erect, and defines a moderate-sized ventral interarea. The pedicle valve has a prominent open, triangular delythrium. The hinge line is short and curved. The maximum width of the shell is developed near midlength. The anterior commissure is rectimarginate. The shell exterior is generally smooth but has a distinct "pebbled" surface texture on the outer shell layer in all silicified shells. A few weakly developed concentric growth lamellae are developed in some shells.

\section{PEDICLE VALVE INTERIOR}

The hinge teeth are small, rounded knobs, which project a short distance above the plane of commissure and are supported by prominent dental lamellae. The dental lamellae converge slightly ventromedially. Muscle scars are not impressed and the shell interior is smooth.

\section{BRACHIAL VALVE INTERIOR}

The floors of the sockets are attached to the posterior margin of the shell wall and curve sharply ventrolaterally, covering a large part of the sockets. The inner hinge plates cap the socket plates and touch medially towards the apex of the shell. The inner hinge plates remain free of the valve floor; they are inclined dorsomedially and are slightly thickened medially near the point of attachment of the crura. The spiralia comprise at least seven laterally directed whorls. The shell interior is smooth, without any traces of muscle scars.

\section{DISCUSSION}

C. lenticula sp. nov. is distinguished from the Late Silurian C. triangularis Johnson, Boucot, and Murphy (1976) by its much more ovoid outline. The type species, C. philomela (Barrande), from the Zlichovian of Bohemia, has less prominent dental plates, which adhere closely to the lateral shell walls (Siehl, 1962, pl. 26, fig. 6; pl. 27, fig. 1). C. philomela minor Biernat (1966) from the Middle Devonian Skaly Beds of Poland has a more pointed ventral beak and more prominent growth lines. $C$. philomela minor and C. triangularis have a "pebbled" surface ornament similar to that of $C$. lenticula. Cryptatrypa sp. of Chatterton and Perry (1978) from beds of probable early Eifelian age in the eastern Mackenzie Mountains show fine, radial structure of the inner shell layers, as do corroded shells of $C$. lenticula (Pl. 40, figs. 24-27). The overall shape of these last two taxa is very similar.

\section{Cryptatrypa sp. 1}

Pl. 39, figs. 30-37

\section{REFERRED SPECIMENS}

Cryptatrypa sp. 1 is represented by $858 \mathrm{~A}, 20 \mathrm{~B}$, and $44 \mathrm{P}$ silicified shells from beds of Lochkovian and early Pragian age at S-1, S-2, and S-3. Most of the shells are filled with quartz, and details of internal structures are difficult to determine. Material illustrated includes ROM 3404934054 from upper Lochkovian strata at S-1, sample A470.9 m.

\section{DISCUSSION}

Most of the shells included here under the designation of Cryptatrypa sp. 1 belong to the genus; however, a small number are undoubtedly assignable to Protathyris. Species of these two genera are externally indistinguishable, and to identify them would require the breaking open or the serial sectioning of almost every specimen. Therefore, all specimens here are provisionally assigned to Cryptatrypa.

The shells are slightly ventribiconvex in lateral profile and subrhomboidal to laterally ovate in outline. The pedicle beak is sharp with an open, triangular delthyrium. The dental lamellae are short, and most of the shells lack a cardinal plate in the brachial valve (definitive of Protathyris).

\section{Suborder Athyrididina Boucot, Johnson, and Staton Superfamily Athyridacea M'Coy Family Meristellidae Waagen, 1883 Subfamily Meristellinae Waagen, 1883}

\section{DISCUSSION}

The distinction drawn between Meristina Hall (1867) and Meristella Hall (1859) is not particularly clear. Shells of Meristina have more prominent dental plates, which extend forward as distinct ridges and bound the muscle area, whereas the dental plates in shells of Meristella are obsolescent and have ventral muscle scars flaring laterally anterior to them (Boucot, Johnson, and Staton, 1964). The two genera are otherwise very similar both on the exterior and on the interior. Superficially, the above distinction seems clear; however, forms identified as Meristella cf. M. robertsensis Merriam by Johnson (1970) possess only very short dental plates. Moreover, since the muscle scars are seldom well preserved in these genera, their actual distinction is difficult. With these problems in mind, the writer has referred all Delorme Formation shells with short dental plates to the earlier-named genus, Meristella. 
Genus Meristella Hall, 1859

TYPE SPECIES

Atrypa laevis Vanuxem, 1842:120.

Meristella cf. $M$. robertsensis Merriam, 1940 Pl. 37, figs. 42-52

Meristella robertsensis Merriam, 1940, pl. 6, figs. 2, 13-16.

Meristella cf. M. robertsensis-Johnson, 1970:176, pl. 49 , figs. 7-25; pl. 50, figs. 1-16.

\section{REFERRED SPECIMENS}

Meristella cf. $M$. robertsensis occurs in beds of latest Lochkovian and early Pragian age in S-1, at 330.7$470.9 \mathrm{~m}$, and in S-2, at $32.0 \mathrm{~m}$, respectively, below the top of the Delorme Formation. $M$. cf. $M$. robertsensis is not a common element in the Delorme Formation and is represented by only $2 \mathrm{~A}, 4 \mathrm{~B}$, and $2 \mathrm{P}$ silicified shells. A few other fragmentary shells identified as Meristella sp. occur in beds close to these collections. Material illustrated includes ROM 34005, 34006 from S-1, sample A330.7 m; ROM 34009 from S-1, sample A470.9 m; and ROM 34007,34008 from S-2, sample B32.0 m.

\section{DISCUSSION}

M. cf. M. robertsensis occurs in the early Pragian Spinoplasia and Trematospira Zones of central Nevada. The articulated Delorme shells fit well the features ascribed to gerontic $M$. robertsensis. The shells are subpentagonal in outline and are strongly inflated; they possess an open apical foramen and have a distinct dorsal fold with subparallel lateral margins. An increased shell depth is shown on gerontic specimens, on which the growth lines are inclined at a considerable angle to the line of commissure.

Meristella is a typical genus of Appohimchi Province, and this is the first documentation of the genus from northwestern or arctic Canada; this documentation again shows that faunal exchange did occur along the Cordilleran seaway, even during the early Pragian, a time of sequence minima (Savage, Perry, and Boucot, 1979).

Family Athyrididae M'Coy, 1844

\section{Subfamily Protathyridinae Boucot, Johnson, and Staton, 1964}

\section{Genus Didymothyris Rubel and Modzalevskaıa, 1967}

\section{TYPE SPECIES}

Terebratula? didyma Dalman, 1828:62, pl. 6, fig. 7.

\section{DISCUSSION}

One seemingly distinctive protathyrid-Protathyris didyma of Kozlowski's usage; Collarothyris canaliculata (Wenjukow) here-is very abundant in Ludlovian and/or Pridolian strata at geographically widespread localities in the Delorme and Gossage formations of the Mackenzie and Wernecke mountains.

The taxonomy of smooth brachiopods of the subfamily Protathyridinae is complex because there are several near external homoeomorphs. Internal characteristics are critical to the recognition of several genera. Relationships between some species of the genera Protathyris, Didymothyris, and Collarothyris are shown by Jones (1978, text-fig. 3). Synonyms of $P$. didyma of Kozlowski (1929) have been split into two groups, some assigned to Didymothyris and others to Collarothyris. Modzalevskaıa (1970) considered $P$. didyma of Kozlowski a synonym of Collarothyris canaliculata. She separated Collarothyris from Didymothyris because of the following features found on the former, as compared to the latter: a very narrow, V-shaped, poorly developed jugal structure, which is located closer to the umbonal region of the shell; a muscle field situated within the limits of the dental plates; more elongate jugal branches, which are joined to the first whorl of the spiralia; and a delthyrial rather than mystrochial plate structure. Collarothyris is distinguished from Protathyris by the presence of dental plates on the former

\section{Didymothyris sp. 1 \\ Pl. 38, figs. 1-13}

\section{REFERRED SPECIMENS}

A few silicified shells (23A, 10B, and 3P) of $\mathrm{Di}$ dymothyris sp. occur in Ludlovian beds in S-6, at $204.2 \mathrm{~m}$ above the base of the Delorme Formation. Material illustrated includes ROM 34010-34017 from S-6, sample C47-248.4 m.

\section{DISCUSSION}

Didymothyris is distinguished from Protathyris by the presence of a small ( $1 \mathrm{~mm}$ in length) spondylium-like structure (mystrochial plates) in the apex of the pedicle posterior to the dental plates. The base of the spondylium rests on the valve floor and is not supported by a septum. Rubel and Modzalevskata (1967) described species of 
Didymothyris from beds of Wenlockian, Ludlovian, and Pridolian ages of the Baltic region and of Podolia. The genus has not previously been reported in North America. Johnson, Boucot, and Murphy (1973) made a confusing statement regarding a Nevada Pridolian Protathyris: "It should be noted that this species lacks mystrochial plates, which would indicate an assignment to Didymothyris Rubel and Modzalevskaia (1967) instead of Protathyris". Presumably the absence of this structure precludes assignment of the Nevada shells to Didymothyris.

The Delorme Formation shells are similar to $D$. didyma (Dalman) as illustrated by Rubel and Modzalevskaia (1967), not Kozlowski (1929). The prominent dorsal myophragm of $D$. didyma is present in the Delorme shells, although the parallel muscle-bounding ridges are not preserved. The anteroventrally directed cardinal plate of the Delorme Didymothyris bears two elongate, pointed marginal projections and a medial pair of subtriangular projections. Details of the spiralia are not preserved.

\section{Genus Collarothyris Modzalevskåâ, 1970}

TYPE SPECIES

Meristella canaliculata Wenjukow, 1899, pl: 7, fig. 21.

Collarothyris cf. C. canaliculata (Wenjukow, 1899)

Pl. 38, figs. 14-30; Text-fig. 9

Protathyris didyma Kozlowski, 1929:227, pl. 12, figs. 28-40; text-figs. 86-88.

Protathyris cf. P. didyma-Lenz in Dineley, 1965:93.

Meristella sp.-Norris in Gabrielse, Blusson, and Roddick, 1973:74.

Protathyris didyma-Smith, 1976b:26, pl. 7, figs. 10-14, text-fig. 18.

\section{REFERRED SPECIMENS}

Collarothyris cf. C. canaliculata is represented by $2300 \mathrm{~A}$, $90 \mathrm{~B}$, and $180 \mathrm{P}$ silicified shells from S-9, at $33.8-74.7 \mathrm{~m}$ below the top of the Delorme Formation; and by approximately $75 \mathrm{~A}$ calcareous shells from S-5, at 115.8 $118.9 \mathrm{~m}$, and from $\mathrm{S}-10$, at $15.2-106.7 \mathrm{~m}$, respectively, above the base of the Delorme. The species is also found in the Snake River area of the northern Yukon $\left(65^{\circ} 22^{\prime} \mathrm{N}\right.$, $133^{\circ} 30^{\prime} \mathrm{W}$ ), in beds now assigned to the Gossage Formation. All of these beds are of probable Ludlovian age. Material illustrated includes ROM 34021, 34022 from S-5, sample C-838.2 m; and ROM 34018-34020 from S-10, sample S1-15.2 m. Five specimens were serially sectioned; ROM 34023 from S-10, sample S1-106.7 m, is illustrated in Text-figure 9.

\section{EXTERIOR}

The small shells (maximum length of approximately $14 \mathrm{~mm}$ ) have an elongate, subpentagonal outline and are variably ventribiconvex to dorsibiconvex in lateral profile. The hinge line is short; the maximum shell width is developed anterior to midlength. The posterior portion of the shell shows greater convexity. The pedicle beak is moderately incurved over the brachial valve. The delthyrium is commonly open and may be partially closed off anteriorly by deltidial plates. The deltidial plates are conjunct only in a few gerontic shells. Only fragments of the deltidial plates are preserved on many of the silicified shells, indicating that the plates were extremely thin and may not have been completely silicified. A prominent ventral sulcus and a corresponding dorsal fold are developed anteriorly. A few shells bear a very shallow median groove in the dorsal valve. Closely spaced growth lines over the anterior one-third of the shell show that the marked increase in valve thickness in mature shells is a result of greater relative growth perpendicular to the plane of commissure

\section{PEDICLE VALVE INTERIOR}

The small, cylindrical hinge teeth are hooked slightly posteriorly. The hinge teeth are supported by prominent, vertical dental plates, which define deep, open lateral cavities. Muscle scars are not impressed in either valve.

\section{BRACHIAL VALVE INTERIOR}

The sockets are directed anterolaterally and are covered posteriorly by part of the cardinal plate. The cardinal plate develops just anterior to the beak, leaving only a small opening. The cardinal plate widens and curves gently anteroventrally. The lateral corners of the cardinal plate curve more strongly and extend farther ventrally. A very weak, threadlike myophragm extends from beneath the cardinal plate to at least midlength of the shell. Serial sections show the variable development of the cardinal plate, and Text-figure 9 (ROM 34023) shows the dorsal myophragm quite clearly.

\section{DISCUSSION}

The characteristic mystrochial plates of the genus $\mathrm{Di}$ dymothyris are absent in these shells. Although a very large number of silicified shells was collected from the Delorme, complete forms of the delicate deltidial plates are preserved on only a few of these shells.

The shells from the Gossage Formation were originally identified as $P$. cf. $P$. didyma and assigned a Late Silurian age. They are distinguishable both externally and internally from the Delorme shells. The shells identified as $P$. cf. $P$. didyma by Norris from GSC locality 68033 (should be 69033, Gabrielse, pers. comm., 1973) do not belong to that genus and clearly belong to $C$. cf. $C$. canaliculata. 


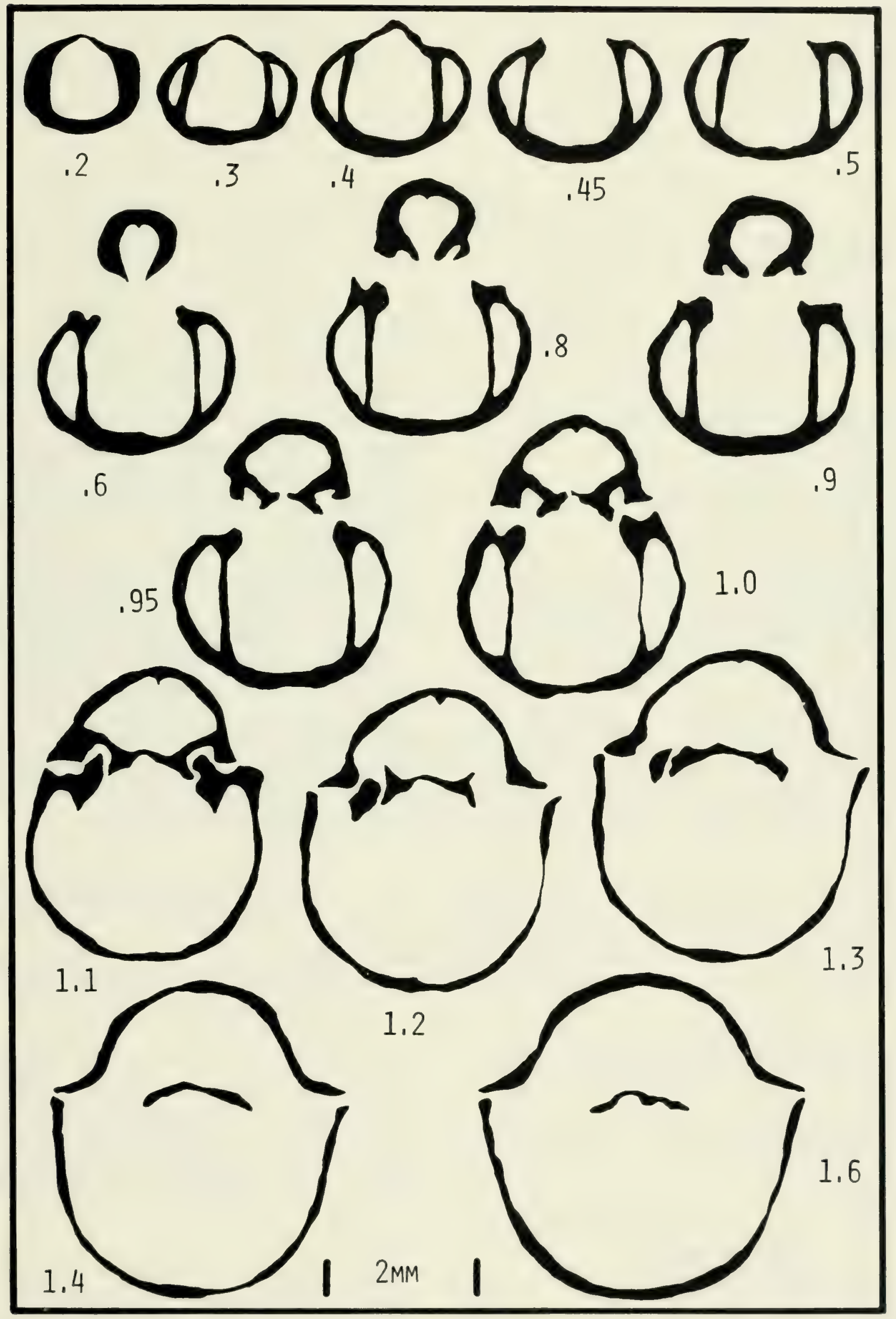

Texi-fig. 9 Collarothyris of. C. canaliculata (Wenjukow)

Camera lucida drawings of serial transverse sections; measurements are distances in $\mathrm{mm}$ from pedicle beak; ROM 34023 
The host strata from which each of these collections was made consists of thin-bedded, platy, orange-weathering dolomitic limestones or limy dolostones, with an associated ostracoderm fauna. C. cf. C. canaliculata is one of the few brachiopods found in the platform dolostone facies of the Delorme Formation, and presumably it lived in a somewhat restricted marine environment.

\section{Family Nucleospiridae Davidson, 1831}

\section{Genus Nucleospira Hall, 1859}

TYPE SPECIES

Spirifer ventricosa Hall, 1857:57 (not figs. 1, 2).

Nucleospira cf. $N$. laevigata Lenz, 1977b

Pl. 39, figs. 1-29

Nucleospira laevigata Lenz, 1977b:125, pl. 30, figs. 17 , 20-32.

\section{REFERRED SPECIMENS}

Nucleospira cf. $N$. laevigata is a common shell in strata of mid-Lochkovian through Zlichovian age in S-1, at 62.5-68.6 $\mathrm{m}$ and OLDA278.9-527.3 $\mathrm{m}$, in $\mathrm{S}-2$, at $105.2-263.7 \mathrm{~m}$, and in S-3, at 53.3-685.8 m, respectively, below the top of the Delorme Formation. It is represented by $435 \mathrm{~A}, 391 \mathrm{~B}$, and $535 \mathrm{P}$ well-preserved silicified shells. Material illustrated includes ROM 34031-34033 from S-2, sample B121.9 m; ROM 34034 34036 from S-1, sample A484.6 m; ROM 34037-34042 from S-1, sample A62.5-68.6 m; and ROM 34044-34048 from S-3, sample S4-502.9-507.5 m.

\section{DISCUSSION}

The Delorme Formation Devonian Nucleospira have been assigned to $N$. cf. $N$. laevigata. The taxon is particularly abundant in high-diversity faunas of late Lochkovian and Zlichovian ages, which are interpreted to have lived in offshore, open-marine environments. $N$. laevigata occurs commonly in Lochkovian and Pragian beds at Royal Creek (Lenz, 1977b).

$N$. cf. $N$. laevigata differs from $N$. ventricosa Hall by its subequally convex valves and its weakly developed palintrope. N. subsphaerica Johnson from the Zlichovian of central Nevada has a much more inflated lateral profile, a minor development of ventral fold and dorsal sulcus, and more pronounced growth lamellae. $N$. robusta Kozlowski is wider than long and has a more pointed cardinal plate. Shell thickness is highly variable in $N$. cf. $N$. laevigata and appears to be a function of the biotope energy regime: thicker shells in more turbulent environments and thinner shells in quieter-water environments.

\section{Suborder Retziidina Boucot, Johnson, and Staton Superfamily Retziacea Waagen \\ Family Rhynchospirinidae Schuchert and LeVene, 1929}

Genus Rhynchospirina Schuchert and LeVene, 1929

\section{TYPE SPECIES}

Rhynchospirina siemiradzkii Kozlowski, 1929:214, pl. 9, figs. 27-34, text-figs. 76, 77.

\section{Rhynchospirina sp. 1 \\ Pl. 30, figs. 60-65}

Rhynchospirina sp. Johnson, 1973a:1027, pl. 5, figs. 7-11.

\section{REFERRED SPECIMENS}

Rhynchospirina sp. 1 occurs in strata of mid-Lochkovian age in S-1, at A538.0, and in S-2, at 245.4-300.2 m, respectively, below the top of the Delorme Formation. It is not a common taxon in the Delorme and is represented by only $7 \mathrm{~A}, 1 \mathrm{~B}$, and $2 \mathrm{P}$ silicified shells. Material illustrated includes ROM 33856, 33857 from S-1, sample A538.0T; and ROM 33858, 33859 from S-2, sample B300.2 m.

\section{EXTERIOR}

The shell is subcircular to elongate and suboval in outline and slightly dorsibiconvex in lateral profile. The apical angle increases with shell size, suggesting that shells progress from an elongate to a more transverse form during ontogeny. The pedicle beak is gently incurved with a circular, mesothyridid foramen. The palintrope is narrow with rounded margins. The dorsal beak is strongly 
incurved and touches the ventral palintrope. The hinge line is gently curved and is approximately one-half of the maximum shell width, which is developed anterior to midlength. The ventral sulcus is weakly developed and widens markedly anteriorly. Radial ornament comprises simple, undivided, rounded costae separated by narrower, U-shaped interspaces. Costae on the sulcus are slightly smaller than those on the flanks. Growth lines are not evident. The shell substance is relatively thick.

\section{PEDICLE VALVE INTERIOR}

The hinge teeth are small and rounded. Dental lamellae are absent. Muscle scars are not impressed. The interior of the shell is weakly corrugated by the impress of the costae.

\section{BRACHIAL VALVE INTERIOR}

The short, wide sockets are directed anterolaterally. The socket plates extend medially from the posterolateral shell wall and then curve sharply ventrally and form the anteromedial wall of the socket. The posteromedial portion of the sockets is joined by a concave cardinal plate, whose anterior edge curves sharply dorsally. A pair of strongly recurved, anteriorly tapered, flat crural plates extends into the ventral cavity from the lateral corners of the cardinal plate. The crural bases form an inverted- $\mathrm{V}$ - shaped indentation of the cardinal plates, as described for R. siemiradzkii by Johnson, Boucot, and Murphy (1973). The cardinal plate is supported by a median septum, which extends over one-quarter of the shell length; the median septum is very thin and is broken in the specimen at hand.

\section{DISCUSSION}

Rhynchospirina sp. 1 occurs with Spirigerina intermedia sp. nov. at S-1, and below occurrences of the stratigraphically younger $S$. supramarginalis at S-2. Occurrences of the species in the lower Windmill Limestone (below the Quadrithyris Zone proper) in Nevada are assigned a mid-Lochkovian age by Johnson (1973a).

The main differences observed in Rhynchospirina sp. 1 when compared to the shells cited as $R$. siemiradzkii from the early Lochkovian of central Nevada (Johnson, Boucot, and Murphy, 1973) are the thicker shell wall, the less well developed dorsal septum, the absence of a dorsal sulcus, and the more transverse nature of the shell, although this last point may well be related to ontogenetic stage.

Johnson (1973a) noted the common occurrence of Rhynchospirina with Cyrtina and with digitate favositid corals in Nevada; the Delorme shells show a wider range of faunal association.

\section{Suborder Spiriferidina Waagen Superfamily Spiriferacea King Family Delthyrididae Phillips, 1841 Subfamily Delthyridinae Phillips, 1841}

\section{Genus Howellella Kozlowski, 1946}

\section{TYPE SPECIES}

Delthyris elegans Muir-Wood, 1925 (=Terebratula crispa Hisinger, 1826, pl. 7, fig. 4); not Linné, 1758.

\section{Howellella cf. H. khalfini Kulkov, 1963 Pl. 38, figs. 31-40}

Howellella aff. H. khalfini-Lenz, 1977b:128, pl. 32, figs. $14,15,17-26$.

\section{REFERRED SPECIMENS}

The Delorme Formation $H$. cf. $H$. khalfini is represented by only $2 \mathrm{~B}$ and $2 \mathrm{P}$ silicified specimens from beds of Zlichovian age in S-3, at 161.5-176.8 $\mathrm{m}$ below the top of the formation. Material illustrated includes ROM 3402634028 from S-3, sample S4-176.8 m; and ROM 34029 from S-3, sample S4-161.5-164.6 m.

\section{DISCUSSION}

H. khalfini Kulkov (1963) occurs in probable upper Lochkovian beds of the Solovikh Limestone in the Altai Mountains of Siberia. The Royal Creek shells illustrated by Lenz (1977b) are from Pragian beds; the Delorme representatives are from Zlichovian strata.

Although very limited, the material available for study shows distinctive features of $H$. khalfini: a sharp, low ventral myophragm; the presence of ventral dental plates and adminicula; and the characteristic lamellose ornament. The Delorme specimens show some close similarity to those illustrated as $H$. aff. $H$. textilis from the "Receptaculites" Limestone (Chatterton, 1973); however, the former generally have more flank costae, as does the type material of $H$. textilis from Victoria in Australia (Talent, 1963). $H$. koneprusiensis Havlícek (1959) has weaker growth lamellae than the Delorme shells. The Nevada representatives of $H$. cf. $H$. textilis have more numerous and more prominent plications. H. aculeata (Schnur), as illustrated by Johnson (1970), is close to the Delorme $H$. cf. $H$. khalfini, although the growth lamellae of the former seem more imbricate. 
Howellella cycloptera (Hall, 1859)?

$$
\text { Pl. 45, figs. 1-7 }
$$

?Howellella cycloptera-Johnson, 1970: 185, pl. 54, figs. $1-24$

\section{REFERRED SPECIMENS}

Beds of mid-Pragian age in the Delorme Formation, in $\mathrm{S}-1$, at 272.8-318.5 $\mathrm{m}$ and OLDA278.9 $\mathrm{m}$ below the top of the formation, yielded a few $(5 \mathrm{~B}, 6 \mathrm{P})$ fragmentary silicified shells of $H$. cycloptera?. Material illustrated includes ROM 34169 from S-1, sample A318.5 m; and ROM 34167, 34168 from S-1, sample OLDA278.9 m.

\section{DISCUSSION}

H. cycloptera? occurs in Pragian beds at S-1; the taxon has also been reported from the Pragian Spinoplasia Zone of central Nevada. The transversely suboval outline and ventribiconvex lateral profile are characteristic features of these large shells. The ventral valve bears a broad, U-shaped sulcus and seven distinct flank plications separated by U-shaped interspaces. The hinge teeth are small and curved dorsoposteriorly. The dental plates are short and widely set apart; they bound the posterior end of the weakly impressed muscle field. Both valves are strongly crenulated internally by the impress of the plications.

The occurrence of $H$. cycloptera? is important because the taxon is believed to be the ancestor of Acrospirifer. The Howellella-Acrospirifer transition occurs near the Spinoplasia Zone in Nevada, at about the same level as the transition from early to late forms of the conodont Eognathodus sulcatus. The transition from early to late forms of $E$. sulcatus in the Delorme Formation occurs at about the same level as the occurrences of $H$. cycloptera?. In Europe the Howellella-Acrospirifer transition occurs at approximately the level of the Gedinnian-Siegenian boundary, and thus the stratigraphic level of the Howellella-Acrospirifer transition may be significant for intercontinental correlation (Johnson, 1975a).

\section{Howellella sp. 1}

Pl. 45, figs. 8-25; Text-fig. 10

\section{REFERRED SPECIMENS}

Howellella sp. 1 occurs in beds of early Lochkovian age in $\mathrm{S}-2$, at $336.8-344.4 \mathrm{~m}$ below the top of the Delorme Formation. It is represented by $9 \mathrm{~A}, 105 \mathrm{~B}$, and $81 \mathrm{P}$ well-preserved silicified shells. Very similar shells, which are regarded here as of the same species, are known from calcareous specimens in S-6, at 323.1-342.9 m, and in $\mathrm{S}-7$, at 106.7-423.7 $\mathrm{m}$, respectively, below the top of the Delorme. Calcareous specimens are represented by $35 \mathrm{~A}$,
13B, and 38P shells. Material illustrated includes ROM 34174-34179 from S-2, sample B336.8 m; ROM 3417034173 from S-6, sample C47-507.5 m; and serially sectioned specimen ROM 34180 from S-7, sample P7WA1912.6 m.

\section{EXTERIOR}

The shells are of moderate size (commonly $10 \mathrm{~mm}$ in width), transversely subsemicircular in outline, and moderately to strongly dorsibiconvex in lateral profile. The cardinal angles are broadly rounded; the maximum shell width is developed posterior to midlength. The ventral beak is gently incurved over the high, triangular, covered, concave, apsacline interarea, which extends over two-thirds of the shell width. The delthyrium encloses an angle of about $45^{\circ}$ and is bounded marginally by the lateral plates, which are oriented perpendicular to the interarea. The dorsal valve has a low, flat, linear, orthocline interarea. The notothyrium encompasses an angle of approximately $135^{\circ}$. The prominent ventral sulcus and dorsal fold are rounded in outline and expand from the beak to the anterior margin, where the sulcus and/or the fold occupy one-quarter of the shell width. The lateral plications are rounded and die out laterally. The flanks bear up to five lateral plications, commonly three or four; there is usually one fewer on the dorsal valve. On calcareous shells fine ornament consists of closely spaced, concentric growth lamellae crossed by seemingly continuous fine radial striae. Silicified shells show more prominent growth lamellae, also crossed by continuous, fine radial striae.

\section{PEDICLE VALVE INTERIOR}

The thin, pointed hinge teeth are directed dorsally. The thin dental lamellae converge medially and then diverge slightly in the form of ventral adminicula to the valve floor. The dental lamellae extend only a short distance anteriorly in the silicified shells, whereas in calcareous shells they extend to about one-third of the shell length. The hinge teeth bear shallow, anteromedially directed crural fossettes. A threadlike ventral myophragm extends from the beak to approximately midlength of the shell. The ventral muscle field is not impressed. The valve interior is crenulated by the impress of the plications.

\section{BRACHIAL VALVE INTERIOR}

The sockets diverge and widen anterolaterally. The socket plates are joined to the underside of the interarea; they extend anteriorly and then curve ventrally to define the sockets. The prominent crural bases are welded to the medial edges of the socket plates, converge dorsally, and diverge anteriorly. The crural bases are joined to the 
posterior shell wall for a short distance, and in some shells they extend to one-quarter of the shell length. Rodlike crural processes are attached to the dorsal edges of the crural bases and extend to at least one-third of the shell length. A small, comblike cardinal process is situated at the valve apex near the posteromedial edge of the crural bases. Details of the cardinal process are not well preserved. A weak, threadlike myophragm extends over the posterior two-thirds of the shell. The muscle field is not impressed, and the valve interior is corrugated by the impress of the plications.

\section{DISCUSSION}

It is possible that the silicified and calcareous shells grouped together here as Howellella sp. 1 represent two species, although the very close similarity of the silicified shells to the small- and medium-sized calcareous shells makes it more likely that they are of the same species. The larger calcareous shells usually have an additional flank plication and have longer dental lamellae. Small shells of Howellella sp. 1 are externally similar to $H$. nucula australis Savage from the late Lochkovian of New South Wales, but internally $H$. nucula australis differs in that it bears a short septum near the apex of the ventral valve. $H$. nucula (Barrande) from the Ludlovian of Bohemia has fewer flank plications than the Delorme shells but shows similar development of the ventral myophragm. Howellella sp. 1 differs from $H$. laeviplicatus (Kozlowski) in its more distinct flank costae. Howellella sp. 1 appears intermediate between $H$. laeviplicatus and $H$. angustiplicatus (Kozlowski) with regard to plication development. The micro-ornament of $H$. angustiplicatus, as illustrated by Kozlowski (1929, pl. 10, fig. 16), is very similar to that on silicified shells of Howellella sp. 1. Kozlowski's serial sections of $H$. angustiplicatus have less prominent dental plates. Both laeviplicatus and angustiplicatus are found in early Lochkovian beds of Podolia.

Johnson, Boucot, and Murphy (1973) suggested that some of the shells formerly regarded as belonging to the Delthyrididae, namely Howellella, should be assigned to the Reticulariidae because of the variable strength and obsolescence of their plications--both common features in the early reticulariids. There is no distinctive fine ornament present in most of the early reticulariids to separate them from members of the Delthyrididae, although a few reticulariid shells show concentric lamellae that bear spine bases on their anterior edges. These spine bases are not continuous with the radially aligned ridges that cross the entire length of the numerous lamellae. The fine ornament of Howellella sp. 1 is fairly well preserved and appears to show radial striae continuous from one lamella to another, supporting assignment of this species to the Delthyrididae. The distinction of a subfamily by this criterion is of little practical value because very well preserved shells are rarely found. The shells assigned here to Howellella sp. 2 may belong to the Reticulariidae, namely to the genus Undispirifer, the taxon to which Johnson, Boucot, and Murphy (1973) assigned $H$. laeviplicatus.

Shells assigned to Undispirifer cf. U. laeviplicatus by Johnson, Boucot, and Murphy (1973) from the early Lochkovian of central Nevada are close to Howellella sp. 1 upon cursory inspection. Notable differences are the apparent absence of crural plates, the supposed absence of a ventral myophragm (a ventral myophragm is clearly visible in the ventral valves illustrated by Johnson, Boucot, and Murphy), and the apparent lack of microornament on the Nevada shells.

\section{Howellella sp. 2}

Pl. 45, figs. 26-34

\section{REFERRED SPECIMENS}

Howellella sp. 2 occurs in beds of Ludlovian age in S-6, at $204.2 \mathrm{~m}$ above the base of the Delorme Formation. Howellella sp. 2 is not abundant and is represented by only 4B and 5P silicified shells. Material illustrated includes ROM 34181-34184 from S-6, sample C47-248.4 m.

\section{EXTERIOR}

The shells are transversely suboval in outline and equibiconvex to strongly dorsibiconvex in lateral profile. The prominent ventral beak has an interarea three times wider than high. The open, triangular delthyrium encloses an angle of approximately $50^{\circ}$. The delthyrium is bounded by weak, posteriorly projecting deltidial plates. The dorsal interarea is low and highly transverse. The pedicle valve has a broad, U-shaped sulcus, whereas the brachial valve has a prominent rounded fold. The rounded flank plications are more weakly developed laterally, with three or four plications on each ventral flank and two or three on each dorsal flank. Concentric growth lamellae cover the entire shell, number approximately 2.5 per millimetre near midlength, and become more prominent and more closely spaced anteriorly. Coarse silicification obscures any possible fine radial ornament.

\section{PEDICLE VALVE INTERIOR}

The small, pointed hinge teeth are directed dorsally and are supported by thin dental lamellae, which converge slightly medially and then diverge towards the shell floor. A low medial myophragm extends a short distance anteriorly. The interior of the shell is corrugated by the impress of plications.

\section{BRACHIAL VALVE INTERIOR}

The unsupported sockets diverge anterolaterally and 
overhang the valve floor. Thin crural bases are attached to the medial edge of the socket plates but do not reach the valve floor. A small, comblike cardinal process is composed of several lobes. The adductor muscle field is not impressed, and the shell interior is corrugated by the impress of the plications.

\section{DISCUSSION}

The marked concentric ornament readily distinguishes this shell from Howellella sp. 1 from beds of early Lochkovian age. The Ludlovian Bohemian taxon $H$. nucula has less prominent and less numerous flank costae and does not show the well-developed concentric growth lamellae.

\section{Genus Delthyris Dalman, 1828}

\section{TYPE SPECIES}

Delthyris elevata Dalman, 1828:120.

\section{Delthyris sp.}

Pl. 45, figs. 35-43

\section{REFERRED SPECIMENS}

Only 5B and 6P coarsely silicified shells of Delthyris sp. were recovered from beds of probable Pridolian age in the transitional facies in S-11, at 185-193.5 m above the top of the Whittaker Formation. Material illustrated includes ROM 34185-34191 from S-11, sample 185.9-193.5 m.

\section{DISCUSSION}

Delthyris has previously been noted in Pridolian strata from Prongs Creek in the Yukon (Lenz, 1970) and from central Nevada (Johnson, Boucot, and Murphy, 1973) in western North America. The prominent concentric growth lamellae displayed by the shells from Prongs Creek are not preserved on the Delorme shells, nor are other delicate features essential for specific identification.

Characteristic features of the taxon are the transversely oval outline, the ventribiconvex lateral profile, and the prominent $\mathrm{V}$-shaped ventral sulcus flanked by two distinct, rounded flank plications. The taxon from the Mackenzie Mountains has a high, apsacline ventral interarea cleft by an open delthyrium, with prominent delthyrial plates projecting perpendicular to the plane of the interarea. The ventral median septum is high and bladelike and extends from the valve apex to about midlength of the shell, where it abruptly terminates. The sockets overhang the valve cavity; thin crural plates attach to the inner edges of the socket plates and extend anteriorly as rodlike crural processes.

\section{Subfamily Hysterolitinae H. and G. Termier, 1949}

\section{Genus Callispirifer gen. nov.}

\section{TYPE SPECIES}

Callispirifer teniostrakon gen. nov. et sp. nov., Pl. 46, figs. 1-26.

\section{DISCUSSION}

Callispirifer gen. nov. is clearly separated from Alatiformia; Struve's (1964) illustrations of the latter genus show a very well developed subdelthyrial plate. The dorsal interior of Alatiformia, unlike that of Callispirifer, possesses a horizontal, shelflike extension of the hinge plates, which partially closes the notothyrial cavity. Acrospirifer is distinguished from Callispirifer by its much thicker umbonal shell deposits, more incurved ventral beak, and lack of crural bases. None of the species of Hysterolites described by Johnson (1970) and Johnson and Kendall (1976) from the Zlichovian of central Nevada, or by Solle (1963) from the "Pragian" of Germany, are closely similar to Callispirifer. All have more prominent dental plates and more numerous and stronger flank plications.
Callispirifer teniostrakon geri. nov. et sp. nov. Pl. 46, figs. 1-26

"Hysterolites" sp. Perry, Boucot, and Gabrielse, 1981:300, pl. 5, figs. 24-30, ?figs. 20, 21.

\section{DIAGNOSIS}

A thin-shelled hysterolitinid with a procline ventral interarea and short ventral adminicula, and lacking any trace of muscle scars

\section{ETYMOLOGY}

The generic name is derived from the Latin callibeautiful; the specific name is from the Latin tenius - thin and the Greek ostrakon-shell, in reference to the thin shell.

\section{REFERRED SPECIMENS}

Callispirifer teniostrakon gen. nov. et sp. nov. is known with certainty only from $\mathrm{S}-1$, at $62.5-68.6 \mathrm{~m}$ below the top of the Delorme Formation, in Zlichovian strata. It is represented by some 20A, 163B, and $61 \mathrm{P}$ well-preserved silicified shells. Material illustrated includes holotype 
ROM 34200, and paratypes ROM 34915, 34198, 34199, 34202 , 34203, 34205, 34206 from S-1, sample A62.5$68.6 \mathrm{~m}$.

\section{EXTERIOR}

The shells are relatively large $(15-25 \mathrm{~mm}$ in width), highly transverse, and markedly ventribiconvex in lateral profile. The pedicle valve is three to four times deeper than the brachial valve. The long, straight hinge line corresponds to the maximum shell width. The cardinal angles are acute and submucronate. The ventral interarea is commonly slightly procline and less often catacline; in gerontic shells it is only slightly incurved. The triangular ventral interarea is flat to convex and cleft medially by a variably covered or open delthyrium, which encompasses an angle of approximately $25^{\circ}$. Thin, low plates bound the delthyrium laterally; they curve medially in some shells, forming a convex deltidial cover over the apical part of the delthyrium in large shells. Small shells bear a deltidial cover over a much larger proportion of the delthyrium and have a small pedicle opening near the dorsal margin. The wide, low dorsal interarea is moderately anacline to orthocline. The dorsal interarea surface is slightly concave and extends only a short distance posterior to the hinge line. The ventral sulcus is moderately deep and U-shaped and flares anteriorly. The dorsal fold is distinct with a low, rounded anterior profile and a medial groove. Anteriorly the fold and sulcus are as wide as three plications and the intervening intercostal spaces. Ornament consists of rounded, U-shaped radial plications and interspaces, which decrease in both height (amplitude) and width away from the fold and the sulcus. Mature shells bear three or four lateral plications on the pedicle valve and four or five on the brachial valve. The shells are covered by micro-ornament of concentric growth lines, which become imbricate over the anterior one-half to one-third of the shell. Gerontic shells develop a strongly geniculated fringe on the dorsal valve. Occasionally growth lines are strongly developed. The position of the growth lines indicates that the shells become more elongate during ontogeny relative to their width. The shell substance is thin.

\section{PEDICLE VALVE INTERIOR}

The hinge teeth are subrounded, bladelike extensions of the dental lamellae and are directed anteromedially. The dental lamellae are very short, strong, and anteromedially convergent. The dental lamellae join basally with the anterolaterally divergent ventral adminicula (sensu Strusz, Chatterton, and Flood, 1970). The ventral adminicula define the wide, open lateral chambers. The bases of the ventral adminicula extend a very short distance anterolaterally along ridges formed by the impressions of the first intercostal spaces lateral to the dorsal sulcus. The muscle area is not impressed. The interior of the shell is coarsely corrugated by the impress of the plications. A subdelthyrial pad or transverse plate is lacking. Even gerontic shells lack umbonal callus.

\section{BRACHIAL VALVE INTERIOR}

The sockets are directed anterolaterally and diverge at approximately $120^{\circ}$. The socket plates are attached to the posterior shell wall and to the base of the interarea. They project horizontally and then curve sharply ventrally. Their inner surfaces are inclined slightly posteroventrally and define the anteromedial wall of the socket. The sockets are free of the valve floor. The anteromedial socket wall is supported by triangular anteriorly expanding, dorsomedially inclined crural bases, which just touch the posterior shell wall. Poorly developed, rodlike thickenings along the crural bases mark the points of attachment of the crura. The crura extend for a short distance anteriorly in the form of vertically elongated, oval processes. The crural bases are thickened and joined to the lateral lobes of the cardinal process posteriorly. The cardinal process is situated apically, free of the posterior wall of the interarea; it is directed ventrally and consists of at least four closely spaced, longitudinally aligned blades. The whole cardinal process is transversely oval in shape. Muscle scars are not impressed. The interior of the shell is crenulated by the impress of plications. Umbonal thickening is lacking in all shells.

\section{DISCUSSION}

Callispirifer teniostrakon gen. nov. et $\mathrm{sp}$. nov. is monotypic. It bears no trace of a musculature system and has a procline ventral interarea and short ventral adminicula.

The taxon is no doubt related to Hysterolites stock. Another possible occurrence of Callispirifer is in Zlichovian beds in the vicinity of Mount Lloyd George in north central British Columbia. Hysterolites is reported from the Lower Devonian of Germany and Czechoslovakia (Solle, 1963; Havlíček, 1959). Solle suggested that Hysterolites was derived from the Appalachians of North America during the Lochkovian, probably from the genus Acrospirifer. The occurrence of Callispirifer in the Zlichovian of the Delorme Formation of the Mackenzie Mountains is somewhat difficult to explain because no Acrospirifer or Hysterolites is known in the Lower Devonian of northwestern Canada. Externally Callispirifer is closely similar to Hysterolites sp. of Chatterton (1973) from the "Receptaculites" and Warroo limestones of New South Wales; however, the latter taxon has a more incurved ventral beak and much more prominent ventral adminicula. 


\section{Genus Howittia Talent, 1956}

TYPE SPECIES

Spirifer howitti Chapman, 1905:18, pl. 5, figs. 4-6.

Howittia sp.

Pl. 45, figs. 44-53

\section{REFERRED SPECIMENS}

Howittia occurs infrequently in Zlichovian strata of S-3, at 176.8-573.0 m, and of $\mathrm{S}-1$, at 7.6-10.7 m, respectively, below the top of the Delorme Formation. It is represented by $2 \mathrm{~B}$ and $2 \mathrm{P}$ silicified shells. Material illustrated includes ROM 34192, 34193 from S-3, sample S4-176.8 m, and ROM 34194 from S-3, sample S4-560.8-573.0 m.

\section{DISCUSSION}

This distinctive, small spiriferid has been reported only from Pragian strata of central Nevada (Johnson, 1971c), from Zlichovian beds of Spain (Vandercammen and
Krans, 1964), and from several Zlichovian localities in eastern Australia (Talent, 1956; Chatterton, 1973). The Nevada shell is from the Trematospira Zone and differs from the Delorme taxon in having much more prominent ventral adminicula, although externally the shells are quite similar. Australian species illustrated by Chatterton (1973) possess prominent ventral adminicula and a greater number of lateral plications; these species commonly show considerable variation in the number of costae developed on the fold and sulcus. The occurrence in the Delorme Formation reported here is the first for the genus in northwestern or arctic Canada.

A feature characteristic of the Delorme shells is the slightly divergent ventral adminicula (sensu Strusz, Chatterton, and Flood, 1970), which reach the valve floor in only the posterior part of the delthyrial cavity. The ventral sulcus is divided by a prominent median rib. The shell substance is considerably thickened in the umbonal regions. The cardinal process consists of several comblike, longitudinally elongated structures.

\section{Subfamily Cyrtinopsinae Boucot, 1957}

\section{Genus Cyrtinopsis Scupin, 1896}

\section{TYPE SPECIES}

Spirifer undosus Schnur, 1853:204.

\section{?Cyrtinopsis cf. C. cooperi Gill, 1942} Pl. 44, figs. 1-9

?Cyrtinopsis aff. C. cooperi Gill, 1942, pl. 6, figs. 6, 7. ?Cyrtinopsis aff. C. cooperi-Chatterton, 1973:108, pl. 28 , figs. $2-14$.

\section{REFERRED SPECIMENS}

The Delorme shells assigned to ?C. cf. C. cooperi are from strata of late Pragian age in S-1, at 207.3-233.2 m below the top of the formation. The specimens are coarsely silicified and are represented by $1 \mathrm{~B}$ and $2 \mathrm{P}$ shells. Material illustrated includes ROM 34151 from S-1, sample A207.3-208.8 m; and ROM 34152, 34153 from S-1, sample A210.3-233.2 m.

\section{DISCUSSION}

Cyrtinopsis cf. C. cooperi has been reported from Zlichovian beds of the "Receptaculites" Limestone in New South Wales by Chatterton (1973). The Delorme shells, despite their poor preservation, appear identical to those illustrated by Chatterton and to some of those illustrated by Gill (1942).

A taxonomic problem exists in the distinction of
Cyrtinopsis and Plicocyrtina. Chatterton (1973) discussed the distinction of his Cyrtinopsis from Megakozlowskiella, although he failed to compare either with Plicocyrtina. Lenz (1972) noted the close similarity between Megakozlowskiella and Plicocyrtina. The presence of the elevated, more distinct spondylium, the plication in the ventral sulcus, and the apparent absence of deltidial plates on both Plicocyrtina and Cyrtinopsis separates them from Megakozlowskiella. The separation of Plicocyrtina from Cyrtinopsis was not discussed by Havlíček (1956) when Plicocyrtina was proposed. The shells are very close morphologically, if not congeneric, and they seem to belong within the same family, although they were separated by Pitrat (1965). The following characteristics of Cyrtinopsis distinguish it from Plicocyrtina in the Delorme collections: the absence of a median rib in the ventral sulcus; the presence of crural plates, which are welded to the valve floor and which project a short distance anteriorly; the slightly more complex cardinal process; the more U-shaped spondylium; the weaker distal curvature of the growth lamellae; and the apparent absence of lateral plates. Such features are characteristics used more to distinguish species than genera. In this study the separation of ?C. cf. C. cooperi from $P$. sinuplicata is made, although their close stratigraphic occurrence and their morphologic similarity lends credence to their being regarded as congeneric. It seems that both taxa were capable of living in similar shallow-water, open-marine carbonate environments. 


\section{Genus Plicocyrtina Havlíček, 1956}

TYPE SPECIES

Plicocyrtina sinuplicata Havlíček, 1956:608, pl. 10, figs. $1,2,7,10$.

\section{Plicocyrtina sinuplicata Havlíček, 1956}

PI. 44, figs. 10-34

Plicocyrtina sinuplicata Havlíček, 1956:608, pl. 10, figs. $1,2,7,10$.

Plicocyrtina sinuplicata-Lenz, 1977b:128, pl. 31, figs. 18-38.

Plicocyrtina sinuplicata-Jackson, Lenz, and Pedder, 1978, pl. 14, figs. 19-32.

\section{REFERRED SPECIMENS}

$P$. sinuplicata occurs in strata of late Pragian age in S-1, at 272.8-390.1 $\mathrm{m}$ and OLDA268.3-388.6 m, and in S-2, at $32.0-39.6 \mathrm{~m}$, respectively, below the top of the Delorme Formation. It is not particularly abundant in the Delorme; however, many of the silicified shells are exquisitely preserved. Material illustrated includes ROM 34154 from S-1, sample A342.9 m; ROM 34155-34157 from S-1, sample OLDA336.8 m; and ROM 34158-34162 from S-2, sample B32.0 m.

\section{DISCUSSION}

At Royal Creek $P$. sinuplicata is confined to the Gypidula 1 (Gypidula boucoti Lenz, 1977a)-Davidsoniatrypa Unit (Lenz, 1967b, 1972) of early Pragian age. The type specimens of Havlíček are from the Zlíchov Limestones of Hlubočepy quarry and are of Zlichovian age.
Features characteristic of the taxon are the high ventral interarea, the fluted, outward-curving growth lamellae; the deep, broad pedicle sulcus and strong dorsal fold; the V-shaped spondylium; and the socket plates, which curve ventrally and are welded to the anterior edge of the interarea. The following features were noted in addition to the detailed description set forth by Lenz (1972): firstly, the plates described by Lenz as possible deltidial plates are lateral plates (sensu Chatterton, 1973) and extend up to $0.8 \mathrm{~mm}$ above the level of the ventral interarea; secondly, the crura are thin blades, inclined dorsomedially, and are attached to the anterior corner of the triangular crural plates, then extend anteriorly to about one-third of the length of the shell.

In the Delorme Formation, as at Royal Creek, $P$. sinuplicata comprises only a small part of the total fauna at the occurrence. As mentioned by Lenz (1972), in northwestern Canada Plicocyrtina occurs to the exclusion of Megakozlowskiella, the near homoeomorphic shell found in strata of similar age in central Nevada. This might indicate that both occupied a similar ecologic niche. Considering the older occurrence of Plicocyrtina in northwestern Canada and in light of the younger occurrence of $P$. sinuplicata in Bohemia, it might be suggested that the genus had its roots in northwestern Canada and migrated to central Europe in much the same manner as suggested for the genus Warrenella (Ludvigsen and Perry, 1975)-hence another example of the close affinity between the brachiopod faunas of the Delorme Formation and those of the Old World Realm. This example of faunal affinity is especially important because the early Pragian represents a time of sequence minima, and thereby of maximum retreat of the epicontinental seas.

\section{Subfamily Spinellinae Johnson, 1970}

\section{Genus Spinella Talent, 1956}

\section{TYPE SPECIES}

Spinella buchanensis Talent, 1956:22, pl. 1, figs. 1-5; pl. 2, figs. $4-10$; text-figs. $5-7$; table 2 .

\section{?Spinella sp.}

PI. 38, figs. 41-44

\section{REFERRED SPECIMEN}

One silicified dorsal posterior fragment (ROM 34030) of ?Spinella sp. was recovered from early Pragian beds of $\mathrm{S}-2$, at $105.2 \mathrm{~m}$ below the top of the Delorme Formation (sample B105.2 m).

\section{DISCUSSION}

Internally the dorsal valve appears very similar to Spinella talenti Johnson from the Zlichovian Eurekaspirifer pinyonensis Zone of central Nevada. The type material of Spinella is from Zlichovian strata of the Buchan Caves Limestone near Victoria, Australia. The specimen is tentatively assigned to Spinella rather than to Eurekaspirifer because of the absence of dorsal adminicula.

The dorsal exterior has a distinct fold flanked posteriorly by relatively deep furrows. The lateral margins of the shell are covered by fine growth lines and a few weakly developed lateral plications. The socket plates are directed posteromedially from beneath the interarea and curve ventrally to bound the flat-bottomed sockets. The 
trapezoidal crural plates are attached to the inner edges of the sockets. The brushlike cardinal process lobes are attached to the sides of the crural plates anterior to the apex of the notothyrial cavity

\section{Family Reticulariidae Waagen, 1883}

\section{DISCUSSION}

The smooth Spiriferidina, commonly with a fold and sulcus, are a difficult group to work with because of different philosophies of classification of various authors, the introduction of several impractical but not necessarily invalid genera, and the failure to recognize synonyms. This group has considerable biostratigraphic zonation potential in the Lower and Middle Devonian. Pitrat (1965) proposed five superfamilies of the Spiriferidina distinguished by punctation, micro-ornament, and the form of the cardinal process. The problem at hand concerns the impunctate superfamily Reticulariacea, particularly two of its families-Reticulariidae and Martiniidae-all three originally proposed by Waagen.

The smooth reticulariid with a fold and sulcus that is common in the upper Lower and Middle Devonian of northwestern Canada is Warrenella. Warrenella was proposed by Crickmay (1953) as a member of the family Martiniidae. Diagnostic features of Warrenella are a variable development of the fold and sulcus, a large delthyrium with variably developed deltidia, a concentric ornament of closely spaced rows of spine bases, dental plates bounding the posterior part of the muscle field, thick shell material near the ventral umbo, and variably developed crural plates. Pitrat (1965) characterized the Martiniidae as smooth shells with a poorly developed fold and sulcus, bald or very weakly plicate lateral slopes, and micro-ornament of concentric growth lamellae and surficial pits; sometimes with capillae; and with or without dental and crural plates. The Reticulariidae are characterized by a fold and sulcus, bald or very weakly plicate lateral slopes, and a micro-ornament of concentric growth lamellae usually with uniramous spines, papillae, or granules; by the presence or absence of dental plates; and usually by the lack of crural plates. The assignment of Warrenella to the Reticulariidae from the Martiniidae was probably governed by the fact that the Martiniidae were regarded as Carboniferous and younger, whereas the Reticulariidae included older forms - hardly a valid criterion. As indicated in the above descriptions, the only difference between the two families other than age might be in the micro-ornament-probably of taxonomic importance but a rather impractical distinction because it is only observed in well-preserved shells

Considerable confusion evolved during the 1950s and 1960 s with the assignment of various species of Warrenella to Martinia because shell interiors were too often overlooked (Martinia lacks dental plates). Vandercammen (1957) proposed the genus Minatothyris, here regarded as a junior synonym of Warrenella. This was recognized by Pitrat (1965) but was disregarded by Struve (1970) when he proposed several new species of Minatothyris. The relationships between various Lower and Middle Devonian Warrenella and Minatothyris species from western North America and Germany are discussed by Ludvigsen and Perry (1975).

Struve (1970) established the genus Rhenothyris to accommodate the Emsian-Eifelian "curvate spirifers" formerly assigned to Reticulariopsis curvatus (and other generic name variants) because of inherent confusion in the description of the type material of curvatus. He found Rhenothyris a useful group for local zonation in Germany. Rhenothyris is characterized by a very prominent dorsal fold and ventral sulcus, micro-ornament of fine concentric growth lines with radially elongated spine bases, basally divergent dental plates, weakly impressed ventral muscle scars, and very short crural plates. Reticulariopsis is characterized by a distinct fold and sulcus, prominent dental plates, variably developed crural plates, and distinct growth lamellae. The taxonomic problem is how to distinguish between Warrenella, Rhenothyris, and Reticulariopsis. Rhenothyris is readily separated by the shape of its fold and sulcus and by the highly divergent dental plates. To distinguish Warrenella from Reticulariopsis is more difficult, if possible at all. Shells identified as Reticulariopsis by other authors are generally smaller than the well-known Warrenella and have a thinner shell. Immature Warrenella look remarkably like Reticulariopsis since both genera commonly have thin shells, a highly variable development of crural and dental plates, and a distinct fold and sulcus. Several species of Warrenella show a remarkable amount of intraspecific variation in crural-plate development. This has been noted in Nevada Warrenella by Johnson (1971a) and in shells of Warrenella from northwestern Canada by the writer. Differentiation of these shells on the basis of crural development alone is invalid. The characteristics of the microornaments might help to distinguish the genera. Reticulariopsis has a micro-ornament of fine, radially arranged striae; some Warrenella have concentric rows of spine bases, some with associated striae, and other Warrenella ( $W$. sekwensis Ludvigsen and Perry) appear to have striae only. However, the problem of inadequate 
preservation makes micro-ornament of less than practical value for distinction.

To compound the confusion of identity, there are three more similar genera. The genus Elythyna Rzhonsnitskaia is very similar to Warrenella, except for its weakly developed lateral plications and its micro-ornament of long, irregularly spaced spines. These flank plications also occur in the Zlichovian $W$. transversa Ludvigsen and Perry from the Michelle Formation of the northern Yukon; more recently, on the basis of its wider, more posteriorly extended ventral muscle scar, $W$. transversa has been assigned to Elythyna (Johnson, 1970). At the same time, Johnson (1975b) assigned Elythyna sp. A Johnson (1970), from the Eurekaspirifer pinyonensis Zone of Zlichovian strata in central Nevada, to Elythyna transversa praekingi. The subspecies $E$. transversa praekingi was probably derived from $E$. transversa transversa. Serious problems exist in the recognition of these two subspecies. Havlíček (1971b) proposed the genus Tenellodermis for small, broadly plicate shells with a fold and sulcus, prominent dental plates, a simple nonsegmented cardinal process, crural plates elevated above the floor of the valve, and a micro-ornament of fine radial capillae and growth lines covered by minute pits. This genus includes Wenlockian-Lochkovian species; another new genus proposed by Havlíček, Cingulodermis, includes PragianEifelian species lacking radial capillae, surficial pits, and plications. Havlíček assigned both genera to the Martiniidae because of their micro-ornament; however, in a subsequent study Johnson, Boucot, and Murphy (1973) placed Tenellodermis in the Reticulariidae, in keeping with the classification of Pitrat (1965). The genus Tenellodermis appears valid. However, an examination of Cingulodermis presents the problem of its distinction from Warrenella. Obviously, on exquisitely preserved calcareous shells the disposition of shell fibres might distinguish Cingulodermis from Warrenella. The only difference that could be observed in most shells would be the nonstriate, simple, or bilobed cardinal process. Otherwise the internal features described from Cingulodermis would fit any of several species of Warrenella equally well.

In conclusion, there is a problem of distinguishing small Warrenella from Reticulariopsis. Reticulariopsis had two different types assigned to it by Frederiks (1916)—one without a dorsal septum, another with a dorsal septum. However, most subsequent workers used Reticulariopsis in the second sense and allied it with Reticularia (a dorsally septate form). Pitrat (1965) pointed out that the genus name was not being used in the first sense, and Reticulariopsis was re-erected for aseptate specimens. The type Reticulariopsis needs restudy because it may include Warrenella. The net result of this taxonomic confusion is that Reticulariopsis has become a "grab-bag" term for any nondescript, smooth spiriferid and holds no real meaning. Cingulodermis is less than adequately known and could easily be confused with Pragian Warrenella and/or Reticulariopsis.

With these problems in mind the Delorme Reticulariidae are discussed. Johnson (1970) illustrated two groups of Reticulariopsis from the Lochkovian and Pragian of central Nevada. These shells are probably conspecific with each other and with ?Reticulariopsis warreni sp. nov. The proliferation of reticulariacean genera (of which only a few are mentioned here) obscures phylogenetic relationships and biostratigraphic significance and results in unnecessary synonymy. The whole superfamily needs careful systematic revision-not just the piecemeal revision attempted by Struve (1970) and Ludvigsen and Perry (1975).

\section{Genus Warrenella Crickmay, 1953}

\section{TYPE SPECIES}

Warrenella eclectea Crickmay, 1953:596, figs. 1-5, 16-19.

\section{Warrenella sekwensis Ludvigsen and Perry, 1975} Pl. 41, figs. 1-28

Warrenella sekwensis Ludvigsen and Perry, 1975:72, pl. 12 , figs. $1-15$.

Warrenella sekwensis Perry, Boucot, and Gabrielse, 1981:300, pl. 5, figs. 37, 38, ?31-36.

\section{REFERRED SPECIMENS}

W. sekwensis occurs in strata of late Pragian and Zlichovian age in S-1, at $62.5-249.9 \mathrm{~m}$, and in S-3, at 53.3-573.0 $\mathrm{m}$, respectively, below the top of the Delorme Formation. It is represented by $13 \mathrm{~A}, 340 \mathrm{~B}$, and $912 \mathrm{P}$ well-preserved silicified shells. Material illustrated includes ROM 34068 from S-1, sample A62.5-68.6 m; ROM 34069-34073 from $S-3$, sample S4-64.0-65.6 m; ROM 34073 from S-3, sample S4-184.4 m; ROM 34074 from S-3, sample S4-466.3 m; ROM 34075-34078 from S-3, sample S4-161.5-164.6 m; ROM 34080, 34081 from S-3, sample S4-519.7 m; and ROM 34079, 34082 from S-3, sample S4-560.8-573.0 m

\section{DISCUSSION}

$W$. sekwensis is the oldest recognized member of the genus Warrenella, and it gave rise to two distinct lineages common in the late Zlichovian to Givetian in northwestern Canada. Pragian representatives of $W$. sekwensis were probably derived from a small, thin-shelled Lochkovian reticulariid, assigned here to 'Reticulariopsis warreni sp. 
nov. W. sekwensis was proposed as the ancestor of the Franklini and Occidentalis lineages of Warrenella, which initiated in the Lower Devonian of northwestern Canada and migrated to Nevada and Germany during the Middle Devonian (Ludvigsen and Perry, 1975). The high, triangular ventral interarea and the well-defined sulcus of $W$. sekwensis show its affinity to the Occidentalis Lineage, while the deeply impressed adductor scars and the transverse outline are characteristic of the Franklini Lineage. The development of the crural plate is highly variable. In most small shells the crural plates are continuous with the dorsal muscle-bounding ridges, as in the Occidentalis Lineage; other shells bear crural plates that terminate against the posterior edge of the muscle field, as in the Franklini Lineage.

The large size and the extreme thickness of the shell at the ventral umbo $(3-4 \mathrm{~mm})$ suggest that the environment at S-3 was ideal for Warrenella. The overlying water column was probably not greater in depth than the photic zone, because associated solitary corals and abundant encrusting tabulates flourished. The abundance of apatite pellets in the acetic-acid insoluble residues from this section suggests that the section was located near a zone of active upwelling of cooler waters that were more rich in nutrients (analogous to the example cited by Brown (1974) in the Upper Ordovician of Iowa); the large size, high diversity, and abundance of the brachiopods in the Delorme S-3 would support this hypothesis. If the depth was only slightly greater than the tidal range, one would expect a much greater number of stromatoporoids and rugose corals.

Several additional morphologic features are added to those noted by Ludvigsen and Perry (1975) for $W$. sekwensis. The crural plates join the muscle-bounding ridges in most small shells, but in large shells they are usually free of the valve floor. This difference is most readily explained by shell thickening, which encompasses the low crural plates on small shells. Shell thickening occurs on the dorsal valves of large shells, although to a much lesser extent than on the ventral valves. Most small shells have a concentric ornament of fine growth lines covered by radial striae. One small shell has a wellpreserved crural process, which projects anteriorly as a vertically inclined blade, parallel to the shell surface of the dorsal valve, and then curves abruptly ventrally near the anterior margin to form the innermost whorl of the spiralium. At about one-third of the length of the crural process a prominent anteroventrally inclined, subcylindrical jugal process develops. A very similar type of arrangement of crural and jugal processes was described by Ludvigsen and Perry (1975) from serial sections of $W$. transversa, a Zlichovian taxon from the Michelle Formation in the northern Yukon. The pedicle deltidial cover is generally absent, although a few gerontic shells have a well-developed apical deltidium. The hinge teeth are triangular in plan view, laterally directed, suberect in posterior profile, and supported by both deltidial and dental plates. The degree to which the dental plates diverge ventrally is controlled by the amount of impression of the muscle scar (gerontic shells with deeply impressed muscle scars have highly divergent dental plates). The ventral diductor scars are narrow, suboval, and confined to the posterior part of the muscle field, which is enclosed by the dental plates. The ventral diductor field is divided medially by a myophragm, which is bounded anteriorly and laterally by the adductor muscle field. The dorsal muscle field comprises two adductor pairs. The posterior adductor pair is deeply impressed, narrow, and about three times longer than wide; however, the posterior adductors are much shorter than the anterior adductors; the latter adductors are impressed immediately anterior to the posterior pair and extend beyond two-thirds of the shell length, widening slightly anteriorly. The two pairs of muscle scars can be distinguished only in mature shells. In gerontic shells the posterior adductor scars appear to increase in width and continue anteriorly round the posterior end of the anterior adductors. This muscle development is probably a response to the great increase in the thickness of the ventral umbo on the gerontic shells and to the resulting need for stronger muscles for opening and closing the shells and/or for better leverage of the muscle system.

\section{Genus Reticulariopsis Frederiks, 1916}

\section{TYPE SPECIES}

Spirifer (Reticularia) dereimsi Oehlert, 1901:236, pl. 6, figs. 2-16.

Reticulariopsis? warreni sp. nov. PI. 41, figs. 29-46

?Reticulariopsis? sp. A Johnson, 1970:208, pl. 67, figs. 16, 17.

?Reticulariopsis sp. B Johnson, 1970:208, pl. 67, figs. 18-24.

Reticulariopsis sp. Lenz, 1977b:128, pl. 32, figs. 27-42.

\section{DIAGNOSIS}

A thin-shelled, transverse reticulariid with very elongate dorsal and ventral muscle fields, variably developed crural plates, and a comblike cardinal process.

\section{ETYMOLOGY}

The species is named after the late P. S. Warren of the University of Alberta, and the name serves to show the close affinity of this species to the genus Warrenella. 


\section{REFERRED SPECIMENS}

Reticulariopsis? warreni sp. nov. occurs in strata of mid-Lochkovian to lower Pragian age in S-1, at 272.8$538.0 \mathrm{~m}$, in S-2, at $105.2-182.9 \mathrm{~m}$, and in S-3, at $685.8 \mathrm{~m}$, respectively, below the top of the Delorme Formation. The thin shells are commonly poorly preserved, and many potential representatives of the tax on are simply referred to Reticulariopsis? in the faunal lists. Material assigned to $R$.? warreni includes 9A, 29B, and $104 \mathrm{P}$ silicified shells. Material illustrated consists of holotype ROM 34083 and paratype 34084 from S-1, sample A442.0 m; paratypes ROM 34085, 34086 from S-1, sample A470.9 m; paratypes ROM 34087-34089 from $\mathrm{S}-1$, sample OLDA336.8 m; paratype ROM 34090 from S-2, sample B121.9 m; and paratypes ROM 34091, 34092 from S-2, sample B166.1-182.9 m.

\section{EXTERIOR}

The shells are commonly less than $2.5 \mathrm{~cm}$ wide. Small shells are markedly transverse and oval in outline; they become more elongate with maturity. The lateral profile is strongly ventribiconvex. The hinge line is about two-thirds of the maximum shell width, and the cardinal angles are rounded and obtuse. The apsacline ventral interarea is high, narrow, and moderately incurved. The interarea is cleft by an open delthyrium, which encompasses an angle of approximately $60^{\circ}$. The low lateral plates extend a short distance perpendicular to the plane of the interarea and are more prominent near the base of the delthyrium. The orthocline to gently anacline dorsal interarea is narrow, low, and flat. The dorsal fold and ventral sulcus are distinct, shallow, and broadly U-shaped, and extend from the posterior to the anterior. Ornament comprises closely spaced concentric growth lines and micro-radial striae; the growth lines are more prominent anteriorly. A few shells bear very weak lateral plications near the anterior margin.

\section{PEDICLE VALVE INTERIOR}

The hinge teeth are triangular in transverse section and project dorsally. The teeth are formed by an extension of the delthyrial margins and are supported by the lateral and dental plates. The closely set dental plates are strong, bow medially, and diverge slightly near the floor of the valve. The dental plates bound the posterior end of the long, narrow muscle field, which extends to near midlength of the shell and is confined to the impress of the ventral sulcus. The muscle field is divided medially by a distinct, threadlike myophragm, which extends from the cardinal area to midlength. The myophragm is flanked by two exceedingly narrow, elongate adductor muscle scars.

\section{BRACHIAL VALVE INTERIOR}

The sockets are shallow and diverge anterolaterally at $30^{\circ}-35^{\circ}$ from the hinge line. The sockets are elevated above the valve floor and are defined by a plate that extends from the interarea and posterior shell wall, curving first dorsally, and then strongly ventrally to form the anterior wall of the socket. The anterior socket wall is reinforced by the crural plates and bases. The crural bases converge dorsally; they are free of the valve floor anteriorly but welded to the valve floor posteriorly. The crural bases are variably developed and are commonly continuous with the adductor muscle-bounding ridges. The muscle scar is confined to the depression of the dorsal fold and extends beyond midlength of the shell. A prominent myophragm divides the posterior two-thirds of the parallel-sided adductor scars. The ventrally directed cardinal process consists of at least six comblike teeth. The crura extend anteriorly from the dorsal edge of the crural plates to a point near the anterior margin before giving rise to the first whorl of the spiralia.

\section{DISCUSSION}

The species occurs in Lochkovian and Pragian strata in the Delorme Formation of the western Mackenzie Mountains and at Royal Creek (Lenz, 1977b). To judge from some of the younger representatives of $R$.? warreni $\mathrm{sp}$. nov., it appears that the species is the probable ancestor of $W$. sekwensis. These stratigraphically younger shells resemble $W$. sekwensis in several features: some shell thickening, more basally divergent plates, a less elongate ventral muscle field, and similar micro-ornament. The shells of Reticulariopsis? sp. A and Reticulariopsis sp. B from the Quadrithyris and Trematospira Zones of central Nevada fall within the range of variation of $R$. ? warreni, judging from Johnson's (1970) illustrations of poorly preserved shells.

\section{Genus Spirinella Johnston, 1941}

\section{TYPE SPECIES}

Spirinella caecistriata Johnston, 1941:161, pl. 7, figs. 1-11, text-fig. 2.

\section{Spirinella rootensis $\mathrm{sp}$. nov. Pl. 46, figs. 27-39}

Spirinella sp. D Johnson, Boucot, and Murphy, 1976:93, pl. 54, figs. $1-20$.

\section{DIAGNOSIS}

This Spirinella has a steeply inclined, apsacline ventral interarea, a well-developed cardinal process, and prominent inner socket plates.

\section{ETYMOLOGY}

The species is named after the Root Basin of the 
Northwest Territories, where the type specimens were found.

\section{REFERRED SPECIMENS}

Spirinella rootensis sp. nov. occurs in S-6, at 193.5$204.4 \mathrm{~m}$ above the base of the Delorme Formation; in $\mathrm{S}-13$ in the Whittaker Formation, at $9.1 \mathrm{~m}$ below the base of the Delorme Formation; and in S-11 in the transitional facies of Gabrielse, Blusson, and Roddick (1973), at 185.9-193.5 $\mathrm{m}$ above the base of the Whittaker Formation. The species is represented by $1 \mathrm{~A}, 35 \mathrm{~B}$, and $42 \mathrm{P}$ well-preserved silicified shells. Material illustrated includes holotype ROM 34211 and paratypes ROM 34208$34210,34212-34215$ from S-6, sample C47-248.4 m.

\section{EXTERIOR}

The shells are small (less than $12 \mathrm{~mm}$ in width), transversely suboval in outline, and markedly ventribiconvex in lateral profile. The pedicle valve is one and one-half to two and one-half times deeper than the brachial valve. The hinge line is straight and is slightly less than the maximum shell width, which is developed near midlength. The cardinal angles are rounded and obtuse. The pedicle beak is gently incurved over the high, steeply inclined, apsacline interarea, which is cleft medially by an open, triangular delthyrium encompassing an angle of $60^{\circ}$. The interarea extends two-thirds to three-quarters of the maximum width of the shell. The delthyrium is bounded by thin, low lateral plates, which project perpendicular to the plane of the interarea. The wide, low dorsal interarea is orthocline to gently apsacline and is cleft medially by a wide, open notothyrium. A shallow, rounded ventral sulcus extends from the umbo to the anterior margin and becomes slightly wider anteriorly. The dorsal fold is less pronounced than the ventral sulcus. The anterior commissure is slightly re-entrant. Concentric ornament comprises very fine micro-growth-lines, whose spacing indicates that the shell became increasingly elongate during ontogeny. An occasional growth line is much more strongly developed than the others. Radial ornament was not observed.

\section{PEDICLE VALVE INTERIOR}

The thin, bladelike hinge teeth are triangular in posterior profile, directed laterally, and moderately inclined anteriorly. The hinge teeth are supported by prominent short dental lamellae, which converge slightly medially, close off the lateral extremities of the delthyrium, and join a pair of vertical ventral adminicula (sensu Strusz, Chatterton, and Flood, 1970) which define large lateral chambers. The ventral adminicula are sigmoid in lateral profile and extend from the beak to near midlength of the delthyrium. The ventral umbo is thickened by secondary shell material, resulting in the formation of an apical callist in mature shells. The diductor muscle field is narrow, elongate, bounded posterolaterally by the ventral adminicula, strongly impressed in mature shells, and confined to the delthyrial cavity. The diductor muscle field is divided medially by a low, wide, rounded myophragm, which has a shallow medial groove and subdivides the narrow, elongate adductor muscle field. The ventral sulcus is gently impressed. Weakly impressed, radiating pallial markings are developed anterolateral to the muscle field.

\section{BRACHIAL VALVE INTERIOR}

The sockets are distinct medially, diverge widely, and expand anterolaterally. The socket plates are attached to the posterior wall of the shell; they extend horizontally for a short distance, curve sharply ventrally to form the floor and anterior wall of the sockets, and then recurve sharply dorsally, and extend slightly below the level of the socket floor to form the crural bases. The sockets are free and unsupported and overhang the valve floor. The exact site of crural attachment is not clear. A pair of posteroventrally curved inner socket plates are welded to the medial portion of the sockets and form the base of the comblike cardinal process, which is composed of several laterally aligned teeth. A low, rounded medial myophragm extends a short distance anteriorly and then widens and bears a shallow medial groove. The adductor muscle field is not differentiated into distinct posterior and anterior muscle scars. The muscle field is narrow and weakly impressed and extends well beyond midlength of the shell. The remainder of the shell interior is smooth.

\section{DISCUSSION}

In central Nevada this species occurs in strata of middle Ludlovian age (siluricus conodont Zone, Klapper and Murphy, 1974). The type species of Spirinella has a much more incurved (anacline) ventral beak; however, other external features such as the shell ornament and the development of the fold and lateral plates are similar to $S$. rootensis sp. nov. The muscle scars of $S$. caecistriata from the Ludlovian of New South Wales are not well known because their description is highly interpretive, being derived from serial sections alone. The serial sections by Johnston (1941) show most of the features observed in $S$. rootensis and also appear to show the development of an inner socket ridge and a cardinal process (text-fig. 2, part 9), although the features are not interpreted in this way by Johnston. The presence of this genus in both Australia and western North America suggests close faunal relationships between the two regions during the Ludlovian.

Sapelnikov (1961) assigned several taxa from the Silurian of the Urals to the genus Eoreticularia; these shells probably are better classified as Spirinella. Lenz (1977b:129) alluded to the problem of distinguishing 
between Spirinella and Reticulariopsis. The taxa are somewhat similar, although Spirinella has less prominent dental plates and its sockets are clearly free of the valve floor.

\section{Family Ambocoeliidae George, 1931}

\section{Genus Ambocoelia Hall, 1860}

\author{
TYPE SPECIES \\ Orthis umbonata Conrad, 1842:264, pl. 14, fig. 4.
}

\section{DISCUSSION}

There is a problem in distinguishing between the genera Ambocoelia and Metaplasia, unless well-preserved, complete shells are available. Pitrat (1965) distinguished Metaplasia by the presence of a weak dorsal fold and ventral sulcus flanked by one or two broad, low plications; Ambocoelia, in contrast is smooth or has a narrow ventral sulcus. These features are not totally reliable, and the crucial feature is the presence of a dorsal cruralium in Metaplasia and its absence in Ambocoelia. The Delorme silicified collections from sections S-1, S-2, and S-3 yielded several hundred silicified Lochkovian through Zlichovian Ambocoelia.

\section{Ambocoelia cf. A. praecox Kozlowski, 1929}

$$
\text { Pl. 42, figs. 1-10 }
$$

?Ambocoelia praecox Kozlowski, 1929:199, pl. 6, figs. 33-37, text-figs. 66, 67.

Ambocoelia aff. A. praecox Lenz, 1977b:126, pl. 30, figs. 33-48.

\section{REFERRED SPECIMENS}

Ambocoelia cf. A. praecox is common in beds of mid-Lochkovian and early Pragian age of the Delorme Formation. It occurs in S-1, at $274.3-551.7 \mathrm{~m}$ and OLDA344.4-537.9 $\mathrm{m}$, in $\mathrm{S}-2$, at $32.0-254.4 \mathrm{~m}$, and in $\mathrm{S}-3$, at $624.8-685.8 \mathrm{~m}$, respectively, below the top of the Delorme Formation, and at selected localities within S-4 and $\mathrm{S}-11$. The species is represented by $141 \mathrm{~A}, 164 \mathrm{~B}$, and 126P well-preserved silicified shells. Material illustrated includes ROM 34093-34096 from S-1, sample A470.9 m.

\section{DISCUSSION}

The Delorme shells are identical to those from beds of similar age at Royal Creek. The shells from northwestern Canada have a prominent myophragm and short apical dental plates in the ventral interior-features which were not noted in the type Podolian materials (Kozlowski, 1929). Characteristics of the species are a strongly ventribiconvex lateral profile, a subpentagonal outline, and a weakly developed ventral sulcus. Ambocoelia sp. of
Johnson (1970) from the Lochkovian Quadrithyris Zone of central Nevada has a smooth ventral interior.

\section{Ambocoelia rugosa sp. nov. $\mathrm{Pl}$. 42, figs. 11-37}

\section{DIAGNOSIS}

An Ambocoelia that has a prominent development of concentric growth lamellae, a distinct dorsal and ventral myophragm, and a well-developed, rodlike cardinal process.

\section{ETYMOLOGY}

The specific name is from the Latin rugosus - rough, in reference to the prominent growth lamellae.

\section{REFERRED SPECIMENS}

Ambocoelia rugosa sp. nov. occurs in S-1, at 62.5$68.6 \mathrm{~m}$, and in S-3, at 36.6-519.7 m, respectively, below the top of the Delorme Formation. It is represented by $124 \mathrm{~A}, 113 \mathrm{~B}$, and 128P well-preserved silicified shells. Material illustrated includes paratypes ROM 34097-34104, 34106, and holotype ROM 34105 from S-1, sample A62.5-68.6 m; paratypes ROM 34107-34110 from S-3, sample $\mathrm{S} 4-502.9-507.5 \mathrm{~m}$.

\section{EXTERIOR}

The shells are small (commonly less than $5 \mathrm{~mm}$ in diameter), semicircular in outline, and essentially planoconvex in lateral profile. The brachial valve is planar to gently convex, whereas the pedicle valve is very high and triangular in lateral profile. The hinge line extends over about two-thirds of the maximum shell width, which is developed just anterior to the rounded, obtuse cardinal angles. The catacline, high, flattened ventral interarea is slightly incurved near the apex of the beak. The high, narrow pedicle opening is bordered by low delthyrial plates, which project a short distance above the plane of the interarea. In some shells the pedicle valve has an extremely weakly developed median sulcus, which is most clearly expressed in a slight deflection of the anterior commissure (Pl. 42, figs. 32, 34). Ornamentation consists of well-developed concentric growth lamellae, which are more strongly and more regularly developed on dorsal valves. Ventral valves bear the concentric ornament near the shell margins only. Some of the more anteriorly located lamellae produce marked offsets in the dorsal valves. Well-preserved shells have a micro-ornament of radial striae on each lamella. 


\section{DISCUSSION}

$A$. rugosa sp. nov. bears close similarity to the Lochkovian and Pragian $A$. cf. A. praecox Kozlowski. The new species is distinguished by its consistently more upright, catacline ventral interarea, more prominent and more numerous growth lamellae (some of which show as distinct concentric impressions internally), less pronounced ventral sulcus, and more planar dorsal valve. Most Middle Devonian representatives of Ambocoelia from northwestern Canada have a much more incurved ventral beak and commonly have a considerable amount of posteroventral callus.

\section{Genus Metaplasia Hall and Clarke, 1893}

TYPE SPECIES

Spirifer pyxidatus Hall, 1859:428, pl. 100, figs. 9-12.

\section{Metaplasia sp.}

Pl. 46, figs. $40-45$

\section{REFERRED SPECIMENS}

Metaplasia is uncommon in the Delorme Ludlovian and is represented by only a few $(1 \mathrm{~A}, 7 \mathrm{~B}$, and 7P) poorly preserved silicified shells. Material illustrated includes ROM 34216-34219 from S-6, sample C47-248.4 m.

\section{DISCUSSION}

The shells available are too poorly preserved for specific identification, although they show the development of a dorsal cruralium, which is distinctive of Metaplasia. Lateral plications are clearly developed, and the pedicle sulcus and the dorsal fold are more prominent than in Ambocoelia cf. A. praecox.

\section{Genus Plicoplasia Boucot, 1959}

\section{TYPE SPECIES}

Plicoplasia cooperi Boucot, 1959:20, pl. 1, figs. 13, 14; pl. 2, figs. 1-5.
Plicoplasia acutiplicata Lenz, 1972

Pl. 44, figs. 35-46

Plicoplasia acutiplicata Lenz, 1972:102, pl. 2, figs. 1-22.

Plicoplasia acutiplicata-Lenz, 1977b:127, pl. 31, figs. $1-17$.

Plicoplasia acutiplicata-Jackson, Lenz, and Pedder, 1978, pl. 10, figs. 24-34.

\section{REFERRED SPECIMENS}

$P$. acutiplicata occurs in strata of late Lochkovian age in $\mathrm{S}-1$, at $470.9 \mathrm{~m}$ below the top of the Delorme Formation. It is represented by $5 \mathrm{~B}$ and $10 \mathrm{P}$ silicified shells. Material illustrated includes ROM 34163-34166 from S-1, sample A470.9 m.

\section{DISCUSSION}

At Royal Creek the species ranges through the late Lochkovian and early Pragian (Lenz, 1977b); the Delorme occurrence is confined to the late Lochkovian.

The Delorme shells resemble most closely those representatives from the Royal Creek collections that have an apsacline ventral interarea, slightly incurved ventral beak, and strong, rounded plications. A few morphologic features additional to those described by Lenz (1972) for $P$. acutiplicata are noted here. Well-developed lateral plates flank the delthyrium of most shells (new collections from Royal Creek yield shells with similar structures). Anteriorly, some shells show faint, microradial striae, which were alluded to by Boucot (1959) on P. cooperi. One of the Delorme shells has well-developed, elongate, oval dorsal adductor muscle scars, which are moderately impressed posteriorly and are confined to the deepest part of the valve. The scars are separated by a very faint, rounded myophragm. Umbonal shell material is relatively thick in both valves.

The small number of $P$. acutiplicata (relative to the Royal Creek population) in the Delorme Lochkovian and the absence of the species in the overlying Pragian of the Delorme are not readily explained because the Lochkovian and Pragian depositional environments appear very similar, and large collections have been made from both of these intervals along the Sekwi Anticline.

\section{Superfamily Suessiacea Waagen \\ Family Cyrtinidae Frederiks, 1912}

\section{Genus Cyrtinaella Frederiks, 1916}

TYPF SPECIES

Cyrtina biplicata Hall, 1857:165.
Cyrtinaella cf. C. causa Johnson, 1970

PI. 46, figs. 46-52

Cyrtinaella causa Johnson, 1970:217, pl. 72, figs. 1-9, $14,15$. 


\section{REFERRED SPECIMENS}

Cyrtinaella cf. C. causa occurs in one collection from near the upper range of Spirigerina supramarginalis and Toquimaella kayi in S-1, at $470.9 \mathrm{~m}$ below the top of the Delorme Formation. It is represented by $16 \mathrm{~A}$ silicified shells. Material illustrated includes ROM 34220, 34221 from S-1, sample A470.9 m.

\section{DISCUSSION}

In Nevada $C$. causa occurs in the late Lochkovian Quadrithyris Zone. Well-preserved interiors are not available; however, $C$. cf. $C$. causa has an external morphology identical to that of the central Nevada shells. The smooth flanks and the broadly U-shaped furrows flanking the pedicle sulcus readily distinguish the shell from Cyrtina. Cyrtinaella has not previously been recorded from northwestern or arctic Canada. The occurrence again shows the close faunal relationships between central Nevada and northwestern Canada during the Lochkovian.

\section{SECTION COMPLETED AFTER THE DEATH OF DAVID G. PERRY}

Before his death on 2 August 1979, David Perry had almost completed this section, and the taxa following were named by him. He had provided illustrations of these taxa (Pls. 42, 43), prepared explanations of figures, and designated all their types, but had not begun diagnoses, descriptions, and discussions of Cyrtina .

The discussion of the genus Cyrtina has been adapted directly from David Perry's Ph.D. thesis. Diagnoses for the two species of Cyrtina have been added in order to comply with the rules for naming new taxa. In an attempt, however, to leave David Perry's work as little altered as possible, descriptions and discussions of these species have been omitted.

\section{Genus Cyrtina Davidson, 1858}

\section{TYPE SPECIES}

Calceola heteroclita Defrance in Cuvier, 1827:306, pl. 80 , figs. $3,3 a$.

\section{REMARKS}

The Delorme representatives of Cyrtina include some one thousand or more well-silicified shells. Cyrtina is a very common element in Lochkovian and younger strata in the Delorme, and it is present in most collections. No
Pridolian or older Cyrtina was recovered. In Nevada, Johnson, Boucot, and Murphy (1973) recorded a possible Pridolian Cyrtina, although they noted that this may be a misplaced specimen. Johnson (1970) reported abundant Cyrtina in the beds of Lochkovian through Zlichovian age in central Nevada and assigned them to four informal species. He noted a general increasing abundance of Cyrtina through the Lochkovian and early Pragian and a decline in the interval from the late Pragian to the Emsian. A grossly similar trend is obvious from the faunal lists of the Delorme.

Identification of Cyrtina beyond the generic level is difficult because of the high degree of variation of shells within a single collection and between collections. During the initial study of the Delorme brachiopods, the cyrtinas were assigned to four species on the basis of such features as the number and type of costae, the number of cardinal process lobes, the type of growth lines, and the type of shell outline. The classification of Cyrtina resulting from the implementation of such criteria appears impractical since the species distribution of this genus is not ordered stratigraphically but seemingly by environmental controls. For example, the thinner-shelled forms with weaker costae appear to occur more commonly in argillaceous limestone beds, whereas thick-shelled forms with strong costae are more abundant in the purer limestones.

Johnson described the Nevada Cyrtina informally, probably because of a high degree of variation in the shells, similar to that in the Delorme shells. If one compares certain individual figures of different species of the Nevada Cyrtina, the problems of distinction are immediately apparent. Lenz (1977b) did not describe any new species of Cyrtina from Royal Creek for much the same reasons.

\section{Cyrtina impressio sp. nov. Pl. 42, figs. 38-51}

\section{DIAGNOSIS}

A species of Cyrtina with acute to weakly obtuse cardinal angles, a deep, subangular sulcus and prominent subrounded fold, one or at the most two distinct plications flanking the fold and sulcus and tending to disappear laterally, an ornament of irregularly spaced growth lamellae over most of the outer surface, an almost catacline ventral interarea, and comparatively long dental lamellae joined to a median septum at some distance anterior to the interarea.

\section{ETYMOLOGY}

The specific name is from the Latin impressio-pressing in upon. 


\section{REFERRED SPECIMENS}

Cyrtina impressio sp. nov. occurs in strata of Zlichovian age in S-1, at 62.5-68.6 m below the top of the Delorme Formation. Material illustrated consists of holotype ROM 34115 and paratypes ROM 34111-34114, 34116 from S-1, sample A62.5-68.6 m.

\section{Cyrtina clagueae sp. nov.}

Pl. 43, figs. $1-22$

\section{DIAGNOSIS}

A small species of Cyrtina with a strong fold and deep sulcus flanked by three or four distinct plications, an ornament of growth lamellae that are usually concentrated towards the outer margins of the valves, a strongly procline ventral interarea incurved towards the beak, and short dental lamellae joined to a median septum close to the interarea.

\section{ETYMOLOGY}

The species is named after Lexi Clague, secretary at the Department of Geological Sciences of the University of British Columbia.

\section{REFERRED SPECIMENS}

Cyrtina clagueae sp. nov. occurs in strata of early to mid-Lochkovian age in S-2, at $336.8 \mathrm{~m}, 254.5 \mathrm{~m}$, and $225.6 \mathrm{~m}$ below the top of the Delorme Formation. Material illustrated consists of holotype ROM 34123 and paratypes ROM 34122, 34124, 34125 from S-2, sample B336.8; paratypes ROM 34126, 34127 from S-2, sample B254.5 m; and paratypes ROM 34128-34134 from S-2, sample B225.6 m.

\section{Cyrtina spp.}

Pl. 43, figs. 23-51

\section{REFERRED SPECIMENS}

Cyrtina spp. occur in strata of late Lochkovian to early Pragian age in the Delorme Formation. Specimens illustrated include ROM 34135, 34136 from S-1, sample A470.9 m; ROM 34137-34143 from S-2, sample B $128.6 \mathrm{~m}$; and ROM 34144-34150 from S-1, sample A 436.5 m. It appears probable that figs . 23-36 and 30-51 represent a single species, while figs. 27-29 represent another (A. C. Lenz, pers. comm., 1980).

\section{Superfamily uncertain}

\section{Indeterminate spiriferid}

Pl. 46, figs. 53-58

\section{REFERRED SPECIMENS}

This taxon is represented by two silicified brachial valves from beds of late Lochkovian age in S-1, at $519.7 \mathrm{~m}$, and in S-2, at 166.1-182.9 m, respectively, below the top of the Delorme Formation. Material illustrated includes ROM 34222 from S-1, sample A519.7 m; and ROM 34223 from S-2, sample B166.1-182.9 m.

\section{DISCUSSION}

Externally the shells are smooth and internally they bear a prominent median septum, which intiates within the anterior part of the notothyrial cavity and gradually increases, then decreases in height before disappearing near midlength of the shell. The interarea is high, narrow, concave, and cleft by an open notothyrium, which encloses an angle of approximately $20^{\circ}$. The medial edges of the notothyrium are supported by distinct plates, which project dorsally perpendicular to the interarea but do not reach the valve floor. The sockets are small, anterolaterally expanding, and situated at the lateral margins of the interarea.

No genus known to the writer has the peculiar dorsal septum development shown on these specimens.

\section{Order Terebratulida Waagen \\ Suborder Centronellidina Stehli Superfamily Stringocephalacea King}

\section{DISCUSSION}

Terebratulid brachiopods have not been reported previously from the Lower Devonian of northern Canada. In the Lower Devonian of Nevada they are rare and are not known from strata older than Pragian. Lower Devonian terebratulids have a much more extensive record in terms of both diversity and longevity through the Lower Devonian in the Appalachians of eastern North America. 


\section{Family Centronellidae Waagen, 1882}

\section{Indeterminate terebratulid}

Pl. 46, figs. 59, 60

\section{REFERRED SPECIMENS}

One silicified dorsal valve (ROM 34224) was recovered from beds of Zlichovian age in S-3, at $176.8 \mathrm{~m}$ below the top of the Delorme Formation (sample S4-176.8 m).

\section{DISCUSSION}

Johnson (1970, 1974b) reported the terebratulids Oriskania, Rensselaeria, and Rensselaerina? from the Pragian of central Nevada. Oriskania is a typical Appalachian Oriskany fossil of eastern North America. Shells assigned to Rensselaerina? sp. by Johnson (1974b) show some similarity to the shell at hand, although the cardinal plate is much more prominent and the muscle scars are more firmly impressed in the Nevada shell.

The small brachial valve is suboval in outline, gently convex, and smooth externally. The sockets are deep. The socket plates rise vertically and form " $\mathrm{T}$ " intersections with the cardinal plate. The cardinal plate covers the medial part of the socket and is perforated posteriorly. The cardinal plate is broken in the specimen available; however it is clear that the plate bridged the gap between the anterior parts of the sockets. A large, oval muscle field extends from the anterior edge of the socket plates to the preserved anterior margin of the shell. The muscle field is divided by a low myophragm. 


\section{Acknowledgements}

Field work was supported by several agencies from 1969 to 1972, and without their support and the assistance of their personnel this study would not have been possible. Field work in 1969 was supported by the Geological Survey of Canada field party of S. L. Blusson, although little was accomplished during the summer of 1969 owing to helicopter crashes and heavy July and August snowfalls. Appreciation is expressed to S. L. Blusson and R. G. Garrett of the Geological Survey of Canada for the use of their camp facilities in 1970. Field work in 1971 was partially sponsored by a National Research Council Operating Grant to A. C. Lenz. Part of the field work in 1972 was carried out while the author was in the employ of V. Zay Smith Associates of Calgary. The remainder of the field work in 1972 was sponsored by a grant from the Department of Indian Affairs and Northern Development. Assistance in the field was provided by Larry Annand, S. L. Blusson, B. D. E. Chatterton, J. F. Conrad, A. C. Lenz, and Rolf Ludvigsen.

Thanks are conveyed to the following companies: Amoco, Chevron, Gulf, Shell, Texaco, and V. Zay Smith Associates; these companies released stratigraphic information and fossil collections, which were utilized where possible to fill gaps in my own field data.

Associated faunas were submitted to specialists, who kindly supplied lists of identification: M. J. Copeland (ostracodes), A. C. Lenz (graptolites), W. W. Nassichuk (ammonoids), and R. Thorsteinsson (fishes).

This monograph is a portion of a thesis supervised by $\mathrm{A}$. C. Lenz, whose interest, advice, and criticism aided immensely in the completion of the project. Laboratory support was funded by various research grants to A. C. Lenz. J. G. Johnson, C. G. Winder, and G. M. Young read and commented upon the original manuscript.

Financial assistance during the preparation of the thesis was from a National Research Council Scholarship for 1971-1974, a University of Western Ontario teaching assistantship during 1971-1973, and a University of Western Ontario Stevenson Memorial Scholarship for 1973. Revision of the manuscript from the thesis was supported in part by National Research Council of Canada grants.

My wife, Kathy Perry, spent many hours typing drafts of the manuscript and provided me with invaluable moral support. I extend a great deal of thanks to her for all her assistance. 



\section{Appendix}

\section{Locality Information and Section Descriptions}

Detailed section descriptions are given for sections S-1 to S-3 only. For these three sections measurements are given relative to the top of the Delorme Formation: positive measurements indicate the stratigraphic distance below the top of the formation, and negative measurements indicate the stratigraphic distance above the top of the formation. Field fossil-collection numbers are included in brackets after the lithology. Unless stated otherwise, all sections were measured with a $1.5 \mathrm{~m}$ Jacob's Staff. For sections S-4 to S-9 only locality and generalized stratigraphic information are provided.

\section{SECTION $1(\mathrm{~S}-1)$}

This section was measured by D. G. Perry and L. Annand on 25-27 July 1970. The section runs along an east-west-trending ridge in the overturned east limb of Sekwi Anticline (Blusson,

Metres from

top of

Delorme

Formation

$-130--30.5$

$-30.5-0$

$0-1.8$

$1.8-6.1$

$6.1-15.2$

$15.2-18.3$

18.3-25.9

$25.9-39.6$

$39.6-44.2$

$44.2-53.3$

$53.3-59.4$

59.4-68.6

$68.6-80.8$

$80.8-88.4$

$88.4-100.1$

\section{Sombre Formation (Partial Section)}

\section{Delorme Formation} blocky; strike $355^{\circ}$, dip $75^{\circ} \mathrm{E}$. (A0 m) recessive; mostly talus-covered. silicified brachiopods. recessive.

Talus cover of underlying limestone. (A51.8-53.3 m) rubbly. (A53.3-59.4 m) (A74.1 m)

Talus cover from underlying limestone.
Dolostone: light buff-grey, weathering light grey-white; finely crystalline, with fair intercrystalline porosity; bedding 10-60 cm; moderately recessive. (A-61.0 m)

Dolostone: light grey-buff, weathering mottled light grey; finely crystalline, with poor intercrystalline porosity; bedding 15-60 cm; moderately recessive. (A-30.5 m)

Limestone: light grey, weathering light grey; very finely crystalline; bedding $1 \mathrm{~m}$ (indistinct); resistant, weathering

Limestone: light grey, weathering light grey; finely crystalline; flaggy, $1.5 \mathrm{~cm}$ beds, locally irregular and nodular;

Limestone: light, weathering light grey; very finely crystalline; bedding $60-90 \mathrm{~cm}$ (indistinct); resistant, weathering blocky; quartz veining throughout; abundant silicified brachiopods and corals; auloporid corals encrusting on brachiopod shells. (A7.6-10.7 m)

Limestone: dark grey, weathering medium grey with a maroon hue; bedding $60 \mathrm{~cm}$; weathering blocky; few

Shale: medium grey; interbeds of argillaceous limestone; flaggy, 1-2 cm beds; recessive; mostly talus-covered. Limestone: black, weathering dark grey; bedding 2-4 mm; shaly, laminated light and dark layers; gypsiferous,

Limestone: medium grey, weathering light grey; medium-grained calcarenite; limonite-filled vugs; light grey chert fragments up to $2.5 \mathrm{~cm}$ in diameter; bedding $15-90 \mathrm{~cm}$; very resistant; coarsely silicified brachiopods.

Limestone: medium grey, weathering light grey; medium-grained; white-weathering chert fragments 4-25 mm in diameter; some beds brecciated; coarsely crystalline calcite veins throughout; bedding 30-90 cm; weathering very

Limestone: dark grey-black, weathering dark grey; very finely crystalline; black chert lenses and nodules weathering dark grey-black; minor calcite veining; bedding $15-30 \mathrm{~cm}$; slightly recessive; abundant finely silicified brachiopods, corals, gastropods, and oncolites; larger fossils slightly abraded. (A62.5-68.6 m)

Limestone: light grey, weathering white; fine to medium crystallinity; bedding $20-60 \mathrm{~cm}$; very resistant.

Talus cover of limestone: light grey, weathering yellow-buff; platy. 
100.1-105.2 Limestone: light grey, weathering white-grey; medium-grained, finely crystalline; minor platy interbeds of cherty limestone breccia; flaggy; faint, $4 \mathrm{~mm}$ laminae; $2 \mathrm{~cm}$ beds. (A100.1 m)

$105.2-111.3$

$111.3-114.3$

Limestone: light grey, weathering light grey; coarsely crystalline; floating sparry calcite crystals; bedding $5-15 \mathrm{~cm}$ with a few $90 \mathrm{~cm}$ beds near base; resistant; stromatoporoids, pelmatozoans, and brachiopods. (A108.2 m, A $111.3 \mathrm{~m})$

Talus cover.

121.9-135.6

135.6-143.9

Dolostone: slightly calcareous; dark grey, weathering medium grey; very finely crystalline; calcite veining, bedding 5-20 cm; resistant; silicified pelmatozoans, corals, and brachiopods. (A118.9 m)

Limestone: slightly dolomitic; dark grey, weathering dark grey; very finely to finely crystalline; light and dark $2 \mathrm{~mm}$ laminae; bedding 3-10 cm; slightly recessive; brachiopod fragments and pelmatozoan plates.

Limestone: light grey, weathering light grey; medium-grained calcarenite; bedding 25-90 cm; very resistant; few silicified brachiopods. (A136.6 m)

Dolostone: dark grey-black, weathering dark grey; finely crystalline; coarsely crystalline, calcite-filled vugs, $3 \mathrm{~cm}$ in diameter; bedding 20-60 cm; resistant; highly stylolitic contact at $143.9 \mathrm{~m}$.

Dolostone: light grey, weathering light grey; fine to medium crystallinity; calcite-filled vugs; bedding $90 \mathrm{~cm}$; recessive.

Dolostone: medium grey, weathering light grey with buff mottling; finely crystalline; $2 \mathrm{~mm}$ laminae locally; bedding 5-10 $\mathrm{cm}$; recessive. (A155.5T m)

Limestone: slightly dolomitic; light grey, weathering light grey; medium crystallinity; locally pelletal; bedding $15-90 \mathrm{~cm}$; very resistant

Talus cover.

Limestone: argillaceous; dark grey, weathering dark maroon-grey; microcrystalline; bedding 5-15 cm; recessive.

Limestone: light grey, weathering light grey; finely crystalline; highly fragmented; resistant; silicified pelmatozoan, brachiopod, and coral debris. (A175.3 m)

Limestone: argillaceous; dark grey, weathering maroon; micritic; $1 \mathrm{~cm}$ laminae; black chert nodules, lenses, and stringers

Limestone: light grey, weathering white; very finely crystalline; bedding $90 \mathrm{~cm}$; recessive; silicified brachiopods and corals. (A178.3-181.4 m)

Limestone: argillaceous; dark grey, weathering maroon-grey; $2-4 \mathrm{~mm}$ laminae; black chert stringers.

Limestone: breccia; light medium grey, weathering light-grey; medium to coarse-grained calcarenite; weathered white chert fragments; bedding $25-90 \mathrm{~cm}$; very resistant.

Limestone: medium grey-brown, weathering light grey-brown; micritic; finely laminated; very silty; thin, flaggy, $1-3 \mathrm{~cm}$ beds; recessive.

Limestone: light grey, weathering light grey; coarse-grained silicified calcarenite; lensoid bed, thinning from 1.5 to $0.6 \mathrm{~m}$ over $18 \mathrm{~m}$ laterally; resistant; abundant brachiopods and corals, all abraded.

Limestone: very argillaceous; dark grey, weathering dark grey; very finely crystalline; black chert lenses comprise 5 per cent of beds; burrows parallel to bedding; flaggy, 2-5 cm beds; recessive; high-spired gastropods, bryozoans, dacryonarid tentaculitids, and brachiopods. (A198.1-199.0 m, A198.1-199.6 m, A204.2-205.7 m, A205.7$208.8 \mathrm{~m}$, A207.3-208.8 m, A207.3-211.8 m)

Limestone: dark grey, weathering dark grey; medium-grained calcarenite; flaggy, $1-3 \mathrm{~cm}$ beds, with a few light grey, $90 \mathrm{~cm}$ limestone interbeds; recessive; abundant pelmatozoan debris, brachiopods, corals, favositids up to $30 \mathrm{~cm}$ in diameter, and a few fish-bone fragments. (A210.3-233.2 m)

Talus cover of limestone: silty, grey-brown, flaggy; abundant brachiopod, coral, and pelmatozoan debris. (A233.2-249.9 m)

Limestone: dark grey-black, weathering medium dark grey; very fine grained calcarenite; black chert lenses and stringers; flaggy, $1-2 \mathrm{~cm}$ beds, with minor, $10 \mathrm{~cm}$ bioclastic limestone interbeds bearing silicified fossils; recessive; abundant tentaculitids; a few brachiopods, bryozoans, and corals. At $262.1 \mathrm{~m}$ weathering with a tinge of maroon; bedding thicker; lamination preserved on weathered surface. At $272.8 \mathrm{~m}$ fossils highly abraded. (A256.0 m, A262.1 m, A265.2 m, A268.2 m)

Limestone: slightly argillaceous; weathering dark grey; micritic with floating sparry calcite crystals; bedding $15-60 \mathrm{~cm}$, becoming thinner and more shaly at $275.8 \mathrm{~m}$; slightly more resistant than underlying beds; abundant silicified brachiopods and corals. (A272.8 m, A274.3 m) 
Limestone: dark grey-brown to black, weathering light buff-yellow; locally fine, $2 \mathrm{~mm}$ laminae show on weathered surface; abundant calcite veining; bedding 1-2 cm, with some irregular, nodular beds; a few very silty maroon-weathering interbeds; recessive; a few silicified brachiopods and corals; conodonts extremely abundant-several thousand specimens from $1350 \mathrm{~g}$ of rock. (OLDA278.9-281.9)

281.9-283.5

283.5-286.5

286.5-291. 1

291.1-292.6

$292.6-295.7$

295.7-298.7

298.7-300.2

300.2-302.4

$302.4-321.6$

$321.6-330.7$

$330.7-336.8$

$336.8-356.6$

$356.6-365.8$

$365.8-374.9$

$374.9-396.2$

$396.2-408.4$

$408.4-411.5$

411.5-414.5

414.5-419.1

$419.1-420.6$

$420.6-424.6$

$424.6-425.2$

$425.2-429.8$

$429.8-436.5$
Limestone: 'very argillaceous; black, weathering maroon; micritic; thin $(2 \mathrm{~cm})$ beds; resistant.

Limestone: argillaceous; black, weathering medium grey; micritic; thin $(4 \mathrm{~cm})$ beds; resistant.

Limestone: argillaceous; black, weathering yellow and maroon; micritic; fine, $1 \mathrm{~mm}$ laminae; thin $(3 \mathrm{~cm})$ interbeds; recessive. (A291.1 m)

Limestone: argillaceous; dark grey, weathering medium light grey; medium-grained calcarenite; bedding $30 \mathrm{~cm}$; weathering blocky.

Limestone: dolomitic; silty; light grey, weathering yellow; finely crystalline; fine, $1 \mathrm{~cm}$ laminae; flaggy; recessive.

Limestone: argillaceous; light grey, weathering maroon; finely laminated; thicker interbeds are $8-15 \mathrm{~cm}$, weathering yellow; slightly resistant. (A295.7-298.7 m)

Limestone: dolomitic; silty; light buff-grey, weathering yellow; bedding 6-10 cm; recessive.

Limestone: dark grey, weathering light grey; micritic; bedding 6-10 cm; abundant coarsely silicified brachiopods, corals, and pelmatozoan fragments. (A301.1 m, A300.2 m)

Mostly talus cover of flaggy, yellow-weathering, silty, dolomitic limestone, with a few interbeds of $15-30 \mathrm{~cm}$, grey siliceous limestone; very recessive. (A307.8 m, A315.5 m, A318.5 m, A321.6 m)

Limestone: dolomitic; silty; weathering yellow with maroon tinge; microcrystalline; interbeds of medium grey micritic limestone with abundant brachiopods, bryozoans, corals, and pelmatozoan ossicles. (A327.7 m)

Dolostone: silty; argillaceous; black to dark grey, weathering maroon; minor yellow-weathering laminae; microcrystalline; bedding 1-5 cm; moderately resistant. (A330.7 m)

Limestone: dark grey, weathering light grey; very finely crystalline with coarsely crystalline floating sparry calcite crystals; interbeds finely laminated, maroon-weathering limestone; bedding 30-60 cm; resistant; abundant silicified fossils. Very silty and argillaceous; does not dissolve readily in $\mathrm{HCl}$. (OLDA336.8 m, A338.3 m, A342.9 m, A345.9 m, A350.5 m, OLDA353.6 m, A355.1 m, A356.6 m)

Limestone: very silty; light yellow-brown, weathering yellow; micritic; minor light grey limestone interbeds, slightly dolomitic; a few interbeds of dark grey limestone, weathering maroon; flaggy; bedding $2-5 \mathrm{~cm}$; recessive; red limestone at $362.7 \mathrm{~m}$. (A359.7 m, A362.7 m)

Limestone: black, weathering dark grey; micritic; massive; fractured; calcite veining; interbeds of maroonweathering argillaceous limestone; resistant; fossils in massive beds; silicified pelmatozoan ossicles, iabulate corals. (A367.2 m, OLDA370.3 m, A371.9 m, OLDA374.9T m)

Limestone: silty; medium brown, weathering yellow; a few maroon-weathering beds; very fine grained; bedding 2-15 cm; generally recessive and talus-covered; a few black limestone interbeds of medium-grained calcarenite, weathering light grey and bearing abundant silicified brachiopods, corals, and pelmatozoan fragments. (OLDA384.0 m, A385.6 m, OLDA388.6 m, A390.1 m)

Dolostone: very silty; slightly calcareous; reddish brown, weathering maroon; finely crystalline; a few interbeds of yellow-brown silty limestone, weathering yellow; a few resistant, 30-90 cm grey limestone beds; recessive; strike $7^{\circ}$, dip $58^{\circ} \mathrm{W}$. (A396.2 m, A406.9 m)

Limestone: dark grey, weathering light grey; massive; medium crystallinity; very resistant; abundant silicified brachiopods and corals. (A410.0 m)

Limestone: black, weathering maroon; micrograined; bedding $15-30 \mathrm{~cm}$; resistant

Limestone: dark grey-black, weathering black with maroon hue; fissile; flaggy; 4-8 mm beds; very recessive. (OLDA416.1 m)

Limestone: black, weathering dark grey with maroon hue; microcrystalline; some beds finely laminated; bedding $4 \mathrm{~mm}$; recessive.

Limestone: dark grey-black, weathering black; fissile; flaggy; thin $(8-15 \mathrm{~mm})$ beds; very recessive. (OLDA423.7 m)

Limestone: dark grey, weathering light grey; medium-grained; bioclastic; resistant; a few silicified coral fragments

Limestone: black, weathering maroon and yellow; thin $(2-5 \mathrm{~cm})$ beds; recessive. (A426.7 m)

Limestone: argillaceous; black, weathering medium grey; microcrystalline; fetid; bedding 4-15 mm; irregular; recessive. (A436.5) 
Appendix (continued)

436.5-441.4 Limestone: argillaceous; dark grey-black, weathering light grey; at $436.5 \mathrm{~m}$, a $45 \mathrm{~cm}$ resistant bed; remainder thin-bedded; micritic, with sparry calcite of medium crystallinity; locally bioclastic; coarsely silicified brachiopods and pelmatozoan ossicles. (A438.0 m)

441.4-452.6 Limestone: light brown-black, weathering medium grey with maroon tinge; a few yellow-weathering, silty limestone interbeds; micritic; highly cleaved; bedding 1-3 cm; recessive; silicified brachiopods and tentaculitids; fossils distorted. (A442.0 m, A448.1 m, A449.6 m, A452.6 m)

452.6-465.1 Limestone: very argillaceous; black, weathering medium grey, locally weathering maroon; micritic; thin (5-15 $\mathrm{mm}$ ) beds; abundant brachiopods in thicker beds. (A457.2)

465. 1-466.3 Limestone: black, weathering light grey; massive, micritic; silicified brachiopods and corals. (A466.3 m)

$466.3-484.6$

$484.6-487.7$

$487.7-490.7$

$490.7-494.4$

Limestone: dark grey, weathering medium grey; coarsely bioclastic; bedding 30-60 cm; resistant; 50 per cent consisting of dolomitic interbeds; with silty and argillaceous, thin-bedded limestones, weathering maroon and yellow and much more recessive; pyrite abundant; abundant brachiopods, bryozoans, and corals. (A468.5 m, A470.9 m, OLDA475.5 m, OLDA481.6T m, A484.6 m)

Limestone: dark grey, weathering light grey; finely crystalline; calcite veining; bedding $25-60 \mathrm{~cm}$; very resistant; abundant silicified brachiopods, bryozoans, corals, and stromatoporoids. (A487.7 m)

Limestone: dark grey, weathering medium grey; microcrystalline; fissile; flaggy; bedding 6-15 mm; recessive; pyrite abundant.

Limestone: silty; light grey-brown, weathering yellow; flaggy; bedding 6-15 mm; recessive; at $493.8 \mathrm{~m}$, resistant, $60 \mathrm{~cm}$ bed of silicified dark grey limestone; abundant brachiopods, bryozoans, corals, and stromatoporoids. (A493.8 m, OLDA493.8 m)

494.4-498.3 Limestone: silty; brownish grey, weathering yellow-grey; microcrystalline; bedding 6-15 mm; recessive; a few interbeds of black limestone; pyrite abundant.

498.3-507.5 Limestone: argillaceous; black, weathering yellow-grey; medium-grained calcarenite; coarse calcite veining; fetid; bedding 20-25 cm; moderately recessive. (A499.9 m, A502.9 m)

507.5-509.6 Limestone: medium grey, weathering light grey; medium crystallinity; bioclastic; calcite veining; bedding 25-60 cm; weathering blocky; resistant; abundant silicified brachiopods and corals. (A508.4 m)

509.6-528.8 Limestone: argillaceous; dark grey, weathering yellowish grey; locally finely laminated horizons; thin ( $1 \mathrm{~cm}$ ) beds, with 5-25 cm beds of medium-grained calcarenite occurring throughout; recessive with more resistant limestone ribs; abundant silicified brachiopods, corals, and pelmatozoan ossicles in calcarenite beds. (A510.5 m, A512.1 m, A514.5 m, A515-516.6 m, A519.6 m, A522.3 m, A528.8 m)

528.8-536.4 Mostly limestone talus cover; a few resistant, 6-8 cm beds of medium-grained calcarenite crop out.

536.4-537.4 Limestone: dark grey, weathering light grey; bioclastic; medium crystallinity; resistant; abundant brachiopods and pelmatozoan ossicles. (A536.4 m)

537.4-544.1 Limestone: argillaceous; dark grey-black, weathering medium grey; finely laminated; platy; bedding 2-10 cm; recessive; mostly talus-covered; abundant silicified brachiopods. (A538.0 m)

544.1-553.2 Mostly talus cover of dark grey limestone, weathering light grey; bioclastic with micritic matrix; a few resistant, $30 \mathrm{~cm}$ outcrops; generally very recessive. (A539.5-545.6 m, A544.1 m, A548.6T m, A551.7T m, A553.2T m)

\section{Road River Formation (Partial Section)}

553.2-560.0 Limestone: very argillaceous; black, weathering yellow-orange; micritic; bedding $1-2 \mathrm{~cm}$, with a few $20 \mathrm{~cm}$ beds; very recessive. (A560.0 m)

560.0-612.6 Limestone: very argillaceous; black, weathering yellow-buff; fine, 2 mm laminae; cleavage at low angle to bedding; bedding 4-8 $\mathrm{mm}$, with a few $15-20 \mathrm{~cm}$ beds; recessive; pyrite abundant; a few poorly preserved graptolites; does not dissolve readily in $\mathrm{HCl}$. (A574.5 m, A582.2 m, A593.4 m, A612.6 m, A701.0 m)

\section{SECTION $2(\mathrm{~S}-2)$}

This section was measured by D. G. Perry and L. Annand on 28 and 29 July 1970. It runs westwards along an east-west-trending ridge in the overturned east limb of Sekwi Anticline (Blusson,
1971), north-northwest of the Natla River, at $63^{\circ} 19^{\prime} 24^{\prime \prime} \mathrm{N}$, $128^{\circ} 36^{\prime} \mathrm{W}$ (Air Photo A12077-255). 
Metres from

top of

Delorme

Formation

$-91.4-0$

\section{$0-10.7$}

$10.7-12.8$

$12.8-24.4$

24.4-32.0

$32.0-36.6$

$36.6-67.1$

$67.1-73.2$

$73.2-76.2$

$76.2-91.4$

91.4-106.1

106. 1-106.7

106.7-117.3

117.3-121.9

121.9-135.6

$135.6-146.3$

146.3-152.4

152.4-155.4

$155.4-166.1$

166. $1-169.2$

169.2-193.5

193.5-195.1

195.1-214.9

214.9-230.1

\section{Sombre Formation (Partial Section)}

Dolostone: light grey, weathering light grey-white; microcrystalline; highly silicified; bedding $20-30 \mathrm{~cm}$; recessive. $(\mathrm{B}-91.4 \mathrm{~m})$

\section{Delorme Formation}

Dolostone: light grey, weathering light grey-white; medium crystallinity; weathering blocky; bedding 60-90 cm; resistant. (B0 m)

Dolostone: dark grey, weathering medium grey; bioclastic; medium-grained; recessive; corals, pelmatozoan columnals, and some crinoid stems with joined double axial canals.

Covered.

Dolostone: silty argillaceous; dark grey, weathering medium grey; fine to medium crystallinity; flaggy; $5 \mathrm{~cm}$ beds; moderately resistant; a few pelmatozoan ossicles.

Dolostone: medium grey, weathering light grey; weathering blocky; beds up to $1.5 \mathrm{~m}$ in thickness; resistant; silicified brachiopods and corals. (B32.0 m)

Dolostone: silty; dark grey, weathering medium grey; very finely crystalline; flaggy; bedding $2-5 \mathrm{~cm}$; recessive; locally very coarsely silicified; a few resistant beds with silicified fossils. (B39.6 m)

Talus cover, light grey dolostone.

Dolostone: light grey, weathering light grey; medium crystallinity; bioclastic; very coarsely silicified; calcite veining throughout.

Dolostone: calcareous; dark grey, weathering light grey-brown; finely laminated; finely crystalline; interbeds of light grey limestone; $5 \mathrm{~cm}$ beds; recessive. (B80.8 m, B86.9 m)

Mostly talus cover of dolostone: argillaceous; light grey, weathering light grey with maroon hue; finely laminated; flaggy. (B105.2 m)

Limestone: dark grey, weathering light grey; medium-grained; $60 \mathrm{~cm}$ bed; resistant; abundant silicified fossils. (B106.7 m)

\section{Talus cover.}

Limestone: silty; dark grey, weathering maroon and yellow; micritic; finely laminated; flaggy; recessive; a few bioclastic limestone interbeds with silicified fossils; phosphatic fish scales. (B121.9 m)

Talus cover of light grey limestone with a small silicified limestone outcrop at $128.6 \mathrm{~m}$; dark grey-black, weathering medium grey with maroon mottle; bioclastic; micritic matrix; silicified brachiopods. (B128.6 m)

Limestone: dark grey, weathering maroon; micritic; flaggy; a few silicified brachiopods. (B140.2 m)

Talus cover.

Dolostone: medium grey, weathering light grey; finely crystalline; bioclastic; stylolitic; thin-bedded; silicified brachiopods and pelmatozoan ossicles. (B153.9 m)

Dolostone: light grey, weathering buff-yellow; microcrystalline; fine, $2 \mathrm{~mm}$ laminae; flaggy; some limy interbeds up to $30 \mathrm{~cm}$ in thickness.

Limestone: medium grey, weathering light grey with a few maroon-weathering argillaceous interbeds; bioclastic: micritic matrix. (B/66.1 m)

Dolostone: calcareous; light grey, weathering yellow-buff; very finely laminated; flaggy; $5-10 \mathrm{~cm}$ beds. Interbeds of dark grey limestone weathering light grey to buff, of medium-grained calcarenite, locally argillaceous, silicified brachiopods, corals, and pelmatozoan ossicles. (B176.8, B166.1-182.9 m, B181.4-182.9 m)

Talus cover.

Limestone: light grey, weathering yellow-buff; micritic; finely laminated; a few black chert nodules; bedding $3 \mathrm{~cm}$; interbeds of bioclastic limestone, $30-90 \mathrm{~cm}$ in thickness; resistant.

Limestone: dolomitic; dark grey, weathering light grey; finely laminated; microcrystalline; platy; bedding $1 \mathrm{~cm}$ : resistant. Interbeds of dark grey limestone, weathering light grey; $1-1.5 \mathrm{~m}$ in thickness; bioclastic with micritic matrix. Abundant silicified brachiopods and pelmatozoan ossicles. (B221.0 m, B225.6 m) 
Appendix (continued)

230.1-248.4 Limestone: light grey, weathering light grey; medium to coarsely grained calcarenite; bedding 8-15 $\mathrm{cm}$; resistant; abundant pelmatozoan fragments and a few brachiopods and conularids; strike $15^{\circ}$, dip $66^{\circ} \mathrm{W}$. (B245.5 m, B246.9 m)

248.4-265.2 Limestone: black, weathering dark grey; micritic; finely laminated; flaggy; 1-5 cm beds; fish, inarticulate brachiopods, and conularids. A few interbeds of medium grey limestone, weathering light grey, moderately resistant; coquinas of brachiopods, bryozoans, and corals with micritic matrix; highly silicified. (B248.4-265.2 m, B254.5 m, B263.7 m)

265.2-291.1 Limestone: dark grey, weathering light grey; flaggy; $8 \mathrm{~cm}$ beds; recessive; a few beds with silicified bryozoans; mostly talus-covered.

291.1-298.7 Limestone: dark grey, weathering light grey; coarse-grained bioclastic; a few silicified beds; bedding 1-10 cm; resistant; abundant pelmatozoan debris.

298.7-318.5 Limestone: medium grey, weathering light grey; medium-grained calcarenite; vugs filled with large, sparry calcite crystals $(1-3 \mathrm{~cm})$; bedding $10-25 \mathrm{~cm}$; resistant; a few silicified beds with abraded brachiopod and coral debris; strike $18^{\circ}$, dip $50^{\circ} \mathrm{W} .(\mathrm{B} 300.2 \mathrm{~m})$

318.5-356.5 Limestone: very argillaceous; black, weathering buff-yellow; finely laminated; micritic; bedding 0.5-5 cm. At 324.6-330.7 m grades laterally into mounds of light grey limestone, weathering white, micro- to cryptocrystalline, massive; large $(3-5 \mathrm{~cm})$ vugs filled with coarsely crystalline calcite, possibly of algal origin; slump breccias of argillaceous limestone on flanks. The argillaceous sediments dissolve very slowly in $\mathrm{HCl}$ and yield abundant pyrite. Samples of limestone mounds yield no insoluble residues. (B327.7 m, B336.8 m, B338.3 m, B344.4 m)

356.6-361.2 Limestone: black, weathering yellow-buff; micritic; platy $1 \mathrm{~cm}$ beds; very recessive; 60 per cent talus-covered.

361.2-365.8 Limestone: dark grey, weathering maroon; micritic; chert nodules 1-3 cm in diameter; bedding 1-3 cm; very recessive; a few silicified tabulate corals.

365.8-384.0 90 per cent talus cover of medium grey limestone, weathering light grey; micritic; platy, 5-8 cm beds; silicified brachiopods and pelmatozoan fragments. (B373.4 m)

\section{Road River Formation (Partial Section)}

384.0-442.0 Talus cover of dark grey limestone, weathering light grey; micritic; a few silicified halysitid corals. At $403.9 \mathrm{~m}$ dolomitic limestone with fine, rounded quartz grains; at B411.5T m very abundant ostracodes. (B411.5T m, B429.8T m, B442.0T m)

\section{SECTION 3 (S-3)}

This section was measured by D. G. Perry and A. C. Lenz on 19-21 July 1971. It runs westwards along an east-west-trending ridge in the overturned east limb of Sekwi Anticline (Blusson,
1971), north-northwest of the Natla River, at $63^{\circ} 16^{\prime} 45^{\prime \prime} \mathrm{N}$, $128^{\circ} 32^{\prime} \mathrm{W}$ (Air Photo A12077-254).

\section{Metres from \\ top of \\ Delorme \\ Formation}

$-15.2-0$

$0-15.2$

$15.2-22.9$

\section{Sombre Formation (Partial Section)}

Dolostone: light brownish grey; fine to medium crystallinity; a few chert nodules; bedding $30 \mathrm{~cm}$; recessive.

\section{Delorme Formation}

Limestone: dolomitic; medium grey, weathering light brownish grey; fine to medium crystallinity; highly sheared, abundant, rounded, light and dark grey chert fragments up to $5 \mathrm{~cm}$ in diameter; bedding $30-60 \mathrm{~cm}$; strike $358^{\circ}$; dip $83^{\circ} \mathrm{E}$. In the heavy portion of acetic acid residues, abundant black, phosphatic nodules $1-2 \mathrm{~mm}$ in diameter. (S4-1.5 m)

Limestone: very argillaceous; dark grey, weathering dark grey to maroon; highly cleaved; platy $3-5 \mathrm{~cm}$ beds; recessive; silicified chonetid brachiopods. Dissolves only partially in $\mathrm{HCl}$. (S4-15.2-22.9 m) 
22.9-30.5

$30.5-48.8$

48.8-53.3

$53.3-64.0$

$64.0-73.2$

$73.2-79.2$

$79.2-86.9$

86.9-93.0

93.0-115.8

115.8-118.9

$118.9-121.9$

121.9-131.1

$131.1-143.3$

143.3-149.4

149.4-158.5

158.5-166.1

$166.1-198.1$

198.1-259.1

259.1-271.2

271.2-280.4

280.4-332.2

$332.2-335.3$

335.3-338.3

338.3-362.7

362.7-371.9

371.9-393.2
Limestone: medium grey, weathering light grey; massive; micritic matrix; a few beds of breccia containing chert and carbonate fragments up to $4 \mathrm{~cm}$ in diameter; sheared; resistant.

Limestone: argillaceous; dark grey, weathering medium grey with maroon hue; micritic; rounded chert fragments up to $1.5 \mathrm{~cm}$ in diameter; sheared; bedding $15-30 \mathrm{~cm}$; resistant; silicified brachiopods, commonly highly abraded, with auloporid corals growing on them. Fossils show marked tectonic stretching. ( $\mathrm{S} 4-36.6 \mathrm{~m}$ )

Limestone: black, weathering dark grey; micritic; flaggy; 2-5 cm beds; recessive

Limestone: argillaceous; black, weathering dark grey; micritic matrix; bioclastic; phosphatic nodules $0.5-2 \mathrm{~mm}$ in diameter; bedding 20-30 cm; resistant; sheared fossils; silicified brachiopods and pelmatozoan ossicles; auloporid corals growing on abraded brachiopod valves. (S4-53.3-54.9 m)

Limestone: medium grey, weathering light grey with buff mottle; bioclastic, medium-grained calcarenite; small, black phosphatic nodules $2 \mathrm{~mm}$ in diameter; sheared; bedding $30-60 \mathrm{~cm}$; resistant; abundant silicified brachiopods, corals, and stromatoporoids. Shells commonly worn, with auloporid corals encrusting them. (S4-64.0-65.5 m)

Limestone: dark grey-black, weathering medium-dark grey; micritic; bedding 5-15 cm; recessive; a few silicified, rugose corals.

Limestone: dark grey-black, weathering dark grey; micritic; very pyritic; black phosphatic nodules $1-2 \mathrm{~mm}$ in diameter; bedding 5-15 cm; recessive. (S4-80.8 m)

Talus cover of platy, black limestone.

Limestone: black, weathering dark grey with maroon hue; bioclastic; micritic matrix; rounded chert fragments $1 \mathrm{~cm}$ in diameter; bedding 30-90 cm; resistant; shaly and more argillaceous interbeds; recessive; abundant silicified brachiopods and corals. (S4-94.5 m, S4-100.6 m)

Vegetation cover.

Limestone: argillaceous; dark grey-black, weathering dark grey with maroon mottle; micritic; bioclastic; $2 \mathrm{~cm}$ vugs filled with coarsely crystalline calcite; bedding $90 \mathrm{~cm}$; resistant; silicified brachiopods and corals; shells abraded. (S4-118.9 m)

Limestone: medium grey, weathering medium-light grey; medium-grained calcarenite; small, rounded chert fragments $2 \mathrm{~cm}$ in diameter; bedding 60-90 cm; resistant; few silicified fossils; fossils broken and abraded. (S4-123.4-125.0 m)

Mostly talus cover with occasional outcrops of dark grey, micritic limestone; thinly bedded with lenses of calcarenite bearing rounded chert fragments $1 \mathrm{~cm}$ in diameter and silicified brachiopods. (S4-134.1T m)

Limestone: dark grey, weathering light grey with maroon hue; micritic matrix; bedding 0.3-1.5 m; resistant; cliff-former; abundant silicified brachiopods; some shells worn and encrusted with auloporid corals. (S4-143.3 m)

Talus cover of overlying dark grey limestone

Limestone: dark grey, weathering medium grey; micritic; bioclastic; bedding 30-60 cm; resistant; abundant silicified brachiopods and corals; abundant pyrite. (S4-161.5-164.9 m)

Limestone: argillaceous; dark grey, weathering medium grey with maroon hue; micritic; bioclastic; bedding 5-10 cm with a few $25 \mathrm{~cm}$ beds; resistant; few silicified brachiopods. (S4-176.8 m, S4-184.4 m, S4-196.6 m)

Limestone: argillaceous; dark grey-black, weathering maroon-grey; micritic; bedding 5-7 cm with a few $20 \mathrm{~cm}$ interbeds; very recessive; few silicified brachiopods. At $217.9 \mathrm{~m}$ shells highly abraded; at $257.6 \mathrm{~m}$ silicified brachiopod shells within black and grey chert nodules. (S4-217.9 m, S4-257.6 m)

Vegetation covered.

Limestone: black, weathering dark grey; massive; micritic; bioclastic; highly fractured; resistant; silicified brachiopods, corals, and pelmatozoan ossicles, with auloporid corals encrusting some shells. Abundant black phosphatic nodules, $0.5-1.0 \mathrm{~mm}$ in diameter, in heavy mineral residue. ( $\mathrm{S} 4-274.3 \mathrm{~m}$ )

Talus cover with a few dark grey limestone outcrops; very rubbly; very recessive.

Limestone: dark grey, weathering light grey; micritic; abundant angular, rounded chert pebbles up to $5 \mathrm{~cm}$ in diameter; bedding $60-90 \mathrm{~cm}$.

Shale: calcareous; maroon, weathering maroon; thin $(5-15 \mathrm{~mm})$ beds; recessive

Vegetation cover.

Dolostone: calcareous; medium grey-brown, weathering light grey; finely crystalline; recessive.

Limestone: very argillaceous; black, weathering medium grey-maroon; micritic; pyritic; nodular, $15-30 \mathrm{~cm}$ beds: recessive; a few brachiopods. ( $\$ 4-384.0 \mathrm{~m}$ ) 
Appendix (continued)

393.2-411.5 Limestone: dolomitic; medium grey, weathering light grey; micritic; abundant, rounded chert pebbles up to $3 \mathrm{~cm}$ in diameter; bedding 15-30 cm; interbeds of recessive maroon shales, locally noncalcareous, comprising 80 per cent of the section.

411.5-452.6 Limestone: black, weathering grey-buff; micritic; bioclastic; rounded chert fragments $3 \mathrm{~cm}$ in diameter; bedding 20-60 cm; larger brachiopods abraded, with auloporid corals encrusting some of them; abundant phosphatic nodules, $0.5 \mathrm{~mm}$ in diameter, in acetic acid residues. (S4-449.5 m)

452.6-472.4 Limestone: dark grey, weathering light grey; micritic; bioclastic; bedding $30 \mathrm{~cm}$; locally lenses of silicified brachiopod coquina bearing abraded shells with encrusting auloporids; abundant, small $(0.5-1.0 \mathrm{~mm})$ phosphatic nodules. (S4-466.3 m, S4-470.9 m, S4-472.4 m)

472.4-495.3 Limestone: medium grey, weathering light grey; fine-grained calcarenite; bedding $30 \mathrm{~cm}$; resistant; interbeds of recessive, argillaceous limestone; silicified brachiopods abundant; phosphatic nodules, 1-2 mm in diameter, common in acetic acid residues. (S4-475.5 m, S4-492.3 m)

495.3-525.8 Limestone: dark grey, weathering light grey-maroon; massive; bioclastic; micritic matrix; rounded chert pebbles up to $2 \mathrm{~cm}$ in diameter; abundant calcite veining; bedding up to $10 \mathrm{~cm}$; resistant; silicified brachiopods, commonly articulated and encrusted with auloporid corals. (S4-502.9-507.5 m, S4-513.6-515.1 m, S4-519.7 m)

525.8-560.8 Talus cover of very recessive, dark grey-black limestone and argillaceous, platy limestone.

560.8-579.1 Limestone: dark grey, weathering light grey; bioclastic; micritic matrix; massive, bedding 1.5-4.5 m; very resistant; cliff-former; abundant silicified brachiopods with large shells abraded and encrusted with auloporid corals. (S4-560.8-573.0 m, S4-576.1 m)

579.1-602.0 Limestone: very argillaceous; dark grey-black, weathering medium grey-maroon; micritic; fetid; platy; bedding $1-3 \mathrm{~cm}$; recessive; a few graptolites, abundant tentaculitids; a few interbeds of more resistant, argillaceous limestone. (S4-580.6 m, S4-594.4 m, S4-597.4 m)

602.0-646.2 Limestone: very argillaceous; black, weathering dark grey; micritic; platy, 1-3 cm beds; recessive; a few very recessive, shaly interbeds; bedding nodular locally. (S4-624.8 m)

646.2-650.7 Limestone: medium grey, weathering light grey; massive; micritic; a few silicified brachiopods .

650.7-685.8 Shale: calcareous; black, weathering buff; fissile, $1-3 \mathrm{~cm}$ beds; recessive; a few limestone interbeds, $15-30 \mathrm{~cm}$ thick, more resistant, and bearing silicified brachiopods. ( $44-685.8 \mathrm{~m}$ )

\section{Road River Formation (Partial Section)}

685.8-716.3 Mostly talus cover of black, calcareous shale; fissile; fine $(2-4 \mathrm{~mm})$ laminae; cleavage at low angle to bedding; very recessive; very poorly preserved indeterminate monograptids at several levels.

\section{SECTION 4 (S-4)}

This section was measured by S. L. Blusson in August 1972 , westwards along an east-west-trending ridge in the overturned east limb of the Sekwi Anticline, west of the Natla River, at

Metres from

top of section

0-190.6

Transitional Facies (incomplete)

$190.6-244$ $63^{\circ} 06^{\prime} 16^{\prime \prime} \mathrm{N}, 128^{\circ} 41^{\prime} \mathrm{W}$ (Air Photo A12249-154). The section thickness was estimated by pacing.

SECTION 5 (S-5)

This section was measured by D. G. Perry and R. Ludvigsen on 16 July 1972, westwards along an east-west-trending ridge,

Metres from

base of section

1272.9-719.5

$719.5-609.8$
Sombre Formation (partial section)

Whittaker Formation (partial section)
$19.2 \mathrm{~km}$ northeast of Divide Lake, $0.8 \mathrm{~km}$ north of the $2212.5 \mathrm{~m}$ peak at $63^{\circ} 10^{\prime} 20^{\prime \prime} \mathrm{N}, 127^{\circ} 59^{\prime} \mathrm{W}$ (Air Photo A 12100-164). 


\section{Appendix (continued)}

\section{SECTION 6 (S-6)}

This section was measured by D. G. Perry and F. Conrad on 11 June 1972, eastwards along an east-west-trending ridge in the

Metres from

base of section

858.2-830.8 Camsell Formation (partial section)

$830.8-44.2$

$44.2-0$
Delorme Range at $62^{\circ} 46^{\prime} \mathrm{N}, 125^{\circ} 15^{\prime} \mathrm{W}$ (Air Photo A 18045-136).

SECTION 7 (S-7)

This section was measured by D. G. Perry, B. D. E. Chatterton, and A. C. Lenz on 15-17 June 1972, eastwards along stream valleys and ridges on the east flank of the Whittaker Anticline,

Metres from

base of section

984.8-939.0 Camsell Formation (partial section)

$939.0-47.3$

Delorme Formation

$47.3-0$
$6.4 \mathrm{~km}$ west of Trench Lake, at $62^{\circ} 28^{\prime} 50^{\prime \prime} \mathrm{N}, 124^{\circ} 47^{\prime} \mathrm{W}$ (Air Photo A 17429-94). It consists of the composite of three sections projected together on aerial photographs.

\section{SECTION 8 ( S-8)}

This section was measured by D. G. Perry and A. C. Lenz on 17, 18 July 1971, eastwards along a northeast-trending ridge in the overturned east limb of the Sekwi Anticline, $3.2 \mathrm{~km}$ southeast of

\section{Metres from}

top of section

0-32.9

Sombre Formation (partial section)

$32.9-490.9$

Delorme Formation

$490.9-562.5$
Road River Formation (partial section)
June Lake, at $63^{\circ} 29^{\prime} \mathrm{N}, 128^{\circ} 37^{\prime} 3^{\prime \prime} \mathrm{W}$ (Air Photo A12107-68). Note that, depending upon definition, the base of the Delorme might be placed at $359.8 \mathrm{~m}$.

\section{SECTION 9 (S-9)}

This section was measured by R. Ludvigsen on 26 July 1973 , $3.2 \mathrm{~km}$ northwest of Grizzly Bear Lake on the west flank of the

Metres from

base of section

213.4-195.1

$195.1-104.6$

$104.6-3.0$

$3.0-0$
Sombre Formation (partial section)

Delorme Formation

Road River Formation

Whittaker Formation (partial section) mountain at $62^{\circ} 41^{\prime} 30^{\prime \prime} \mathrm{N}, 127^{\circ} 52^{\prime} \mathrm{W}$ (Air Photos A12347. 290-292) 



\section{Literature Cited}

ALEKSEEVA, R. E.

1959 Novyĭ rod semeǐstva Atrypidae Gill (Brachiopoda). Akademia nauk SSSR, Doklady 126:389-391.

1960a O rode Spirigerina d'Orbigny. Paleontologicheskii zhurnal 4:63-68.

1960b O novom podrode Atrypa (Desquamatia) subgen. semeǐstva Atrypidae Gill (Brakhiopody). Akademila nauk SSSR, Doklady 131:421-424.

1962 Devonskie atrypidy Kutznetskogo i Minusinskogo basseĭnov i vostochnogo sklona severnogo Urala. Akademiia nauk SSSR, Sibirskoe otdelenie, Institut geologii i geofiziki, Trudy, pp. 1-195.

1968 Sibirispira-novyǐ rod otryada Atrypida. Akademiıa nauk SSSR, Doklady 197:198-201.

ALEKSEEVA, R. E., R. T. GRATSIANOVA, E. A. ËLKIN, and N. P. KULKOV

1970 Stratigrafia i brakhiopoda nizhnego devona severovostochnogo Salaira. Akademiia nauk SSSR, Sibirskoe otdelenie, Institut geologii i geofiziki, Trudy $72: 1-188$

AMSDEN, T. W

1953 Some notes on the Pentameracea, including a description of one new genus and one new subfamily. Journal of the Washington Academy of Science 43:137-147.

1958 Stratigraphy and paleontology of the Hunton Group in the Arbuckle Mountain region. Oklahoma Geological Survey, Bulletin 78:1-199.

1964 Brachial plate structure in the brachiopod family Pentameridae. Palaeontology 7:220-239.

1974 Late Ordovician and Early Silurian articulate brachiopods from Oklahoma, southwestern Illinois, and eastern Missouri. Oklahoma Geological Survey, Bulletin 119:1-154

AMSDEN, T. W., A. J. BOUCOT, and J. G. JOHNSON

1967 Conchidium and its separation from the subfamily Pentamerinae. Journal of Paleontology 41:861-867.

ANDERSON, E. J. and J. H. MAKURATH

1973 Paleoecology of Appalachian gypidulid brachiopods Palaeontology 16:381-390.

ANDERSON, M. M., A. J. BOUCOT, and J. G. JOHNSON

1969 Eifelian brachiopods from Padaukpin, Northern Shan States, Burma. Bulletin of the British Museum (Natural History) Geology 18:107-163

ANDRONOV.S. M

1961 Nekotore predstaviteli semeǐstva Pentameridae iz devonskikh otlozheniy okrestnostey severouralvska. Akademiı nauk SSSR, Institut geologicheskikh nauk, Trudy 55:38-108.

BANCROFT, B. B

1928 On the notational representation of the rib-system in Orthacea. Manchester Literary and Philosophical Society, Memoirs and Proceedings 72:53-90

BARRANDE.

1847 Über die Brachiopoden der silurischen Schichten von Böhmen I. Naturwissenschaftliche Abh, 1:1-347.
1848 Über die Brachiopoden der silurischen Schichten von Böhmen. Naturwissenschaftliche Abh. 2(2):153-256.

1879 Système silurien du centre de la Bohême. Ptie 1: Recherches paléontologiques. Prague, l'auteur, vol. 5, pp. 1-226.

BAYLE, C. E

1878 Explication de la carte géologique de la France. (Atlas). Paris, vol. 4, ptie 1.

BEECHER, C. E.

1890 On Leptaenisca, a new genus of brachiopod from the Lower Helderberg Group. American Journal of Science, ser. 3, 140:238-240.

BIERNAT, G

1959 Middle Devonian Orthoidea of the Holy Cross Mountains and their ontogeny. Palaeontologia Polonica 10:1-78.

1966 Middle Devonian brachiopods of the Bodzentyn Syncline (Holy Cross Mountains, Poland). Palaeontologia Polonica 17:7-162

BILLINGS, E

1860 Description of some new species of fossils from the lower and middle Silurian rocks of Canada. Canadian Naturalist 5:49-69.

BLUSSON, S. L.

1971 Sekwi Mountain map-area, Yukon Territory and District of Mackenzie. Geological Survey of Canada, Paper 71-22:1-17.

BOUČEK, B.

1964 The tentaculites of Bohemia; their morphology, taxonomy, ecology, phylogeny and biostratigraphy. Prague, Czechoslovak Academy of Sciences. 215 pp.

BOUČEK, B., R. HORNÝ, and I. CHLUPÁČ

1964 On some atrypoid, retzioid, and athyridoid Brachiopoda. Journal of Paleontology 38:805-822.

BOUCOT, A. J.

1957 A Devonian brachiopod, Cyrtinopsis, redescribed. Senckenbergiana lethaea 35:37-48.

1959 Early Devonian Ambocoeliinae (Brachiopoda). Journal of Paleoniology 33:16-24.

1960 Lower Gedinnian brachiopods of Belgium. Louvain, Institut géologique de l'Université de Louvain, Mémoire 21:283-324.

1975 Evolution and extinction rate controls. New York, Elsevier. $427 \mathrm{pp}$.

BOUCOT. A. J.. E. D. GILL. J. G. JOHNSON, A. C. LENZ, and J. A TALENT

1966 Skenidioides and Leptaenisca in the Lower Devonian of Australia (Victoria. Tasmania) and New Zealand. with notes on other Devonian occurrences of Skenidioides. Proceedings of the Royal Society of Victoria 79:363-369.

BOUCOT, A. J. and J. G. JOHNSON

1968 Brachiopods of the Bois Blanc Formation in New York. United States Geological Survey Professional Paper 584B: $1-27$ 
1972 Callicalyptella, a new genus of notanopliid brachiopod from the Devonian of Nevada. Journal of Paleontology 46:299-302.

BOUCOT, A. J.. J. G. JOHNSON, and R. D. STATON

1964 On some atrypoid, retzioid, and athyridoid Brachiopoda Journal of Paleontology 38:805-822.

1965 Suborder Atrypidina. In Moore, R. C., ed., Treatise on invertebrate paleontology, part $\mathrm{H}$, Brachiopoda. Lawrence, Geological Society of America and University of Kansas Press, pp. 637-677.

BOUCOT, A. J., J. G. JOHNSON, and J. A. TALENT

1969 Early Devonian brachiopod zoogeography. Geological Society of America, Special Paper 119:1-113.

BOWEN, Z. P.

1967 Brachiopoda of the Keyser Limestone (SilurianDevonian) of Maryland and adjacent areas. Geological Society of America, Memoir 102:1-103.

BROWN, C. E.

1974 Phosphatic zone in the lower part of the Maquoketa Shale in northeastern Iowa. United States Geological Survey, Journal of Research 2:219-232.

BUBLITSCHENKO, N. L.

1927 Die Brachiopodenfauna des unteren Palaeozoicums aus der Umgegend des Dorfes Sara-Tschumysch aus dem Kohlenbassin von Kusnetzk. Leningrad, Bulletins du Comité géologique 46:976-1008.

CASTER, K. E

1939 A Devonian fauna from Colombia. Bulletins of American Paleontology 24:7-218.

1945 New names for two homonyms. Journal of Paleontology $19: 319$.

CHAPMAN, F

1905 New or little-known Victorian fossils in the National Museum, Melbourne. Part V, On the genus Receptaculites. Proceedings of the Royal Society of Victoria 18:16-19.

CHATTERTON, B. D. E

1973 Brachiopods of the Murrumbidgee Group, Taemas, New South Wales. Australia Bureau of Mineral Resources, Geology and Geophysics, Bulletin 137:1146.

CHATTERTON, B. D. E. and D. G. PERRY

1977 Lochkovian trilobites and conodonts from northwestern Canada. Journal of Paleontology 51:772-796.

1978 An early Eifelian invertebrate faunule, Whittaker Anticline, northwestern Canada. Journal of Paleontology 52:28-39.

CHERKESOVA, S. V

1969 Dentatrypa (Brachiopoda) iz srednedevonskikh otlozheniǐ Novoĭ Zemli. Paleontologîa i biostratigrafia, Vypusk 28:35-46.

CHERNYSHEV, B. B.

1937 Siluriǐskie brakhiopody Mongoli i Tuvy. Akademira nauk SSSR, Nauchno-issledovatel'skii komitet MNR, Tom mongolskoi komisii 29(5):1-94.
CHERNYSHEV, T.

1885 Die Fauna des unteren Devon am Westabhange des Urals. St. Petersburg, Mémoires du comité géologique 3(1):1-107.

1893 Die Fauna des unteren Devon am Ostabhange des Urals. St. Petersburg, Mémoires du comité géologique $4(3): 1-221$.

CONRAD, T. A

1842 Observations on the Silurian and Devonian systems of the United States, with descriptions of new organic remains. Academy of Natural Sciences of Philadelphia, Journal 8:228-280.

COOPER, G. A

1942 New genera of North American brachiopods. Journal of the Washington Academy of Sciences 32:228-235.

1944 Phylum Brachiopoda. In Shimer, H. W. and R. R. Shrock, Index fossils of North America. New York, J. Wiley, pp. 277-365.

1955 New genera of Middle Paleozoic brachiopods. Journal of Paleontology 29:45-63.

COOPER, G. A. and H. M. MUIR-WOOD

1951 Brachiopod homonyms. Washington Academy of Sciences, Journal 41:195-196.

COPPER, P.

1967a Brachidial structures of some Devonian atrypid brachiopods. Journal of Paleontology 41:1176-1183.

1967b Spinatrypa and Spinatrypina (Devonian Brachiopoda). Palaeontology 10:489-523.

1973 New Siluro-Devonian atrypoid brachiopods. Journal of Paleontology 47:484-500.

1977 The late Silurian brachiopod genus Atrypoidea. Geologiska Föreningens i Stockholm Förhandlingar 99:10-26.

1979 Devonian atrypoids from western and northern Canada. Geological Association of Canada, Special Paper 18:289-331.

CRICKMAY, C. H.

1953 Warrenella, a new genus of Devonian brachiopods. Journal of Paleontology 27:596-600.

CUVIER, F, G., ed

1827 Dictionnaire des sciences naturelles. Paris, vol. 51.

DALMAN, J. W.

1828 Uppställning och Beskrifning af de $\mathrm{i}$ sverige funne Terebratuliter. Kungliga Svenska Vetenskapsakademiens, Handlingar 1827:85-155.

DAVIDSON, T

1847 Description of some species of Brachiopoda. Annals and Magazine of Natural History 20:250-257.

1848 Sur les brachiopodes du système silurien supérieur de l'Angleterre. Société géologique de France, Bulletin, sér. 2, 5:309-338, 370-374.

1858 A monograph of the British fossil Brachiopoda, pt. 5, 2nd part. Palaeontographical Society 11:49-80, pls 9-16.

DINELEY, D. L.

1965 An occurrence of Corvaspis (Ostracodermi) in Canada. Canadian Journal of Earth Sciences 2:93-97. 
d'ORBIGNY, A.

1847 Considérations zoologiques et géologiques sur les brachiopodes ou palliobranches. Académie des sciences de Paris, Comptes rendus 25:193-195.

1848- Paléontologie française, Terrains crétacés, 4, Brachio1851 poda. Paris. 390 pp.

DOUGLAS, R. J. W. and D. K. NORRIS

1960 Virginia Falls and Sibbeston Lake map-areas, Northwest Territories. Geological Survey of Canada, Paper 60-19:1-26.

1961 Camsell Bend and Root River map-areas, District of Mackenzie, Northwest Territories. Geological Survey of Canada, Paper 61-13:1-36.

1963 Dahadinni and Wrigley map-areas, District of Mackenzie, Northwest Territories. Geological Survey of Canada, Paper 62-33:1-33.

DROT, J

1964 Rhynchonelloidea et Spiriferoidea siluro-dévoniens du Maroc pré-saharien. Notes et mémoires du service des mines et de la carte géologique du Maroc 178:1-287.

1969 Clorindinae (Pentamerida) devoniens du Maroc présaharien. Notes et mémoires du service des mines et de la carte géologique du Maroc 213:33-43.

DUN, W. S.

1904 Notes on some new species of Palaeozoic Brachiopoda from New South Wales. Records of the Geological Survey of New South Wales 7:318-329.

DUNBAR, C. O

1919 Stratigraphy and correlation of the Devonian of western Tennessee. Tennessee Geological Survey, Bulletin 21:1-127.

FOERSTE, A. F

1909 Fossils from the Silurian formations of Tennessee, Indiana and Illinois. Denison University Science Laboratory, Bulletin 14:61-116.

FORTIER, Y. O., R. G. BLACKADAR, B. F. GLENISTER, H. R. GREINER, D. J. McLAREN, N. J. McMILlAN, A. W. NORRIS, E. F. ROOTS, J. G. SOUTHER, R. THORSTEINSSON, and E. T. TOZER

1963 Geology of the north-central part of the Arctic Archipelago, Northwest Territories (Operation Franklin). Geological Survey of Canada, Memoir 320:1-671

FREDERIKS, G

1916 Über einige oberpaläozoische Brachiopoden von Eurasien. Comité géologique, Mémoires 156:1-87.

FUCHS, A.

1919 Beitrag zur Kenntnis der Devonfauna der Verse- und Hobräcker Schichten des sauerländischen Faciesgebietes. Preussische Geologische Landesanstalt und Bergakademie, Jahrbuch 39:58-95.

GABRIELSE, H., S. L. BLUSSON, and J. A. RODDICK

1973 Geology of Flat River, Glacier Lake, and Wrigley Lake map-areas, District of Mackenzie and Yukon Territory. Geological Survey of Canada, Memoir 355, pt. 1:1-153, pt. 2:1-268
GAURI, K. L. and A. J. BOUCOT

1968 Shell structure and classification of Pentameracea M'Coy, 1844. Palaeontographica (Abt. A) 131:79135.

GILL, E. D

1942 On the thickness and age of the type Yeringian strata Lilydale, Victoria. Proceedings of the Royal Society of Victoria 57:21-57.

GRATSIANOVA, R. T

1967 Brakhiopody i stratigrafiıa nizhnego devona gornogo Altaía. Moscow, Akademiía nauk SSSR, Sibirskoe otdelenie, Institut geologii i geofiziki, pp. 1-177.

1974 "Shukertelly" rannego i srednego devona na yuge zapadnoĭ Sibiri. Sistematicheskaya prinadlezhnost', zhizn' v geologicheskom proshlom. Paleoekologicheskie problemy. Novosibirsk, "Nauka", pp. 77-87.

HALL, J

1843 Geology of New York, Part IV, comprising the survey of the fourth geological district. In Natural History of New York. Albany. 525 pp.

1852 Descriptions of the organic remains of the lower middle divisions of the New York System (equivalent in part to the Middle Silurian rocks of Europe). In Palaeontology of New York. Albany, vol. 2, pp. $1-362$.

1857 Descriptions of Palaeozoic fossils. New York, State Cabinet of Natural History, Annual Report 10:41-186.

1858 Palaeontology of Iowa. Iowa Geological Survey, Report 1:473-724

1859- Descriptions and figures of the organic remains of the

1861 lower Helderberg Group and the Oriskany sandstone. In Palaeontology of New York. Albany, Geological Survey of New York, vol. 3, pp. 1-532.

1860 Contributions to palaeontology. New York, State Cabinet of Natural History, Annual Report 13:55-125.

1863 Notice of some new species of fossils from a locality of the Niagara Group in Indiana; with a list of identified species from the same place. Transactions of the Albany Institute 4:195-228

1867 Descriptions and figures of the fossil Brachiopoda of the upper Helderberg, Hamilton, Portage and Chemung groups. In Palaeontology of New York. Albany, Geological Survey of New York, vol. 4, pt. 1, pp. $1-428$.

1879 The fauna of the Niagara Group. New York State Museum of Natural History, Annual Report 28:98203.

HALL, J. and J. M. CLARKE

1892 An introduction to the study of the genera of Palaeozoic Brachiopoda. In Palaeontology of New York. Albany, Geological Survey of the State of New York, vol. 8, pt. 1, pp. 1-367.

1893 An introduction to the study of the genera of Palaeozoic Brachiopoda. In Palaeontology of New York. Albany, Geological Survey of the Siate of New York, vol. 8, pt. 2, pp. 1-394. 
HARPER, C. W. Jr .

1973 Brachiopods of the Arisaig Group (Silurian-Lower Devonian) of Nova Scotia. Geological Survey of Canada. Bulletin 215:1-163.

HARPER, C. W. Jr., J. G. JOHNSON, and A. J. BOUCOT

1967 The Pholidostrophiinae (Brachiopoda; Ordovician, Silurian, Devonian). Senckenbergiana lethaea 48: 403-461.

HAVLICEK, V

1953 O několika nových ramenonožcích českého a moravského středního devonu. Ústřední ústav geologický, Vèstník 28:4-9.

1956 The brachiopods of the Branik and Hlubočepy limestones in the immediate vicinity of Prague. Ustrední ústav geologický, Sborník 22:535-665.

1959 Spiriferidae v českém siluru a devonu. Ústřední ústav geologický, Rozpravy 25:1-275.

1960 Bericht über die Ergebnisse der Revision der böhmischen altpaläozoischen Rhynchonelloidea. Ústřední ústav geologický, Věstník 35:241-244.

1961 Rhynchonelloidea des böhmischen älteren Paläozoikums (Brachiopoda). Ústřední ústav geologický, Rozpravy $27: 1-211$.

1965 Superfamily Orthotetacea (Brachiopoda) in the Bohemian and Moravian Palaeozoic. Ústřední ústav geologický, Věstník 40:291-294.

1967 Brachiopoda of the suborder Strophomenidina in Czechoslovakia. Ústřední ústav geologioký, Rozpravy $33: 1-235$.

1971 a Non-costate and weakly costate Spiriferidina (Brachiopoda) in the Silurian and Lower Devonian of Bohemia. Sborník geologických věd, Paleontologie, Řada, P, $14: 7-34$.

$1971 \mathrm{~b}$ New genera of enteletacean brachiopods in the Devonian of Bohemia. Ústřední ústav geologický, Věstnik 46:229-232.

1973 New brachiopod genera in the Devonian of Bohemia. Ústřední ústav geologický, Věstnik 48:337-340.

1974 New genera of Orthidina (Brachiopoda) in the Lower Palaeozoic of Bohemia. Ústřední ústav geologický, Věstník 49:167-170.

1977a Brachiopoda of the order Orthida in Czechoslovakia. Ústřední ústav geologický, Rozpravy 44:1-327.

1977b Minute Devonian brachiopods (Notanopliidae, Leptostrophiidae) in Bohemia. Ústřední ústav geologický, Věstnik 52:299-302.

HISINGER, W.

1799 Minerographiske anmarkingar ofer Gottland. Kungliga Svenska Vetenskapsakademiens, Handlingar 19:267287.

1826 Gottland, Geognostiskt beskrifvit. Kungliga Svenska Vetenskapsakademiens, Handlingar 1826:311-336.

JACKSON, D. E, and A, C, LENZ

1962 Zonation of Ordovician and Silurian graptolites in northern Yukon. Canada. American Association of Petroleum Geologists, Bulletin 46:30-45
JACKSON, D. E. A C LENZ, and A. E. H. PEDDER

1978 Late Silurian and Early Devonian graptolite, brachiopod and coral faunas of northwestern and arctic Canada. Geological Association of Canada, Special Paper 17:1-159.

JAHNKE, $H$.

1971 Fauna and Alter der Erbslochgrauwacke (Brachiopoden und Trilobiten, Unter-Devon, Rheinisches Schiefergebirge und Harz). Göttinger Arbeiten zur Geologie und Paläontologie 9:1-105.

JOHNSON, J, G

1965 Lower Devonian stratigraphy and correlation, northern Simpson Park Range, Nevada. Bulletin of Canadian Petroleum Geology 13:365-381.

1966 Parachonetes, a new Lower and Middle Devonian brachiopod genus. Palaeontology 9:365-370.

1967 Toquimaella, a new genus of karpinskiinid brachiopod. Journal of Paleontology 41:874-880.

1968 A new species of Vagrania (Devonian, Brachiopoda) from Nevada. Journal of Paleontology 42:1200-1204.

1970 Great Basin Lower Devonian Brachiopoda. Geological Society of America, Memoir 121:1-421.

1971 a Lower Givetian brachiopods from central Nevada. Journal of Paleontology 45:301-326.

$197 \mathrm{lb}$ Timing and coordination of orogenic, epeirogenic, and eustatic events. Geological Society of America, Bulletin 82:3263-3298

1971c Some new and problematical brachiopods from the Lower Devonian of Nevada. Journal of Paleontology 45:95-99.

1972 Teichertina, the last dicaelosiid brachiopod. Journal of Paleontology 46:830-835.

1973a Late Early Devonian rhynchonellid genera from arctic and western North America. Journal of Paleontology $47: 465-472$

$1973 \mathrm{~b}$ Mid-Lochkovian brachiopods from the Windmill Limestone of central Nevada. Journal of Paleontology 47:1013-1030.

1974 a Early Devonian brachiopod biofacies of western and arctic North America. Journal of Paleontology 48:809-819

1974b Oriskania (terebratulid brachiopod) in the Lower Devonian of central Nevada. Journal of Paleontology 48:1207-1212.

1975a Devonian brachiopods from the Quadrithyris Zone (Upper Lochkovian) Canadian Arctic Archipelago. Geological Survey of Canada, Bulletin 235:5-57.

1975b Late Early Devonian brachiopods from the Disappointment Bay Formation, Lowther Island, arctic Canada. Journal of Paleontology 49:947-978.

1976 Chattertonia n. gen. (Brachiopoda), the chonetidproductid link. Journal of Paleontology 50:789-791.

1977 Lower and Middle Devonian faunal intervals in central Nevada based on brachiopods. In Murphy, M. A., et al., eds., Western North America: Devonian. University of California, Riverside, Museum Contribution $4: 16-33$ 
JOHNSON, J. G. and A. J. BOUCOT

1967 Gracianella, a new Late Silurian genus of atrypoid brachiopods. Journal of Paleontology 41:868-873.

1968 External morphology of Anatrypa (Devonian, Brachiopoda). Journal of Paleontology 42:1205-1207.

1972 Origin and composition of the Carinatininae (Devonian Brachiopoda). Journal of Paleontology 46:31-38.

JOHNSON, J. G., A. J. BOUCOT, and M. A. MURPHY

1973 Pridolian and Early Gedinnian age brachiopods from the Roberts Mountains Formation of central Nevada. University of California, Publications in Geological Sciences 100:1-75.

1976 Wenlockian and Ludlovian age brachiopods from the Roberts Mountains Formation of central Nevada. University of California, Publications in Geological Sciences 115:1-102.

JOHNSON, J. G. and R. A. FLORY

1972 A Rasenriff fauna from the Middle Devonian of Nevada. Journal of Paleontology 46:892-899.

JOHNSON, J. G. and G. W. KENDALL

1976 Late Early Devonian brachiopods and biofacies from central Nevada. Journal of Paleontology 50:11131128 .

JOHNSON, J. G. and R. LUDVIGSEN

1972 Carinagypa, a new genus of pentameracean brachiopod from the Devonian of western North America. Journal of Paleontology 46:125-129.

JOHNSON, J. G., N. L. PENROSE, and M. T. WISE

1978 Biostratigraphy, biotopes aild biogeography in the Lower Devonian (Upper Lochkovian, Lower Pragian) of Nevada. Journal of Paleontology 52:793-806.

JOHNSON, J. G. and A. RESO

1964 Probable Ludlovian brachiopods from the Sevy Dolomite of Nevada. Journal of Paleontology 38:74-84.

JOHNSON, J. G. and J. A. TALENT

1967a Muriferella, a new genus of Lower Devonian septate dalmanellid. Proceedings of the Royal Society of Victoria 80:43-50.

1967b Cortezorthinae, a new subfamily of Siluro-Devonian dalmanellid brachiopods. Palaeontology 10:142-170.

JOHNSTON, J.

1941 Studies in Silurian Brachiopoda. Proceedings of the Linnean Society of New South Wales 66:160-168.

JONES, B.

1974 A biometrical analysis of Arrypella foxi n. sp. from the Canadian Arctic. Journal of Paleontology 48:963-977.

1977 Variation in the Upper Silurian brachiopod Atrypella phoca (Salter) from Somerset and Prince of Wales Islands, arctic Canada. Journal of Paleontology $51: 459-479$.

1978 Taxonomy and intraspecific variation of Protathyris praecursor Kozlowski, 1929 from the Upper Silurian of Somerset Island, arctic Canada. Journal of Paleontology 52:8-27.

1979 Airvpoidea erebus n. sp. from the Late Silurian of arctic Canada. Journal of Palcontology 53:187-196.
KAYSER, E

1871 Die Brachiopoden des Mittel- und Ober-Devon der Eifel. Zeitschrift der Deutschen geologischen Gesellschaft 23:491-647.

KHALFIN, L. L.

1948 Fauna i stratigrafía devonskikh otlozheniĭ gornogo Altaia. Zapadno-sibirskoe geologicheskoe upravlenie-Tomsk. Politekhnicheskiĩ institut, Izvestila 65(1):1-464.

KHALFIN, L. L., ed.

1956 Atlas rukovodiaschikh form iskopaemykh fauny i flory zapadnoĭ Sibiri. Moscow, Gosudarstvennoe nauchnotekhnicheskoe izdatel'stvo literatury po geologii i okhrane nedr. 2 vols.

1960 Biostratigrafiıa paleozôa Sayano-altaĭskờ gornō̆ oblasti, tom II. Sibirskiĭ nauchno-issledovatel'skiī institut geologii, geofiziki i mineralnogo syr'ia, Trudy 20:99-109.

KHODALEVICH, A. N.

1939 Verkhne-siluriǐskie brakhiopody vostochnogo sklona Urala. Ural'skoe geologischeskoe upravlenie, Trudy, pp. 1-135.

1951 Nizhnedevonskie i eifel'skie brakhiopody Ivdelakogoi i Servoskogo răonov Sverdlovskoĭ oblasti. Sverdlovskiĭ gornyı̆ institut, Trudy 18:1-107.

KHODALEVICH, A. N. and M. G. BRIEVEL

1959 Brakhiopody i korally iz eifel'skikh boksitonosnyikh otlozheniǔ vostochnogo sklona srednego i severnogo Urala. Ural'skoe geologischeskoe upravlenie, pp. $1-282$

KING, W

1850 A monograph of the Permian fossils of England. Palaeontographical Society, Monograph 3:1-258.

KIRK. E. and T. W. AMSDEN

1952 Upper Silurian brachiopods from southeastern Alaska. United States Geological Survey, Professional Paper 223-C: $53-66$

KLAPPER, G. and M. A. MURPHY

1974 Silurian-Lower Devonian conodont sequence in the Roberts Mountains Formation of central Nevada. University of California, Publications in Geological Sciences 111:1-68.

KOKEN, E. F. R.

1889 Ueber die Entwicklung der Gastropoden vom Cambrium bis zur Trias. Neues Jahrbuch für Mineralogie, Geologie, und Paläontologie 6:305-484.

KOZLOWSKI, R.

1929 Les brachiopodes gothlandiens de la Podolie polonaise. Palaeontologica Polonica 1:1-254

1946 Howellella, a new name for Crispella Kozlowski. 1929. Journal of Palcontology 20:295.

KULKOV, N.P.

1960 O faune brakhiopod pesterevskikh izvestnıakov i ikh fatsial'nykh analogov. Akademia nauk SSSR. Sibirskoe otdelenie, Institut geologii i geofiziki, Trudy 1:153-193. 
1963 Brakhiopody solovikhinskikh sloev nizhnego devona gornogo Altaia. Moscow, Akademina nauk SSSR. $131 \mathrm{pp}$.

1967 Brakhiopody i stratigrafiia silura gornogo Altaia. Akademiáa nauk SSSR, Sibirskoe otdelenie, Institut geologii i geofiziki. $140 \mathrm{pp}$.

1970 Biostratigraficheskoe sopostavlenie siluriǐskikh otlozheniǐ gornogo Altaia i Salaira. Akademiâa nauk SSSR. Sibirskoe otdelenie, Geologira i geofizika $6: 72-79$

KUTORGA. S. S

1848 Über die Brachiopoden-Familie der Siphonotretacea. Russische-Kaiserliche mineralogische Gesellschaft zu St. Petersburg, Verhandlungen, pp. 250-286.

LENZ, A. C

1966 Upper Silurian and Lower Devonian paleontology and correlations, Royal Creek, Yukon Territory: a preliminary report. Bulletin of Canadian Petroleum Geology 14:604-612

1967a Thliborhynchia, a new Lower Devonian rhynchonellid from Royal Creek, Yukon, Canada. Journal of Paleontology 41:1188-1192.

1967b Upper Silurian and Lower Devonian biostratigraphy, Royal Creek, Yukon Territory, Canada. In Oswald, D. H., ed., International symposium on the Devonian system, Calgary, 1967. Calgary, Alberta Society of Petroleum Geologists, vol. 2, pp. 587-599.

1968 Two new lower Devonian atrypid brachiopods from Royal Creek, Yukon Territory, Canada. Journal of Paleontology 42:180-185

1970 Late Silurian brachiopods of Prongs Creek, northern Yukon. Journal of Paleontology 44:480-500

1971 Werneckeella, a new Lower Devonian rhynchonellid brachiopod, Royal Creek, Yukon Territory. Journal of Paleontology 45:844-848.

1972 Plicocyrtina and Plicoplasia (Brachiopoda) from the Lower Devonian of the northern Canadian Cordillera. Journal of Paleontology 46:99-103.

1973 Quadrithyris Zone (Lower Devonian) near-reef brachiopods from Bathurst Island, arctic Canada; with a description of a new rhynchonellid brachiopod Franklinella. Canadian Journal of Earth Sciences 10:1403-1409.

1974 Silurian Brachiopoda, Upper Allen Bay Formation, Griffiths Island, Arctic Archipelago, and uppermost Whittaker Formation, Mackenzie Mountains, Northwest Territories. Canadian Journal of Earth Sciences 11:1123-1135.

1977a Upper Silurian and Lower Devonian brachiopods of Royal Creek, Yukon, Canada. Part 1, Orthida, Strophomenida, Pentamerida, Rhynchonellida. Palaeontographica (Abt. A) 159:37-109.

1977b Upper Silurian and Lower Devonian brachiopods of Royal Creek, Yukon, Canada. Part 2, Spiriferida: Atrypacea, Dayiacea, Athyridacea, Spiriferacea. Palaeontographica (Abt. A) 159:111-138.

LENZ, A. C. and A. E. H. PEDDER

1972 Lower and middle sediments and paleontology of
Royal Creek and Peel River, Yukon, and Powell Creek, N.W.T. 24th International Geological Congress, Montreal, 1972, Field Excursion A14 Guidebook. 43 pp.

LINDSTRÖM, G

1860 Bidrag till Kännedomen on Gotlands Brachiopoder. Öfversigt af Kungliga Vetenskapsakademiens, Förhandlingar 17:337-382.

LINNÉ, C. von

1758 Systema naturae. 10th ed. Stockholm, L. Salvii. 823 pp.

LUDVIGSEN, R.

1970 Age and fauna of the Michelle Formation, northern Yukon Territory. Bulletin of Canadian Petroleum Geology 18:407-429.

1974 A new Devonian acrotretid (Brachiopoda, Inarticulata) with unique protegular ultrastructure. Neues Jahrbuch für Geologie und Paläontologie, Monatshefte 3:133148.

LUDVIGSEN, R. and D. G. PERRY

1975 The brachiopod Warrenella in the Lower and Middle Devonian Formations of northwestern Canada Geological Survey of Canada, Bulletin 235:59-107.

MALYGINA, A. A. and V. P. SAPELNIKOV

1973 Siluriŭskie, rannedevonskie i eifel'skie Pentamerida iuzhnogo Tyan'-Shanya. Akademira nauk SSSR, Ural'skii nauchnyǐ tsentr, Institut geologii i geokhimii, Trudy 104:1-212.

MARTIN, W

1809 Petrificata derbiensia: or, figures and descriptions of petrifications collected in Derbyshire. Wigan, D. Lyon. $28 \mathrm{pp}$.

MCLAREN, D. J., A. W. NORRIS, and L. M. CUMMING

1970 Devonian faunas. In Douglas, R. J. W., ed., Geology and economic minerals of Canada. Geological Survey of Canada, Economic Geology Report 1:614-622.

McLAREN, D. J., A. W. NORRIS, and D. C. McGREGOR

1962 Illustrations of Canadian fossils, Devonian of western Canada. Geological Survey of Canada, Paper 62-4:130 .

MCLEARN, F. H.

1924 Paleontology of the Silurian rocks of Arisaig, Nova Scotia. Geological Survey of Canada, Memoir 137:1179.

M'COY, F

1844 A synopsis of the characters of the Carboniferous limestone fossils of Ireland. Dublin. 207 pp.

MERRIAM, C. W

1940 Devonian stratigraphy and paleontology of Roberts Mountain region, Nevada. Geological Society of America, Special Paper 25:1-114.

MITCHELL, J. and W. S. DUN

1920 The Atrypidae of New South Wales, with reference to those recorded from other states of Australia. Linnean Society of New South Wales, Proceedings, 45(4): $543-551$. 
MODZALEVSKA $\widehat{I A}, T$. L.

1970 Siluriŭskie i rannedevonskie atrypidy (Brakhiopody) Vaĭgacha. In Cherkesova, S. V., ed., Stratigrafiia i fauna siluriīskikh otlozheniĩ Vaĭgacha. Leningrad, Nauchno-issledovatel'skiǐ institut geologii Arktiki, pp. $150-164$.

MOORE, R. C., ed.

1965 Treatise on invertebrate paleontology, part $H$, Brachiopoda. Lawrence, Geological Society of America and University of Kansas Press, pp. 1-927.

MUIR-WOOD, H. M.

1925 Notes on the Silurian brachiopod genera Delthyris, Uncinulina, and Meristina. Annals and Magazine of Natural History 15:83-95.

1962 On the morphology and classification of the brachiopod suborder Chonetoidea. London, British Museum (Natural History). $132 \mathrm{pp}$.

MUIR-WOOD, H. M. and G. A. COOPER

1960 Morphology, classification and life habits of the Productoidea (Brachiopoda). Geological Society of America, Memoir 81:1-447.

MURCHISON. R. I.

1839 The Silurian system founded on geological researches in the counties of Salop, Hereford, Radnor, Montgomery, Caerthmarthen, Brecon, Pembroke, Monmouth, Gloucester, Worcester, and Stafford; with descriptions of the coalfields and overlying formations. London, $\mathrm{J}$. Murray. 2 vols, in one.

NALIVKIN, D. V.

1930 Brakhiopody verkhnego i srednego devona Turkestana. Comité géologique, Mémoires, nouv. sér. 180:1221.

1936 Srednepaleozoiskie fauny verkhovykh rek Kolymy i Khandigi. Contributions to Knowledge of OkhotskKolyma Land 1 (4): 1-28.

1941 Brakhiopody glavnogo devonskogo polía. In Batalina, M. A., et al., Fauna glavnogo devonskogo polía. Moscow, Akademiıa nauk SSSR, Institut paleontologii, pp. 139-226.

NIKIFOROVA, O. I.

1937 Brakhiopody verkhnego silura sredneaziatskoì chasti SSSR. Akademiia nauk SSSR, Institut paleontologii, Monographii po paleontologii SSSR 35(1):1-94

1954 Stratigrafiia i brakhiopody siluriǐskikh otlozheniĭ Podolii. Vsesoiuznyĩ nauchno-issledovatel'skiı̌ geologicheskiü institut, Trudy 1:1-178.

1970 Brachiopoda grebenskogo gorizonta Vaĭgacha (pozdniǐ silur). In Cherkesova, S. V., ed., Stratigrafiıa i fauna siluriǐskikh otlozheniī Vaigacha. Leningrad, Nauchno-issledovatel'skiĩ institut geologii Arktiki, pp. 97-149.

NIKIFOROVA, O. I. and D. I. IAKOVLEV

1937 Materialy $k$ izucheniü verkhnesiluriīskikh otlozheniī zapadnogo Pribalkhashia. Leningrad, Tsentralnyi nauchno-issledovatel'skiì geologorazvedochnyi institut.
OEHLERT. D. P

1887 Appendice sur les brachiopodes. In Fischer, P. H., ed., Manuel de conchyliologie et de paléontologie conchyliologique, ou histoire naturelle des mollusques vivants et fossiles. Paris, F. Savy, pp. 1189-1334.

1901 Fossiles dévoniens de Santa-Lucia (Province de Léon, Espagne). Société géologique de France, Bulletin, sér. 4. $1: 233-250$

ORMISTON, A. R

1973 A coiled tentaculite from the Salmontrout Limestone, Alaska. Journal of Paleontology 47:1065-1068.

PEDDER, A. E. H. and G. KLAPPER

1977 Fauna and correlation of the type section of the Cranswick Formation (Devonian), Mackenzie Mountains, Yukon Territory. Geological Survey of Canada, Paper 72-1B:227-234

PERRY, D. G

1979 Late Early Devonian reef associated brachiopods of the Prongs Creek Formation, northern Yukon. Journal of Paleontology 53:1094-1111.

PERRY, D. G., A. J. BOUCOT, and H. GABRIELSE

1981 Late Early Devonian brachiopods from the Mount Lloyd George area, northern British Columbia. Geological Survey of Canada, Bulletin 300:15-40.

PERRY, D. G., G. KLAPPER, and A. C. LENZ

1974 Age of the Ogilvie Formation (Devonian), northern Yukon: based primarily on the occurrence of brachiopods and conodonts. Canadian Journal of Earth Sciences 11:1055-1097

PERRY, D. G. and A. C. LENZ

1979 Emsian paleogeography and shelly fauna biostratigraphy of arctic Canada. Geological Association of Canada, Special Paper 18:133-160.

PHILLIPS, J

1836 Illustrations of the geology of Yorkshire: Pt. 2, the Mountain Limestone district. London, J. Murray. 253 $\mathrm{pp}$

1841 Figures and descriptions of the Palaeozoic fossils of Cornwall, Devon, and West Somerset. London, Longman. $231 \mathrm{pp}$.

PITRAT. C. W

1965 Suborder Spiriferida. In Moore, R. C., ed., Treatise on invertebrate paleontology, part $\mathrm{H}$, Brachiopoda Lawrence, Geological Society of America and University of Kansas Press, pp. 668-727

QUENSTEDT, F, A.

1868- Petrefactenkunde Deutschlands. Tübingen, L. F

1871 Fues. Vol. 2. $748 \mathrm{pp}$

RODRIGUEZ. J. and R. C. GUTSCHICK

1967 Brachiopods from the Sappington Formation (Devonian-Mississippian) of western Montana. Journal of Paleontology 41:364-384.

ROWLEY, R.R

1908 The geology of Pike County. Missouri Bureau of Geology and Mines, 2nd series, 8:1-122 
RUBEL, M. P. and T. L. MODZALEVSKAIA

1967 Novye siluriǔskie brakhiopody semeǐstva Athyrididae. Eesti NSV Teaduste Akademi Toimestised, Keemia-Geología 16:238-249.

RZHONSNITSKAIA, M. A.

1960 Die Korrelation der Karbonatischen Sedimente des Unter und Mittel Devons in der Sowjetunion und in Westeuropa. Prague, Arbeitstagung über die Stratigraphie des Silurs und des Devons, pp. 123-125.

1964 Devonian intervals of the principal sections of Siberia and their correlation with the Devonian of Europe International Geology Review 6:1085-1098.

1975 Biostratigrafiıa devona okrain Kuznetskogo basseĩna. Tom 2, Opisanie Brakhiopod Chast'l. Pentamerida i Atrypida. Vsesoluznyǐ nauchno-issledovatel'skiî geologicheskiǐ institut 244:1-232.

RZHONSNITSKAIA, M. A. and L. I. MIZENS

1977 Novy diagnoz roda Vagrania i novi rod Totia (Brachiopoda). Ezhegodnik Vsesoyuznogo Paleontologicheskogo obshchestva 19:92-101.

SADLICK, W

1965 Anderidium, a new term for lateral septa of chonetids (Brachiopoda). Journal of Paleontology 39:157-159.

SAPELNIKOV, V. P

1961 Nekotorye venlokskie Spiriferidae iz okrestnostei der. Elvy na vostochnom sklone srednego Urala. Geologira i poleznye iskopaemye Urala. Sverdlovskiǐ gornyî institut imenii V. V. Vakhrusheva, Trudy 38:50-60.

1972 Silurǐ̌skie Pentameracea vostochnogo sklona srednego i severnogo Urala. Akademiia nauk SSSR, Ural'skiî nauchnyǐ tsentr, Institut geologii i geokhimii, Trudy 98:1-295.

SARTENAER, $P$.

1961 Redescription of Leiorhynchus quadricostatus (Vanuxem), type species of Leiorhynchus Hall, 1860 (Rhynchonellacea). Journal of Paleontology 35:963976.

SARYCHEVA, T, G.

1960 Osnovy paleontologii: spravochnik dlia paleontologov i geologov SSSR. Mshanki, Brakhiopody; Prilozhenie, Foronidy. Moscow, Akademía nauk SSSR. Vol. 7, $343 \mathrm{pp}$.

SAVAGE, N. M

1970 New atrypid brachiopods from the Lower Devonian of New South Wales. Journal of Paleontology 44:655668.

1971 Brachiopods from the Lower Devonian Mandagery Park Formation, New South Wales. Palaeontology 14:387-422.

1974 The brachiopods of the Lower Devonian Maradana Shale, New South Wales. Palaeontographica (Abt. A) 146: $1-51$

SAVAGE, N. M., D. G. PERRY, and A. J. BOUCOT

1979 A quantitative analysis of Lower Devonian brachiopod distribution. Oregon State University, Annual Biology Colloquium and selected papers 37:169-200.
SCHMIDT, $H$. and D. J. MCLAREN

1965 Paleozoic Rhynchonellacea. In Moore, R. C., ed., Treatise on invertebrate paleontology, part $\mathrm{H}$, Brachiopoda. Lawrence, Geological Society of America and University of Kansas Press, pp. 552-597.

SCHNUR, J.

1953 Zusammenstellung und Beschreibung sammtlicher im Uebergangsgebirge der Eifel vorkommenden Brachiopoden. Paleontographica 3:169-248.

SCHUCHERT, C. and G. A. COOPER

1931 Synopsis of the brachiopod genera of the suborders Orthoidea and Pentameroidea with notes on the Telotremata. American Journal of Science 22:241251.

1932 Brachiopod genera of the suborders Orthoidea and Pentameroidea. Memoirs of the Peabody Museum of Natural History 4(1): 1-270

SCHUCHERT, C. and C. M. LEVENE

1929 Brachiopoda (Generum et genotyporum index et bibliographia). In Fossilium catalogus 1: Animalia. Berlin, W. Junk, pars 42, pp. 1-140.

SCHUCHERT, C. and T. P. MAYNARD

1913 Systematic paleontology of the lower Devonian deposits of Maryland, Brachiopoda. In Lower Devonian of Maryland. Baltimore, Maryland Geological Survey, pp. $290-450$.

SCUPIN, H.

1896 Versuch einer Classification der Gattung Spirifer. Neues Jahrbuch für Mineralogie, Geologie, und Paläontologie 2:239-248

1906 Das Devon der Ostalpen IV. Die Fauna des devonischen II. Lamellibranchiaten und Brachiopoden Fortsetzung, Brachiopoden. Zeitschrift der Deutschen geologischen Gesellschaft 58:213-306.

SHALER, N. S

1865 List of the Brachiopoda from the island of Anticosti sent by the Museum of Comparative Zoology to different institutions in exchange for other specimens, with annotations. Harvard University, Museum of Comparative Zoology, Bulletin 1:61-70.

SIEHL, A

1962 Der Greifensteiner Kalk (Eiflium, rheinisches Schiefergebirge) und seine Brachiopodenfauna. 1, Geologie: Atrypacea und Rostrospiracea. Palaeontographica (Abt . A) 119:173-221.

SIEMIRADZKI, J.

1906 Monografia warstw paleozoichzynch Podola. Akademiej Umiejetnosci. Krakow Komisja Fizyograficzna Sprawozdania, Czesc 2, 39:87-196

SMITH, R. E

1976a Lower Devonian (Lochkovian) brachiopods, paleoecology and biostratigraphy of the Canadian Arctic Islands. Ph.D. Thesis, Oregon State University. 362 pp.

1976b Biostratigraphy and paleoecology of the Atrypella community, Upper Silurian Douro Formation, Devon 
Island, District of Franklin. Geological Survey of Canada, Bulletin 256:13-37.

SMITH, R. E. and J. G. JOHNSON

1977 Atrypella scheii (Holtedahl) and Atrypella phoca (Salter), (Silurian Brachiopoda). Journal of Paleontology $51: 350-356$.

SOLLE, G.

1963 Hysterolites hystericus (Schlotheim) (Brachiopoda; Unterdevon), die Einstufung der oberen Graptolithenschiefer in Thüringen und die stratigraphische Stellung der Zone des Monograptus hercynicus. Geologisches Jahrbuch 81:171-220.

SOWERBY, J.

1815- The mineral conchology of Great Britain. London, B

1818 Meredith. Vol. 2, 235 pp.

STAINBROOK, M. A.

1951 Substitution for the preoccupied brachiopod name Hystricina. Washington Academy of Science, Journal $41: 196$

STRUSZ, D. L., B. D. E. CHATTERTON, and P. G. FLOOD

1970 Revision of the New South Wales Devonian brachiopod "Spirifer" yassensis. Proceedings of the Linnean Society of New South Wales 95:170-190.

STRUVE, W.

1955 Grunewaldtia aus dem Schonecker Richtschnitt (Brachiopoda, Mittel-Devon der Eifel). Senckenbergiana lethaea 36:205-234.

1956 Spinatrypa kelusiana, n. sp., eine Zeitmarke im Rheinischen Mittel-Devon (Brachiopoda). Senckenbergiana lethaea 37:383-409.

1961 Zur Stratigraphie der südlichen Eifler Kalkmulden (Devon: Emsium, Eifelium, Givetium). Senckenbergiana lethaea 42:291-345.

1964 Über Alatiformia-Arten und andere, äusserlich ähnliche Spiriferacea. Senckenbergiana lethaea 45:325-346.

1970 “Curvate Spiriferen" der Gattung Rhenothyris und einige andere Reticulariidae aus dem Rheinischen Devon. Senckenbergiana lethaea 51:449-577.

TALENT, J. A.

1956 Devonian brachiopods and pelecypods of the Buchan Caves Limestone, Victoria. Proceedings of the Royal Society of Victoria $68: 1-56$

1963 The Devonian of the Mitchell and Wentworth Rivers. Geological Survey of Victoria, Memoir 24:1-118.

TANSEY, V. O

1922 The fauna and correlations of the Bailey Limestone in the Little Saline Creek area of Ste. Genevieve County, Missouri. Missouri Bureau of Geology and Mines, Report, ser. 2, 17:166-212.

TORLEY, $K$

1934 Die Brachiopoden des Massenkalks der Oberen Givet-Stufe von Bilveringsen bei Iserlohn. Abhandlungen hrsg. von der Senckenbergischen naturforschenden Gesellschaft 43:69-148.
TRETTIN, H. P.

1978 Devonian stratigraphy, west-central Ellesmere Island, Arctic Archipelago. Geological Survey of Canada, Bulletin 302:1-119.

TYAZHEVA, A. P. and R. A. ZHAVORONKOVA

1972 Korally i brackhiopody pogranichnykh otlozheniĭ silura i nizhnego devona zapadnogo sklona iuzhnogo Urala. Moscow, Akademiía nauk SSSR, Bashkirskii filial, Institut geologii, pp. 56-141.

VANDERCAMMEN, A.

1957 Révision du genre Gurichella W. Paeckelmann, 1913 Mémoires de l'Institut royal des sciences naturelles de Belgique 138:1-50

VANDERCAMMEN, A. and T. F. KRANS

1964 Révision de quelques types de Spiriferidae de l'Espagne. Bulletin de l'Institut royal des sciences naturelles de Belgique 40(16): 1-40.

VANUXEM, L.

1842 Geology of New York, part III, comprising the survey of the third geological district. In Natural History of New York. Albany. 306 pp.

VEEVERS, J. J.

1959 The type species of Productella, Emanuella, Crurithyris, and Ambocoelia (Brachiopoda). Journal of Paleontology, 33:902-908.

von PEETZ, $\mathrm{H}$.

1901 Beiträge zur Kenntniss der Fauna aus den devonischen Schichten am Rande des Steinkohlenbassins von Kuznetzk. St. Petersburg, Travaux de la section géologique du Cabinet de Sa Majesté, 4:1-394.

WAAGEN, W. H.

1882- Salt Range fossils, part 4(2), Brachiopoda. Palaeon-

1885 tologia Indica, Memoir, ser. 13, 1:329-770.

WALCOTT, C. D.

1884 Paleontology of the Eureka District. United States Geological Survey, Monograph 8:1-298.

WALLISER, O. H

1964 Conodonten des Silurs. Abhundlungen des Hessischen Landesamtes für Bodenforschung 46:1-106.

1971 Conodont biostratigraphy of the Silurian of Europe. Geological Society of America, Memoir 127:195-206

WALMSLEY, V. G

1965 Isorthis and Salopina (Brachiopoda) in the Ludlovian of the Welsh borderland. Palaeontology 8:454-477.

WALMSLEY, V. G. and A. J. BOUCOT

1971 The Resserellinae-a new subfamily of Late Ordovician to Early Devonian dalmanellid brachiopods Palaeontology 14:487-531.

1975 The phylogeny, taxonomy and biogeography of Silurian and Early to Mid Devonian Isorthinae (Brachiopoda). Palaeontolographica (Abt. A) 148:34-108.

WATERHOUSE. J. B

1973 Communal hierarchy and significance of environmental parameters for brachiopods: the New Zealand 
Permian model. Royal Ontario Museum, Life Sciences Contributions 92:1-49.

WENJUKOV, P. N.

1899 Fauna siluriǐskikh otlozheniǐ Podol'skoi gubernii. Materialy dla geol. Rossii 19:25-256.

WHITE. C. A

1862 Description of new species of fossils from the Devonian and Carboniferous rocks of the Mississippi Valley. Proceedings of the Boston Society of Natural History 9:8-33.

WILLIAMS, A.

1950 New stropheodontid brachiopods. Washington Academy of Sciences, Journal 40:277-282.

1953 North American and European stropheodontids: their morphology and systematics. Geological Society of America, Memoir 56:1-67.

1963 The Caradocian brachiopod faunas of the Bala District,
Merionethshire. Bulletin of the British Museum (Natural History) Geology 8:327-471.

WILLIAMS, J. S.

1943 Stratigraphy and fauna of the Louisiana Limestone of Missouri. United States Geological Survey, Professional Paper 203:1-133.

WRIGHT, A. D.

1965 Superfamily Enteletacea Waagen, 1884. In Moore, R. C., ed., Treatise on invertebrate paleontology, part H, Brachiopoda. Lawrence, Geological Society of America and University of Kansas Press, pp. 328-346.

1968a The brachiopod Dicoelosia biloba (Linnaeus) and related species. Arkiv för Zoologi 20:261-319.

1968b A new genus of dicoelosiid brachiopod from Dalarna. Arkiv för Zoologi 22:127-138.

1972 The brachiopod Acanthocrania in the Ordovician of Wales. Palaeontology 15:473-475. 


\section{Plates}

All stratigraphic measurements in the following plates were taken with the top of the Delorme Formation as the datum, unless stated otherwise. 
Plate 1, figs. 1-23

Fossiliferous hand specimens and inarticulate brachiopods Craniops, Orbiculoidea, and Schizotreta of the Delorme Formation, Mackenzie Mountains.

Figs. 1-3. Views of a partially etched silicified coquina, Delorme Formation (Zlichovian), S-3, sample S4560.8-573.0 m, ROM $33101 \mathrm{~m}, \times 0.5$.

1. Upper bedding-plane surface. Note the abundance of Cortezorthis maclareni Johnson and Talent, Warrenella sekwensis Ludvigsen and Perry, and digitate lenses of brachiopods.

2. Lateral view perpendicular to the bedding surface. Note the distinct lenses of brachiopods, the pelmatozoan debris, and the corals with most of the disarticulated brachiopod shells resting with concave side downwards, indicating the presence of bottom currents with sufficient energy to overturn the shells.

3. Lower bedding-plane surface. Note the Atrypa cf. $A$. nevadana Merriam oriented with the pedicle valve downwards.

Fig. 4. Partially etched silicified coquina of pelmatozoan debris, Delorme Formation (Pragian), S-1, sample A385.6 m, ROM $33102, \times 0.6$. Note the large pelmatozoan ossicles of which only the outer part is silicified.

Fig. 5. Upper bedding-plane surface of limy, argillaceous dolostone with abundant conularids and a few fish scales, Delorme Formation (mid-Lochkovian), S-2, sample B248.4-265.2 m, ROM 33103, × 1.0.

Figs. 6-14. Craniops sp. 1.

6,7 . Exterior and interior views of brachial valve, Delorme Formation (Zlichovian), S-3, sample S4-466.3 m, ROM 33104, $\times 6.0$
8, 9. Dorsal and ventral views of articulated shell, Delorme Formation (Zlichovian), S-3, sample S4-466.3 m, ROM 33105, $\times 6.0$. Note the concentric ornament and the ventral attachment scar.

10, 11. Exterior and interior views of pedicle valve, Delorme Formation (Zlichovian), S-3, sample S4-466.3 m, ROM 33106, $\times 6.0$. Note the $\mathrm{V}$-shaped anterior adductor muscle scars situated near midlength in fig. 11 , and also in fig. 13 .

12, 13. Exterior and interior views of pedicle valve, Delorme Formation (Zlichovian), S-3, sample S4-466.3 m, Rом 33107, $\times 6.0$.

14. Interior view of brachial valve, Delorme Formation (Zlichovian), S-3, sample S4-466.3 m, ROM 33108, × 6.0 .

Figs. 15-20. Orbiculoidea sp. 1.

15, 16. Exterior and oblique exterior views of brachial valve, Delorme Formation (Lochkovian), S-2, sample B248.4$265.2 \mathrm{~m}$, ROM $33109, \times 1.2$.

17, 18. Oblique interior and interior views of pedicle valve, Delorme Formation (Lochkovian), S-2, sample B248.4$265.2 \mathrm{~m}$, ROM $33110, \times 2.3$. Note the pedicle slit (?) near the base of the "keyhole" structure.

19, 20. Oblique exterior and exterior views of brachial valve, Delorme Formation (Lochkovian), S-1, sample A548.6T m, ROM $33111, \times 1.4$

Figs. 21-23. Schizotreta sp. 1. Interior, exterior, and oblique exterior views of brachial valve; Delorme Formation (early Pragian), S-2, sample B 105.2 m, ROM $33112, \times 6.0$. Note the well-developed V-shaped muscle scar in fig. 21. 


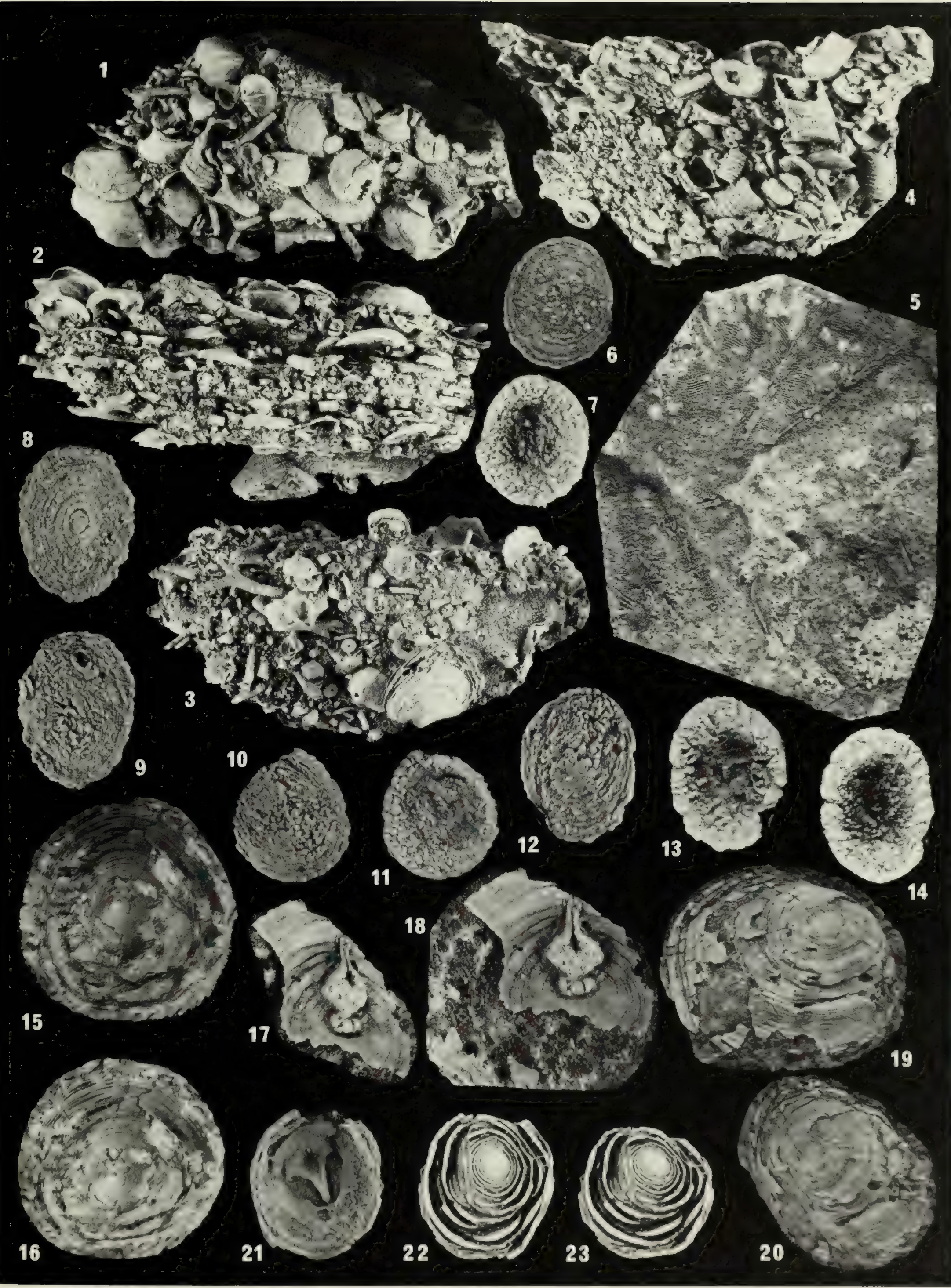


Plate 2, figs. 1-62

Inarticulate brachiopods Schizotreta, Philhedra, and Acanthocrania; articulate brachiopods new genus hesperorthid, "Dolerorthis", and Ptychopleurella.

Figs. 1, 2. Schizotreta sp. 1. Exterior and interior views of brachial valve, Delorme Formation (early Pragian), S-2, sample B128.6 m, ROM 33113, × 6.0.

Figs. 3-8. Philhedra sp. 1.

3, 4. Interior and exterior views of brachial valve, Delorme Formation (Zlichovian), S-1, sample A62.5-68.6 m, ROM $33114, \times 5.2$ and $\times 3.1$ respectively. Note the well-developed, paired adductor muscle scars in fig. 3 , and also in fig. 6 .

5, 6. Exterior and interior views of brachial valve, Delorme Formation (Zlichovian), S-1, sample A62.5-68.6 m, ROM $33115, \times 3.1$.

7, 8. Lateral and exterior views of brachial valve, Delorme Formation (Zlichovian), S-1, sample A62.5-68.6 m, ROM $33116, \times 3.1$

9, 10. Acanthocrania sp. 1. Exterior and interior views of brachial valve, Delorme Formation (Zlichovian), S-1, A62.5$68.6 \mathrm{~m}$, ROM $33117, \times 3.1$.

Figs. 11-19. New genus hesperorthid sp. 1.

11-13. Oblique interior, interior, and exterior views of brachial valve; Delorme Formation (Pragian), S-1, sample OLDA336.8 m, ROM $33118, \times 2.0$.

14-16. Exterior, posterior, and lateral views of pedicle valve; Delorme Formation (Pragian), S-1, sample OLDA336.8 m, ROM $33119, \times 2.0$.

17-19. Exterior, interior, and oblique interior views of pedicle valve; Delorme Formation (late Lochkovian), S-1, sample OLDA481.6T m, ROM $33120, \times 2.0$.

Figs. 20-22. "Dolerorthis" sp. 1. Oblique interior, interior, and exterior views of brachial valve; transitional facies (Pridolian), S-11, 186.0-193.5 m above the top of the Whittaker Formation, GSC locality 69062 , ROM $33121, \times 1.6$.

Figs. 23-26. "Dolerorthis"' borealis Lenz?. Exterior, interior, oblique interior, and lateral views of pedicle valve; Delorme Formation (late Lochkovian), S-1, sample OLDA493.8T m, ROM 33122, × 4.2.

Figs. 27-43. "Dolerorthis" smithi sp. nov.

27,28 . Interior and exterior views of brachial valve, Delorme Formation (late Lochkovian), S-1, sample A493.8 m, holotype
ROM $33123, \times 1.6$. Note the complex system of dendritic pallial markings on fig. 27.

29, 30. Exterior and interior views of pedicle valve, Delorme Formation (late Lochkovian), S-1, sample A484.6 m, paratype ROM $33124, \times 1.6$.

31,32 . Interior and exterior views of brachial valve, Delorme Formation (late Lochkovian), S-1, sample A470.9 m, paratype ROM $33125, \times 1.6$.

33-36. Exterior, interior, oblique interior, and lateral views of pedicle valve; Delorme Formation (late Lochkovian), S-1, sample A470.9 m, paratype Rом $33126, \times 1.6$.

37-39. Oblique interior, exterior, and posterior views of pedicle valve; Delorme Formation (late Lochkovian), S-1, sample A470.9 m, paratype ROM $33127, \times 1.6$.

40,41 . Interior and exterior views of a small brachial valve, Delorme Formation (late Lochkovian), S-1, sample A470.9 m, paratype ROM 33128, × 1.6 .

42,43 . Oblique interior and exterior views of a small brachial valve, Delorme Formation (late Lochkovian), S-1, sample A470.9 m, paratype ROM $33129, \times 1.6$.

Figs. 44-58. "Dolerorthis" borealis Lenz.

44,45 . Interior and oblique interior views of brachial valve, Delorme Formation (Lochkovian-Pragian), S-2, sample B166.1-182.9 m, ROM 33130, $\times 1.6$.

46. Interior view of brachial valve, Delorme Formation (Lochkovian-Pragian), S-2, sample B166.1-182.9 m, ROM $33131, \times 1.6$.

47-49. Exterior, oblique interior, and posterior views of pedicle valve; Delorme Formation (Lochkovian-Pragian), S-2, sample B166.1-182.9 m, ROM 33132, × 1.6 .

50,51 . Exterior and interior views of pedicle valve, Delorme Formation (Lochkovian-Pragian), S-2, sample B166.1-182.9 m, ROM $33133, \times 1.6$.

52-55. Anterior, exterior, interior, and oblique interior views of brachial valve; Delorme Formation (late Lochkovian), S-2, sample B181.4-182.9 m, ROM 33134, × 1.6.

56-58. Posterior, oblique interior, and exterior views of pedicle valve; Delorme Formation (late Lochkovian), S-2, sample B181.4-182.9 m, Rом 33135, × 1.6 .

Figs. 59-62. Ptychopleurella sp. 1. Oblique exterior, exterior, posterior, and oblique interior views of pedicle valve; Delorme Formation (Ludlovian), S-9, sample $\mathrm{L} 161.2 \mathrm{~m}(33.8 \mathrm{~m}$ below the top of the Delorme Formation), Rom $33136, \times 6.0$. Note the lamellose growth lines on fig. 60 . 

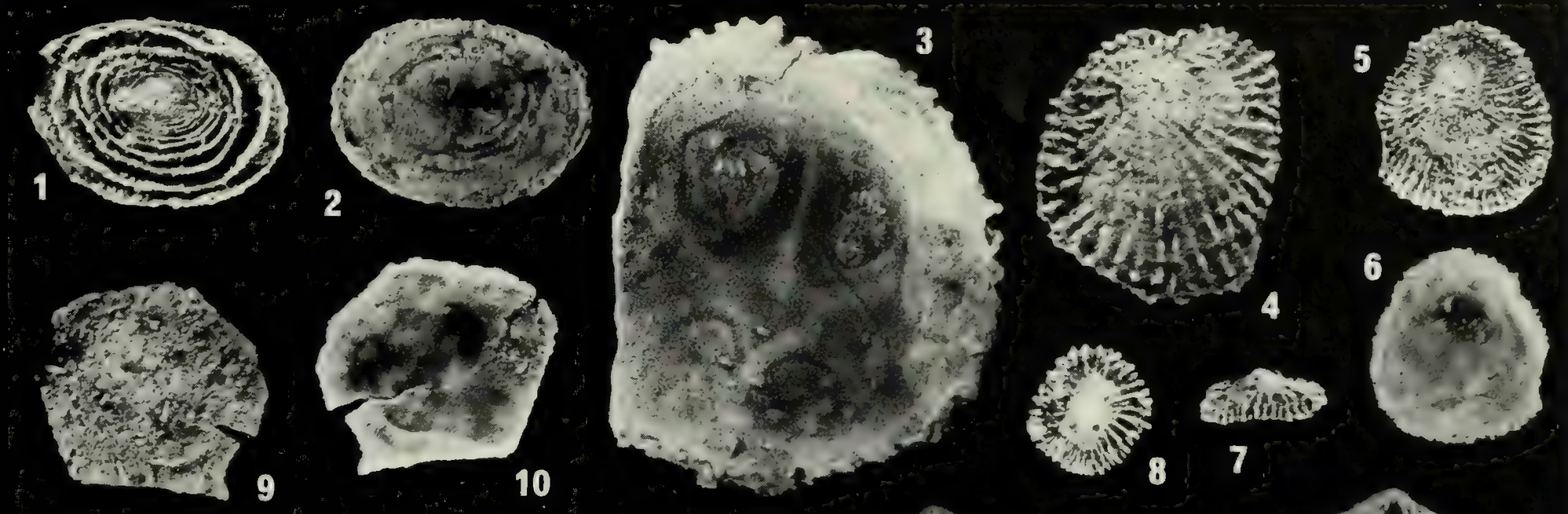

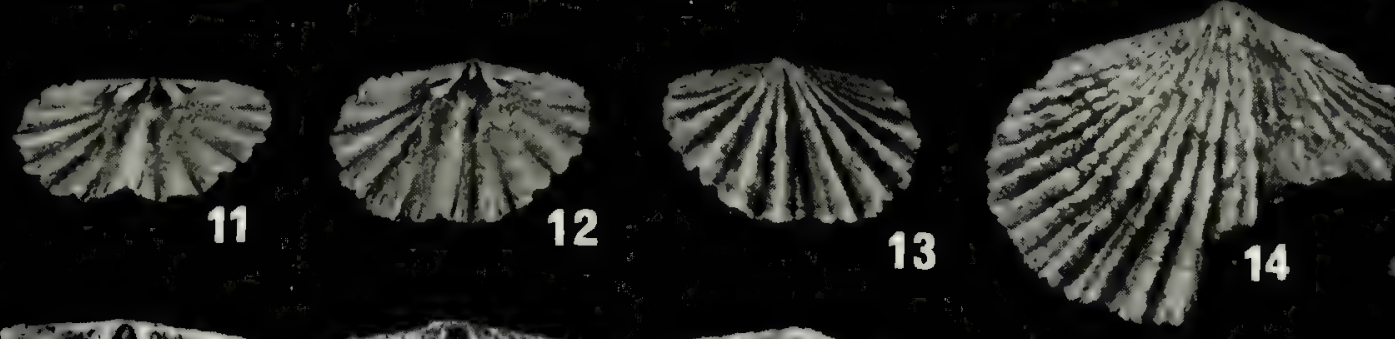

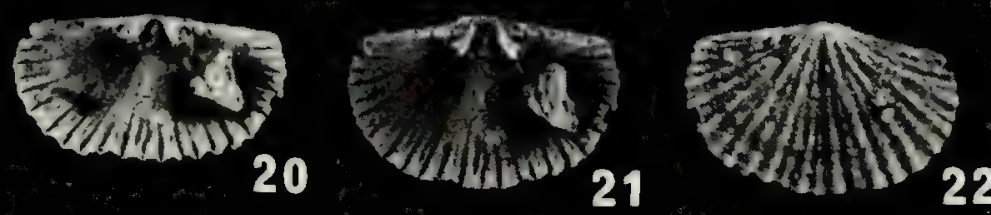

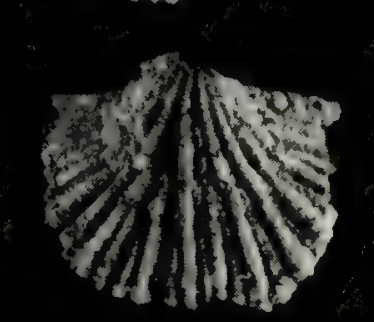

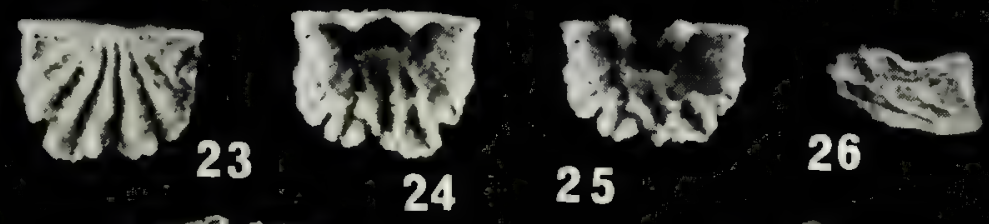
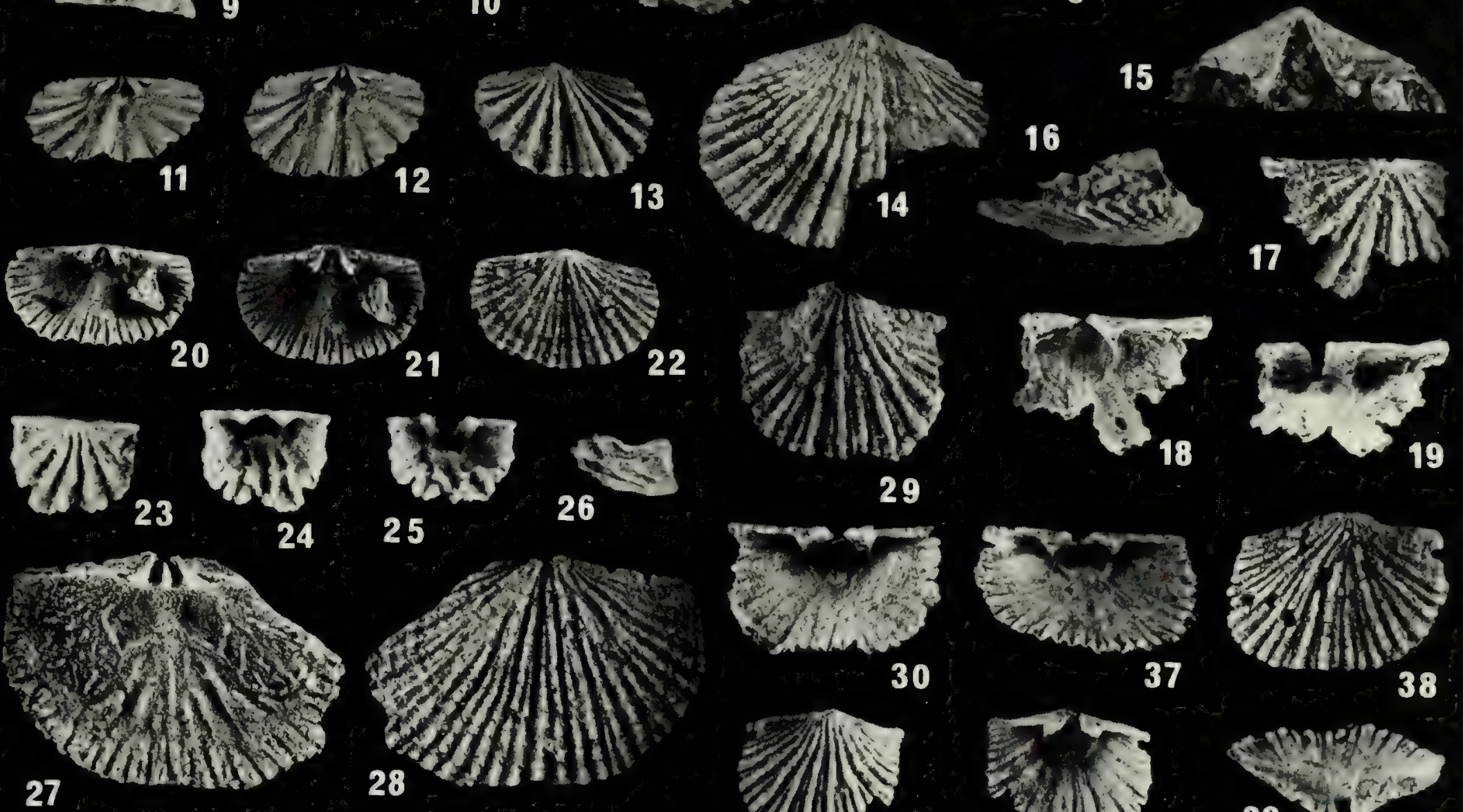

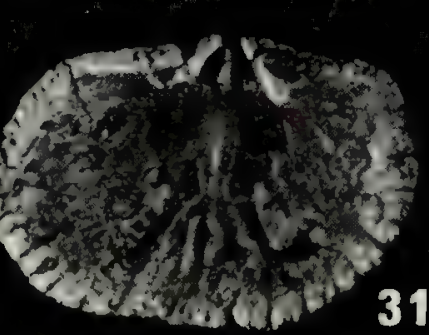

atesto

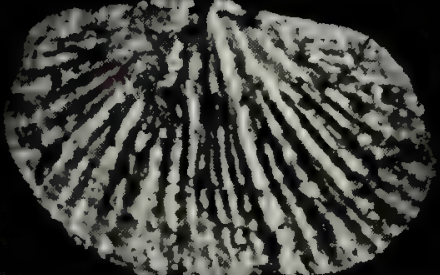

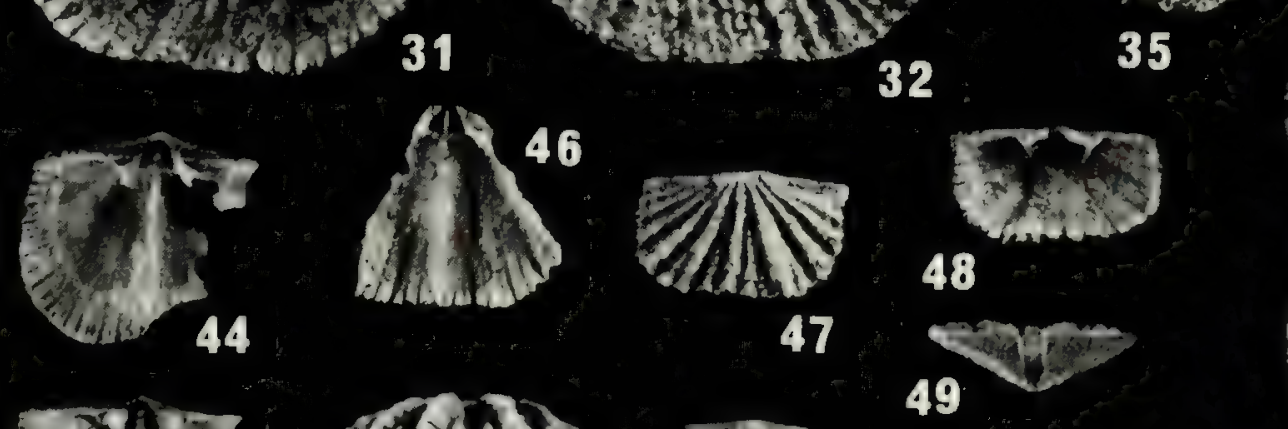

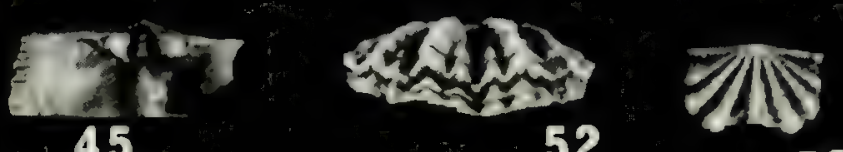

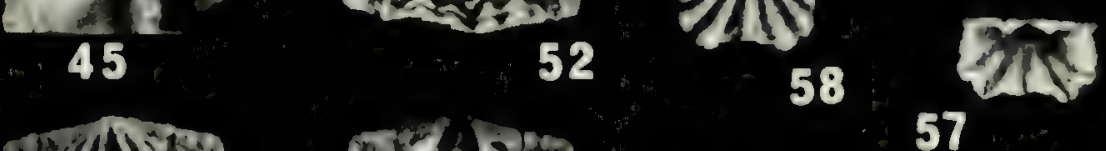

רश:
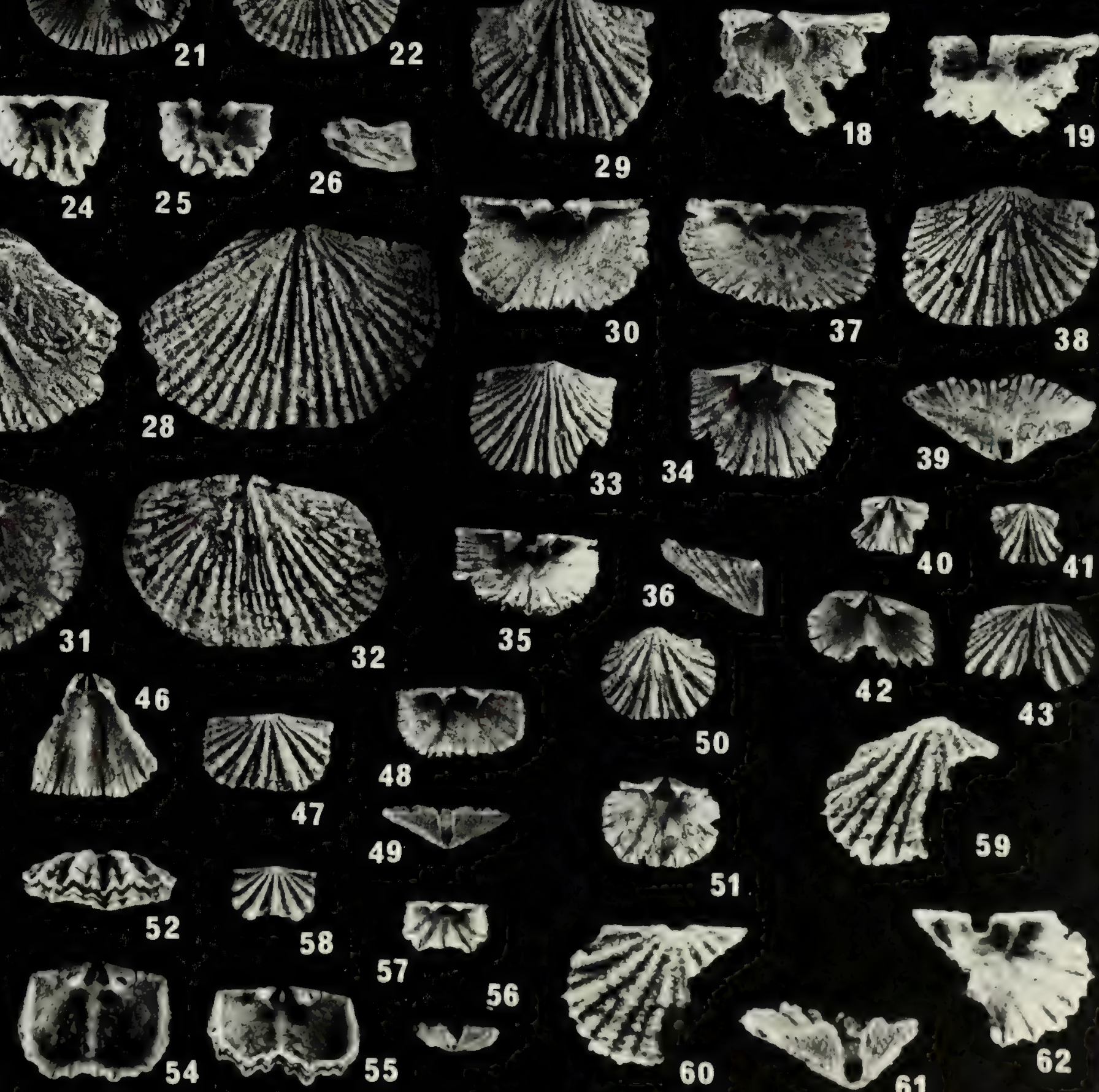

19

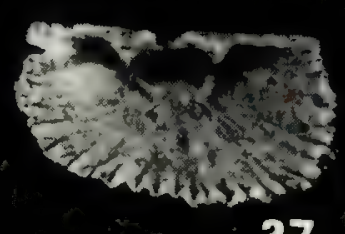

37
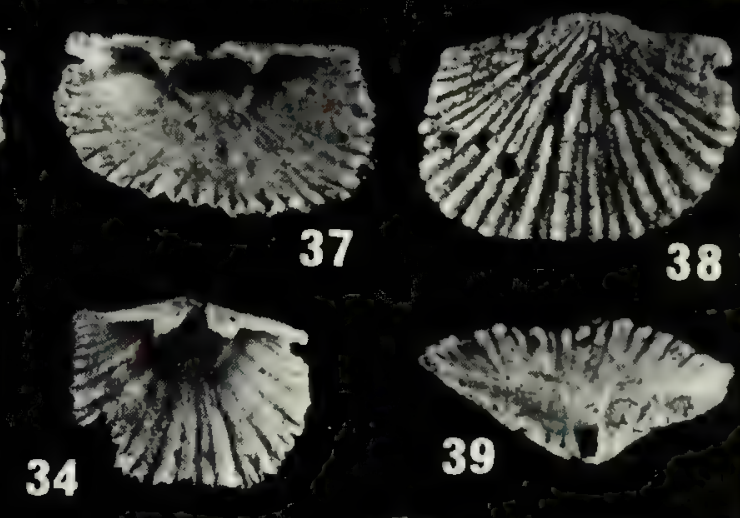

33

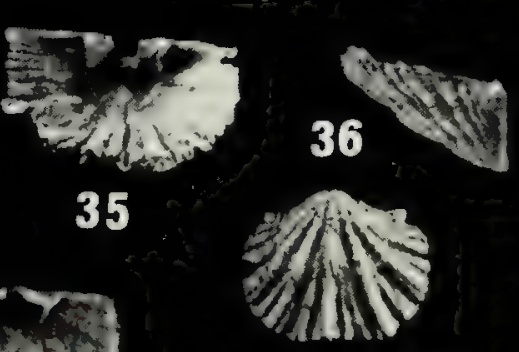

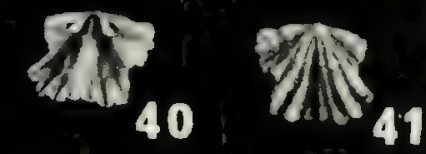

50

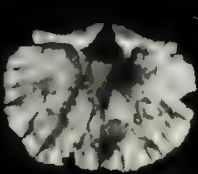

51.
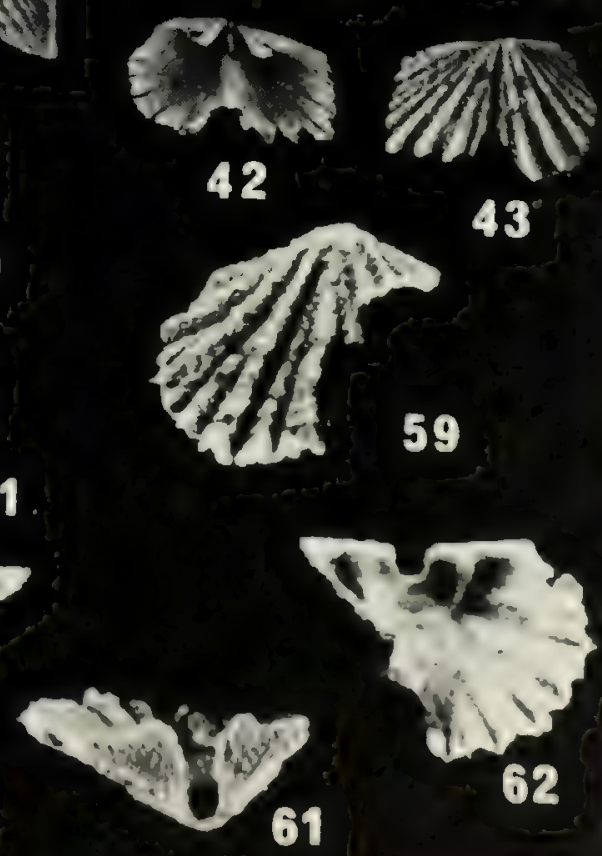
Plate 3, figs. 1-96

Articulate brachiopod Skenidioides

Figs, 1-53. Skenidioides variabilis Lenz, $\times 3.2$.

1-3. Interior, oblique interior, and posterior views of brachial valve; Delorme Formation (Zlichovian), S-1, sample A62.5$68.6 \mathrm{~m}$. ROM 33137.

4-6. Exterior, interior, and oblique posterior views of brachial valve; Delorme Formation (Zlichovian), S-1, sample A62.5$68.6 \mathrm{~m}$, ROM 33138 .

7-9. Exterior, interior, and posterior views of pedicle valve; Delorme Formation (Zlichovian), S-1, sample A62.5-68.6 m, ROM 33139.

10-12. Interior, exterior, and anterior views of pedicle valve; Delorme Formation (Zlichovian), S-1, sample A62.5-68.6 m, ROM 33140 .

13, 14. Oblique posterior and exterior views of pedicle valve; Delorme Formation (Zlichovian), S-1, sample A62.5-68.6 m, ROM 33141

15-17. Exterior, oblique interior, and interior views of brachial valve; Delorme Formation (Zlichovian), S-1, sample A62.5$68.6 \mathrm{~m}$, ROM 33142 .

18-20. Interior, oblique lateral, and oblique interior views of brachial valve; Delorme Formation (Zlichovian), S-1, sample A62.5-68.6 m, ROM 33143.

21, 22. Exterior and anterior views of pedicle valve, Delorme Formation (early Pragian), S-1, sample A410.0 m, ROM 33144. Note the flange development on the interarea in fig. 22, and also in fig. 24 .

23, 24. Exterior and anterior views of pedicle valve, Delorme Formation (early Pragian), S-1, sample A410.0 m, ROM 33145.

$25,26,29$. Anterior, exterior, and posterior views of pedicle valve; Delorme Formation (early Pragian), S-1, OLDA384.0 m, ROM 33146.

27, 28. Posterior and exterior views of pedicle valve, Delorme Formation (early Pragian), S-1, OLDA384.0 m, ROM 33147.

30, 31. Exterior and interior views of brachial valve, Delorme Formation (early Pragian), S-1, OLDA388.6 m, ROM 33148.

32, 33. Exterior and interior views of brachial valve, Delorme Formation (early Pragian), S-1, OLDA388.6 m, ROM 33149.

34-36. Posterior, anterior, and interior views of pedicle valve; Delorme Formation (early Pragian), S-1, sample OLDA388.6 m, ROM 33150

37-39. Posterior, anterior, and lateral views of articulated shell; Delorme Formation (early Pragian), S-2, sample B105.2 m, ROM 33151 .

40. Posterior view of articulated shell, Delorme Formation (early Pragian), S-2, sample B105.2 m, ROM 33152.

41,42 . Interior and exterior views of brachial valve, Delorme Formation (early Pragian), S-2, sample B128.6 m, ROM 33153.

43. Anterior view of pedicle-valve fragment showing a welldeveloped flange, Delorme Formation (early Pragian), S-2, sample B 128.6 m, ROM 33154

44, 45. Exterior and anterior views of pedicle valve, Delorme Formation (early Pragian), S-2, sample B128.6 m, ROM 33155.
46-48. Exterior, anterior, and posterior views of pedicle valve; Delorme Formation (late Lochkovian), S-2, sample B225.6 m, ROM 33156.

49-51. Interior, oblique lateral, and exterior views of brachial valve; Delorme Formation (late Lochkovian), S-2, sample B225.6 m, ROM 33157 .

52, 53. Exterior and interior views of brachial valve, Delorme Formation (early Pragian), S-3, sample S4-624.8 m, ROM 33158.

Figs. 54-96. Skenidioides blussoni sp. nov., $\times 3.2$.

54, 55. Interior and exterior views of brachial valve, Delorme Formation (Zlichovian), S-3, sample S4-64.0-65.5 m, holotype ROM 33159

56-59. Ventral, posterior, anterior, and lateral views of articulated shell; Delorme Formation (Zlichovian), S-3, sample S4-64.0-65.5 m, paratype Rом 33160.

60-64. Dorsal, ventral, posterior, anterior, and lateral views of articulated shell; Delorme Formation (Zlichovian), S-3, sample S4-64.0-65.5 m, paratype ROM 33161.

65-68. Exterior, anterior, posterior, and lateral views of pedicle valve; Delorme Formation (Zlichovian), S-3, sample S4-64.0$65.5 \mathrm{~m}$, paratype ROM 33162.

69-71. Exterior, interior, and oblique lateral views of brachial valve; Delorme Formation (Zlichovian), S-3, sample S4-64.0$65.5 \mathrm{~m}$, paratype ROM 33163.

72-74. Interior, exterior, and posterior views of pedicle valve; Delorme Formation (Zlichovian), S-3, sample S4-64.0-65.5 m, paratype ROM 33164.

75, 76. Interior and exterior views of brachial valve, Delorme Formation (Zlichovian), S-3, sample S4-64.0-65.5 m, paratype ROM 33165.

77-80. Exterior, interior, posterior, and lateral views of pedicle valve; Delorme Formation (Zlichovian), S-3, sample S4-64.0$65.5 \mathrm{~m}$, paratype ROM 33166.

81-83. Lateral, exterior, and posterior views of pedicle valve; Delorme Formation (Zlichovian), S-3, sample S4-143.3 m, paratype ROM 33167.

84,85 . Interior and exterior views of brachial valve, Delorme Formation (Zlichovian), S-3, sample S4-143.3 m, paratype ROM 33168.

86, 87. Exterior and interior views of pedicle valve, Delorme Formation (Zlichovian), S-3, sample S4-143.3 m, paratype ROM 33169

88, 89. Exterior and interior views of pedicle valve, Delorme Formation (Zlichovian), S-3, sample S4-143.3 m, paratype ROM 33170 .

90-92. Lateral, posterior, and exterior views of pedicle valve; Delorme Formation (Zichlovian), S-3, sample S4-466.3 m, paratype ROM 33171.

93. Exterior view of pedicle valve, Delorme Formation (Zlichovian), S-3, sample S4-466.3 m, paratype ROM 33172.

94-96. Interior, oblique lateral, and exterior views of brachial valve; Delorme Formation (Zlichovian), S-3, sample S4$466.3 \mathrm{~m}$, paratype Rом 33173. 


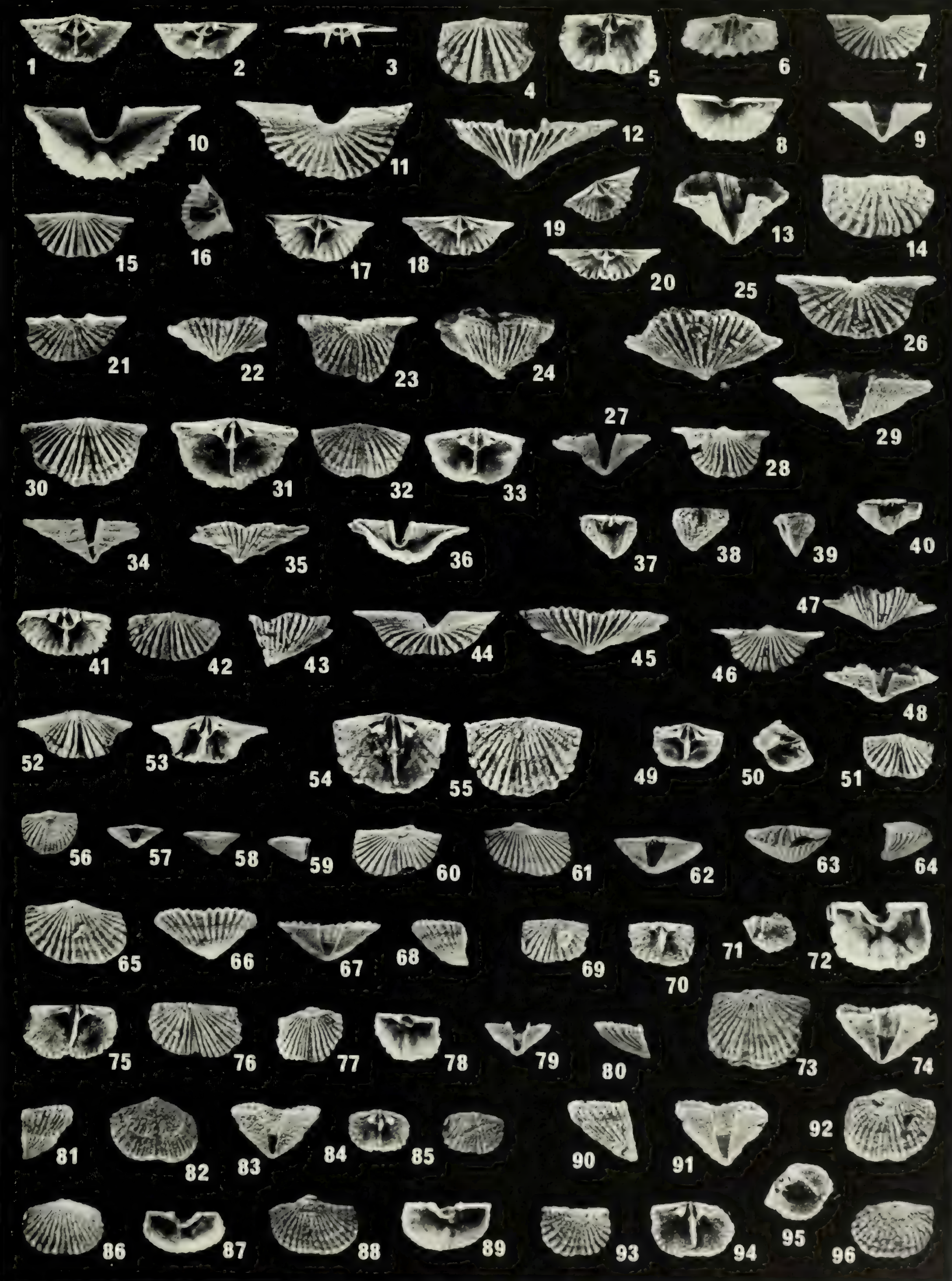


Plate 4, figs. $1-46$

Articulate brachiopod Cortezorthis.

Figs. 1-40. Cortezorthis maclareni Johnson and Talent.

1,2. Oblique lateral and posterior views of tectonically sheared shell, Delorme Formation (Zlichovian), S-3, sample S4-53.3$54.9 \mathrm{~m}$, ROM $33174, \times 1.0$.

3-5. Ventral, dorsal, and anterior views of slightly distorted shell; Delorme Formation (Zlichovian), S-3, sample S4-53.3$54.9 \mathrm{~m}$, вом $33175, \times 1.0$.

6-8. Oblique dorsal, dorsal, and ventral views of natural, silicified internal mould; Delorme Formation (Zlichovian), S-3, sample S4-64.0-65.5 m, ROM 33176, × 1.5.

9-11. Interior, exterior, and oblique interior views of brachial valve; Delorme Formation (Zlichovian), S-3, sample S4$143.3 \mathrm{~m}$, ROM 33177, figs. 9 and $10 \times 1.1$, fig. $11 \times 1.3$.

12-14. Oblique interior, interior, and exterior views of pedicle valve; Delorme Formation (Zlichovian), S-3, sample S4$143.3 \mathrm{~m}$, ROM 33178 , fig. $12 \times 1.3$, figs. 13 and $14 \times 1.1$.

15, 16. Ventral and anterior views of articulated shell, Delorme Formation (Zlichovian), S-3, sample S4-143.3 m, ROM 33179 , $\times 1.1$. Note that the modes of distortion of the small, attached $C$. maclareni and the large shell are similar, proving the tectonic origin of the asymmetry.

17-19. Lateral, posterior, and anterior views of articulated shell; Delorme Formation (Zlichovian), S-3, sample S4-143.3 m, ROM $33180, \times 1.1$.

20. Interior view of brachial valve, Delorme Formation (Zlichovian), S-3, sample S4-143.3 m, ROM 33181, $\times 1.1$. Note the striated posterior adductor muscle scars.

21,22 . Interior and anterior views of margin of brachial valve, Delorme Formation (Zlichovian), S-3, sample S4-257.6 m, ROM $33182, \times 1.1$ and $\times 1.4$ respectively.
23-27. Dorsal, ventral, lateral, anterior, and posterior views of articulated shell; Delorme Formation (Zlichovian), S-3, sample S4-502.9-507.5 m, ROM 33183, × 1.1. Note the well-developed ventral carina.

28-31. Ventral, dorsal, lateral, and anterior views of a small shell; Delorme Formation (Zlichovian), S-3, sample S4-502.9 $507.5 \mathrm{~m}$, ROM $33184, \times 1.1$.

32, 33. Exterior and interior views of brachial valve, Delorme Formation (Zlichovian), S-3, sample S4-502.9-507.5 m, ROM $33185, \times 1.1$. Note the presence of encrusting auloporid corals; corallites are directed anteriorly.

34-38. Dorsal, ventral, lateral, posterior, and anterior views of very small shell; Delorme Formation (Zlichovian), S-3, sample S4-519.7 m, ROM 33186, × 2.7 .

39, 40. Exterior and interior views of brachial valve, Delorme Formation (Zlichovian), S-1, sample A7.6-10.7 m, ROM 33187, $\times 1.0$.

Figs. 41-46. Cortezorthis cf. C. windmillensis (Johnson and Talent).

41, 42. Exterior and interior views of brachial valve, Delorme Formation (late Lochkovian), S-1, sample A470.9 m, ROM $33188, \times 1.8$. Note the low septum developed anteriorly in fig. 42 , and also in fig. 46.

43. Interior view of pedicle valve, Delorme Formation (late Lochkovian), S-1, sample A470.9 m, ROM 33189, × 1.8 .

44,45 . Interior and exterior views of pedicle valve, Delorme Formation (late Lochkovian), S-2, sample B166.1-182.9 m, ROM 33190, × 1.8 .

46. Interior view of brachial valve, Delorme Formation (late Lochkovian), S-2, sample B166.1-182.9 m, ROM $33191 \times 1.8$. 


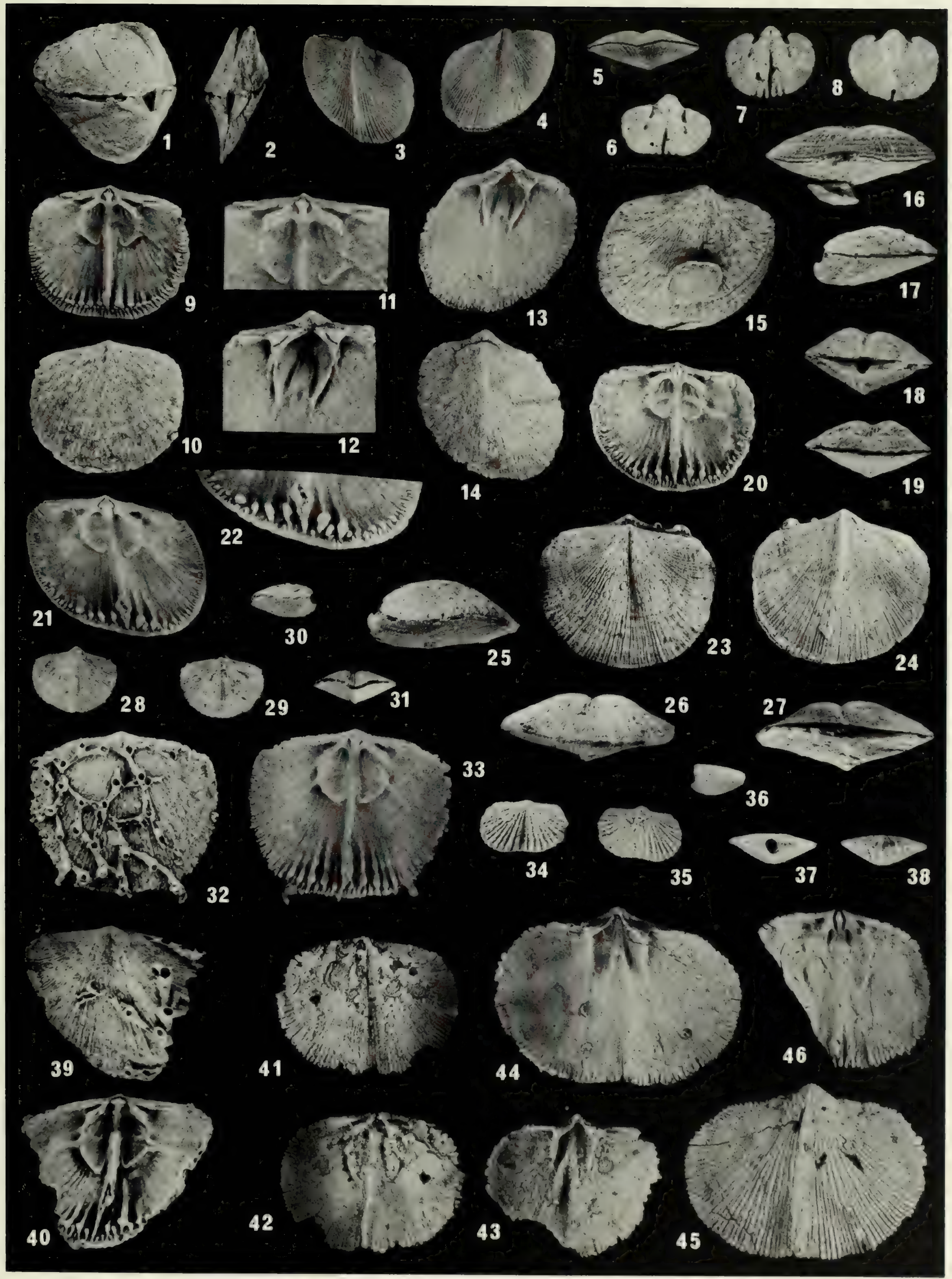


Plate 5, figs. $1-48$

Articulate brachiopods Cortezorthis, Protocortezorthis, and ?Protocortezorthis

Figs. 1-11. Cortezorthis norfordi Lenz.

1, 2. Interior and exterior views of pedicle valve, Delorme Formation (early Pragian), S-1, sample A442.0 m, ROM 33192, $\times 1.3$. Note the elongate ventral muscle field in fig. 1 , and also in figs. 6 and 7 .

3. Interior view of brachial valve, Delorme Formation (early Pragian), S-1, sample A442.0 m, ROM 33193, $\times 1.3$.

4. Interior view of brachial valve, Delorme Formation (early Pragian), S-1, sample A442.0 m, ROM 33194, $\times 1.3$.

5. Anterior view of articulated shell, Delorme Formation (early Pragian), S-1, sample A442.0 m, ROM 33195, $\times 1.3$. Note poorly developed ventral carina.

6-8. Interior, oblique interior, and exterior views of pedicle valve; Delorme Formation (early Pragian), S-1, sample A442.0 m, ROм 33196, $\times 1.3$.

9, 10. Interior and exterior views of pedicle valve, Delorme Formation (early Pragian), S-2, sample B121.9 m, ROM 33197 , $\times 1.8$.

11. Interior view of brachial valve, Delorme Formation (early Pragian), S-2, sample B121.9 m, ROM 33198, × 1.8

\section{Figs. 12-18. Cortezorthis perryi Lenz.}

12, 14. Exterior and interior views of brachial valve, Delorme Formation (Pragian), S-1, sample A342.9 m, ROM 33199, $\times$ 2.0. Note the coarse, bifurcating and trifurcating costae in fig. 12 , and also in fig. 18.

13. Interior view of brachial valve, Delorme Formation (Pragian), S-1, sample A342.9 m, ROM $33200, \times 2.0$.

15, 16. Exterior and interior views of brachial valve, Delorme Formation (Pragian), S-1, sample OLDA336.8 m, ROM 33201, $\times 2.0$.

17, 18. Interior and exterior views of pedicle valve fragment, Delorme Formation (Pragian), S-1, sample OLDA336.8 m, ROM $33202, \times 2.0$.

Figs. 19-33. Protocortezorthis aff. P. fornicatimcurvata (Fuchs)

19, 20. Exterior and interior views of brachial valve, Delorme Formation (Lochkovian), S-1, sample A528.8 m, ROM 33203, × 1.9. Note the very weakly impressed dorsal muscle field in fig. 20 , and also in figs. 29 and 33.
21, 22. Interior and exterior views of brachial valve, Delorme Formation (Lochkovian), S-1, sample A528.8, ROM 33204, × 1.9 .

23. Anterior view of articulated shell, Delorme Formation (Lochkovian), S-1, sample A528.8 m, ROM 33205, × 1.9.

24. Interior view of pedicle valve, Delorme Formation (Lochkovian), S-1, sample A536.4 m, ROM 33206, $\times 1.9$. Note the elongate, divided ventral muscle field, also apparent in figs. 26 , 27,31 , and 32 .

25-27. Exterior, interior, and oblique interior views of pedicle valve; Delorme Formation (Lochkovian), S-1, sample A536.4 m, ROM 33207, $\times 1.9$.

28, 29. Exterior and interior views of brachial valve, Delorme Formation (Lochkovian), S-2, sample B221.0 m, ROM 33208, × 1.9 .

30-32. Exterior, interior, and oblique interior views of pedicle valve; Delorme Formation (Lochkovian), S-2, sample B221.0 m, ROM 33209, × 1.9 .

33. Interior view of brachial valve, Delorme Formation (Lochkovian), S-2, sample B221.0 m, ROM 33210, × 1.9 .

Figs. 34-44. Protocortezorthis natlensis sp. nov.

34-36. Exterior, interior, and oblique interior views of brachial valve; Delorme Formation (Zlichovian), S-3, sample S4$143.3 \mathrm{~m}$, holotype ROM $33211, \times 3.2$.

37-40. Exterior, interior, oblique interior, and lateral views of pedicle valve; Delorme Formation (Zlichovian), S-3, sample S4-143.3 m, paratype ROM 33212, × 3.2.

41, 42. Exterior and interior views of pedicle valve, Delorme Formation (Zlichovian), S-3, sample S4-143.3 m, paratype ROM $33214, \times 3.2$.

43. Interior view of brachial valve, Delorme Formation (Zlichovian), S-3, sample S4-143.3 m, paratype ROM $33215 \times 3.2$.

44. Interior view of brachial valve, Delorme Formation (Zlichovian), S-3, sample S4-143.3 m, paratype ROM 33216, × 3.2 .

Figs. 45-48. ?Protocortezorthis sp. 1.

45-47. Exterior, oblique interior, and interior views of brachial valve; Delorme Formation (Pragian), S-1, sample OLDA336.8 m, ROM $33217, \times 1.5$.

48. Interior view of pedicle valve, Delorme Formation (Pragian), S-1, sample OLDA336.8 m, ROM 33218, × 1.5. External ornament of shell is not preserved. 


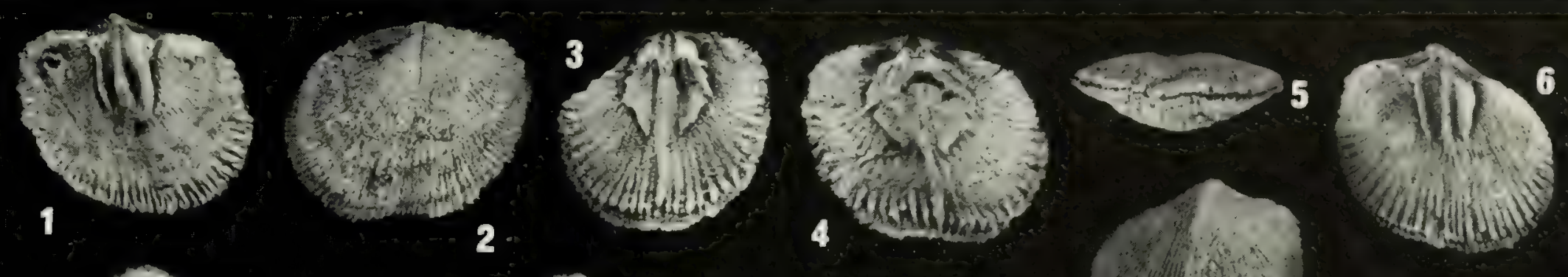

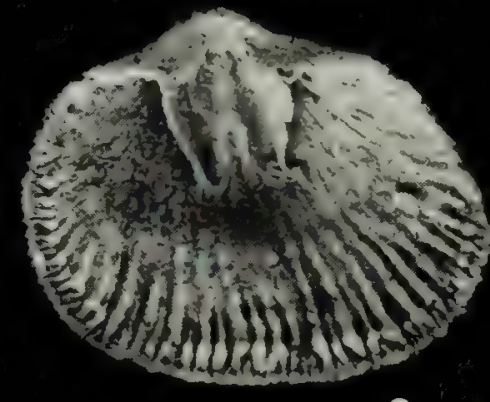

9

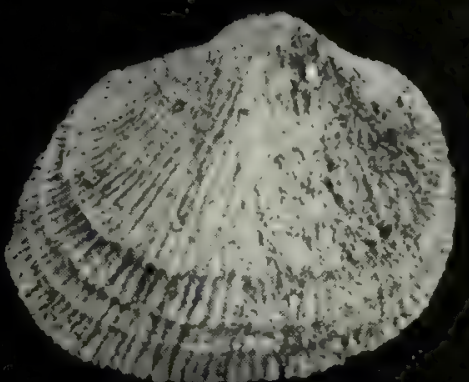

10

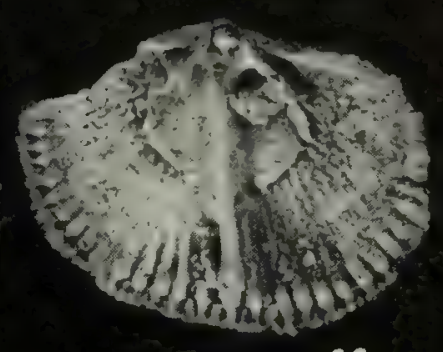

11
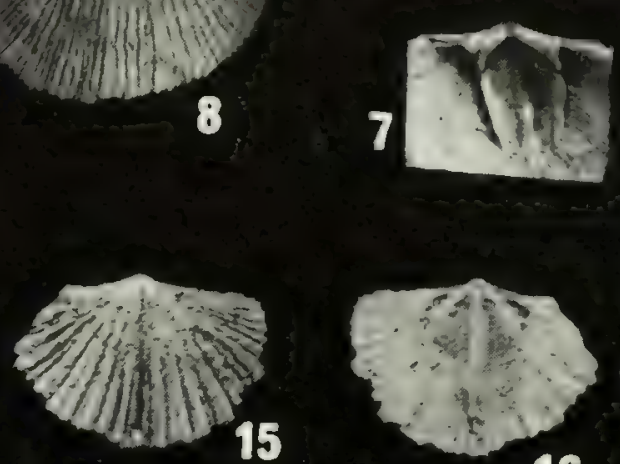

15

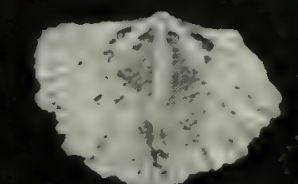

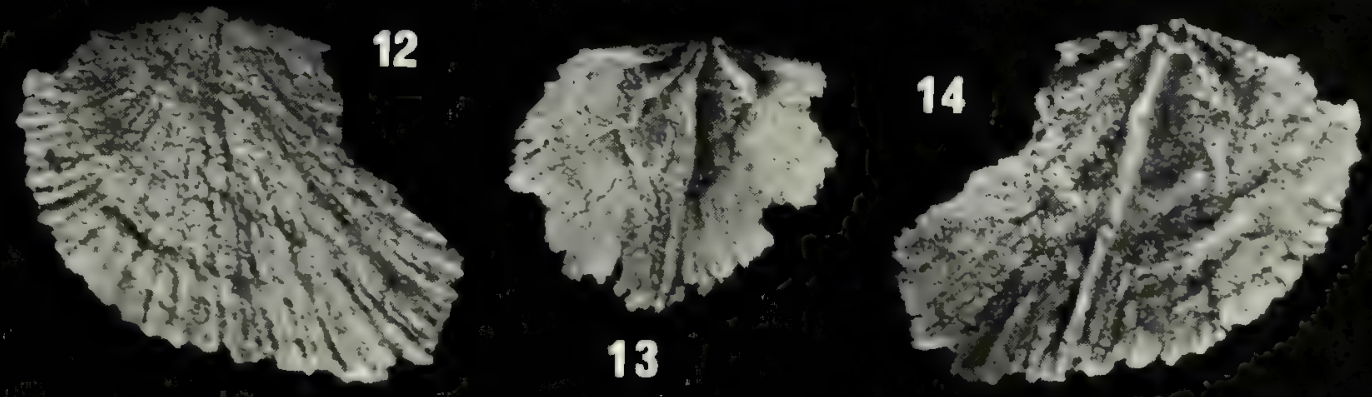

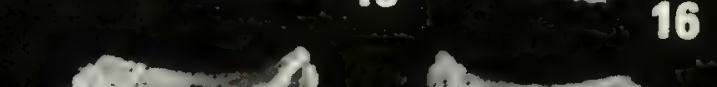

16

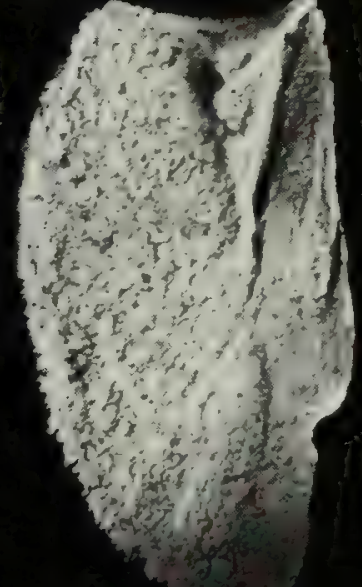

17

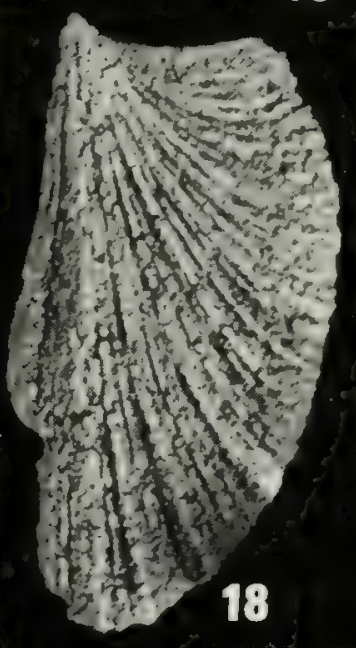

22

23

21

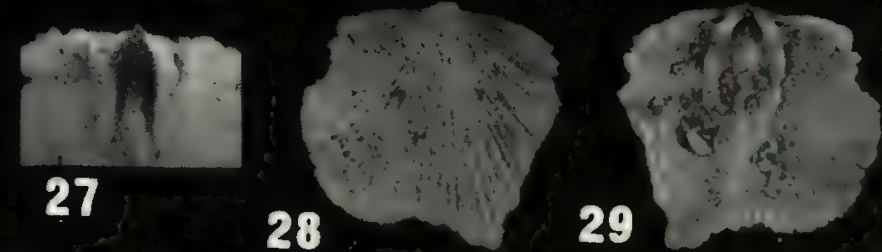

24
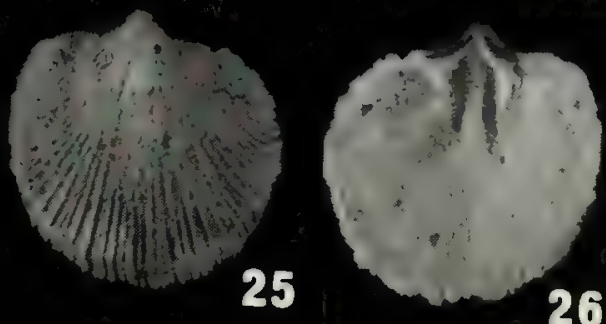

26
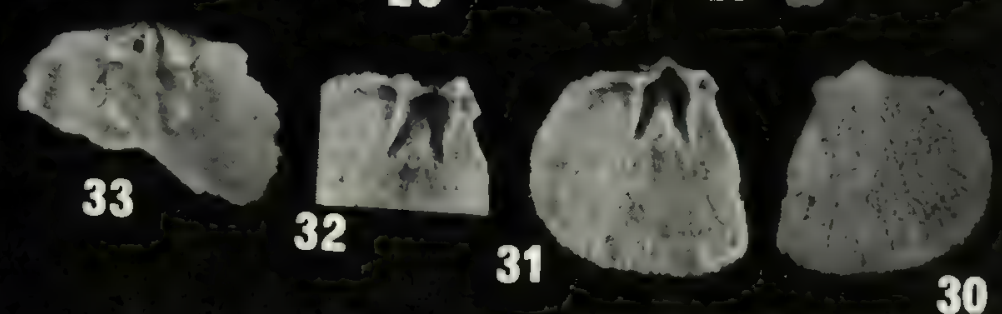

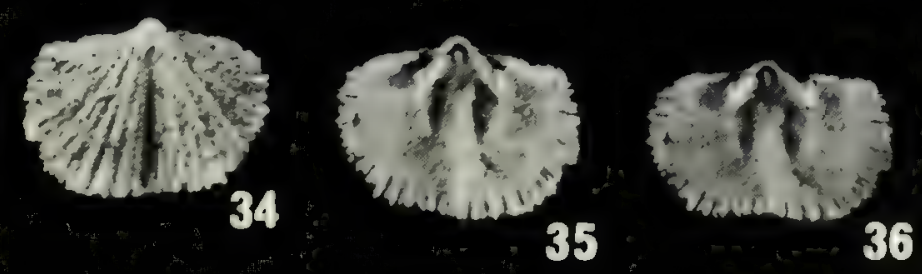

E)
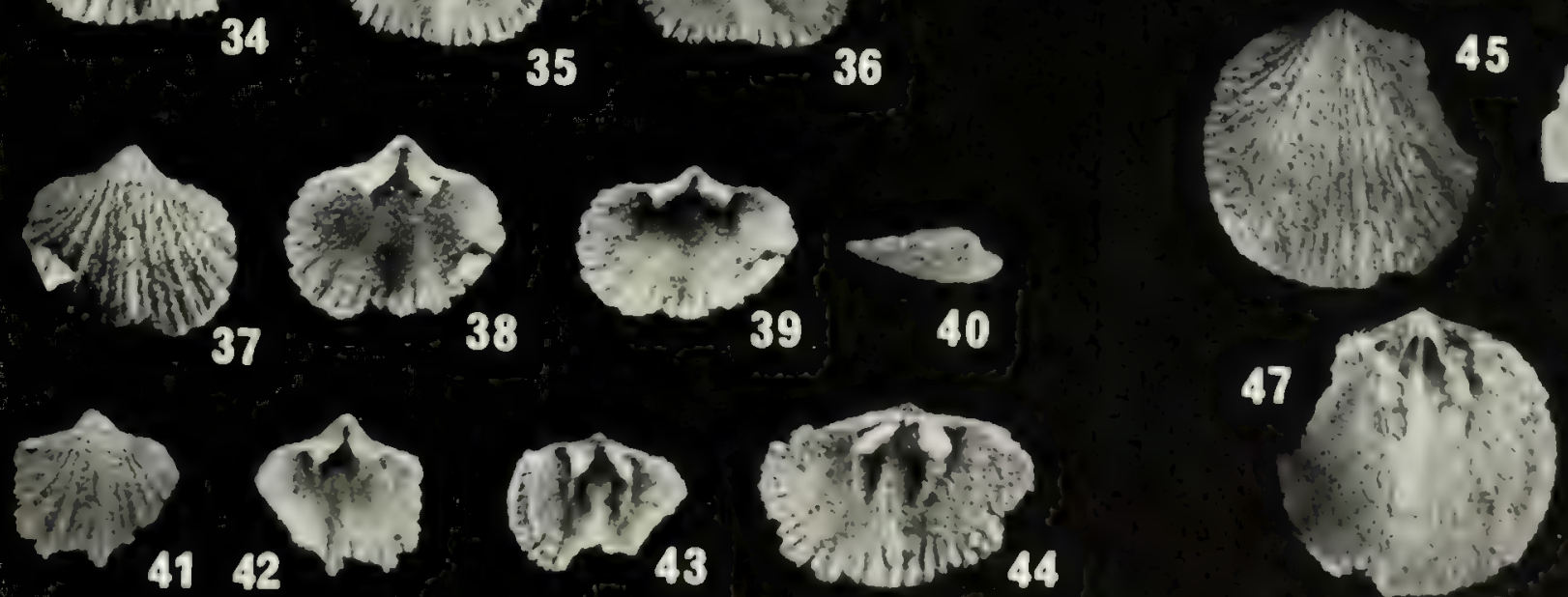

\section{r.h. 46}

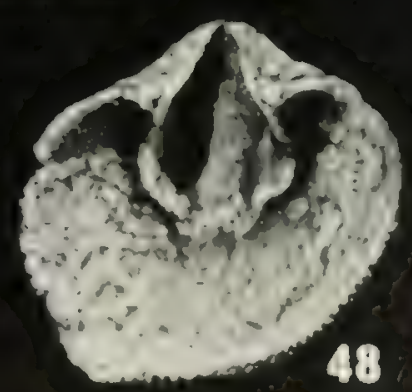


Plate 6, figs. 1-50

Articulate brachiopod Dalejina.

Figs. 1-3. Dalejina sp. 1. Interior, exterior, and oblique interior views of brachial valve; Delorme Formation (early Pragian), S-1, sample A442.0 m, ROM $33219, \times 2.4$. Note the plates extending from the brachiophores towards the midline. Such plates are not present in other representatives of Dalejina sp. 1.

Figs. 4-28. Dalejina sp. 1.

4-6. Posterior, dorsal, and ventral views of articulated shell; Delorme Formation (early Pragian), S-1, sample A442.0 m, ROM $33220, \times 2.4$.

7-11. Dorsal, ventral, lateral, posterior, and anterior views of articulated shell; Delorme Formation (Pragian), S-1, sample OLDA388.6 m, ROM 33221, × 3.3 .

12-14. Oblique interior, interior, and exterior views of pedicle valve; Delorme Formation (Pragian), S-1, sample OLDA388.6 m, ROM 33222, × 3.3.

15,16 . Oblique interior and exterior views of pedicle valve, Delorme Formation (Pragian), S-1, sample OLDA388.6 m, ROM $33223, \times 3.3$.

17-21. Ventral, dorsal, anterior, lateral, and posterior views of articulated shell; Delorme Formation (Pragian), S-1, sample OLDA388.6 m, ROM 33224, × 3.3 .

22, 23. Interior and exterior views of brachial valve, Delorme Formation (Pragian), S-1, sample OLDA388.6 m, ROM 33225 , $\times 3.3$.

24. Interior view of brachial valve, Delorme Formation (Pragian), S-1, sample OLDA416.1 m, ROM 33226, × 2.4 .

25,26 . Exterior and interior views of pedicle valve, Delorme Formation (Pragian), S-2, sample B105.2 m, RoM 33227, $\times$ 2.4 .
27. Interior view of brachial valve, Delorme Formation (Pragian), S-2, sample B105.2 m, ROM 33228, × 2.4 .

28. Interior view of brachial valve, Delorme Formation (Pragian), S-2, sample B105.2 m, ROM 33229, × 2.4 .

Figs. 29-50. Dalejina gabrielsei sp. nov.

29-31. Interior, exterior, and oblique interior views of brachial valve; Delorme Formation (Zlichovian), S-1, samplé A62.5$68.6 \mathrm{~m}$, holotype ROM $33230, \times 2.8$.

32-34. Anterior, posterior, and lateral views of articulated shell; Delorme Formation (Zlichovian), S-1, sample A62.5-68.6 m, paratype ROM $33231, \times 2.8$.

35. Interior view of brachial valve, Delorme Formation (Zlichovian), S-1, sample A62.5-68.6 m, paratype ROM 33232, × 2.5 .

36-38. Oblique interior, interior, and exterior views of pedicle valve; Delorme Formation (Zlichovian), S-1, sample A62.5$68.6 \mathrm{~m}$, paratype ROM $33233, \times 2.8$.

39,40 . Interior and exterior views of pedicle valve, Delorme Formation (Zlichovian), S-3, S4-64.0-65.5 m, paratype ROM $33234, \times 2.8$.

41,42 . Interior and exterior views of brachial valve, Delorme Formation (Zlichovian), S-3, sample S4-64.0-65.5 m, paratype ROM $33235, \times 2.8$.

43-45. Anterior, lateral, and posterior views of articulated shell; Delorme Formation (Zlichovian), S-3, sample S4-64.0-65.5 m, paratype ROM 33236, × 2.8 .

46, 47. Exterior and interior views of brachial valve, Delorme Formation (Zlichovian), S-3, sample S4-466.3 m, paratype ROM $33237, \times 2.8$.

48. Interior view of pedicle valve, Delorme Formation (Zlichovian), S-3, sample S4-466.3 m, paratype ROM $33238, \times 2.8$.

49, 50. Posterior and lateral views of articulated shell, Delorme Formation (Zlichovian), S-3, sample S4-466.3 m, paratype ROM $33239, \times 2.8$. 


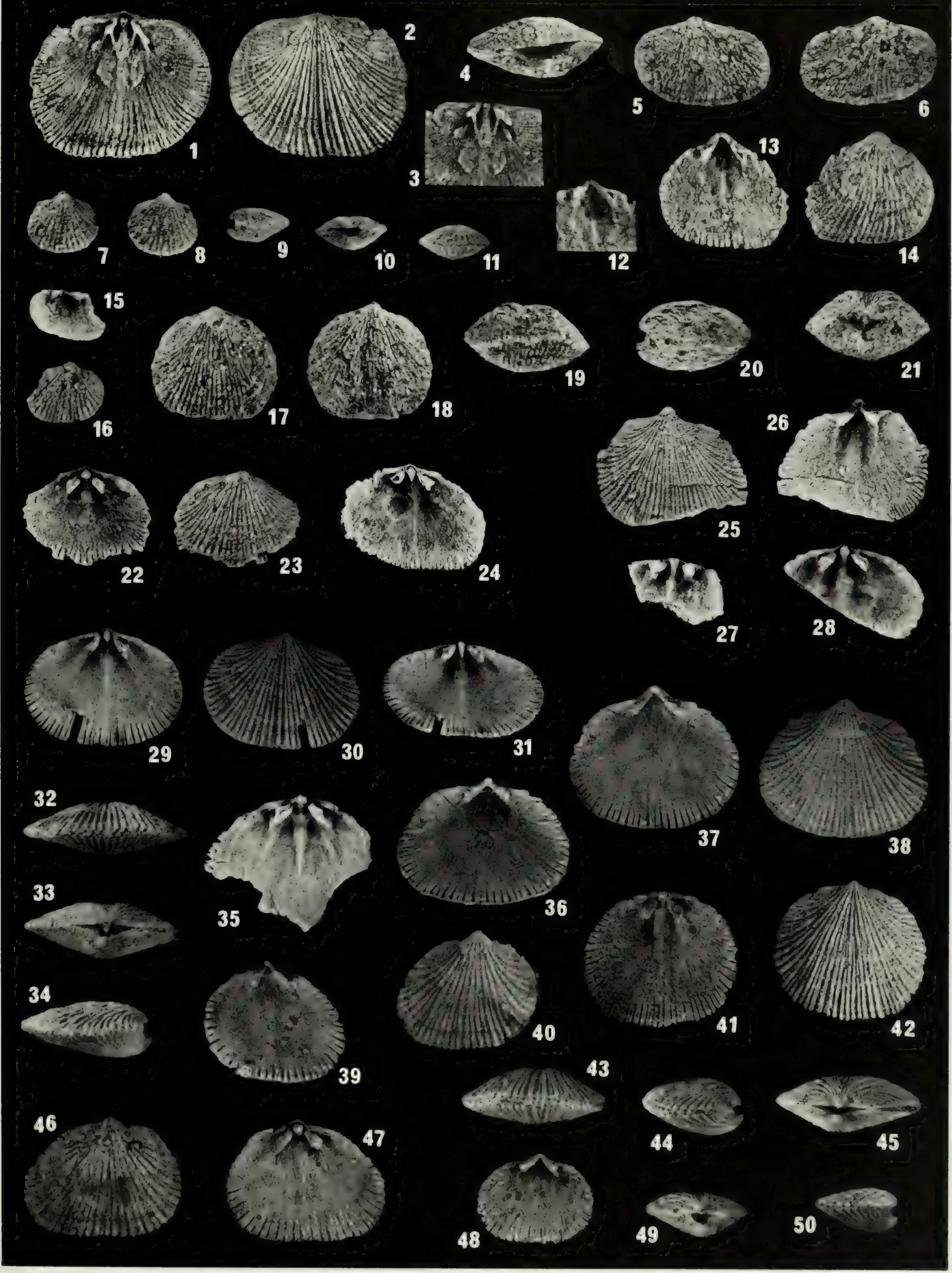


Plate 7, figs. 1-56

Articulate brachiopods Resserella, Salopina, Didymoparcium, and Schizophoria.

\section{Figs. 1-10. Resserella elegantuloides (Kozlowski)}

1-3. Exterior, interior, and posterior views of pedicle valve; Delorme Formation (Lochkovian), S-2, sample B225.6 m, ROM $33240, \times 3.1$. Note the parvicostellate ornament displayed on fig. 1, and also on fig. 9 .

4-7. Exterior, interior, antero-oblique interior, and posterooblique interior views of brachial valve; Delorme Formation (Lochkovian), S-2, sample B225.6 m, ROM 33241, × 3.1 .

8-10. Interior, exterior, and posterior views of pedicle valve; Delorme Formation (Lochkovian), S-2, sample B225.6 m, ROM $33242, \times 3.1$.

Figs. 11, 12. Salopina cf. S. submurifer Johnson, Boucot, and Murphy. Oblique interior and interior views of brachial valve, Delorme Formation (Lochkovian), S-2, sample B225.6 m, ROM 33243, $\times 4.4$. Note the subrectangular muscle field, more prominent than on $R$. elegantuloides.

\section{Figs. 13-21. Didymoparcium costata Lenz.}

13-17. Posterior, lateral, dorsal, anterior, and ventral views of articulated shell; Delorme Formation (Zlichovian), S-3, sample S4-36.6 m, ROM 33244, $\times 12.4$.

18. Interior view of brachial valve, Delorme Formation (Zlichovian), S-3, sample S4-502.9-507.5 m, ROM 33245, × 12.4 .

19. Interior view of pedicle valve, Delorme Formation (Zlichovian), S-3, sample S4-502.9-507.5 m, Rом 33246, × 12.4 .

20. Interior view of brachial valve, Delorme Formation (Zlichovian), S-3, sample S4-502.9-507.5 m, ROM 33247, × 12.4 .

21. Interior view of pedicle valve, Delorme Formation (Zlichovian), S-3, sample S4-502.9-507.5 m, ROM 33248, × 12.4 .

Figs. 22-32. Schizophoria paraprima Johnson, Boucot, and Murphy.

22-24. Exterior, oblique interior, and interior views of brachial valve; Delorme Formation (early Lochkovian), S-2, sample B336.8 m, ROM $33249, \times 2.4$.

25, 26. Exterior and interior views of pedicle valve, Delorme Formation (early Lochkovian), S-2, sample B336.8 m, ROM $33250, \times 2.4$. Note the rectangular ridge dividing the pedicle muscle field in fig. 26, and also in figs. 31 and 32 .

27-29. Exterior, interior, and oblique interior views of brachial valve; Delorme Formation (early Lochkovian), S-2, sample B336.8 m, ROM 33251, $\times 2.4$. Note the bifurcating vascula media in figs. 28 and 29.
30-32. Exterior, interior, and oblique interior views of pedicle valve; Delorme Formation (early Lochkovian), S-2, sample B336. $8 \mathrm{~m}$, ROM $33252, \times 2.4$.

Figs. 33-56. Schizophoria cf. S. nevadaensis Merriam.

33-36. Interior, exterior, posterior, and oblique interior views of pedicle valve; Delorme Formation (Zlichovian), S-1, sample A62.5-68.6 m, ROM 33253, $\times 1.7$. Note the weakly developed pedicle sulcus in fig. 34 , and also in figs. 38 and 52.

37, 38. Posterior and exterior views of partly exfoliated pedicle valve, Delorme Formation (Zlichovian), S-1, sample A62.5$68.6 \mathrm{~m}$, Rом $33254, \times 1.7$.

39, 40. Exterior and interior of brachial valve, Delorme Formation (Zlichovian), S-1, sample A62.5-68.6 m, ROM $33255, \times 1.7$. Note the adventitious growths in the posterior regions of fig. 40 .

41-43. Interior, oblique interior, and exterior views of pedicle valve; Delorme Formation (Zlichovian), S-1, sample A62.5$68.6 \mathrm{~m}$, ROM $33256, \times 1.7$.

44, 45. Exterior and interior views of brachial valve, Delorme Formation (Zlichovian), S-1, sample A62.5-68.6 m, ROM $33257, \times 1.7$.

46. Interior view of brachial valve, Delorme Formation (Zlichovian), S-1, sample A62.5-68.6 m, ROM 33258, × 1.7 .

47,48 . Interior and oblique interior views of brachial valve, Delorme Formation (Zlichovian), S-1, sample A62.5-68.6 m, ROM $33259, \times 1.7$. Note the prominent fulcral plates and auxiliary cardinal process lobes, also apparent in fig. 54.

49, 50. Exterior and interior views of brachial valve, Delorme Formation (Zlichovian), S-3, S4-53.3-54.9 m, ROM 33260, $\times$ 1.7 .

51. Interior view of brachial valve, Delorme Formation (Zlichovian), S-3, sample S4-64.0-65.5 m, ROM 33261, × 1.7.

52, 53. Exterior and interior views of large pedicle valve, Delorme Formation (Zlichovian), S-3, sample S4-473.4 m, ROM $33262, \times 0.8$

54. Interior view of brachial valve, Delorme Formation (Zlichovian), S-3, sample S4-502.9-507.5 m, ROM 33263, × 1.6.

55. Interior view of pedicle valve, Delorme Formation (Zlichovian), S-3, sample S4-502.9-507.5 m, ROM 33264, $\times 0.8$. Note the tubelike growth flanking, and appearing to open into, the adductor muscle field; this was possibly formed by a parasite living beneath the mantle of the brachiopod.

56. Interior view of pedicle valve, Delorme Formation (Zlichovian), S-3, sample S4-502.9-507.5 m, ROM 33265, × 1.6 . 


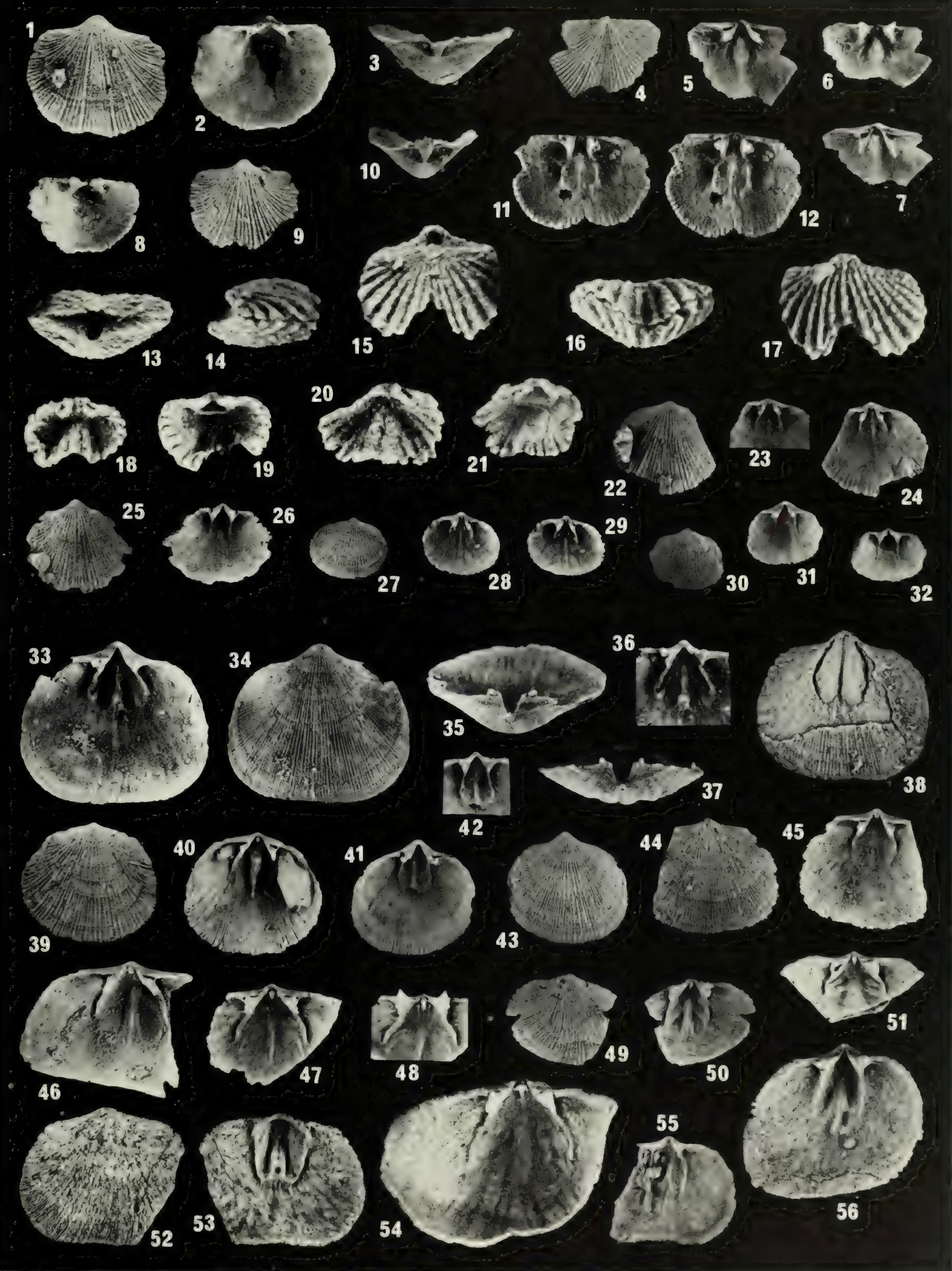


Plate 8, figs. 1-54

Articulate brachiopods Schizophoria and Salopina.

Figs. 1-21. Schizophoria delormensis sp. nov.

1. Interior view of brachial valve, Delorme Formation (Lochkovian), S-1, sample A544.1 m, ROM paratype $33266, \times 1.7$.

2. Interior view of pedicle valve, Delorme Formation (Lochkovian), S-1, sample A544.1 m, ROM paratype $33267, \times 1.7$.

3, 4. Interior and exterior views of pedicle valve, Delorme Formation (Lochkovian), S-2, sample B254.5 m, ROM holotype $33268, \times 1.7$

5, 6. Exterior and interior views of pedicle valve, Delorme Formation (Lochkovian), S-2, sample B254.5 m, ROM paratype $33269, \times 1.7$

7. Oblique lateral view of brachial valve, Delorme Formation (Lochkovian), S-2, sample B254.5 m, ROM paratype 33270, $\times$ 1.7. Note the development of the fulcral plates.

8. Interior view of pedicle valve, Delorme Formation (Lochkovian), S-2, sample B254.5 m, ROM paratype $33271, \times 1.7$.

9. Interior view of brachial valve, Delorme Formation (Lochkovian), S-2, sample B254.5 m, ROM paratype $33272, \times 1.7$.

10, 11. Exterior and interior views of pedicle valve, Delorme Formation (Lochkovian), S-2, sample B254.5 m, ROM paratype $33273, \times 1.7$.

12. Interior view of brachial valve, Delorme Formation (Lochkovian), S-2, sample B254.5 m, ROM paratype $33274, \times 1.7$.

13-15. Interior, exterior, and oblique interior views of pedicle valve; Delorme Formation (Lochkovian), S-3, sample S4$685.8 \mathrm{~m}$, ROM paratype $33275, \times 1.7$.

$16,17,21$. Oblique interior, interior, and exterior views of brachial valve; Delorme Formation (Lochkovian), S-3, sample S4-685.8 m, ROM paratype $33276, \times 1.7$.

18, 19. Exterior and interior views of brachial valve, Delorme Formation (Lochkovian), S-3, sample S4-685.8 m, ROM paratype $33277, \times 1.7$.

20. Interior view of pedicle valve, Delorme Formation (Lochkovian), S-3, sample S4-685.8 m, ROM paratype 33278, × 1.7.

Figs. 22-44. Schizophoria sp. 1.

22. Interior view of pedicle valve, Delorme Formation (early Pragian), S-1, sample A442.0 m, ROM 33279, × 1.5

23. Interior view of pedicle valve, Delorme Formation (early Pragian), S-1, sample A442.0 m, ROM 33280, × 1.5

24. Oblique interior view of brachial valve, Delorme Formation (early Pragian), S-1, sample A442.0 m, ROM 33281, $\times 1.5$. Note the anterolaterally directed ridges dividing the muscle field, also apparent in figs. $25,28,30,33$, and 38 ; note as well the prominent medial ridge dividing the adductor muscle field in all views of brachial valves of this species.

25. Interior view of brachial valve, Delorme Formation (early Pragian), S-1, sample A442.0 m, ROM 33282, × 1.5 .
26. Lateral view of brachial valve showing the fulcral plate, Delorme Formation (early Pragian), S-1, sample A442.0 m, ROM $33283, \times 1.5$.

27, 29. Exterior and interior views of pedicle valve, Delorme Formation (Lochkovian), S-1, sample A487.7 m, ROM 33284, × 1.5. Note the pseudofascicostellate ornament developed on fig. 27 , and also on figs. 33-44, which are incompletely silicified and/or slightly abraded shells

28. Interior view of brachial valve, Delorme Formation (Lochkovian), S-1, sample A487.7 m, ROM 33285, × 1.5 .

30. Interior view of brachial valve, Delorme Formation (Pragian), S-1, sample OLDA374.9 m, ROM 33286, $\times 1.5$.

31-33. Interior, exterior, and oblique interior views of brachial valve; Delorme Formation (Pragian), S-1, sample OLDA388.6 m, ROM $33287, \times 1.5$. Note the auxiliary cardinal process lobes in fig. 33 .

34-36. Exterior, interior, and oblique interior views of pedicle valve; Delorme Formation (Pragian), S-2, sample B166.1$182.9 \mathrm{~m}$, Rом $33288, \times 1.7$.

37, 38. Oblique interior and interior views of brachial valve; Delorme Formation (Pragian), S-2, sample B166.1-182.9 m, ROM $33289, \times 1.7$.

39. Interior view of brachial valve, Delorme Formation (Pragian), S-2, sample B166.1-182.9 m, ROM 33290, × 1.7.

40, 41. Exterior and interior views of pedicle valve, Delorme Formation (Pragian), S-2, sample B166.1-182.9 m, ROM 33291, $\times 1.7$.

42, 43. Exterior and interior views of brachial valve, Delorme Formation (Pragian), S-2, sample B166.1-182.9 m, ROM 33292, $\times 1.7$.

44. Exterior view of pedicle valve, Delorme Formation (Pragian), S-2, sample B166.1-182.9 m, ROM 33293, × 1.7 .

Figs. 45-54. Salopina submurifer Johnson, Boucot, and Murphy.

45, 46. Interior and exterior views of brachial valve, Delorme Formation (early Lochkovian), S-2, sample B336.8 m, ROM $33294, \times 4.4$. Note the elongate muscle field and the low medial myophragm in fig. 45 , and also in figs. 53 and 54 .

47-50, 52. Dorsal, ventral, posterior, anterior, and lateral views of articulated shell; Delorme Formation (early Lochkovian), S-2, sample B336.8 m, ROM $33295, \times 4.4$.

51. Oblique interior view of pedicle valve, Delorme Formation (early Lochkovian), S-2, sample B336. 8 m, ROM 33296, $\times 4.4$.

53. Interior view of brachial valve, Delorme Formation (early Lochkovian), S-2, sample B336.8 m, ROM 33297, $\times 4.4$.

54. Interior view of brachial valve, Delorme Formation (early Lochkovian), S-2, sample B336.8 m, ROM 33298, $\times 4.4$. 

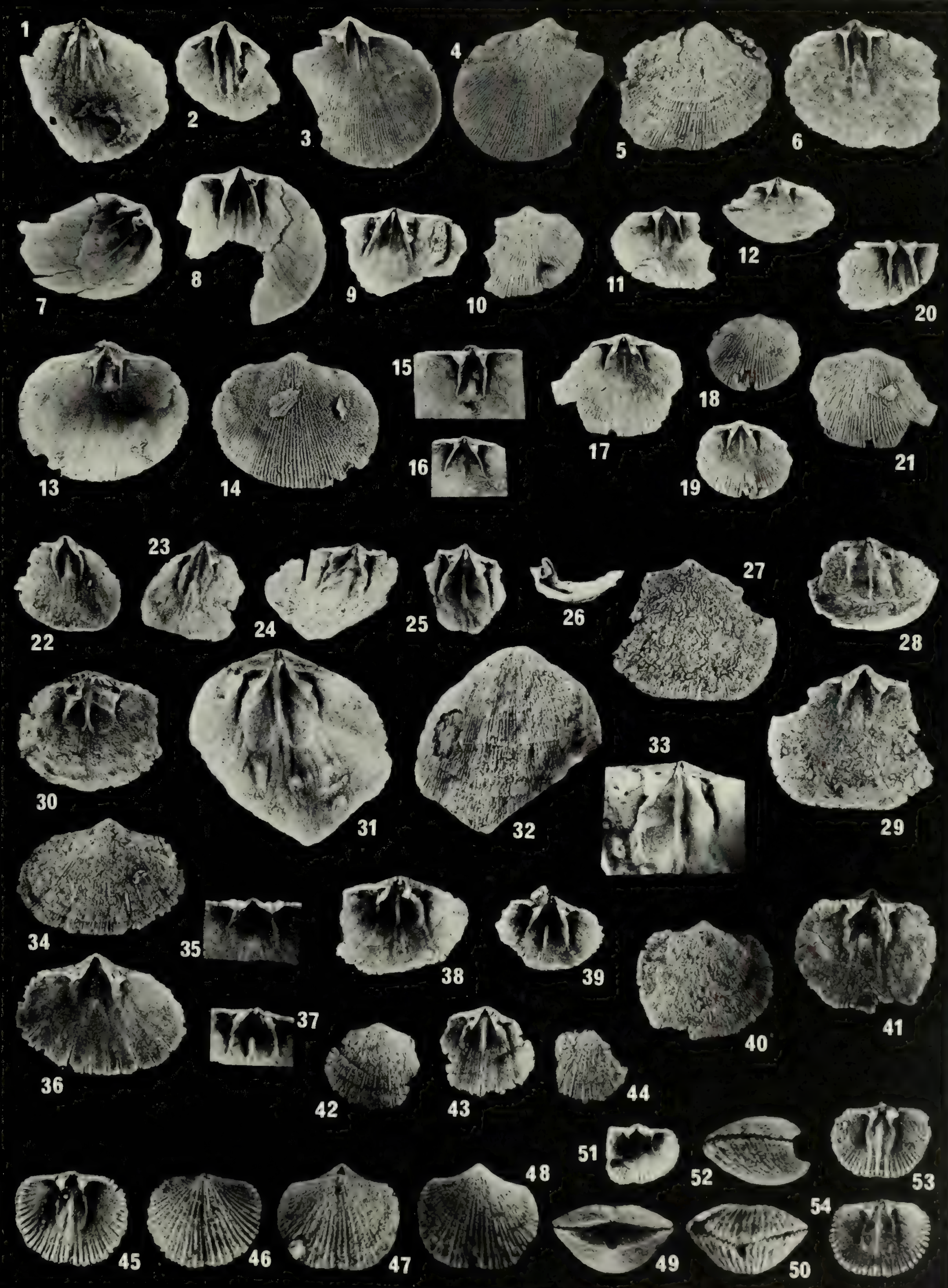
Plate 9, figs. 1-67

Articulate brachiopods Salopina and Muriferella.

Figs. 1-25. Salopina submurifer Johnson, Boucot, and Murphy. 1. 2. Exterior and interior views of brachial valve, Delorme Formation (Lochkovian), S-2, sample B225.6 m, ROM 33299, × 4.4.

3. Interior view of pedicle valve, Delorme Formation (Lochkovian), S-2, sample B225.6 m, ROM $33300, \times 4.4$.

4-8. Ventral, dorsal, posterior, anterior, and lateral views of articulated shell; Delorme Formation (Lochkovian), S-2, sample B225.6 m, ROM 33301, × 4.4.

9. 10. Exterior and interior views of brachial valve, Delorme Formation (Lochkovian), S-1, sample A536.4 m, ROM 33302, x 4.4. Note in fig. 10, and also in figs. 15 and 16 , the development of a higher medial myophragm, which is morphologically close to Muriferella.

11. Interior view of pedicle valve, Delorme Formation (Lochkovian), S-1, sample A536.4 m, ROM 33303, × 4.4 .

12, 13. Interior and oblique lateral views of brachial valve, Delorme Formation (Lochkovian), S-1, sample A536.4 m, ROM $33304, \times 4.4$.

14-16. Exterior, interior, and oblique interior views of brachial valve; Delorme Formation (Lochkovian-Pragian), S-3, sample S4-624.8 m, ROM 33305, $\times 4.4$.

17, 18, 25. Interior, exterior, and oblique lateral views of brachial valve; Delorme Formation (Lochkovian), S-3, sample S4-685.8 m, ROM 33306, $\times 4.4$.

19, 20. Exterior and interior views of large brachial valve, Delorme Formation (Lochkovian), S-3, sample S4-685.8 m, ROM $33307, \times 4.4$.

21,22 . Exterior and oblique interior views of pedicle valve, Delorme Formation (Lochkovian), S-3, sample S4-685.8 m, ROM $33308, \times 4.4$.

23,24 . Interior and exterior views of brachial valve, Delorme Formation (Lochkovian), S-3, sample S4-685.8 m, ROM 33309 , $\times 4.4$.

Figs. 26-67. Muriferella masurskyi Johnson and Talent.

26, 27. Interior and exterior views of brachial valve, Delorme Formation (early Pragian), S-1, sample A442.0 m, ROM 33310 , $\times 4.4$.

28, 29. Oblique lateral and interior views of brachial valve, Delorme Formation (early Pragian), S-1, sample A442.0 m, ROM $33311, \times 4.4$.

30, 32. Interior and exterior views of pedicle valve, Delorme Formation (early Pragian), S-1, sample A442.0 m, ROM 33312 , $\times 4.4$.

31, 33. Exterior and oblique interior views of pedicle valve, Delorme Formation (early Pragian), S-1, sample A442.0 m, ROM $33313, \times 4.4$.
34, 35. Interior and exterior views of brachial valve, Delorme Formation (Zlichovian), S-1, sample A62.5-68.6 m, ROM $33314, \times 4.1$.

36, 37. Interior and exterior views of small pedicle valve, Delorme Formation (Zlichovian), S-1, sample A62.5-68.6 m, ROM $33315, \times 4.1$.

38. Interior view of brachial valve, Delorme Formation (Zlichovian), S-1, sample A62.5-68.6 m, ROM 33316, × 4.1.

39-41. Interior, oblique interior, and exterior views of brachial valve; Delorme Formation (Pragian), S-3, sample S4-624.8 m, ROM $33317, \times 4.4$. Note that the specimen illustrated here is from the same sample as Salopina submurifer illustrated in figs. $14-16$.

42. Oblique interior view of pedicle valve, Delorme Formation (Lochkovian), S-2, sample B254.5 m, ROM 33318, $\times 4.4$.

43. Interior view of brachial valve, Delorme Formation (Lochkovian), S-2, sample B254.5 m, ROM 33319, × 4.4 .

44,45 . Interior and exterior views of brachial valve, Delorme Formation (Lochkovian), S-2, sample B254.5 m, ROM 33320, × 4.4. The specimens illustrated in figs. $42-45$ are from a stratigraphically lower collection than the specimens of Salopina submurifer in figs. 1-8.

46. Interior view of brachial valve, Delorme Formation (Pragian), S-2, sample B128.6 m, ROM 33321, × 4.4 .

47, 48. Exterior and oblique interior views of pedicle valve, Delorme Formation (Pragian), S-2, sample B $128.6 \mathrm{~m}$, ROM $33322, \times 4.4$.

49, 52, 53. Oblique lateral, exterior, and interior views of brachial valve; Delorme Formation (Pragian), S-2, sample B। $28.6 \mathrm{~m}$, ROM 33323, $\times 4.4$.

50, 51. Exterior and oblique interior views of pedicle valve, Delorme Formation (Pragian), S-2, sample B128.6 m, ROM $33324, \times 4.4$.

54-56. Oblique interior, interior, and exterior views of pedicle valve; Delorme Formation (Zlichovian), S-3, sample S4-64.0$65.5 \mathrm{~m}$, ROM $33355, \times 4.1$.

57,58 . Interior and oblique interior views of brachial valve, Delorme Formation (Zlichovian), S-3, sample S4-64.0-65.5 m, ROM $33325, \times 4.1$.

59. Interior view of brachial valve, Delorme Formation (Zlichovian), S-3, sample S4-64.0-65.5 m, ROM 33326, × 4.1.

60. Exterior view of pedicle valve, Delorme Formation (Zlichovian), S-3, sample S4-64.0-65.5 m, ROM 33327, × 4.1.

61,62 . Oblique interior and interior views of brachial valve, Delorme Formation (Zlichovian), S-3, sample S4-64.0-65.5 m, ROM $33328, \times 4.1$.

63-67. Lateral, posterior, anterior, dorsal, and ventral views of articulated shell; Delorme Formation (Zlichovian), S-3, sample S4-64.0-65.5 m, ROM 33329, × 4.1. 


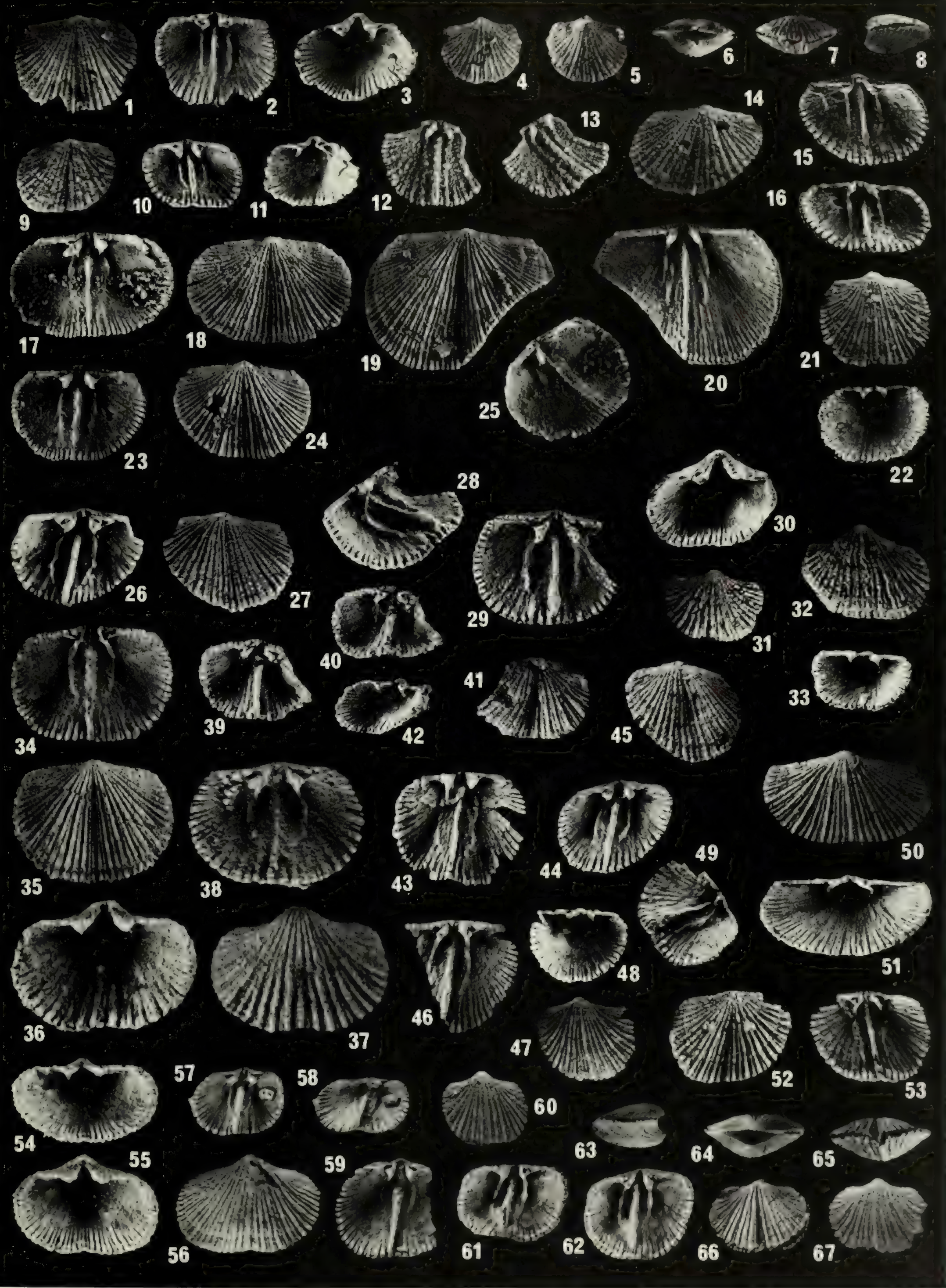


Plate 10, figs. 1-63.

Articulate brachiopods Muriferella, Miniprokopia, and Phragmophora.

Figs. 1-12. Muriferella masurskyi Johnson and Talent.

1, 2. Interior and exterior views of brachial valve, Delorme Formation (Zlichovian), S-3, sample S4-513.6-515.1 m, ROM $33330, \times 4.4$.

3, 4. Exterior and oblique interior views of pedicle valve, Delorme Formation (Zlichovian), S-3, sample S4-513.6$515.1 \mathrm{~m}$, ROM $33331, \times 4.4$.

5 , 6. Interior and exterior views of brachial valve, Delorme Formation (Zlichovian), S-3, sample S4-161.5-164.9 m, ROM $33332, \times 4.1$.

$7,8,12$. Interior, exterior, and oblique interior views of pedicle valve; Delorme Formation (Zlichovian), S-3, sample S4-161.5$164.9 \mathrm{~m}$, Rом $33333, \times 4.1$.

9. Interior view of brachial valve, Delorme Formation (Zlichovian), S-3, sample S4-161.5-164.9 m, ROM 33334, × 4.1.

10, 11. Interior and oblique interior views of pedicle valve, Delorme Formation (Zlichovian), S-3, sample S4-161.5$164.9 \mathrm{~m}$, ROM $33335, \times 4.1$.

Figs. 13-41. Miniprokopia havliceki sp. nov.

13, 14. Interior and oblique interior views of brachial valve, Delorme Formation (Zlichovian), S-1, sample A62.5-68.6 m, paratype ROM $33336, \times 8.4$.

15, 16. Interior and oblique interior views of brachial valve, Delorme Formation (Zlichovian), S-1, sample A62.5-68.6 m, paratype ROM 33337, × 8.4.

17, 18. Interior and oblique interior views of pedicle valve, Delorme Formation (Zlichovian), S-1, sample A62.5-68.6 m, paratype ROM $33338, \times 7.5$.

19-21. Oblique interior, interior, and exterior views of pedicle valve; Delorme Formation (Zlichovian), S-1, sample A62.5$68.6 \mathrm{~m}$, paratype ROM $33339, \times 7.5$.

22-25. Ventral, dorsal, lateral, and posterior views of articulated shell; Delorme Formation (Zlichovian), S-1, sample A62.5-68.6 m, paratype ROM 33340, $\times 7.5$.

26-28. Interior, oblique interior, and exterior views of brachial valve; Delorme Formation (Zlichovian), S-1, sample A62.5$68.6 \mathrm{~m}$, paratype ROM $33341, \times 7.5$.
29-31. Oblique lateral, oblique interior, and interior views of brachial valve; Delorme Formation (Zlichovian), S-1, sample A62.5-68.6 m, holotype ROM 33342, × 7.5.

32-34. Dorsal, anterior, and ventral views of articulated shell; Delorme Formation (Zlichovian), S-1, sample A62.5-68.6 m, paratype ROM 33343, × 7.5.

$35,36,38$. Exterior, interior, and anterior views of gerontic pedicle valve; Delorme Formation (Zlichovian), S-1, sample A62.5-68.6 m, paratype ROM 33344, $\times 7.5$.

37. Exterior view of pedicle valve, Delorme Formation (Zlichovian), S-1, sample A62.5-68.6 m, paratype ROM 33345, × 7.5. 39-41. Exterior, interior, and oblique interior views of brachial valve; Delorme Formation (Zlichovian), S-1, sample A62.5$68.6 \mathrm{~m}$, paratype ROM $33346, \times 7.5$.

Figs. 42-63. Phragmophora cooperi sp. nov.

42-44. Exterior, interior, and oblique lateral views of brachial valve; Delorme Formation (Zlichovian), S-1, sample A62.5$68.6 \mathrm{~m}$, paratype ROM $33347, \times 5.3$.

45, 46. Interior and exterior views of pedicle valve, Delorme Formation (Zlichovian), S-1, sample A62.5-68.6 m, paratype ROM $33348, \times 5.3$. Note the short, slightly laterally directed dental plates in fig. 45, and also in figs. 48, 58, and 60 .

47-49. Posterior, oblique interior, and exterior views of pedicle valve; Delorme Formation (Zlichovian), S-1, sample A62.5$68.6 \mathrm{~m}$, paratype ROM $33349, \times 5.3$.

$50,62,63$. Interior, oblique lateral, and exterior views of brachial valve; Delorme Formation (Zlichovian), S-1, sample A62.5-68.6 m, paratype ROM 33350, × 5.3.

51-54. Exterior, interior, oblique interior, and lateral views of brachial valve; Delorme Formation (Zlichovian), S-1, sample A62.5-68.6 m, holotype ROM 33351, $\times 5.3$.

55-57. Interior, exterior, and oblique lateral views of brachial valve; Delorme Formation (Zlichovian), S-1, sample A62.5$68.6 \mathrm{~m}$, paratype ROM $33352, \times 5.3$.

58-61. Interior, exterior, oblique interior, and lateral views of pedicle valve; Delorme Formation (Zlichovian), S-1, sample A62.5-68.6 m, paratype ROM 33353, $\times 5.3$. 

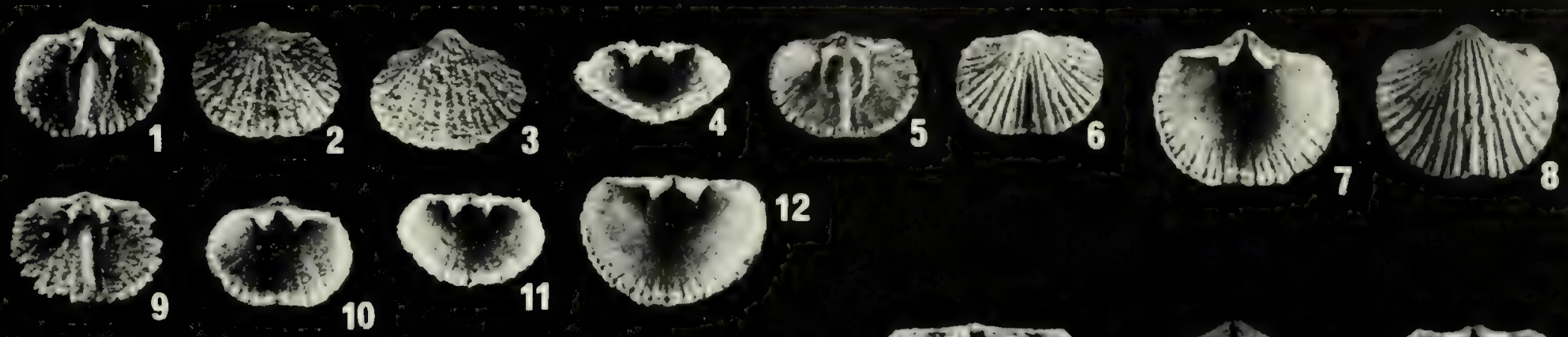

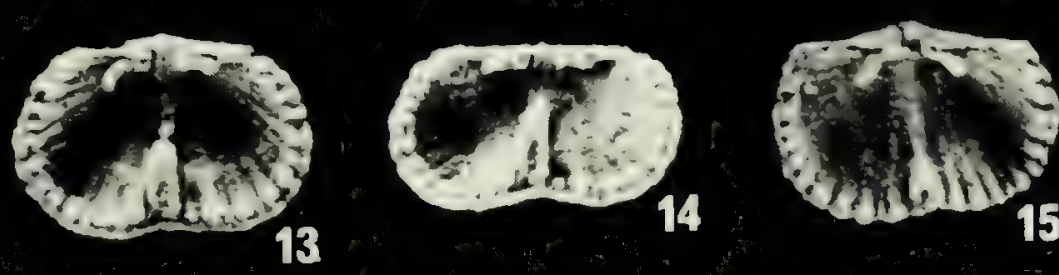
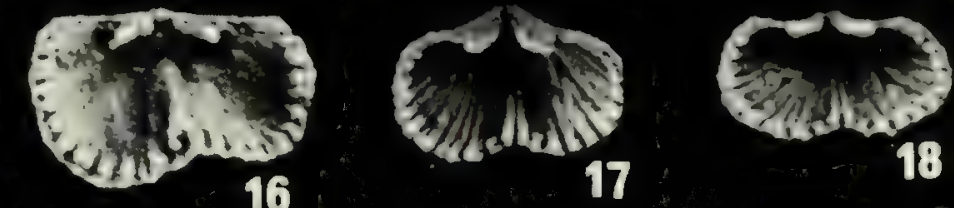

18 17

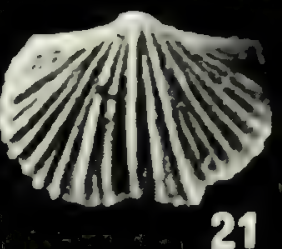

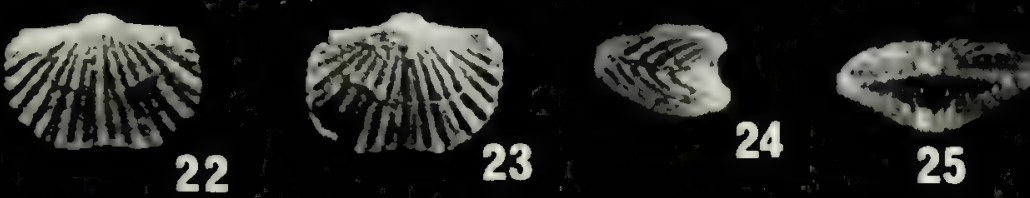

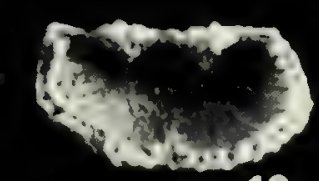

19

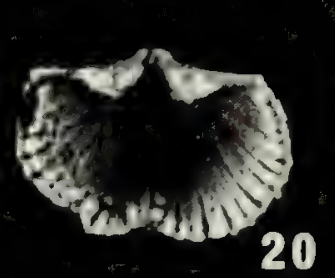

21

Eantions

26

(r)

Cofflition

39

32

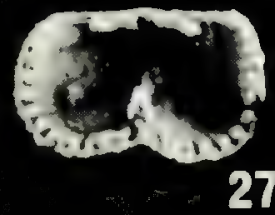

27

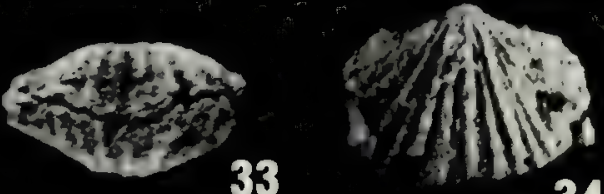

34

$4 a^{2}$

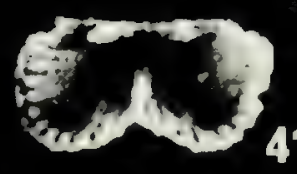

29 30
0

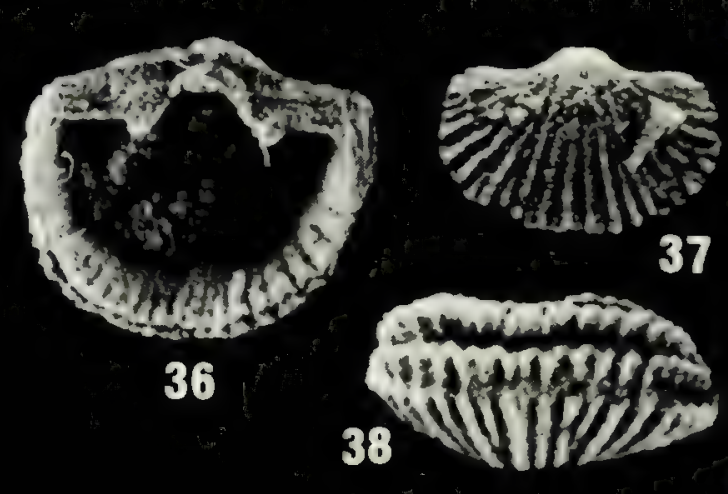

41

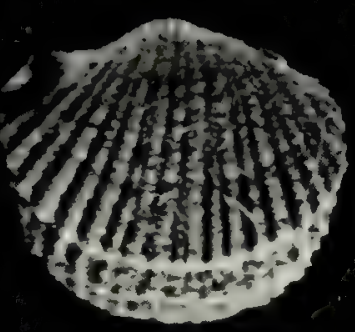

35

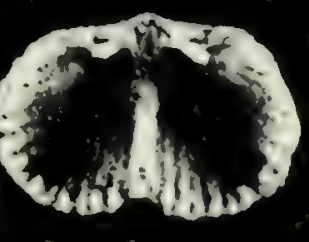

.

Int

42
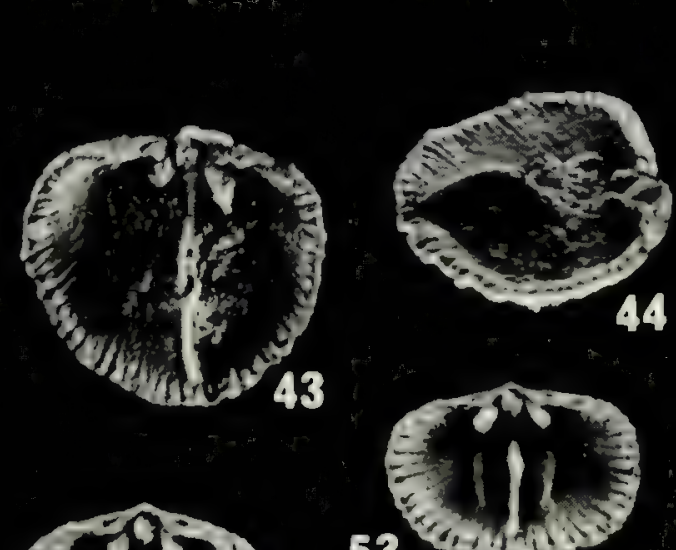

2)

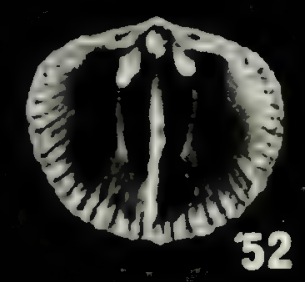

53
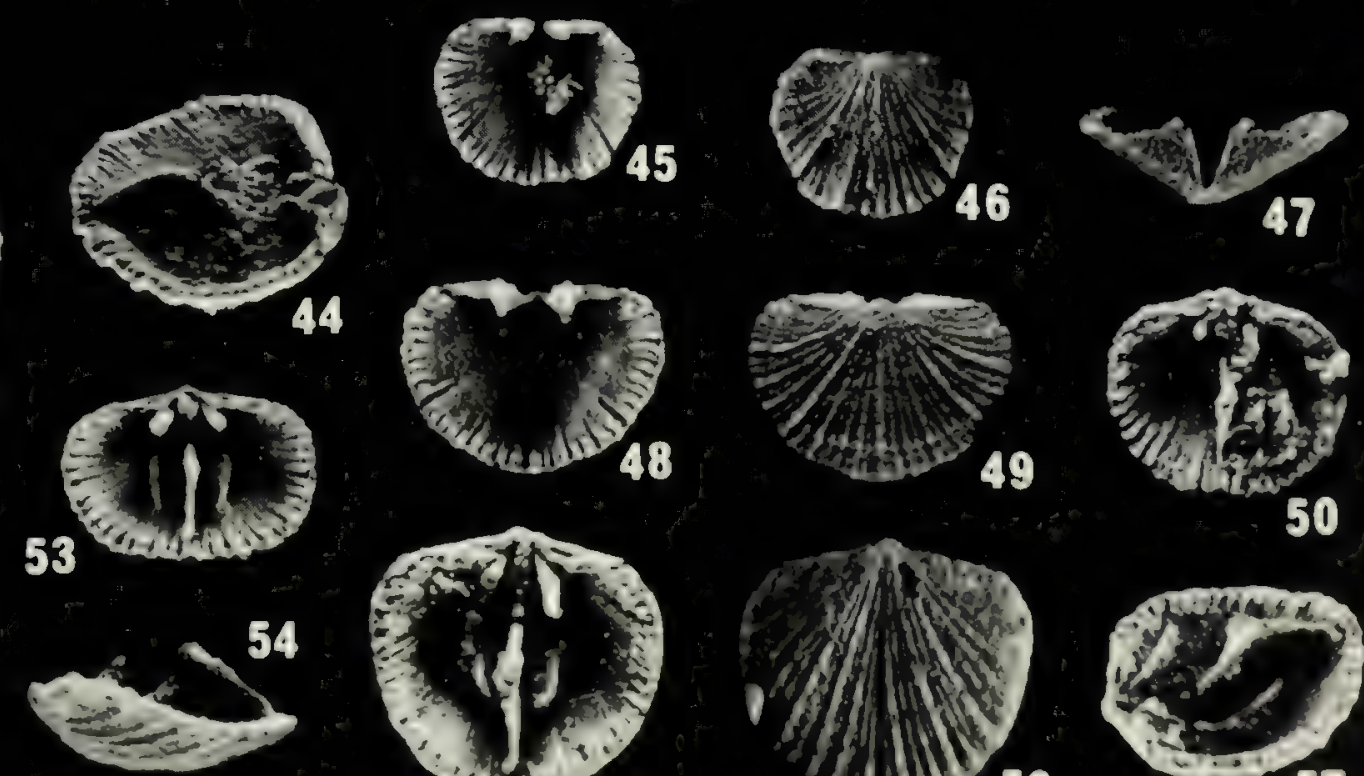

Eक 12

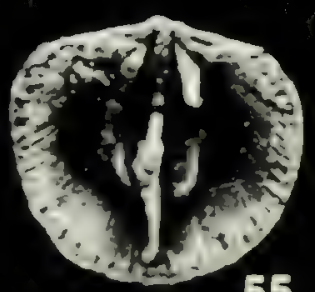

55
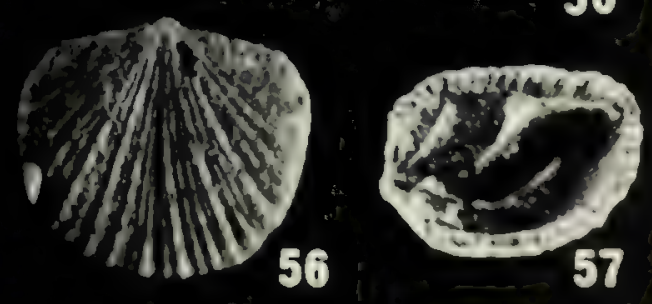

Erind 58
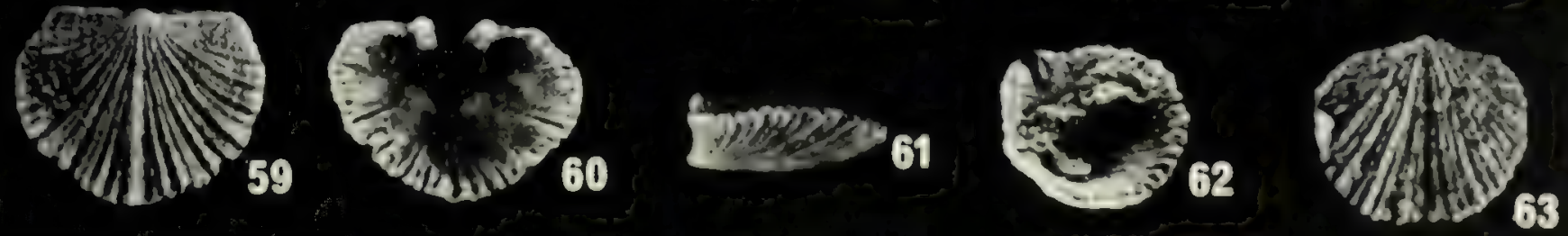
Plate 11, figs. 1-55

Articulate brachiopods Mystrophora, Kayserella, Grayina, Gypidula, and ?Procerulina

Figs. 1-20. Mystrophora arctica Lenz.

1, 2. Interior and oblique interior views of brachial valve, Delorme Formation (Zlichovian), S-3, sample S4-64.0-65.5 m, ROM $33356, \times 3.4$.

3 , 4. Interior and oblique interior views of pedicle valve, Delorme Formation (Zlichovian), S-3, sample S4-64.0-65.5 m, ROM 33357, $\times 3.4$.

5-9. Dorsal, ventral, posterior, anterior, and lateral views of articulated shell; Delorme Formation (Zlichovian), S-3, sample S4-64.0-65.5 m, ROM 33358, × 3.4.

10, 11. Lateral and posterior views of articulated shell, Delorme Formation (Zlichovian), S-3, sample S4-64.0-65.5 m, ROM $33359, \times 3.4$.

12, 13. Posterior and lateral views of a deep pedicle valve, Delorme Formation (Zlichovian), S-3, sample S4-80.8 m, ROM $33360, \times 3.4$.

14. Exterior view of brachial valve, Delorme Formation (Zlichovian), S-3, sample S4-466.3 m, ROM 33361, × 3.4.

15, 16. Interior and exterior views of brachial valve, Delorme Formation (Zlichovian), S-3, sample S4-466.3 m, ROM 33362 , $\times 3.4$.

17-20. Oblique interior, interior, exterior, and lateral views of pedicle valve; Delorme Formation (Zlichovian), S-3, sample S4-466.3 m, ROM 33363, $\times 3.4$. Note the plate elevated above the valve floor in fig. 17 and the pedicle callist development in fig. 18.

Figs. 21-23. Kayserella cf. K. costatula Lenz. Interior, exterior, and oblique interior views of brachial valve; Delorme Formation (Zlichovian), S-3, sample S4-143.3 m, ROM 33364, × 3.4.

Figs. 24-45. Grayina magnifica arctica Lenz.

24, 25. Exterior and interior views of pedicle valve, Delorme Formation (Pragian), S-1, sample OLDA388.6 m, ROM 33377 , $\times 1.9$.
26-28. Interior, exterior, and posterior views of pedicle valve; Delorme Formation (Pragian), S-1, sample OLDA388.6 m, ROM $33365, \times 1.9$.

29, 30. Interior and exterior views of pedicle valve, Delorme Formation (Lochkovian), S-3, sample S4-685.8 m, ROM 33366 , $\times 1.9$.

31-33. Exterior, interior, and posterior views of pedicle valve; Delorme Formation (Lochkovian), S-2, sample B225.6 m, ROM $33367, \times 1.9$.

34-36. Anterior, interior, and exterior views of pedicle valve; Delorme Formation (Lochkovian), S-2, sample B225.6 m, ROM $33368, \times 1.9$.

37, 38. Oblique interior and interior views of pedicle valve, Delorme Formation (Lochkovian), S-1, sample A528.8 m, ROM $33369, \times 1.9$.

39. Interior view of pedicle valve, Delorme Formation (Lochkovian), S-1, sample A528.8 m, ROM 33370, × 1.9 .

40, 41. Exterior and interior views of brachial valve, Delorme Formation (early Pragian), S-1, sample A448.1 m, ROM 33371, $\times 1.9$

42-45. Exterior, interior, oblique interior, and anterior views of brachial valve fragment; Delorme Formation (early Pragian), S-1, sample A448.1 m, ROM 33372, × 1.9 .

Figs. 46-53. Gypidula pelagica lux Johnson, Boucot, and Murphy.

46-50. Anterior, lateral, dorsal, ventral, and posterior views of articulated shell; Delorme Formation (Cathedral Mountain, $\left.61^{\circ} 43^{\prime} \mathrm{N}, 125^{\circ} 38^{\prime} \mathrm{W}\right), 91.4 \mathrm{~m}$ below the top of the Delorme, ROM $33373, \times 1.1$.

51-53. Oblique lateral, posterior, and dorsal views of articulated shell; Delorme Formation (Cathedral Mountain, $61^{\circ} 43^{\prime} \mathrm{N}$, $\left.125^{\circ} 38^{\prime} \mathrm{W}\right), 91.4 \mathrm{~m}$ below the top of the Delorme, ROM 33374 , $\times 1.1$.

Figs. 54, 55. ?Procerulina sp. 1. Exterior and interior views of pedicle valve, Delorme Formation (Lochkovian), S-3, S4-685.8 m, ROM 33378, $\times 5.0$. 
000
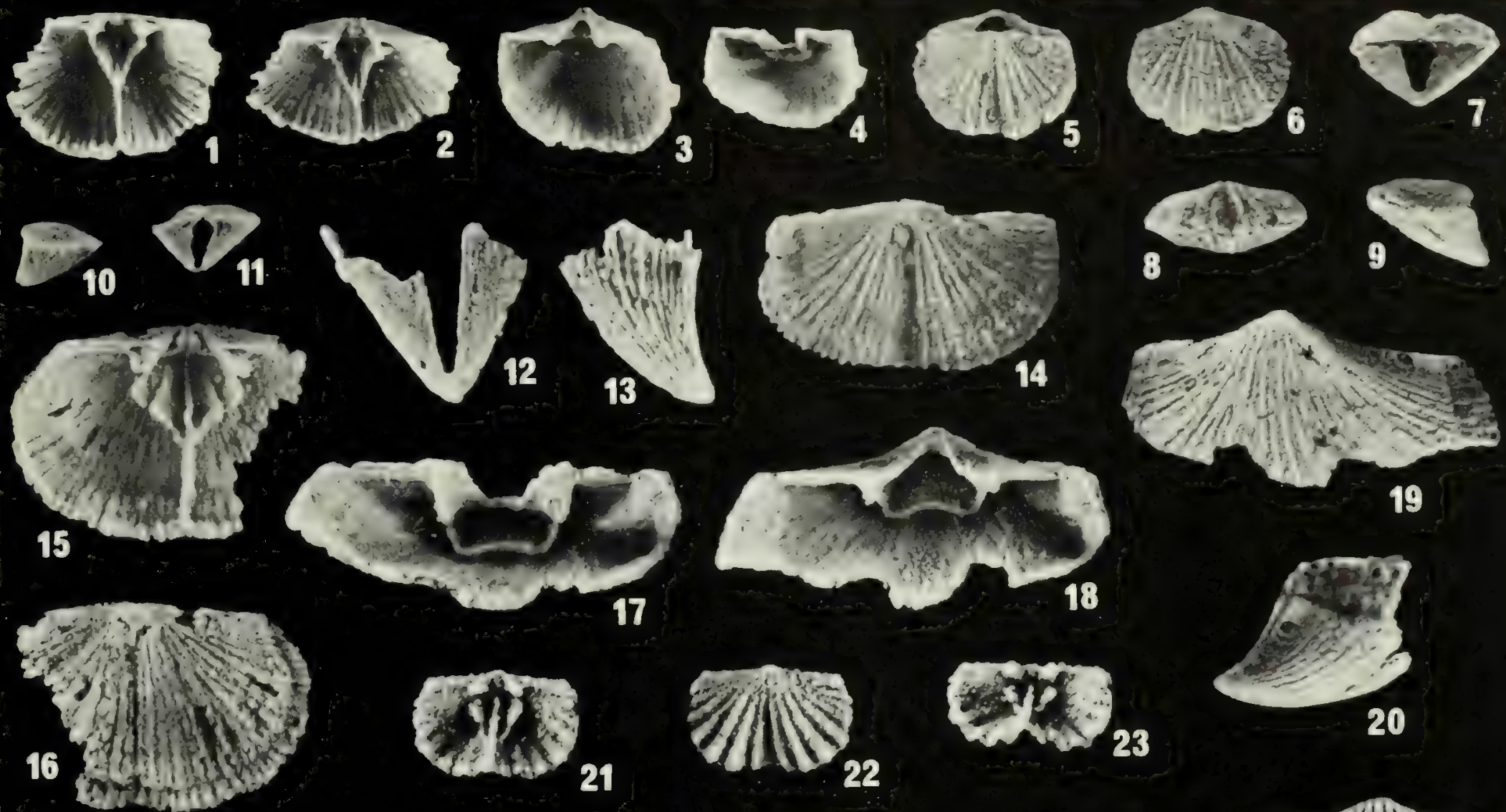

19
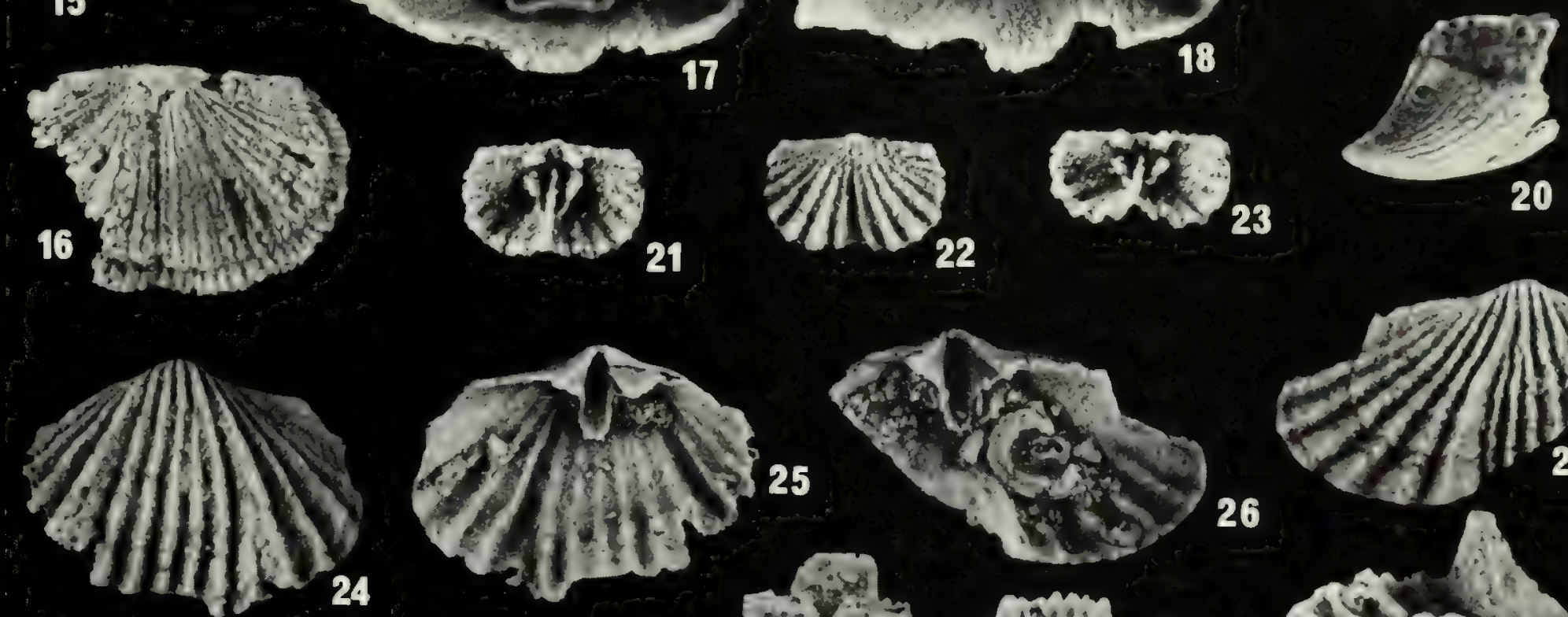

6)

29

(in)
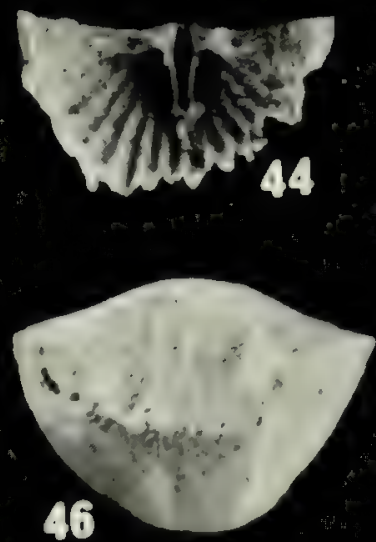
$(23)$
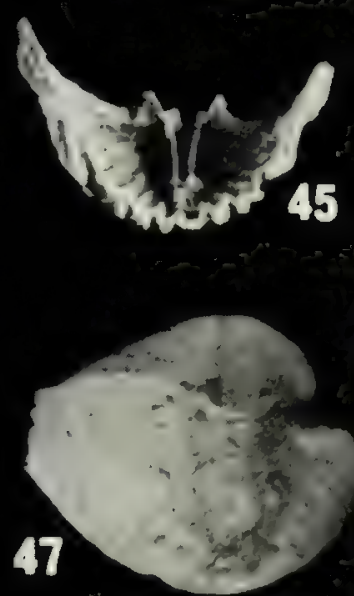

52

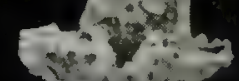
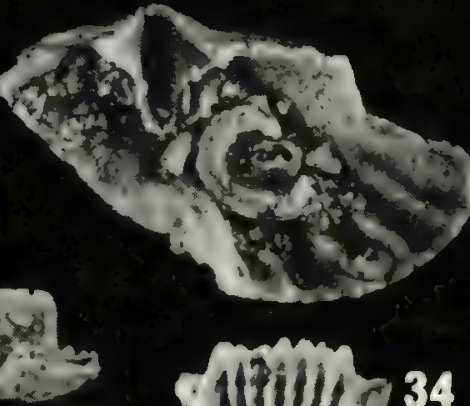

26

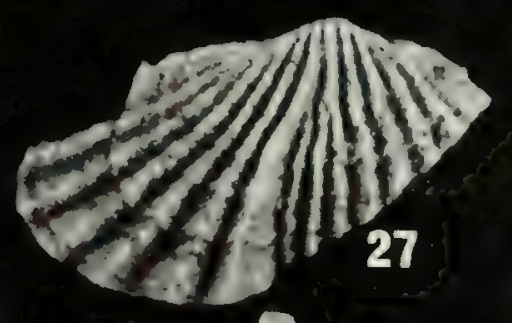

33 (lil) $>3$

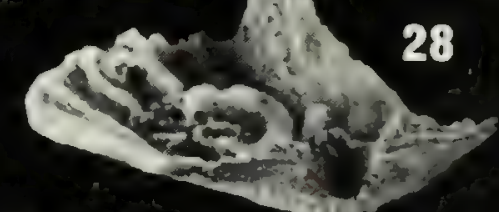

28

$-2 x-1,+2 x-3$

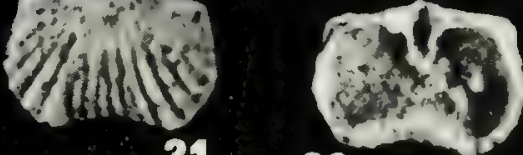

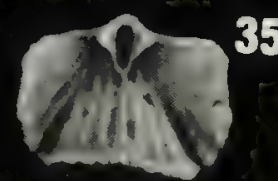 \\ Embilly}
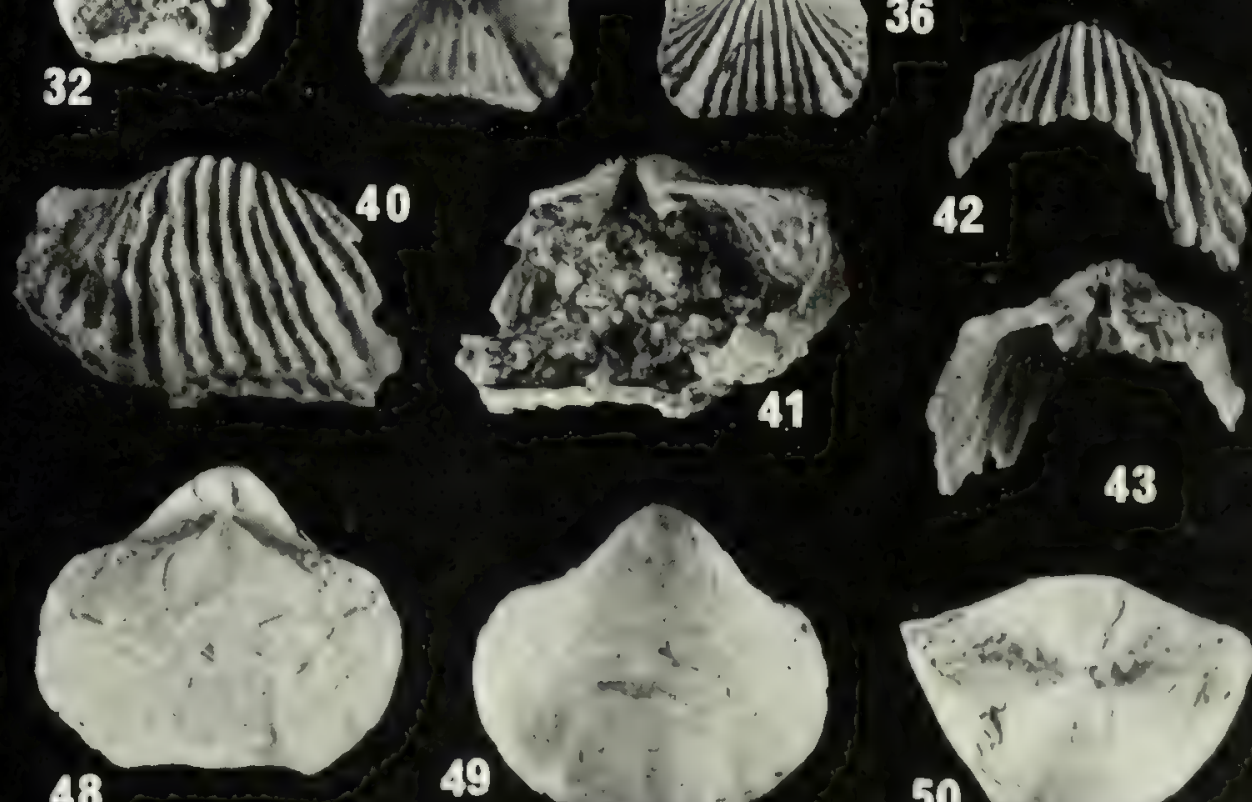

48
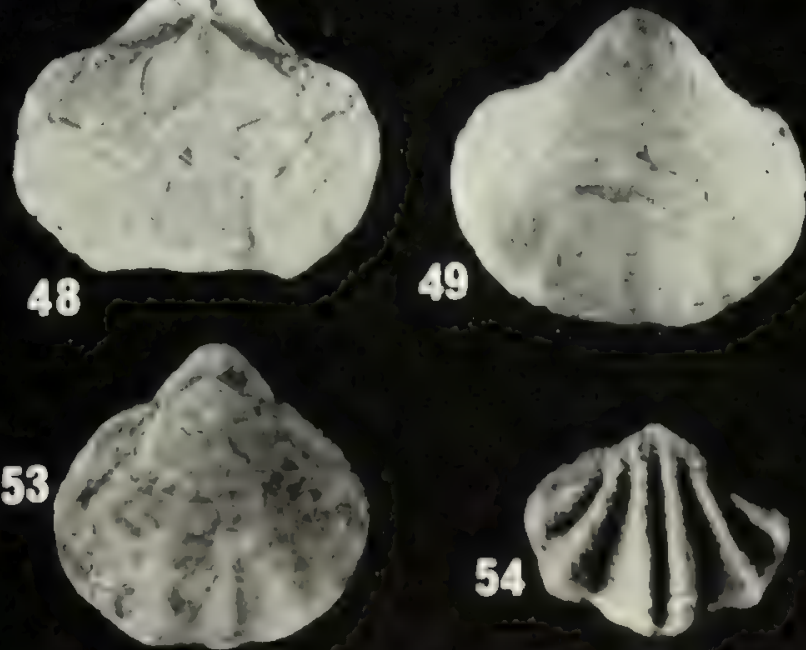

43
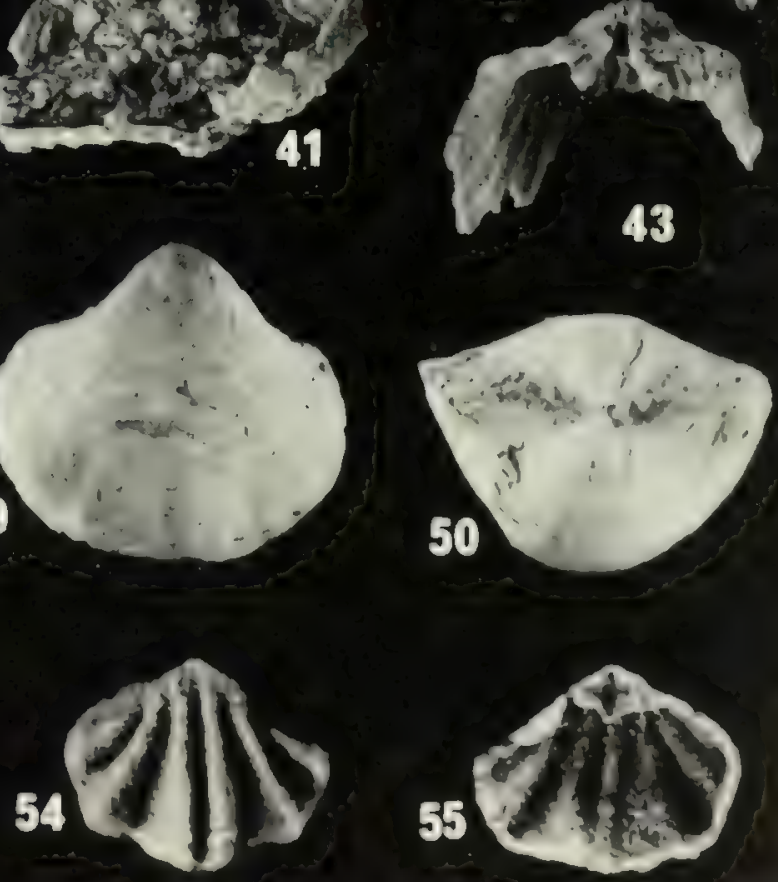
Plate 12, figs. $1-47$

Articulate brachiopods Conchidium, Gypidula, and Carinagypa

Figs. 1-26. Conchidium sp. 1.

1-5. Dorsal, anterior, lateral, posterior, and ventral views of articulated shell; Delorme Formation (Ludlovian), S-8, sample S2-0-12.2 m, ROM 33379, $\times 1.0$.

6. Interior view of pedicle valve, Delorme Formation (Ludlovian), S-6, sample C47-237.7 m, ROM 33380, × 1.0 .

7, 8. Exterior and interior views of pedicle valve, Delorme Formation (Ludlovian), S-6, sample C47-237.7 m, ROM 33381,

$\times 1.0$.

9, 10. Interior and exterior views of pedicle valve, Delorme Formation (Ludlovian), S-6, sample C47-237.7 m, ROM 33382, $\times 1.0$.

11. Exterior view of brachial valve, Delorme Formation (Ludlovian), S-6, sample C47-237.7 m, ROM 33383, $\times 1.0$.

12. Interior view of brachial valve, Delorme Formation (Ludlovian), S-6, sample C47-237.7 m, ROM 33384, × 1.0.

13. Interior view of brachial valve, Delorme Formation (Ludlovian), S-6, sample C47-237.7 m, ROM 33385, $\times 1.0$.

14. Interior view of brachial valve, Delorme Formation (Ludlovian), S-6, sample C47-237.7 m, RoM 33386, × 1.0.

15. Interior view of brachial valve, Delorme Formation (Ludlovian), S-6, sample C47-237.7 m, ROM 33387, × 1.0.

16. Interior view of brachial valve, Delorme Formation (Ludlovian), S-6, sample C47-248.4 m, ROM 33388, × 2.1.

17-19. Exterior, interior, and anterior views of brachial valve; Delorme Formation (Ludlovian), S-9, sample L146.3 m, ROM $33389, \times 1.0$.

20. Exterior view of brachial valve, Delorme Formation (Ludlovian), S-9, sample L166.1-173.7 m, ROM 33390, × 1.0.

21,22 . Exterior and posterior views of brachial valve, Delorme Formation (Ludlovian), S-9, sample L166.1-173.7 m, ROM $33391, \times 1.0$.

23. Interior view of brachial valve, Delorme Formation (Ludlovian), S-9, sample L166.1-173.7 m, ROM 33392, × 2.0.

24. Interior view of pedicle valve, Delorme Formation (Ludlovian), sample L166.1-173.7 m, ROM 33393, $\times 2.0$.

25,26 . Interior and exterior views of pedicle valve, Delorme Formation (Ludlovian), sample L166.1-173.7 m, ROM 33394, $\times 2.0$.
Figs. 27-33. Gypidula cf. G. boucoti Lenz.

27, 28. Ventral and posterior views of pedicle valve, Delorme Formation (Pragian), S-1, sample A342.9 m, ROM 33395, $\times$ 1.0 .

29. Interior view of brachial valve, Delorme Formation (Pragian), S-1, sample A342.9 m, ROM 33396, × 1.0 .

30. Lateral view of pedicle valve fragment, Delorme Formation (Pragian), S-1, sample A342.9 m, ROM 33397, × 1.0.

31,32 . Interior and exterior views of pedicle valve, Delorme Formation (Pragian), S-1, sample A274.3 m, ROM 33398, × 1.0 .

33. Interior view of brachial valve, Delorme Formation (Pragian), S-1, sample A274.3 m, ROM 33399, × 1.0 .

Figs. 34-44. Gypidula sp. 1.

$34,35,37$. Interior, exterior, and lateral views of pedicle valve; Delorme Formation (Pragian), S-1, sample OLDA336. 8 m, ROM $33400, \times 0.8$.

36. Interior view of brachial valve fragment, Delorme Formation (Pragian), S-1, sample OLDA336.8 m, ROM 33401, $\times 0.8$. 38, 39. Interior and exterior views of brachial valve, Delorme Formation (Pragian), S-1, sample OLDA336.8 m, ROM 33402, $\times 0.8$.

40, 41. Exterior and interior views of brachial valve, Delorme Formation (Pragian), S-2, sample B32.0 m, ROM 33403, × 1.0 . 42. Interior view of brachial valve, Delorme Formation (Pragian), S-2, sample B32.0, ROM 33404, × 1.0 .

43, 44. Interior and exterior views of pedicle valve, Delorme Formation (Pragian), S-2, sample B32.0, ROM 33405, $\times 1.0$.

Figs. 45-47. ?Carinagypa cf. C. careopleura Johnson.

45, 46. Exterior and interior views of pedicle valve, Delorme Formation (early Pragian), S-1, sample A442.0 m, ROM 33406, $\times 1.6$.

47. Interior view of brachial valve, Delorme Formation (early Pragian), S-1, sample A442.0 m, ROM 33407, $\times$ 1.6. Note the prominent flange developed at the junction of the inner and outer crural plates. 


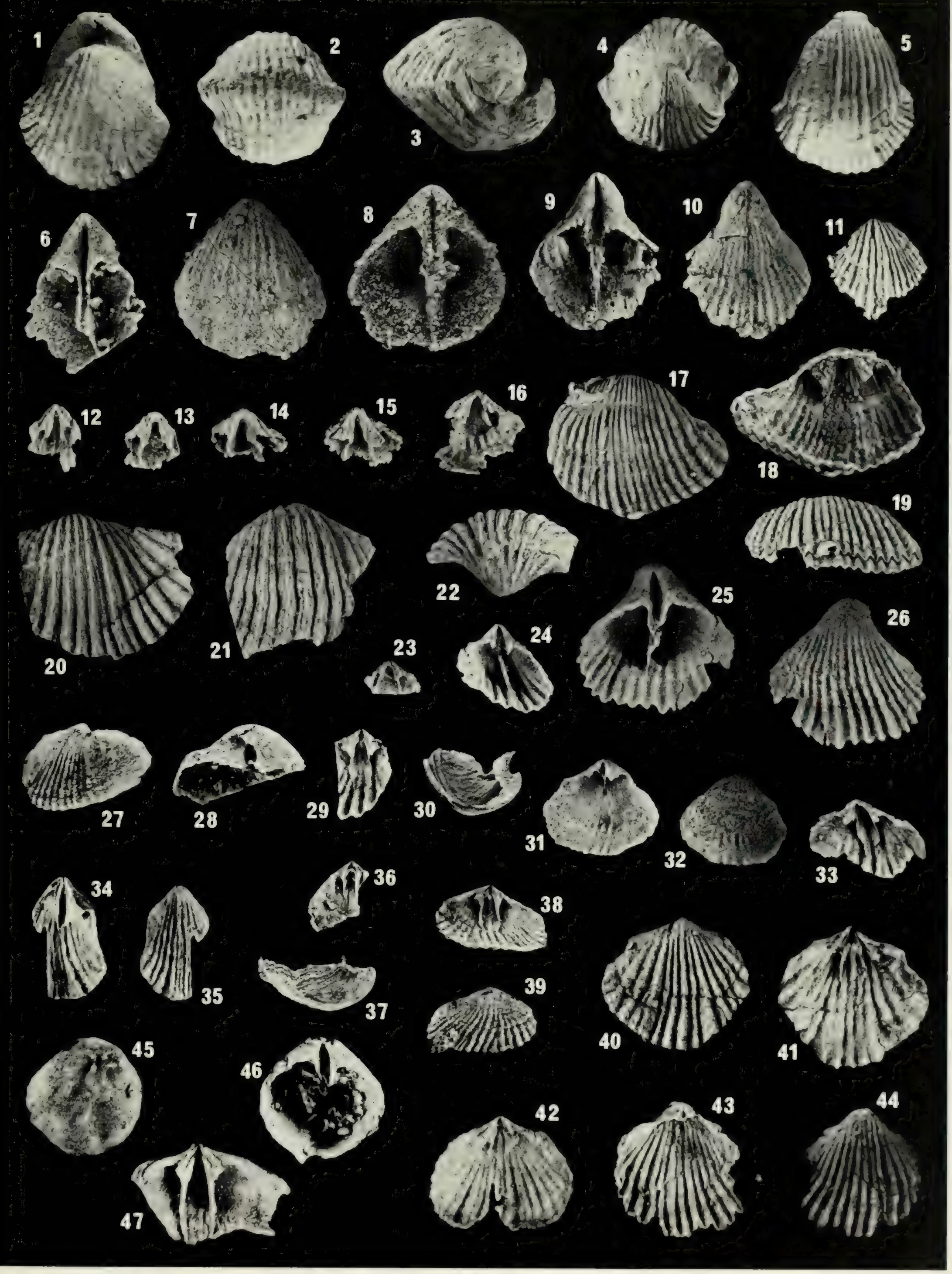


Plate 13, figs. 1-46

Articulate brachiopods Carinagypa and Gypidula .

Figs. 1-4. ?Carinagypa cf. C. careopleura Johnson.

1, 2. Interior and exterior views of brachial valve, Delorme Formation (Pragian), S-1, sample OLDA336.8 m, ROM 33458, $\times 1.6$.

3. Interior view of brachial valve, Delorme Formation (Pragian), S-1, sample OLDA336.8 m, ROM 33408, × 1.6.

4. Interior view of pedicle valve, Delorme Formation (Pragian), $\mathrm{S}-1$, sample OLDA336.8 $\mathrm{m}$, ROM $33409, \times 1.6$. Note the dimpled area lateral to the spondylium, possible impression of gonadal sacs?

Figs. 5-16. Gypidula cf. G. kayseri (von Peetz).

$5,9,10$. Lateral, exterior, and interior views of pedicle valve; Delorme Formation (Pragian), S-2, sample B128.6 m, ROM $33410, \times 1.5$.

6, 7. Exterior and interior views of brachial valve, Delorme Formation (Pragian), S-2, sample B128.6 m, ROM 33411, × 1.5 .

8. Exterior view of pedicle valve, Delorme Formation (Pragian), S-2, sample B128.6 m, ROM 33412, × 1.5 .

11,12 . Interior and exterior views of large brachial valve, Delorme Formation (late Lochkovian or early Pragian), S-2, sample B166.1-182.9 m, ROM 33413, × 1.5.

13, 14. Interior and exterior views of brachial valve, Delorme Formation (late Lochkovian or early Pragian), S-1, sample A484.6 m, ROM 33414, $\times 1.5$.

15. Exterior view of pedicle valve, Delorme Formation (late Lochkovian or early Pragian), S-1, sample A484.6 m, ROM $33415, \times 1.5$.

16. Interior view of brachial valve, Delorme Formation (late Lochkovian or early Pragian), S-1, sample A484.6 m, ROM $33416, \times 1.5$. Note the conjunct Sieberella-like brachial plates; these are developed in a few specimens.

Figs. 17-29. Gypidula sp. 2.

17-19. Interior, exterior, and lateral views of large pedicle valve; Delorme Formation (Lochkovian), S-1, sample A470.9 m, ROM 33417, $\times 1.0$.

20, 21. Interior and exterior views of brachial valve, Delorme Formation (Lochkovian), S-1, sample A470.9 m, ROM 33418, × 1.0

22. Exterior view of pedicle valve, Delorme Formation (Lochkovian), S-1, sample A470.9 m, ROM 33419, × 1.0

23. Interior view of brachial valve, Delorme Formation (Lochkovian), S-1, sample A470.9 m, ROM 33420, $\times 1.0$.
24. Interior view of brachial valve, Delorme Formation (Lochkovian), S-1, sample A466.3 m, ROM 33421, × 1.5 .

25,26 . Exterior and interior views of pedicle valve, Delorme Formation (Lochkovian), S-1, sample A466.3 m, ROM 33422, $\times$ 1.5.

27. Exterior view of pedicle valve, Delorme Formation (Lochkovian), S-2, sample B225.6 m, ROM 33423, × 1.5 .

28. Interior view of brachial valve, Delorme Formation (Lochkovian), S-2, sample B225.6 m, ROM 33424, × 1.5 .

29. Interior view of brachial valve, Delorme Formation (Lochkovian), S-2, sample B225.6 m, ROM 33425, $\times 1.5$.

Figs. 30-36. Gypidula sp. 3.

30,31 . Interior and exterior views of pedicle valve, Delorme Formation (Zlichovian), S-1, sample A62.5-68.6 m, ROM $33426, \times 1.1$.

32. Lateral view of pedicle valve fragment, Delorme Formation (Zlichovian), S-1, sample A62.5-68.6 m, ROM 33427, × 1.1.

33,34 . Interior and exterior views of brachial valve, Delorme Formation (Zlichovian), S-1, sample A62.5-68.6 m, ROM $33428, \times 1.1$.

35,36 . Interior and exterior views of brachial valve, Delorme Formation (Zlichovian), S-1, sample A62.5-68.6 m, ROM $33429, \times 1.1$.

Figs. 37-47. Gypidula sp. 4.

37. Interior view of brachial valve, Delorme Formation (Ludlovian), S-6, sample C47-248.4 m, ROM 33430, × 2.0.

38,39 . Exterior and interior views of pedicle valve, Delorme Formation (Ludlovian), S-6, sample C47-248.4 m, ROM 33431 , $\times 2.0$.

40. Interior view of brachial valve, Delorme Formation (Ludlovian), S-6, sample C47-248.4 m, Rом 33432, × 2.0 .

41,47 . Exterior and lateral views of pedicle valve, Delorme Formation (Ludlovian), S-6, sample C47-248.4 m, ROM 33438 , $\times 2.0$.

42. Interior view of pedicle valve, Delorme Formation (Ludlovian), S-6, sample C47-248.4 m, ROM 33434, × 2.0 .

43. Exterior view of pedicle valve, Delorme Formation (Ludlovian), S-6, sample C47-248.4 m, ROM 33435, $\times 2.0$.

44,45 . Interior and exterior views of brachial valve, Delorme Formation (Ludlovian), S-6, sample C47-248.4 m, ROM 33436 , $\times 2.0$.

46. Interior view of pedicle valve, Delorme Formation (Ludlovian), S-6, sample C47-248.4 m, ROM 33437, × 2.0. 

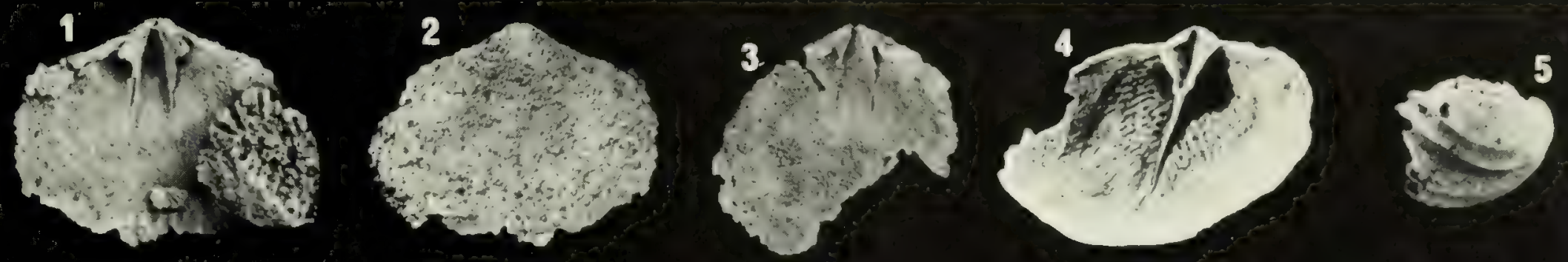

rins
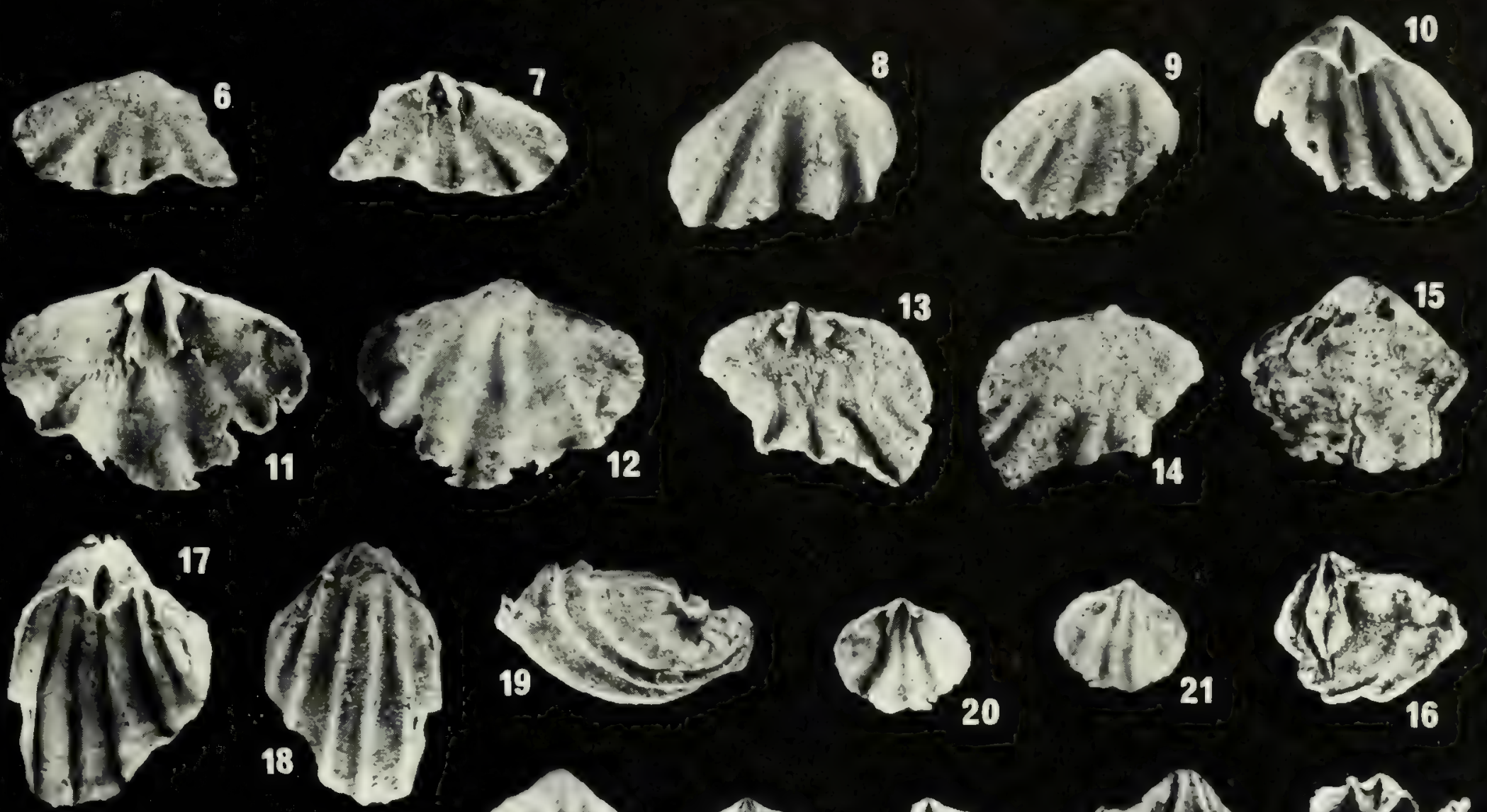

A 100
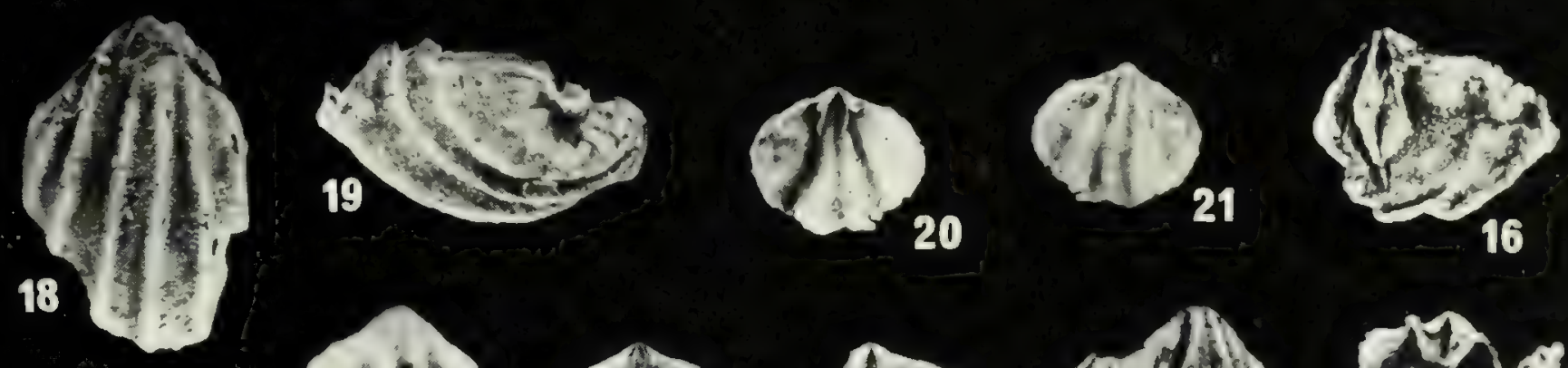

$(1)_{22}$
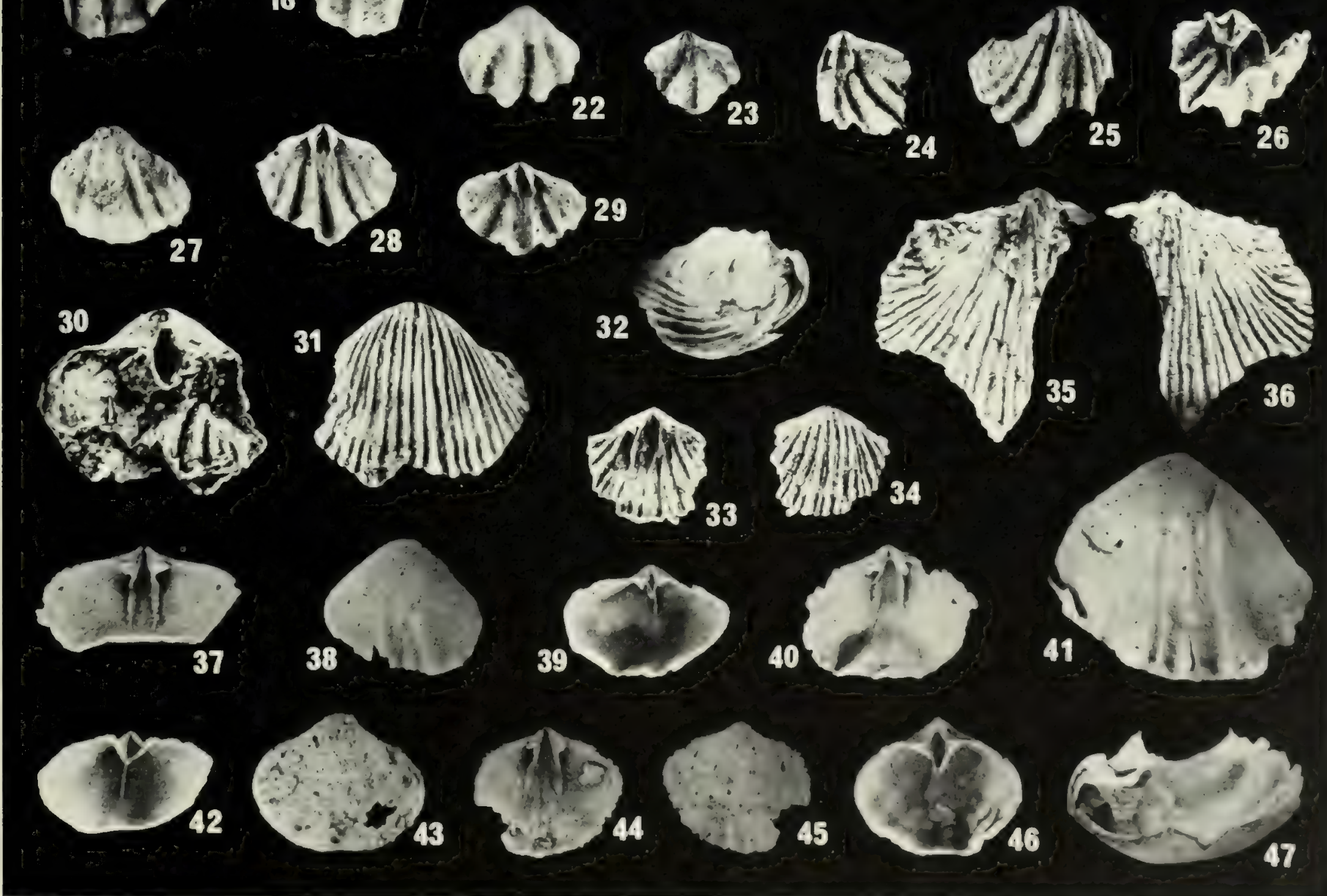
Plate 14, figs. 1-48

Articulate brachiopods Sieberella, Carinagypa, Clorinda, Clorindina, Leptaenisca, and Leptagonia.

Figs. 1-4. Sieberella sp. 1.

1. Anterior view of pedicle valve fragment, Delorme Formation (Lochkovian), S-1, sample A470.9 m, ROM 33439, $\times 2.0$.

2. Interior view of brachial valve, Delorme Formation (Lochkovian), S-1, sample A470.9 m, ROM $33440, \times 2.0$.

3. Interior view of brachial valve, Delorme Formation (Lochkovian), S-1, sample A470.9 m, ROM $33441, \times 2.0$.

4. Interior view of brachial valve, Delorme Formation (Pragian), S-1, sample A318.5 m, ROM 33442, × 2.0 .

Figs. 5-7. Carinagypa cf. C. loweryi (Merriam). Interior, oblique, and exterior views of brachial valve; Delorme Formation (Zlichovian), S-3, sample S4$466.3 \mathrm{~m}$, ROM $33443, \times 1.5$. Note the carinae in figs. 5 and 6

Figs. 8-14. Carinagypa praeloweryi (Johnson).

8, 9. Interior and exterior views of pedicle valve, Delorme Formation (early Zlichovian), S-3, sample S4-560.8-573.0 m, ROM $33444, \times 1.1$.

10-12. Exterior, interior, and oblique interior views of brachial valve; Delorme Formation (early Zlichovian), S-3, sample S4-560.8-573.0 m, ROM 33445, $\times 1.1$. Note the carinae in figs. 11 and 12 , and also in figs. 13 and 14 .

13, 14. Interior and oblique interior views of brachial valve, Delorme Formation (early Zlichovian), S-1, sample A62.5$68.6 \mathrm{~m}, \mathrm{ROM} 33446, \times 1.8$.

Figs. 15-27. Clorinda garretti sp. nov.

15-19. Posterior, anterior, dorsal, ventral, and lateral views of articulated shell; Delorme Formation (late Lochkovian to early Pragian), S-2, sample B166.1-182.9 m, holotype ROM 33447, $\times$ 2.9 .

20-22. Exterior, interior, and anterior views of brachial valve;
Delorme Formation (late Lochkovian to early Pragian), S-2, sample B166.1-182.9 $\mathrm{m}$, paratype ROM $33448, \times 2.9$. Note the prominent carinae in figs. 21 and 22, and also in figs. 23 and 24 .

23. Interior view of brachial valve, Delorme Formation (Lochkovian), S-1, sample A528.8 m, paratype ROM 33449, × 2.9 .

24, 25. Interior and exterior views of brachial valve, Delorme Formation (Lochkovian), S-1, sample A528.8 m, paratype ROM $33450, \times 2.9$

26, 27. Interior and exterior views of pedicle valve, Delorme Formation (Lochkovian), S-1, sample A528.8 m, paratype ROM $33451, \times 2.9$

Figs. 28-32. Clorindina sp. 1. Lateral, exterior, interior, and oblique interior views of brachial valve; Delorme Formation (Pragian), S-1, sample OLDA388.6 m, ROM $33452, \times 2.3$.

Figs. 33-44. Leptaenisca cf. L. concava (Hall).

33-35. Exterior, interior, and oblique interior views of brachial valve; Delorme Formation (Pragian), S-2, sample B105.2 m, ROM $33453, \times 2.5$.

36-40. Interior, oblique lateral interior, oblique posterior interior, lateral, and oblique anterior interior views of brachial valve; Delorme Formation (Pragian), S-2, sample B105.2 m, ROM $33454, \times 2.5$.

41. Oblique anterior interior view of pedicle valve fragment, Delorme Formation (Pragian), S-2, sample B105.2 m, ROM $33455, \times 2.5$.

42-44. Interior, oblique posterior interior, and exterior views of brachial valve; Delorme Formation (Pragian), S-1, sample OLDA $384.0 \mathrm{~m}$, ROM $33456, \times 2.5$.

Figs. 45-48. Leptagonia sp. Posterior, anterior, lateral, and dorsal views of articulated shell; Delorme Formation (Pragian), S-1, sample OLDA370.3 m, ROM $33457 \times 1.1$ 


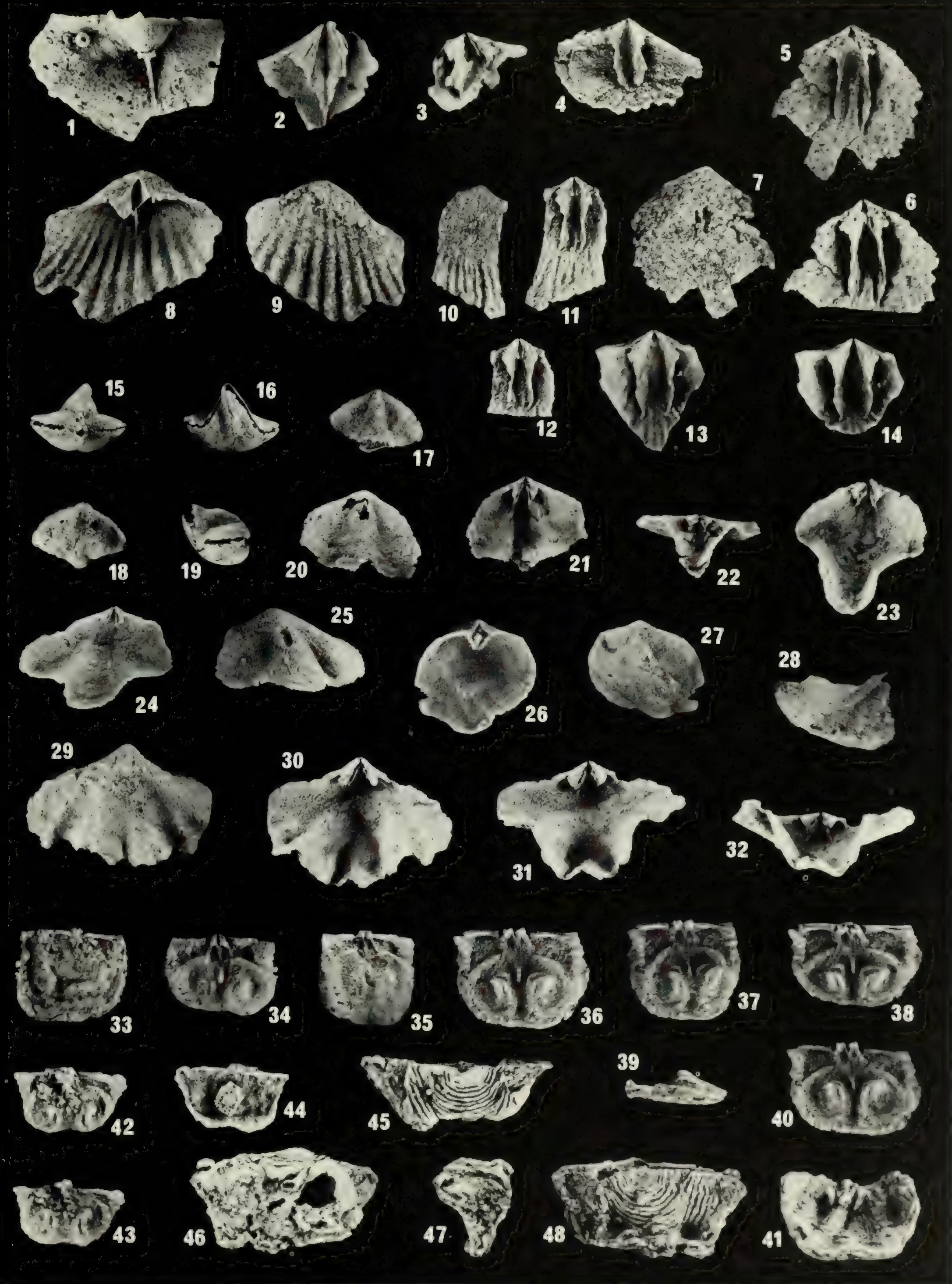


Plate 15, figs. $1-48$

Articulate brachiopods Leptagonia, Eoschuchertella, and "Brachyprion".

Figs. 1-12. Leptagonia costarugosa sp. nov.

1-3. Interior, exterior, and oblique posterior views of brachial valve; Delorme Formation (Zlichovian), S-1, sample A62.5$68.6 \mathrm{~m}$, holotype ROM $33459, \times 1.3$.

4-6. Oblique anterior, exterior, and interior views of pedicle valve; Delorme Formation (Zlichovian), S-1, sample A62.5$68.6 \mathrm{~m}$, paratype ROM $33460, \times 1.3$.

7-9. Oblique anterior, interior, and exterior views of brachial valve; Delorme Formation (Zlichovian), S-1, sample A62.5$68.6 \mathrm{~m}$, paratype ROM $33461, \times 1.3$.

10. Interior view of brachial valve, Delorme Formation (Zlichovian), S-1, sample A62.5-68.6 m, paratype ROM 33462, × 1.3.

11, 12. Exterior and interior views of pedicle valve, Delorme Formation (Zlichovian), S-1, sample A62.5-68.6 m, paratype ROM 33463, × 1.3 .

Figs. 13-19. Eoschuchertella cf. E. murphyi (Chatterton).

13, 14. Exterior and oblique interior views of pedicle valve, Delorme Formation (Zlichovian), S-1, sample A62.6-68.6 m, ROM 33464, × 1.6 .

15. Posterior view of pedicle valve, Delorme Formation (Zlichovian), S-1, sample A62.5-68.6 m, ROM 33465, × 1.6.

16-18. Oblique interior, interior, and exterior views of brachial valve; Delorme Formation (Zlichovian), S-1, sample A62.5$68.6 \mathrm{~m}$, ROM $33466, \times 1.6$.

19. Interior view of brachial valve, Delorme Formation (Zlichovian), S-1, sample A62.5-68.6 m, ROM 33467, × 1.6.

Figs. 20-34. Eoschuchertella sp. 1.

20-23. Interior, exterior, oblique interior, and posterior views of pedicle valve; Delorme Formation (Pragian), S-2, sample B $32.0 \mathrm{~m}$, ROM $33468, \times 1.8$.
24-26. Oblique interior, exterior, and interior views of brachial valve; Delorme Formation (Pragian), S-2, sample B32.0 m, ROM $33469, \times 1.8$.

27-29. Exterior, interior, and oblique interior views of brachial valve; Delorme Formation (Pragian), S-2, sample B32.0 m, ROM $33470, \times 1.8$

30, 31. Interior and exterior views of brachial valve, Delorme Formation (Pragian), S-2, sample B32.0 m, ROM 33471, × 1.8.

32. Oblique interior view of pedicle valve, Delorme Formation (Pragian), S-2, sample B32.0 m, ROM 33472, × 1.8 .

33,34 . Interior and exterior views of brachial valve, Delorme Formation (Pragian), S-2, sample B32.0 m, ROM 33473, $\times 1.8$.

Figs. 35-45. Eoschuchertella sp. 2.

35,36 . Exterior and interior views of pedicle valve, Delorme Formation (early Pragian), S-1, sample A442.0 m, ROM 33474 , $\times 1.3$.

37, 38. Exterior and interior views of brachial valve, Delorme Formation (early Pragian), S-1, sample A442.0 m, ROM 33475, $\times 1.3$.

39-41. Exterior, interior, and posterior views of brachial valve; Delorme Formation (early Pragian), S-1, sample A442.0 m, ROM 33476, × 1.3.

42, 43. Exterior and interior views of pedicle valve, Delorme Formation (late Lochkovian), S-3, S4-685.8 m, ROM 33477, $\times$ 1.3 .

44, 45. Interior and exterior views of brachial valve, Delorme Formation (late Lochkovian), S-3, S4-685.8 m, ROM 33478, $\times$ 1.3 .

Figs. 46-48. "Brachyprion"' sp. 1. Exterior, oblique posterior, and interior views of brachial valve; Delorme Formation (Zlichovian), S-3, sample S4-502.9$507.5 \mathrm{~m}$, ROM $33479, \times 1.2$. 

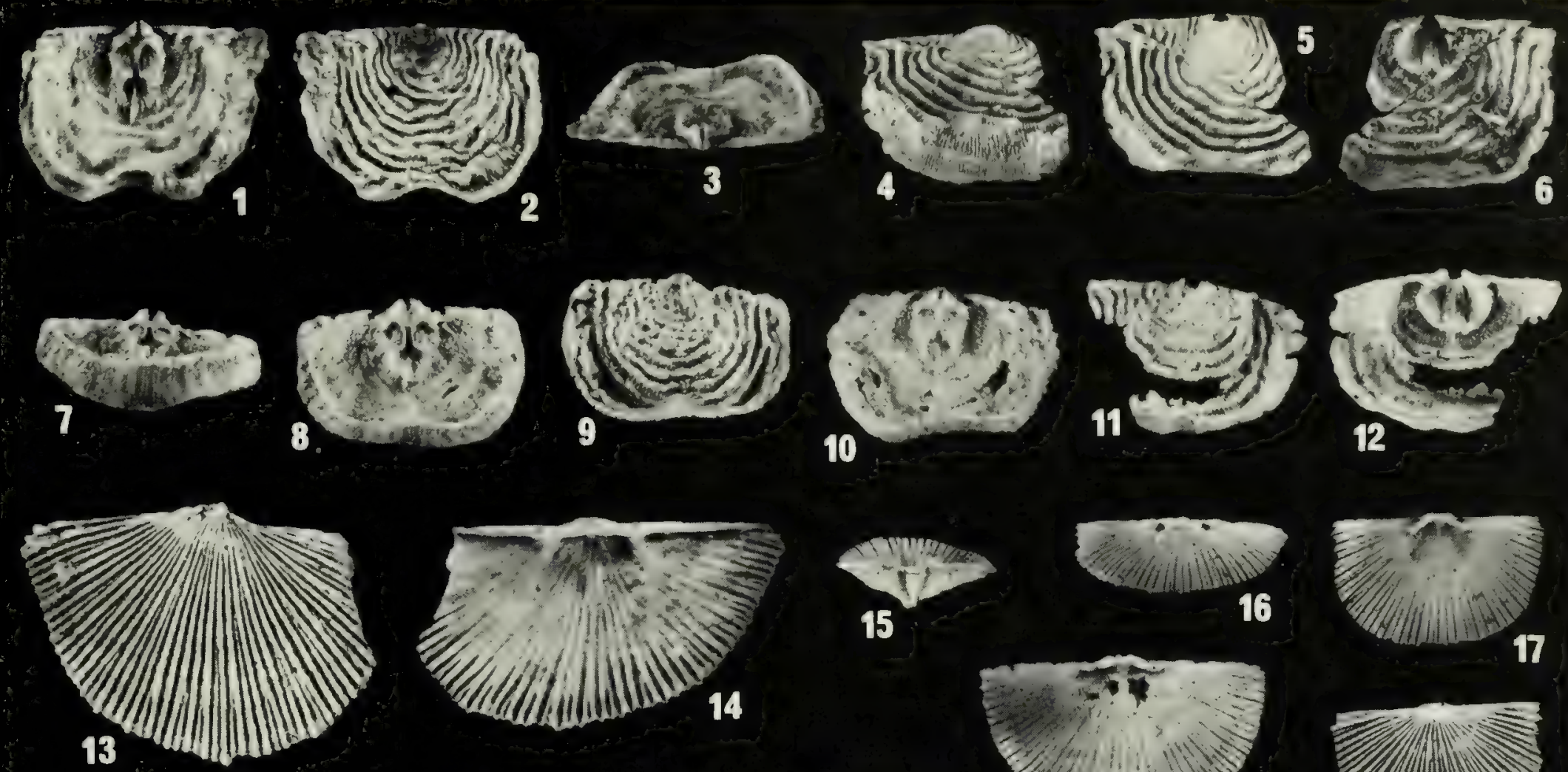

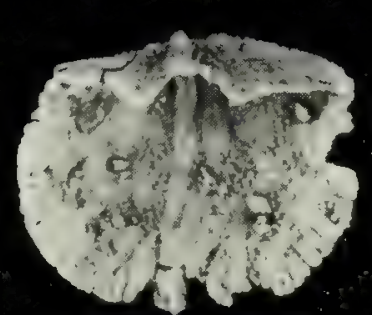

20

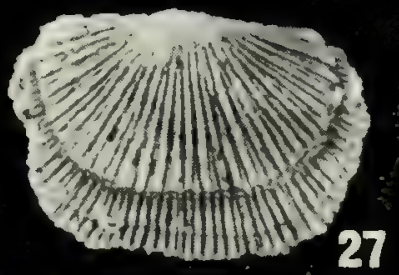

27

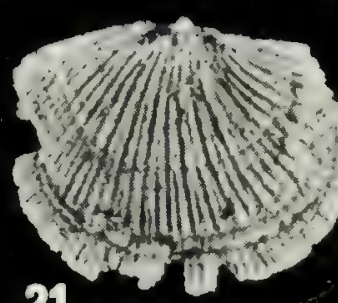

21

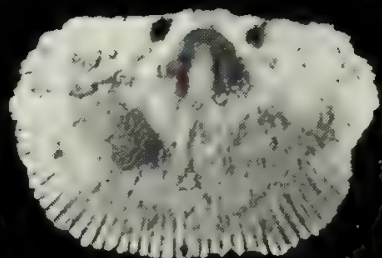

28

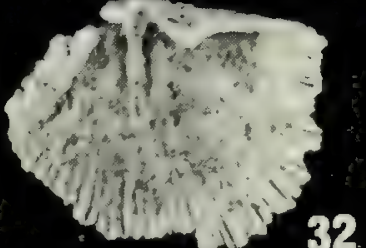

32

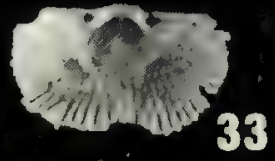

33
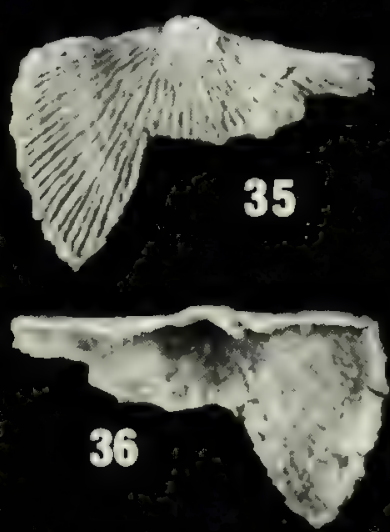

$Q_{42} D_{13}\left[D_{44}\right.$

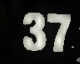

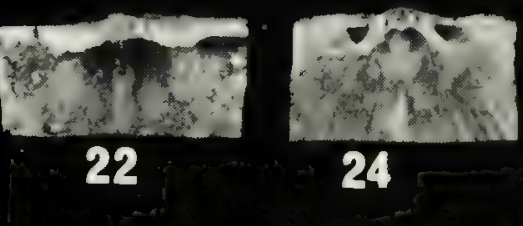

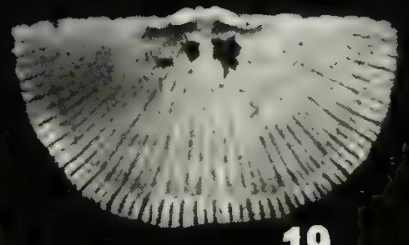

19
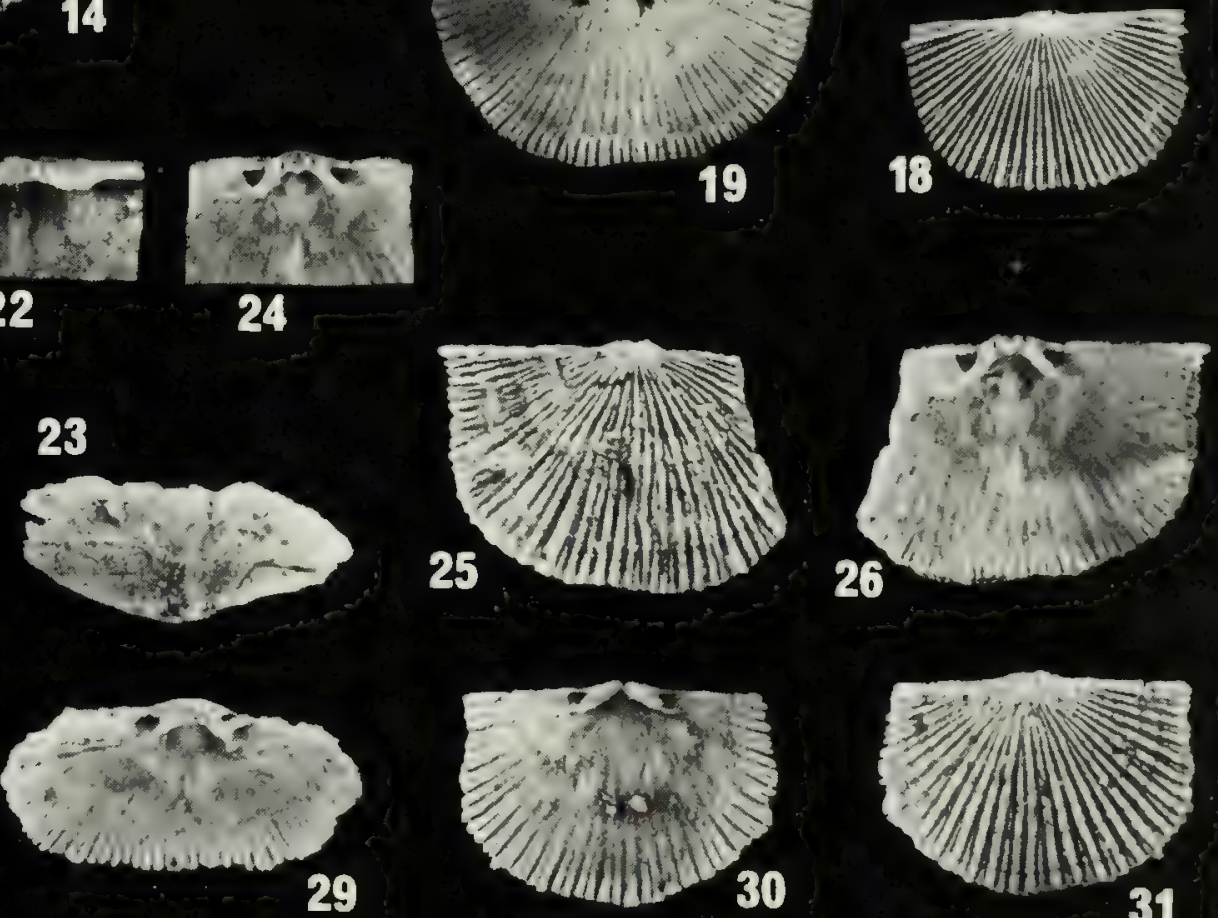

29

30

31
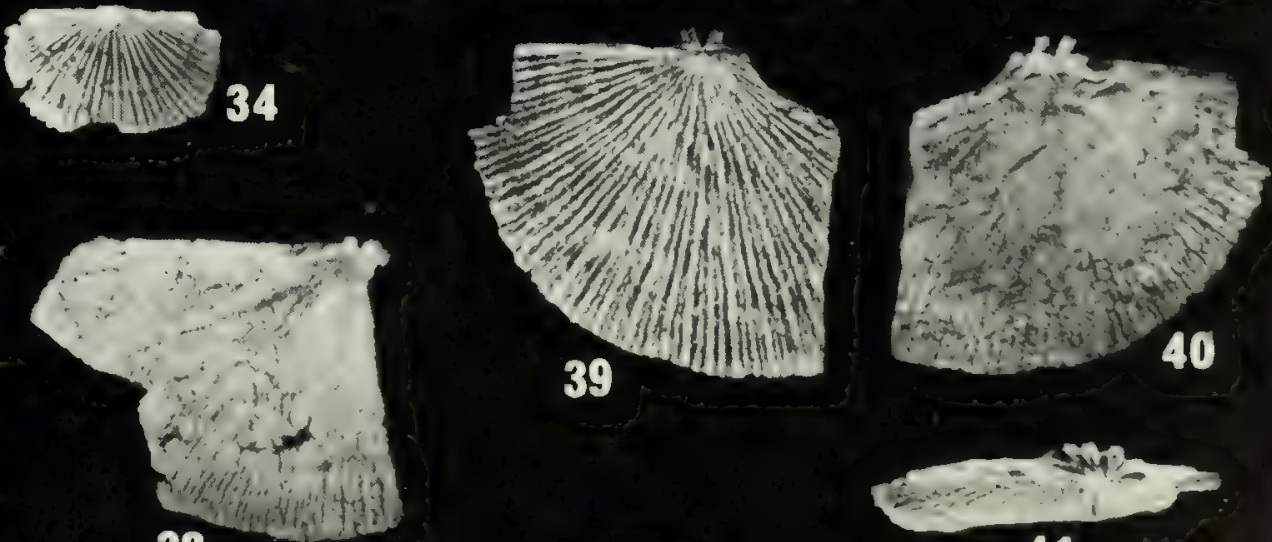

41

38

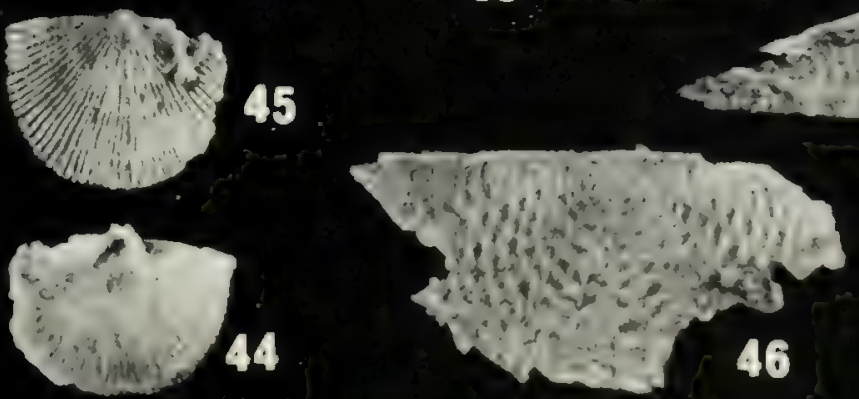

47.

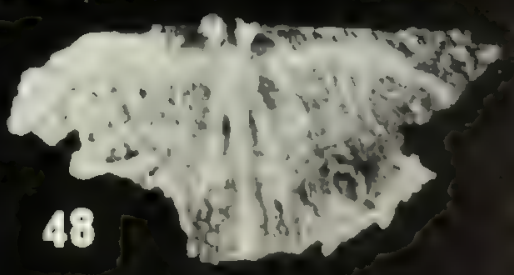


Plate 16, figs. $1-41$

Articulate brachiopods Aesopomum, Strophonella, and Mesodouvillina .

Figs. 1-2. Aesopomum sp. Exterior and interior views of brachial valve, Delorme Formation (Zlichovian), S-3, sample S4-176.8 m, ROM 33480, × 1.5.

Figs. 3-13. Aesopomum varistriatus Johnson.

3-5. Interior, posterior, and lateral views of brachial valve; Delorme Formation (Lochkovian), S-11, sample $211.5 \mathrm{~m}$ above the Road River Formation, ROM 33481, × 3.0 .

6, 7. Lateral and posterior views of pedicle valve, Delorme Formation (Lochkovian), S-11, sample $211.5 \mathrm{~m}$ above the Road River Formation, ROM 33482, × 3.0 .

8, 9. Oblique exterior and interior views of brachial valve, Delorme Formation (Lochkovian), S-2, sample B344.4 m, ROM $33483, \times 1.5$

10, 11. Exterior and interior views of brachial valve, Delorme Formation (Lochkovian), S-2, sample B181.4-182.9 m, ROM $33484, \times 1.5$.

12, 13. Lateral and interior views of brachial valve, Delorme Formation (Lochkovian), S-2, sample B181.4-182.9 m, ROM $33485, \times 1.5$.

Figs. 14-30. Aesopomum irregularis sp. nov.

14. Interior view of brachial valve, Delorme Formation (Pragian), S-1, sample A338.3 m, paratype ROM 33486, $\times 1.5$.

15, 16. Interior and oblique lateral views of brachial valve, Delorme Formation (Pragian), S-1, sample A338.3 m, holotype ROM $33487, \times 1.5$.

17-19. Exterior, interior, and lateral views of pedicle valve; Delorme Formation (Pragian), S-1, sample A338.3 m, paratype ROM $33488, \times 1.5$.

20-22. Exterior, interior, and posterolateral views of pedicle valve; Delorme Formation (Pragian), S-1, sample A345.9 m, paratype ROM $33489, \times 1.5$. Note the dental plate development in fig. 21

23, 24. Exterior and interior views of pedicle valve, Delorme Formation (Pragian), S-1, sample OLDA336.8 m, paratype ROM $33490, \times 1.5$.

25,26 . Interior and lateral views of brachial valve, Delorme Formation (Pragian), S-1, sample OLDA336.8 m, paratype ROM $33491, \times 1.5$.

27, 28. Exterior and interior views of pedicle valve, Delorme Formation (Pragian), S-1, sample OLDA336.8 m, paratype ROM $33492, \times 1.5$.

29, 30. Interior and exterior views of brachial valve, Delorme Formation (Pragian), S-1, sample OLDA336.8 m, paratype ROM $33493, \times 1.5$.

Figs. 31-33. Strophonella sp. 1. Interior, oblique lateral, and exterior views of pedicle valve; Delorme Formation (Zlichovian), S-3, sample S4-64.0-65.5 m, ROM 33494, × 1.0 .

Figs. 34-38. Mesodouvillina sp. 1.

34-36. Ventral, dorsal, and oblique lateral views of articulated shell; Delorme Formation (Zlichovian), S-3, sample S4-64.0$65.5 \mathrm{~m}$, ROM $33495, \times 1.2$.

37, 38. Interior and exterior views of brachial valve, Delorme Formation (Zlichovian), S-3, sample S4-64.0-65.5 m, ROM $33496, \times 1.2$.

Figs. 39-41. Mesodouvillina cf. M. stelcki Lenz. Interior, exterior, and oblique posterior views of brachial valve; Delorme Formation (Pragian), S-2, sample B $121.9 \mathrm{~m}$, ROM $33497, \times 1.2$. 

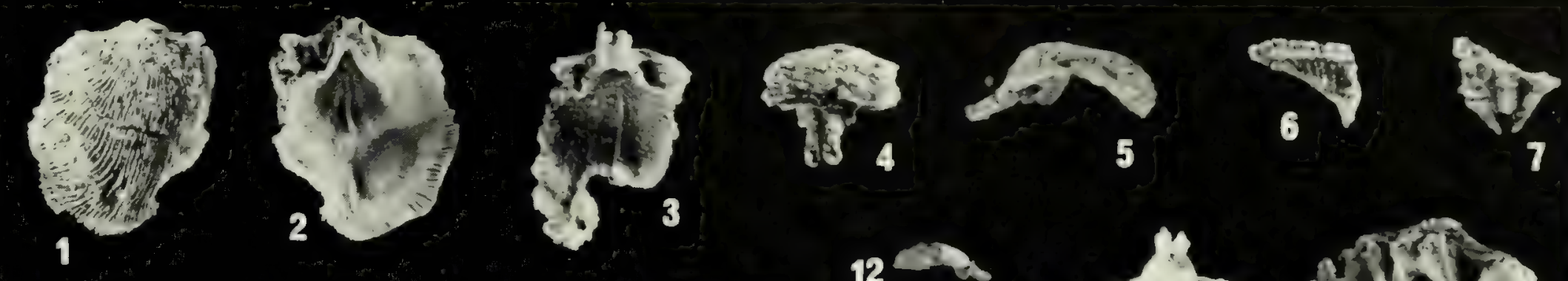

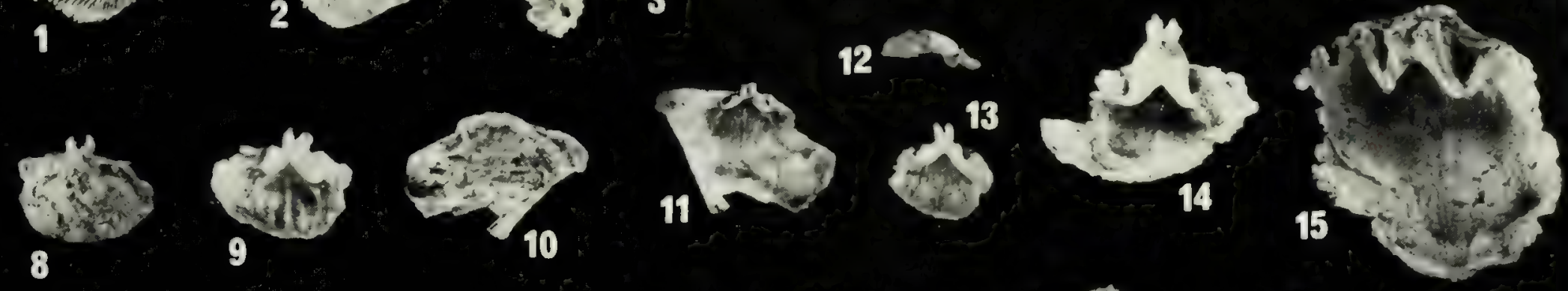
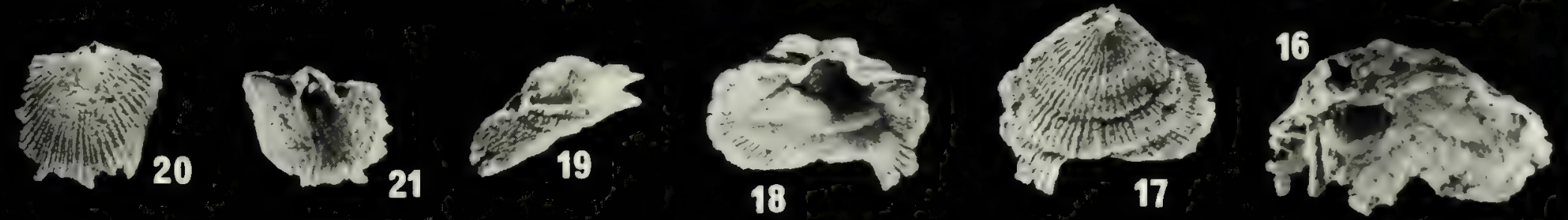

$+22$
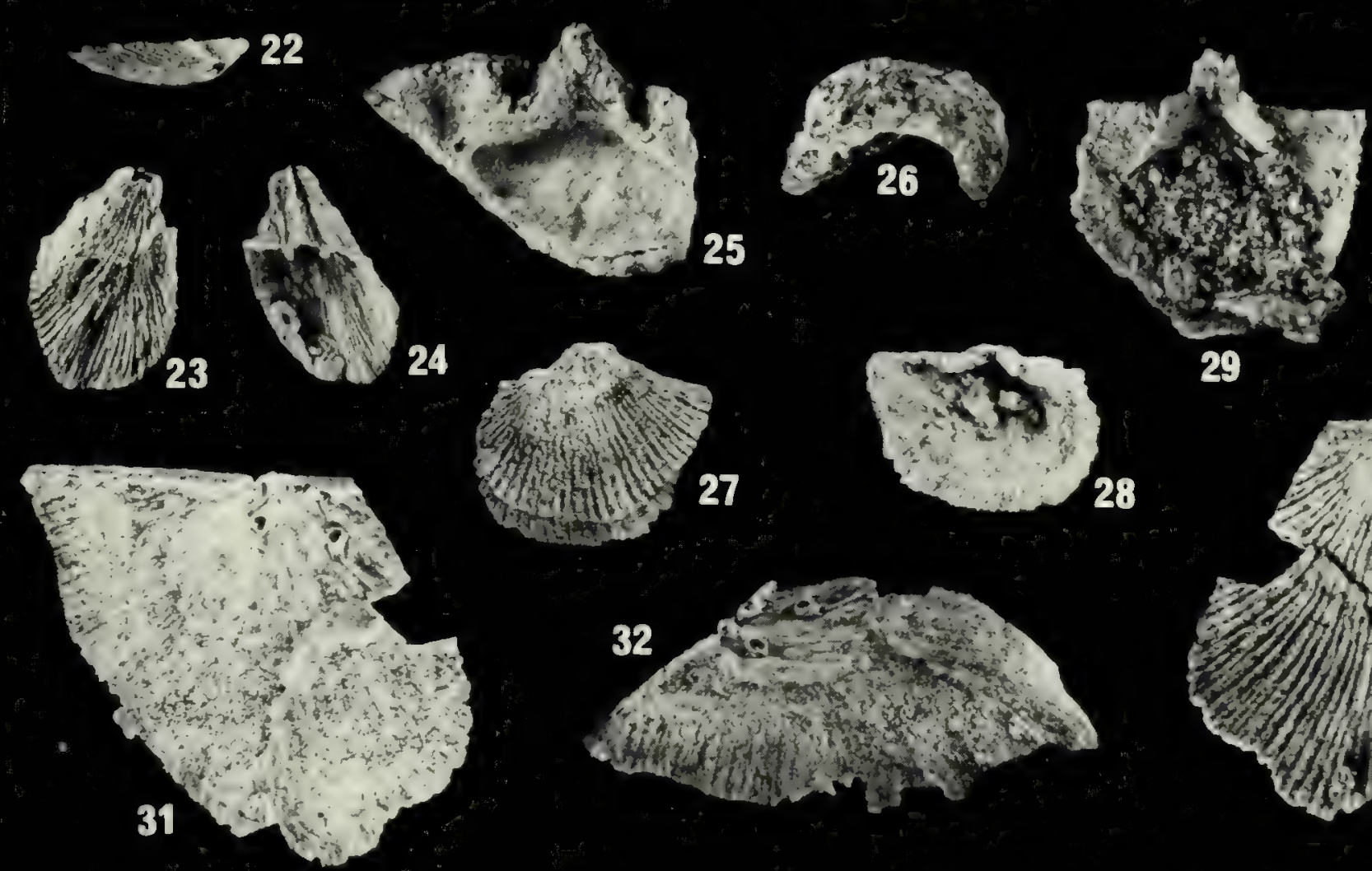

29
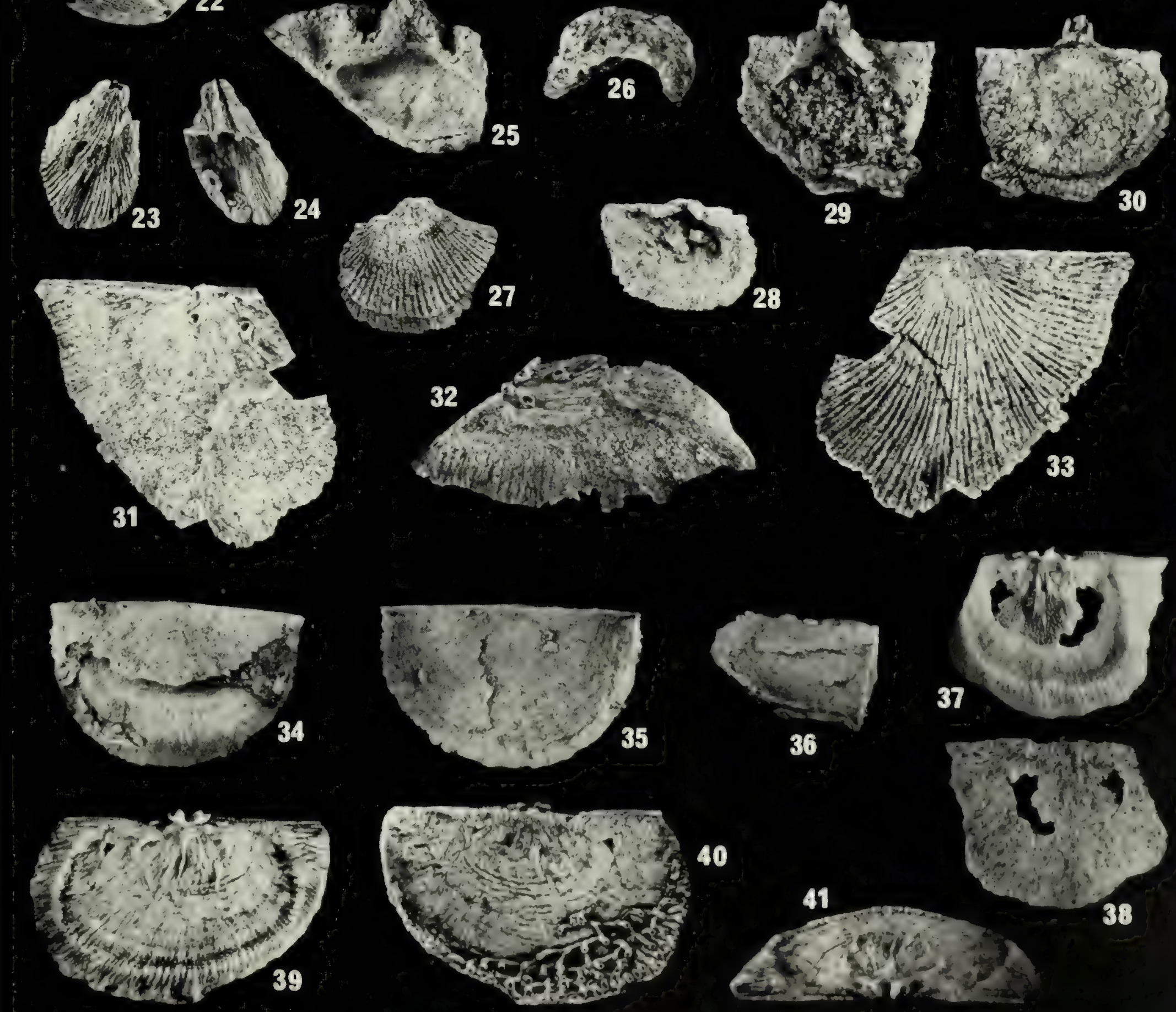

36

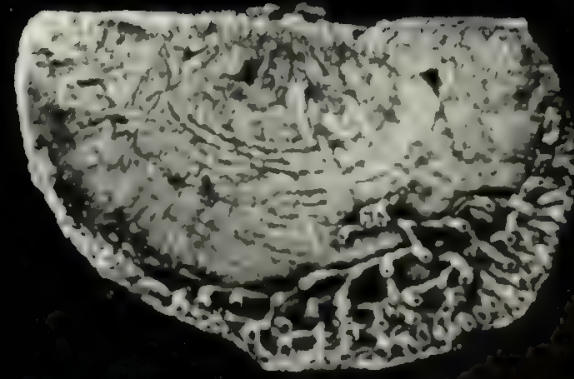

40

41

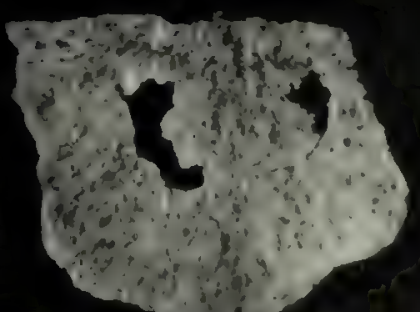

38 
Plate 17, figs. 1-38

Articulate brachiopods Mesodouvillina, Mclearnites, Cymostrophia, and Strophodonta.

Figs. 1, 2. Mesodouvillina sp. 1. Interior and exterior views of brachial valve, Delorme Formation (Zlichovian), S-3, sample S4-492.2 m, ROM 33498, × 1.1 .

Figs. 3, 4. Mesodouvillina cf. M. stelcki Lenz. Exterior and interior views of brachial valve, Delorme Formation (early Pragian), S-1, sample A436.5 m, ROM $33499, \times 0.9$.

Figs. 5-25. Mesodouvillina delormei sp. nov.

5, 6. Exterior and interior views of pedicle valve, Delorme Formation (Lochkovian), S-7, sample CH27WA181.4 m, paratype ROM $33500, \times 4.0$.

$7,8,10$. Exterior, interior, and oblique exterior views of brachial valve; Delorme Formation (Lochkovian), S-7, sample CH27WA181.4 m, paratype ROM 33501, $\times 4.0$. Note the weakly developed "seersucker" ornamentation on figs. 7 and 10 , and also on fig. 24.

9. Interior view of brachial valve, Delorme Formation (Lochkovian), S-7, sample CH27WA181.4 m, paratype ROM 33502, × 4.0

11, 12. Exterior and interior views of pedicle valve, Delorme Formation (Lochkovian), S-7, sample P7WA2033.3 m, holotype ROM $33504, \times 2.1$.

13. Interior view of brachial valve, Delorme Formation (Lochkovian), S-7, sample P7WA2033.3 m, paratype ROM 33505, $\times$ 2.1.

14, 15. Interior and exterior views of pedicle valve, Delorme Formation (Lochkovian), S-7, sample P7WA2033.3 m, paratype ROM $33506, \times 2.1$.

16-18. Interior, exterior, and oblique posterior views of brachial valve; Delorme Formation (Lochkovian), S-7, sample P7WA2033.3 m, paratype ROM 33507, × 2.1.

19, 20. Interior and oblique interior views of brachial valve, Delorme Formation (Lochkovian), S-7, P7WA1731.3 m, paratype ROM 33508, × 2.1.
21. Oblique interior view of pedicle valve fragment, Delorme Formation (Lochkovian), S-7, sample P7WA1731.3 m, paratype ROM $33509, \times 2.1$.

22. Oblique interior view of pedicle valve, Delorme Formation (Lochkovian), S-7, sample P7WA1731.3 m, paratype ROM $33510, \times 2.1$.

23. Oblique interior view of pedicle valve, Delorme Formation (Lochkovian), S-7, sample P7WA1731.3 m, paratype ROM $33511, \times 2.1$.

24, 25. Ventral and dorsal views of articulated shell, Delorme Formation (Lochkovian), S-7, sample P7WA1731.3 m, paratype ROM $33512, \times 2.1$.

Figs. 26, 27. Mclearnites cf. $M$. invasor Johnson. Interior and exterior views of brachial valve, Delorme Formation (Zlichovian), S-3, sample S4-492.3 m, ROM $33513, \times 1.7$

Figs. 28, 29. Cymostrophia sp. Exterior and interior views of pedicle valve, Delorme Formation (Pragian), S-1, sample A330.7 m, ROM 33514, × 0.9 .

Figs. 30-34. Strophodonta sp. 2.

30, 31. Interior and exterior views of pedicle valve, Delorme Formation (early Pragian), S-1, sample A442.0 m, ROM 33515, $\times 1.1$.

32, 33. Interior and exterior views of pedicle valve, Delorme Formation (early Pragian), S-1, sample A442.0 m, ROM 33516 , $\times 1.1$.

34. Interior view of brachial valve fragment, Delorme Formation (early Pragian), S-1, sample A442.0 m, ROM 33517, $\times 1.1$.

Figs. 35-38. Strophodonta sp. 1.

35,36 . Interior and exterior views of brachial valve, Delorme Formation (Zlichovian), S-3, sample S4-143.3 m, ROM 33518 , $\times 1.0$.

37, 38. Interior and exterior views of pedicle valve, Delorme Formation (Zlichovian), S-3, sample S4-560.8-573.0 m, ROM $33519, \times 0.7$. 

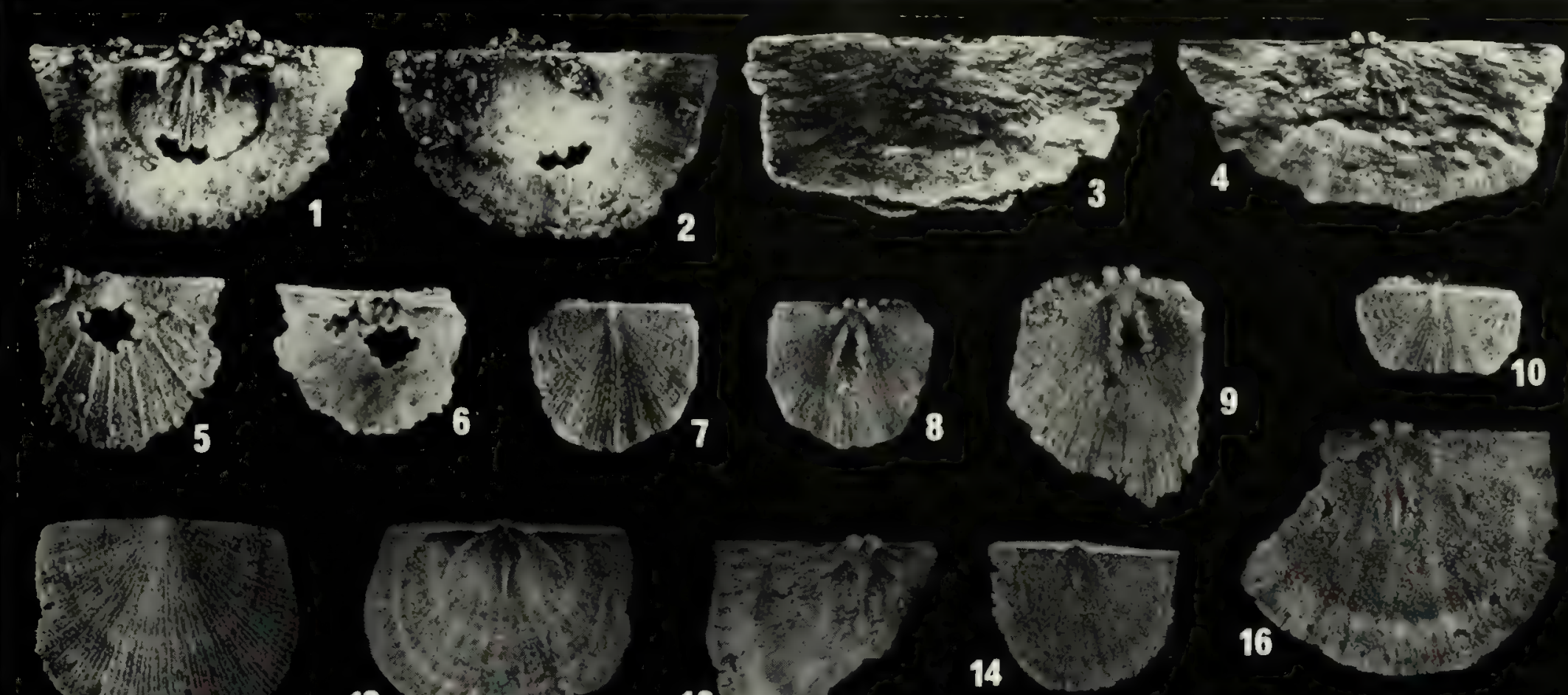

11
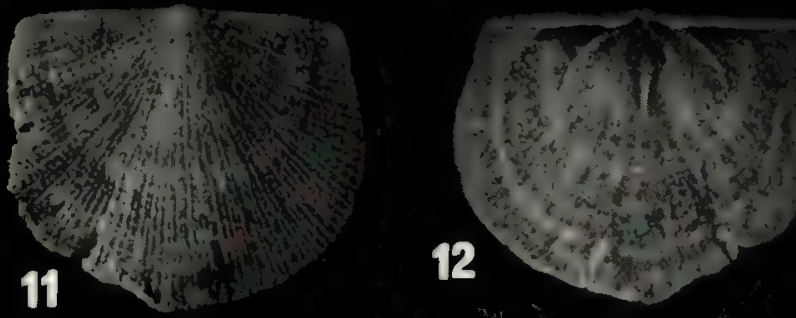

13
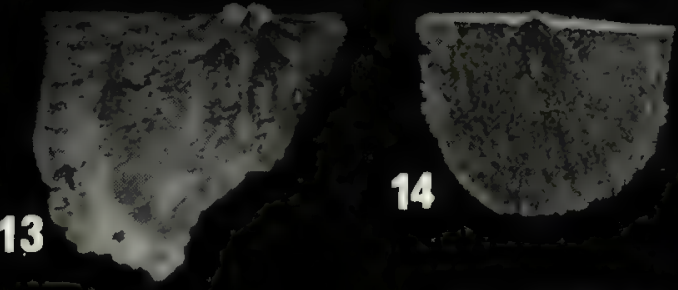

20

15

19
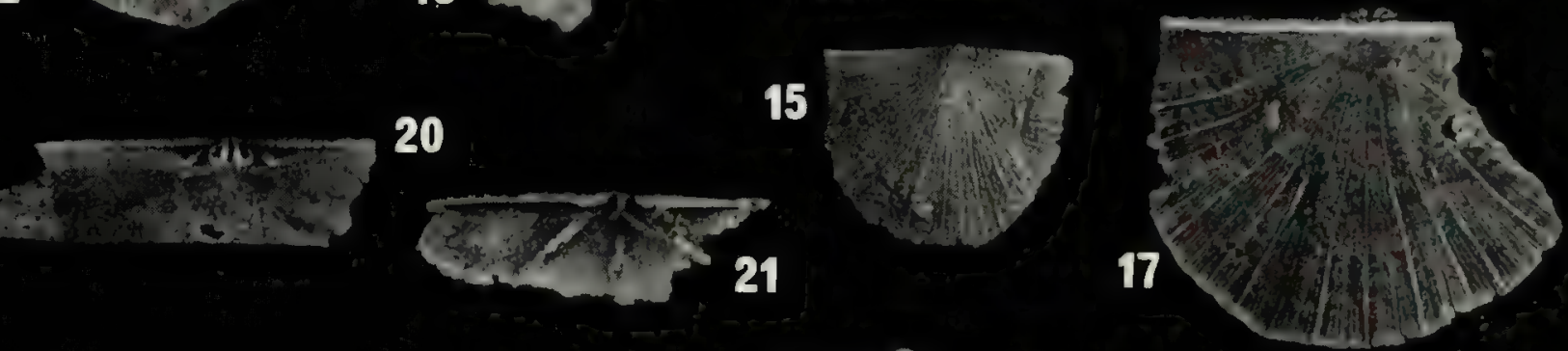

22

23
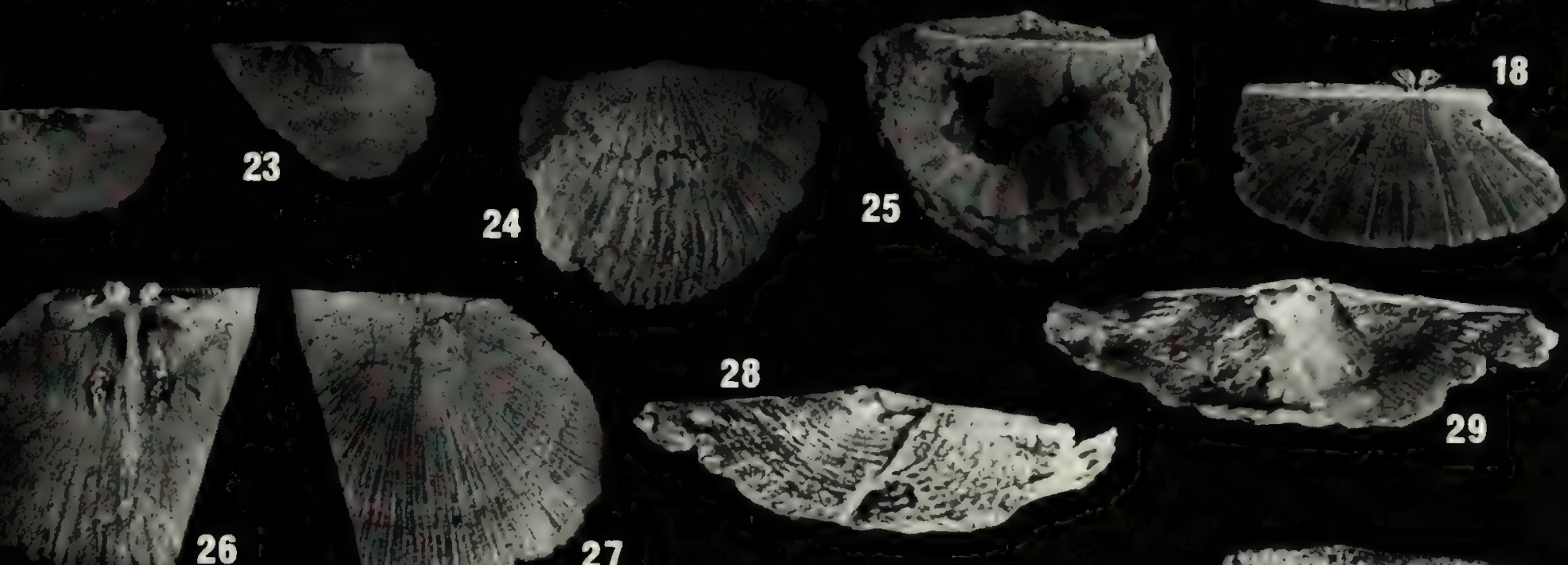

26

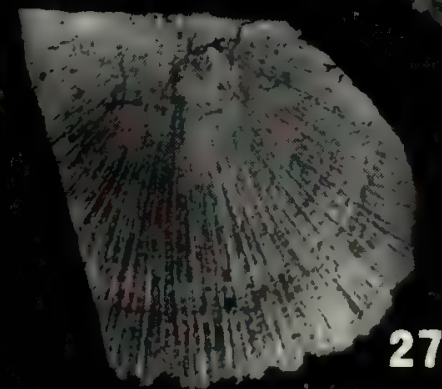

25
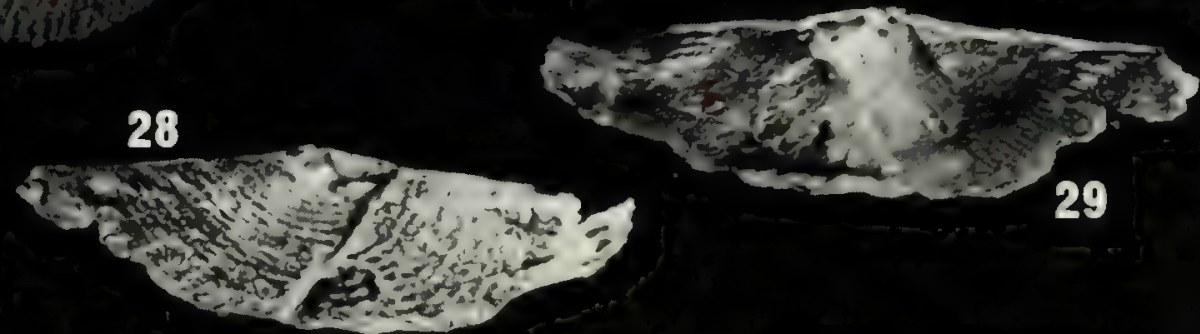

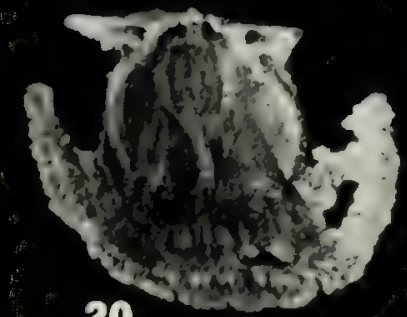

30

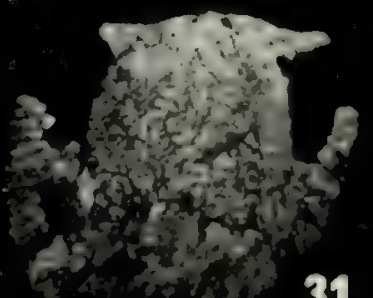

31
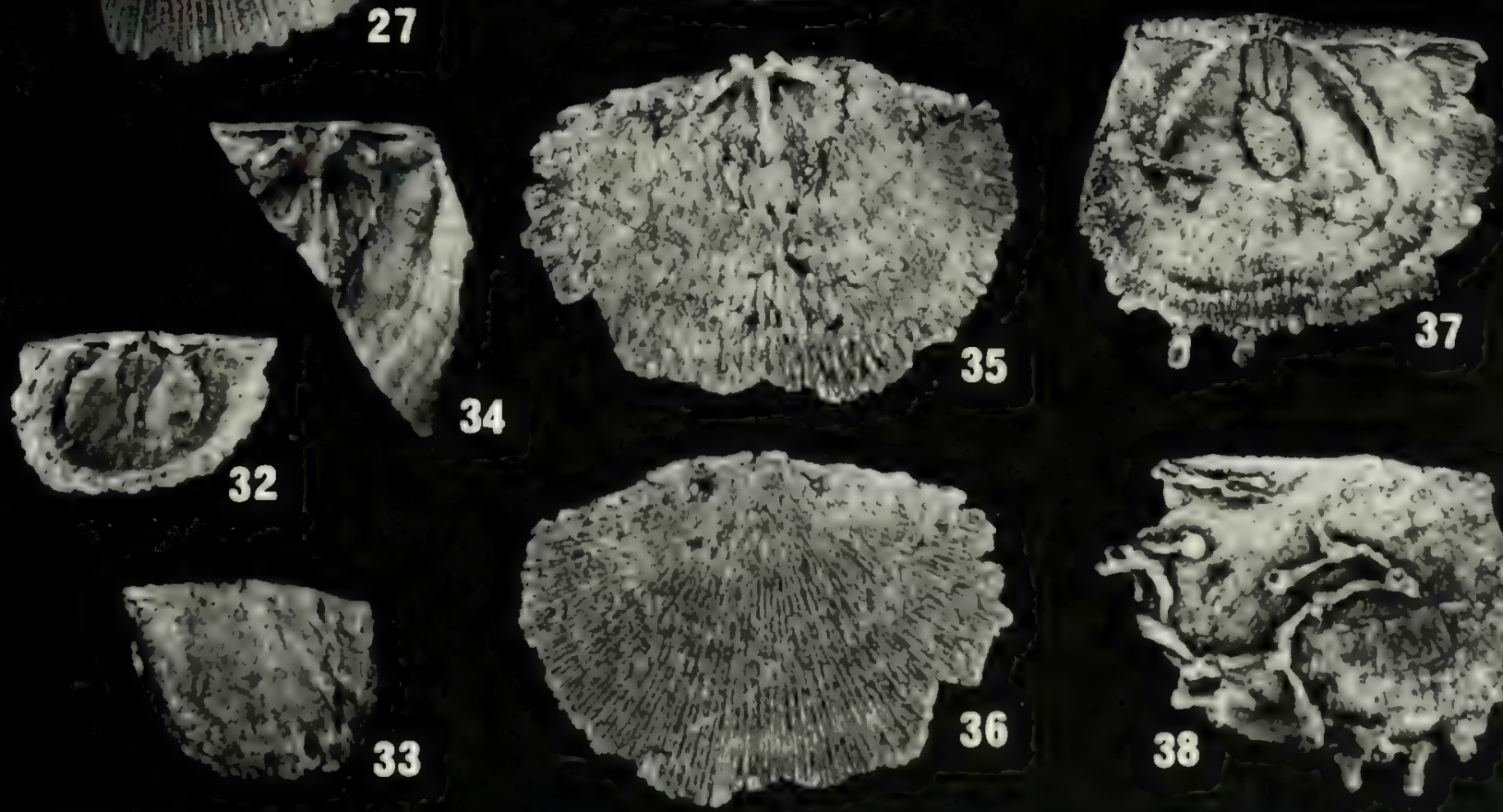

35

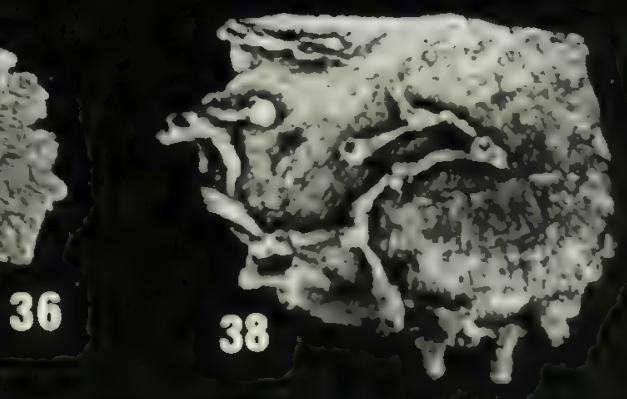


Plate 18, figs. $1-48$

Articulate brachiopod Megastrophia .

Figs. 1-41. Megastrophia iddingsi (Merriam).

1, 2. Interior and posterior views of brachial valve, Delorme Formation (Zlichovian), S-1, sample A62.5-68.6 m, ROM $33520, \times 2.1$.

3, 4. Exterior and interior views of pedicle valve, Delorme Formation (Zlichovian), S-1, sample A62.5-68.6 m, ROM $33521, \times 2.1$.

5. Interior view of brachial valve, Delorme Formation (Zlichovian), Delorme Formation, S-1, sample A62.5-68.6 m, ROM $33522, \times 2.1$

6. Interior view of brachial valve, Delorme Formation (Zlichovian), Delorme Formation, S-1, sample A62.5-68.6 m, ROM $33523, \times 2.1$.

7. Interior view of brachial valve, Delorme Formation (Zlichovian), Delorme Formation, S-1, sample A62.5-68.6 m, ROM $33524, \times 2.1$.

8-10. Dorsal, lateral, and ventral views of articulated shell; Delorme Formation (Zlichovian), S-3, sample S4-143.3 m, ROM $33525, \times 1.4$.

11-13. Dorsal, lateral, and ventral views of articulated shell; Delorme Formation (Zlichovian), S-3, sample S4-64.0-65.5 m, ROM $33526, \times 1.8$.

14, 15. Ventral and oblique dorsal views of articulated shell, Delorme Formation (Zlichovian), S-3, sample S4-143.3 m, ROM $33527, \times 1.8$

16, 17. Ventral and dorsal views of articulated shell, Delorme Formation (Zlichovian), S-3, sample S4-143.3 m, ROM 33528, $\times 1.8$.

18-20. Interior, oblique posterior, and posterior views of brachial valve; Delorme Formation (Zlichovian), S-3, sample S4-143.3 m, ROM 33529, × 1.8 .

21, 22. Interior and posterior views of brachial valve, Delorme Formation (Zlichovian), S-3, sample S4-143.3 m, ROM 33530, $\times 1.8$.

23, 24. Interior and posterior views of brachial valve, Delorme
Formation (Zlichovian), S-3, sample S4-143.3 m, ROM 33531, $\times 1.8$.

25,26 . Oblique interior view of pedicle muscle field and interior view of pedicle valve, Delorme Formation (Zlichovian), S-3, sample S4-143.3 m, ROM 33532, × 1.8 .

27. Interior view of pedicle valve, Delorme Formation (Zlichovian), S-3, sample S4-143.3 m, ROM 33533, × 1.8 .

28, 29. Exterior and interior views of pedicle valve, Delorme Formation (Zlichovian), S-3, sample S4-143.3 m, ROM 33534, $\times 1.8$.

30-32. Posterior, interior, and oblique posterolateral views of brachial valve; Delorme Formation (Zlichovian), S-3, sample S4-176.8 m, ROM 33535, × 1.4 .

33, 34. Interior and oblique interior views of pedicle valve, Delorme Formation (Zlichovian), S-3, sample S4-176.8 m, ROM $33536, \times 1.4$.

35-37. Exterior, lateral, and dorsal views of articulated shell; Delorme Formation (Zlichovian), S-3, sample S4-176.8 m, ROM $33537, \times 1.4$.

38, 39. Posterior and interior views of brachial valve, Delorme Formation (Zlichovian), S-3, sample S4-176.8 m, ROм 33538, $\times 1.4$.

40, 41. Posterior and interior views of brachial valve, Delorme Formation (Zlichovian), S-3, sample S4-176.8 m, Rом 33539 , $\times 1.4$.

Figs. 42-48. Megastrophia transitans Johnson.

42, 43. Exterior and interior views of pedicle valve, Delorme Formation (Pragian), S-1, sample A436.5 m, ROM 33540, $\times$ 2.5 .

44. Interior view of small brachial valve, Delorme Formation (Pragian), S-1, sample A436.5 m, ROM 33541, $\times 2.5$.

45. Interior view of pedicle valve, Delorme Formation (Pragian), S-1, sample A436.5 m, ROM 33542, × 2.5 .

46-48. Exterior, lateral, and dorsal views of articulated shell; Delorme Formation (Pragian), S-1, sample A436.5 m, ROM $33543, \times 2.5$. 


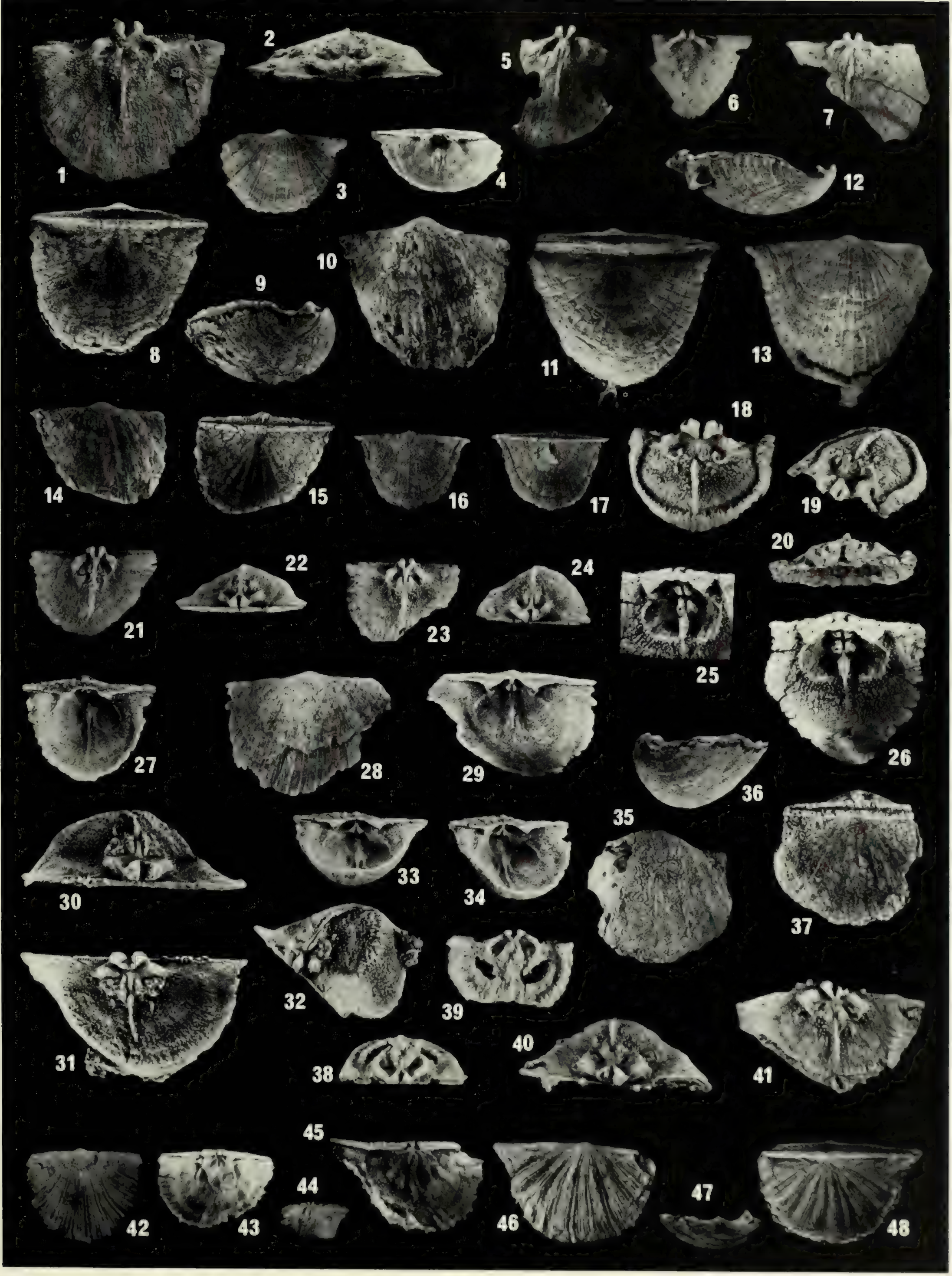


Plate 19, figs. 1-31

Articulate brachiopods Leptostrophia and Parapholidostrophia.

Figs. 1-17. Leptostrophia magna sp. nov.

1,2. Interior and exterior views of large pedicle valve, Delorme Formation (Zlichovian), S-3, sample S4-176.8 m, holotype ROM $33544, \times 1.4$ and $\times 0.8$ respectively.

3, 4. Interior and exterior views of pedicle valve, Delorme Formation (Zlichovian), S-3, sample S4-176.8 m, paratype ROM $33545, \times 0.8$.

5-7. Oblique posterior, posterior, and interior views of pedicle valve fragment; Delorme Formation (Zlichovian), S-3, sample S4-176.8 m, paratype ROM $33546, \times 0.8$.

8, 9. Interior and exterior views of pedicle valve, Delorme Formation (Zlichovian), S-3, sample S4-257.6 m, paratype ROM $33547, \times 0.9$.

10. Interior view of pedicle valve, Delorme Formation (Zlichovian), S-3, sample S4-257.6 m, paratype ROM 33548, × 0.9 .

11, 12. Dorsal and ventral views, Delorme Formation (Zlichovian), S-3, sample S4-100.6 m, paratype ROM 33549, × 0.9 .

13,14 . Oblique posterior and interior views of brachial valve, Delorme Formation (Zlichovian), S-3, sample S4-502.9 $507.5 \mathrm{~m}$, paratype ROM $33550, \times 1.1$.

15. Interior view of brachial valve, Delorme Formation (Zlichovian), S-3, sample S4-502.9-507.5 m, paratype ROM 33551, X 1.1.

16, 17. Interior and exterior views of pedicle valve, Delorme Formation (Zlichovian), S-3, sample S4-502.9-507.5 m, paratype ROM $33552, \times 0.9$. Note the fragment of Warrenella sekwensis attached to the shell interior.

Figs. 18-31. Parapholidostrophia prima sp. nov.

18. Interior view of brachial valve, Delorme Formation (Zlichovian), S-3, sample S4-519.7 m, paratype ROM 33553, $\times 1.0$.

19. Interior view of pedicle valve, Delorme Formation (Zlichovian), S-3, sample S4-519.7 m, paratype Rом 33554, × 1.0 .

20-22. Ventral, dorsal, and posterior views of articulated shell; Delorme Formation (Zlichovian), S-3, sample S4-519.7 m, holotype ROM $33555, \times 1.0$.

23. Interior view of brachial valve, Delorme Formation (Zlichovian), S-3, sample S4-519.7 m, paratype ROM 33556, $\times 1.0$.

24, 25. Dorsal and ventral views of small shell, Delorme Formation (Zlichovian), S-3, sample S4-519.7 m, paratype ROM $33557, \times 1.0$.

26. Interior view of pedicle valve, Delorme Formation (Zlichovian), S-3, sample S4-519.7 m, paratype ROM 33558, × 1.0 .

27. Interior view of pedicle valve, Delorme Formation (Zlichovian), S-3, sample S4-176.8 m, paratype ROM 33559, × 1.4 .

28. Interior view of pedicle valve, Delorme Formation (Zlichovian), S-3, sample S4-176.8 m, paratype Rом $33560, \times 1.4$. 29-31. Oblique interior, exterior, and interior views of pedicle valve; Delorme Formation (Zlichovian), S-3, sample S4$176.8 \mathrm{~m}$, paratype ROM $33561, \times 1.4$. 


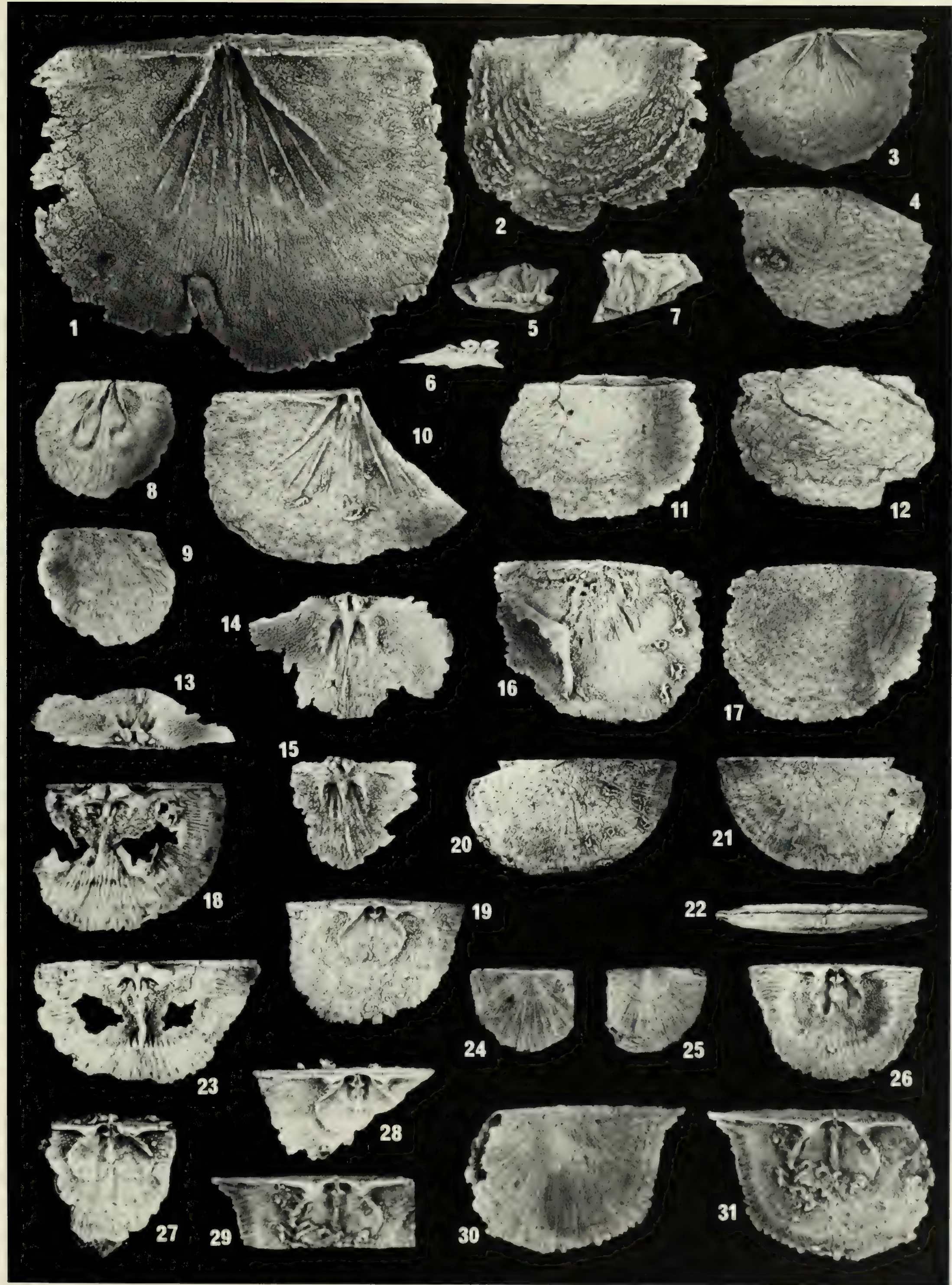


Plate 20, figs. 1-54

Articulate brachiopods Phragmostrophia, new genus chonetid sp. 1, and Chattertonia.

Figs. 1-31. Phragmostrophia merriami Harper, Johnson, and Boucot.

1, 2. Interior and posterior views of brachial valve, Delorme Formation (Zlichovian), S-1, sample A62.5-68.6 m, ROM $33562, \times 2.1$

3. Interior view of brachial valve, Delorme Formation (Zlichovian), S-1, sample A62.5-68.6 m, ROM 33563, × 2.1.

4. Interior view of pedicle valve, Delorme Formation (Zlichovian), S-3, sample S4-64.0-65.5 m, ROM 33564, $\times 1.4$.

5. Interior view of brachial valve, Delorme Formation (Zlichovian), S-3, sample S4-64.0-65.5 m, Rом 33565, × 1.4.

6. Interior view of brachial valve, Delorme Formation (Zlichovian), S-3, sample S4-64.0-65.5 m, ROM 33566, × 1.4 .

7-9. Lateral, ventral, and dorsal views of articulated shell; Delorme Formation (Zlichovian), S-3, sample S4-143.3 m, ROM $33567, \times 1.4$

10. Interior view of pedicle valve, Delorme Formation (Zlichovian), S-3, sample S4-143.3 m, ROM 33568, × 1.4

11-13. Ventral, dorsal, and oblique lateral views of articulated shell; Delorme Formation (Zlichovian), S-3, sample S4$143.3 \mathrm{~m}$, ROM $33569, \times 1.4$

14, 15. Interior and oblique lateral views of brachial valve, Delorme Formation (Zlichovian), S-3, sample S4-143.3 m, ROM $33570, \times 1.4$.

16, 17. Interior and exterior views of pedicle valve, Delorme Formation (Zlichovian), S-3, sample S4-143.3 m, ROM 33571, $\times 1.4$.

18. Interior view of brachial valve, Delorme Formation (Zlichovian), S-3, sample S4-161.5-164.6 m, ROM 33572, $\times 2.1$.

19-21. Dorsal, ventral, and anterior views of articulated shell; Delorme Formation (Zlichovian), S-3, sample S4-161.5$164.6 \mathrm{~m}$, ROM $33573, \times 2.1$

22. Interior view of pedicle valve, Delorme Formation (Zlichovian), S-3, sample S4-449.6 m, ROM $33574, \times 1.3$.

23,24 . Oblique interior and interior views of brachial valve, Delorme Formation (Zlichovian), S-3, sample S4-449.6 m, ROM $33575, \times 1.3$.

25,26 . Lateral and interior views of brachial valve, Delorme Formation (Zlichovian), S-3, sample S4-449.6 m, ROM 33576, $\times 1.3$.
27-29. Dorsal, lateral, and ventral views of articulated shell; Delorme Formation (Zlichovian), S-3, sample S4-449.6 m; ROM $33577, \times 1.3$. Fig. 28 is illustrated with the pedicle valve upwards for aesthetic purposes.

30. Interior view of brachial valve, Delorme Formation (Zlichovian), S-3, sample S4-560.8-573.0 m, ROM 33578, × 1.3.

31. Interior view of brachial valve, Delorme Formation (Zlichovian), S-3, sample S4-560.8-573.0 m, ROM 33579, $\times 1.3$.

\section{Figs. 32-43. Phragmostrophia mucronata Lenz.}

32. Interior view of brachial valve, Delorme Formation (Pragian), S-1, sample A321.6 m, ROM 33580, $\times 2.5$.

33, 34, 36. Dorsal, ventral, and lateral views of articulated shell; Delorme Formation (Pragian), S-1, sample A442.0 m, ROM $33581, \times 2.5$. Fig. 36 is oriented with the pedicle valve upwards for aesthetic purposes.

35. Interior view of brachial valve, Delorme Formation (Pragian), S-1, sample A442.0 m, ROM 33582, × 2.5 .

37, 38. Exterior and interior views of pedicle valve, Delorme Formation (Pragian), S-1, sample A436.5 m, ROM 33583, $\times$ 2.5 .

39. Oblique interior view of brachial valve, Delorme Formation (Pragian), S-1, sample A436.5 m, ROM 33584, $\times 2.5$.

40,41 . Interior and oblique posterolateral views of brachial valve, Delorme Formation (Pragian), S-1, sample A436.5 m, ROM $33585, \times 2.5$.

42, 43. Ventral and dorsal views of articulated shell, Delorme Formation (Pragian), S-1, sample A436.5 m, ROM 33586, $\times$ 2.5 .

Figs : 44-48. New genus chonetid sp. 1. Dorsal, ventral, oblique dorsal, anterior, and lateral views of articulated shell; Delorme Formation (Zlichovian), S-1, sample A62.5-68.6 m, ROM 33587, $\times$ 6.0. Note the prominent marginal spine and spine bases on the ventral valve. Fig. 48 is oriented with the pedicle valve upwards for aesthetic purposes.

Figs. 49-54. Chattertonia mackenzia sp. nov. Anterior, ventral, dorsal, oblique lateral, lateral, and posterior views of articulated shell; Delorme Formation (Zlichovian), S-3, sample S4-161.5-164.6 m, paratype ROM $33588, \times 2.8$. 


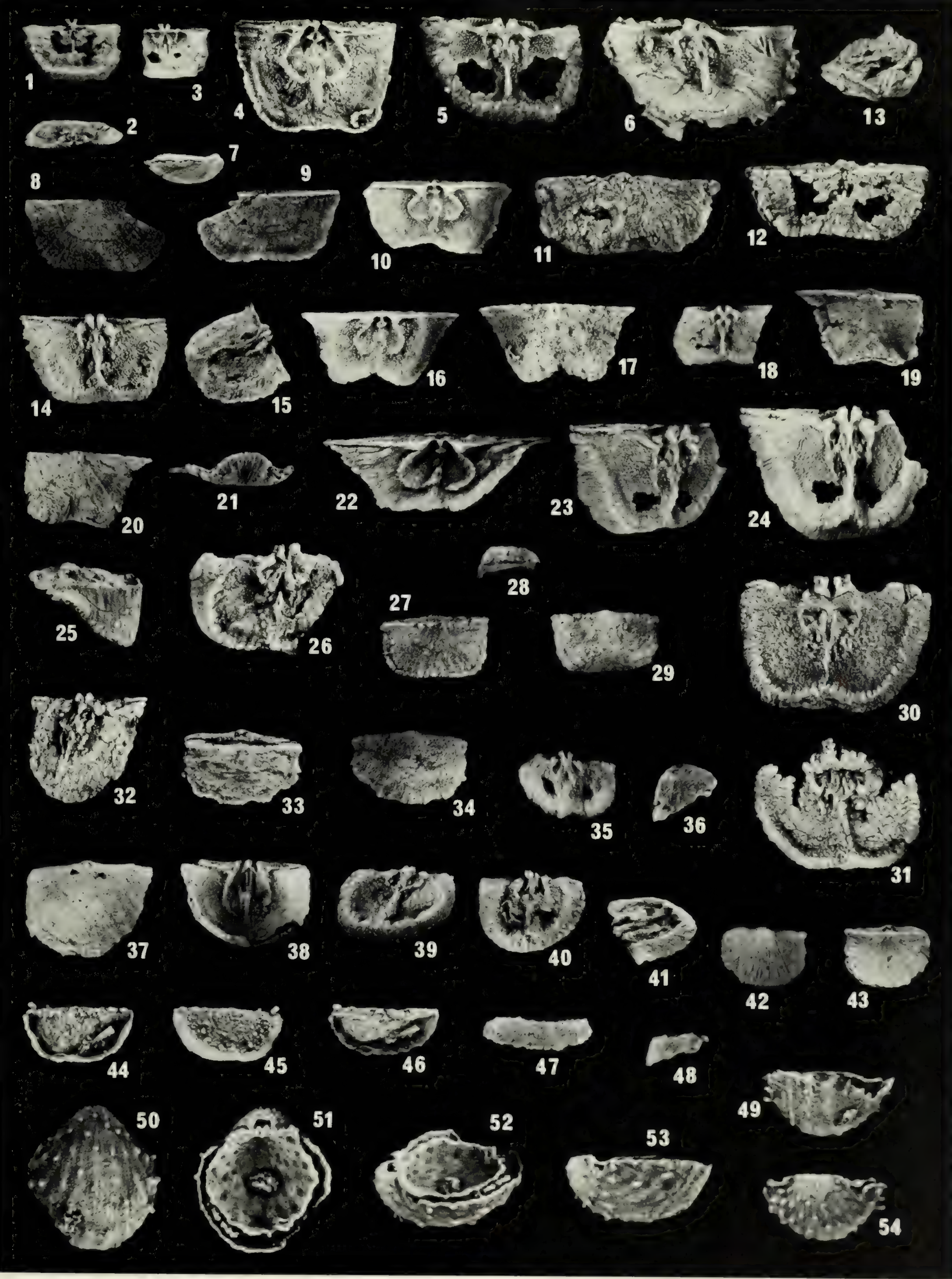


Plate 21, figs. 1-64

Articulate brachiopods "Strophochonetes" and Parachonetes.

Figs. 1-40. "Strophochonetes" filistriata (Walcott).

1, 2. Ventral and dorsal views of articulated shell, Delorme Formation (Zlichovian), S-3, sample S4-519.7 m, Rом 33589, $\times 2.0$.

3, 4. Dorsal and ventral views of articulated shell, Delorme Formation (Zlichovian), S-3, sample S4-519.7 m, ROM 33590, $\times 2.0$.

5,6 . Exterior and interior views of small pedicle valve, Delorme Formation (Zlichovian), S-3, sample S4-519.7 m, ROM 33591, $\times 2.0$.

7, 8. Interior and exterior views of pedicle valve, Delorme Formation (Zlichovian), S-3, sample S4-492.2 m, ROM 33592, $\times 2.0$.

9. Lateral view of pedicle valve, Delorme Formation (Zlichovian), S-3, sample S4-492.2 m, ROM 33593, $\times 2.0$. Note the ventral curvature of the marginal spine.

10. Interior view of brachial valve, Delorme Formation (Zlichovian), S-3, sample S4-64.0-65.5 m, ROM 33594, × 2.0. Note the low, divergent lateral anderidia and the low median septum, also apparent in figs. $11,16,18$, and 19 .

11. Interior of brachial valve, Delorme Formation (Zlichovian), S-3, sample S4-64.0-65.5 m, ROM 33595, × 2.0.

12-14. Ventral, dorsal, and posterior views of articulated shell; Delorme Formation (Zlichovian), S-3, sample S4-64.0-65.5 m, ROM $33596, \times 2.0$.

15. Interior view of pedicle valve, Delorme Formation (Zlichovian), S-3, sample S4-64,0-65.5 m, ROM 33597, × 2.0.

16. Interior view of brachial valve, Delorme Formation (Zlichovian), S-3, sample S4-64.0-65.5 m, ROM 33598, × 2.0.

17-19. Exterior, interior, and posterior views of brachial valve; Delorme Formation (Zlichovian), S-3, sample S4-64.0-65.5 m, ROM $33599, \times 2.0$.

20-22. Interior, exterior, and oblique exterior views of pedicle valve; Delorme Formation (Zlichovian), S-3, sample S4-64.0$65.5 \mathrm{~m}$, ROM $33600, \times 2.0$.

23. Oblique interior view of pedicle valve, Delorme Formation (Zlichovian), S-3, sample S4-64.0-65.5 m, ROM 33601, × 2.0.

24,35 . Oblique dorsal and dorsal views of articulated shell, Delorme Formation (Zlichovian), S-3, sample S4-15.2-22.9 m, ROM $33602, \times 2.0$.

25-27. Exterior, oblique interior, and interior views of pedicle valve; Delorme Formation (Zlichovian), S-3, sample S4-15.2$22.9 \mathrm{~m}, \mathrm{ROM} 33603, \times 2.0$. Note the disruption of the costellae and their regeneration beyond points of injury, also apparent in figs. 28,29 , and 34

28, 29. Interior and exterior views of pedicle valve, Delorme Formation (Zlichovian), S-3, sample S4-15.2-22.9 m, ROM $33604, \times 2.0$.
$30,31,32$. Oblique posterior, exterior, and interior views of pedicle valve; Delorme Formation (Zlichovian), S-3, sample S4-15.2-22.9 m, ROM 33606, × 2.0.

33,34 . Oblique interior and exterior views of pedicle valve, Delorme Formation (Zlichovian), S-3, S4-15.2-22.9 m, ROM $33607, \times 2.0$.

36,37 . Exterior and interior views of pedicle valve, Delorme Formation (Zlichovian), S-3, S4-15.2-22.9 m, ROM 33608, $x$ 2.0.

38-40. Dorsal, ventral, and anterior views of articulated shell; Delorme Formation (Zlichovian), S-3, S4-15.2-22.9 m, ROM $33609, \times 2.0$.

Figs. 41-64. Parachonetes macrostriatus (Walcott).

41, 42. Exterior and interior views of pedicle valve, Delorme Formation (Zlichovian), S-3, S4-502.9-507.5 m, ROM 33610, $x$ 1.0 .

43, 44. Oblique lateral and interior views of brachial valve, Delorme Formation (Zlichovian), S-3, S4-502.9-507.5 m, ROM $33611, \times 1.0$. Note the cross struts joining the median septum and the posterior portion of the anderidia in fig. 44 , and also in figs. 63 and 64

45, 46. Ventral and dorsal views, Delorme Formation (Zlichovian), S-3, sample S4-257.6 m, ROM 33612, × 1.0 .

47, 48. Dorsal and ventral views, Delorme Formation (Zlichovian), S-3, sample S4-257.6 m, ROM 33613, × 1.0 .

49-52. Exterior, interior, oblique interior, and uncoated interior views of pedicle valve; Delorme Formation (Zlichovian), S-3, sample S4-64.0-65.5 m, ROM 33614, $\times 1.0$. Note the distinct, elongate posterior and anterior adductor muscle scars, which are surrounded by weakly impressed, flabellate diductor scars. Coloration of the muscle scars results from the slight difference in texture on this part of the shell, which becomes apparent upon silicification.

53. Interior view of brachial valve fragment, Delorme Formation (Zlichovian), S-3, sample S4-64.0-65.5 m, ROM 33615, $\times$ 1.0 .

54-57. Exterior, posterior, oblique lateral and interior views of brachial valve; Delorme Formation (Zlichovian), S-3, sample S4-64.0-65.5 m, ROM 33616, × 1.0 .

58,59 . Exterior and interior views of pedicle valve, Delorme Formation, (Zlichovian), S-3, sample S4-64.0-65.5 m, ROM $33617, \times 1.0$.

60,61 . Interior and oblique interior views of pedicle valve, Delorme Formation (Zlichovian), S-3, sample S4-64.0-65.5 m, ROM $33618, \times 1.0$.

62-64. Exterior, interior, and oblique lateral views of brachial valve; Delorme Formation (Zlichovian), S-3, sample S4-64.0$65.5 \mathrm{~m}$, Rом $33619, \times 1.0$. 


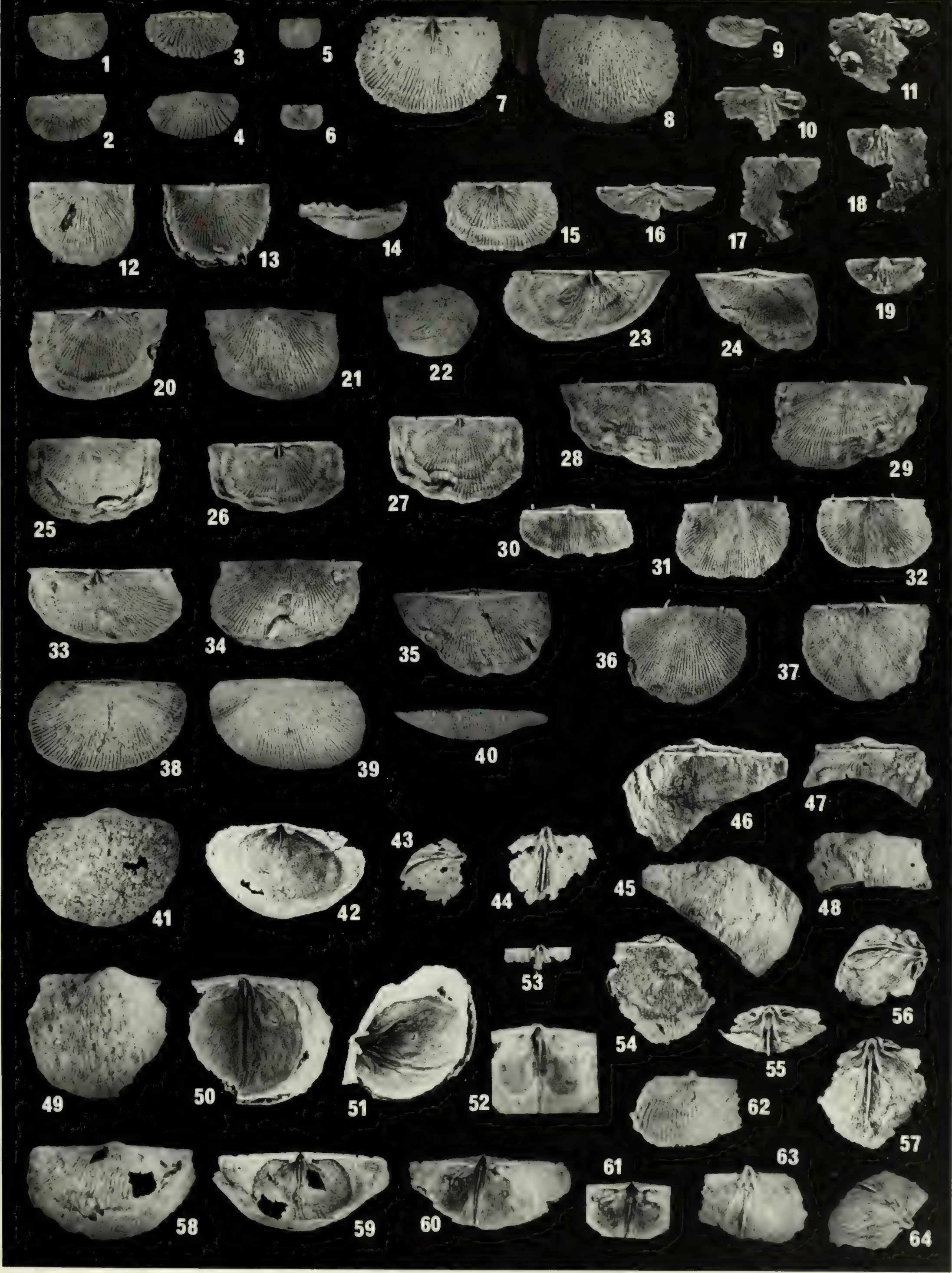


Plate 22, figs. $1-48$

Articulate brachiopods Chattertonia, Stegerhynchus, and Thliborhynchia.

Figs. 1-16. Chattertonia mackenzia sp. nov.

1-4. Interior, exterior, oblique lateral, and posterior views of brachial valve; Delorme Formation (Zlichovian), S-1, sample A62.5-68.6 m, holotype ROM 33620, × 5.3.

5,6 . Exterior and interior views of pedicle valve, Delorme Formation (Zlichovian), S-1, sample A62.5-68.6 m, paratype ROM 33621, × 2.8 .

7-10. Interior, exterior, oblique interior, and posterior views of pedicle valve; Delorme Formation (Zlichovian), S-1, sample A62.5-68.6 m, paratype ROM 33622, × 2.8 .

11-13. Lateral, exterior, and posterior views of pedicle valve; Delorme Formation (Zlichovian), S-1, sample A62.5-68.6 m, paratype ROM $33623, \times 2.8$.

14-16. Ventral, dorsal, and lateral views of articulated shell; Delorme Formation (Zlichovian), S-3, sample S4-492.2 m, paratype ROM $33624, \times 3.3$.

Figs. 17-31. Stegerhynchus cf. S. angaciensis Chernyshev.

17-21. Posterior, anterior, dorsal, ventral, and lateral views of articulated shell; Delorme Formation (Pridolian), S-10, sample S1-152.4 m, ROM 33625, × 2.7.

22-24. Lateral, dorsal, and posterior views of articulated shell; Delorme Formation (Pridolian), S-10, sample S1-152.4 m, ROM $33626, \times 2.7$.
25-28. Lateral, anterior, dorsal, and ventral views of articulated shell; Delorme Formation (Pridolian), S-10, sample S1-152.4 m, ROM $33627, \times 2.7$.

29-31. Lateral, ventral, and dorsal views of articulated shell; Delorme Formation (Pridolian), S-10, sample S1-152.4 m, ROM $33628, \times 2.7$.

Figs. 32-43. Stegerhynchus sp. 1.

32-36. Dorsal, ventral, lateral, posterior, and anterior views of articulated shell; Delorme Formation (Lochkovian), S-2, sample B221.0, ROM 33629, $\times 2.7$.

37. Interior view of articulated shell, Delorme Formation (Lochkovian), S-2, sample B221.0 m, ROM 33630, $\times 2.7$. Note the well-developed crura and dorsal myophragm, also apparent in fig. 38.

38. Interior view of articulated shell, Delorme Formation (Lochkovian), S-2, sample B221.0 m, ROM 33631, × 2.7.

39-43. Dorsal, ventral, lateral, posterior, and anterior views of articulated shell; Delorme Formation (Lochkovian), S-2, sample B221.0 m, ROM 33632, × 2.7 .

Figs. 44-48. Thliborhynchia cf. T. pedderi (Lenz). Anterior, lateral, ventral, dorsal, and posterior views of articulated shell; Upper Windmill Limestone (late Lochkovian), east side of Coal Canyon, Nevada, ROM 33633, × 1.2 . 

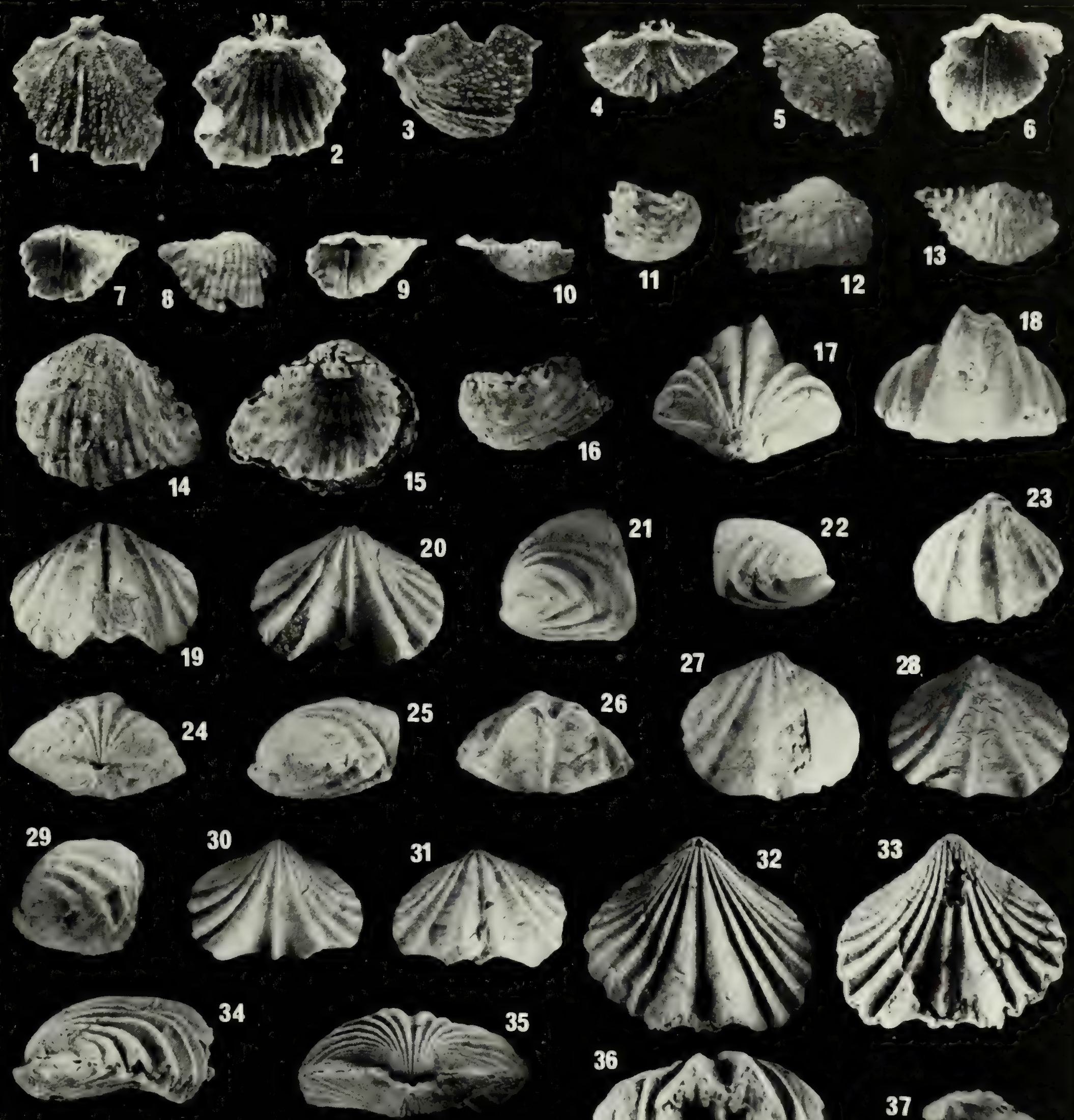

35
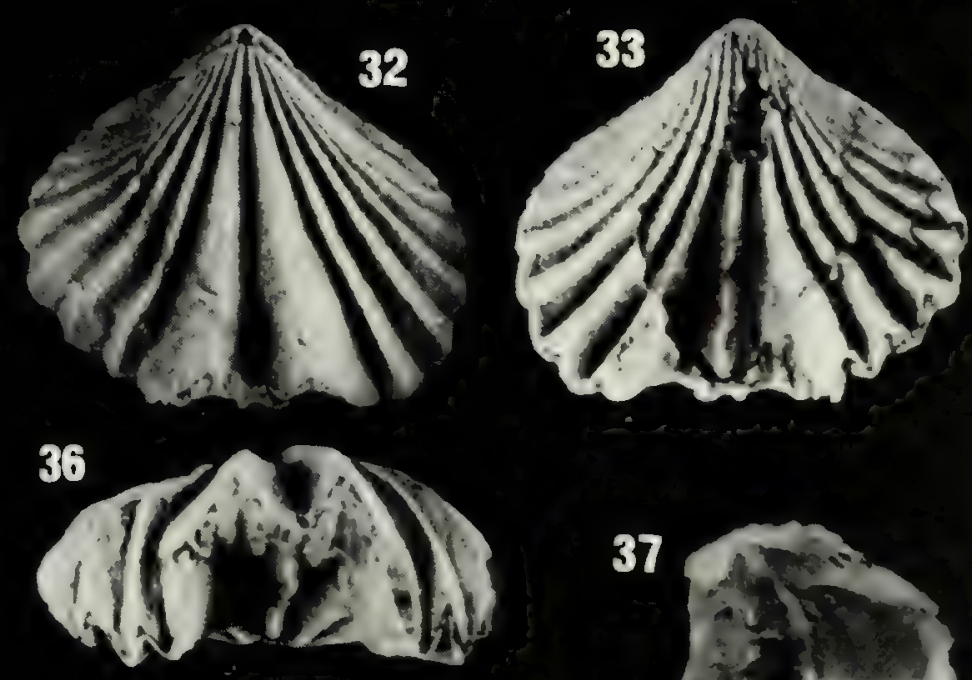

4)

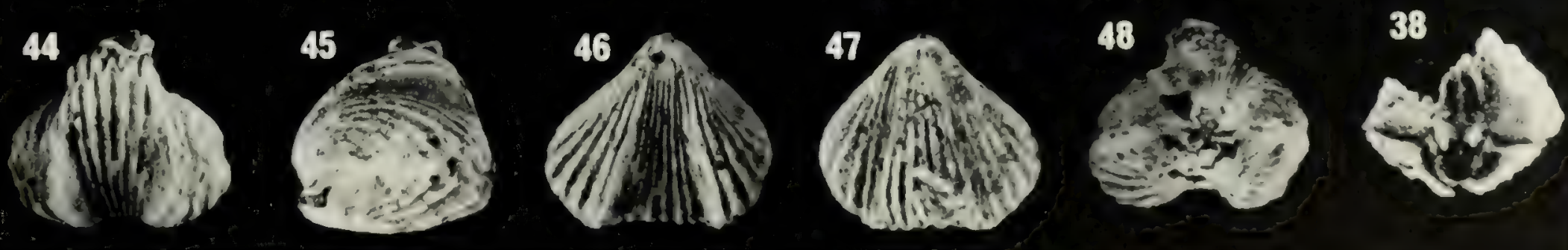


Plate 23, figs. $1-71$

Articulate brachiopods Machaeraria and Thliborhynchia.

Figs. 1-42. Machaeraria paraformosa Lenz.

Note the bifurcating costae on many of the smaller shells.

1-3. Dorsal, ventral, and lateral views of large, transverse shell;

Delorme Formation (Lochkovian), S-1, sample A515.1$516.6 \mathrm{~m}$, Rом $33634, \times 2.0$.

4. Interior view of pedicle valve, Delorme Formation (Lochkovian), S-1, sample A515.1-516.6 m, ROM 33635, × 2.0.

5. Interior view of articulated shell fragment, Delorme Formation (Lochkovian), S-1, sample A515.1-516.6 m, ROM 33636, $\times 2.0$.

6. Interior view of brachial valve, Delorme Formation (Lochkovian), S-1, sample A528.8 m, ROM 33637, × 2.0 .

7. Interior view of pedicle valve, Delorme Formation (Lochkovian), S-1, sample A528.8 m, ROM 33638, × 2.0 .

8-12. Anterior, lateral, ventral, dorsal, and posterior views of articulated shell; Delorme Formation (Lochkovian), S-1, sample A $528.8 \mathrm{~m}$, ROM $33639, \times 2.0$.

13. Interior view of pedicle valve, Delorme Formation (Lochkovian), S-1, sample A528.8 m, ROM $33640, \times 2.0$.

14. Interior view of brachial valve, Delorme Formation (Lochkovian), S-1, sample A536.4 m, ROM $33641, \times 2.0$

15. Interior view of pedicle valve, Delorme Formation (Lochkovian), S-1, sample A536.4 m, ROM 33642, × 2.0 .

16-18. Dorsal, ventral, and anterior views of articulated shell; Delorme Formation (Lochkovian), S-1, sample A536.4 m, ROM $33643, \times 2.0$.

19-21. Lateral, anterior, and ventral views of small shell; Delorme Formation (Lochkovian), S-1, sample A536.4 m, ROM $33644, \times 2.0$.

22. Interior view of pedicle valve, Delorme Formation (Lochkovian), S-2, sample B221.0 m, ROM 33645, × 2.4 .

23. Interior view of brachial valve, Delorme Formation (Lochkovian), S-2, sample B221.0 m, ROM 33646, × 2.4 .

24. Interior view of brachial valve, Delorme Formation (Lochkovian), S-2, sample B221.0 m, ROM 33647, × 2.4

25-27. Lateral, dorsal, and anterior views of articulated shell; Delorme Formation (Lochkovian), S-2, sample B221.0 m, ROM $33648, \times 2.4$.

28. Interior view of brachial valve, Delorme Formation (Lochkovian), S-2, sample B221.0 m, ROM $33649, \times 2.8$.

29-33. Dorsal, ventral, anterior, posterior, and lateral views of articulated shell; Delorme Formation (Lochkovian), S-2, sample B221.0 m, ROM 33650, $\times 2.4$
34-36. Anterior, lateral, and dorsal views of articulated shell; Delorme Formation (Lochkovian), S-2, sample B221.0 m, ROM $33651, \times 2.8$.

37, 38. Lateral and dorsal views of articulated shell, Delorme Formation (Lochkovian), S-2, sample B221.0 m, ROM 33652, $\times$ 2.8

39-42. Anterior, lateral, dorsal, and ventral views of articulated shell; Delorme Formation (Lochkovian), S-2, sample B221.0 m, ROM $33653, \times 2.8$.

Figs. 43-64. Thliborhynchia julli Lenz.

43, 44. Exterior and interior views of pedicle valve fragment, Delorme Formation (Pragian), S-2, sample B80.8 m, ROM $33654, \times 1.2$.

45-47. Oblique interior, exterior, and interior views of brachial valve; Delorme Formation (Pragian), S-2, sample B 80.8 m, ROM $33655, \times 1.2$.

48-52. Ventral, dorsal, anterior, posterior, and lateral views of articulated shell; Delorme Formation (Pragian), S-1, sample A330.7 m, ROM 33656, $\times 1.2$.

53-55. Dorsal, oblique lateral, and internal views of articulated valve fragment; Delorme Formation (Pragian), S-1, sample A359.7 m, ROM $33657, \times 1.2$.

56, 57. Interior and exterior views of brachial valve, Delorme Formation (Pragian), S-1, sample A374.9 m, ROM $33658 \times 1.2$. 58-62. Ventral, dorsal, anterior, posterior, and lateral views of articulated shell; Delorme Formation (Pragian), S-1, sample A318.5 m, ROM 33659, $\times 1.2$.

63, 64. Ventral and lateral views of small shell, Delorme Formation (Pragian), S-1, sample A318.5 m, ROM 33660, $\times$ 2.8.

Figs. 65-71. Thliborhynchia spp.

65-66. Interior and exterior views of pedicle valve, Delorme Formation (Zlichovian), S-3, sample S4-94.5 m, ROM 33661, X 1.2 .

67,68 . Interior and exterior views of brachial valve fragment, Delorme Formation (Zlichovian), S-3, sample S4-123.4$125.0 \mathrm{~m}$, ROM 33662. $\times 1.2$.

69, 70. Interior and exterior views of pedicle valve, Delorme Formation (Pragian), S-1, sample A327.7 m, ROM 33663, $\times$ 1.2 .

71. Interior view of brachial valve, Delorme Formation (Pragian), S-2, sample B166.1 m, ROM 33664, × 1.2 . 

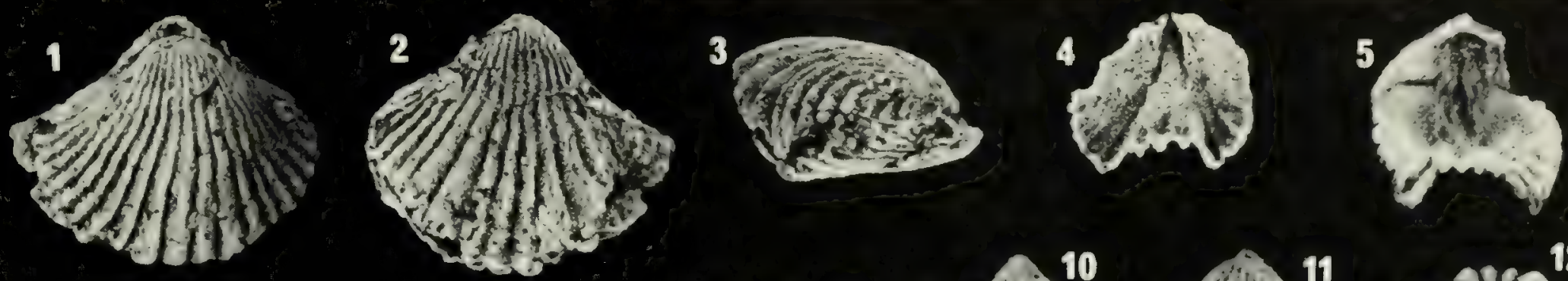

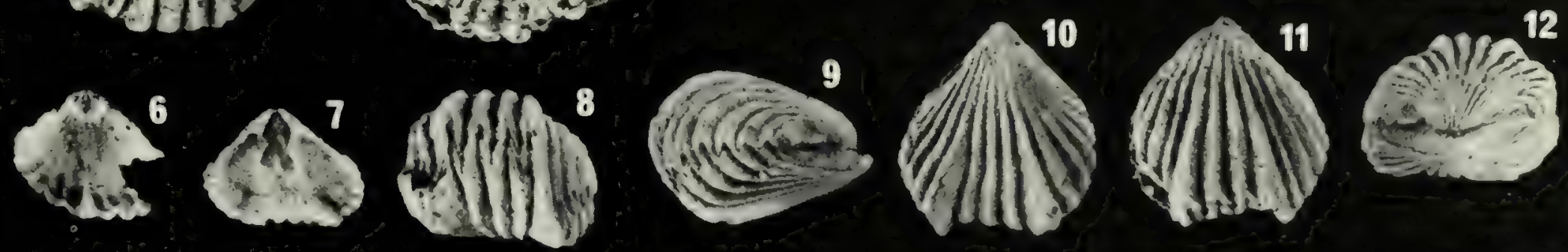
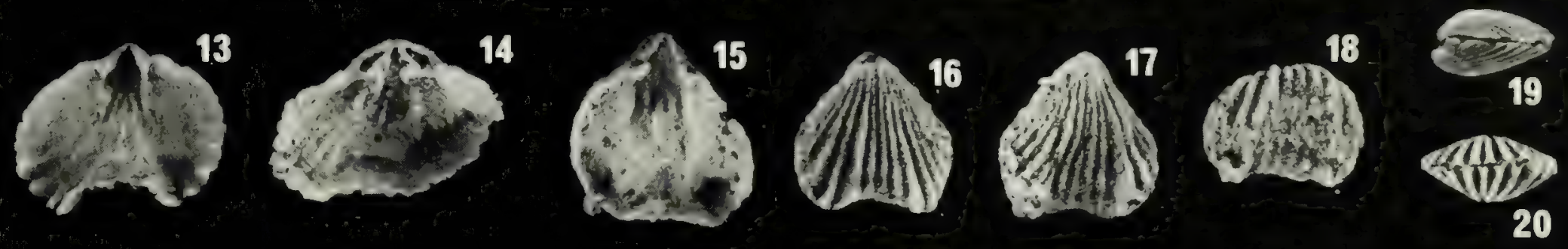

a
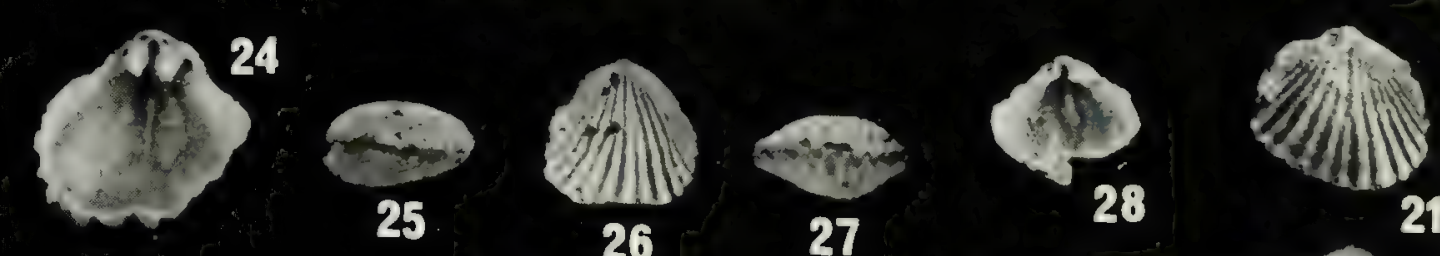

4)

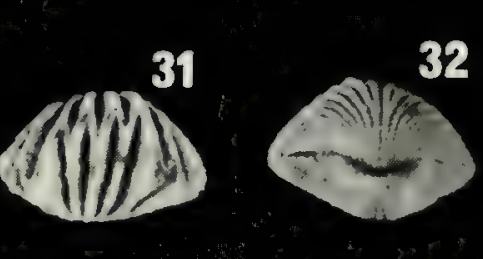

$\left.\left.(4)^{33}\right)^{26}\right)^{34}$
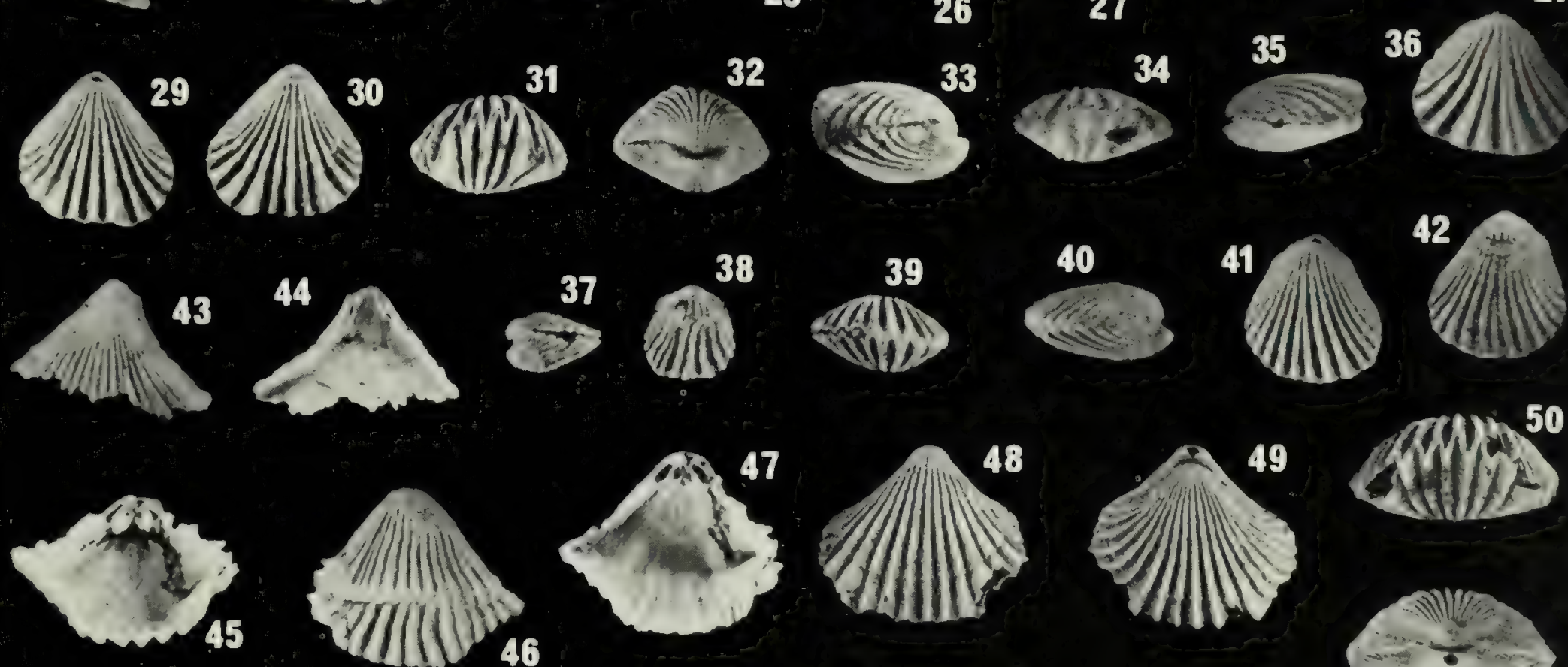
45 -

48
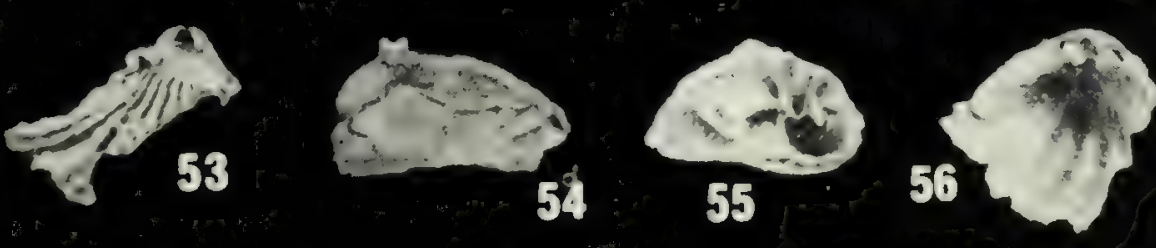

Qfiflititits

\section{9}

(ivilitio 60
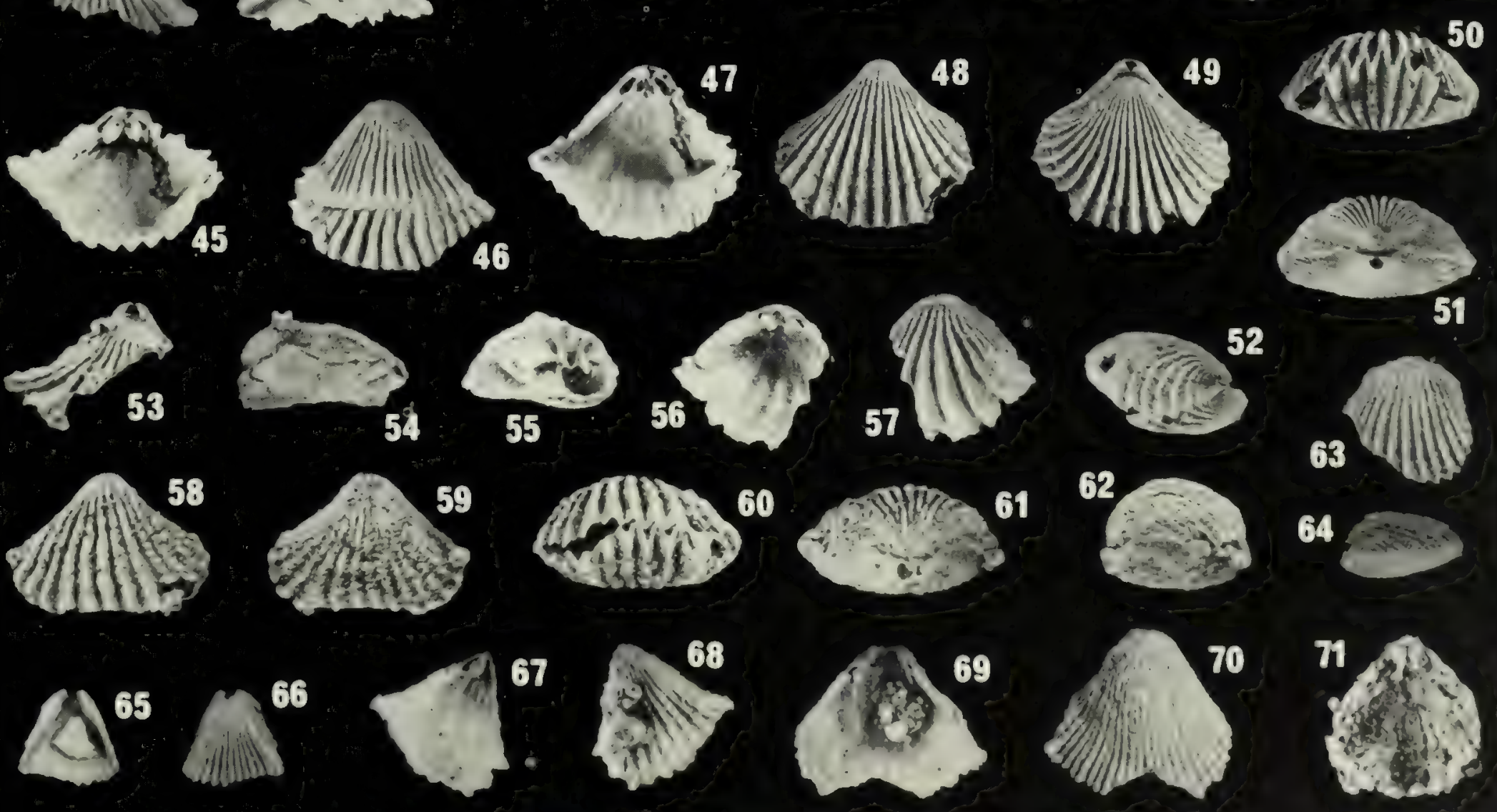
Plate 24, figs. 1-60

Articulate brachiopods Thliborhynchia and Ancillotoechia.

Figs. 1-41. Thliborhynchia pedderi (Lenz).

1. Dorsal view of small shell, Delorme Formation (late Lochkovian), S-1, sample A466.3 m, ROM 33665, $\times 1.2$.

$2,4,6,11$. Ventral, posterior, anterior internal, and oblique internal views of a fragmentary articulated shell; Delorme Formation (late Lochkovian), S-1, sample A466.3 m, ROM $33666, \times 1.2$

3. Interior view of small brachial valve, Delorme Formation (late Lochkovian), S-1, sample A466.3 m, ROM 33667, $\times 1.2$.

5. Anterior view of interior of small articulated shell, Delorme Formation (late Lochkovian), S-1, sample A466.3 m, ROM $33668, \times 1.2$.

7, 8. Dorsal and lateral views of small shell, Delorme Formation (late Lochkovian), S-1, sample A466.3 m, ROM 33669, $\times 2.3$.

9, 10. Lateral and dorsal views of small shell, Delorme Formation (late Lochkovian), S-1, sample A466.3 m, ROM $33670, \times 3.4$.

12-16. Interior, posterior, anterior, exterior, and lateral views of large shell; Delorme Formation (late Lochkovian), S-1, sample A470.9 m, ROM 33671, × 1.2

17. Oblique interior view of pedicle valve, Delorme Formation (late Lochkovian), S-1, sample A470.9 m, ROM 33672, × 1.2.

18. Interior view of brachial valve, Delorme Formation (late Lochkovian), S-1, sample A470.9 m, ROM 33673, × 1.2.

19, 20. Anterior internal view and posterior view of fragmentary articulated shell, Delorme Formation (late Lochkovian), S-1, sample A470.9 m, ROM 33674, $\times 1.2$.

21, 22. Dorsal and ventral views of articulated shell, Delorme Formation (late Lochkovian), S-1, sample A470.9 m, ROM $33675, \times 1.2$

23. Interior view of small pedicle valve, Delorme Formation (late Lochkovian), S-1, sample A470.9 m, ROM 33676, × 1.2. 24-27. Posterior, ventral, lateral, and anterior views of highly inflated shell, Delorme Formation (late Lochkovian), S-1, sample A470.9 m, ROM 33677, × 1.2 .
28-32. Dorsal, ventral, anterior, lateral, and posterior views of articulated shell; Delorme Formation (Lochkovian), S-2, sample B221.0 m, ROM 33678, × 1.8 .

33-36. Ventral, dorsal, lateral, and anterior views of articulated shell; Delorme Formation (Lochkovian), S-2, sample B221.0 m, ROM $33679, \times 1.8$.

$37-39,41$. Dorsal, anterior, lateral, and posterior views of articulated shell; Delorme Formation (Lochkovian), S-2, sample B221.0 m, ROM $33680, \times 1.8$.

40. Ventral view of articulated shell, Delorme Formation (Lochkovian), S-2, sample B221.0 m, ROM 33681, $\times 1.8$.

Figs. 42-46. Ancillotoechia sp. 1. Interior view of pedicle valve; ventral, dorsal, and lateral views of articulated shell; and interior view of brachial valve; Delorme Formation (Lochkovian), S-1, sample A538.0T m, ROM 33692, × 2.4.

Figs. 47-55. Ancillotoechia sp. 2.

$47,48,51$. Dorsal, anterior, and ventral views of articulated shell; Delorme Formation (Lochkovian), S-1, sample A538.0 T m, ROM 33682, $\times 3.5$.

49, 50. Ventral and anterior views of articulated shell, Delorme Formation (Lochkovian), S-1, sample A538.0T m, ROM 33683, $\times 3.5$.

52, 54, 55. Lateral, dorsal, and ventral views of articulated shell; Delorme Formation (Lochkovian), S-1, sample A538.0T m, ROM 33684, $\times 3.5$.

53. Interior view of articulated shell fragment, Delorme Formation (Lochkovian), S-1, sample A538.0T m, ROM 33685, $\times 3.5$.

Figs. 56-60. Ancillotoechia cf. A. gutta Johnson, Boucot, and Murphy. Posterior, anterior, lateral, dorsal, and ventral views of articulated shell; Delorme Formation (early Lochkovian), S-7, sample P7WA1911.1 m, ROM 33686, $\times 2.8$. 


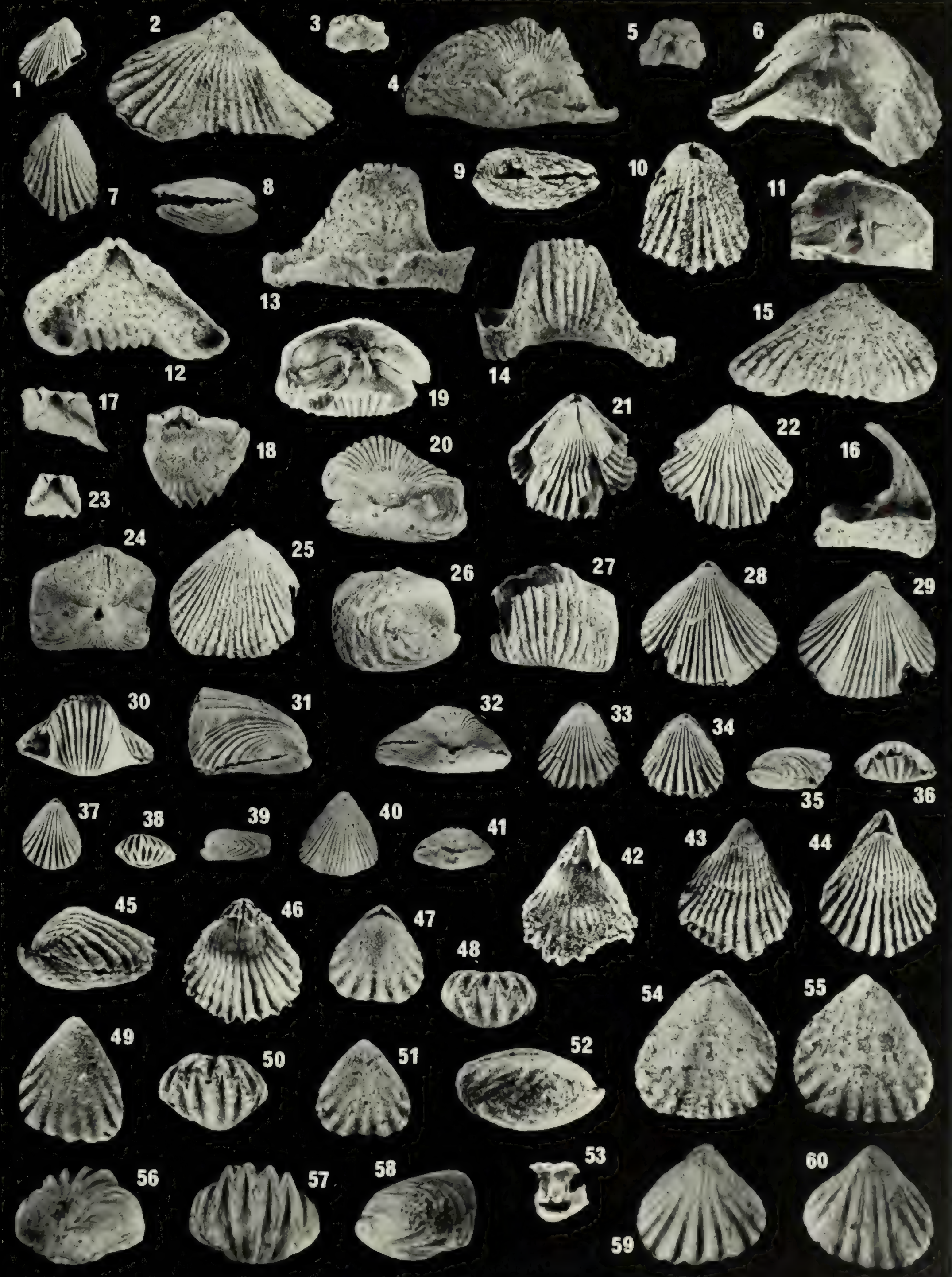


Plate 25, figs. 1-69

Articulate brachiopods Thliborhynchia, Ancillotoechia, and ?Heberoechia.

Figs. 1-30. Thliborhynchia kerri mackenziensis subsp. nov.

1-3. Lateral, posterior, and dorsal views of articulated shell; Delorme Formation (early to mid-Lochkovian), S-1, sample A515.1-516.6 m, paratype ROM 33687, × 1.7 .

4, 5. Interior and anterior views of pedicle valve, Delorme Formation (early to mid-Lochkovian), S-1, sample A515.1$516.6 \mathrm{~m}$, paratype ROM $33688, \times 1.7$.

6. 7. 10. Anterior, dorsal, and lateral views of small shell; Delorme Formation (early to mid-Lochkovian), S-1, sample A528.8 m, paratype ROM $33689, \times 1.7$.

8. Interior view of articulated shell fragment, Delorme Formation (early to mid-Lochkovian), S-1, sample A528.8 m, paratype ROM $33690, \times 1.7$.

9, 11-13. Lateral, ventral, dorsal, and anterior views of small shell; Delorme Formation (early to mid-Lochkovian), S-1, sample A528.8 m, paratype ROM 33691, × 1.7 .

14, 16-19. Posterior, dorsal, ventral, lateral, and anterior views of articulated shell; Delorme Formation (early to midLochkovian), S-1, sample OLDA423.7 m, holotype ROM 33694 , $\times 1.7$.

15. Interior view of brachial valve, Delorme Formation (early to mid-Lochkovian), S-1, sample OLDA423.7 m, paratype ROM $33695, \times 3.3$.

20-22. Oblique interior, exterior, and oblique lateral views of incomplete articulated shell; Delorme Formation (early to mid-Lochkovian), S-2, sample B221.0 m, paratype ROM 33696, $\times 1.7$.

23-25. Lateral and oblique interior views of brachial valve and enlargement of cardinalia, Delorme Formation (early to midLochkovian), S-2, sample B221.0 m, paratype ROM 33697, × $1.7, \times 1.7$, and $\times 3.3$ respectively

26, 27. Interior and exterior views of pedicle valve, Delorme Formation (early to mid-Lochkovian), S-2, sample B $221.0 \mathrm{~m}$, paratype ROM 33698, × 1.7 .

28,29 . Exterior and interior views of pedicle valve, Delorme Formation (early to mid-Lochkovian), S-2, sample B221.0 m, paratype ROM 33699, × 1.7 .

30. Interior view of articulated shell fragment, Delorme Formation (early to mid-Lochkovian), S-2, sample B221.0 m, paratype ROM $33700, \times 1.7$.

Figs. 31-60. Ancillotoechia sp. 3.

31-33. Dorsal, ventral, and lateral views of articulated shell; Delorme Formation (early Pragian), S-1, sample A385.6 m, ROM $33701, \times 2.2$

34, 35. Dorsal and anterior views of articulated shell, Delorme Formation (early Pragian), S-1, sample A385.6 m, ROM 33702 , $\times 2.2$
36. Interior view of brachial valve, Delorme Formation (early Pragian), S-1, sample A385.6 m, ROM 33703, × 2.2 .

37. Oblique interior view of pedicle valve, Delorme Formation (early Pragian), S-1, sample A385.6 m, ROM 33704, $\times 2.2$.

38. Dorsal view of articulated shell, Delorme Formation (early Pragian), S-1, sample A390.1 m, ROM 33705, × 2.2 .

39. Interior view of brachial valve, Delorme Formation (early Pragian), S-1, sample A390.1 m, ROM 33706, $\times 2.2$.

40. Interior view of brachial valve, Delorme Formation (late Lochkovian-early Pragian), S-3, sample S4-685.8 m, ROM $33707, \times 3.2$.

41. Interior view of articulated shell fragment, Delorme Formation (late Lochkovian-early Pragian), S-3, sample S4$685.8 \mathrm{~m}$, Rом $33708, \times 3.2$.

42. Interior view of brachial valve, Delorme Formation (late Lochkovian-early Pragian), S-3, sample S4-685.8 m, ROM $33709, \times 3.2$.

43. Interior view of pedicle valve, Delorme Formation (late Lochkovian-early Pragian), S-3, sample S4-685.8 m, ROM $33710, \times 3.2$.

44-46. Ventral, lateral, and dorsal views of articulated shell; Delorme Formation (early Pragian), S-1, sample OLDA336.8 m, ROM $33711, \times 2.2$.

47, 48. Interior and exterior views of pedicle valve, Delorme Formation (late Lochkovian-early Pragian), S-3, sample S4$685.8 \mathrm{~m}$, ROM $33712, \times 3.2$.

49. Oblique interior view of pedicle valve, Delorme Formation (late Lochkovian-early Pragian), S-3, sample S4-685.8 m, ROM $33713, \times 3.2$.

50-54. Dorsal, ventral, lateral, posterior, and anterior views of articulated shell; Delorme Formation (late Lochkovian-early Pragian), S-3, sample S4-685.8 m, ROM 33714, $\times 3.2$.

55,56 . Posterior and dorsal views of articulated shell, Delorme Formation (late Lochkovian-early Pragian), S-3, sample S4$685.8 \mathrm{~m}$, ROM $33715, \times 3.2$.

57-60. Anterior, posterior, dorsal, and lateral views of articulated shells; Delorme Formation (late Lochkovian-early Pragian), S-3, sample S4-685.8 m, ROM 33716, $\times 3.2$.

Figs. 61-67. Hebetoechia cf. H. hebe (Barrande).

61-63. Posterior, dorsal, and lateral views of articulated shell; Delorme Formation (early Lochkovian), S-12, sample TRDW3483.9 m, ROM 33717, $\times 2.8$.

64-67. Anterior, ventral, lateral, and dorsal views of articulated shell; Delorme Formation (early Lochkovian), S-7, sample CH27WA274.3 m, ROM 33718, × 2.8 .

Figs. 68, 69. Indeterminate rhynchonellid. Exterior and interior views of brachial valve, Delorme Formation (early Zlichovian), S-3, sample S4-519.7 m, ROM $33719, \times 2.4$ 


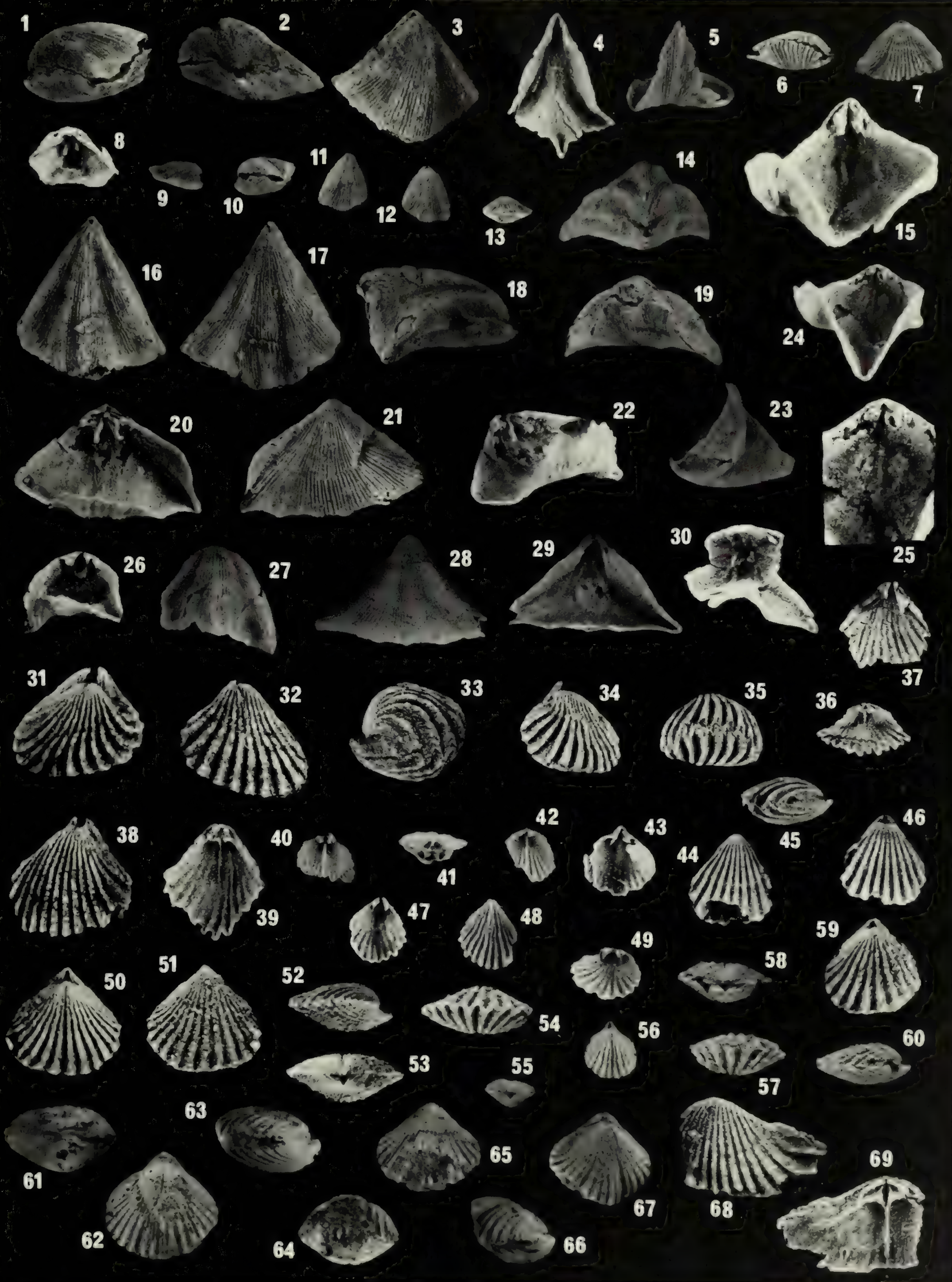


Plate 26, figs. 1-63

Articulate brachiopods Nymphorhynchia and Trigonirhynchia.

Figs. 1-37. Nymphorhynchia nympha (Barrande).

1-5. Posterior, ventral, anterior, dorsal, and lateral views of articulated shell; Delorme Formation (early Pragian), S-2, sample B128.6 m, ROM 33722, $\times 1.7$.

6. Interior view of brachial valve, Delorme Formation (early Pragian), S-2, sample B128.6 m, ROM 33723, × 1.7 .

7-11. Posterior, ventral, dorsal, anterior, and lateral views of articulated shell; Delorme Formation (early Pragian), S-2, sample B128.6 m, ROM $33724, \times 1.7$.

12, 13. Interior and exterior views of small pedicle valve, Delorme Formation (early Pragian), S-2, sample B128.6 m, ROM $33725, \times 3.3$.

14-17. Exterior, anterior, oblique interior, and interior views of large pedicle valve; Delorme Formation (early Pragian), S-2, sample B128.6 m, ROM 33726, × 1.7 .

18,19 . Interior and enlarged oblique interior views of brachial valve, Delorme Formation (early Pragian), S-2, sample B $128.6 \mathrm{~m}$, ROM $33727, \times 1.7$ and $\times 3.3$ respectively. Note the prominent cover plate over the septalium.

20. Interior view of brachial valve, Delorme Formation (early Pragian), S-2, sample B128.6 m, ROM 33728, × 3.3.

21-24. Anterior, posterior, dorsal, and lateral views of articulated shell; Delorme Formation (early Pragian), S-1, sample OLDA388.6 m, ROM $33729, \times 1.6$.

25. Interior view of brachial valve, Delorme Formation (latest Lochkovian-early Pragian), S-3, sample S4-685.8 m, ROM $33730, \times 1.4$.

26, 27. Oblique interior and exterior views of pedicle valve, Delorme Formation (latest Lochkovian-early Pragian), S-3, sample S4-685.8 m, ROM 33731, × 1.4.

28-31. Ventral, anterior, dorsal, and posterior views of articulated shell; Delorme Formation (latest Lochkovian-early Pragian), S-3, sample S4-685.8 m, ROM 33732, × 1.4 .

32. Dorsal view of partially crushed shell, Delorme Formation (latest Lochkovian-early Pragian), S-3, sample S4-685.8 m, ROM $33733, \times 1.4$.
33. Interior view of brachial valve, Delorme Formation (latest Lochkovian-early Pragian), S-3, sample S4-685.8 m, ROM $33734, \times 1.4$.

34. Oblique interior view of brachial valve, Delorme Formation (latest Lochkovian-early Pragian), S-3, sample S4-685.8 m, ROM $33735, \times 1.4$.

35-37. Interior, anterior, and oblique interior views of pedicle valve; Delorme Formation (latest Lochkovian-early Pragian), S-3, sample S4-685.8 m, ROM 33736, × 1.4.

Figs. 38-42. Nymphorhynchia sp. Lateral, anterior, dorsal, posterior, and ventral views of articulated shell; Delorme Formation (Lochkovian), S-2, sample B221.0 m, ROM 33737, $\times 2.3$.

Figs. 43-63. Trigonirhynchia cf. T. occidens (Walcott).

43-45. Interior, exterior, and oblique interior views of brachial valve; Delorme Formation (Zlichovian), S-1, sample A7.6$10.7 \mathrm{~m}$, ROM $33738, \times 2.3$.

46-48. Interior, exterior, and lateral views of pedicle valve; Delorme Formation (Zlichovian), S-1, sample A7.6-10.7 m, ROM $33739, \times 2.3$.

49-53. Ventral, oblique interior, lateral, anterior, and dorsal views of articulated shell; Delorme Formation (Zlichovian), S-1, sample A62.5-68.6 m, ROM 33740, × 2.3.

54,56 . Interior and exterior views of brachial valve, Delorme Formation (Zlichovian), S-3, sample S4-64.0-65.5 m, ROM $33741, \times 2.3$.

55. Oblique interior view of pedicle valve, Delorme Formation (Zlichovian), S-3, sample S4-64.0-65.5 m, ROM 33742, × 2.3.

57-59. Dorsal, anterior, and ventral views of articulated shell; Delorme Formation (Zlichovian), S-3, sample S4-143.3 m, ROM $33743, \times 2.5$.

60. Interior view of pedicle valve, Delorme Formation (Zlichovian), S-3, sample S4-143.3 m, ROM 33744, $\times 2.5$.

61-63. Ventral, anterior, and dorsal views of articulated shell; Delorme Formation (Zlichovian), S-1, sample A7.6-10.7 m, ROM $33745, \times 2.3$. 
ㄴ.

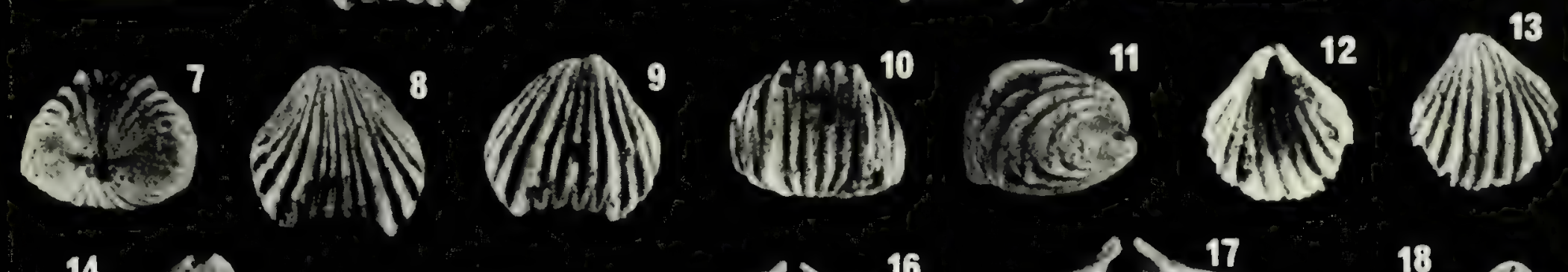
"I)

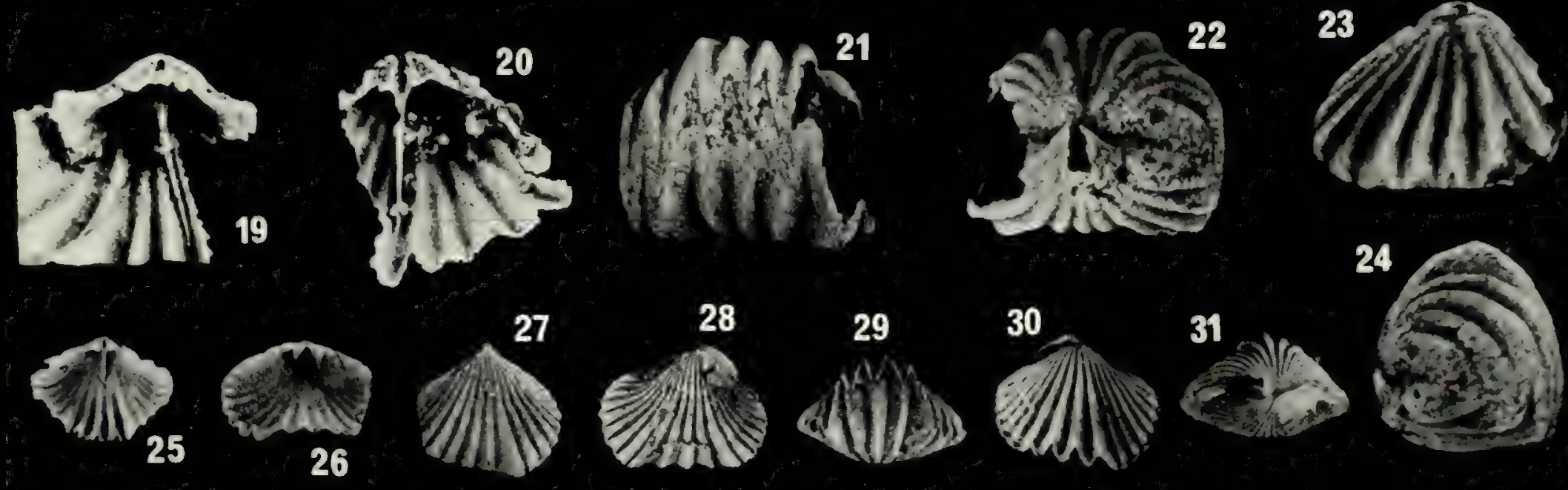

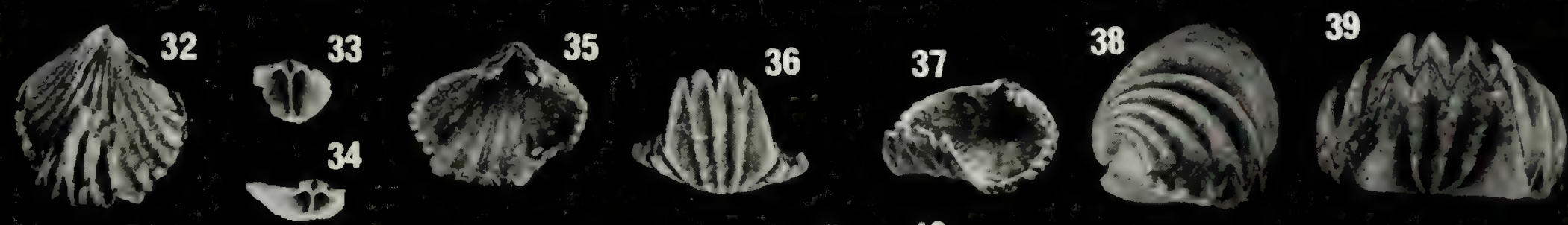
4. a s 
Plate 27, figs. 1-59

Articulate brachiopods Sphaerirhynchia, ?Decoropugnax, Isopoma, Linguopugnoides, "Leiorhynchus", and Werneckeella

Figs. 1-3. Sphaerirhynchia sp.

1, 2. Ventral and dorsal views of articulated shell, Delorme Formation (early Lochkovian), S-2, sample B300.2 m, ROM $33749, \times 2.4$.

3. Posterior internal view of an articulated shell fragment, Delorme Formation (early Lochkovian), S-2, sample B300.2 m, ROM $33750, \times 2.4$.

Figs. 4-8. ?Decoropugnax sp.

4. Posterior internal view of an articulated shell fragment, Delorme Formation (early Lochkovian), S-1, sample A536.4 m, ROM $33751, \times 3.0$.

5-8. Ventral, dorsal, anterior, and lateral views of articulated shell; Delorme Formation (early Lochkovian), S-1, sample A536.4 m, ROM $33752, \times 3.0$.

Figs. 9-22. Isopoma cf. I. alecto (Barrande).

9. Interior view of pedicle valve, Delorme Formation (late Lochkovian), S-1, sample A470.9 m, ROM $33753 \times 2.2$

10. Interior view of brachial valve, Delorme Formation (late Lochkovian), S-1, sample A470.9 m, ROM 33754, × 2.2.

11, 12. Lateral and ventral views of articulated shell, Delorme Formation (late Lochkovian), S-1, sample A470.9 m, ROM $33755, \times 2.2$.

13-15. Dorsal, lateral, and posterior views of articulated shell; Delorme Formation (late Lochkovian), S-1, sample A493.8 m, ROM $33756, \times 2.2$.

16. Posterior internal view of an articulated shell fragment, Delorme Formation (late Lochkovian), S-1, sample A493.8 m, ROM $33757, \times 2.2$.

17, 21, 22. Ventral, dorsal, and lateral views of pedicle valve; Delorme Formation (late Lochkovian), S-2, sample B181.4$182.9 \mathrm{~m}$, ROM $33758, \times 2.2$.

18. Interior view of brachial valve, Delorme Formation (late Lochkovian), S-2, sample B181.4-182.9 m, ROM 33759, × 2.2.

19. Interior view of brachial valve, Delorme Formation (late Lochkovian), S-2, sample B181.4-182.9 m, ROM 33760, × 2.2.

20. Interior view of pedicle valve fragment, Delorme Formation (late Lochkovian), S-2, sample B 181.4-182.9 m, ROM 33761, X 2.2

Figs. 23-28. Linguopugnoides cf. L. carens (Barrande).

23-25. Dorsal, anterior, and ventral views of articulated shell; Delorme Formation (late Lochkovian), S-1, sample A470.9 m, ROM $33763, \times 1.8$.

26. Interior view of brachial valve fragment, Delorme Forma- tion (late Lochkovian), S-1, sample OLDA475.5 m, ROM 33764 , $\times 1.8$. Note the prominent septum and septalium.

27. Posterior internal view of articulated shell fragment, Delorme Formation (late Lochkovian), S-2, sample B166.1 m, ROM $33765, \times 1.8$. Septum is obscured by siliceous matrix

28. Posterior internal view of articulated shell fragment, Delorme Formation (late Lochkovian), S-2, sample B166.1 m, ROM 33766, × 1.8 .

Figs. 29-46. Linguopugnoides stelcki sp. nov.

29, 30. Dorsal and anterior views of articulated shell, Delorme Formation (early Zlichovian), S-1, sample A62.5-68.6 m, paratype ROM $33767, \times 1.3$

31,32 . Interior and exterior views of brachial valve, Delorme Formation (early Zlichovian), S-1, sample A62.5-68.6 m, paratype ROM $33768, \times 1.3$

33-35. Dorsal, lateral, and anterior views of articulated shell; Delorme Formation (early Zlichovian), S-1, sample A62.5$68.6 \mathrm{~m}$, holotype ROM $33769, \times 1.3$.

36,37 . Interior and oblique interior views of dorsal valve, Delorme Formation (early Zlichovian), S-1, sample A62.5$68.6 \mathrm{~m}$, paratype ROM $33770, \times 1.3$

38-40. Lateral, posterior, and anterior views of articulated shell; Delorme Formation (early Zlichovian), S-1, sample A62.5$68.6 \mathrm{~m}$, paratype ROM $33771, \times 1.3$.

41-43. Dorsal, ventral, and posterior views of articulated shell; Delorme Formation (early Zlichovian), S-1, sample A62.5$68.6 \mathrm{~m}$, paratype ROM $33772, \times 1.3$.

44-46. Dorsal, ventral, and lateral views of articulated shell; Delorme Formation (early Zlichovian), S-1, sample A62.5$68.6 \mathrm{~m}$, paratype ROM $33773, \times 1.3$.

Figs. 47-56. "Leiorhynchus"' sp

47-49. Exterior, interior, and oblique interior views of pedicle valve; Delorme Formation (late Pragian), S-1, sample A272.8 m, ROM 33774, $\times 1.1$.

50-53. Anterior, interior, exterior, and oblique interior views of pedicle valve; Delorme Formation (late Pragian), S-1, sample A272.8 m, ROM 33775, $\times 1.1$.

54, 55. Interior and exterior views of pedicle valve, Delorme Formation (late Pragian), S-1, sample A272.8 m, ROM 33776, × 1.1. Note the circular boring.

56. Exterior view of pedicle valve fragment, Delorme Formation (late Pragian), S-1, sample A272.8 m, ROM 33777, $\times 1.1$.

Figs. 57-59. Werneckeella hartensis Lenz. Ventral, anterior, and dorsal views of articulated shell; Delorme Formation (early Pragian), S-2, sample B105.2 m, ROM 33778, $\times 2.4$. Note the dorsal furrow in fig. 59 . 


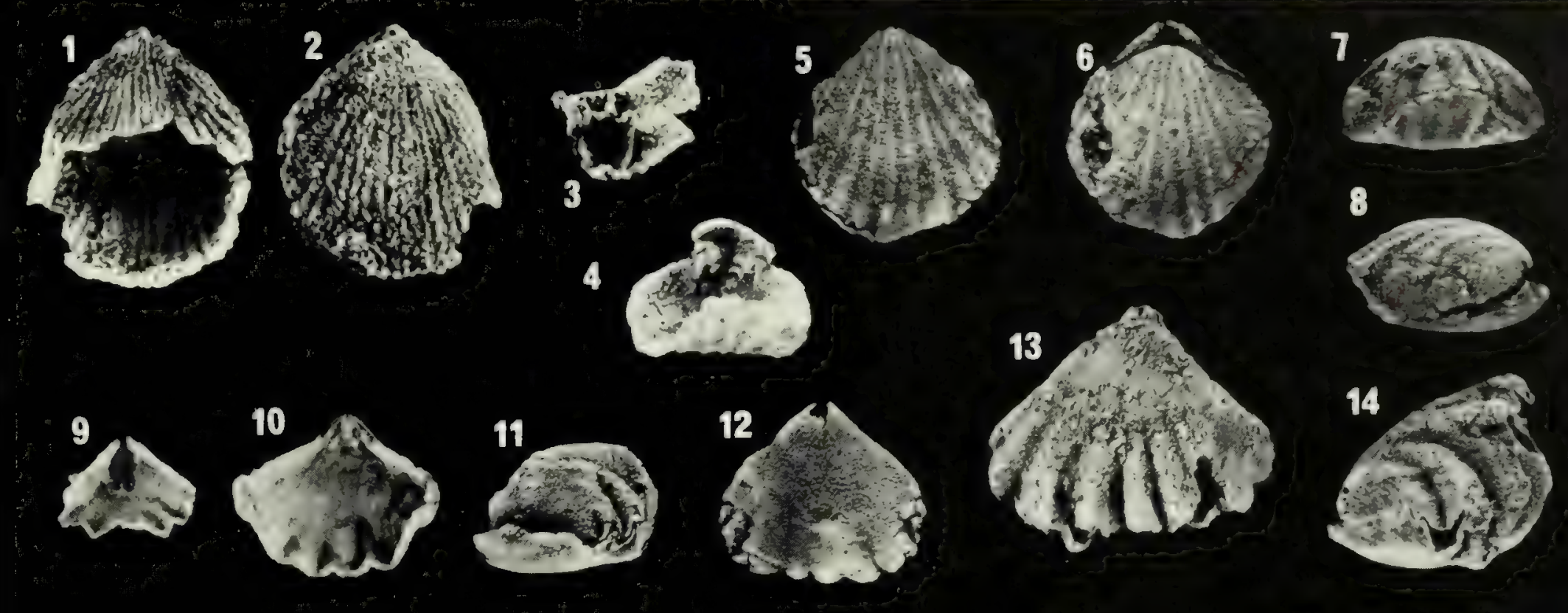

$4^{17} 8^{18} a^{10} \Delta^{21} \underbrace{22}{ }^{16}$
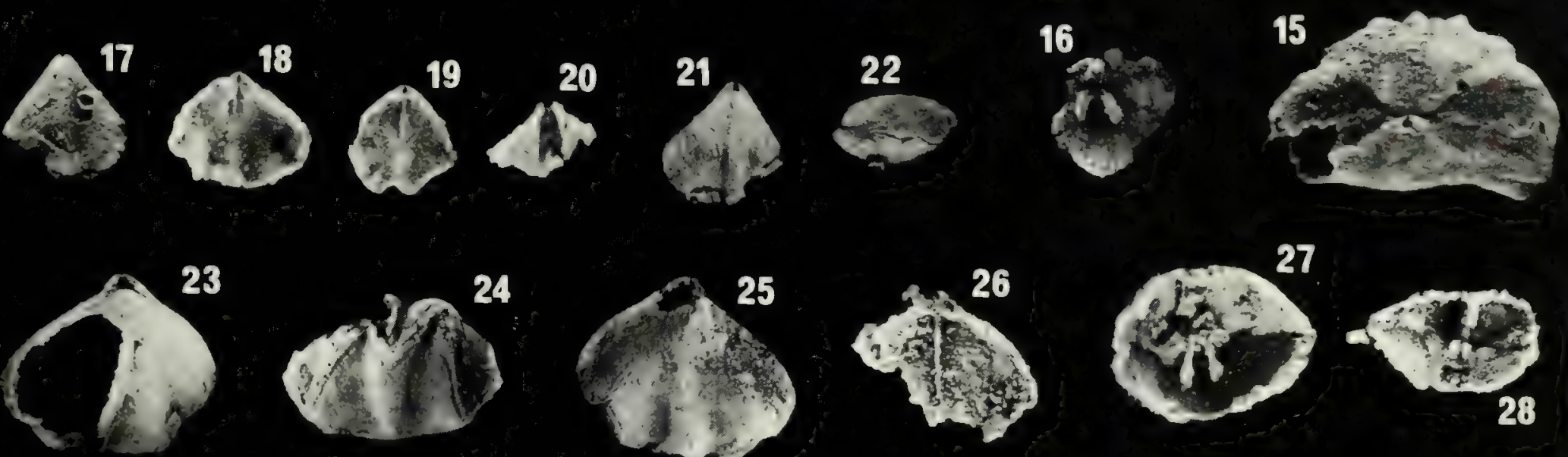

$20^{24} 0^{25}$

27

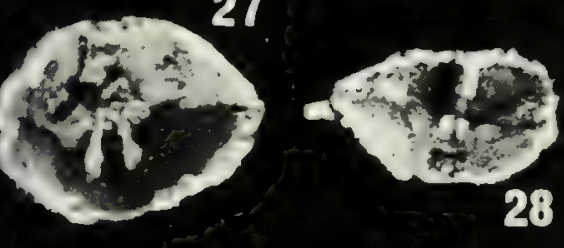

$(v){ }^{29}$

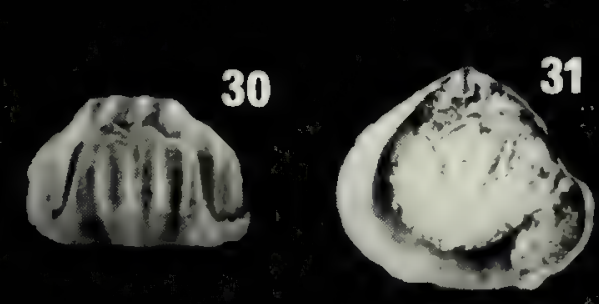

32
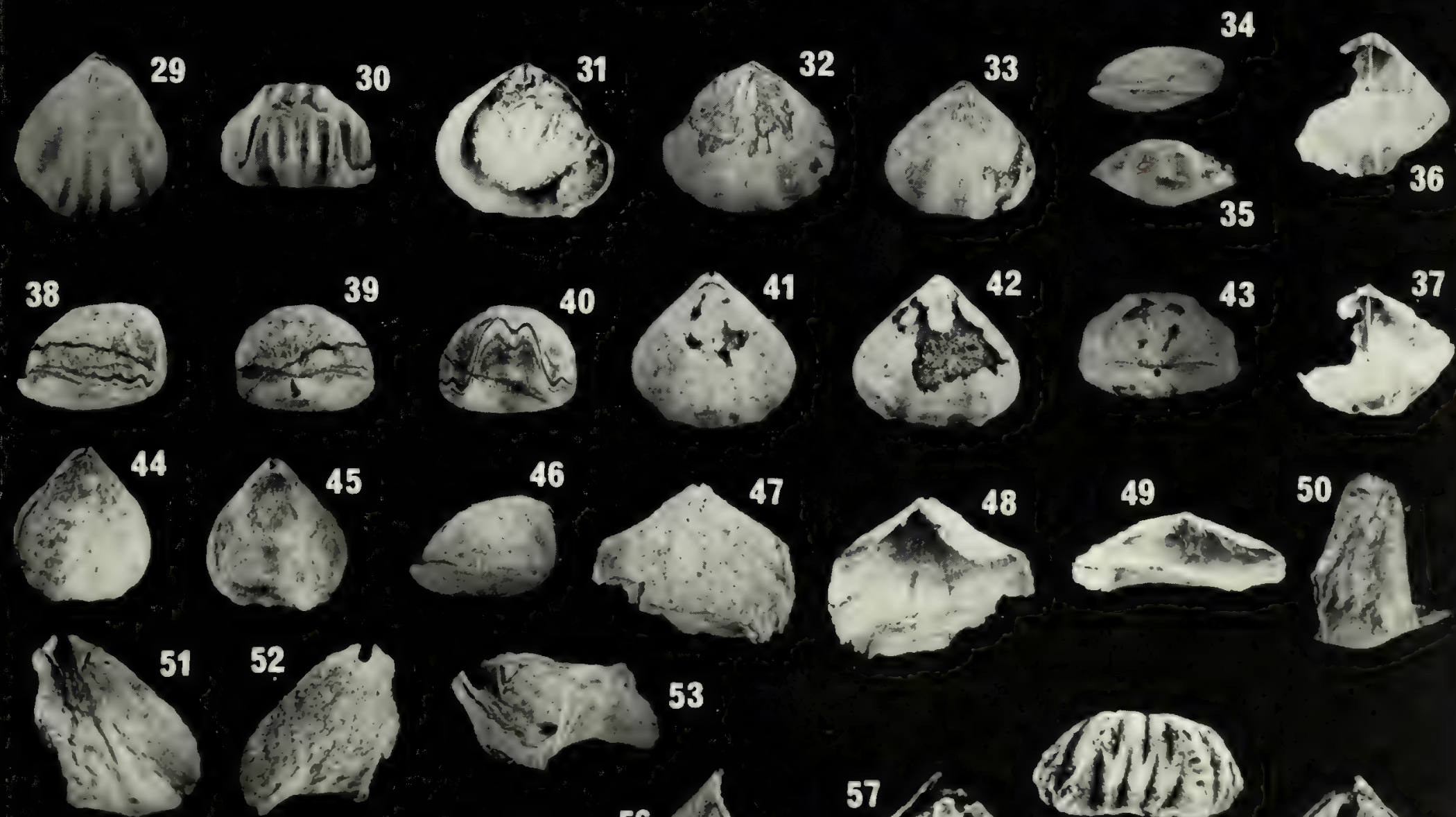

54

5556

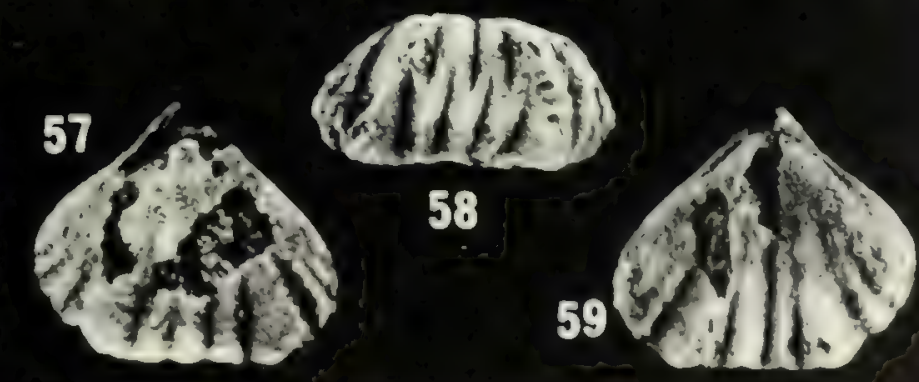


Plate 28, figs. 1-47

Articulate brachiopods Athyrhynchus, ?Phoenicitoechia, and Atrypa

Figs. 1-7. Athyrhynchus sp.

1, 2. Ventral and dorsal views of articulated shell, Delorme Formation (Zlichovian), S-3, sample S4-176.8 m, ROM 33779 , $\times 1.9$.

3-7. Oblique interior, exterior, oblique anterior, lateral, and oblique posterior views of brachial valve; Delorme Formation (Zlichovian), S-3, sample S4-161.5-164.6 m, ROM 33780, $\times$ 2.6. This shell is probably a gerontic $A$. susanae Johnson.

Figs. 8-17. Athyrhynchus susanae Johnson.

8-13. Anterior, lateral, ventral, oblique ventral, posterior, and dorsal views of silicified internal mould; Delorme Formation (Zlichovian), S-3, sample S4-161.5-164.6 m, ROM 33781, $\times$ 1.0. Note the saccate (apocopate) mantle canal system and the arcuate areas of the gonadal sac adjacent to the ventral diductor muscle field in figs. 10 and 11 .

14. Interior view of brachial valve fragment, Delorme Formation (Zlichovian), S-3, sample S4-176.8 m ROM 33782, $\times 1.3$.

15. Interior view of brachial valve fragment, Delorme Formation (Zlichovian), S-3, sample S4-176.8 m, ROM 33783, $\times 1.3$.

16. Oblique interior view of pedicle valve, Delorme Formation (Zlichovian), S-3, sample S4-176.8 m, ROM 33784, $\times 1.3$.

17. Interior view of brachial valve fragment, Delorme Formation (Zlichovian), S-3, sample S4-217.9 m, ROм 33785, × 1.3.

Figs. 18-28. Athyrhynchus sp. 1.

18. Interior view of pedicle valve, Delorme Formation (early Zlichovian), S-1, sample A62.5-68.6 m, ROM 33786, × 0.9.

19. Oblique interior view of pedicle valve, Delorme Formation (early Zlichovian), S-1, sample A62.5-68.6 m, ROM 33787, $\times$ 0.9 .

20, 21. Exterior and interior views of brachial valve, Delorme Formation (early Zlichovian), S-1, sample A62.5-68.6 m, ROM $33788, \times 0.9$

22. Interior view of pedicle valve fragment, Delorme Formation (early Zlichovian), S-1, sample A62.5-68.6 m, ROM 33789, × 0.9 .

23. Oblique interior view of brachial valve fragment, Delorme Formation (early Zlichovian), S-1, sample A62.5-68.6 m, ROM $33790, \times 0.9$

24. Interior view of brachial valve, Delorme Formation (early Zlichovian), S-1, sample A62.5-68.6 m, ROM 33791, $\times 0.9$.
25. Interior view of brachial valve fragment, Delorme Formation (early Zlichovian), S-1, sample A62.5-68.6 m, ROM 33792, $\times 0.9$.

26. Interior view of brachial valve fragment, Delorme Formation (late Pragian), S-1, sample A205.7-208.8 m, Rом 33793, $\times 1.0$.

27, 28. Exterior and interior views of pedicle valve, Delorme Formation (late Pragian), S-1, sample A205.7-208.8 m, ROM $33794, \times 1.0$.

Figs. 29-39. Athyrhynchus boucoti sp. nov.

29. Interior view of brachial valve fragment, Delorme Formation (late Pragian), S-1, sample A210.3-233.2 m, paratype ROM $33795, \times 1.2$.

30-33. Lateral, interior, exterior, and oblique interior views of brachial valve, Delorme Formation (late Pragian), S-1, sample A210.3-233.2 m, holotype ROM 33796, × 1.2.

34,35 . Interior and exterior views of pedicle valve, Delorme Formation (late Pragian), S-1, sample A210.3-233.2 m, paratype ROM $33797, \times 1.2$.

36,37 . Interior and exterior views of pedicle valve, Delorme Formation (late Pragian), S-1, sample A210.3-233.2 m, paratype ROM $33798, \times 1.2$.

38. Interior view of brachial valve fragment, Delorme Formation (late Pragian), S-1, sample A210.3-233.2 m, paratype ROM $33799, \times 1.2$.

39. Interior view of brachial valve fragment, Delorme Formation (late Pragian), S-1, sample A210.3-233.2 m, paratype ROM $33800, \times 1.2$.

Figs. 40-44. ?Phoenicitoechia sp.

40. Interior view of articulated shell fragment. Delorme Formation (late Lochkovian), S-1, sample OLDA475.5T m, ROM $33801, \times 3.4$.

41-43. Ventral, dorsal, and anterior views of articulated shell; Delorme Formation (late Lochkovian), S-1, sample OLDA475.5T m, ROM 33802, $\times 3.4$.

44. Interior view of pedicle valve, Delorme Formation (late Lochkovian), S-1, sample OLDA475.5T m, ROM 33803, × 3.4.

Figs. 45-47. Atrypa sp. Dorsal, ventral, and lateral views of articulated shell; Delorme Formation (early Pragian), S-1, sample A438.0 m, ROM 33804, × 2.4 . 

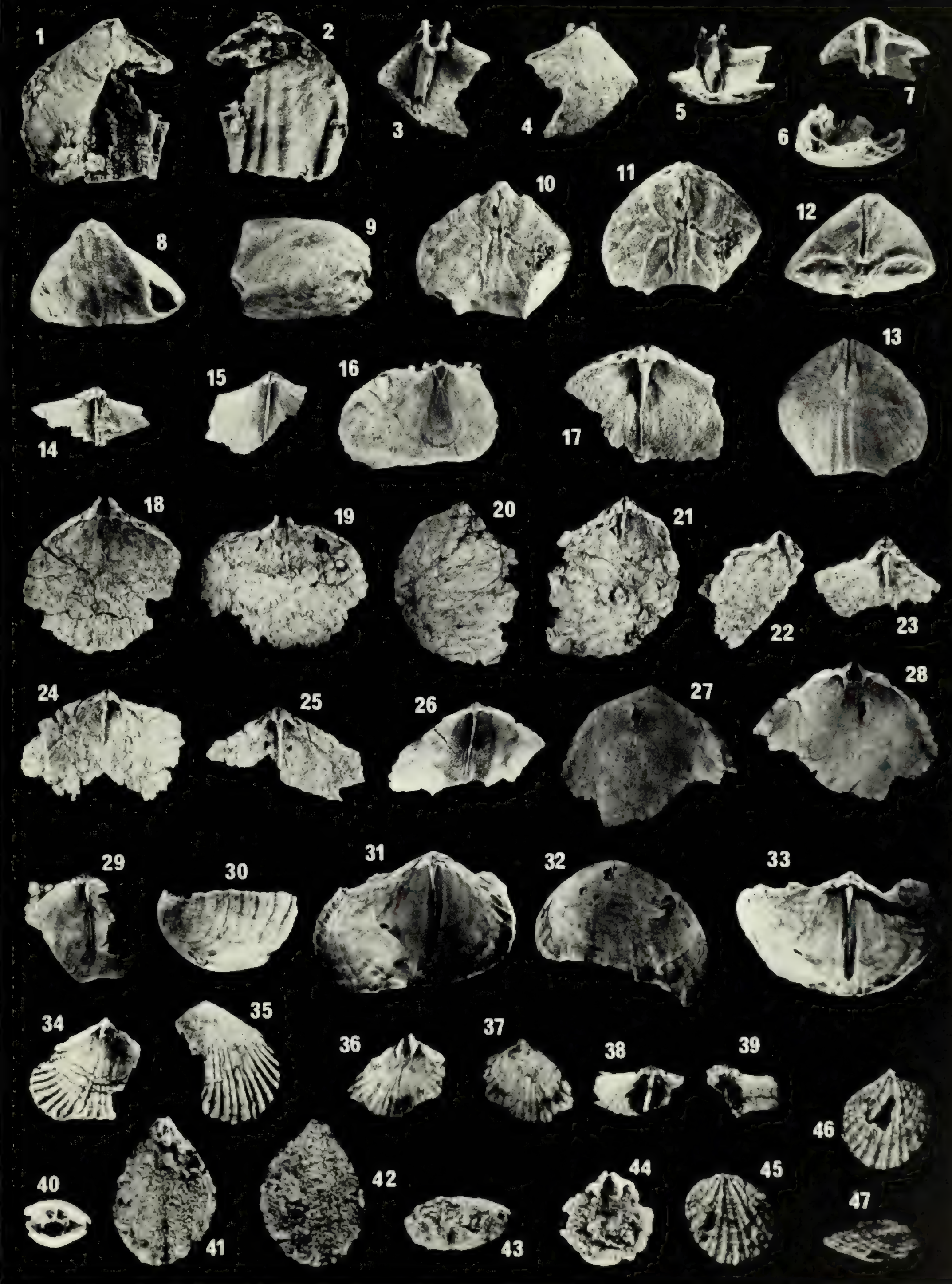
Plate 29, figs. $1-45$

Articulate brachiopod Atrypa .

Figs. 1-17. Atrypa cf. A. nevadana Merriam.

1. Interior view of brachial valve fragment, Delorme Formation (Zlichovian), S-3, sample S4-492.3 m, ROM 33805, $\times 1.7$. Note the cardinal process.

2. Interior view of articulated shell fragment, Delorme Formation (Zlichovian), S-3, sample S4-475.5 m, ROM 33806, × 1.7.

Note the disconnected jugum.

3-5. Exterior, interior, and oblique interior views of brachial valve; Delorme Formation (Zlichovian), S-3, sample S4$274.3 \mathrm{~m}$, ROM $33807, \times 1.1$.

6. Interior view of articulated shell fragment, Delorme Formation (Zlichovian), S-3, sample S4-274.3 m, ROM 33808, $\times 1.1$.

7, 8. Exterior and interior views of pedicle valve, Delorme Formation (Zlichovian), S-3, sample S4-274.3 hे, ROM 33809, $\times 1.1$.

9, 10. Exterior and interior views of brachial valve, Delorme Formation (Zlichovian), S-1, sample A7.6-10.7 m, ROM 33810, $\times 1.1$.

11, 17. Oblique anterior and interior views of articulated shell fragment showing a well-developed fold, Delorme Formation (Zlichovian), S-1, sample A7.6-10.7 m, ROM 33811, $\times 1.1$. Several A. cf. A. nevadana shells are welded together in a silicified mass, forming a nestlike structure.

12, 13. Exterior and interior views of pedicle valve, Delorme Formation (Zlichovian), S-1, sample A7.6-10.7 m, ROM 33812, $\times 1.1$.

14-16. Ventral, dorsal, and posterior views of articulated shell; Delorme Formation (Zlichovian), S-1, sample A7.6-10.7 m, ROM $33813, \times 1.1$.

Figs. 18-23. Atrypa nieczlawiensis Kozlowski.

18-20. Exterior, interior, and oblique interior views of pedicle valve; Delorme Formation (early Lochkovian), S-11, $211.5 \mathrm{~m}$ above the top of the Whittaker Formation, ROM 33815, $\times 1.3$. 21-23. Lateral, ventral, and dorsal views of articulated shell; Delorme Formation (early Lochkovian), S-7, sample P7WA1912.6 m, ROM 33816, × 1.1.

Figs. 24-45. Atrypa cf. A. aspiformis Lenz.

24-27. Dorsal, ventral, anterior, and lateral views of articulated shell; Delorme Formation (late Lochkovian), S-1, sample A470.9 m, ROM 33817, $\times 1.2$.

28, 29. Interior and exterior views of brachial valve, Delorme Formation (late Lochkovian), S-1, sample A470.9 m, ROM $33818, \times 1.2$.

30,31 . Interior and exterior views of pedicle valve, Delorme Formation (late Lochkovian), S-1, sample A470.9 m, ROM $33819, \times 1.2$.

32, 33. Exterior and interior views of brachial valve, Delorme Formation (late Lochkovian), S-1, sample A470.9 m, ROM $33820, \times 1.2$.

34, 35. Anterior and dorsal views of small shell, Delorme Formation (late Lochkovian), S-1, sample A470.9 m, ROM $33821, \times 1.2$.

36. Interior view of brachial valve, Delorme Formation (early Pragian), S-2, sample B128.6 m, ROM 33822, $\times 1.2$.

37, 41, 42. Exterior, lateral, and anterior views of articulated shell; Delorme Formation (early Pragian), S-2, sample B128.6 m, ROM 33825, $\times 1.2$.

38-40. Ventral, dorsal, and lateral views of articulated shell; Delorme Formation (early Pragian), S-2, sample B128.6 m, ROM $33824, \times 1.2$.

43. Interior view of pedicle valve, Delorme Formation (late Lochkovian), S-2, sample B181.4-182.9 m, ROM 33826, × 1.2.

44,45 . Interior and exterior views of pedicle valve, Delorme Formation (late Lochkovian), S-2, sample B181.4-182.9 m, ROM $33827, \times 1.2$. 


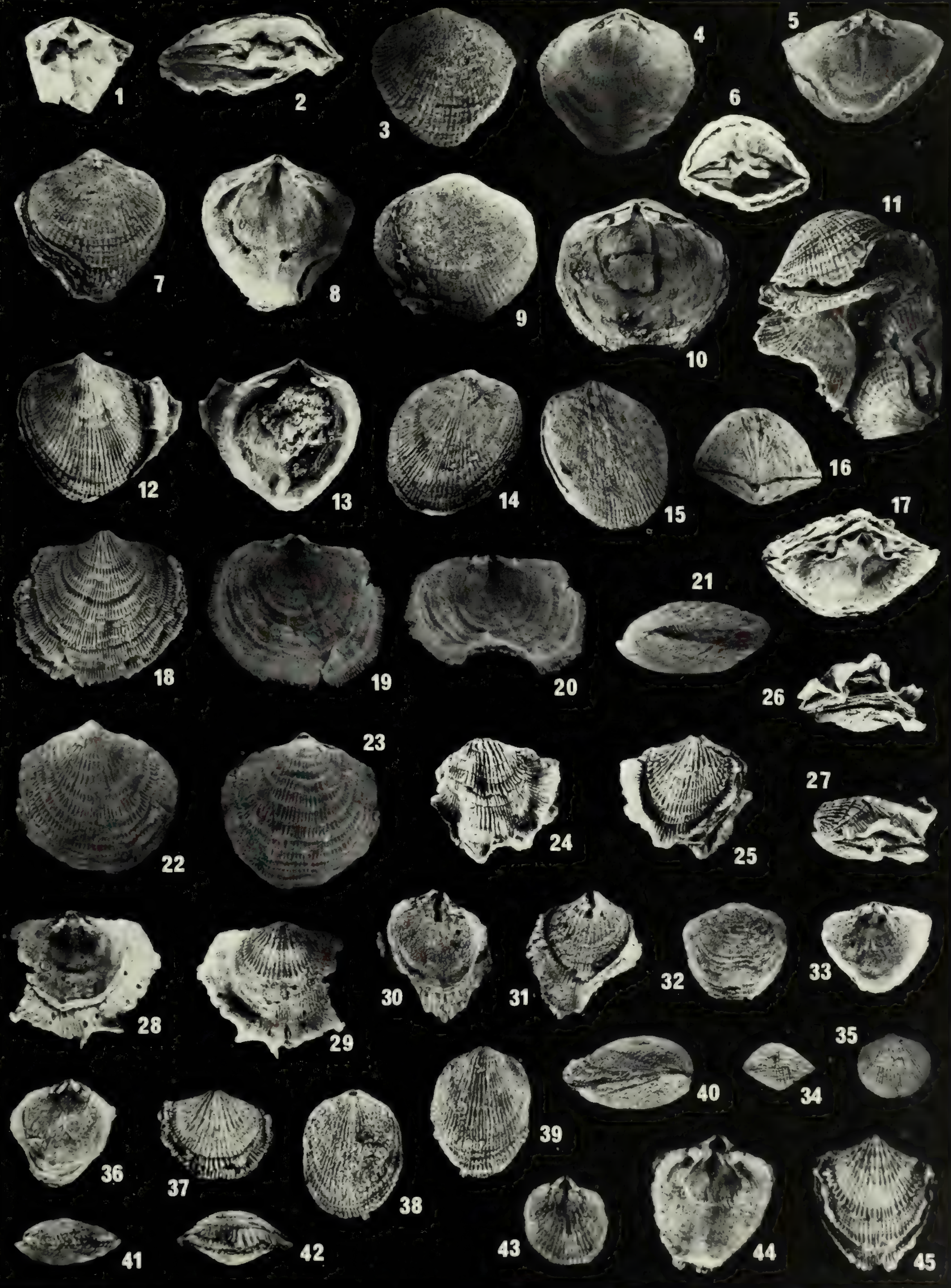


Plate 30, figs. 1-65.

Articulate brachiopods Desquamatia, Ogilviella, Reticulatrypa, and Rhynchospirina .

Figs. 1-5. Desquamatia cf. D. filistriata Lenz.

1-3. Dorsal, ventral, and lateral views of articulated shell; Delorme Formation (Zlichovian), S-3, sample S4-560.8$573.0 \mathrm{~m}, \mathrm{ROM} 33828, \times 1.6$

4. Interior view of pedicle valve, Delorme Formation (Zlichovian), S-3, sample S4-560.8-573.0 m, ROM 33829, $\times 1.6$

5. Interior view of brachial valve, Delorme Formation (Zlichovian), S-3, sample S4-560.8-573.0 m, ROM 33830, $\times 1.6$

Figs. 6-12. Desquamatia sp. 1.

6. Interior view of articulated shell fragment, Delorme Formation (Lochkovian), S-1, sample A528.8 m, ROM 33831, × 1.6.

7-9. Ventral, dorsal, and lateral views of articulated shell; Delorme Formation (Lochkovian), S-1, sample A528.8 m, ROM $33832, \times 1.6$.

10-12. Anterior, ventral, and dorsal views of articulated shell; Delorme Formation (Lochkovian), S-1, sample A528.8 m, ROM $33833, \times 1.6$.

\section{Figs. 13-28. Ogilviella rotunda Lenz.}

13-15. Ventral, dorsal, and lateral views of articulated shell; Delorme Formation (Lochkovian), S-1, sample A528.8 m, ROM 33834. $\times 2.0$.

16-18. Ventral, dorsal, and anterior views of articulated shell; Delorme Formation (Lochkovian), S-1, sample A528.8 m, ROM $33835, \times 2.0$.

19. Interior view of pedicle valve, Delorme Formation (Lochkovian), S-1, sample A528.8 m, ROM 33836, × 2.0 .

20,21 . Interior and oblique interior views of pedicle valve, Delorme Formation (Lochkovian), S-1, sample A528.8 m, ROM $33837, \times 2.0$.

22. Interior view of brachial valve, Delorme Formation (Lochkovian), S-1, sample A528.8 m, ROM 33838, $\times 2.0$.

23. Interior view of brachial valve, Delorme Formation (Lochkovian), S-2, sample B221.0 m, ROM 33839, × 2.0 .

24-28. Ventral, dorsal, lateral, posterior, and anterior views of articulated shell; Delorme Formation (Lochkovian), S-2, sample B221.0 m, ROM 33840, $\times 2.0$.

Figs. 29-38. Reticulatrypa neutra Johnson, Boucot, and Murphy?.

29, 30. Exterior and interior views of brachial valve, Delorme Formation (early Lochkovian), S-2, sample B336.8 m, ROM $33841, \times 2.0$.

31,32 . Interior and exterior views of pedicle valve, Delorme Formation (early Lochkovian), S-2, sample B336.8 m, ROM $33842, \times 2.0$

33, 34. Dorsal and ventral views of crushed shell, Delorme
Formation (early Lochkovian), S-2, sample B336.8 m, ROM $33843, \times 2.0$.

35-37. Dorsal, ventral, and lateral views of small shell; Delorme Formation (early Lochkovian), S-2, sample B336.8 m, ROM $33844, \times 2.0$.

38. Exterior view of dorsal valve, Delorme Formation (early Lochkovian), S-2, sample B336.8 m, ROM 33845, × 2.0 .

Figs. 39-59. Reticulatrypa variabilis Johnson, Boucot, and Murphy.

39-42. Dorsal, ventral, lateral, and posterior views of articulated shell; Delorme Formation (Ludlovian), S-6, sample C47-248.4 m, Rом 33846, × 3.6.

43, 50. Dorsal and lateral views of articulated shell, Delorme Formation (Ludlovian), S-6, sample C47-248.4 m, ROM 33847 , $\times 3.6$.

44,45 . Interior and exterior views of pedicle valve, Delorme Formation (Ludlovian), S-6, sample C47-248.4 m, ROM 33848, $\times 3.6$.

46, 47. Exterior and interior views of pedicle valve, Delorme Formation (Ludlovian), S-6, sample C47-248.4 m, ROM 33849 , $\times 3.6$.

48, 49. Exterior and interior views of brachial valve, Delorme Formation (Ludlovian), S-6, sample C47-248.4 m, ROM 33850, $\times 3.6$.

51. Oblique interior view of pedicle valve, Delorme Formation (Ludlovian), S-6, sample C47-248.4 m, ROM 33851, × 3.6.

52. Interior view of brachial valve, Delorme Formation (Ludlovian), S-6, sample C47-248.4 m, ROM 33852, × 3.6.

53. Interior view of brachial valve, Delorme Formation (Ludlovian), S-6, sample C47-248.4 m, ROM 33853, × 3.6.

54-57. Dorsal, ventral, posterior, and lateral views of articulated shell; Delorme Formation (Ludlovian), S-6, sample C47-248.4 m, ROM 33854, $\times 2.3$.

58,59 . Ventral and anterior views of articulated shell, Delorme Formation (Ludlovian), S-6, sample C47-237.7 m, ROM 33855, $\times 5.2$.

Figs. 60-65. Rhynchospirina sp. 1.

60, 61. Anterior external and posterior external views of articulated shell fragment, Delorme Formation (early Lochkovian), S-1, sample A538.0T m, ROM 33856, × 2.0 .

62. Interior view of articulated shell fragment, Delorme Formation (early Lochkovian), S-1, sample A538.0T m, ROM $33857, \times 2.0$.

63. Oblique interior view of pedicle valve, Delorme Formation (early Lochkovian), S-2, sample B300.2 m, ROM 33858, × 2.0.

64,65 . Oblique interior and exterior views of articulated shell fragment, Delorme Formation (early Lochkovian), S-2, sample B300.2 m, ROM 33859, $\times 2.0$. 

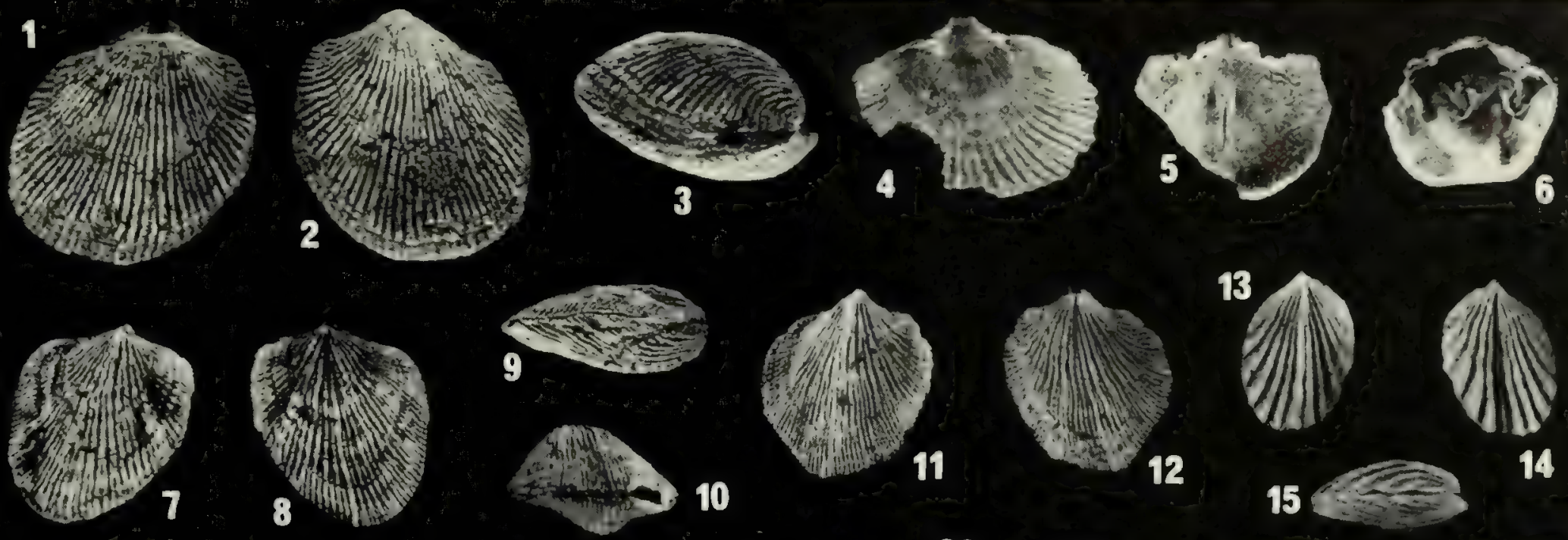

$\mathbb{2}^{16} \mathrm{C}^{18} \mathrm{~A}^{18}$
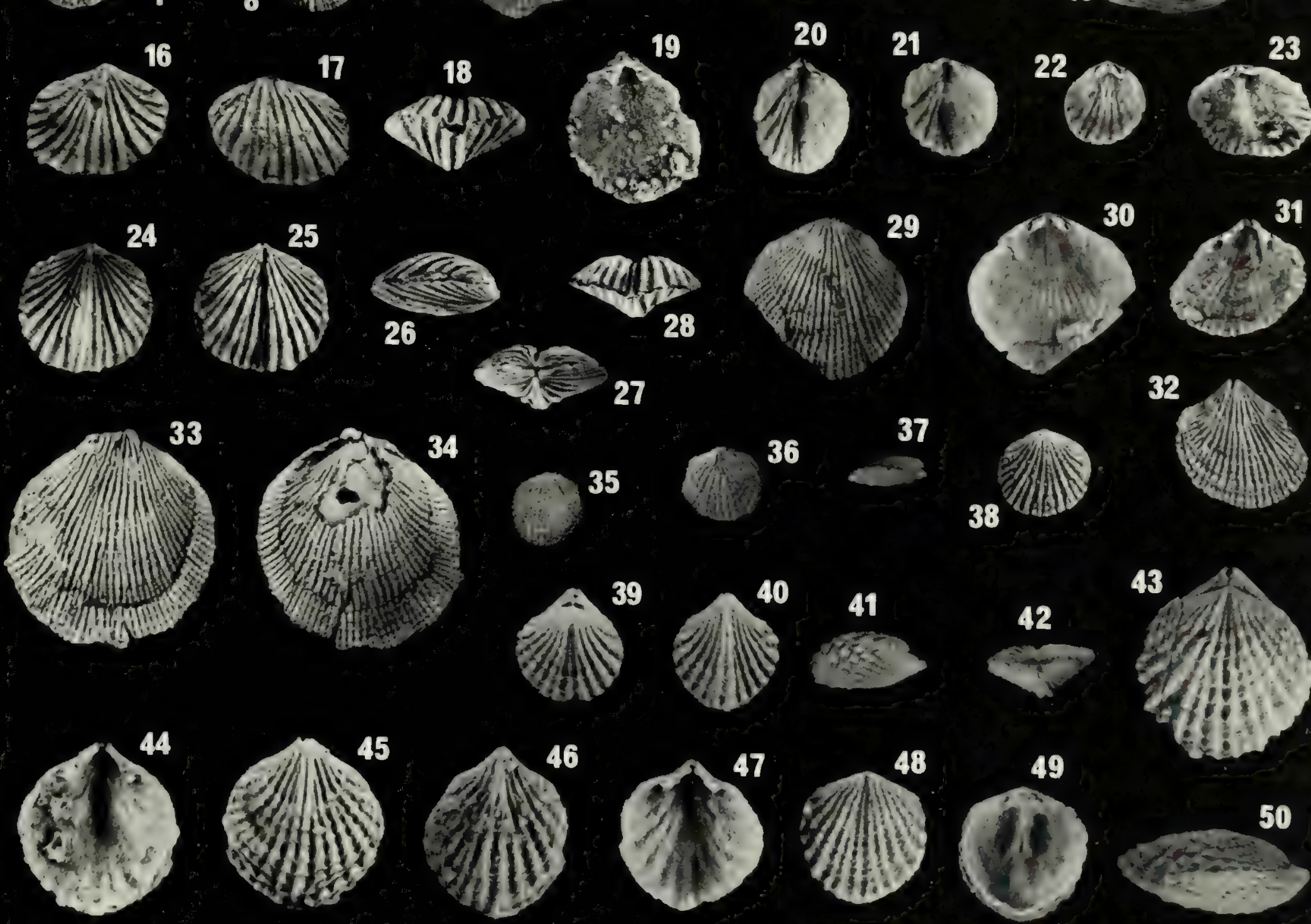

32

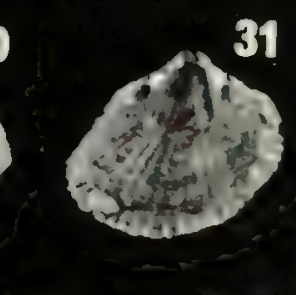

31 
Plate 31 , figs. $1-52$

Articulate brachiopods Spinatrypa, Spinatrypa (Invertrypa), Spinatrypina, and Spirigerina.

Figs. 1-11. Spinatrypa jonesi sp. nov.

1, 2. Exterior and interior views of pedicle valve, Delorme Formation (late Pragian), S-1, sample A207.3-208.8 m, holotype ROM $33860, \times 1.1$. Note the preservation of the spinelike growth lamellae at the junctions of the costae and the growth lines.

3, 4. Interior and exterior views of pedicle valve, Delorme Formation (late Pragian), S-2, sample B $32.0 \mathrm{~m}$, paratype ROM $33861, \times 1.1$.

5-7. Ventral, dorsal, and lateral views of articulated shell; Delorme Formation (Pragian), S-1, sample OLDA336.8 m, paratype ROM $33862, \times 1.1$

8-10. Ventral, dorsal, and anterior views of articulated shell; Delorme Formation (Pragian), S-1, sample OLDA336.8 m, paratype ROM $33863, \times 1.1$.

11. Interior view of brachial valve, Delorme Formation (Pragian), S-1, sample OLDA336.8 m, paratype ROM $33864, \times 1.1$.

Figs. 12-20. Spinatrypina symmetrica Perry, Boucot, and Gabrielse

12, 13. Dorsal and ventral views of articulated shell, Delorme Formation (Zlichovian), S-3, sample S4-64.0-65.5 m, ROM $33865, \times 2.4$

14, 15. Interior and exterior views of brachial valve, Delorme Formation (Zlichovian), S-3, sample S4-64.0-65.5 m, ROM $33866, \times 2.4$

16-18. Ventral, dorsal, and lateral views of articulated shell; Delorme Formation (Zlichovian), S-3, sample S4-502.9$507.5 \mathrm{~m}$, Rом $33867, \times 2.4$.

19, 20. Ventral and dorsal views of articulated shell, Delorme Formation (Zlichovian), S-3, sample S4-176.8 m, ROM 33868, $\times 2.4$

Figs. 21-27. Spinatrypa (Invertrypa) echinocostata (Lenz).

21,22 . Ventral and dorsal views of articulated shell, Delorme
Formation (Pragian), S-1, sample OLDA370.3 m, ROM 33869, $\times 1.1$.

23, 24. Ventral and dorsal views of articulated shell, Delorme Formation (late Pragian), S-1, sample A175.2 m, ROM 33870, $x$ 1.1 .

25-27. Abraded ventral exterior, interior, and oblique interior views of an incomplete articulated shell; Delorme Formation (late Pragian), S-2, sample B32.0 m, ROM 33871, × 1.1 .

Figs. 28-47. Spirigerina supramarginalis (Khalfin).

28-30. Interior, exterior, and anterior views of pedicle valve, Delorme Formation (late Lochkovian), S-1, sample A470.9 m, ROM $33872, \times 1.5$.

31. Oblique interior view of brachial valve, Delorme Formation (late Lochkovian), S-1, sample A470.9 m, ROM 33873, $\times 1.5$. 32-36. Lateral, anterior, posterior, ventral, and dorsal views of articulated shell; Delorme Formation (late Lochkovian), S-1, sample A519.7 m, ROM $33874, \times 1.5$.

37, 38. Ventral and anterior views of articulated shell, Delorme Formation (late Lochkovian), S-1, sample A519.7 m, ROM $33875, \times 1.5$.

39-41. Ventral, dorsal, and lateral views of small shell, Delorme Formation (Lochkovian), S-2, sample B221.0 m, ROM $33876, \times 1.5$.

42-44. Lateral, ventral, and dorsal views of articulated shell; Delorme Formation (Lochkovian), S-2, sample B221.0 m, ROM $33877, \times 1.5$.

45-47. Anterior, dorsal, and ventral views of small shell; Delorme Formation (Lochkovian), S-2, sample B221.0 m, ROM $33878, \times 1.5$

Figs. 48-52. Spirigerina marginaliformis Alekseeva. Lateral, posterior, anterior, ventral, and dorsal views of articulated shell; Delorme Formation (early Lochkovian), S-1, sample A544.1 m, ROM 33879, x 1.4 . 

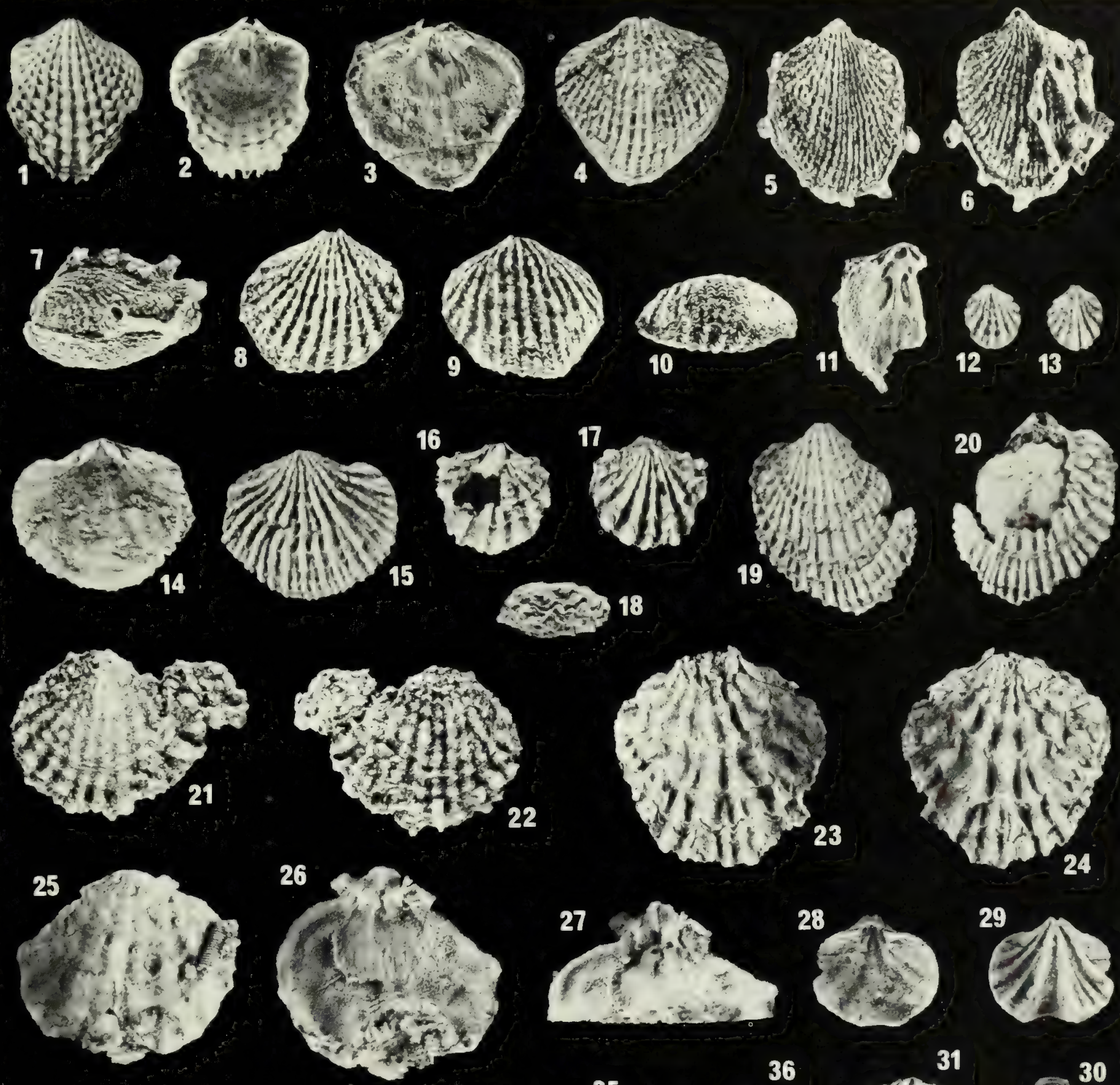
24 32 (1)

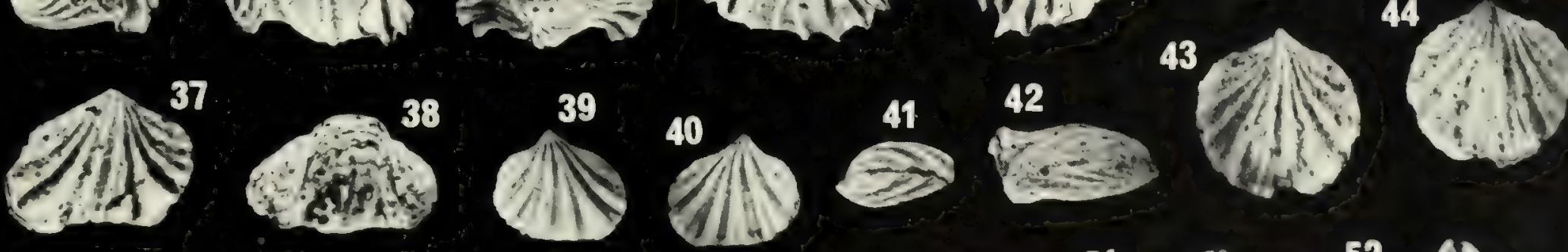

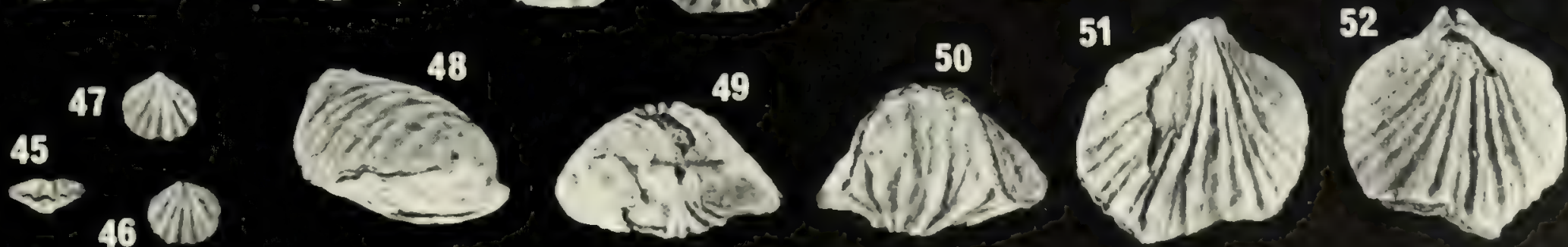


Plate 32, figs. 1-53

Articulate brachiopods Atrypina, Spirigerina, and Notoparmella .

Figs. 1-12. Atrypina simpsoni Johnson.

1-5. Ventral, dorsal, posterior, anterior, and lateral views of articulated shell; Delorme Formation (early Pragian), S-1, sample A330.7 m, ROM 33880, × 6.0 .

6, 7. Ventral and dorsal views of articulated shell, Delorme Formation (early Pragian), S-1, sample A330.7 m, ROM 33881, $\times 6.0$.

8-12. Anterior, lateral, posterior, dorsal, and ventral views of articulated shell; Delorme Formation (early Pragian), S-1, sample OLDA336.8 m, ROM 33882, × 6.0.

Figs. 13-32. Atrypina chattertoni sp. nov.

13-17. Dorsal, ventral, posterior, anterior, and lateral views of articulated shell; Delorme Formation (early Zlichovian), S-1, sample A62.5-68.6 m, holotype ROM 33883, × 3.0.

18. Interior view of pedicle valve, Delorme Formation (early Zlichovian), S-1, sample A62.5-68.6 m, paratype ROM 33884, $\times 3.0$.

19-21. Anterior, lateral, and posterior views of articulated shell; Delorme Formation (early Zlichovian), S-1, sample A62.5$68.6 \mathrm{~m}$, paratype ROM $33885, \times 3.0$.

22,23 . Interior and exterior views of pedicle valve, Delorme Formation (early Zlichovian), S-1, sample A62.5-68.6 m, paratype ROM $33886, \times 3.0$.

24,25 . Exterior and interior views of brachial valve, Delorme Formation (early Zlichovian), S-1, sample A62.5-68.6 m, paratype ROM $33887, \times 3.0$.

26, 27. Exterior and interior views of pedicle valve, Delorme Formation (early Zlichovian), S-1, sample A62.5-68.6 m, paratype ROM 33888, × 3.0 .

28-32. Dorsal, ventral, posterior, lateral, and anterior views of articulated shell; Delorme Formation (early Zlichovian), S-1, sample A62.5-68.6 m, paratype ROM 33889, × 3.0
Figs. 33-40. Atrypina sp. 1.

33-36. Ventral, posterior, anterior, and lateral views of articulated shell; Delorme Formation (early Pragian), S-2, sample B105.2 m, ROM 33890, $\times 5.0$.

37-40. Lateral, anterior, posterior, and ventral views of articulated shell; Delorme Formation (early Pragian), S-2, sample B105.2 m, ROM 33891, × 5.0.

Figs. 41-49. Spirigerina intermedia sp. nov.

41, 42. Ventral and dorsal views of articulated shell, Delorme Formation (mid-Lochkovian), S-1, sample A536.4 m, paratype ROM $33892, \times 1.5$.

43,44 . Interior and exterior views of brachial valve, Delorme Formation (mid-Lochkovian), S-1, sample A536.4 m, paratype ROM $33893, \times 1.5$.

45-47. Dorsal, lateral, and ventral views of articulated shell; Delorme Formation (mid-Lochkovian), S-1, sample A536.4 m, holotype ROM $33894, \times 1.5$.

48. Interior view of brachial valve, Delorme Formation (midLochkovian), S-1, sample A536.4 m, paratype ROM 33895, × 1.5 .

49. Interior view of pedicle valve, Delorme Formation (midLochkovian), S-1, sample A536.4 m, paratype ROM 33896, $\times$ 1.5 .

Figs. 50-53. Notoparmella gilli Johnson.

50, 51. Exterior and interior views of brachial valve, Delorme Formation (mid-Lochkovian), S-2, sample B254.5 m, ROM $33897, \times 4.2$.

52, 53. Exterior and interior views of brachial valve, Upper Windmill Limestone (late Lochkovian), east side of Coal Canyon, central Nevada, ROM 33898, × 4.2 . 


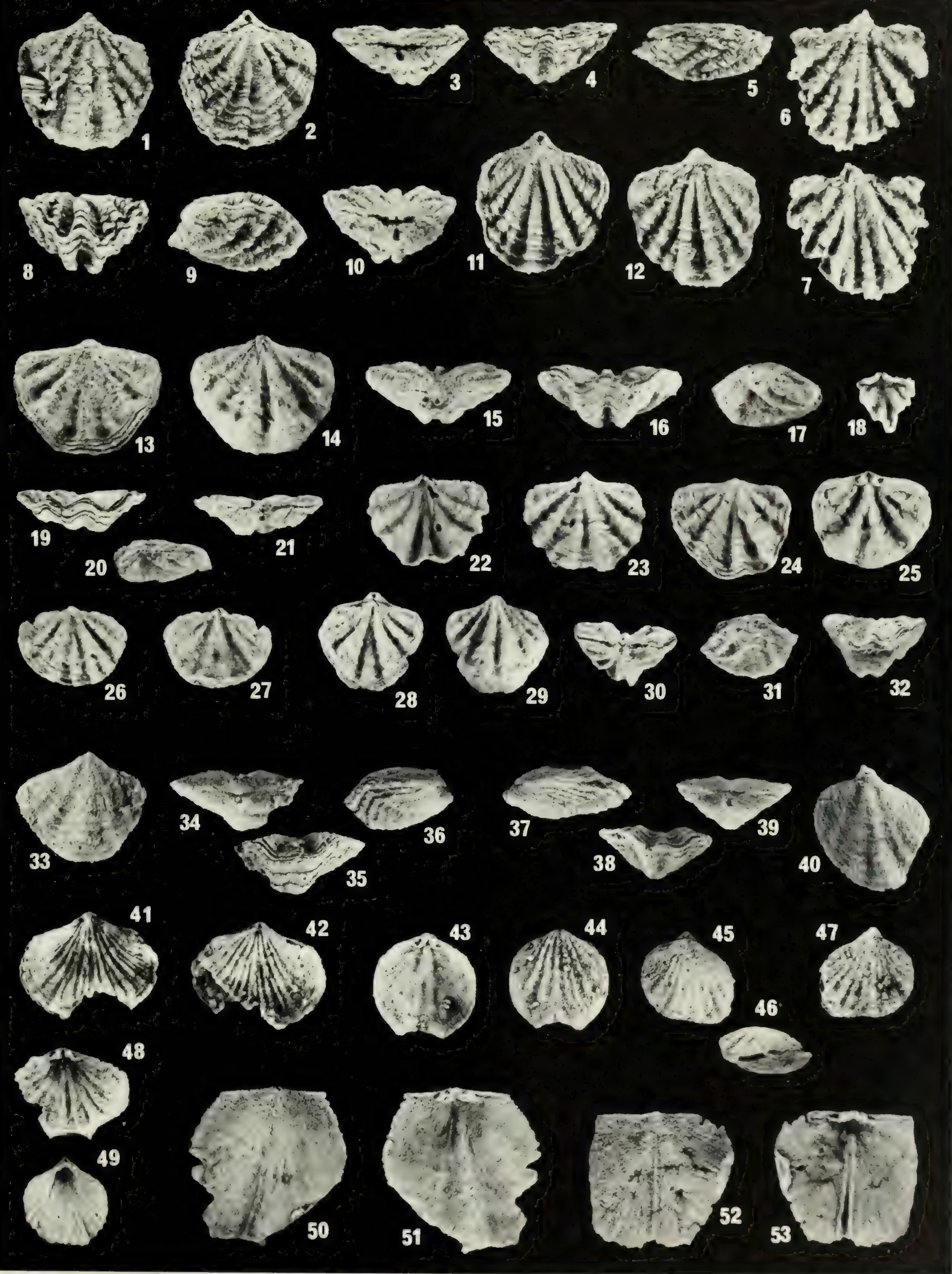


Plate 33, figs. 1-40

Articulate brachiopod Vagrania.

Figs. 1-13. Vagrania $\mathrm{cf}$. V. intermediafera (Khodalevich). Note the prominent bifurcating costae on all exterior views.

1, 2. Interior and exterior views of pedicle valve, Delorme Formation (early Pragian), S-1, sample A342.9 m, ROM 33899 ,

$\times 1.1$.

3. Interior view of pedicle valve, Delorme Formation (early Pragian), S-1, sample A342.9 m, ROM 33900, × 1.1.

4, 5. Dorsal and ventral views of articulated shell, Delorme Formation (early Pragian), S-1, sample A345.9 m, ROM 33901, $\times 1.1$.

6, 7. Dorsal and ventral views of small shell, Delorme Formation (early Pragian), S-1, sample A345.9 m, ROM 33902,

$\times 1.1$

8. Interior view of brachial valve, Delorme Formation (early Pragian), S-1, sample A385.6 m, ROM 33903, × 1.1.

9. Interior view of pedicle valve, Delorme Formation (early Pragian), S-1, sample A385.6 m, ROM 33904, × 1.1.

10. Interior view of brachial valve, Delorme Formation (early Pragian), S-1, sample A385.6 m, ROM 33905, × 1.1.

11-13. Dorsal, ventral, and lateral views of large shell; Delorme Formation (early Pragian), S-1, sample OLDA353.6 m, ROM $33906, \times 1.1$.

Figs. 14-34. Vagrania johnsoni sp. nov

14-18. Dorsal, ventral, anterior, lateral, and posterior views of articulated shell; Delorme Formation (late Pragian), S-1, sample A 178.3-181.4 m, holotype ROM 33907, $\times 1.3$.

19, 20. Exterior and interior views of pedicle valve, Delorme
Formation (late Pragian), S-1, sample A178.3-181.4 m, paratype ROM $33908, \times 1.3$.

21-23. Oblique interior view of cardinalia and exterior and interior views of brachial valve, Delorme Formation (late Pragian), S-1, sample A178.3-181.4 m, paratype ROM 33909, $\times$ 1.3 .

24-26. Oblique interior, interior, and exterior views of pedicle valve; Delorme Formation (late Pragian), S-1, sample A178.3$181.4 \mathrm{~m}$, paratype ROM $33910, \times 1.3$

$27,28,34$. Interior, exterior, and oblique interior views of brachial valve; Delorme Formation (late Pragian), S-1, sample A178.3-181.4 m, paratype ROM 33911, $\times 1.3$. Note the prominent vascular system.

29-33. Ventral, dorsal, posterior, anterior, and lateral views of articulated shell; Delorme Formation (late Pragian), S-1, sample A178.3-181.4 m, paratype ROM 33912, × 1.3.

Figs. 35-40. Vagrania sp. 1.

35, 36. Interior and exterior views of brachial valve, Ogilvie Formation (Zlichovian), S-15, sample $100.6 \mathrm{~m}$ of Perry, Klapper, and Lenz (1974), вом 33913, × 1.1.

37. Interior view of brachial valve fragment, Ogilvie Formation (Zlichovian), S-15, sample $100.6 \mathrm{~m}$ of Perry, Klapper, and Lenz (1974), ROM 33914, × 1.1.

38, 39. Exterior and interior views of pedicle valve, Ogilvie Formation (Zlichovian), S-15, sample $100.6 \mathrm{~m}$ of Perry, Klapper, and Lenz (1974), ROM 33915, × 1.1.

40. Interior view of pedicle valve, Ogilvie Formation (Zlichovian), S-15, sample $100.6 \mathrm{~m}$ of Perry, Klapper, and Lenz (1974), ROM 33916, × 1.1. 

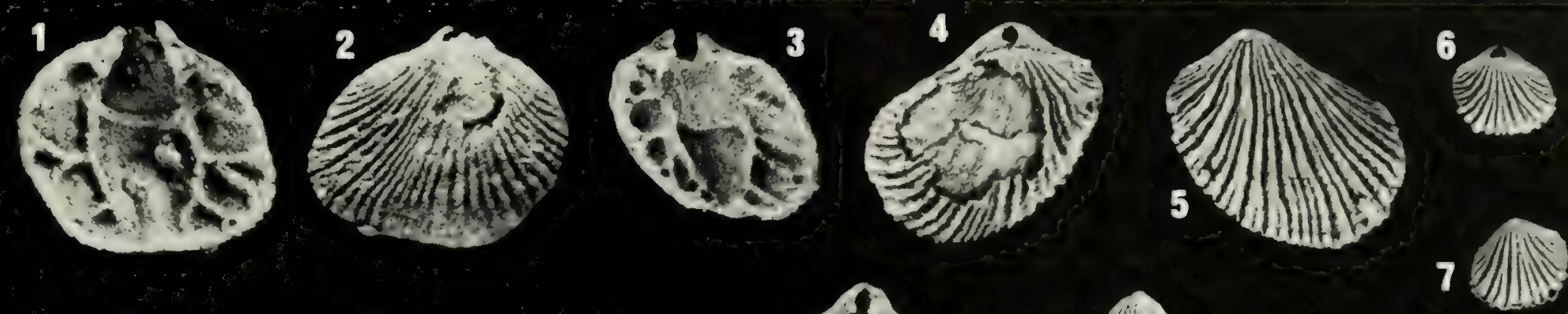

(4).
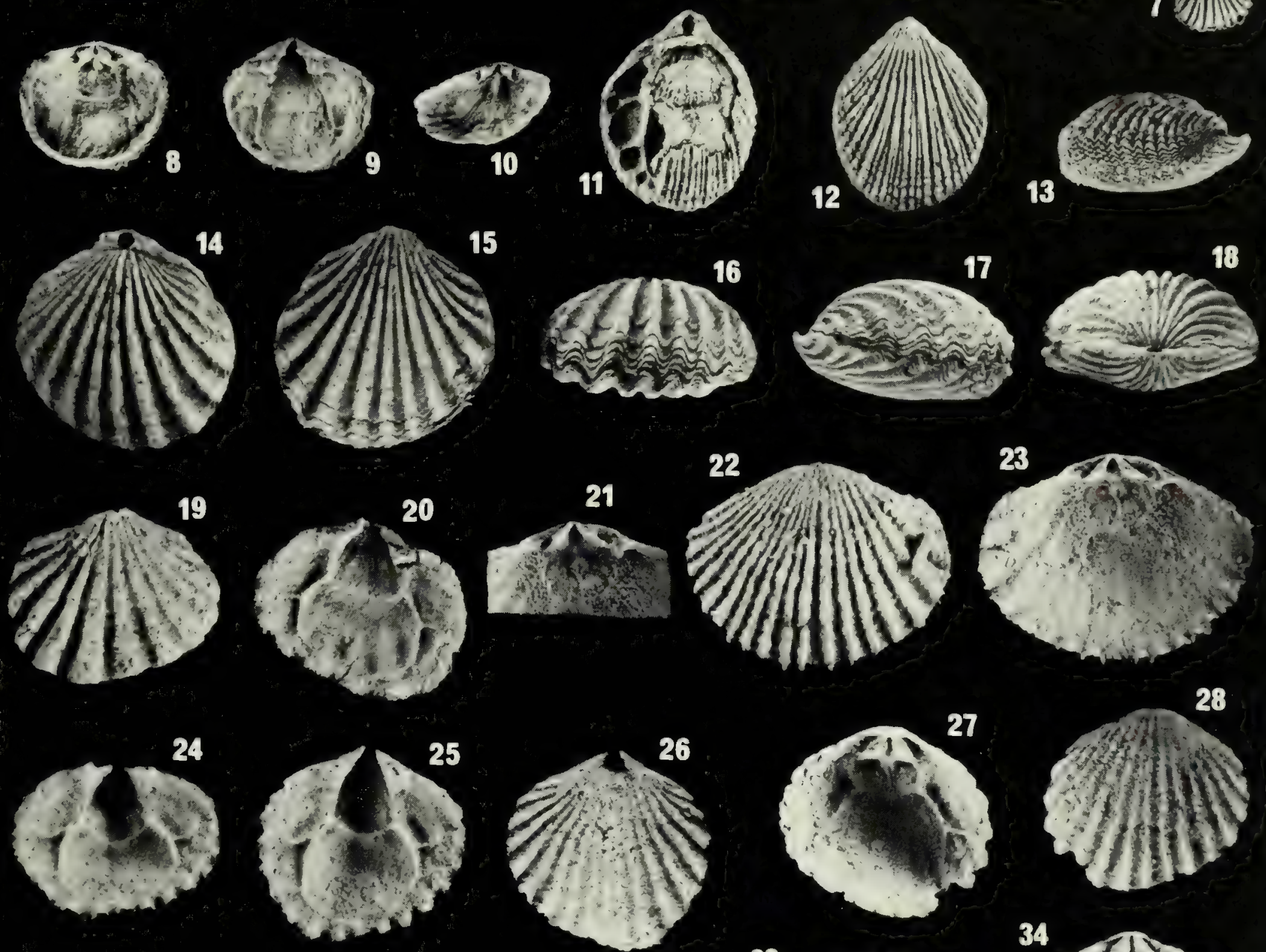

28
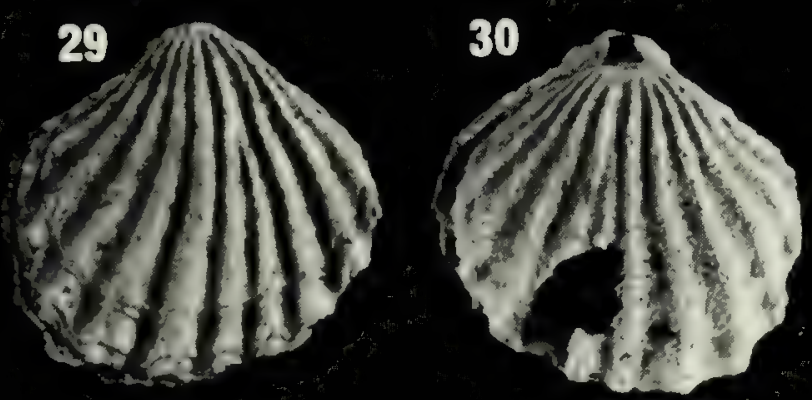

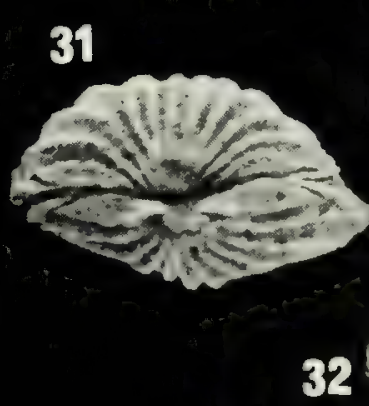

33
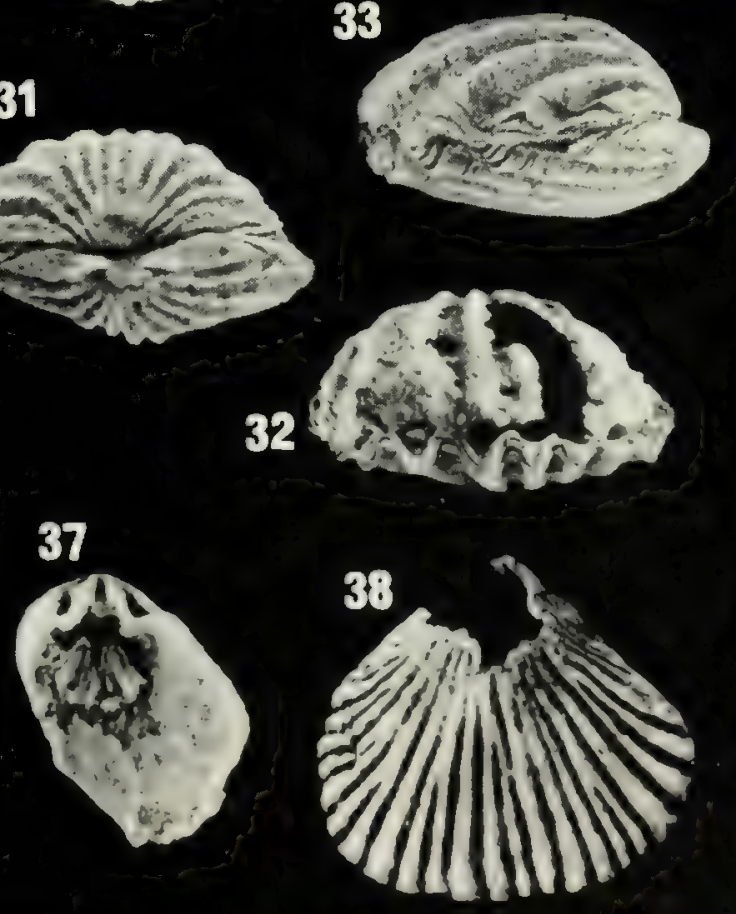
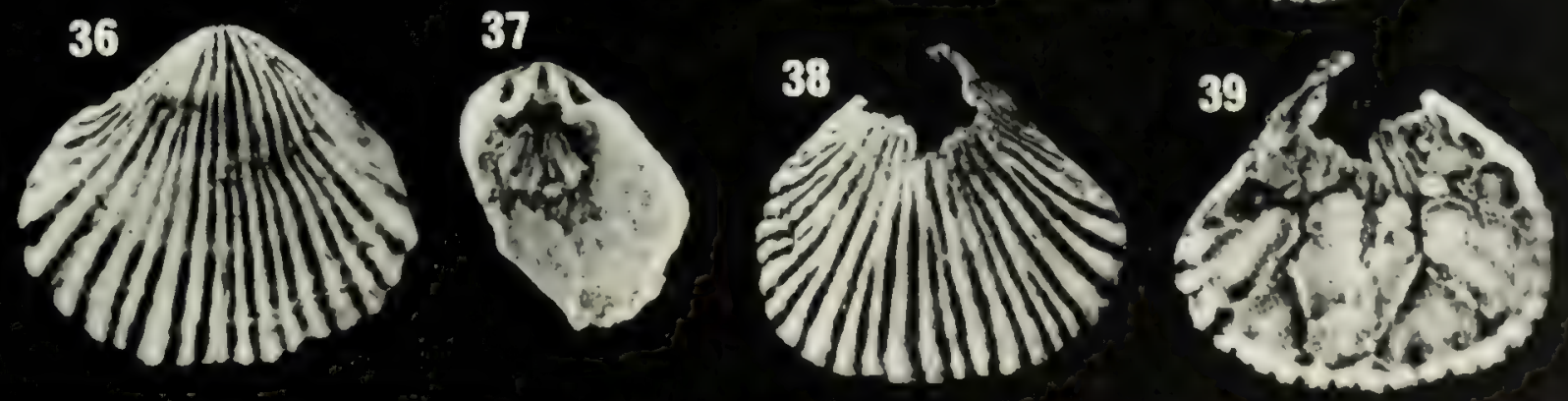
Plate 34, figs. $1-58$

Articulate brachiopods Toquimaella, Plicanoplites, Notoparmella, and indeterminate ?notanopliid.

Figs, 1-14. Toquimaella kayi Johnson.

1-3. Dorsal, ventral, and lateral views of articulated shell; Delorme Formation (late Lochkovian), S-1, sample A484.6 m, ROM 33917, × 1.8 .

4. Interior view of pedicle valve, Delorme Formation (late Lochkovian), S-1, sample A484.6 m, ROM 33918, × 1.8 .

5. Interior view of articulated shell fragment, Delorme Formation (late Lochkovian), S-1, sample A484.6 m, ROM 33919, $\times$ 1.8

6-8. Ventral, lateral, and dorsal views of articulated shell; Delorme Formation (late Lochkovian), S-1, sample A487.7 m, ROM $33920, \times 1.8$.

9. Interior view of pedicle valve, Delorme Formation (late Lochkovian), S-1, sample A487.7 m, ROM 33921, × 1.8 .

10. Interior view of brachial valve, Delorme Formation (late Lochkovian), S-1, sample A487.7 m, ROM 33922, $\times 1.8$.

11. Oblique interior view of brachial valve, Delorme Formation (late Lochkovian), S-1, sample A487.7 m, ROM 33923, × 1.8.

12-14. Interior, lateral, and dorsal views of articulated shell; Delorme Formation (late Lochkovian), S-2, sample B166.1$182.9 \mathrm{~m}$, ROM $33924, \times 1.8$.

Figs. 15-42. Plicanoplites bisulcata (Lenz).

15-17. Lateral, posterior, and ventral views of articulated shell; Delorme Formation (early Zlichovian), S-1, sample A62.5$68.6 \mathrm{~m}$, ROM $33925, \times 5.2$

18. Interior view of articulated shell fragment, Delorme Formation (early Zlichovian), S-1, sample A62.5-68.6 m, ROM $33926, \times 5.2$.

19-21. Dorsal, posterior, and anterior views of articulated shell; Delorme Formation (early Zlichovian), S-1, sample A62.5$68.6 \mathrm{~m}$, ROM $33927, \times 5.2$

22. Interior view of small pedicle valve, Delorme Formation (late Pragian), S-1, sample A62.5-68.6 m, ROM 33928, $\times$ 5.2.

23-25. Ventral, anterior, and lateral views of articulated shell; Delorme Formation (late Pragian), S-1, sample A62.5-68.6 m, ROM $33929, \times 5.2$.

26. Interior view of small pedicle valve, Delorme Formation (late Pragian), S-1, sample A62.5-68.6 m, ROM 33930, × 5.2.

27. Interior view of pedicle valve, Delorme Formation (late Pragian), S-3, sample S4-143.3 m, ROM 33931, × 5.2.
28. Interior view of brachial valve fragment, Delorme Formation (late Pragian), S-3, sample S4-143.3 m, ROM 33932, × 5.2.

29,30 . Oblique interior and interior views of pedicle valve, Delorme Formation (late Pragian), S-3, sample S4-143.3 m, ROM 33933, × 5.2 .

31,32 . Interior and oblique interior views of pedicle valve, Delorme Formation (late Pragian), S-3, sample S4-143.3 m, ROM 33934, × 5.2.

33. Oblique interior view of pedicle valve, Delorme Formation (late Pragian), S-3, sample S4-143.3 m, ROM 33935, $\times 5.2$.

34-36. Ventral, lateral, and posterior views of articulated shell; Delorme Formation (late Pragian), S-3, sample S4-143.3 m, ROM 33936, $\times 5.2$.

37. Exterior view of pedicle valve, Delorme Formation (late Pragian), S-3, sample S4-143.3 m, ROM 33937, $\times$ 5.2.

38. Interior view of brachial valve, Delorme Formation (late Pragian), S-3, sample S4-143.3 m, ROM 33938, $\times$ 5.2.

39-42. Ventral, anterior, lateral, and posterior views of articulated shell; Delorme Formation (late Pragian), S-3, sample S4-143.3 m, ROM 33939, $\times 5.2$.

Figs. 43-50. Notoparmella fila sp. nov.

43, 44. Interior and exterior views of brachial valve, Delorme Formation (late Lochkovian-early Pragian), S-3, sample S4$685.8 \mathrm{~m}$, paratype ROM $33940, \times 4.2$.

45, 46. Dorsal and ventral views of articulated shell, Delorme Formation (late Lochkovian-early Pragian), S-3, sample S4 $685.8 \mathrm{~m}$, paratype ROM $33941, \times 4.2$.

47, 48. Exterior and interior views of pedicle valve, Delorme Formation (late Lochkovian-early Pragian), S-3, sample S4$685.8 \mathrm{~m}$, holotype ROM $33942, \times 4.2$.

49,50 . Interior and exterior views of pedicle valve, Delorme Formation (late Lochkovian-early Pragian), S-3, sample S4$685.8 \mathrm{~m}$, paratype ROM $33943, \times 4.2$

Figs. 51-58. Indeterminate ?notanopliid sp.

51-53. Dorsal, ventral, and anterior views of articulated shell; Delorme Formation (Ludlovian), S-10, sample S1C, ROM 33944 , $\times 7.0$.

54, 55. Posterior and dorsal views of articulated shell, Delorme Formation (Ludlovian), S-10, sample S1C, ROM 33945, × 7.0.

56-58. Ventral, lateral, and posterior views of articulated shell; Delorme Formation (Ludlovian), S-10, sample S1C, ROM 33946 , $\times 7.0$. 

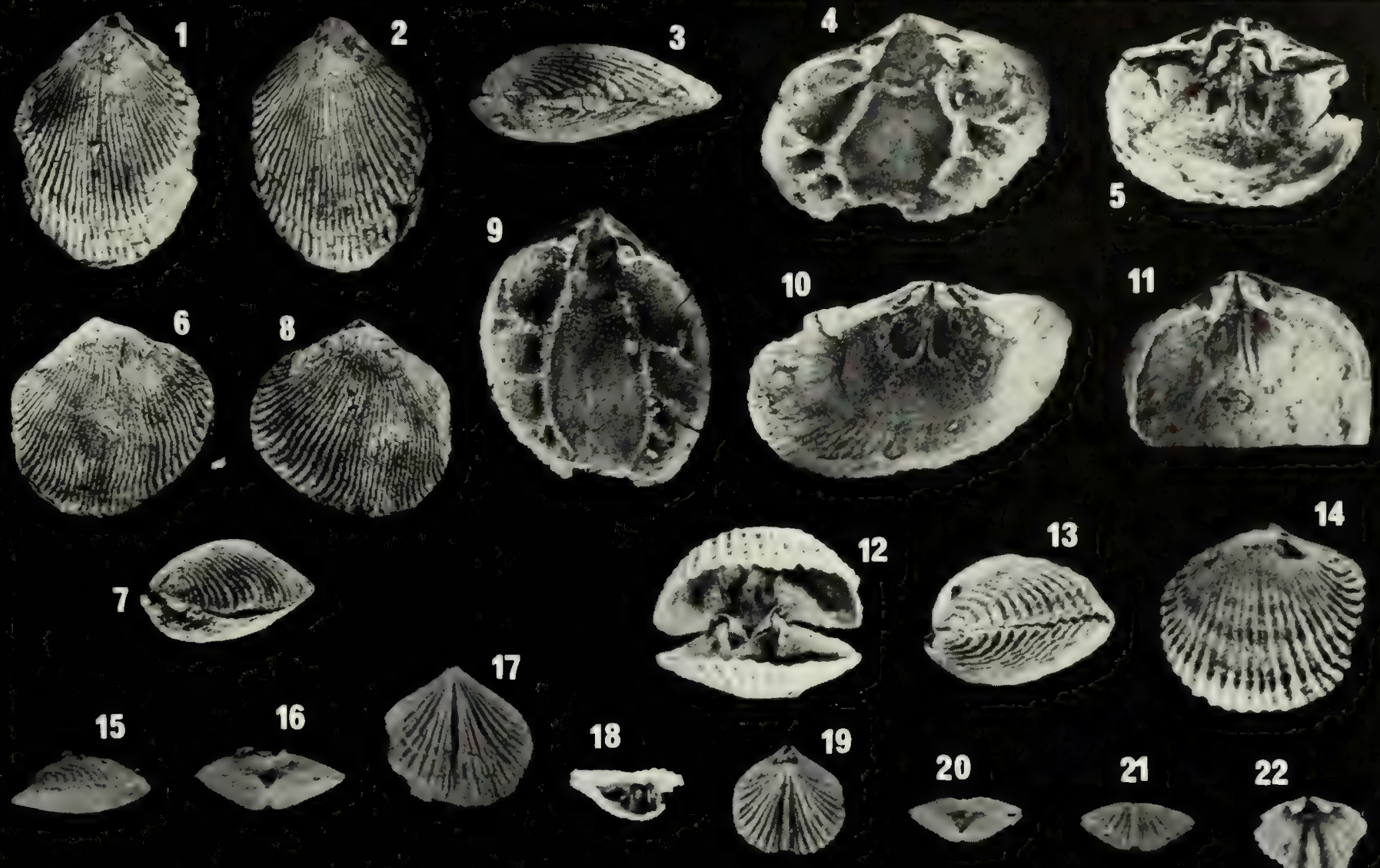

22

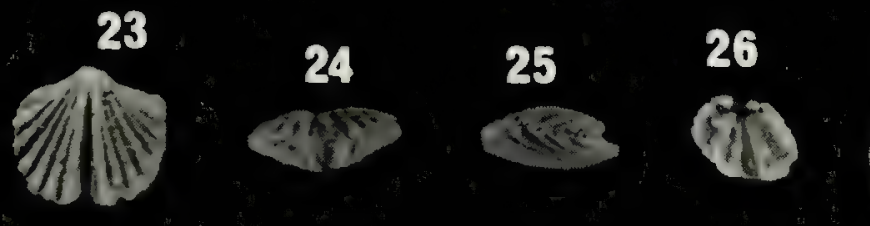

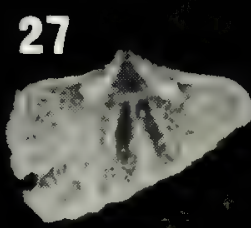

28

29

30

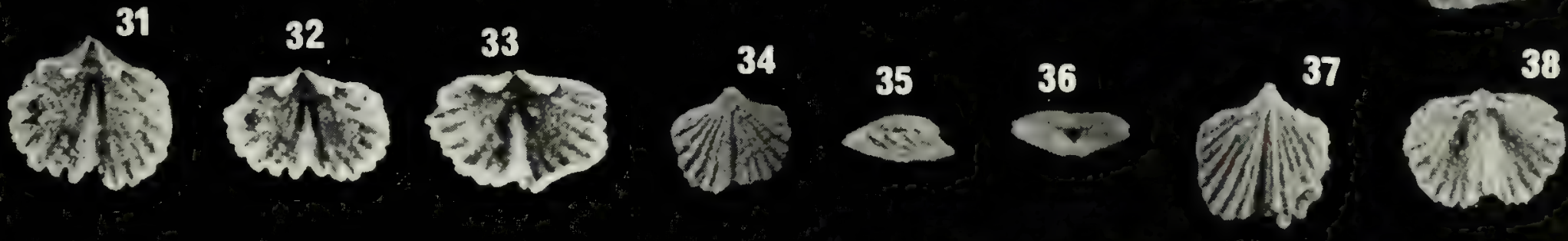
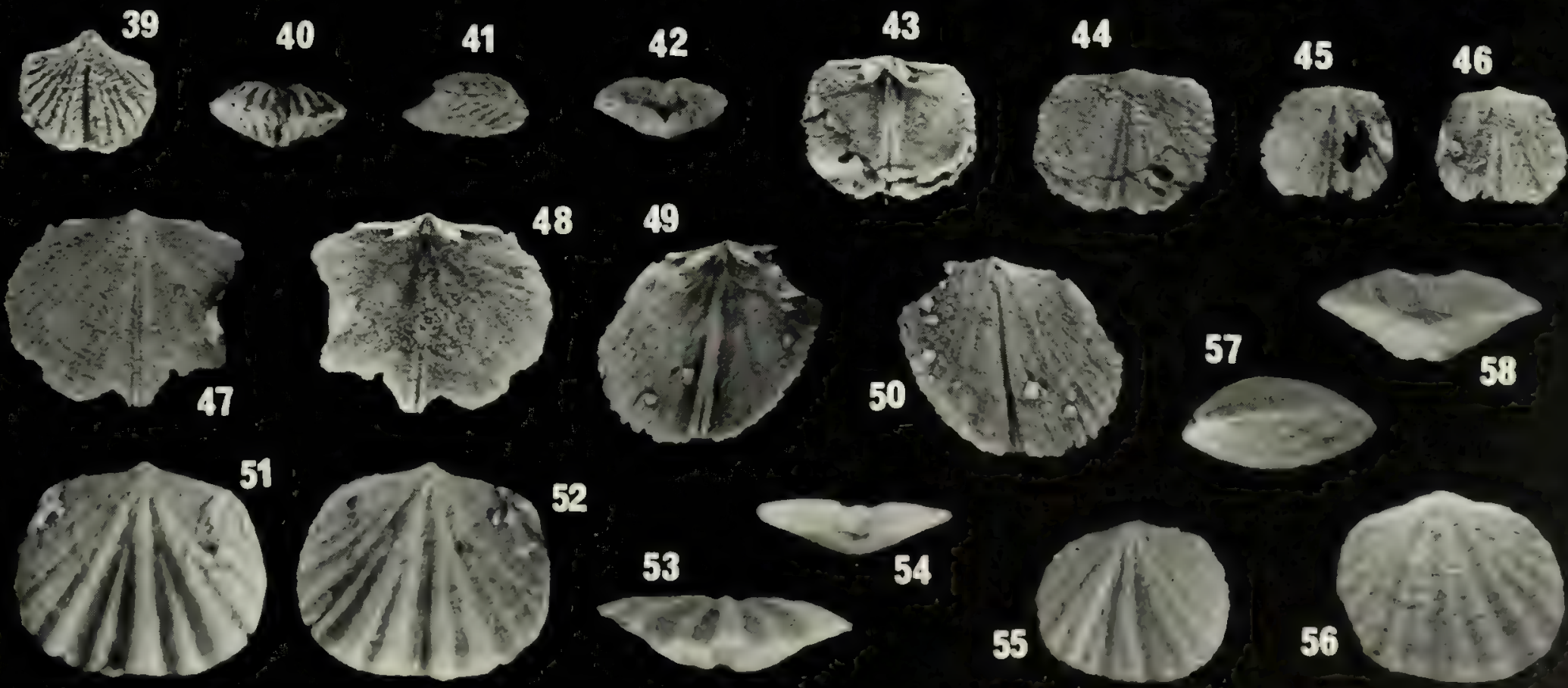
Plate 35, figs. 1-52

Articulate brachiopods Gracianella and Carinatina.

Figs. 1-4. Gracianella plicumbra Johnson and Boucot?. Dorsal, ventral, lateral, and posterior views of phosphatised internal mould; Delorme Formation, S-10, $121.9 \mathrm{~m}$ above the base of the Delorme, ROM 33947, $\times 5.2$. Note the peculiar "dimpled" surface texture.

Figs. 5-12. Gracianella lissumbra lissumbra Johnson, Boucot, and Murphy.

5, 9. Interior and oblique interior views of brachial valve, Delorme Formation (Ludlovian), S-9, sample L166.1-173.7 m, ROM $33948, \times 7.8$.

6, 7. Oblique interior and interior views of pedicle valve, Delorme Formation (Ludlovian), S-9, sample L166.1-173.7 m, ROM $33949, \times 7.8$.

8. Interior view of small brachial valve, Delorme Formation (Ludlovian), S-9, sample L166.1-173.7 m, ROM 33950, × 7.8.

10. Exterior view of pedicle valve, Delorme Formation (Ludlovian), S-9, sample L166.1-173.7 m, ROM 33503, × 7.8.

11, 12. Interior and oblique interior views of pedicle valve, Delorme Formation (Ludlovian), S-9, sample L166.1-173.7 m, ROM $33951, \times 7.8$.

Figs. 13-49. Gracianella plicumbra Johnson and Boucot.

13-15. Exterior, interior, and oblique interior views of pedicle valve; transitional facies (Ludlovian), S-11, 185.9-193.5 m above the top of the Whittaker Formation, GSC locality 69062, ROM $33592, \times 5.2$.

16-20. Ventral, dorsal, lateral, anterior, and posterior views of articulated shell; transitional facies (Ludlovian), S-11, 185.9$193.5 \mathrm{~m}$ above the top of the Whittaker Formation, GSC locality 69062, ROM 33593, × 5.2.
21-25. Dorsal, ventral, anterior, lateral, and posterior views of articulated shell; transitional facies (Ludlovian), S-11, 185.9$193.5 \mathrm{~m}$ above the top of the Whittaker Formation, GSC locality 69062 , Rом $33594, \times 5.2$.

26, 27. Exterior and interior views of brachial valve, Delorme Formation (Ludlovian), S-9, sample L166.1-173.7 m, ROM $33955, \times 5.2$.

28-30. Interior, oblique posterior, and oblique interior views of brachial valve; Delorme Formation (Ludlovian), S-9, sample L166.1-173.7 m, ROM 33956, × 5.2.

31-35. Ventral, dorsal, lateral, posterior, and anterior views of articulated shell; Delorme Formation (Ludlovian), S-6, sample C47-237.7 m, ROM 33957, × 5.2

36-38. Interior, exterior, and oblique interior views of brachial valve; Delorme Formation (Ludlovian), S-9, sample L161.2 m, ROM 33958, × 5.2.

39-42. Posterior, lateral, dorsal, and ventral views of articulated shell; Delorme Formation (Ludlovian), S-6, sample C47$237.7 \mathrm{~m}$, ROM $33959, \times 5.2$.

43, 44. Oblique interior and interior views of pedicle valve, Delorme Formation (Ludlovian), S-6, sample C47-248.4 m, ROM $33960, \times 5.2$.

45-49. Lateral, anterior, posterior, dorsal, and ventral views of articulated shell; Delorme Formation (Ludlovian), S-6, sample C47-248.4 m, ROM 33961, × 5.2.

Figs. 50-52. Carinatina sp. Exterior, oblique interior, and interior views of pedicle valve; Delorme Formation (Zlichovian), S-3, sample S4-64.0-65.5 m, ROM 33962 , × 1.5 . 


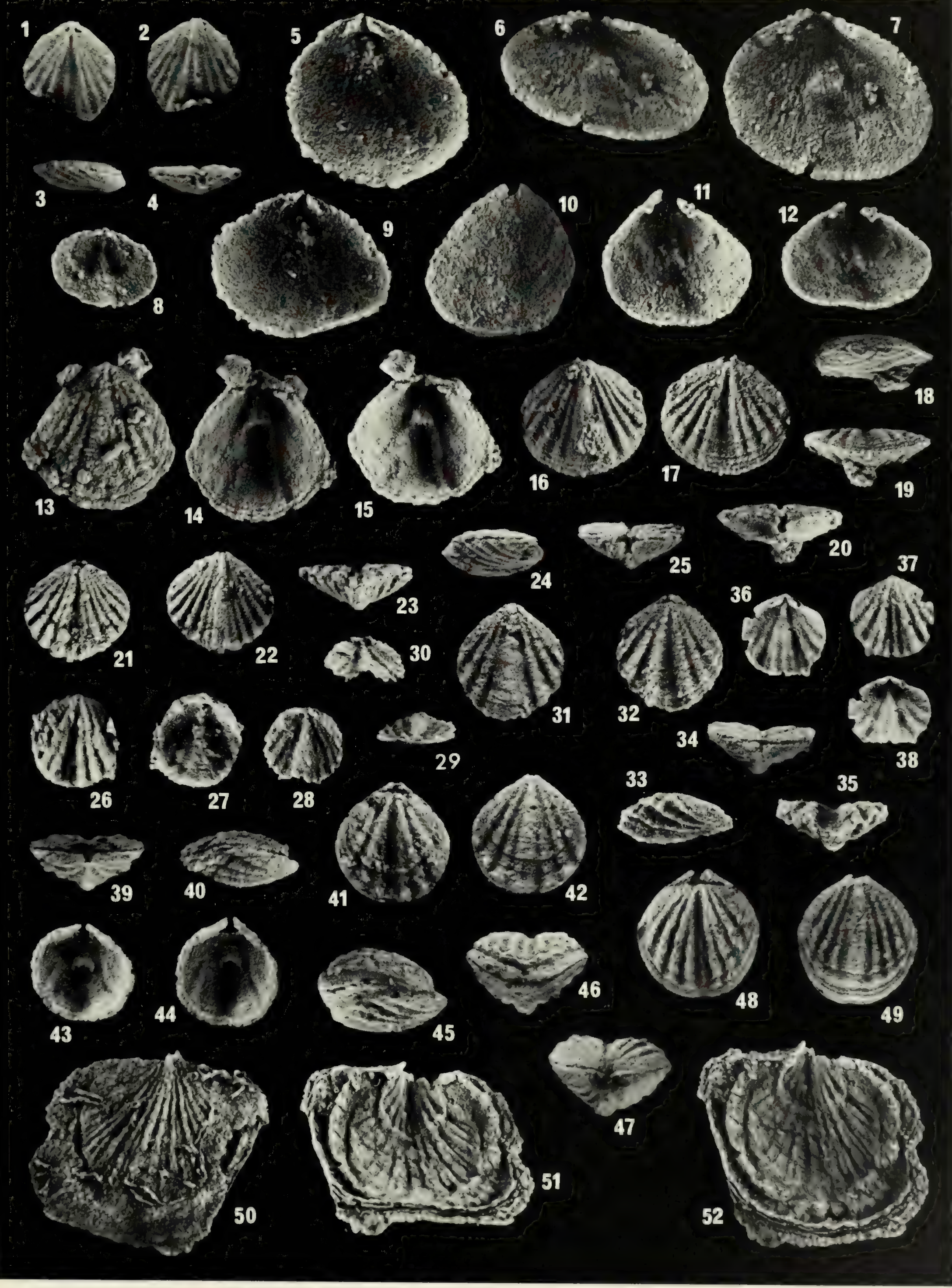


Plate 36, figs. 1-64

Articulate brachiopod genera Gracianella, Davidsoniatrypa, and Biconostrophia.

Figs. 1-25. Gracianella cryptumbra Johnson, Boucot, and Murphy.

1-3. Exterior, interior, and oblique interior views of pedicle valve; Delorme Formation (Pridolian), S-2, sample B373.4 m, ROM 33963, × 5.2 .

4. Exterior view of pedicle valve, Delorme Formation (Pridolian), S-2, sample B373.4 m, ROM 33964, × 5.2 .

5-7. Exterior, interior, and oblique interior views of pedicle valve; Delorme Formation (Pridolian), S-2, sample B373.4 m, ROM 33965, × 5.2 .

8-10. Oblique interior, interior, and exterior views of pedicle valve; Delorme Formation (Pridolian), S-2, sample B373.4 m, ROM $33966, \times 5.2$.

11-13. Interior, exterior, and oblique posterior views of brachial valve; Delorme Formation (Pridolian), S-2, sample B373.4 m, ROM $33967, \times 5.2$.

14, 15. Exterior and interior views of brachial valve, Delorme Formation (Pridolian), S-2, sample B373.4 m, ROM 33968, × 5.2 .

16-20. Dorsal, ventral, posterior, anterior, and lateral views of articulated shell; Delorme Formation (Pridolian), S-2, sample B373.4 m, ROM 33969, × 5.2 .

21. Interior view of brachial valve, Delorme Formation (Pridolian), S-2, sample B373.4 m, ROM 33970, $\times 5.2$.

22-25. Ventral, dorsal, anterior, and lateral views; Delorme Formation (Pridolian), S-2, sample B373.4 m, ROM 33971, $\times$ 5.2 .

\section{Figs. 26-61. Davidsoniatrypa johnsoni Lenz.}

26, 27. Interior and exterior views of brachial valve, Delorme Formation (early Pragian), S-1, sample A385.6 m, ROM 33972, $\times 1.6$

28-32. Dorsal, ventral, lateral, anterior, and posterior views of small shell; Delorme Formation (early Pragian), S-1, sample A385.6 m, ROM 33973, $\times 1.6$.

33-35. Interior, oblique lateral, and exterior views of pedicle valve; Delorme Formation (early Pragian), S-1, sample A385.6 m, ROM $33974, \times 1.6$.

36,37 . Exterior and interior views of brachial valve, Delorme Formation (early Pragian), S-1, sample A385.6 m, ROM 33975, $\times 1.6$.

38, 39. Exterior and oblique interior views of pedicle valve, Delorme Formation (early Pragian), S-1, sample A385.6 m, ROM 33976, × 1.6 .

40-44. Dorsal, lateral, ventral, posterior, and anterior views of articulated shell; Delorme Formation (early Pragian), S-1, sample A385.6 m, ROM 33977, × 1.6 .

45,46 . Interior and exterior views of brachial valve, Delorme Formation (early Pragian), S-1, sample OLDA336.8 m, ROM $33978, \times 1.6$.

47-49. Dorsal, ventral, and anterior views of partially open shell; Delorme Formation (early Pragian), S-1, sample OLDA336. $8 \mathrm{~m}$, ROM $33979, \times 1.1$.

50, 51. Lateral and dorsal views of articulated shell, Delorme Formation (early Pragian), S-1, sample OLDA336.8 m, ROM $33980, \times 1.1$.

52-54. Oblique posterior, exxterior, and interior views of brachial valve; Delorme Formation (early Pragian), S-1, sample OLDA336.8 m, ROM 33981, × 1.6 .

55, 56. Exterior and interior views of small brachial valve, Delorme Formation (early Pragian), S-1, sample OLDA336. $8 \mathrm{~m}$, ROM 33982, × 1.6 .

57-59. Interior, exterior, and oblique interior views of brachial valve; Delorme Formation (early Pragian), S-1, sample OLDA370.3 m, ROM 33983, × 1.6. Note the "dimpled" callus anterior to the muscle field in fig. 57.

60,61 . Ventral and anterior views of large, sheared shell, Delorme Formation (early Pragian), S-1, sample OLDA370.3 m, ROM 33984, × 1.6 .

62-64. Biconostrophia cf. B. knorrensis Perry. Interior, exterior, and oblique interior views of pedicle valve; Delorme Formation (Zlichovian), S-3, sample S4$36.6 \mathrm{~m}$, ROM $33985, \times 1.8$. 
40.0 .4 .9600

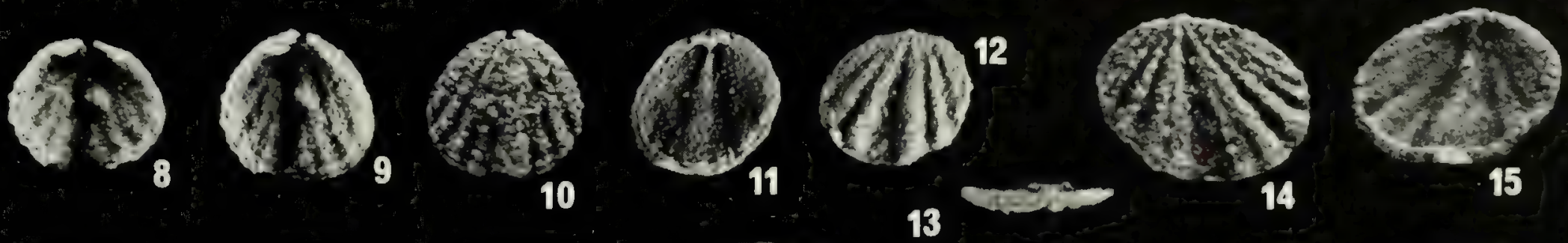
4.

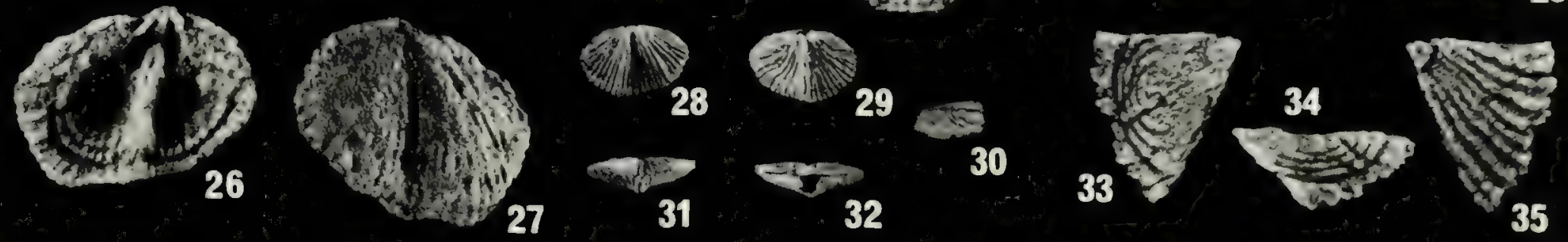
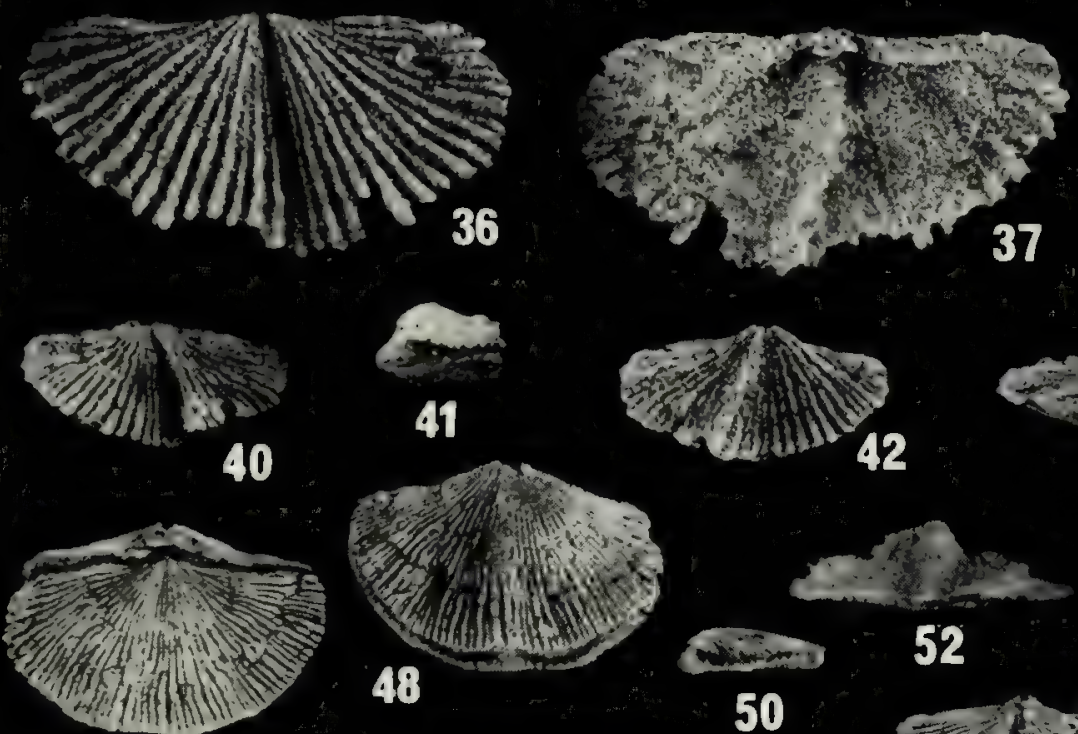

47
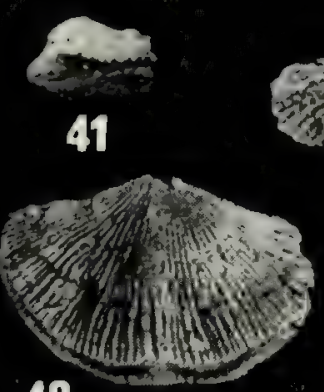

48

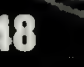

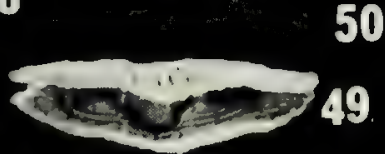

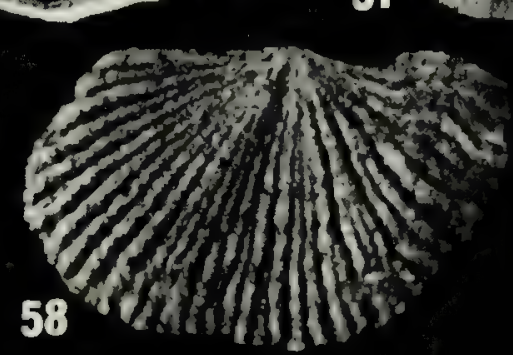

$57,+20$
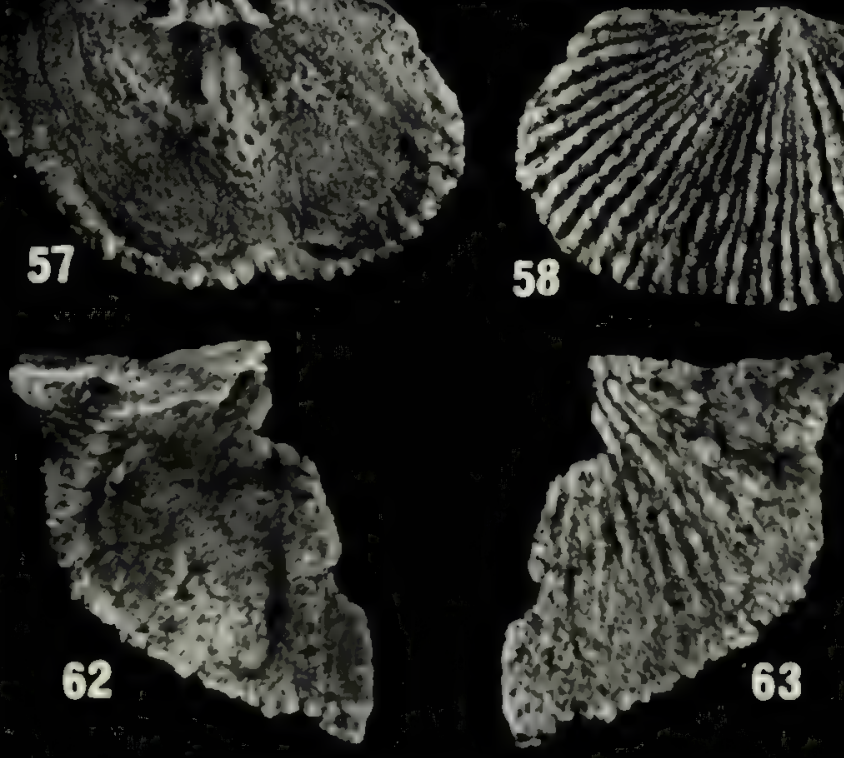

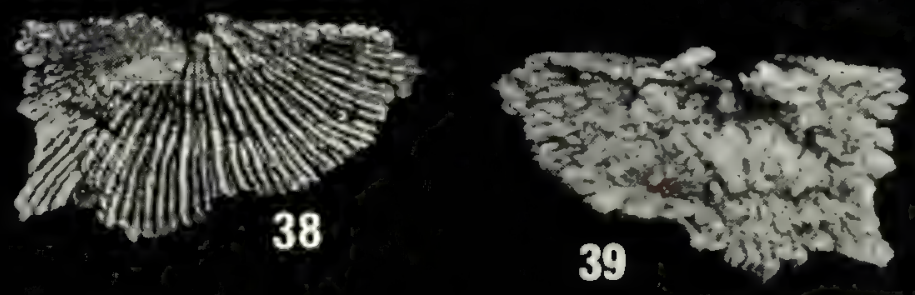

Frip 72

44

43

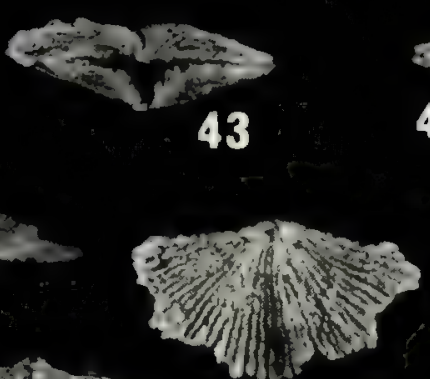

53
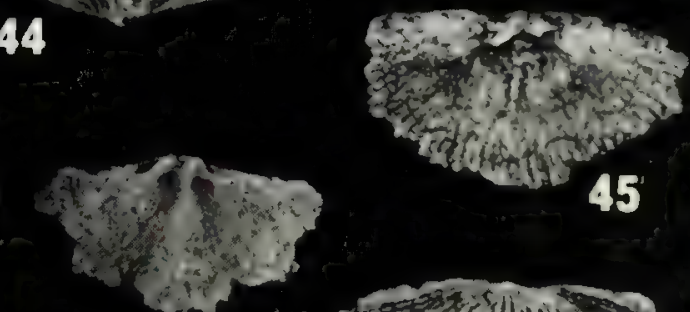

45

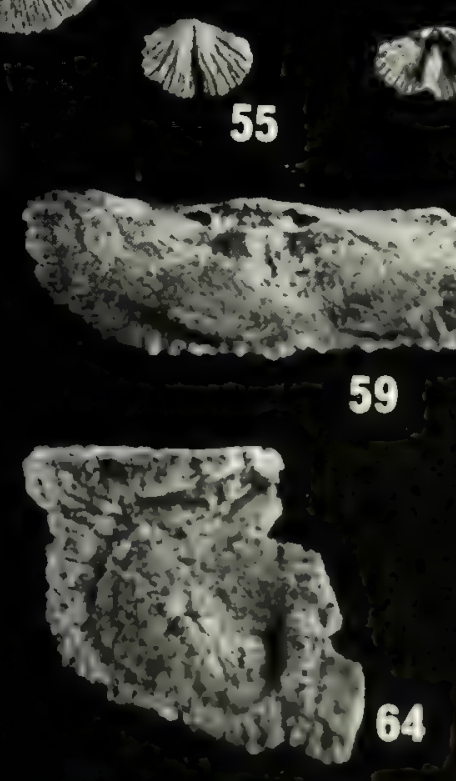

56

46

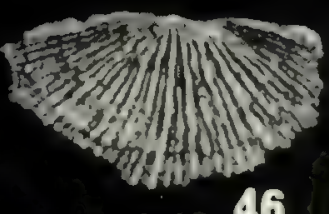


Plate 37 , figs, $1-52$

Articulate brachiopods Biconostrophia, Atrypoidea, and Meristella.

Figs. 1-16. Biconostrophia cf. B. knorrensis Perry.

1-5. Ventral, dorsal, posterior, anterior, and lateral views of articulated shell; Delorme Formation (Zlichovian), S-3, sample S4-449.6 m, ROM 33986, × 6.0.

6, 7. Exterior and oblique interior views of pedicle valve, Delorme Formation (Zlichovian), S-3, sample S4-449.6 m, ROM $33987, \times 6.0$.

8-10. Exterior, interior, and oblique interior views of pedicle valve; Delorme Formation (Zlichovian), S-3, sample S4$449.6 \mathrm{~m}$, ROM 33988, $\times 2.8$.

11, 12. Interior and exterior views of brachial valve, Delorme Formation (Zlichovian), sample S4-449.6 m, ROM 33989, $\times$ 2.8.

13, 14. Oblique interior and exterior views of pedicle valve, Delorme Formation (Zlichovian), sample S4-449.6 m, ROM $33990, \times 2.8$.

15, 16. Exterior and interior views of brachial valve, Delorme Formation (Zlichovian), sample S4-449.6 m, ROM 33991, $\times$ 2.8 .

\section{Figs. 17-21. Atrypoidea sp.}

17. Interior view of brachial valve, transitional facies (Ludlovian), S-11, at 185.9-193.5 $\mathrm{m}$ above the top of the Whittaker Formation, GSC locality 69062, ROM 33992, × 1.7.

18, 19. Dorsal and anterior views of articulated shell, transitional facies (Ludlovian), S-11, 185.9-193.5 $\mathrm{m}$ above the top of the Whittaker Formation, GSC locality 69062, ROM 33993, $\times$ 1.7 .

20. Interior view of pedicle valve, transitional facies (Ludlovian), S-11, 185.9-193.5 $\mathrm{m}$ above the top of the Whittaker Formation, GSC locality 69062, ROM 33994, $\times 1.7$.

21. Interior view of brachial valve, transitional facies (Ludlovian), S-11, 185.9-193.5 $\mathrm{m}$ above the top of the Whittaker Formation, GSC locality 69062, ROM 33995, × 1.7.
Figs. 22-41. Atrypoidea planata sp. nov.

22-24. Dorsal, ventral, and lateral views of articulated shell; Delorme Formation (Ludlovian), S-6, sample C47-248.4 m, holotype ROM 33997, × 1.7 .

25-28. Ventral, dorsal, lateral, and anterior views of articulated shell; Delorme Formation (Ludlovian), S-6, sample C47$248.4 \mathrm{~m}$, paratype ROM $33998, \times 1.7$.

29-32. Dorsal, ventral, lateral, and anterior views of articulated shell; Delorme Formation (Ludlovian), S-6, sample C47$248.4 \mathrm{~m}$, paratype ROM $33999, \times 1.7$.

33,34 . Exterior and oblique interior views of pedicle valve, Delorme Formation (Ludlovian), S-6, sample C47-248.4 m, paratype ROM $34000, \times 1.7$.

35. Interior view of pedicle valve fragment, Delorme Formation (Ludlovian), S-6, sample C47-248.4 m, paratype ROM 34001, $\times$ 1.7 .

36. Oblique interior view of brachial valve, Delorme Formation (Ludlovian), S-6, sample C47-248.4 m, paratype ROM 34002, $x$ 1.7 .

37. Interior view of brachial valve, Delorme Formation (Ludlovian), S-6, sample C47-248.4 m, paratype ROM 34003, × 1.7.

38-41. Lateral, dorsal, ventral, and anterior views of articulated shell; Delorme Formation (Ludlovian), S-6, sample C47$248.4 \mathrm{~m}$, paratype ROM $34004, \times 2.3$.

Figs. 42-52. Meristella $\mathrm{cf}$. $M$. robertsensis Merriam.

42-46. Anterior, dorsal, posterior, lateral, and ventral views of articulated shell; Delorme Formation (early Pragian), S-1, sample A330.7 m, ROM 34005, × 1.1 .

47. Interior view of brachial valve, Delorme Formation (early Pragian), S-1, sample A330.7 m, ROM 34006, × 1.1.

48. Interior view of brachial valve, Delorme Formation (early Pragian), S-2, sample B32.0 m, ROM 34007, × 1.1 .

49. Interior view of pedicle valve, Delorme Formation (early Pragian), S-2, sample B32.0 m, ROM 34008, $\times 1.1$.

50-52. Ventral, lateral, and dorsal views of articulated shell; Delorme Formation (late Lochkovian), S-1, sample A470.9 m, ROM $34009, \times 2.0$. 


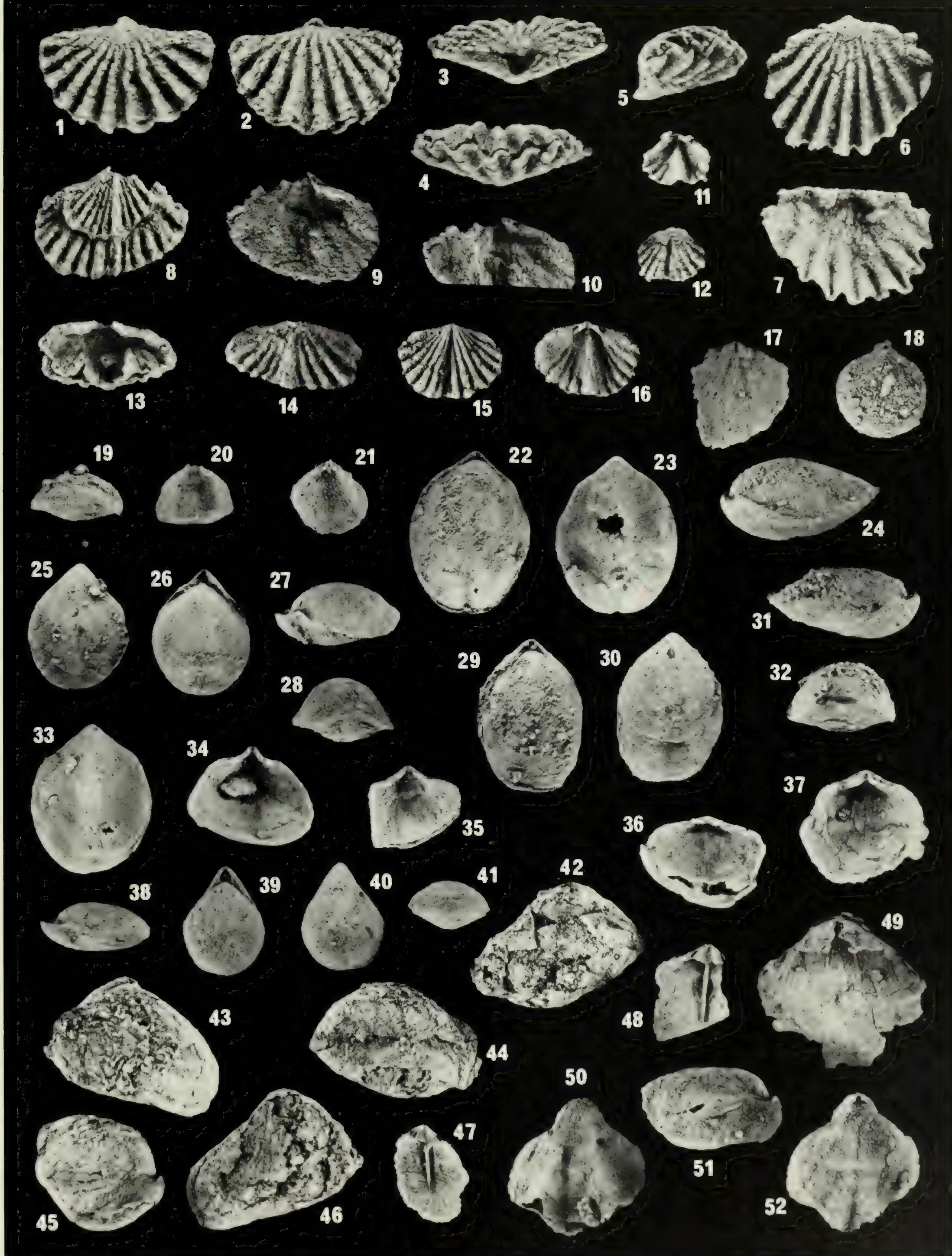


Plate 38 , figs. $1-44$

Articulate brachiopods Didymothyris, Collarothyris, Howellella, and ?Spinella.

Figs. 1-13. Didymothyris sp. 1.

1-3. Posterior, interior, and oblique interior views of articulated shell fragment; Delorme Formation (Ludlovian), S-6, sample C47-248.4 m, ROM 34010, × 2.4.

4. Interior view of articulated shell fragment, Delorme Formation (Ludlovian), S-6, sample C47-248.4 m, ROM 34011, × 2.4.

5 , 6. Lateral and ventral views of articulated shell, Delorme Formation (Ludlovian), S-6, sample C47-248.4 m, ROM 34012, $\times 2.4$.

7. Interior view of brachial valve, Delorme Formation (Ludlovian), S-6, sample C47-248.4 m, ROM 34013, × 2.4.

8. Interior view of pedicle valve, Delorme Formation (Ludlovian), S-6, sample C47-248.4 m, ROM $34014, \times 2.4$. Note the spondylium-like structure at the apex.

9. Interior view of small brachial valve fragment, Delorme Formation (Ludlovian), S-6, sample C47-248.4 m, ROM 34015 , $\times 2.4$.

10. Interior view of brachial valve fragment, Delorme Formation (Ludlovian), S-6, sample C47-248.4 m, ROM 34016, × 2.4.

11-13. Lateral, anterior, and dorsal views of articulated shell; Delorme Formation (Ludlovian), S-6, sample C47-248.4 m, ROM $34017, \times 2.4$.

Figs. 14-30. Collarothyris cf. C. canaliculata (Wenjukow). 14-18. Dorsal, posterior, ventral, lateral, and anterior views of articulated shell; Delorme Formation (Ludlovian), S-10, sample S1-15.2 m, ROM $34018, \times 4.8$.
19, 20. Anterior and lateral views of small shell, Delorme Formation (Ludlovian), S-10, sample S1-15.2 m, ROM 34019, $\times$ 4.8 .

21, 22. Lateral and anterior views of articulated shell, Delorme Formation (Ludlovian), S-10, sample S1-15.2 m, ROM 34020, $\times$ 4.8 .

23-25. Dorsal, anterior, and lateral views of small shell; Delorme Formation (Ludlovian), S-5, sample C838.2 m, ROM $34021, \times 3.1$.

26-30. Ventral, dorsal, lateral, posterior, and anterior views of articulated shell; Delorme Formation (Ludlovian), S-5, sample C838.2 m, ROM 34022, × 3.1.

Figs. 31-40. Howellella cf. H. khalfini Kulkov.

31-35. Exterior, oblique interior, interior, posterior, and lateral views of pedicle valve; Delorme Formation (Zlichovian), S-3, sample S4-176.8 m, ROM 34026, × 2.1.

36,37 . Interior and exterior views of pedicle valve, Delorme Formation (Zlichovian), S-3, sample S4-176.8 m, ROM 34027 , $\times 2.1$.

38, 39. Exterior and interior views of brachial valve, Delorme Formation (Zlichovian), S-3, sample S4-176.8 m, ROM 34028, $\times 2.1$.

40. Interior view of brachial valve, Delorme Formation (Zlichovian), S-3, sample S4-161.5-164.6 m, ROM 34029, × 3.1.

Figs. 41-44. ?Spinella sp. Oblique interior, oblique posterior, posterior, and exterior views of brachial valve fragment; Delorme Formation (early Pragian), S-2, sample B105.2 m, ROM $34030, \times 2.0$. 


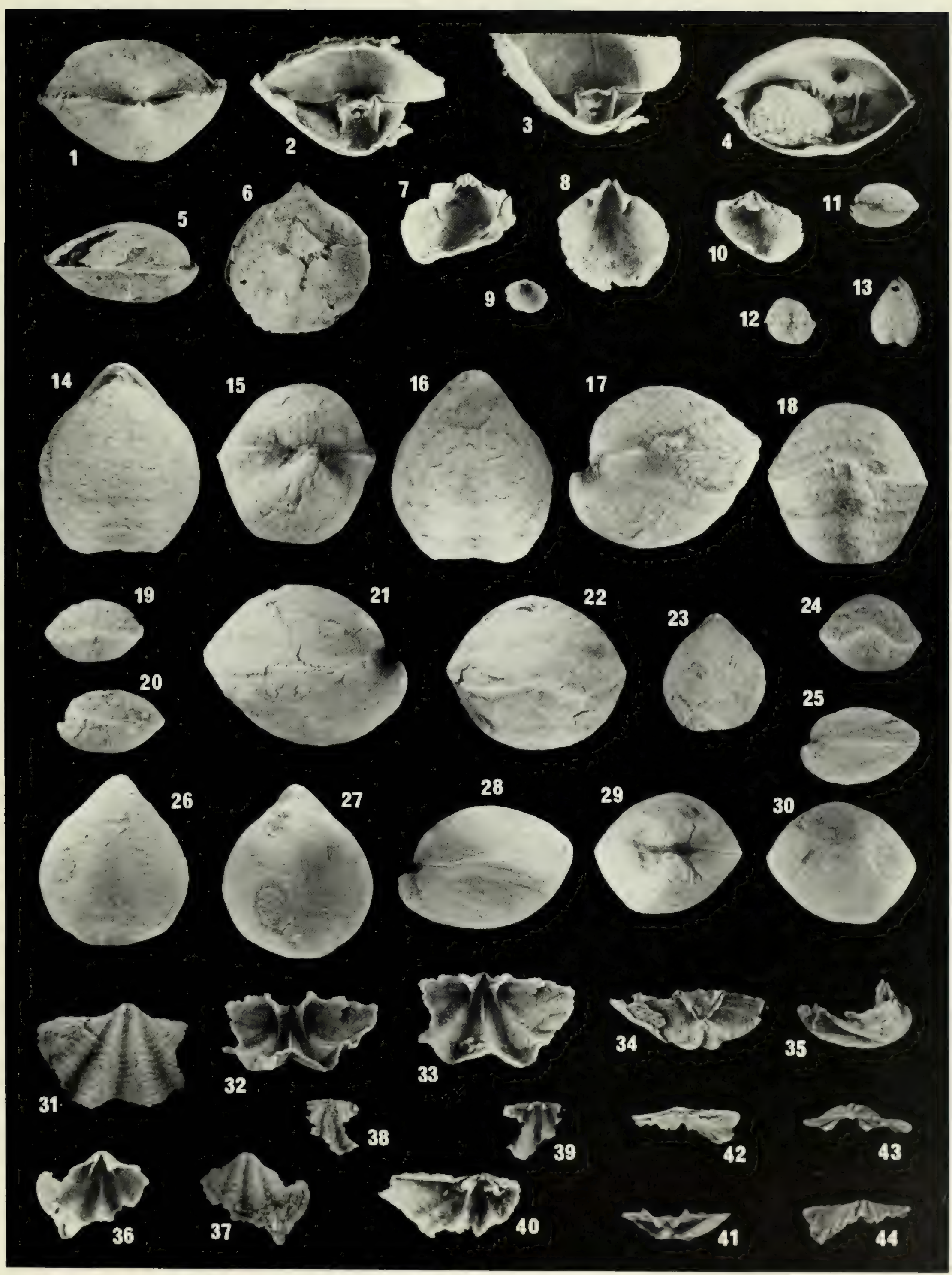


Plate 39, figs. 1-47

Articulate brachiopods Nucleospira, Cryptatrypa, and Holynatrypa.

Figs. 1-29. Nucleospira cf. N. laevigata Lenz.

1. Interior view of pedicle valve, Delorme Formation (early Pragian), S-2, sample B121.9 m, ROM 34031, × 2.0 .

2. Interior view of pedicle valve, Delorme Formation (early Pragian), S-2, sample B121.9 m, ROM 34032, × 2.0

3. Interior view of brachial valve, Delorme Formation (early Pragian), S-2, sample B121.9 m, ROM 34033, × 2.0

4, 5. Ventral and posterior views of articulated shell, Delorme Formation (late Lochkovian), S-1, sample A484.6 m, ROM $34034, \times 2.0$

6-8. Ventral, posterior, and lateral views of articulated shell; Delorme Formation (late Lochkovian), S-1, sample A484.6 m, ROM $34035, \times 2.0$.

9. Interior view of pedicle valve, Delorme Formation (late Lochkovian), S-1, sample A484.6 m, ROM 34036, × 2.0.

10, 11. Exterior and interior views of pedicle valve, Delorme Formation (Zlichovian), S-1, sample A62.5-68.6 m, ROM $34037, \times 1.9$.

12. Interior view of pedicle valve, Delorme Formation (Zlichovian), S-1, sample A62.5-68.6 m, ROM 34038, $\times 1.9$.

13. Interior view of brachial valve with epifauna attached anteriorly, Delorme Formation (Zlichovian), S-1, sample A62.5-68.6 m, ROM 34039, × 1.9 .

14-16. Lateral, interior, and exterior views of brachial valve; Delorme Formation (Zlichovian), S-1, sample A62.5-68.6 m, ROM $34040, \times 1.9$

17. Interior view of nested brachial valves, Delorme Formation (Zlichovian), S-1, sample A62.5-68.6 m, ROM 34041, × 1.9.

18-22. Ventral, lateral, dorsal, anterior, and posterior views of articulated shell; Delorme Formation (Zlichovian), S-1, sample A62.5-68.6 m, ROM 34042, × 2.5

23, 24. Dorsal and posterior views of articulated shell, Delorme Formation (Zlichovian), S-3, sample S4-502.9-507.5 m, ROM $34044, \times 4.1$
25,26 . Interior and lateral views of brachial valve fragment, Delorme Formation (Zlichovian), S-3, sample S4-502.9$507.5 \mathrm{~m}$, ROM $34045, \times 4.1$.

27. Interior view of pedicle valve, Delorme Formation (Zlichovian), S-3, sample S4-502.9-507.5 m, ROM 34046, × 4.1.

28. Interior view of brachial valve, Delorme Formation (Zlichovian), S-3, sample S4-502.9-507.5 m, ROM 34047, $\times 4.1$.

29. Interior view of brachial valve, Delorme Formation (Zlichovian), S-3, sample S4-502.9-507.5 m, ROM 34048, × 4.1.

Figs. 30-37. Cryptatrypa sp. 1

30. Interior view of pedicle valve, Delorme Formation (late Lochkovian), S-1, sample A470.9 m, ROM 34049, $\times 5.0$.

31. Interior view of brachial valve, Delorme Formation (late Lochkovian), S-1, sample A470.9 m, ROM $34050, \times 5.0$.

32. Interior view of articulated shell fragment, Delorme Formation (late Lochkovian), S-1, sample A470.9 m, ROM $34051, \times 5.0$

33. Interior view of pedicle valve, Delorme Formation (late Lochkovian), S-1, sample A470.9 m, ROM 34052, × 5.0.

34. Interior view of brachial valve fragment, Delorme Formation (late Lochkovian), S-1, sample A470.9 m, ROM 34053, $\times$ 5.0

35-37. Ventral, anterior, and lateral views of articulated shell; Delorme Formation (late Lochkovian), S-1, sample A470.9 m, ROM $34054, \times 5.0$

Figs. 38-47. Holynatrypa sp.

38-40. Dorsal, ventral, and lateral views of articulated shell; Delorme Formation (Zlichovian), S-3, sample S4-161.5$164.6 \mathrm{~m}$, Rом $34055, \times 3.8$.

41-43. Dorsal, lateral, and ventral views of articulated shell; Delorme Formation (Zlichovian), S-1, sample A62.5-68.6 m, ROM $34056, \times 6.0$.

44-47. Anterior, lateral, dorsal, and ventral views of articulated shell; Delorme Formation (Zlichovian), S-1, sample A62.5$68.6 \mathrm{~m}$, ROM $34057, \times 6.0$ 


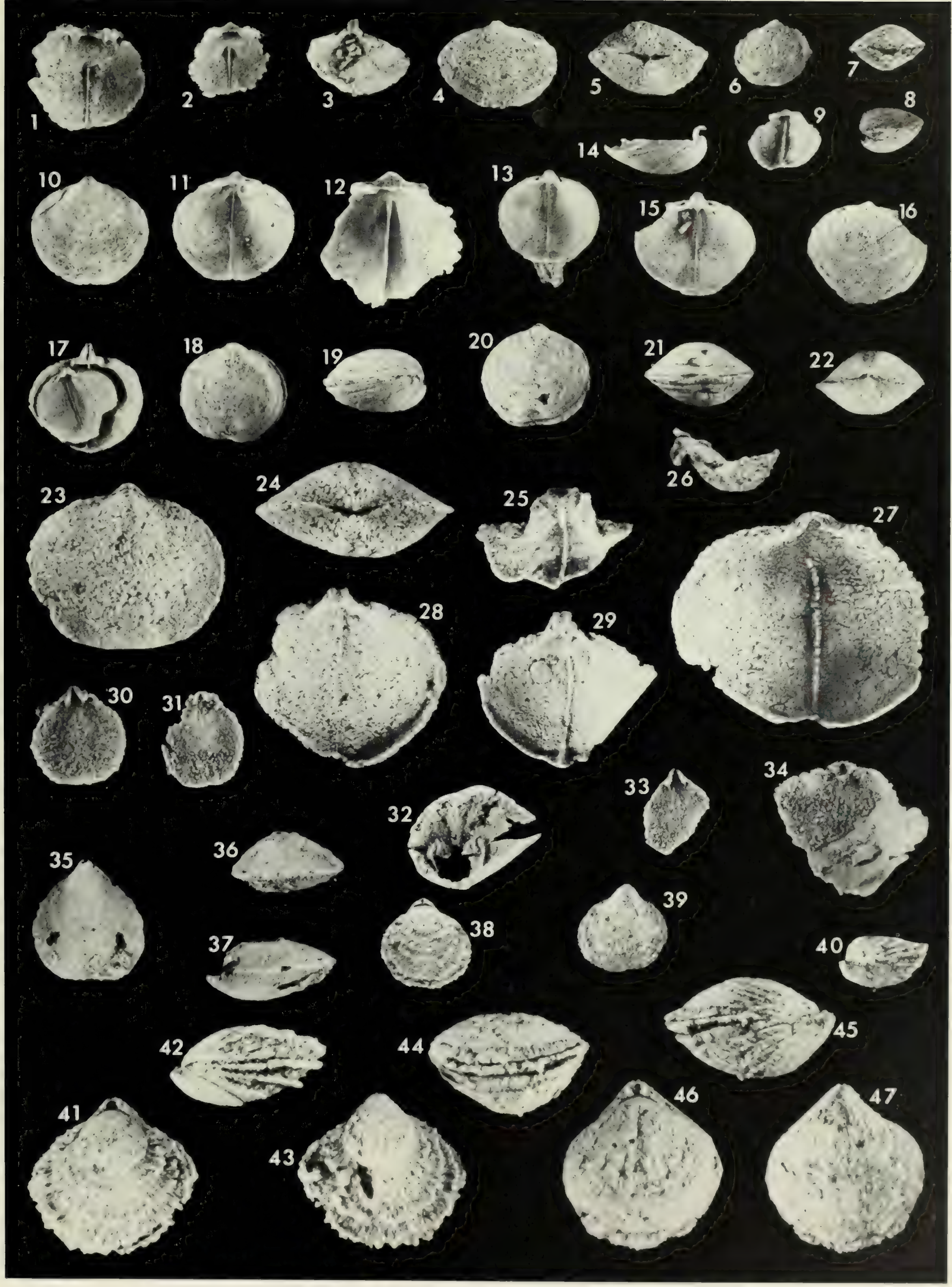


Plate 40, figs. 1-27

Articulate brachiopod Cryptatrypa.

Figs. 1-27. Cryptatrypa lenticula sp. nov.

1-4. Dorsal, ventral, lateral, and anterior views of articulated shell; Delorme Formation (Zlichovian), S-3, sample S4-161.5$164.6 \mathrm{~m}$, holotype ROM $34058, \times 3.8$.

5, 6. Interior and exterior views of brachial valve, Delorme Formation (Zlichovian), S-3, sample S4-161.5-164.6 m, paratype ROM $34059, \times 3.8$.

7, 8. Interior and exterior views of pedicle valve, Delorme Formation (Zlichovian), S-3, sample S4-161.5-164.6 m, paratype ROM $34060, \times 3.8$.

9, 10. Ventral and lateral views of articulated shell, Delorme Formation (Zlichovian), S-3, sample S4-161.5-164.6 m, paratype ROM $34061, \times 3.8$.

$11,15,16,18$. Ventral, anterior, dorsal, and lateral views of articulated shell; Delorme Formation (Zlichovian), S-3, sample S4-161.5-164.6 m, paratype ROM 34062, × 3.8 .
12-14, 17. Lateral, dorsal, ventral, and posterior views of articulated shell; Delorme Formation (Zlichovian), S-3, sample S4-161.5-164.6 m, paratype ROM 34063, × 3.8.

19. Interior view of pedicle valve with dorsal spiralia preserved, Delorme Formation (Zlichovian), S-3, sample S4-161.5$164.6 \mathrm{~m}$, paratype ROM $34064, \times 3.8$.

20. Interior view of articulated shell fragment, Delorme Formation (Zlichovian), S-3, sample S4-161.5-164.6 m, paratype ROM $34065, \times 3.8$.

21-23. Lateral, ventral, and dorsal views of articulated shell; Delorme Formation (Zlichovian), S-3, sample S4-502.9$507.5 \mathrm{~m}$, paratype ROM $34066, \times 4.0$.

24-27. Ventral, dorsal, posterior, and lateral views of articulated shell; Delorme Formation (Zlichovian), S-1, sample A62.5-68.6 m, paratype ROM $34067, \times 6.0$. 


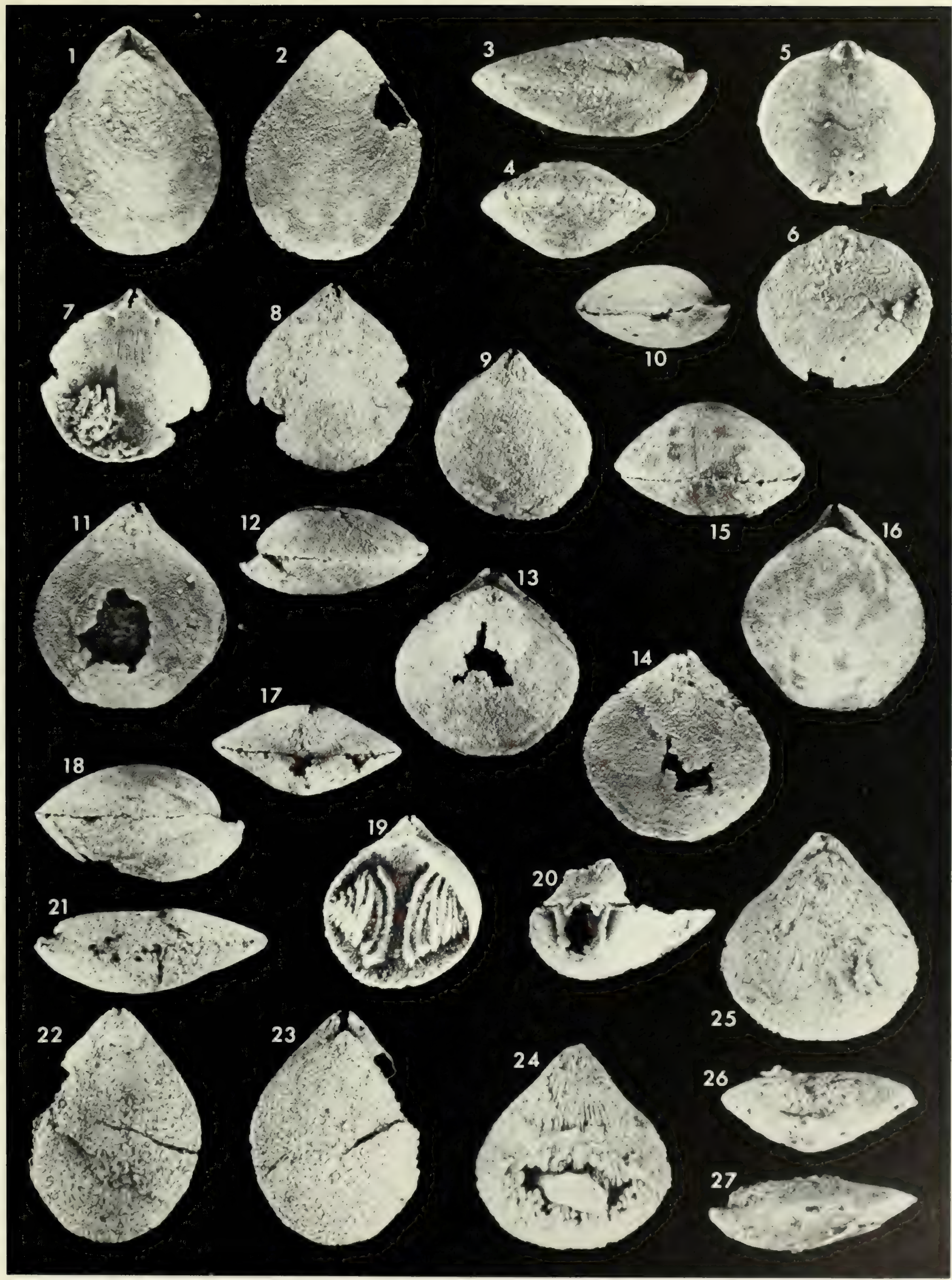


Plate 41 , figs. $1-46$

Articulate brachiopods Warrenella and Reticulariopsis?

Figs. 1-28. Warrenella sekwensis Ludvigsen and Perry. Note the difference in crural-plate development in different ontogenetic stages in figs. 3-9, 11, 12, and 16-19. Note the well-developed cardinal process in figs. $4,5,9$, and 18 .

1-3. Interior, exterior, and oblique interior views of brachial valve; Delorme Formation (Zlichovian), S-1, sample A62.5$68.6 \mathrm{~m}$, ROM $34068, \times 1.1$. Note the well-developed concentric growth lines

4. Oblique interior view of brachial valve, Delorme Formation (Zlichovian), S-3, sample S4-64.0-65.5 m, ROM 34069, × 3.3.

5. Oblique interior view of brachial valve, Delorme Formation (Zlichovian), S-3, sample S4-64.0-65.5 m, ROM 34070, × 3.3.

6. Oblique interior view of brachial valve, Delorme Formation (Zlichovian), S-3, sample S4-64.0-65.5 m, ROM 34071, × 3.3.

7. Oblique interior view of brachial valve, Delorme Formation (Zlichovian), S-3, sample S4-64.0-65.5 m, ROM 34072, $\times 3.3$.

8-10. Interior, oblique interior, and exterior views of brachial valve; Delorme Formation (Zlichovian), S-3, sample S4$184.4 \mathrm{~m}$, ROM $34073, \times 1.1$.

11,12 . Oblique interior and interior views of brachial valve, Delorme Formation (Zlichovian), S-3, sample S4-466.3 m, ROM $34074, \times 1.1$. Note how the posterior adductor muscle scars flare and encompass the posterior part of the anterior adductor field.

13-15. Exterior, lateral, and interior views of pedicle valve; Delorme Formation (Zlichovian), S-3, sample S4-161.5$164.6 \mathrm{~m}$, ROM 34075 , figs. 13 and $14 \times 1.1$, fig. $15 \times 1.4$. Note the well-developed apical deltidial cover and the encrusting auloporid corals in fig. 15 .

16. Interior view of brachial valve, Delorme Formation (Zlichovian), S-3, sample S4-161.5-164.6 m, ROM 34076, × 1.1.

17. Interior view of articulated shell fragment, Delorme Formation (Zlichovian), S-3, sample S4-161.5-164.6 m, ROM $34077, \times 1.1$

18, 19. Oblique interior and interior views of brachial valve, Delorme Formation (Zlichovian), S-3, sample S4-161.5$164.6 \mathrm{~m}$, ROM $34078, \times 1.1$.

20-23. Exterior, posterior, interior, and oblique interior views of pedicle valve; Delorme Formation (Zlichovian), S-3, sample S4-560.8-573.0 m, ROM 34079, × 1.1.

24,25 . Ventral and oblique lateral views of small shell,
Delorme Formation (Zlichovian), S-3, sample S4-519.7 m, ROM $34080, \times 4.3$. Note the crus visible in fig. 25 .

26. Lateral view of crus, Delorme Formation (Zlichovian), S-3, sample S4-519.7 m, ROM 34081, × 4.3. Note jugal process.

27,28 . Ventral and oblique dorsal views of silicified internal mould, Delorme Formation (Zlichovian), S-3, sample S4$560.8-573.0 \mathrm{~m}$, ROM $34082, \times 1.1$. Note the white area of undissolved shell calcite, which is a portion of the thick umbonal callus developed in large shells of the species.

Figs. 29-46. Reticulariopsis? warreni sp. nov.

29,30 . Interior and exterior views of brachial valve, Delorme Formation (early Pragian), S-1, sample A442.0 m, holotype ROM $34083, \times 2.5$. Note the weakly developed plications lateral to the dorsal fold in fig. 30 .

31. Interior view of pedicle valve, Delorme Formation (early Pragian), S-1, sample A442.0 m, paratype ROM 34084, $\times 2.5$. Note the medially bowed dental plates, also apparent in figs. 43 and 44 .

32-35. Dorsal, anterior, ventral, and lateral views of articulated shell; Delorme Formation (late Lochkovian), S-1, sample A470.9 m, paratype ROM $34085, \times 2.5$.

36. Interior view of brachial valve, Delorme Formation (late Lochkovian), S-1, sample A470.9 m, paratype ROM 34086, $\times$ 2.5 .

37. Interior view of brachial valve, Delorme Formation (early Pragian), S-1, sample OLDA336.8 m, paratype ROM 34087, $\times$ 2.5 .

38. Interior view of brachial valve, Delorme Formation (early Pragian), S-1, sample OLDA336.8 m, paratype ROM 34088, $\times$ 2.5 .

39-41. Anterior, posterior, and ventral views of articulated shell; Delorme Formation (early Pragian), S-1, sample OLDA336.8 m, paratype ROM $34089, \times 2.5$.

42, 43. Exterior and interior views of pedicle valve, Delorme Formation (early Pragian), S-2, sample B121.9 m, paratype ROM $34090, \times 2.5$.

44. Interior view of articulated shell fragment, Delorme Formation (late Lochkovian-early Pragian), S-2, sample B166.1-182.9 m, paratype ROM 34091, × 2.5.

45, 46. Exterior and interior views of pedicle valve, Delorme Formation (late Lochkovian-early Pragian), S-2, sample B166.1-182.9 m, paratype ROM 34092, × 2.5 . 


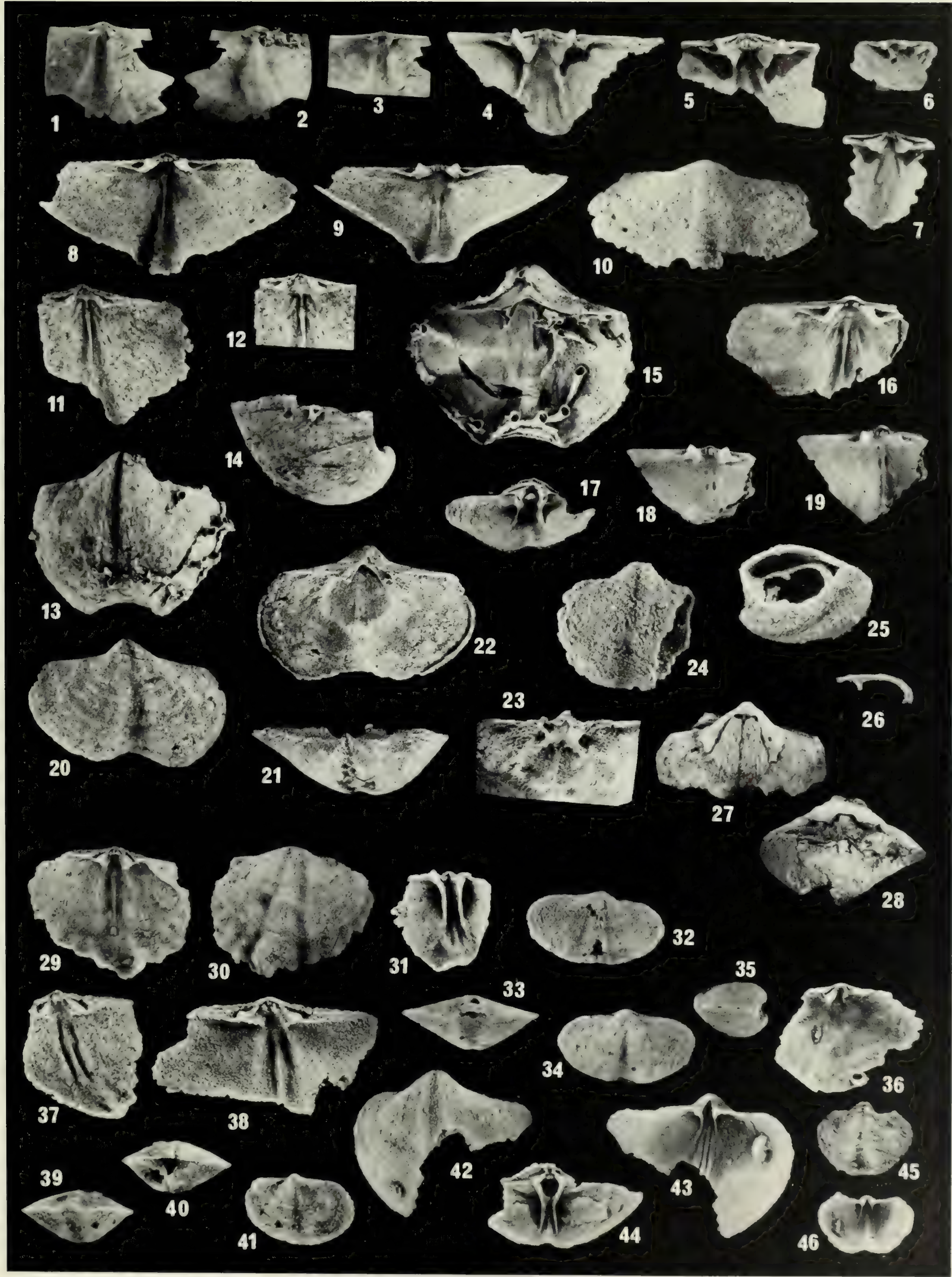


Plate 42, figs. $1-59$

Articulate brachiopods Ambocoelia, Cyrtina, Holynatrypa, and Plicanoplites.

Figs. 1-10. Ambocoelia cf. A. praecox Kozlowski.

1-3. Lateral, anterior, and ventral views of articulated shell; Delorme Formation (late Lochkovian), S-1, sample A470.9 m, ROM 34093, × 2.2 .

4-6. Dorsal, ventral, and anterior views of articulated shell; Delorme Formation (late Lochkovian), S-1, sample A470.9 m, ROM 34094, × 2.2 .

7-9. Lateral, dorsal, and posterior views of articulated shell; Delorme Formation (late Lochkovian), S-1, sample A470.9 m, ROM $34095, \times 2.2$.

10. Interior view of pedicle valve, Delorme Formation (late Lochkovian), S-1, sample A470.9 m, ROM 34096, $\times 2.2$.

Figs. 11-37. Ambocoelia rugosa sp. nov.

11,12 . Interior and exterior views of brachial valve, Delorme Formation (Zlichovian), S-1, sample A62.5-68.6 m, paratype ROM $34097, \times 6.0$.

13. Interior view of brachial valve, Delorme Formation (Zlichovian), S-1, sample A62.5-68.6 m, paratype ROM 34098, × 6.0. 14. Interior view of brachial valve, Delorme Formation (Zlichovian), S-1, sample A62.5-68.6 m, paratype ROM 34099, ×6.0. 15,16 . Interior and exterior views of brachial valve, Delorme Formation (Zlichovian), S-1, sample A62.5-68.6 m, paratype ROM $34100, \times 6.0$.

17, 18. Exterior and interior views of brachial valve, Delorme Formation (Zlichovian), S-1, sample A62.5-68.6 m, paratype ROM $34101, \times 6.0$.

19. Interior view of pedicle valve, Delorme Formation (Zlichovian), S-1, sample A62.5-68.6 m, paratype ROM 34102, × 6.0.

20. Interior view of pedicle valve fragment, Delorme Formation (Zlichovian), S-1, sample A62.5-68.6 m, paratype ROM 34103, $\times 6.0$.

21, 22. Dorsal and ventral views of articulated shell, Delorme Formation (Zlichovian), S-1, sample A62.5-68.6 m, paratype ROM $34104, \times 6.0$.

23-26. Dorsal, ventral, anterior, and posterior views of articulated shell; Delorme Formation (Zlichovian), S-1, sample A62.5-68.6 m, holotype ROM 34105, $\times 6.0$.

27-29. Lateral, posterior, and anterior views of articulated shell; Delorme Formation (Zlichovian), S-1, sample A62.5-68.6 m, paratype ROM $34106, \times 6.0$

30-32. Ventral, dorsal, and anterior views of articulated shell; Delorme Formation (Zlichovian), S-3, sample S4-502.9$507.5 \mathrm{~m}$, paratype ROM $34107, \times 6.0$.
33. Interior view of brachial valve, Delorme Formation (Zlichovian), S-3, sample S4-502.9-507.5 m, paratype ROM 34108, $\times$ 6.0 .

34, 35. Anterior and lateral views of articulated shell, Delorme Formation (Zlichovian), S-3, sample S4-502.9-507.5 m, paratype ROM $34109, \times 6.0$

36, 37. Lateral and interior views of pedicle valve, Delorme Formation (Zlichovian), S-3, sample S4-502.9-507.5 m, paratype ROM $34110, \times 6.0$.

Figs. 38-51. Cyrtina impressio sp. nov.

38, 39. Exterior and interior views of brachial valve, Delorme Formation (Zlichovian), S-1, sample A62.5-68.6 m, paratype Rом $34111, \times 1.9$.

40, 41. Exterior and interior views of brachial valve, Delorme Formation (Zlichovian), S-1, sample A62.5-68.6 m, paratype ROM $34112, \times 1.9$.

42-44. Anterior, ventral, and interior views of pedicle valve; Delorme Formation (Zlichovian), S-1, sample A62.5-68.6 m, paratype ROM $34113, \times 1.9$.

45, 46. Exterior and interior views of brachial valve, Delorme Formation (Zlichovian), S-1, sample A62.5-68.6 m, paratype ROM $34114, \times 1.9$.

47-50. Posterior, dorsal, lateral, and anterior views of articulated shell; Delorme Formation (Zlichovian), S-1, sample A62.5-68.6 m, holotype ROM $34115, \times 1.3$.

51. Interior view of pedicle valve, Delorme Formation (Zlichovian), S-1, sample A62.5-68.6 m, paratype ROM 34116, × 1.9.

Figs. 52-55. Holynatrypa sp.

52. Interior view of pedicle valve fragment, Delorme Formation (Zlichovian), S-3, sample S4-161.5-164.6 m, ROM 34117, $\times$ 4.0

53. Interior view of brachial valve, Delorme Formation (Zlichovian), S-3, sample S4-161.5-164.6 m, Rом 34118, $\times 4.0$.

54, 55. Exterior and interior views of brachial valve, Delorme Formation (Zlichovian), S-3, sample S4-161.5-164.6 m, ROM $34119, \times 4.0$.

Figs, 56-59. Plicanoplites sp

56, 57. Interior and exterior views of brachial valve, transitional facies (early Lochkovian), S-11, 211.5 $\mathrm{m}$ above the top of the Whittaker Formation, ROM $34120, \times 6.0$.

58, 59. Exterior and interior views of pedicle valve, transitional facies (early Lochkovian), S-11, 211.5 $\mathrm{m}$ above the top of the Whittaker Formation, ROM 34121, × 6.0. 


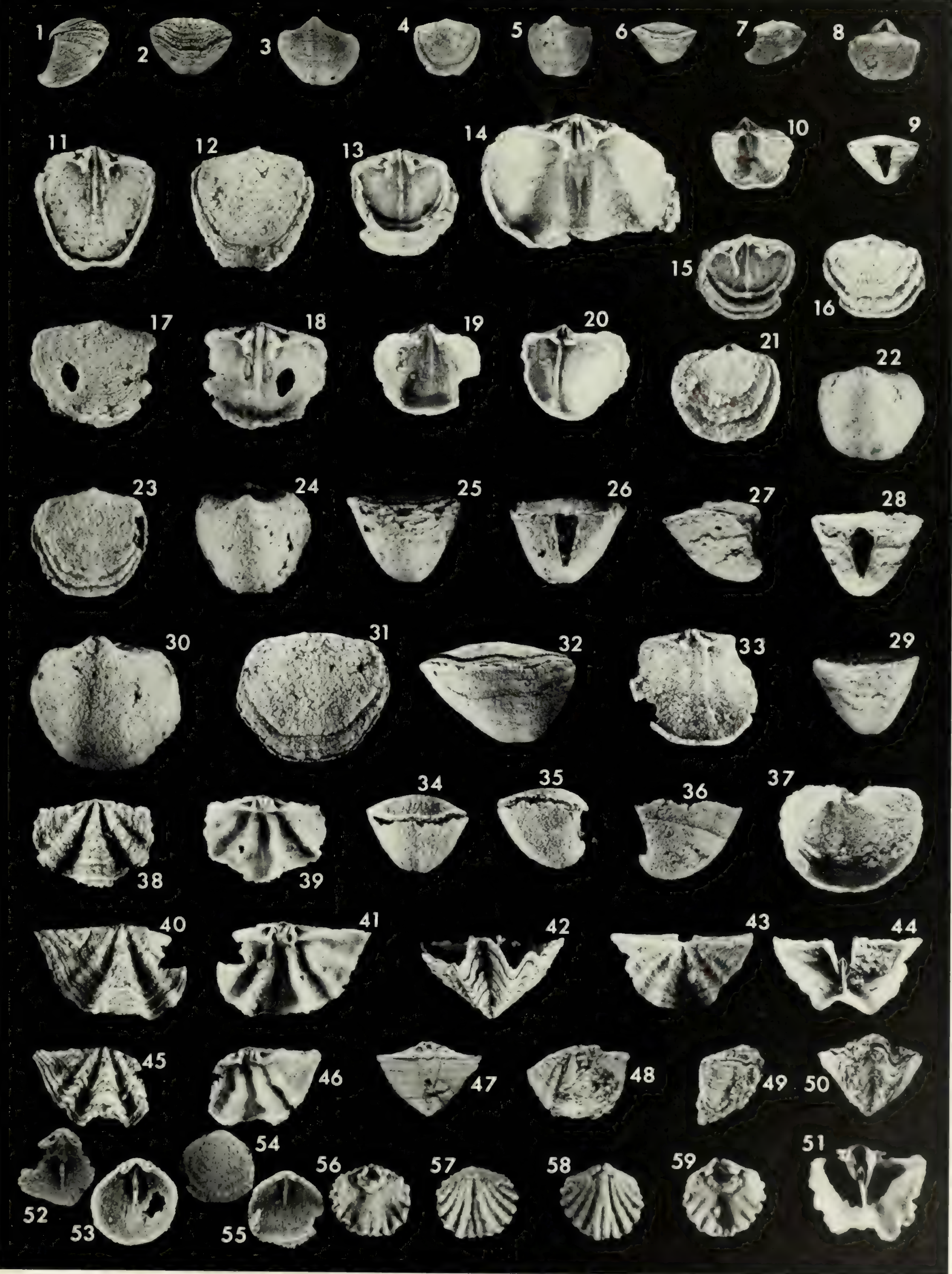


Plate 43, figs. 1-51

Articulate brachiopod Cyrtina.

Figs. 1-22. Cyrtina clagueae sp. nov.

1. Interior view of brachial valve, Delorme Formation (early Lochkovian), S-2, sample B336.8 m, paratype ROM 34122, $\times$ 3.0

2-5. Dorsal, ventral, anterior, and lateral views of articulated shell; Delorme Formation (early Lochkovian), S-2, sample B336.8 m, holotype Roм $34123, \times 3.0$.

6,7 . Dorsal and posterior views of articulated shell, Delorme Formation (early Lochkovian), S-2, sample B336.8 m, paratype ROM $34124, \times 3.0$.

8. Interior view of brachial valve, Delorme Formation (early Lochkovian), S-2, sample B336.8 m, paratype ROM 34125, $\times$ 3.0.

9. Interior view of brachial valve, Delorme Formation (early Lochkovian), S-2, sample B254.5 m, paratype ROM 34126 , $\times$ 3.0.

10. Interior view of brachial valve, Delorme Formation (early Lochkovian), S-2, sample B254.5 m, paratype Rom 34127, $\times$ 3.0

11. Interior view of pedicle valve, Delorme Formation (midLochkovian), S-2, sample B225.6 m, paratype ROM 34128, $\times$ 1.7

12. Interior view of brachial valve, Delorme Formation (midLochkovian), S-2, sample B225.6 m, paratype ROM 34129, × 1.7.

13. Exterior view of brachial valve, Delorme Formation (mid-Lochkovian), S-2, sample B225.6 m, paratype, ROM $34130, \times 1.7$.

14-16. Lateral, posterior, and dorsal views of articulated shell; Delorme Formation (mid-Lochkovian), S-2, sample B225.6 m, paratype ROM $34131, \times 2.3$.

17-20. Lateral, posterior, ventral, and dorsal views of articulated shell; Delorme Formation (mid-Lochkovian), S-2, sample B225.6 m, paratype ROM $34132, \times 1.7$.

21. Interior view of brachial valve, Delorme Formation, (mid-Lochkovian), S-2, sample B225.6 m, paratype ROM 34133, $\times 1.7$.

22. Oblique interior view of brachial valve, Delorme Formation (mid-Lochkovian), S-2, sample B225.6 m, paratype ROM 34134 , $\times 1.7$.
Figs. 23-51. Cyrtina spp.

23, 24. Lateral and posterior views of articulated shell, Delorme Formation (late Lochkovian), S-1, sample A470.9 m, ROM $34135, \times 2.0$.

$25,26,30$. Lateral, anterior, and posterior views of articulated shell, Delorme Formation (late Lochkovian), S-1, sample A470.9 m, ROM 34136, $\times 2.0$.

27-29. Interior, anterior, and exterior views of pedicle valve, Delorme Formation (early Pragian), S-2, sample B128.6 m, ROM $34137, \times 1.7$

31-33. Anterior, dorsal, and lateral views of articulated shell, Delorme Formation (early Pragian), S-2, sample B128.6 m, ROM $34138, \times 3.4$.

34. Interior view of pedicle valve fragment, Delorme Formation (early Pragian), S-2, sample B128.6 m, ROM 34139, × 1.7 .

35, 36. Posterior and dorsal views of distorted specimen, Delorme Formation (early Pragian), S-2, sample B128.6 m, ROM $34140, \times 1.9$.

37. Interior view of brachial valve, Delorme Formation (early Pragian), S-2, sample B $128.6 \mathrm{~m}$, ROM $34141, \times 3.4$.

38. Exterior view of brachial valve, Delorme Formation (early Pragian), S-2, sample B128.6 m, ROM 34142, × 1.7 .

39. Interior view of brachial valve, Delorme Formation (early Pragian), S-2, sample B128.6 m, ROM $34143, \times 3.4$

40, 41. Posterior and ventral views of articulated shell, Delorme Formation (early Pragian), S-1, sample A436.5 m, ROM 34144, $\times 1.8$.

42-44. Posterior, ventral, and anterior views of articulated shell, Delorme Formation (early Pragian), S-1, sample A436.5 m, ROм $34145, \times 1.8$.

45, 46. Lateral and dorsal views of articulated shell, Delorme Formation (early Pragian), S-1, sample A436.5 m, ROM 34146, $\times 1.8$.

47. Interior view of brachial valve, Delorme Formation (early Pragian), sample A436.5 m, ROM 34147, × 1.8 .

48. Interior view of brachial valve fragment, Delorme Formation (early Pragian), S-1, sample A436.5 m, ROM 34148, $\times 1.8$.

49. Interior view of brachial valve fragment, Delorme Formation (early Pragian), S-1, sample A436.5 m, ROM 34149, $\times 1.8$.

50, 51. Lateral and ventral views of articulated shell, Delorme Formation (early Pragian), S-1, sample A436.5 m, ROM 34150 $\times 1.8$. 


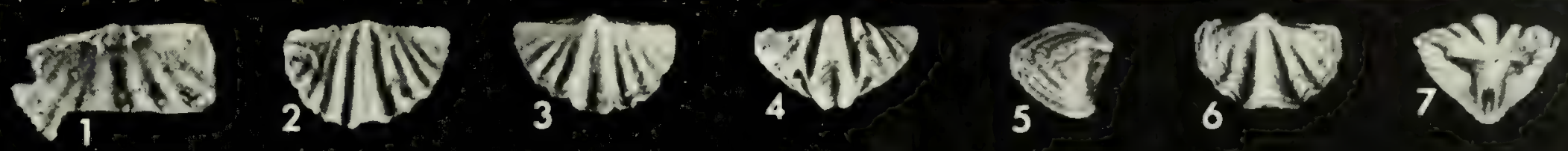

(12)
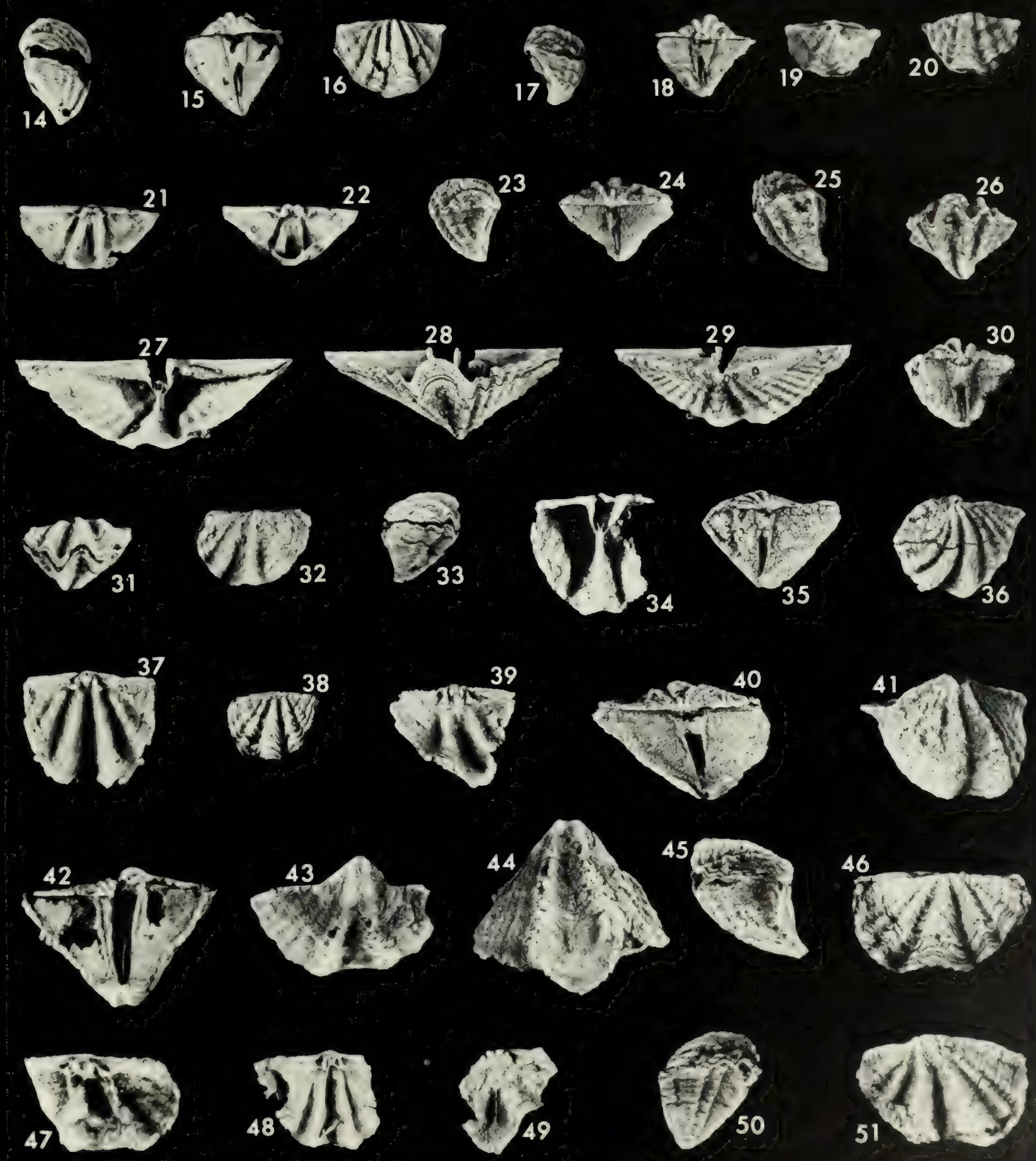
Plate 44, figs. $1-46$

Articulate brachiopods?Cyrtinopsis, Plicocyrtina, and Plicoplasia

Figs. 1-9. ?Cyrtinopsis of. C. cooperi Gill.

1-3. Interior, lateral, and exterior views of pedicle valve; Delorme Formation (late Pragian), S-1, sample A207.3$208.8 \mathrm{~m}$, ROM $34151, \times 1.8$.

4-6. Exterior, interior, and oblique interior views of brachial valve; Delorme Formation (late Pragian), S-1, sample A210.3$233.2 \mathrm{~m}$, ROM $34152, \times 1.8$.

7-9. Oblique exterior, interior, and exterior views of pedicle valve fragment; Delorme Formation (late Pragian), S-1, sample A210.3-233.2 m, ROM 34153, $\times 1.8$.

Figs. 10-34. Plicocyrtina sinuplicata Havliček.

Note the strongly overlapping growth lamellae with free anterior margins in all the exterior views.

10-14. Posterior, anterior, lateral, ventral, and dorsal views of articulated shell; Delorme Formation (early Pragian), S-1, sample A342.9 m, ROM 34154, × 1.8 .

15-18. Lateral, anterior, interior, and posterior views of pedicle valve; Delorme Formation (early Pragian), S-1, sample OLDA336.8 m, ROM $34155, \times 1.8$.

19-21. Exterior, oblique interior, and interior views of brachial valve; Delorme Formation (early Pragian), S-1, sample OLDA336.8 m, ROM $34156, \times 1.8$.

22, 23. Interior and exterior views of brachial valve, Delorme Formation (early Pragian), S-1, sample OLDA336.8 m, ROM $34157 . \times 1.8$.
24-27. Posterior, oblique lateral, oblique exterior, and lateral views of pedicle valve; Delorme Formation (early Pragian), S-2, sample B32.0, ROM 34158, $\times 1.7$. Note the prominent lateral plates in fig. 25 .

28-30. Interior, exterior, and oblique interior views of brachial valve; Delorme Formation (early Pragian), S-2, sample B32.0 m, ROM $34159, \times 1.7$.

31. Interior view of pedicle valve, Delorme Formation (early Pragian), S-2, sample B32.0 m, ROM 34160, × 1.7 .

32. Interior view of brachial valve, Delorme Formation (early Pragian), S-2, sample B32.0 m, ROM $34161, \times 1.7$.

33,34 . Interior and exterior views of brachial valve, Delorme Formation (early Pragian), S-2, sample B32.0 m, ROM 34162, $\times$ 1.7.

Figs. 35-46. Plicoplasia acutiplicata Lenz.

35-37. Exterior, oblique interior, and interior views of pedicle valve; Delorme Formation (late Lochkovian), S-1, sample A470.9 m, ROM 34163, $\times 1.8$.

38-40. Interior, oblique interior, and exterior views of brachial valve; Delorme Formation (late Lochkovian), S-1, sample A470.9 m, ROM $34164, \times 1.8$.

41-43. Oblique interior, interior, and exterior views of brachial valve; Delorme Formation (late Lochkovian), S-1, sample A470.9 m, ROM $34165, \times 1.8$.

44-46. Lateral, exterior, and interior views of pedicle valve; Delorme Formation (late Lochkovian), S-1, sample A470.9 m, ROM 34166, × 1.8 . 

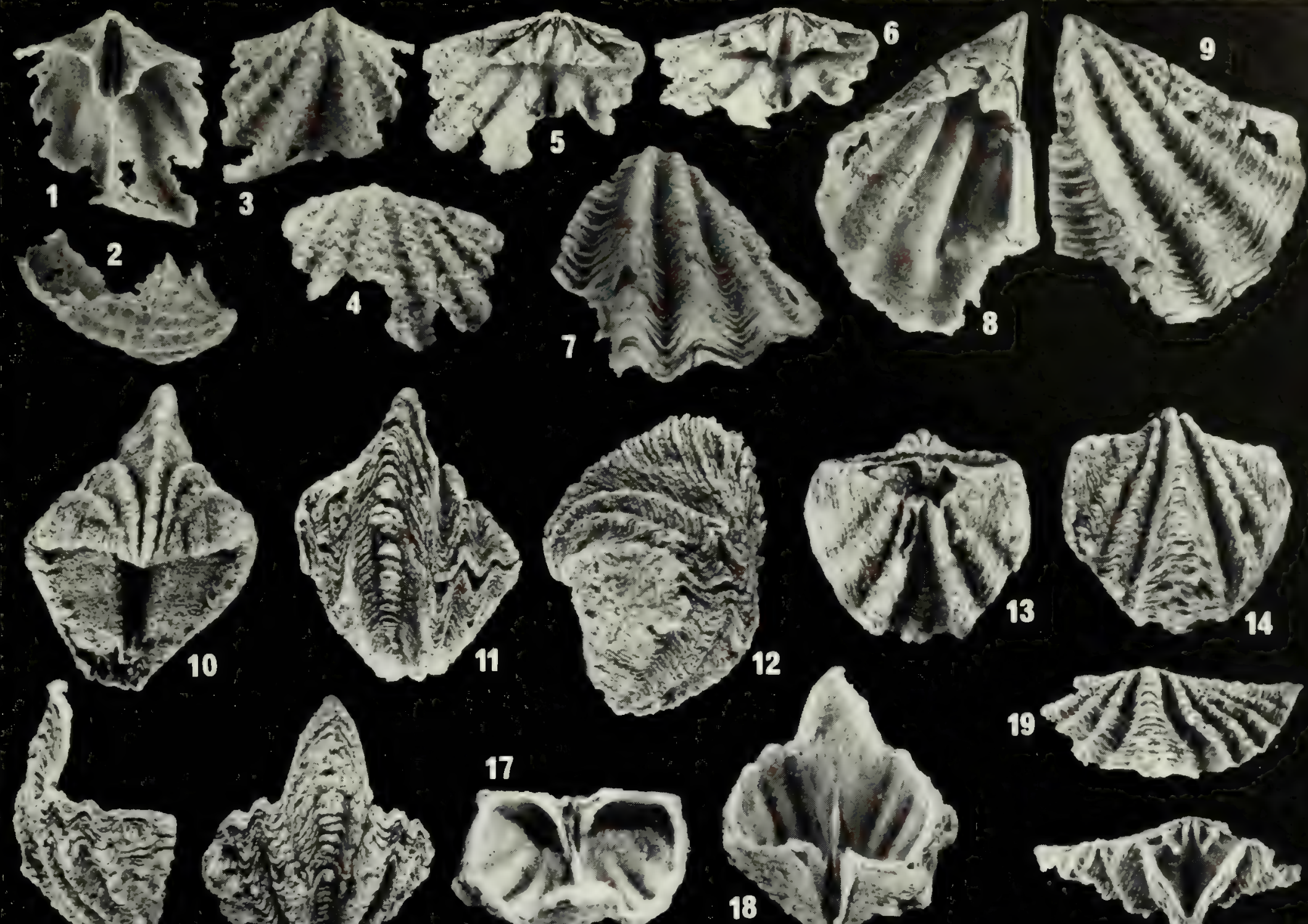

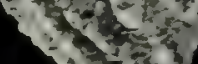

15 a

\section{6}

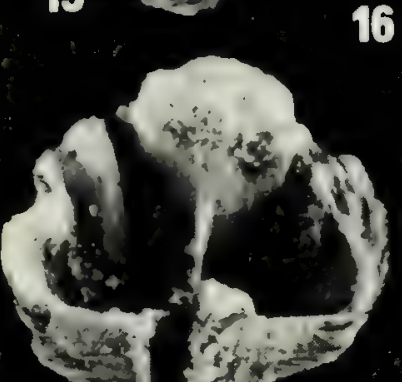

$24{ }^{2}$
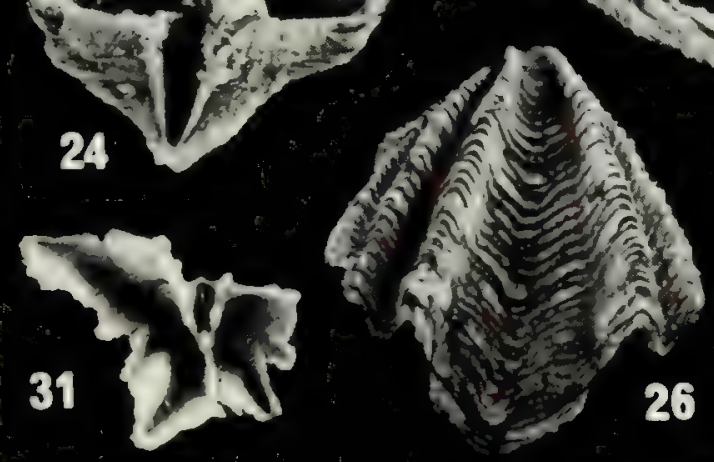

(2)

$x^{1} \sqrt{2} 32$

\section{W 4}
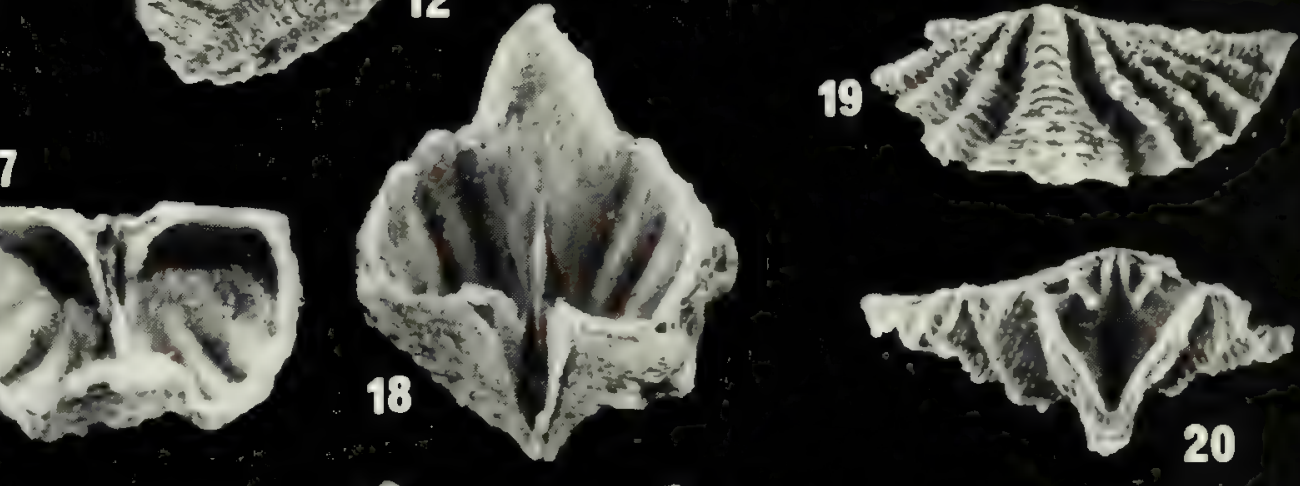
Plate 45, figs. 1-53

Articulate brachiopods Howellella, Delthyris, and Howitia.

Figs. 1-7. Howellella cycloptera (Hall)?.

1-3. Exterior, oblique interior, and lateral views of pedicle valve; Delorme Formation (early Pragian), S-1, sample OLDA278.9 m, ROM $34167, \times 1.3$.

4, 5. Interior and exterior views of pedicle valve, Delorme Formation (early Pragian), S-1, sample OLDA278.9 m, ROM $34168, \times 1.3$.

6, 7. Interior and exterior views of brachial valve, Delorme Formation (early Pragian), S-1, sample A318.5 m, ROM 34169, $\times 1.3$.

Figs. 8-25. Howellella sp. 1.

8, 9. Ventral and posterior views of internal mould of pedicle valve, Delorme Formation (probable Pridolian), S-6, sample C47-507.5 m, ROM 34170, × 1.3 .

10,11. Dorsal and posterior views of internal mould of brachial valve, Delorme Formation (probable Pridolian), S-6, sample C47-507.5 m, ROM 34171, × 1.3

12,13 . Dorsal and posterior views of internal mould of brachial valve, Delorme Formation (probable Pridolian), S-6, sample C47-507.5 m, ROM 34172, × 1.3 .

14,15 . Posterior and ventral views of internal mould of pedicle valve, Delorme Formation (probable Pridolian), S-6, sample C47-507.5 m, ROM $34173, \times 1.3$

16, 17. Exterior and interior views of pedicle valve, Delorme Formation (early Lochkovian), S-2, sample B336.8 m, ROM $34174, \times 3.7$.

18. Interior view of brachial valve fragment, Delorme Formation (early Lochkovian), S-2, sample B336.8 m, ROM 34175, $\times$ 3.7 .

19, 20. Exterior and interior views of brachial valve, Delorme Formation (early Lochkovian), S-2, sample B336.8 m, ROM $34176, \times 3.7$

21. Interior view of pedicle valve fragment, Delorme Formation (early Lochkovian), S-2, sample B336.8 m, ROM 34177, × 3.7.

22. Interior view of brachial valve fragment, Delorme Formation (early Lochkovian), S-2, sample B336.8 m, ROM 34178, × 3.7 .

23-25. Ventral, dorsal, and posterior views of small shell; Delorme Formation (early Lochkovian), S-2, sample B336.8 m, ROM $34179, \times 3.7$.

\section{Figs. 26-34. Howellella sp. 2}

26-28. Oblique interior, exterior, and interior views of brachial valve, Delorme Formation (Ludlovian), S-6, sample C47$248.4 \mathrm{~m}, \mathrm{ROM} 34181, \times 2.4$.
29, 30. Oblique anterior and interior views of brachial valve, Delorme Formation (Ludlovian), S-6, sample C47-248.4 m, ROM $34182, \times 2.4$.

31, 32. Exterior and interior views of brachial valve, Delorme Formation (Ludlovian), S-6, sample C47-248.4 m, ROM 34183, $\times 2.4$.

33, 34. Exterior and interior views of pedicle valve, Delorme Formation (Ludlovian), S-6, sample C47-248.4 m, ROM 34184, $\times 2.4$.

Figs. 35-42. Delthyris sp.

35. Interior view of pedicle valve, transitional facies (probable Ludlovian), S-11, 185.9-193.5 $\mathrm{m}$ above the top of the Whittaker Formation, GSC locality 69062, ROM $34185, \times 3.1$.

36,37 . Posterior and lateral views of pedicle valve, transitional facies (probable Ludlovian), S-11, 185.9-193.5 $\mathrm{m}$ above the top of the Whittaker Formation, GSC locality 69062, ROM 34186, × 3.1.

38. Oblique interior view of pedicle valve, transitional facies (probable Ludlovian), S-11, 185.9-193.5 $\mathrm{m}$ above the top of the Whittaker Formation, GSC locality 69062, ROM 34187, × 3.1 .

39. Interior view of small brachial valve, transitional facies (probable Pridolian), S-11, 185.9-193.5 $\mathrm{m}$ above the top of the Whittaker Formation, GSC locality 69062, ROM $34188, \times 3.1$.

40,41 . Interior and exterior views of brachial valve, transitional facies (probable Pridolian), S-11, 185.9-193.5 $\mathrm{m}$ above the top of the Whittaker Formation, GSC locality 69062 , ROM 34189 , $\times$ 3.1 .

42. Interior view of pedicle valve, transitional facies (probable Pridolian), S-11, 185.9-193.5 $\mathrm{m}$ above the top of the Whittaker Formation, GSC locality 69062, ROM $34190, \times 3.1$.

43. Interior view of small brachial valve, transitional facies (probable Pridolian), S-11, 185.9-193.5 $\mathrm{m}$ above the top of the Whittaker Formation, GSC locality 69062, ROM 34191, × 3.1 .

Figs. 44-53. Howittia sp.

44-46. Oblique interior, interior, and exterior views of brachial valve; Delorme Formation (Zlichovian), S-3, sample S4$176.8 \mathrm{~m}$, ROM $34192, \times 3.6$.

47-51. Interior, oblique interior, lateral, exterior, and anterior views of pedicle valve; Delorme Formation (Zlichovian), S-3, sample S4-176.8 m, ROM $34193, \times 3.6$.

52, 53. Exterior and interior views of pedicle valve, Delorme Formation (Zlichovian), S-3, sample S4-560.8-573.0 m, ROM $34194, \times 2.5$. 

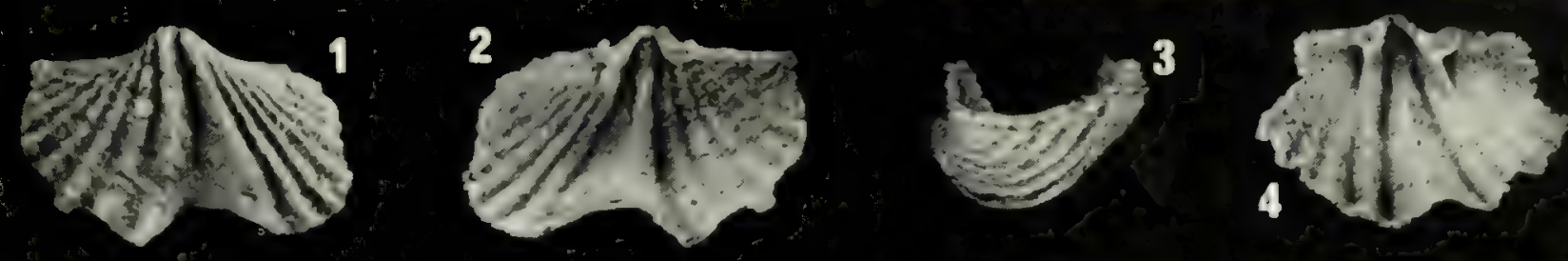

$5-6 \times 1)$

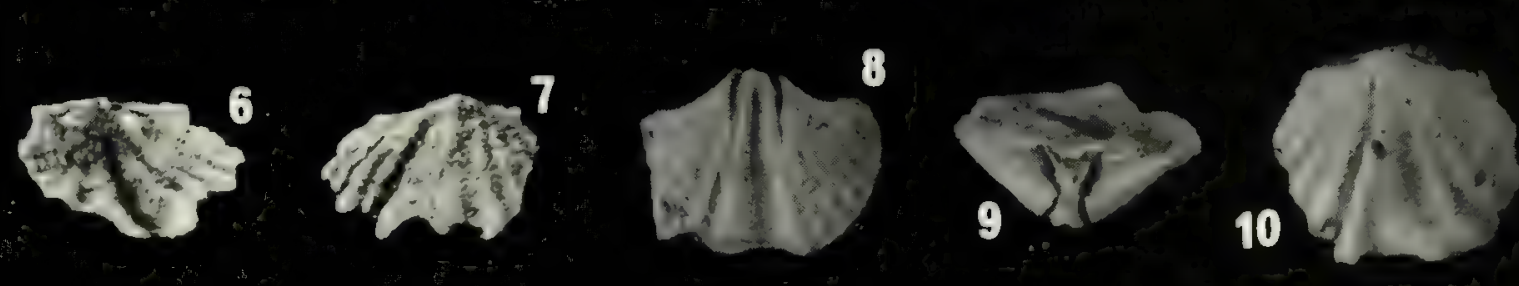

난 11

$12 \times 4$

$13 \quad 014$

15
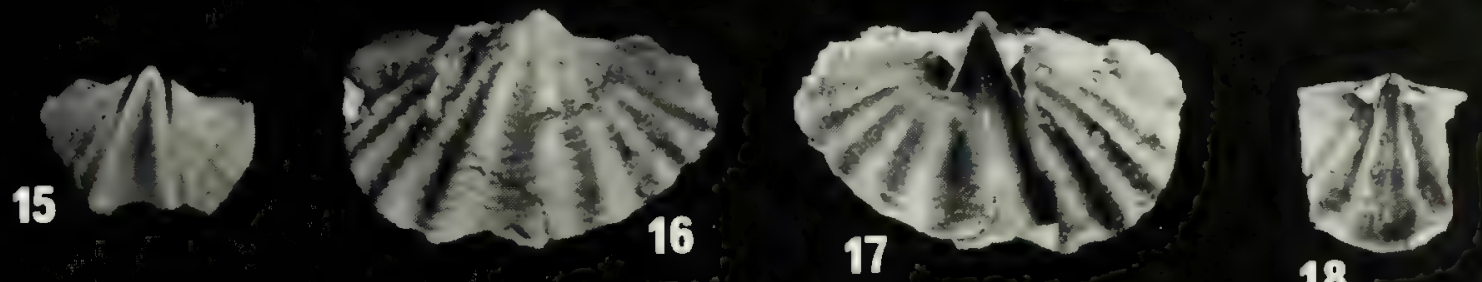

$9 / 110$
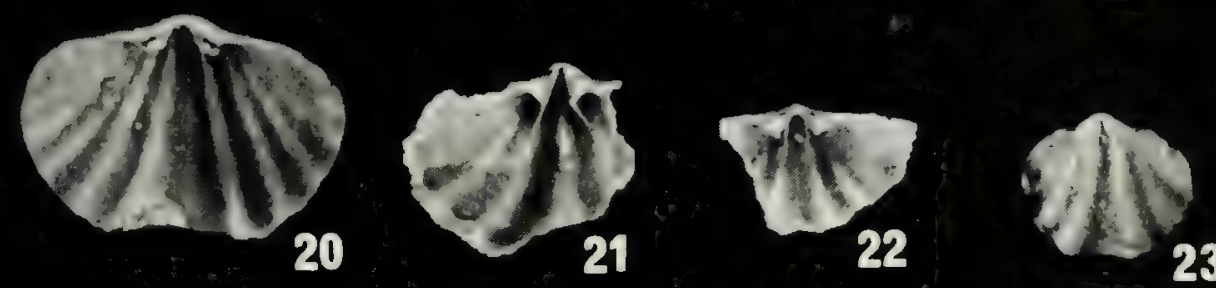

$8 \operatorname{liv}_{24}$

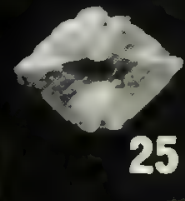

${ }_{26}$
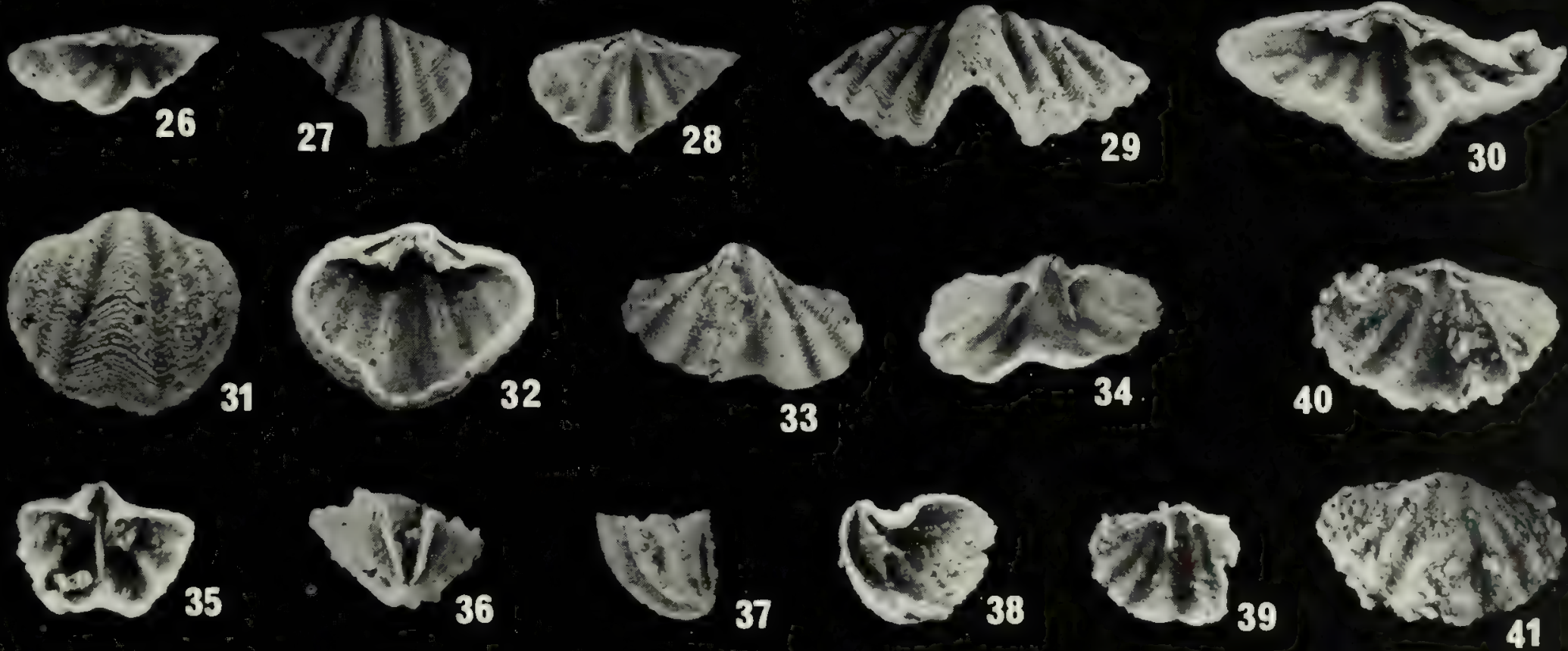

(x)

$\left.42 \beta_{43}{ }^{2}\right)^{44}$ 37 38

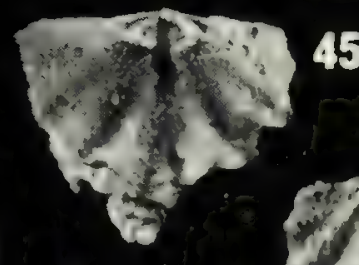

45
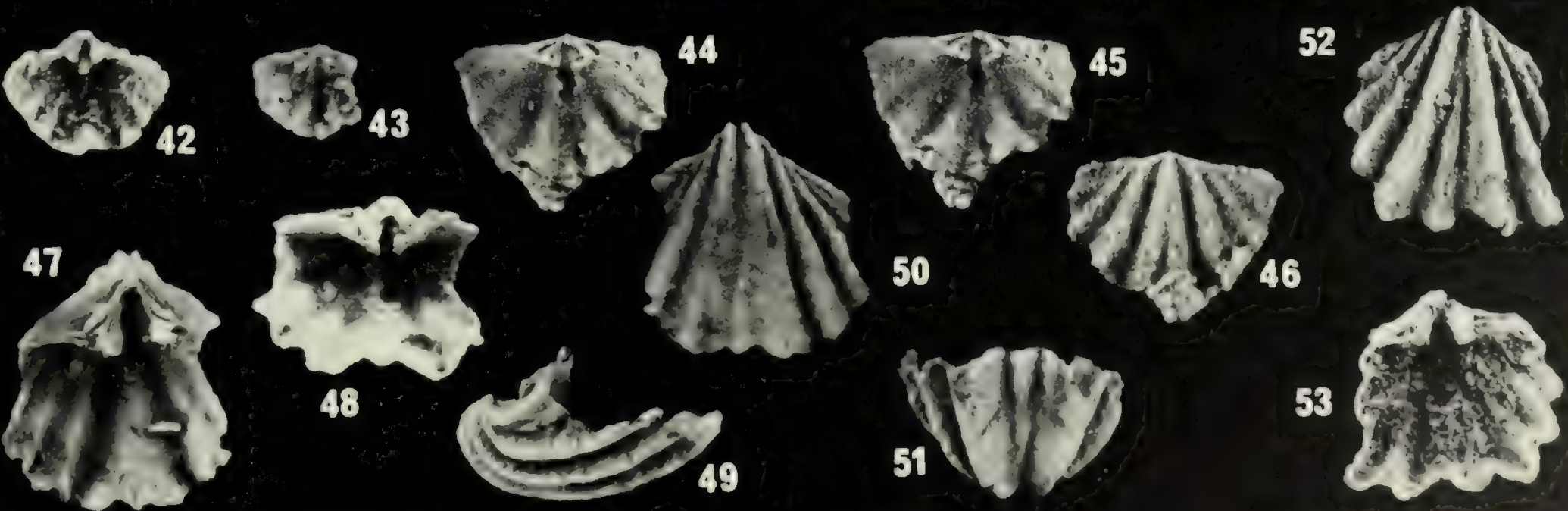
Plate 46, figs. 1-60

Articulate brachiopods Callispirifer gen. nov., Spirinella, Metaplasia, Cyrtinaella, indeterminate spiriferid, and indeterminate terebratulid.

Figs, 1-26. Callispirifer teniostrakon gen. nov. et sp. nov.

1-5. Posterior, anterior, lateral, ventral, and dorsal views of articulated shell; Delorme Formation (Zlichovian), S-1, sample A62.5-68.6 m, paratype Rom 34195, × 1.3 .

6-10. Dorsal, ventral, lateral, anterior, and posterior views of articulated shell; Delorme Formation (Zlichovian), S-1, sample A62.5-68.6 m, paratype ROM 34198, × 1.3.

11, 12. Interior and oblique interior views of pedicle valve, Delorme Formation (Zlichovian), S-1, sample A62.5-68.6 m, paratype ROM $34199, \times 1.3$.

13-16. Exterior, interior, and oblique interior views of cardinalia and oblique interior view of brachial valve; Delorme Formation (Zlichovian), S-1, sample A62.5-68.6 m, holotype ROM 34200, figs, $13-15 \times 2.5$, fig. $16 \times 1.3$.

17-19. Exterior, interior, and oblique anterior views of brachial valve; Delorme Formation (Zlichovian), S-1, sample A62.5$68.6 \mathrm{~m}$, paratype ROM $34202, \times 1.3$.

20-22, 26. Two oblique interior views, an anterior view, and an interior view of pedicle valve; Delorme Formation (Zlichovian), S-1, sample A62.5-68.6 m, paratype ROM 34203, $\times 1.3$.

23,24 . Interior and oblique interior views of brachial valve, Delorme Formation (Zlichovian), S-1, sample A62.5-68.6 m, paratype ROM 34205, × 1.3 .

25. Interior view of pedicle valve, Delorme Formation (Zlichovian), S-1, sample A62.5-68.6 m, paratype ROM 34206, × 1.3.

Figs. 27-39. Spirinella rootensis sp. nov.

27, 29. Exterior and oblique interior views of pedicle valve, Delorme Formation (Ludlovian), S-6, sample C47-248.4 m, paratype ROM $34208, \times 2.3$

28. Interior view of pedicle valve, Delorme Formation (Ludlovian), S-6, sample C47-248.4 m, paratype ROM 34209, $\times 2.3$.

30,31 . Interior and exterior views of brachial valve, Delorme Formation (Ludlovian), S-6, sample C47-248.4 m, paratype ROM $34210, \times 2.3$

32,33 . Oblique interior and exterior views of brachial valve, Delorme Formation (Ludlovian), S-6, sample C47-248.4 m, holotype ROM $34211, \times 2.3$.

34, 35. Exterior and interior views of pedicle valve, Delorme Formation (Ludlovian), S-6, sample C47-248.4 m, paratype ROM 34212, × 2.3 .
36, 37. Oblique posterior and lateral views of articulated shell fragment, Delorme Formation (Ludlovian), S-6, sample C47$248.4 \mathrm{~m}$, paratype ROM $34213, \times 2.3$.

38. Interior view of brachial valve, Delorme Formation (Ludlovian), S-6, sample C47-248.4 m, paratype ROM $34214, \times 2.3$. 39. Oblique posterior view of pedicle valve, Delorme Formation (Ludlovian), S-6, sample C47-248.4 m, paratype ROM 34215, $\times$ 2.3 .

Figs. 40-45. Metaplasia sp.

40,41 . Interior and lateral views of pedicle valve, Delorme Formation (Ludlovian), S-6, sample C47-248.4 m, ROM 34216 , $\times 4.0$.

42, 43. Interior and exterior views of brachial valve, Delorme Formation (Ludlovian), S-6, sample C47-248.4 m, ROM 34217 , $\times 4.0$.

44. Interior view of brachial valve fragment, Delorme Formation (Ludlovian), S-6, sample C47-248.4 m, ROM 34218, $\times 4.0$.

45. Oblique interior view of brachial valve fragment, Delorme Formation (Ludlovian), S-6, sample C47-248.4 m, ROM 34219 , $\times 4.0$.

Figs. 46-52. Cyrtinaella cf. C. causa Johnson.

46-48. Posterior, anterior, and dorsal views of articulated shell; Delorme Formation (late Lochkovian), S-1, sample A470.9 m, ROM $34220, \times 2.0$.

49-52. Posterior, anterior, lateral, and ventral views of articulated shell; Delorme Formation (late Lochkovian), S-1, sample A470.9 m, Rом $34221, \times 2.0$.

Figs. 53-58. Indeterminate spiriferid sp.

53-56. Interior, exterior, oblique interior, and lateral views of brachial valve, Delorme Formation (late Lochkovian), S-2, sample B166.1-182.9 m, ROM 34223, × 3.5 .

57,58 . Oblique interior and interior views of brachial valve, Delorme Formation (late Lochkovian), S-1, sample A519.7 m, ROM $34222, \times 3.5$.

Figs. 59, 60. Indeterminate terebratulid sp. Oblique interior and interior views of brachial valve, Delorme Formation (Zlichovian), S-3, sample S4-176.8 m, ROM $34224, \times 5.0$. 

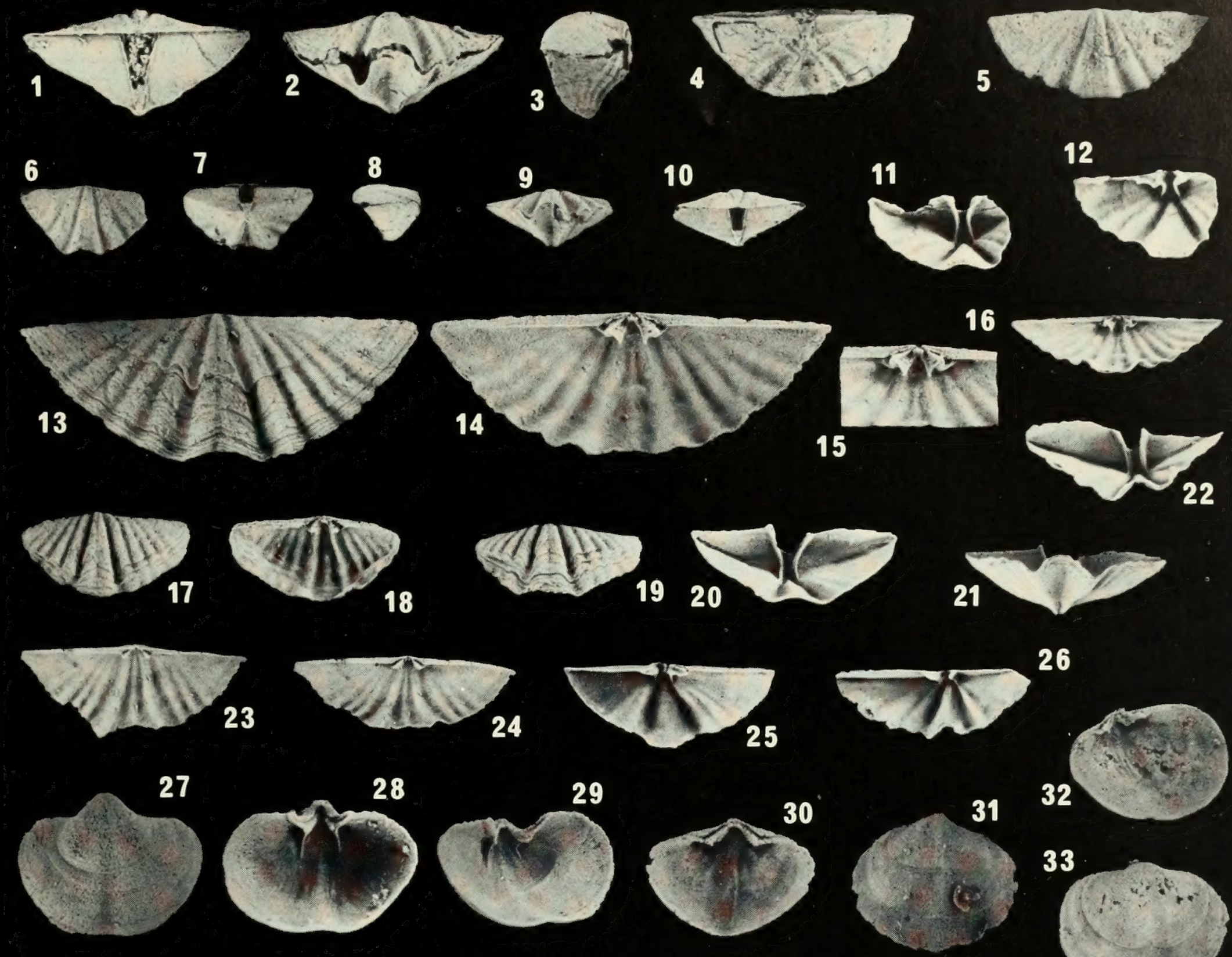

32

33
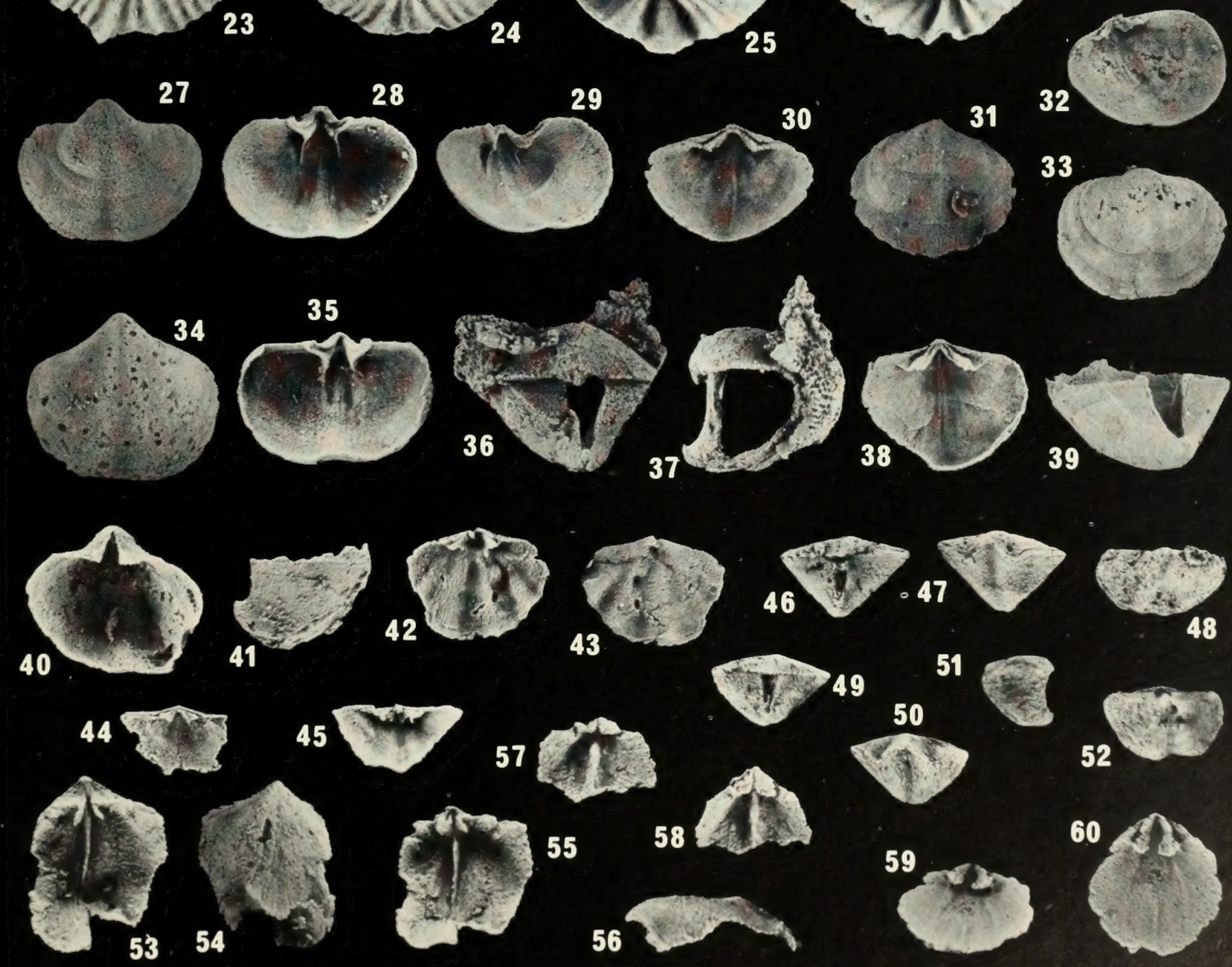




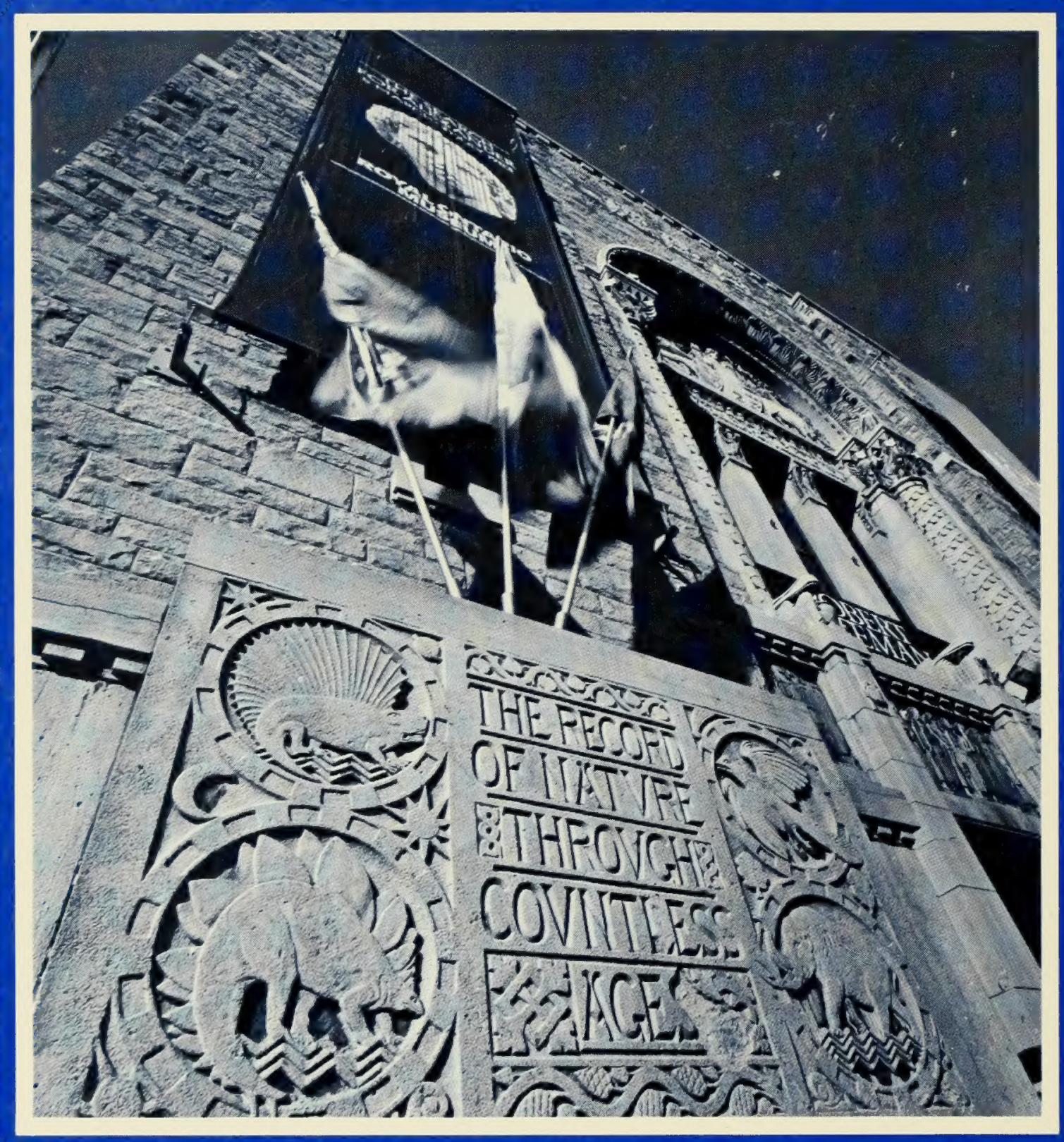

ISBN 0-88854-304-2

ISSN 0384-8159 